\title{
Report to the Congress on Alternative Financing Methods for the Strategic Petroleum Reserve
}

\section{Volume I: Study \& Appendices}

Submitted in Response to the Strategic Petroleum Reserve Amendments Act of 1989 (Public Law No. 101-42).

February 1, 1990

Department of Energy

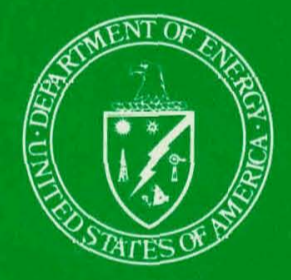




\section{DISCLAIMER}

This report was prepared as an account of work sponsored by an agency of the United States Government. Neither the United States Government nor any agency Thereof, nor any of their employees, makes any warranty, express or implied, or assumes any legal liability or responsibility for the accuracy, completeness, or usefulness of any information, apparatus, product, or process disclosed, or represents that its use would not infringe privately owned rights. Reference herein to any specific commercial product, process, or service by trade name, trademark, manufacturer, or otherwise does not necessarily constitute or imply its endorsement, recommendation, or favoring by the United States Government or any agency thereof. The views and opinions of authors expressed herein do not necessarily state or reflect those of the United States Government or any agency thereof. 


\section{DISCLAIMER}

Portions of this document may be illegible in electronic image products. Images are produced from the best available original document. 


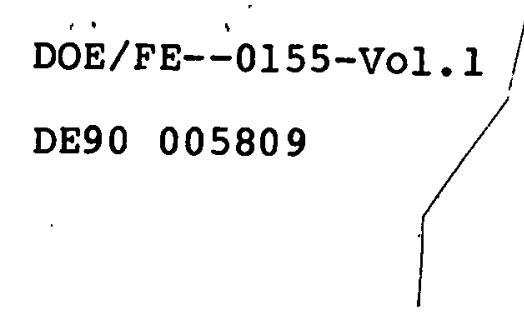

\section{Report to the Congress on Alternative Financing Methods for the Strategic Petroleum Reserve}

\section{Volume I: Study \& Appendices}

Submitted in Response to the Strategic Petroleum Reserve Amendments Act of 1989 (Public Law No. 101-42).

February 1, 1990

Department of Energy

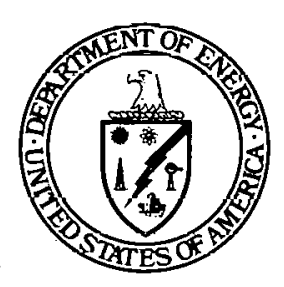

\section{MASTER}

DISTRIBUTION OF THIS DOCUMENT IS UNLIMITED 


\section{TABLE OF CONTENTS}

\section{INTRODUCTION}

A. Purpose of Study and Legislative Requirements . . . . . . . I -1

B. Policy Framework $\ldots \ldots \ldots \ldots \ldots \ldots \ldots \ldots \ldots \ldots \ldots \ldots \ldots \ldots \ldots$

C. Study Process . . . . . . . . . . . . . . . . . I I-10

D. Analytic Framework and Evaluation Criteria $\ldots \ldots \ldots \ldots \ldots \ldots$ I-11

E. Study Outline $\ldots \ldots \ldots \ldots \ldots \ldots \ldots \ldots \ldots \ldots \ldots \ldots \ldots \ldots$

II. SPR BACKGROUND

A. Program History $\ldots \ldots \ldots \ldots \ldots \ldots \ldots \ldots \ldots \ldots \ldots$ II -1

B. Financial History.$\ldots \ldots \ldots \ldots \ldots \ldots \ldots \ldots \ldots \ldots \ldots \ldots \ldots \ldots$

III. RELEVANT LEGAL. FACTORS

A. The Existing Legal Framework $\ldots \ldots \ldots \ldots \ldots \ldots$ III-1

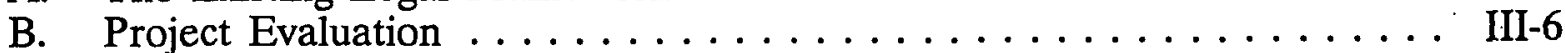

C. The Contracting Process $\ldots \ldots \ldots \ldots \ldots \ldots \ldots \ldots \ldots \ldots \ldots$ III-14

D. Contract Structure $\ldots \ldots \ldots \ldots \ldots \ldots \ldots \ldots \ldots \ldots \ldots \ldots \ldots \ldots \ldots$ III-26

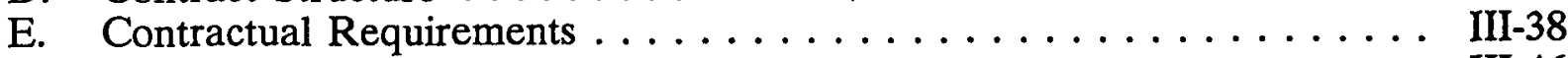

F. Taxes and Fees $\ldots \ldots \ldots \ldots \ldots \ldots \ldots \ldots \ldots \ldots \ldots \ldots \ldots \ldots \ldots$ III-46

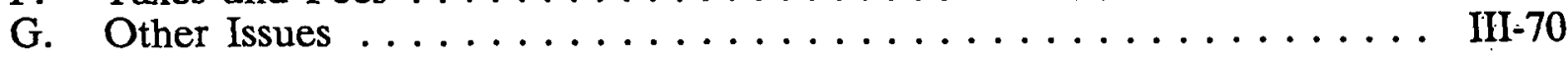

IV. MAJOR ISSUES

A. Effects on Drawdown and Distribution . . . . . . . . . . . IV-1

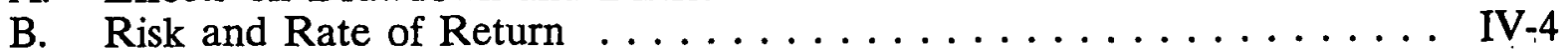

C. Market for Strategic Petroleum Investment $\ldots \ldots \ldots \ldots \ldots \ldots \ldots$ IV-13

Exhibit A: Source Data for Debt Calculations $\ldots \ldots \ldots \ldots \ldots \ldots \ldots$ IV-21

V. REFERENCE CASE

A. Introduction $\ldots \ldots \ldots \ldots \ldots \ldots \ldots \ldots \ldots \ldots \ldots \ldots \ldots \ldots \ldots$

B. Assumptions ..................... V-3

C. Reference Scenario ..................... V-12

D. Price Sensitivity Analysis .................... V-15

E. Fill Rate Sensitivity $\Lambda$ nalysis . . . . . . . . . . . . . . V-19

Exhibit A: Fill Rate, Oil Price, and Size Sensitivities . . . . . . . . V V-26

VI. OIL LEASING

A. General . . . . . . . . . . . . . . . . . VI-1

B. Lease Design Features . . . . . . . . . . . . . . . VI-y 


\section{TABLE OF CONTENTS (continued)}

VI. OIL LEASING (continued)

C. Specific Proposals $\ldots \ldots \ldots \ldots \ldots \ldots \ldots \ldots \ldots \ldots \ldots$ VI-42

D. Evaluation of the Leasing Option $\ldots \ldots \ldots \ldots \ldots \ldots \ldots \ldots$ VI-43

E. Budget Analysis . . . . . . . . . . . . . . . . . . . VI-84

F. Legislation to Authorize Oil and Facilities Leasing . . . . . . . . . . . VI-102

Exhibit A: Draft Legislative Language Authorizing Oil Leasing . . . . . . . . VI-112

Exhibit B: Draft Legislative Language Authorizing Defense Petroleum

Inventory

VI-115

VII. OIL-INDEXED BONDS

A. General . . . . . . . . . . . . . . . . . . VIII-1

B. Bond Design Features $\ldots \ldots \ldots \ldots \ldots \ldots \ldots \ldots \ldots \ldots$ VII-7

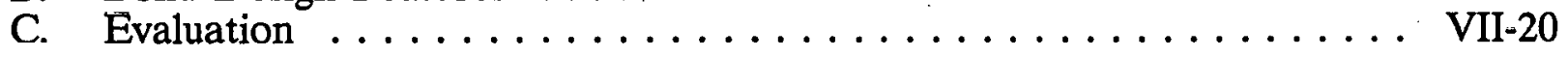

VIII. NAVAL PETROLEUM RESERVES ALTERNATIVES

A. Background $\ldots \ldots \ldots \ldots \ldots \ldots \ldots \ldots \ldots \ldots$ VIII-1

B. Alternative 1: The Movement of NPR-1 Oil to the SPR . . . . . . . VIII-7

C. Alternative 2: A Revolving Fund Link Between NPR-1 and the SPR .. VIII-13

D. Alternative 3: Divestiture Options . . . . . . . . . . . . . VIII-18

E. Alternative 4: Leasing . . . . . . . . . . . . . . . VIII-25

F. Summary $\ldots \ldots \ldots \ldots \ldots \ldots \ldots \ldots \ldots \ldots \ldots \ldots \ldots \ldots \ldots \ldots$ VIII -32

IX. FEES AND CHARGES

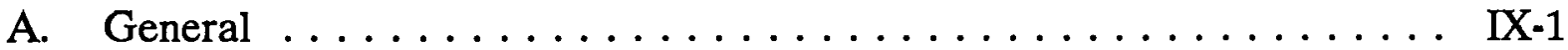

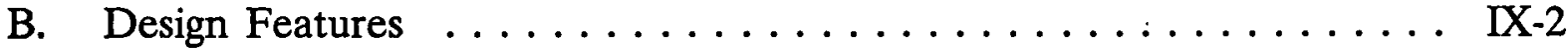

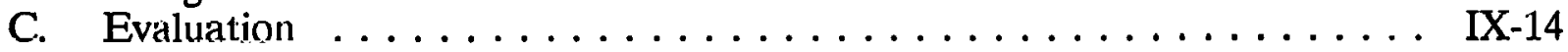

X. INDUSTRIAL PETROLEUM RESERVE

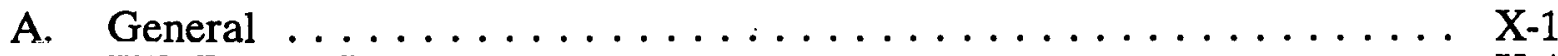

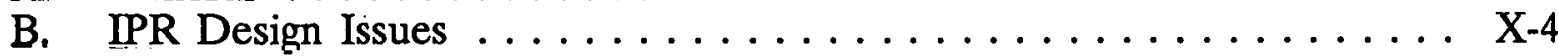

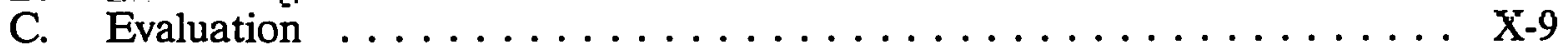

Exhibit A: Petroleum Reserves in Other Countries . . . . . . . . . . X X-13

XI. FACILITY FINANCING ALTERNATIVES

A. Introduction $\ldots \ldots \ldots \ldots \ldots \ldots \ldots \ldots \ldots \ldots \ldots \ldots$ XI-1

B. History of SPR Facilities Leasing Efforts in the SPR Program . . . . . . XI-2

C. Lease Design Issues $\ldots \ldots \ldots \ldots \ldots \ldots \ldots \ldots \ldots$ XI-4 


\section{TABLE OF CONTENTS (continued)}

XI. FACILITY FINANCING ALTERNATIVES (continued)

D. Methodology and Assumptions $\ldots \ldots \ldots \ldots \ldots \ldots \ldots \ldots \ldots \ldots$ XI-12

E. Analysis of Facility Lease Reference Case . . . . . . . . . . . . XI-13

F. Finance Charge Sensitivity Analysis $\ldots \ldots \ldots \ldots \ldots \ldots \ldots \ldots$ XI-16

G. Construction Cost Sensitivity Analysis . . . . . . . . . . . . . . X XI-18

H. Break-Even Analysis: Finance Charges and Construction Costs . . . . . XI-19

I. Fill Rate/Interim Storage Analysis . . . . . . . . . . . . . . . XI-25

J. Fill Rate Break-Even Analysis: Reduced Oil Price . . . . . . . . . . . XI-27

\section{APPENDICES}

1. Interagency Steering Group Membership

2. Interagency Working Group Membership

3. Interim Report to Congress

4. Public Response to Notice of Inquiry

5. Draft Solicitation: Oil Leasing

6. Draft Solicitation: Facility Storage Leasing 


\section{Abbreviations}

$-A-$

AFR Applicable Federal Rate

ANS Alaskan North Slope (crude oil)

ARAC Average Refiner Acquisition Cost: all oil

$-B-$

BBLS Barrels

BBLS/D Barrels Per Day

BIT Bilateral Investment Treaty

$-\mathrm{C}-$

CDA Contract Disputes Act

CEQ Council on Environmental Quality

CFTC Commodity Futures Trading Commission

CICA Competition in Contracting Act

CIF. Cost, Insurance and Freight

$-\mathrm{D}-$

DEAR Department of Energy Acquisition Regulation

DFSC Defense Fuels Supply Center (of the Department of Defense)

DOE Department of Energy

DPI Defense Petroleum Inventory

DPA Deepwater Port Act

DRAC Refiner Acquisition Cost: domestic oil

$-\mathrm{E}-$

EA Environmental Assessment

EAA Export Administration Act

EAR Export Administration Regulations

EEC European Economic Community

EEPA Energy Emergency Preparedness Act

EIA Energy Information Administration

EIS Environmental Impact Statement

EPCA Energy Policy and Conservation Act

$-\mathrm{F}-$

FAR Federal Acquisition Regulations

FCN Friendship, Commerce, and Navigation (treaty)

FDAP Fixed or Determinable Annual or Periodical Income.

FEA Federal Energy Administration

FERC Federal Energy Regulatory Commission 


\section{Abbreviations (cont'd)}

FIFO First In/First Out

FOB Free on Board

FPMR Federal Property and Management Regulations

FSIA Foreign Sovereign Immunities Act

FTZ Foreign Trade Zone

$-G-$

GAO General Accounting Office

GATT General Agreement on Tariffs and Trade

GSA General Services Administration

GSAR General Services Acquisition Regulations

$-\mathrm{H}-$

HPA Head of Procuring Activity

HTS Harmonized Tariff Schedule of the United States

$-\mathrm{I}-$

IEA International Energy Agency

IEP Agreement on an International Energy Program

IFB Invitation for Bids

IPR Industrial Petroleum Reserve

IRAC Refiner Acquisition Cost: imported oil

ITC Investment Tax Credit

$-\mathrm{L}-$

LOOP Louisiana Offshore Oil Port

$-\mathrm{M}-$

MACRS Modified Accelerated Cost Recovery System

MARAD Maritime Administration

MB Thousands of Barrels

MB/D Thousands of Barrels Per Day

MFN Most Favored Nation

MMB Millions of Barrels

MMB/D Millions of Barrels Per Day

MOIP Mandatory Oil Import Program

$-\mathrm{N}-$

NEPA National Environmental Policy Act

NOI Nulice of Inquiry

NPR Naval Petroleum Reserve 


\section{Abbreviations (cont'd)}

NYMEX New York Mercantile Exchange

$-\mathrm{O}-$

OID Original Issue Discount

$\mathrm{OMB}$ Office of Management and Budget

OPEC Organization of Petroleum Exporting Countries

$$
\text { -P- }
$$

PEMEX Petroleos Mexicanos (state oil company of Mexico)

PIAP Petroleum Import Adjustment Program

$-\mathrm{R}-$

RFP Request for Proposals

RPR Regional Petroleum Reserve

$-S-$

SPR Strategic Petroleum Reserve

SSP Standard Sales Provision

$-\mathrm{T}-$

TECA Temporary Emergency Court of Appeals

$-\mathrm{UT}$.

USG United States Government

$-W-$

WTI West Texas Intermediate (crude oil) 


\section{CHAPTER I. INTRODUCTION}

\section{A. PURPOSE OF STUDY AND LEGISLATIVE REQUIREMENTS}

The purpose of this study is to fulfill the requirements of Public Law No. 101-46, approved June 30, 1989. The study describes and evaluates alternative methods for financing the future expansion of the Strategic Petroleum Reserve (SPR), both to the current target level of 750 million barrels and to potential future levels of up to one billion barrels.

In signing Public Law No. 101-46, the President advised the Congress of the need for an interagency study on the question of whether the Strategic Petroleum Reserve should be expanded beyond the current SPR target of 750 million barrels. The Administration views the policy questions of SPR size and SPR financing as closely interrelated. In August 1989 the Department of Energy created an Interagency Steering Group to ensure that a broad range of policy perspectives and technical expertise would be brought to bear on both the size and financing issues.

In recently extending Title I of the Energy Policy and Conservation Act, the Congress required the Secretary of Energy to study alternative financing methods that could be used to finance completion of a one billion barrel Strategic Petroleum Reserve. Specifically, section 2 of Public Law No. 101-46 sets out the following requirements:

(a) IN GENERAL. -- The Secretary of Energy shall carry out a study on potential financial arrangements (including long-term leasing of crude oil and storage facilities) that could be used to provide additional, alternative means of financing the filling of the Strategic Petroleum Reserve to une billion barrels. In carrying out such study, the Secretary shall --

(1) assume that the legislation that extends title I of the Energy Policy and Conservation Act beyond April 1, 1990, will require the Secretary to amend, by July 1, 1990, the Strategic Petroleum Reserve Plan to provide plans for completion of storage of one billion barrels of petroleum products in the Reserve at an average fill-rate of at least seventy-five thousand barrels per day;

(2) consider a broad array of such arrangements;

(3) consult with persons in the private sector who might be interested in leasing crude oil or storage facilities;

(4) initiate, in cooperation with the Department of State, to the extent consistent with the interests of the United States, discussions with representatives of foreign governments and other entities as to the types of financial arrangements (including crude oil leasing arrangements) that would interest them; and

(5) produce preliminary written solicitations for proposed alternative financial arrangements (including long-term leasing of crude oil and storage facilities) to assist in filling the Strategic Petroleum Reserve to one billion barrels. 
(b) REPORTS. -- (1) The Secretary shall, no later than October 15, 1989; transmit to the Committee on Energy and Natural Resources of the Senate and the Committee on Energy and Commerce of the House of Representatives an interim. report containing --

(A) an enumeration of the specific resources (both personnel and funding) committed to the study described in subsection (a);

(B) a description of the progress made toward completing the study; and

(C) any preliminary findings and conclusions made by such date.

(2) The Scorctary shall, no later than February 1, 1990, transmit: to such committees a copy of the solicitations described in paragraph (5) of the subsection (a) and a final report containing the findings and the conclusions of the study carried out under this section, together with a draft of the legislative changes that would be necessary to authorize the most significant alternative financial arrangements studied by the Secretary (including long-term leasing of crude oil and storage facilities) and recommendations of the Secretary with respect to the need for and desirability of such financial arrangement (including long-term leasing of crude oil and storage facilities).

On October 13, 1989, the Deputy Secretary of Energy transmitted an interim report to the Congress containing the information required by section (b)(1).

This report is the final report required by section 2(b)(2). It contains the findings and conclusions of the study and a draft of the legislative changes that would be necessary to authorize long-term leasing of crudc oil and storage facilities. Volume II contains the draft solicitations for oil leasing and facilities leasing, as required by law. These draft sulicitatious ıepresent the prcliminary work of DOE staff; they might undergo substantial revision in the course of preparing to undertake an actual leasing effort.

No recommendations are included in this study. Any recommendations of the Secretary of Energy will be transmitted separately.

Section 2(a)(1) of the law mandating this study requires the assumption that the SPR would be filled at a minimum rate of at least 75,000 barrels per day until one billion barrels is in storage. The study incorporates this assumption, along with alternative SPR size and fill rate levels. The Administration's current plan is to achieve a total of 750 millium bantels. A parallel study has been undertaken on the economic costs and benefits of alternative SPR sizes. 


\section{B. POLICY FRAMEWORK}

\section{Background}

Under current law and policy, the Department of Energy (DOE) is developing a Strategic Petroleum Reserve that has the following characteristics:

- Although not required by law, under existing policy the U.S. Government owns, controls, and manages the Reserve facilities and oil inventory.

- Crude oil is the commodity stored, with technical specifications aligned with those of U.S. refiners; this involves storing both sour and sweet crude oils meeting certain specifications.

- The crude oil is acquired through market-like methods, which over the life of the Reserve have included a mix of short-term, openmarket purchases or exchanges, and longer-term contracts with prices reflecting market conditions.

- The inventory is to be stored in salt caverns at six sites in Louisiana and Texas, connected by DOE-owned pipelines to the commercial crude oil distribution system.

- The Reserve is financed through the normal Federal budget process, with the Department of Energy budgeting for facilities development, operation, management and oil acquisition and transportation. To the extent that debt proceeds, rather than taxes or other current income, are used to finance the Reserve costs, the Treasury Department arranges for the sale and servicing of debt; interest costs on this debt are reflected in appropriations to the Treasury Department.

- The President is authorized to decide whether, how, and when the Reserve inventory is to be sold, under broad criteria outlined in the EPCA.

- The Secretary of Energy, through a "Strategic Petroleum Reserve Plan," including a "Distribution Plan" component thereof, which must be transmitted to Congress, is empowered to prescribe the mode of Reserve storage and drawdown.

- Under current plans, the primary method for distributing the Reserve is open, competitive sales. 
- $\quad$ The Reserve inventory target has been set at 750 million barrels by the mid-1990's.

As illustrated above, the financing method is only one of a number of key characteristics of the Reserve, and one general question encountered in the financing study is whether, and to what extent, changes in the method of financing would imply changes in other dimensions of SPR policy.

For the conduct of this study, the Administration established three objectives:

- To comply with both the letter and the intent of the Congress in enacting the requirement for the study;

- $\quad$ To remain open to a wide variety of possible financing methods that might be proposed by the private sector, other nations, or other Federal agencies; and

- $\quad$ To preserve the character of the SPR as an economic and national security asset, the deployment of which is subject to the control of the President.

Over the decade and a half since the SPR was created, there have been many proposals for different ways of financing facilities development and oil acquisition. In order to meet the stated intent of the Congress to pursue some options in depth -- including preparation of procurement documentation and legislative changes -- a broad array of alternatives were screened before some were selected for more intensive examination in this study. The purpuse of this cliapter is to describe the outcome of this screening process and to explain why alternatives were included in or excluded from the primary set.

\section{Policy Criteria}

The following were the major decisions that established the boundary conditions for the study.

\section{a. Storage of Crude Oil}

The Working Group assumed that the SPR would continue to consist exclusively of crude oil. The Department of Energy's April 1989 report to the Congress $\underline{y}$ concluded that expansion of the Reserve beyond the planned level of 750 million barrels should include crude oil only, rather than some mix of crude oil and refined products.

The Administration is not aware of any changed circumstances since the earlier study that would imply the need to reanalyze this issue. Refined product storage is more expensive than crude oil storage. Furthermore, because refined products require frequent turnover to prevent deterioration while in storage, a product storage effort involves a continuous process of buying and selling, or

1/ Report to the Congress on Expansion of the Strategic Petroleum Reserve to One Billion Barrels. 
exchanging, the physical commodities. Incorporation of this approach into the financing study would likely lead the Department's study efforts into different and complex areas which would not be relevant to the financing of crude oil storage.

\section{b. Use of Solution-Mined Salt Caverns For Permanent Storage}

Where applicable in analyzing facilities financing methods, the study group has assumed that permanent storage of the SPR crude oil inventory would be in solution-mined caverns.

The principal reasons for electing salt cavern storage are set forth in the April 1989 report to Congress. Foremost among these reasons is cost; steel tank development, on a per barrel basis, is much more expensive ( 2 to 6 times) than solution-mined storage.

\section{c. Continue Current Facilities Development}

The study group assumed full implementation of current plans to develop 750 million barrels in storage capacity in salt caverns at the six SPR storage sites in Texas and Louisiana. Thus, consideration of new facility options by leasing or otherwise will be relevant to capacity which may be required to expand the size of the Reserve beyond 750 million barrels.

At the SPR's new site at Big Hill, Texas, an estimated $\$ 358$ million has been obligated through Fiscal Year (FY) 1989. This represents nearly 90 percent of the total estimated cost of $\$ 404$ million, even though initial oil fill capability at Big Hill is becoming available during. FY 1990. The Administration believes it would be clearly uneconomic to curtail Big Hill development to attempt a lease development method at a different location.

\section{d. Oil Fill for $\mathbf{7 5 0}$ Million Barrcls}

Options for financing oil acquisition for the fill of the Reserve from 600 million barrels to 750 million barrels will assume retention of the basic physical specifications for crude oil that have been established as part of the SPR program.

The study considers private financing alternatives for remaining portions of the 750 million barrel system, but retains the basic principle that decisions to draw down SPR oil will be vested in the President. This position is consistent with the current SPR Distribution Plan (SPR Plan Amendment No. 4), for the 750 million barrel system. Near-term oil lease or other alternatives would need to bc structured to permil the Department to deploy the crude oil in accordance with both the President's decisions and the basic distribution procedures which apply to the existing inventory.

The United States has encouraged its fellow members of the International Energy Agency to undertake strategic oil stockpiling in a manner that ensures the strategic character of the reserves, preferably through direct governmental ownership. To date, this country has chosen outright government ownership of stocks as an appropriate means to achieve these objectives, but other countries have chosen different approaches. Financing options considered in this study should 
assure our allies that, while the Congress has asked for a study of alternative financing methods, the Administration has not changed its position on the fundamental aspects of oil stockpiling.

\section{e. No Financing Change for Reserve Inventory Already Acquired}

The Department has analyzed alternatives for future increments of the Reserve. The study has not considered options for refinancing the first 600 million barrels of the Reserve inventory. In the past, a number of proposals were received involving the refinancing of the current SPR oil inventory, with proceeds used to acquire additional oil. Due to the focus of Federal budget scorekeeping on current revenues and costs, without the private sector "balance sheet" of assets and liabilities, sale of an existing asset inttally can apppear attractive in the year in which the salco proceeds are received.

Previous analyses of these proposals indicate that the sale (or other forms of divestiture such as mortgaging) of portions of the existing inventory to pay for both the principal and interest on future oil acquisition, while reducing current budget appearances, would involve a decrease over time in the current equity ownership of the Federal Government. They could entail loss of control over oil that has already been bought and paid for by the Federal Government.

\section{Overview of Alternatives}

The Department examined three general categories of financing methods for the SPR: voluntary investment by the private sector or other govertnments; ways of usiing the profitability of the Naval Petroleum Reserves on behalf of the SPR; and methods for requiring the ultimate beneficiaries of the Reserve to contribute to its development and maintenance.

Voluntary investment alternatives include the facility and oil leasing options which Congress required the Department of Energy to address. In addition, the study considered the putential for using oil-denominated bonds to raise private capital.

Oil in storage in the SPR may increase in market value over the life of the program, and some approaches to oil leasing and oil denominated bonds would rely on the expectations of invesluis regarding asset appreciation as a way of allempling to avoid some port of the financing costs of the Reserve. Changes in the value of SPR assets are not recognized in the Federal budget process, but asset valuation changes are normally teflected in privatc business finance. Thus these. two classes of financing techniques call seek to take advantage of differences in formal financial analyses to attract private financing for a portion of the costs. By their voluntary character, these alternatives would require attracting investors, and much of the discussion in Chapters VI and VII addresses ways of structuring lease contracts or financial instruments to gain market acceptance while meeting Federal requirements.

The NPR options involve various ways of rearranging the financial relationships between the profitable operation of the Elk Hills oil field in California and the SPR program. At one extreme, the ownership of Elk Hills would be left unaffected, but profits from operations would be dedicated to the SPR. At the other extreme, future Elk Hills profits would be capitalized through 
the transfer of the assets to the private sector, with proceeds dedicated to SPR development. Within this range, there are a number of different approaches that could be employed.

The fee and tax alternatives, and regulatory concepts to compel private storage, offer a broad class of options involving different ways of compelling importers or consumers of petroleum to contribute to the SPR. The general theoretical basis for these options is that energy security costs associated with oil imports or oil consumption are not now fully reflected in the market price of oil. Fees on storage requirements are ways of internalizing into oil prices, the cost of insuring oil consumers against the risk of a sudden reduction in foreign supplies.

\section{Alternatives Not Included}

Over the nearly fiftccn years since the SPR was created, there have been numerous suggestions for ways to finance the SPR. The following is a brief description of options that have been identified, but which were not analyzed in depth:

\section{a. Sale or Exchange of Unrelated Assets}

From time to time, there have been proposals to use other Federal assets to acquire SPR oil through sale or exchange. As discussed above, Federal business-type assets do not have a formal role in the annual budget process, as they would in private sector financial analysis, except in periods during which they are bought or sold. When assets are acquired, their costs are accorded the same budget treatment as operating costs or transfer payments, even though property of lasting value may be received. When assets are sold, the sales proceeds are treated as a cash inflow to the Government, similar to tax receipts or other current income, even though Federal property is relinquished in such a sale.

Since the SPR, at least up to the point of an emergency drawdown, has been managed as an asset acquisition program, its annual budget profile is more pronounced than would be the case in a private sector income statement. Consideration has been given to asset exchanges or simultaneous . sales of other Federal asscts to neutralize the apparent effect of SPR oil purchases.

Examples of these proposals include the agricultural barter concepts considered in the mid-1980's. Under those proposals, surplus agricultural commodities owned by the Commodity Credit Corporation within the Department of Agriculture would have been traded for oil to be delivered to the Strategic Petroleum Reserve.

A similar concept was considered in a study in the early 1980's concerning the disposal of a portion of the silver stocks owned by the Federal Government. A further example was the budget amendment submitted by the prior Administration to link the costs of increasing the SPR fill rate to 100,000 barrels per day to the expected proceeds from the sale of the Great Plains Coal Gasification Project.

One general issue with these asset sale proposals is that it is difficult to rationalize why the asset sales should be directly linked to the Strategic Petroleum Reserve. The position taken in this 
study is that, with the exception of the Naval Petroleum Reserves concepts, the merits of the sale of the other Federal assets can and should be considered independent from SPR development.

\section{b. Simple Budget Scorekeeping Changes}

Some of the financing alternatives would, under current Federal practices, change the appearance of the SPR program in the annual budget. In discussing each alternative, an effort is made to describe such changes. However, this study has not addressed alternatives that would simply change the rules by which SPR transactions are recorded in the budget.

In 1981; the Reagan Administration and the Congress considered alternatives to direct Federal funding of the SPR, including some of the alternatives analyzed in this study. In May 1981, DOE Secretary Edwards, Treasury Secretary Regan, and OMB Director Stockman testified before both the House and the Senate on this subject. The focus of the discussion was the assel charactcr of the SPR oil inventory. OMB Director Stockman likencd SPR oil purchases to Federal gnld transactions, referring to them as asset swaps. The result of these dcliberations was the inclusion of a provision in the Omnibus Budget Reconciliation Act of 1981, Public Law No. 97-35, which established the "SPR Petroleum Account." Appropriations to, and expenditures from, the Account were to be excluded from Federal budget totals. In subsequent years, the information on SPR oil purchases was presented in the "off-budget" chapter of the annual President's budget appendix. However, no change was made to the initial source of SPR funds, which continued to be derived from an undifferentiated mix of Fedcral tax revenue and debt, and no changes were made to the accountability processes for managing the funds.

In 1985, the "Gramm-Rudman-Hollings" deficit reduction legislation ${ }^{2 /}$ effectively reversed the 1981 action to treat SPR oil purchases as an "off-budget" transaction. This study did not consider either a return to "off-budget" status for the SPR or any other simple changes in budget treatment, for two basic reasons. First, changes in budget scorekeeping, by themsclves, would neither change the underlying sources of financing for the Reserve, nor address any of the underlying economic issues which have created concern about the Federal budget deficit. Second, there may be other Federal programs that have characteristics similar to the SPR, and a full analysis of this subject would logically lead to consideration of the broader issues that have been debated regarding methods for distinguishing between operating and capital costs in the Federal budget process.

\section{c. Use of Futures or Options in SPR Inventory Management Transactions}

As discussed further in this study, there is a very large market today for trading in oil tutures contracts, and there is a growing market for oil options and so-called "swaps." These are techniques available to oil sellers and purchasers to share the risk of fluctuations in oil prices. Among other things, a producer can establish an effective floor price for future production, and an oil consumer can mitigate the risk of upward pressure on its purchase cousts.

2) The Balanced Budget and Emergency Deficit Control Act of 1985, Public Law No. 99-177, Title II (Dec. 12, 1985). 
As a purchaser -- and eventually a seller -- of oil, the SPR could participate in these markets in a variety of ways. First it could acquire "call" options to establish a ceiling on its annual purchase costs (a "call" is an option to buy at a specified price within a specific time period, as opposed to an option to purchase or lease). Secondly, it could sell "puts" by guaranteeing to acquire oil at specific prices. Finally, the Government could contract to sell SPR oil at specific prices, either through the sale of futures contracts for firm delivery or through the sale of call options which would be exercised under specific market conditions.

Within the voluntary investment alternatives studied, there are some clear analogies to futures and options transactions. However, such transactions by themselves would generate, in the near term, cash for only a fraction of the cost of each barrel for which rights were sold to the private sector. At best, such trading could only be employed in conjunction with one or more of the primary options being considered.

Furthermore, each of the futures and options concepts raises complex policy and management issues. The principal policy question is whether the President's current flexibility in making SPR use decisions should be encumbered by commercial agreements committing to future SPR oil sales. The management questions involve the ability of the Government to participate effectively in these markets, as well as the appropriateness of this type of trading by a public agency. While options on existing SPR inventory have not been analyzed in this study, this alternative could be studied in the future. 


\section{STUDY PROCESS}

To accomplish the study objectives within the schedule constraints, an Interagency Steering Group was established on August 11, 1989 under the leadership of DOE Deputy Under Secretary Linda G. Stuntz. Through the Steering Group, a broad range of perspectives were brought to bear on the interrelated policy issues of SPR size and SPR financing. For the SPR Financing Study, an Interagency Working Group was formed and periodic meetings were held to discuss the design and evaluation of policy options. The specialized expertise of certain agencies was used to address key issues as they were identified.

The Working Group conducted an active outreach program to oblain ideas from the privatc sector and from other governments. Highlights of this outreach effort included the following:

- The Working Group reviewed eleven responses to an October 2, 1989 Notice of Inquiry in the Federal Register. These comments are summarized in Appendix B.

- Six other members of the International Energy Agency (IEA) responded to an August 29, 1989 letter from the Department of Energy requesting suggestions about alternative financing methods.

- The Department of Energy, in cooperation with the Department of State, held a series of exploratory discussions with foreign oil producing nations, the results of which are reported in Chaptcr VI.

- Members of the Working Group met with over a dozen private fiu IIIs, either in conjunction with oil leasıng, oil bonds, or factlites leasing.

Preparation of the study document was undertaken by personnel from a number of Federal agencies and several parts of the Department of Euergy, with the hclp of DOE support services contracturs. 


\section{ANALYTIC FRAMEWORK AND EVALUATION CRITERIA}

The purpose of this part is to summarize the manner in which the Department conducted the evaluation of the policy options being considered in the Study.

Section 151(a) of the 1975 Energy Policy and Conservation Act, Public Law No. 94-163, provided a finding by the Congress "that the storage of substantial quantities of petroleum products will diminish the vulnerability of the United States to the effects of a severe energy supply interruption and provide limited protection from the short-term consequences of interruptions in supplies of petroleum products." Some of the financing alternatives being discussed in this study are intended to identify ways in which the U.S. Government could meet these "insurance" objectives without direct ownership of the oil.

Section 160(b) of the EPCA provided additional criteria for the manner in which petroleum would be acquired by the Government for such storage:

The Secretary shall, to the greatest extent practicable, acquire petroleum products for the Reserve ... in a manner consonant with the following objectives:

(1) minimization of the cost of the Reserve;

(2) orderly development of the Naval Petroleum Reserves to the extent authorized by law;

(3) minimization of the Nation's vulnerability to a severe energy supply interruption;

(4) minimization of the impact of such acquisition upon supply levels and market forces; and

(5) encouragement of competition in the petrolcum industry.

The study team adopted the five criteria outlined above as a framework for evaluating policy alternatives. The following subsections describe some of the issues arising from application of these criteria to financing issues.

\section{Minimization of Cost}

The costs of strategic oil stockpiling can be categorized as follows:

- Capital cost of storage facilities construction;

- Capital cost of nil acquisition and transportation;

- Interest or "holding" cost on the capital investments in storage facilities and oil; 
- Management and operating costs during and after the period of capacity development and fill; and

- Indirect economic effects of oil purchases in terms of impacts on prices paid by other oil purchasers and impacts, if any, on inventory levels and costs for other market participants.

\section{a. Direct and Indirect Costs}

The first four categories of cost can be considered direct costs that would be incurred by any entity creating a strategic stockpile. Under current practice, these direct costs are borne by the Federal Government, with the Department of Energy budgeting for the capital cost of oil and facilities and the ongoing management and operating costs. To the extent that the SPR is financed out of Federal borrowing, there is an explicit interest cost which is borne by the Department of the Treasury budget. However, even if the SPR is financed out of current Federal revenues, there is an implicit holding cost for the oil, sometimes characterized as an opportunity cost of invested capital, as discussed further in Part C of Chapter IV and in Chapter V.

The fifth category of cost is termed an indirect' cost because it accrues to other oil purchasers rather than to the owner of the stockpile. In a purely private financial analysis, these costs would be disregarded in deciding whether, when, and how to accumulate strategic stocks. In some forms of SPR policy analysis, notably those relating to decisions on SPR size, such price effects of SPR purchases could be taken into account in benefit/cost analysis. In this financing study, howcver, it is generally assumed that the method of SPR financing would not affect the level of indircct costs.

While this is a useful assumption in terms of simplifying the analysis, it should be noted that if the method of SPR financing had an impact on the overall levels of oil market supply and demand, there could be a feedback effect on the level of such indirect costs. Specifically, if, as argued by somc, the leasing of oil from a major producing nation might cause that nation to produce more oil than would have been produced under a different SPR tinancing approach, then the use of the leasing method would reduce the indirect costs of S'PK oll acquisition.

Another example of feedback effects involves the class of alternatives under which some or all of the direct costs of maintaining the Reserve would be borne by oil market participants under une of the fee or mandatory alternatives discussed in Chapters IX and $X$. To the extent that the financing method increases the costs of consuming oil, somewhat lower levels of consumption and imports of petroleum would be expected.

Estimating the indirect costs of SPR oil acquisition is difficult because of the small proportion of world oil supplies being added each year to the Reserve. Estimating the change in indirect costs associated with different financing approaches is even more difficult. The approach taken in the study is to describe such feedback effects in qualitative terms, and to focus the quantitative analysis of costs on the direct measures described above. 


\section{b. Measurement of Cost}

In evaluating the direct costs of each alternative, comparisons are made to the current method of financing the Reserve. A number of different measures are employed in making such comparisons, as follows:

\section{(1) Effects on the U.S. economy}

Even if the Government adopted a policy of requiring the private sector to bear the direct financial costs of future increments of the SPR, removing some or all of such costs from the Federal budget, there would still be an economic cost associated with the SPR. Private resources invested in the SPR and payments to foreign oil producers for incremental U.S. imports to fill the Reserve divert wealth from other purposes within the economy, just as public SPR expenditures do. The cost of diverting wealth in this manner can be characterized as an opportunity cost of capital and is susceptible to the types of benefit/cost analysis called for in Office of Management and Budget (OMB) Circular A-94 (revised), "Discount rates to be used in evaluating the timedistributed costs and benefits."

\section{(2) Effects on the Total Federal Budget}

Some alternatives involve rearranging the pattern of financial transactions within the Federal budget. In some cases, such as leasing, there would be a decrease in Treasury borrowing costs, with the holding costs of the Reserve being borne instead by the DOE budget. In other cases, financing alternatives might reduce the DOE budget, but with offsetting effects in terms of Treasury receipts from income tax collections. By analyzing total budget effects, carefully defining the effects on a number of different budget aggregates, these offsetting impacts can be understood.

In such analysis, the study will examine the effects of financing alternatives on both budget authority and outlays. Under the current financing approach, SPR cash outlays follow relatively rapidly from the obligation of budget authority. However, under some alternatives, cash budget oullays could be deferred, creating different effects on the two budget measures.

\section{(3) Present Value Life-Cycle Costs}

Some alternatives would change the timing of cash flows from and to the Federal Government, and provision has been made for including present value analysis in the evaluation of each alternative. Such analysis rcquircs the use of discount rates to reflect the time value of money, and Chapter IV provides a discussion of some of the issues which pertain to the selection of such discount rates.

\section{(4) Risk/Reward Tradeoffs}

Under the current financing method, the Government earns the benefits and bears the costs of any fluctuation in oil prices between the time the oil is acquired for the Reserve and the time when it is resold to the public. Under some alternative approaches, notably the oil denominated bond concept discussed in Chapter VII, the Government would share these risks with other parties. The 
risk/reward tradeoff analysis permits decision-makers to have a fuller understanding of the consequences of a financing alternative in the context of the potential for continuing fluctuation in oil prices in the coming years.

In the conduct of these forms of analysis, care has been taken to employ the standards and analytic approaches of applicable Federal guidelines, notably OMB Circulars.

\section{c. Life Cycle Concepts}

The purposes of the Reserve as set forth in EPCA section 151, quoted above, have two dimensions. Congress referred both to diminishing the vulncrability of the United States and to providing limited protection against the consequences of a supply disruption. One interpretation of these statements is that a distinction was being drawn betwecn the benefits of having the Reserve as a deterrent against a supply disruption, and the benefits of drawing down the Reserve in the event that a supply disruption occurred, akin to redeeming an insurance policy.

This distinction has consequences for the approach taken to life-cycle cost analysis. In the latter case, one would consider the life-cycle of the Reserve to include both the acquisition of the stockpile and its resale under either emergency or non-emergency conditions. Under this interpretation, the resale value of the oil at the end of the period of analysis would be factored into the financing analysis. Under an alternative interpretation, the Reserve is an insurance policy which is held essentially in perpetuity, in which case the future resale value of the oil would have little if any significance for financing analysis. One private sector response to the Department's Notice of Inquiry addressed this alternative formulation by suggesting that there are some portions of the SPR oil inventory which would be less likely to be sold than others, implying the possibility of using different life-cycle approaches for different increments of the Reserve. In general, the Department's analysis of cost takes the approach that additional SPR volumes acquired are available for resale at a future date, such that the owner -- whether the Federal Government as under current practice or possibly another party under one of the financing alternatives -- would receive any appreciation in the value of the oil during storage. However, the alternative formulation is also introduced in certain evaluations for purposcs of sensitivity analysis.

\section{Orderly Development of the Naval Petrulemu Rescrves (NPRs)}

This criterion is applicable primarily to the cluster of NPR financing alternatives discussed in Chapter VIII. In this study, the term, "orderly development," is taken to mean the efficient use of resources in the development and operation of the NPRs.

\section{Minimization of Vulnerability}

This criterion bears on the evaluation of financing alternatives in a number of ways. First, since the SPR is the Nation's primary defense against interruptions in the supply of foreign oil, one highly relevant question about a financing alternative is whether it would be likely to permit a more rapid rate of oil fill than would other alternatives. Second, some SPR financing alternatives would provide investors with an opportunity to share in the appreciation in the value of the oil in the event of a major supply interruption. Another relevant question is whether and to what 
extent providing this opportunity could induce private parties within the United States to reduce their direct holdings of oil inventories. Any reduction in private oil inventories would diminish the degree to which the incremental barrels added to the SPR would reduce U.S. vulnerability. Fourth, as discussed further in Chapter IV, some SPR financing alternatives could affect the flexibility with which the Federal Government would be able to deploy the SPR oil inventory during a supply disruption. Finally, some financing alternatives would involve participation by foreign producing nations in the SPR. Depending on the specific circumstances, this could either enhance or detract from the vulnerability of the United States to supply interruptions.

\section{Impacts on Market Forces}

Some alternatives represent different ways of providing funds to the Department with which to acquire oil for the SPR. All other things being equal, SPR purchases from one source of funds should have market effects equivalent to SPR purchases from other sources of funds. However, under some alternatives, there could be effects on either the overall level of market supplies or on the availability of particular crude streams in the market, and these effects need to be examined in evaluating the financing alternatives.

\section{Effects on Competition}

At present, the SPR uses market-like approaches to both the acquisition and sale of crude oil. Financing policy alternatives need to be analyzed in terms of the potential for affecting market structure and the degree of competition among purchasers and sellers of crude oil. 


\section{E. STUDY OUTLINE}

The study is printed in three volumes:

- $\quad$ Executive Summary

- Study and Appendices

- Preliminary draft solicitations for oil and storage leasing

\section{Chapter I. Introduction}

The overall purpose of the study, its statutory requirements, legislative history and policy framework are introduced in Chapter I. Additional details of the study process, key assumptions, the analytic framework and evaluation criteria are also provided.

\section{Chapter II. SPR Background}

Some of the significant events in the SPR's legislative history, plan amendments, program milestones, funding and oil fill are mentioned in skeleton outline form in this chapter.

\section{Chapter III. Relevant Legal Factors}

Chapter III discusses a number of legal considerations that appear to be relcvant to the leasing of oil or facilities for the SPR and that also may apply to other appruaches lo SPR financing. $\Lambda$ fter setting nut the existing legal framework within which the $\mathrm{SPR}$ program is conducted, the chaptcr describes certain administrative and environmental evaluation requirements for new vil ui facilitics programs. It next explains applicable U.S. Government contracting procedures, and addresses the structure and content of a potential lease, particularly legal principles governing the obligation of Federal funds, and required contractual provisions. It then cuvers a range of Fcderal, State and local tax issues that can affect oil and facilities leasing. Finally, it concludes with a discussion of miscellaneous other topics such as legally permissible commercial uses of SPR storage facilitics.

\section{Chapter IV. Major Issues}

Key issues are identified and examined in considerable detail here. The effects on SPR drawdown and distribution are explored, as well as Federal budget scorekeeping associated with a range of leasing options. The market for investment in the SPR is evaluated in terms of risk and rate of return concepts, especially the underlying issues in selecting proper interest and discount rates.

\section{Chapter V. Reference Case}

This chapter describes SPR development and fill alternatives. The costs of three SPR size increments are explored here: 600 to 750 million barrels, 750 to 850 million barrels and 850 to 1,000 million barrels. Further variations in fill rate and oil price path assumptions are also analyzed and evaluated with respect to a range of financial measures, including direct budget outlays, real 
dollar and present value costs, total costs to the U.S. Treasury over the life of the program, and the market value of incremental SPR oil fill.

\section{Chapter VI. Oil Leasing}

This chapter provides a detailed discussion of possible oil leasing options available. Lease design features are evaluated for their financial and SPR systems effects. As required by Public Law No. 101-46, legislative changes that would bc necessary to implement these options are included.

\section{Chapter VII. Oil-Indexed Bonds}

Another set of financing options is evaluated, where a new type of debt instrument would be established in a commercial market. Bonds would convey the right to investors to earnings equivalent to growth in the value of oil.

\section{Chapter VII. Naval Petroleum Reserves Alternatives}

Use of NPR assets sales as a source of funding for SPR fill is described, including a range of options from complete divestiture to employing current revenues in a revolving fund used to purchase SPR oil.

\section{Chapter IX. Fees and Charges}

Three petroleum fees or taxes are explored as alternatives for financing the SPR. These include oil import fees or increased customs duties, taxes on end use of transportation fuels, and a general consumption tax on both imported and domestic crude oils.

\section{Chapter X. Industrial Petroleum Reserves}

This group of options would require industry to either purchase certificates guaranteeing a supply of oil during a disruption or to establish petroleuin reserves in which industry holds stocks (crude or product), possibly in Federal storage facilities. Additional cffects on market forces and competition are examined.

\section{Chapter XI. Facility Financing Alternatives}

This chapter analyzes the costs and systems effects of both leasing and purchasing storage in salt domes, and suggests a framework for comparing leasing proposals. Several aspects of designing a lease are examined.

\section{Appendices}

A. I: Interagency Steering Group For Strategic Petroleum Reserve Alternative Financing and Size Studies 
B. II: Interagency Working Group For Strategic Petroleum Reserve

Alternative Financing Study

C. III: Interim Report to Congress on SPR Alternative Financing Study

D. IV: Public Response to Notice of Inquiry

E. V: Preliminary Draft Solicitation for SPR Oil Leasing

T. VI: Preliminary Draft Solicitation for SPR Storage Facilities Leasing 


\section{CHAPTER II. SPR BACKGROUND}

\section{A. PROGRAM HISTORY}

This part of the chapter presents a selective outline of the SPR's history, highlighting events that are relevant background for this study.

\section{Legislative History}

The Strategic Petroleum Reserve was authorized by Congress with the enactment of the Energy Policy and Conservation Act, (EPCA), Public Law No. 94-163, which was signed into law on December 22, 1975. The Strategic Petroleum Reserve was one of a number of initiatives prompted by the oil embargo of 1973-74. The legislation declared it to be U.S. policy to establish a Strategic Petroleum Reserve of up to one billion barrels of petroleum to reduce the effect of disruptions in petroleum supplies and to carry out the obligations of the United States under the Agreement on an International Energy Program.

Title VIII of the 1980 Energy Security Act, Public Law No. 96-294, amended the EPCA to mandate a minimum average SPR fill rate of 100,000 barrels, and essentially precluded sale of Naval Petroleum Reserve No. 1 (Elk Hills, California) crude oil except to fill the SPR, unless the SPR was being filled at the minimum rate or had reached 500 million barrels in inventory. The latter provision sometimes is referred to as the "Elk Hills shut-in sanction."

The Congress added to the 1981 Department of the Interior and Related Agencies Appropriations Act, Public Law No. 96-514, a requirement that the President "seek to" undertake SPR fill activities at a level sufficient to assure that crude oil storagc in the SPR is increased at an average annual rate of at least 300,000 barrels per day, or a sustained average annual daily rate of fill that would fully utilize appropriated funds.

Congress reenacted essentially the same 300,000 barrels per day "seek to" requirement as an amendment to the EPCA in the Omnibus Budget Reconciliation Act of 1981, Public Law No. 97 35 , but without reference to a sustained average that would fully utilize appropriated funds. The requirement was made applicable until 750 million barrels were in SPR storage.

In the Energy Emergencies Preparedness Act of 1982, Public Law No. 97-229, the Congress replaced the previous hortatory oil fill language with a new fill mandate, which was incorporated into the EPCA. This new mandate, to be applicable until 500 million barrels were in storage, was to fill the SPR at a 300,000 barrel per day rate or, based on a discretionary Presidential finding, at the higher of 220,000 barrels per day or the highest practicable rate that would utilize all available appropriations. An obligation to "seek to" achieve 300,000 barrels per day was established for SPR oil acquisition beyond the level of a 500 million barrel SPR, until 750 million barrels were in storage.

The Comprehensive Omnibus Budget Reconciliation Act of 1986, Public Law No. 99-272, added to the EPCA a new SPR fill rate directivc, not expressed as hortatory. This new directive was to 
carry out acquisition activities at a level sufficient to assure a yearly fill rate, through fiscal year 1988, of at least 35,000 barrels per day, until 527 million barrels of crude oil were in SPR storage. The Elk Hills shut-in sanction also was revised to stipulate a minimum 35,000 barrels per day fill rate, until 527 million barrels of oil were in storage in the SPR.

Shortly thereafter, the Omnibus Budget Reconciliation Act of 1986, Public Law No. 99-509, further amended both provisions. It modified the new fill directive created by Public Law No. 99-272, to require that, through fiscal year 1989, and until 750 million barrels of crude oil are in storage in the SPR, the President carry out SPR oil acquisition at "the highest practicable fill rate achievable, cubject to the availability of appropriated funds." 42 U.S.C. 6240(c)(3). It also amended the Elk Hills shut-in sanction to make it applicuble unlcss at least 750 millon bartrels of sil ate in storage in the SPR, or the SPR is being filled at a rate of at least 75,000 barrels pcr day in each fiscal year. 42 U.S.C. $6240(d)(1)$.

Public Law No. 101-46 (June 30, 1989), which mandated this study, also extended, until.April 1, 1989, Title I, Part B of the EPCA, including the SPR fill requirement and the Elk Hills shut-in sanction as thus amended in 1986.

\section{SPR Plan Amendments}

As the EPCA required, the Federal Energy Administration in February 1977 submitted to Congress a plan for developing and implementing the Strategic Petroleum Reserve. The SPR Plan provided for the establishment of an Early Storage Reserve of at least 150 million barrels of crude oil by December 1978 and an increase to 500 million barrels by December 1982 .

Strategic Petroleum Reserve Plan Amendment No. 1, Junc 1977, changed the 500 million barrel target date to December 1980, advancing the original schedule by two years.

Another Plan amendment transmitted to Congress in June 1978 revised the goal for total SPR inventory from 500 million barrels to one billion barrels: the first 750 million barrels were to be stored in centralized underground storage caverns; location and financing of the additional 250 million barrels remained undecided.

On October 31, 1979, the Department of Energy submitted Plan Amendment No. 3, the Distribution Plan for the SPR. This Plan Amendment, effective November 15, 1989, described methods for drawdown and distribution of crude oil from the existing SPR storage sites.

A new Distribution Plan required by the Energy Emergency Prcparedness Act of 1982 was transmitted to the Congress on December 1, 1982, and pursuant to that Act, became effective immediately. Strategic Petroleum Reserve Plan Amendment No. 4 established new and basically price-competitive procedures for the drawdown, sale, and distribution of crudo oil from the SPR. 


\section{Major Milestones}

\section{a. Facility Development and Fill}

The SPR Plan identified underground caverns created in salt domes as the preferred means for storage for the SPR oil and, with a concentration of more than 500 salt domes along the coast of the Gulf of Mexico, the Gulf Coast was selected for the location. In June 1976, the first of a series of environmental impact statements on the proposed storage sites was published and in April 1977, the first storage sites were acquired in Louisiana and Texas. Construction of the initial surface facilities at West Hackberry and Bayou Choctaw, Louisiana, began in June 1977.

The first cargo of crude oil for the SPR was received on July 21, 1977 at the West Hackberry site. At the end of 1978, the SPR had 68.5 million barrels of crude oil in storage and had procurements for an additional 75 million barrels under way.

In June 1978 the Department of Energy outlined plans to achieve 750 million barrels of stored oil. Storage capacity was to be developed in three phases. In Phase I, five existing sites in Louisiana and Texas would be used to store the first 260 million barrels of crude oil. Phase II would add new caverns at three of the existing sites to increase storage capacity to 550 million barrels. Phase III would consist of the expansion of the same three sites by 60 million barrels and the addition of a new site. Decisions on the timing and method of achieving the remaining 250 million barrels to reach a one billion barrel SPR, were deferred.

SPR oil fill was disrupted in the spring of 1979, when the Iranian Revolution, followed by the Iran-Iraq War, induced substantial world oil price volatility. With oil supplies constrained, SPR purchases were suspended for 18 months.

No further oil purchases were made for the SPR until the Energy Security Act, enacted on June 30, 1980, directed that the President "immediately undertake and thereafter continue crude oil acquisition . . . at a level sufficient to assure that crude oil in storage in the Strategic Petroleum Reserve will be increased at an average rate of at least 100,000 barrels per day for fiscal year 1981 and for each fiscal year thereafter." The Act also essentially precluded sale of crude oil from Naval Petroleum Reserve No. 1 (Elk Hills, California) except to fill the Strategic Petroleum Reserve, unless the Strategic Petroleum Reserve was being filled at the minimum rate or had reached 500 million barrels in inventory.

The Carter Administration, in compliance with the Energy Security Act, initiated action to implement the Act's provisions. The Secretary of Energy decided to utilize Naval Petroleum Reserve oil in exchange for oil for the SPR, and the President in August 1980 delegated authority to the Secretary for this purpose. The Defense Fuel Supply Center acted as purchasing agent for the Department of Energy in the competitive exchange of Naval Petroleum Reserves oil that ensued. By October 31, 1980, the Defense Fuel Supply Center had awarded contracts under the competitive SPR/Naval Petroleum Reserves exchange solicitation in the amount of 36.6 million barrels. An agreement was also concluded with Pacific Refining Company to provide for the direct delivery to the SPR by pipeline from Elk Hills of 641,490 barrels of crude oil. 
In August 1981, the first of four long-term commercial oil purchase contracts was signed with Petroleos Mexicanos (PEMEX). Table II-1 illustrates the SPR oil fill history from that time forward. SPR fill rates increased from 4,000 barrels per day in FY 1980 to 292,000 barrels per day in FY 1981, with peak rates exceeding 400,000 barrels per day. In calendar year 1981, an average of 336,000 barrels of crude oil was added daily to the SPR, the fastest fill rate achieved to date.

High fill rates, averaging 215,000 barrels per day (bbl/d), continued during FY 1982. A second purchase agreement with PEMEX in 1982 provided for a $\$ 1.0$ billion advance payment to PEMEX in return for Isthmus sour crude oil to be delivered to the SPR beginning October 1, 1982.

Table II-1

Strategic Petroleum Reserve Oil Fill History

\section{d \\ Inventory \\ (Million bbl)}

1977

1978

1979

1980

1981

1982

1983

1984

1985

1986

1987

1988

1.1
49.1
91.2
92.8
199.2
277.9
361.0
431.1
489.3
506.4
533.9
554.7

49.1

91.2

199.2

277.9

361.0

431.1

489.3

533.9

554.7

\section{Fiscal Year}

\author{
Average Daily \\ Fill Rate \\ (Thousand bbl/d)
}

3
131
115
4
292
215
228
191
159
47 a
75
57

\section{Calendar Year}

\begin{tabular}{c} 
Year-End \\
Inventory \\
(Million bbl) \\
\hline
\end{tabular}

7.2

68.5

91.7

107.8

230.3

293.8

379.1

450.5

493.3

511.6

540.6

559.5

\author{
Average Daily \\ Fill Rate \\ (Thousand bbl/d)
}

a/ Fill rate unadjusted for oil deliveries under the 1985/86 test sale.

In December 1982 approximately 294 acres of land at Big Hill, Texas were acquired in preparation for site development. During the same month, the President transmitted to Congress a finding that it would not be in the national interest to fill the SPR at the rate of 300,000 barrels per day for 1983. In May 1983, development of the new Big Hill sturage facility commenced, with the initiation of drilling.

During 1983-85, contracts for crude oil were awarded by the SPR's oil procurement agent, the Defense Fuel Supply Center, both under an open continuous solicitation and through the award of term contracts. In December 1983 the SPR reached 375 million barrels--the midpoint of its 750- 
million barrel goal--and five months later it passed the 400 million barrel level. On June 1, 1986, the 500 millionth barrel of crude oil was added to the growing stockpile.

During FY 1986 and FY 1987, the Administration proposed moratoria on SPR fill and on further SPR development, but in both cases Congress overturned deferrals of unspent funds and continued SPR fill and development. As noted above, the Omnibus Budget Reconciliation Act of 1986 amended the EPCA to require the SPR to be filled at a minimum rate of 75,000 barrels per day until at least $\mathbf{7 5 0}$ million barrels of oil were in storage.

Within the DOE, the SPR was combined organizationally with the Naval Petroleum and Oil Shale Reserves in October 1985 under management of a new Office of the Deputy Assistant Secretary for Petroleum Reserves under the Assistant Secretary for Fossil Energy.

In a June 1987 report to Congress, DOE analyzed the policy issues associated with a sale of the Federal Government's ownership interests in Naval Petroleum Reserve No. 1 (Elk Hills, in California), and Naval Petroleum Reserve No. 3 (Teapot Dome, in Wyoming), including the concept of using the sale revenues as a means of financing the SPR. In December 1987 the Department submitted to Congress proposed legislation to authorize the sale of the two oil fields. Under the proposed bill, revenues from the sale were to be used to fill the SPR at a minimum rate of 100,000 barrels per day and to create a 10 million barrel Defense Petroleum Inventory. Congress did not act on the proposal. Similar proposed legislation, which would have directly linked the sale of the Naval Petroleum Reserves with the acquisition of crude oil for both the SPR and a new Defense Petroleum Inventory, was submitted in June 1989 and again was not acted on by the Congress.

The full-year Continuing Resolution for FY 1988 provided development funds for a 750 million barrel Reserve and sufficient funding to fill at approximately 50,000 barrels per day. Continued support was also provided in 1989. Figure III-1 illustrates appropriations for facilities development and operations and oil acquisition and transportation on an annual and cumulative basis, respectively. In April 1989, the DOE submitted to Congress a report addressing the steps required to develop facilities to expand to one billion barrels.

\section{b. Drawdown and Distribution}

Each SPR site is connected to one or more terminals, which are tied into the nation's commercial oil transport network. From these terminals, oil can be distributed through interstate pipelines or to local refineries, or it can be loaded into waterborne vessels for transportation to other regions of the country.

Originally, the SPR was designed to serve refineries in the interior of the country by transporting crude oil through three major interstate pipelines: Seaway, Texoma and Capline. By 1984, however, considerable change had occurred: two of the three major U.S. interstate crude oil pipclines, Texoma and Seaway, were sold and converted to natural gas transmission. Thus, to restore access to major U.S. refining areas, construction of new docks and pipelines began in 1985 
Figure II-1

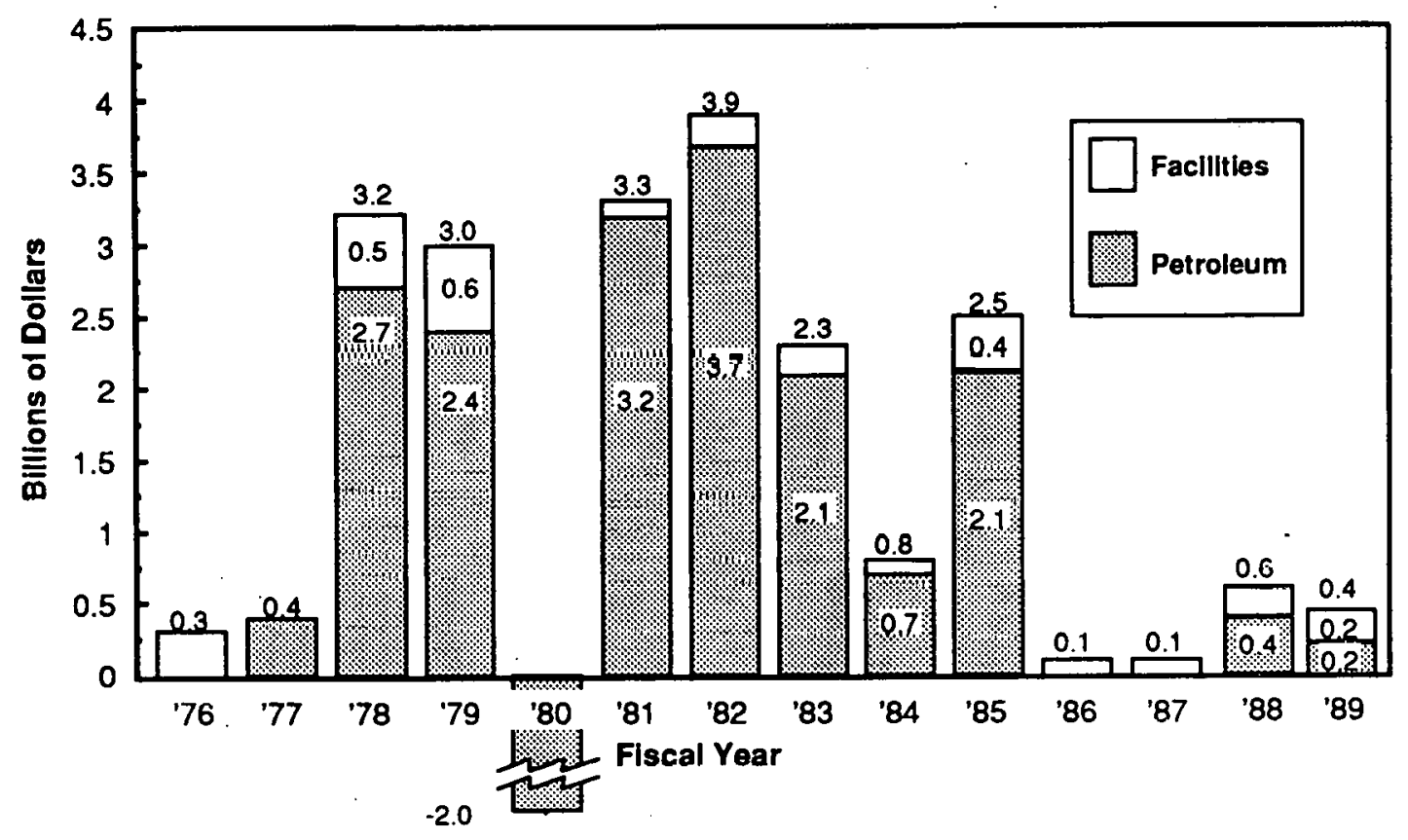

Strategic Petroleum Reserve Annual Funding

Storage Facilities Development/Operations and Petroleum Acquisition/Transportation

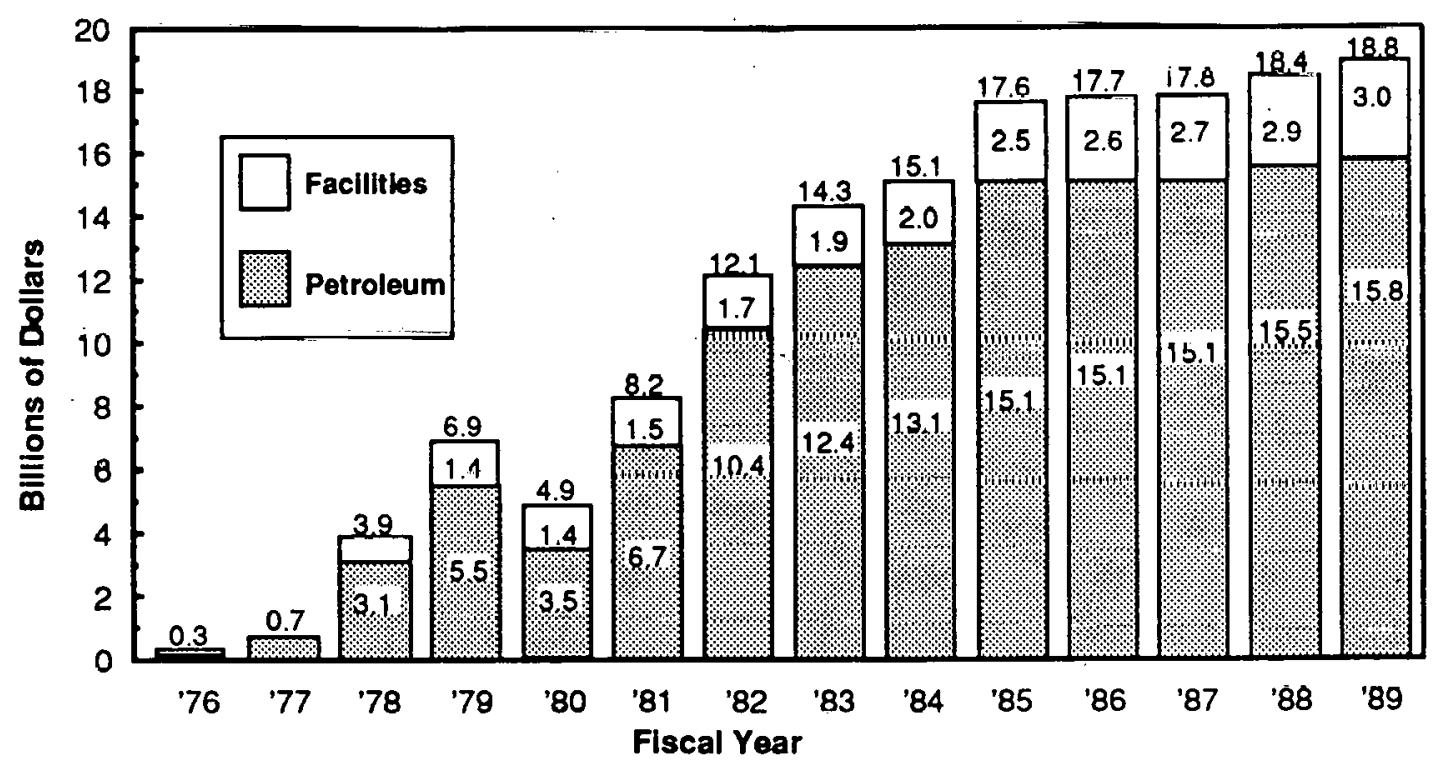

Strategic Petroleum Reserve Cumulative Funding 
and was completed in 1987. A 46-mile, 40-inch diameter pipeline connecting Bryan Mound, near Freeport, Texas, to the ARCO terminal in Texas City has been completed, and smaller pipelines in Louisiana, from the West Hackberry site to Lake Charles, and between the Government-owned St. James terminal and the Capline terminal, are being added to the distribution system. These distribution enhancements increased SPR distribution capability by more than 30 percent, from 2.3 million barrels per day to more than 3.0 million barrels per day.

Drawdown tests are conducted at all SPR sites to ensure that oil can be withdrawn from the storage caverns. The first drawdown test was conducted at the West Hackberry site in February 1980. Since 1983, actual or simulated drawdown tests have been conducted regularly. In 1985 and 1986, in response to the Energy Policy and Conservation Amendments Acts of 1985, DOE implemented an actual test sale of SPR oil involving the sale of one million barrels of crude oil to private purchasers.

\section{B. FINANCIAL HISTORY}

Several unusual financing arrangements have been used to supplement the funds appropriated by Congress for the Strategic Petroleum Reserve. In addition to the Naval Petroleum Reserve exchange that realized 36.6 million barrels for the SPR and the direct delivery of 641,490 barrels by Pacific Refining Company, funds from the Naval Petroleum Reserves' Special Account; offbudget financing; special entitlements benefits; and payments in the form of oil from companies found by DOE to have had questionable compliance with pricing regulations, all have been used to one degree or another, as means of financing the SPR.

The Naval Petroleum Reserves Production Act of 1976, Public Law No. 94-258, originally established a special fund to deposit receipts from the sale of petroleum products produced from the Naval Petroleum Reserves. The fund could be used to finance the exploration and development of the Naval Petroleum Reserves, exploration of the National Petroleum Reserve in Alaska, and petroleum and facilities for the Strategic Petroleum Reserve. In fiscal year 1977, funds totaling $\$ 440$ million were transferred from the special Naval Petroleum Reserves account to the SPR.

As part of the effort to reduce the size of the Federal deficit, the Congress has sought other means of financing the SPR over the past decade. In 1981, the Congress enacted legislation which simply declared expenditures for SPR oil purchases to be off-budget. This provision, incorporated into the Omnibus Budget Reconciliation Act of 1981, Public Law No. 97-35, established an off-budget account funded from gencral Treasury revenuès to finance oil acquisition and an on-budget account for administration and physical expansion of the Reserve. Oil purchases were to be funded hy appropriations, as bcfore, bul the sums would not enter into the formal accounting of the Federal budget process. Off-budget status for the SPR meant that a larger fill rate for the SPR could be supported. The SPR Petroleum Account was moved back to on-budget status in FY 1986. The vehicle was the so-called "Gramm Rudman-Hollings" law, Title-II of the Balanced Budget and Emergency Deficit Control Act of 1985, Public Law No. 99-177.

Another special financiing arrangement involved entitlements benefits. In 1974, the crude oil entitlements program was adoptcd by the Federal Energy Administration, the predecessor agency 
of DOE, to allocate benefits of price-controlled domestic crude oil equitably among all scctors of the petroleum industry and among all users. The entitlements program was designed to reduce cost disparities among refiners that resulted from price controls. Without the program, refiners with access to domestic price-controlled crude oil would have enjoyed a significant advantage over refiners with access primarily to higher-priced crude oil, principally imports.

Under the entitlements program the benefit of access to price-controlled domestic crude oil was "allocated" through a system of direct payments by entitlement "buyers" to entitlement "sellers." An entitlement was defined as the right to receive into inventory and refine one barrel of pricesnntrolled crude oil in a particular month, and refiners were required to possess the exact number of entitlements each month to cover therr recelpts of price-controlled crude oil. Eash month refiners were issued a number of entitlements equal to the national average amount of pricecontrolled crude oil receipts. Refiners having access to an above-average percentage of pricecontrolled crude oil were required to purchase entitlenents to use that crude oil. Likewise, refiners having a lower-than-avcrage supply of price-controlled crude oil were permitted to sell their surplus entitlements. The price of an entitlement was determined monthly as the difference between the weighted average cost of price-controlled crude oil and the weighted average cost of market-priced crude oil, both imported and domestic.

For a period prior to 1980, a company that supplied imported crude oil to the SPR received entitlements as if the imported crude oil had been processed in a domestic refinery, rather than placed in storage. The effect of these provisions was to reduce the Government's cost of imported crude oil for the SPR to approximately the national average cost of crude oil for all refiners.

Section 801 of the Energy Security Act directed the President to amend the Entitlements Program no later than August 29, 1980, su as to achiovo the same effest as if lower-tier (price-controlled) crude oil were directly allocated to the Federal Government for storage in the SPR. Under a final rule issued by the DOE on August 21, 1980, suppliers of crude oil for the SPR did not receive any entitlement for such crude oil. Rather, until January 28, 1981, the Government received entitlements benefits for each barrel of crude oil, other than lower-tier crude oil, that it acquired for the SPR. These benefits were sufficient to lower the actual cost of crude oil for the SPR to approximately the lower-tier ceiling pricc.

One of the activities undertaken in 1980 to meet the requirement of section 801 of the Energy Security Act, that the President undertake fill of the SPR at an average rate of at least 100,000 barrels per day in FY 1981, was a competitive exchange of Naval Petroleum Reserve (NPR) crude oil. Under the competitive SPR/NPR exchange, executed on the DOE's bchalf by the Defense Fuel Supply Center, contracts were awarded in the amount of 36.6 million barrels by October 31, 1980. Also, as a result of a NPR contract settlement with Pacific Refining Company, a 1980 direct purchaser of NPR crude oil, the SPR received 641,490 barrels of crude oil from the NPR. 
Finally, as part of a 1981 Consent Order in the settlement of allegations regarding compliance with Federal petroleum price and allocation regulations between Standard Oil Company of California (Chevron) and the Department of Energy, Chevron agreed to deliver to the SPR a quantity of Alaskan North Slope crude oil with a delivered value of approximately $\$ 34.5$ million. The amount of oil delivered under the Consent Order was 1,029,000 barrels, of which 772,000 barrels were received in 1981, and the balance was delivered in January 1982. 


\section{CHAPTER III. RELEVANT LEGAL FACTORS}

This chapter discusses a number of legal considerations that appear to be relevant to the "leasing" of oil or facilities for the SPR, and that may also apply to various other approaches to SPR financing.

The chapter consists of seven parts identified as A through G. Part A presents the SPR's legal framework for site development and fill, and oil drawdown and distribution, under the Energy Policy and Conservation Act. Part B describes several preconditions to undertaking proposed Federal projects, including environmental assessment and such administrative evaluations as leaseversus-purchase analysis. Part $\mathrm{C}$, on the Federal Government's contracting process, explains the competitive modalities and the governing regulatory procedures. Part $\mathrm{D}$, dealing with the structure of U.S. Government contracts generally, and of an oil or facility lease in particular, covers obligation of funds principles, multi-year contracting, and other funding issues. Part E on contractual requirements sets out mandatory Federal Government contract clauses, and discusses the dispute resolution and cargo preference requirements. Part $\mathrm{F}$ on taxes and fees addresses a range of relevant Federal, state and local tax and fee considerations. Finally, Part G deals with a variety of other issues, including commercial uses of SPR facilities, oil export controls, and pertinent Federal and state statutory powers.

\section{A. THE EXISTING LEGAL FRAMEWORK}

The basic statutory framework for the development and use of the SPR is contained in Title I, Part B of the Energy Policy and Conservation Act (EPCA), as amended, Public Law No. 94-163 (Dec. 22, 1975), 42 U.S.C. 6201. et seq. That Act required the Secretary of Energy to promulgate a Strategic Petroleum Reserve Plan detailing proposals for designing, constructing, filling and using the SPR, and it generally provides the DOE with statutory authorities to implement the SPR Plan. The Plan can be amended, subject to a sixty-day waiting period, $\frac{1}{1}$ by transmitting an amendment to the Congress. The original SPR Plan was transmitted to the Congress in February 1977; there subsequently have been four amendments to the Plan, the most recent of which, a Distribution Plan, was transmitted to the Congress in December 1982.

\section{Site Development and Fill}

The EPCA itself puts few restrictions on the development and fill of SPR storage facilities. Section 159(f) authorizes their acquisition by various means, including development, purchase, condemnation and lease. Petroleum may be stored in facilities not owned by the Federal Government if the facilities are "subject to audit" by the Government, for which purpose the Act vests the Secretary with special powers to require recordkeeping and to inspect. Sections 159(f)(F), 163. Privately-owned facilities thus might be leased to the United States for SPR storage, or they could be made available pursuant to a "services contract," e.g., one in the nature of a "warehousing

1/ The waiting period can be waived if circumstances exist which would warrant an SPR drawdown. 
agreement." Section 154(e) requires that the SPR Plan contain certain information about SPR facilities (other than "interim" facilities), including their type, location, size, cost and ownership.

The EPCA authorizes the use of a discrete category of storage facilities designated as "interim" facilities. The term is undefined, but the Congressional intent in adding this authority in the Energy Emergency Preparedness Act of 1982 (EEPA), Public Law No. 97-229, was to permit SPR fill to proceed at a faster rate than could be accommodated by the SPR's "permanent" facilities. See S. Rep. No. 393, 97th Cong., 2d Sess. at 13-15 (1982). Up to ten percent of amounts obligated from the section 167 "SPR Petroleum Account" in a fiscal year may be used for "interim" facilities, subject to a carry-forward of unused amounts. Section $167(\mathrm{c})(2)$. "Interim" facilities need not be identified in SPR Plan amendments, and certain facilities in existence in 1982 qualify for a waiver of the environmental impact statement requirement of the National Envirommental Policy Act of 1969. Section 159(h).

The EPCA does not require that SPR storage facilitics be located in the United States. The Conference Report on the EPCA stated:

The existence of a potential storage facility, located within the territorial limits of Canada, has been called to the attention of the conferees. This potential facility may be uniquely situated to serve a substantial portion of the reserve requirements of the Northeastern United States. The conference substitute does not prohibit utilization of such a facility, illustrating the flexibility granted the Administrator under the conterence substitute. The Stralegic Petroleum Reserve Plan must include details regarding siting of storage facilitics. The conference substitute does not require that each storage facility be located within the geographic borders of the United States. 'The conferees anticipate huwever, that any proposal to locate storage facilities outside the borders of the United States would be supported by justifications regarding the need for, and desirability of, locating the storage facility at the proposed site, as well as assurances that petroleum products stored in such a storage facility would be available for drawdown and distribution by the United States without foreign interference. (S. Conf. Rep. No. 516, 94th Cong., 1st Sess. at 138 (1975))

The SPR Plan is required to estimate the volumes and types of oil to be stored in each SPR facility. The EPCA recognizes that the Federal Government need not acquire SPR oil by purchase; sections $160(\mathrm{a})(3)$ and $159(\mathrm{f})(\mathrm{E})$ contemplate oil acquisition "by purchase, exchange, or otherwise," and section 154(e)(10) calls for disclosure, in the SPR Plan, of the ownership of oil stored in the SPR in any case where the oil is not owned by the Federal Government. The storage of oil owned by others in the SPR has come to be thought of as "leasing" the oil, and a lease is one possible legal arrangement; however, it also is possible that such storage might be pursuant to an "option" to purchase the stored oil or to sell it on behalf of the provider, or based on some other legal instrument. 
Oil acquisition activities for the SPR are subject to the following directive:

The Secretary shall, to the greatest extent practicable, acquire petroleum products for the Reserve ... in a manner consonant with the following objectives:

(1) minimization of the cost of the Reserve;

(2) orderly development of the Naval Petroleum Reserves to the extent authorized by law;

(3) minimization of the Nation's vulnerability to a severe energy supply interruption;

(4) minimization of the impact of such acquisition upon supply levels and market forces; and

(5) encouragement of competition in the petroleum industry. (Section 160(b))

\section{Drawdown and Distribution}

Under existing law, the EPCA's preconditions for withdrawals of oil from the SPR pose a potential limitation on alternative financing approaches. Section 161(d) of the EPCA stipulates that no drawdown and distribution of the SPR may be made unless the President finds that such actions are "required by a severe energy supply interruption or by obligations of the United States under the international energy program." $\underline{2} /$

Another potentially limiting EPCA provision is section 160 (d), which restricts the uses of the Government's oil produced from the DOE-opcrated Naval Petroleum Reserve No. 1 at Elk Hills, California, unless either the SPR contains at least 750 million barrels, or:

acquisition, transportation, and injection activities for the [Strategic Petroleum] Reserve are being undertaken for that fiscal year at a level sufficient to assure that crude oil in storage in the Strategic Petroleum Reserve will be increased at an average rate of at least 75,000 barrels per day for that fiscal year. (Scction $160(\mathrm{~d})(\mathrm{B})$ )

Section 154(e)(12) of the EPCA requires that the SPR Plan contain a Distribution Plan "setting forth the method of drawdown and distribution of the Reserve." Any SPR drawdown and distribution must be in accordance with this Distribution Plan. Section 161(b).

The currently effective SPR Distribution Plan, SPR Plan Amendment No. 4, was transmitted to the Congress and took effect on December 1, 1982, pursuant to a provision of the EEPA which gave

2/ The International Energy Program referred to in section 161(d) is the Agreement on an International Energy Program (IEP) signed by the United States on November 18, 1974. 27 U.S.T. 1685, T.I.A.S. No. 8278 (Nov. 18, 1974). This Agreement authorizes, under specific conditions, an emergency program among participating countries pursuant to which member countries would share the worldwide crude oil supplies available to them. The existence of IEP obligations can serve as a basis for authorizing an SPR drawdown; however, there is no requirement that the SPR be drawn down and used to satisfy these obligations. 
it immediate effectiveness. This Distribution Plan provides that the principal method of distributing SPR oil will be price competitive sale; the purchase price for the competitive sale will be determined by price competition, with the oil being sold to the highest eligible bidders. The Plan provides that price competitive sales of SPR petroleum will be open to all interested bidders; the universe of eligible offerors is to be as large as possible in order to facilitate the efficient distribution of SPR petroleum. It also provides for performance and financial responsibility measures in the SPR oil sale process to reduce the risk that a buyer of SPR oil might fail to meet its contractual obligations to lift this oil on schedule or to pay the Government all amounts due. Under the Plan, such measures are the only permissible limitations on the universe of eligible bidders.

The Plan further provides that in any calendar month, the Secretary of Energy may "direct" the distribution of (i.e., allocate) up to ten percent of the volume of the SPR oil sold in that calendar month, in such manner as he determines; the price of this oil is to be the average price of SPR oil sold at the most recent competitive sale. No further administrative action has been taken to implement this provision.

On December 20, 1983, the DOE published in the Federal Kegister its final rule establishing a framework for the price competitive sale of SPR petroleum. 3/ This framework includes the promulgation of Standard Sales Provisions (SSPs) containing contract clauses which a Notice of Sale may make applicable to particular price competitive sales of SPR petroleum; they will include purchaser performance and financial responsibility measures or descriptions thereof. The competitive sales rule requires the publication of the SSPs in the Federal Register and in the Code of Federal Regulations as an appendix to the final rule. It is anticipated that the Notice of Sale will specify, by referencing the Federal Register and the Code of Federal Regulations in which the latest version of the SSPs was published, the contractual provisions contained therein that apply to the particular sale. The Notice of Sale may revise the terms and conditions, or add new ones which would apply to the particular sale.

The price competitive sale of SPR petroleum involves four basic steps: the adoplion of the SSPs; the issuance of a Notice of Sale; the selection of the highest priced offers; and award of sales contracts. The SSPs are contract sale terms and conditions published as an appendix to the SPR sales rule. Proposed SSPs were published in the Federal Register for public comment on June 15, 1983 (48 F.R. 27482). Interim final SSPs were published on June 3, 1988, and became effective on that date (53 F.R. 20508). I $^{\prime}$

Notices of Sale will announcc the amount, type and location of the SPR petroleum to be sold, the delivery period, procedures for submitting offers and which SSPs are applicable to that particular sale, and provide other pertinent information. Contracts will be awarded to those offerors, complying with the terms and conditions specified in the applicable Notice of Sale, who offer the highest prices.

3/ 10 C.F.R. Part 625, 48 F.R. 56538 (Dec. 21, 1983).

4I The June 3, 1988, SSPs are not referred to as final because, in accordance with the sales rule, it is anticipated that they may undcrgo additional revisions. 
The SSPs include contract clauses required by law, regulation, SPR programmatic considerations or sound business practice. The SSPs establish procedures for submitting offers and for selecting among the competing offers. They also include purchaser financial and performance responsibility measures or descriptions thereof. Such measures are intended to reduce the risk of purchases by persons who lack the capability or intent to take timely delivery of the SPR petroleum, or the financial ability to pay for it. 


\section{B. PROJECT EVALUATION}

Before proceeding with a program for the leasing of oil or facilities for the SPR, or with other SPR financing alternatives, it may be necessary to conduct administrative evaluations and environmental assessments. Potentially relevant requirements include Office of Management and Budget circulars and regulations promulgated to ensure compliance with the National Environmental Policy Act of 1969.

\section{Administrative Evaluation Requirements}

\section{a. Analysis of Project Initiation}

Among the evaluations that may have to be conducted in determining whether to pursue a new undertaking, such as an effort to acquire crude oil or new storage facilities for the SPR, is that required by Office of Management and Budget (OMB) Circular A-94 (revised), "Discount rates to be used in evaluating the time-distributed costs and benefits." This Circular, which applics to all Executive Branch agencies except the U.S. Postal Service, prescribes discount rates for:

... the evaluation of Government decisions concerning the initiation, renewal or expansion of all programs or projects ... for which the adoption is cxpected to commit the Government to a series of measurable costs extending over three or more years or which result in a series of benefits that extend three or more years beyond the inception date. (Paragraph 3.a.)

Circular A-94 provides an analytical framework that examines expected costs and benefits. The discount rates prescribed in the Circular are: (1) suggested for use in the internal planning dncuments of covered agencies; and (2) required lor use in program unalyses submitted to the OMB in support of legislative and budget programs. Paragraph 3.d. There are no waiver provisions and the only "specifically exempted" decisions are those concerning wales icsourcc projects, the District of Columbia Government and non-Federal recipients of Federal loans or grants. Paragraph 3.b. The Circular also provides for exemptions based on "the secondary nature of the decisions involved; that is, how to acquire assets or proceed with a program after an affirmative decision to initiate, renew, or expand such a program using this Circular." (Emphasis added) It then cites three exemptions, including the following: "(1) This Circular would nut apply to the evaluation of decisions concerning how to obtain the use of real property, such as by lease or purchase." (Emphasis in original) Paragraph 3.c.(1).

\section{b. Lease-Versus-Purchase Analysis}

Although existing law does not require that a lease-versus-purchase analysis be performed prior to the acquisition of real or personal property in general, or of oil storage facilitics in particular, $\underline{5}$ as a matter of Executive Branch policy, OMB Circular A-104, "Evaluating Leases of Capital

5/ Federal Acquisition Regulation (FAR) Subpart 7.4, Federal Property Management Regulation (FPMR) Subpart 101-25.5, and the Department of Energy Acquisition Regulation (DEAR) Subpart 907.4, do contain provisions that apply to lease-versus-purchase determinations for equipment. These provisions have no direct application to the acquisition of SPR oil or sturage facilities. 
Assets," requires that such an analysis be performed to assist in the determination of the appropriate ownership interest of capital assets for acquisition. 6/ Paragraph 4 of the circular, "Scope and Applicability," states, in subsection a, that the circular applies to all Executive agencies and, in subsection $b$, that:

The guidelines in this Circular are suggested for use in the internal planning documents of the executive agencies in the Executive Branch and required for use in all prospectuses, proposed legislation, budget justifications or other proposals submitted to the Office of Management and Budget and to the Congress. (Emphasis added)

Paragraph 4 continues in subsection c, specifying that the circular covers the leasing of "capital assets," which for purposes of the circular are defined, inter alia, as:

.. . any tangible property, including durable goods, equipment, buildings, facilities, installations, or land, which: (a) is leased to the Federal Government for a term of five or more years. . . . (Emphasis added)

In Paragraph 4.d, the circular exempts from applicability only two specific types of acquisitions: (1) leases of assets having a fair market value of less than $\$ 1$ million; and (2) service contracts that involve the use of capital assets by the contractor incidental to the provision of services. I/ Therefore, in light of its "applicability" section and its lack of waiver provisions, OMB Circular A104 would appear to apply to the proposed acquisition by lease of either storage facilities or crude oil for the SPR.

Supplementary to OMB Circular A-104, the OMB, on October 19, 1988, issued a memorandum to Heads of Executive Departments and Agencies regarding "Lease-Purchase Arrangements" (M89-01). This memorandum discussed the recent approval of Domestic Policy Council recommendations to opposc the use of lease-purchase arrangements, excepting only special purpose facilities, which would be reviewed on a case-by-case basis. Although issued in the preceding Administration, this memorandum has not been revoked or revised by the current Administration, and thus remains in effect. Oil storage facilities, if considered "special purpose" facilities, would be subject to the exception specified in the memorandum and entitled to review on the merits of the particular situation.

\section{c. Major System Acquisition Process}

Under current OMB circulars and DOE orders, the acquisition of leased facilities and leased oil for the SPR would be viewed as a "major system acquisition," and therefore subject to OMB Circular A-109, "Major System Acquisitions" and to DOE Order 4700.1, "Project Management

6/ The application of OMB Circular A-104 is premised on a predetermination to acquire the capital asset by some means. As discussed above, OMB Circular A-94 provides applicable guidance for the analysis of whether to acquire the asset or initiate the program in the first instance.

7/ As noted in OMB Circular A-104, economic analyses of service contracts are governed by OMB Circular A-76, "Performing Commercial Activities," dated August 4, 1983. 
System." OMB Circular A-104, discussed above, suggests their applicability by specifying in Paragraph 6:

All leases of capital assets must be justified as preferable to direct government purchase and ownership. In general, this can be done in one of three ways [ $\left.{ }^{8}\right]$ :

(a) By conducting a separate lease-versus-buy analysis of each lease of one or more capital assets that the agency proposes to enter into. This is the only acceptable method for major acquisitions.

(1) A lease of one or more capital assets is [a] major acquisition if:

(b) The agency determines that the significance of the acquisition to the agency merits designating it as major;

(c) The Office of Management and Budget designates it as a major acquisition; or

(d) The total value of the acquisition, as measured by the purchase price of the assets to be leased, exceeds $\$ 500$ million. (Emphasis added)

Likewise, DOE Order 4240.1I, "Designation of Major System Acquisitions and Major Projects," lists the Strategic Petroleum Reserve as a "major system acquisition," which is to be managed in accordance with OMB Circular A-109 and DOE Order 4700.1.

OMB Circular A-109 and DOE Order 4700.1 set forth complementary structures and procedures for the management of the acquisition process for major systems and major projects that cstablish a systematic, integrated, and coordinated approach for the program or project. OMB Circular A109 also, inter alia, specifies certain "key decisions" and outlines a sequence of actions in the major system acquisition process. DOE Order 4700.1, inter alia, sets out a formalized Project Management System and requires the establishment and documentation of project missions and time-phased goals, the monitoring of project planning and execution, and periodic project management review. However, the SPR for some time has been designated in the DOE Order as a "major system acquisition", and the management approach set forth in these issuances already has been incorporated into the SPR's planning, budgeting and acquisition processes.

8/ The other ways to perform the analyses which are described in the Circular are: (1) a generic analysis to address an entire class of assets, which would use the same analytic method used to evaluate individual leases and be pursuant to a written statement of the scope of the generic analysis which has been approved by OMB; and (2) generally for smaller leases, adopting a formal policy, approved by $\mathrm{OMB}$, regarding lease-versus-purchase decisions. 


\section{Environmental Assessment Requirements}

The National Environmental Policy Act of 1969 (NEPA), 42 U.S.C. 4321 et seq., requires, "to the fullest extent possible," that all agencies of the Federal Government include "in every recommendation or report on proposals for legislation and other major Federal actions significantly affecting the quality of the human environment," an assessment of the environmental impacts of such projects. Title I, section $102(2)(C), .42$ U.S.C. $4332(2)(C) . ~ \underline{~}$

\section{a. CEQ and DOE Regulations}

As directed in Executive Order No. 11514, as amended by Executive Order No. 11991, the Council on Environmental Quality (CEQ), established under Title II of the NEPA, adopted, in 40 C.F.R. Part 1500, regulations for Federal agency compliance with NEPA. The CEQ regulations require Federal agencies to integrate the NEPA process with project planning at the earliest possible time to assure that planning and decision-making reflect environmental values early in the decision-making process. If an Environmental Impact Statement (EIS) is required, an agency is to commence preparation of the EIS as close as possible to the time it is "developing" or "presented with" a proposal. 40 C.F.R. 1502.5 .

In accordance with the CEQ regulations, the DOE has adopted guidelines for complying with the NEPA that are applicable to each stage of the Department's decision-making process for proposed actions. ${ }^{10 /}$ The DOE NEPA guidelines appear in 52 F.R. 47662 (December 15, 1987), as amended by 54 F.R. 12474 (March 27, 1989). $\underline{11}$

9/ The Supreme Court has held that although Title I of the NEPA declares a national environmental policy and significant substantive policy goals for the Nation, its mandate is essentially procedural. Vermont Yankee Nuclear Power Corp. v. NRDC, 444 U.S. 223 (1978).

10/ The CEQ regulations (40 C.F.R. 1502.25) and DOE's implementing guidelines (Section C.4) require DOE, to the fullest extent possible, to integrate NEPA compliance with other Federal, state and local environmental review requirements. Federal requirements that may be applicable to the construction and operation of a storage facility for the SPR, irrespective of whether the facility is constructed and operated by the DOE or by a DOE contractor, include those under the Clean Air Act, the Clean Water Act, the Coastal Zone Management Act, the Endangered Species Act, the Fish and Wildlife Coordination Act, the Wild and Scenic Rivers Act, the National Historic Preservation Act, the Marine Protection, Research and Sanctuaries Act, the Resource Conservation and Recovery Act, the Comprehensive Environmental Response, Compensation, and Liability Act, Executive Order No. 11988 (Floodplain Management) and Executive Order No. 11990 (Protection of Wetlands). In addition, the draft EIS is required to list all Federal, state and local environmental permits and licenses that must be obtained in implementing a proposal. Major Federal permits that may be required to construct and operate storage facilities in salt domes include permits issued by the Corps of Engineers under the Rivers and Harbors Act and the Clean Water Act regulating dredge and fill operations in navigable water bodies and wetlands and permits issued by the Environmental Protection Agency or a state with an approved program under the Clean Water Act regulating the discharge of substances into surface water bodies. Permits regulating underground storage of petroleum and air emissions also may be required.

11 Section D of the DOE's NEPA guidelines identifies classes of typical DOE actions that normally require an EIS, those that do not require either an EIS or EA, and those that normally require an EA but not necessarily an EIS. If the proposed action is not encompassed within these categories, 
The first step in the NEPA process is to determine whether or not the proposed action is a major Federal action. The CEQ regulations define "major Federal action" to encompass "actions which may be major and which are potentially subject to Federal control and responsibility." $\underline{12}$ If it is determined that a proposed action is a major Federal action, and if the action is neither within categorical exclusions nor within the category of actions designated by the agency as requiring an EIS, then an Environmental Assessment (EA) is required.

The purpose of an EA is to provide a basis for determining whether to prepare an EIS or a finding of "no significant impact." In addition to an analysis of the environmental impacts of a proposed action, the EA must include a discussion of the need for the proposed action, the alternatives, possible mitigating factors, and a listing of agencies and persons consulted. If, on the basis of the EA, the proposed action is determined not to require an EIS, the agency must issue a "finding of no significant impact" which briefly explains why the proposed action will not have significant environmental effects.

If the proposed action is found to have a significant environmental impact, an EIS is required, and a public scoping process must be commenced to identify the significant environmental issues related to the proposed action and to establish the scope of analysis for each issue. A draft EIS must be issued and a minimum of 45 days allowed for public and other Federal agency comment on the EIS. Final EISs must respond to all substantive comments received.

As required by the NEPA, an EIS must address: (i) the environmental impact of an action; (ii) any unavoidable adverse environmental impacts of the action; (iii) alternatives to the proposed action; (iv) the relationship between short-term uses and long-term productivity; and (v) any irreversible and unretrievable commitments of resources involved in the proposed action. $\underline{13}$

No sooner than 30 days after issuance of a tinal EIS, an agency is required to issue a concise public record of decision (ROD). Prior to issuing the ROD, the agency may not take any action in regard to the proposed action that would have an adverse environmental impact or limit the reasonable alternatives to the proposed action. .44

\section{b. Extraterritorial Application}

Executive Order No. 12114 requires Federal agencies to conduct environmental reviews with respect to certain Federal actions having significant environmental effects outside the United States. The Executive Order is designed to enable Federal decision-makers to be informed of pertinent

the DOE will determine the appropriate type of NEPA documentation that is required. Included in the category of actions that normally require an EIS are "DOE actions which are expected to result in the construction and operation of a large scale project."

12/ 40 C.F.R. 1508.18. The regulation specifically includes: projects financed, assisted, conducted, regulated or approved by Federal agencies; new or revised agency rules, regulations, plans, policies or procedures; and legislative proposals. 40 C.F.R. 1508.18(a).

NEPA section 102(2)(C), 42 U.S.C. $4332(2)(C)$. 
environmental considerations concerning actions having effects outside the geographical boundaries of the United States, and to take such considerations into account when decisions are made.

The Executive Order requires Federal agencies to prepare an EIS, a bilateral or multilateral environmental study, or a concise review of the environmental issues involved, when undertaking certain types of major Federal actions outside the United States. Section 2-3 of the Executive Order lists four categories of Federal actions that are subject to the Order:

(a) major Federal actions significantly affecting the environment of the global commons outside the jurisdiction of any nation (e.g., the oceans or Antarctica);

(b) major Federal actions significantly affecting the environment of a foreign nation not participating with the United States and not otherwise involved in the action;

(c) major Federal actions significantly affecting the environment of a foreign nation which provide to that nation:

a product, or physical project producing a principal product or an emission or effluent, which is prohibited or strictly regulated by Federal law in the United States because its toxic effects on the environment create a serious public health risk; or

(2) a physical project which in the United States is prohibited or strictly regulated by Federal law to protect the environment against radioactivc substances.

(d) Major Federal actions outside the United States, its territories and possessions which significantly affect natural or ecological resources of global importance designated for protection under this subsection by the Prcsidcnt, or, in llie cuse of such a resource protected by international agreement binding on the United States, by the Secretary of State. Recommendations to the President under this subsection shall be accompanied by the view of the Council on Environmental Quality and the Secretary of State.

Section 2-4(a) of the Executive Order specifies which of the three types of environmental documents described above must be prepared for each category of Federal action.

\section{c. SPR-Related Environmental Laws}

Title I, Part B of the EPCA, which contains the statutory framework for the SPR, includes two provisions pertaining to environmental analyses in connection with the development of the SPR. First, section 154(e)(1) requires that the SPR Plan include a "comprehensive environmental assessment." According to the 1975 Joint Explanatory Statement of the Committee of Conference on the EPCA, this environmental assessment is "separate from any other statutory requirement 
relating to analysis of environmental impacts"; however, this requirement may be satisfied by preparing an EIS under the NEPA. S. Conf. Rep. No. 516, 94th Cong., 1st Sess. 134 (1975). 15/ Second, as noted in Section A(1) of this chapter, section 159(h) of the EPCA provides that "no action relating to the storage of petroleum products in existing interim facilities in the Reserve shall be deemed to be 'a major Federal action significantly affecting the quality of the human environment" within the meaning of the NEPA (emphasis added). An interim storage facility qualifies as an "existing interim storage facility" if it:

(i) is in existence on July 1, 1982;

(ii) was constructed in a manner appropriate for storing petroleum products; and

(iii) is not modified after July 1, 1982, in any manner which substantially increases the storage capacity of the facility. Any modification of such facility may not include replacement or reconstruction. (Section 159(h)(3)(B))

\section{d Application to SPR Oil and Facilities Leasing}

Based on the provisions of the NEPA and the CEQ and DOE implementing guidelines, it is likely that NEPA environmental analyses will be required in connection with proposals for SPR facilities and oil leasing. 16/ Leasing new storage capacity for the SPR, irrespective of whether the facility is filled with leased oil or oil purchased by the DOE, may well require a site-specific EIS addressing the environmental impacts associated with the development and operation of the facility, and the transportation of petroleum to and from the site. $17 /$ Leasing oil for new or expanded

15/ At the inception of the SPR program the DOE's predecessor agency, the Federal Energy Administration prepared, in 1976, a programmatic EIS pcrtaining to the creation of a 500-millionbarcel SPR. Subscquently, the DOE prepared a supplement to the programmatic EIS examining the expansion of the SPR flum 500 million to ono billion barrels of oil. The DOF also has prepared site-specific EISs for each of the proposed SPR storage sites and EAs for actions being undertaken to enhance the SPR's distribution capability. The length of time for preparation of the programmatic EIS was approximately 12 months. 'The preparation time for the site-specific EISs averaged approximately 18 months each, and the preparation of the supplemental EIS also took approximately 18 months.

16/ In its April 1989 "Report to Congress on Expansion of the Strategic Petroleum Reserve to One Billion Barrels," DOE indicated that activities increasing the SPR to one billion barrels would require "NEPA compliance activities" p. 26. 'The Report observes that the supplement to the SPR programmatic EIS issued by DOE in 1979 pertaining to the expansion of the SPR to one billion barrels is:

outdated and does not meet current procedural or substantive requirements of NEPA; e.g., it predates most regulations concerned with groundwater protection, hazardous waste cleanup and disposal, and Departmental regulations for compliance with floodplains and wetlands environmental review requirements. (p. 39)

17) DOE's 1976 programmatic EIS for the SPR contains a comprehensive analysis of the potential environmental impacts associated with the ocean transportation of crude oil to and from the SPR storage facilities along the Gulf Coast, and it may be possible to supplement this analysis with updated information pertaining to shipping routes, types and construction of tankers, oil spill cleanup technology, etc. 
DOE-owned storage facilities also could require new environmental analyses or supplements to existing site-specific EIS's. Leasing certain storage facilities in existence in 1982, however, might qualify for the EPCA section 159(h) waiver of the NEPA requirements for actions relating to the storage of petroleum products in "existing interim storage facilities."

Pursuant to Executive Order No. 12114, environmental analyses also might be required in connection with the development, operation and fill of leased storage facilities in a foreign country, such as Canada. As noted above, the Executive Order, by its terms, exempts from its requirements Federal actions in a foreign nation that is "participating with the United States" or is "otherwise involved in the action." Although the Executive Order does not define "participating" or "otherwise involved," these criteria might be met by the host government's issuance of approvals or licenses for the project, which likely would be required in the case of the construction and operation of an oil storage facility. However, even if environmental analyses were not necessary with respect to the construction and operation of an SPR storage facility in a foreign country, assuming the requisite participation or involvement of the host country, they nonetheless may be required to address environmental impacts, such as oil spills, associated with the marine transportation of petroleum to and from the site. The Executive Order requires an EIS for major Federal actions significantly affecting the global commons outside the jurisdiction of any nation, e.g., the oceans.

As indicated above, the DOE's NEPA guidelines contain comprehensive procedures applicable to all DOE decision-making processes pertaining to actions subject to the NEPA. These procedures would apply, inter alia, to procurement actions for leasing storage facilities and/or oil for the SPR. For projects involving noncompetitive procurements, the DOE guidelines provide that the DOE will prepare, consider, and publish the relevant environmental document before making a go/nogo decision on the project. If the project requires an EIS, the guidelines state that "DOE will not take an action concerning the project which would have an adverse environmental effect or which would limit the choice of reasonable alternatives until the required record of decision is issued." Section B.3(c)(1). In the case of acquisition of a major system or project involving selection by competitive procurement, the guidelines state that the DOE will require submission of environmental data as a discrete part of an offeror's proposal and will compare and evaluate environmental impacts of each proposal before selection. For proposals in the competitive range, the DOE will prepare and consider before selection, an environmental impact analysis. However, the environmental impact analysis will not contain business, confidential or trade secret information that is protected from public disclosure by 18 U.S.C. 1905. Following the selection, the DOE will make public a selection statement to record that the relevant environmental consequences of reasonable alternatives have been evaluated in the selection process. If the proposal selected is likely to have significant effects on the quality of the human environment, the guidelines require the DOE to "phase subsequent contract work to allow publicly available EIS's to be prepared, considered and published in full conformance with the [CEQ NEPA guidelines] and in advance of a go/no go derision." Section B.3(c)(2). 


\section{THE CONTRACTING PROCESS}

This part of the chapter explains the statutory requirement to conduct acquisitions of oil and of oil storage facilities competitively, as well as the exceptions from this requirement; identifies the regulations that govern the acquisition process; and discusses some of the difficulties involved in competitively procuring SPR oil or facilities leases.

\section{The Competition in Contracting Act of 1984}

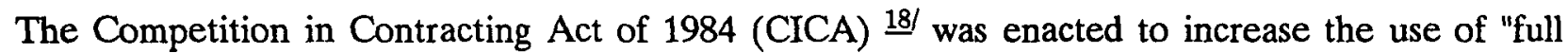
and open" competition in Federal Government procurement and to impose more stringent restrictions on the award of "other than competitive", e.g., "sole source" contracts. Except in certain enumerated circumstances discussed below, the Act requires that:

an executive agency in conducting a procurement for property or services --

(A) shall obtain full and open competition through the use of competitive procedures in accordance with the requirements of this title and the modifications to the regulations promulgated pursuant to [CICA]; and

(B) shall use the competitive procedure or combination of competitive procedures that is best suited under the circumstances of the procurement. (41 U.S.C. $253(\mathrm{a})(1)$ )

\section{a. Applicability to Leasing}

No distinction is made in the Act between the procurement of property or services through lease and their acquisition by purchase, $\underline{19}$ and it appears that the CICA would apply equally to the leasing of oil or storage facilities for the SPR as well as to their purchase.

\section{b. Negotiated and Formally Advertised Contracting}

A principal objective of the CICA was to place competitively negotiated contracts on a par with formally advertised contracts (termed "sealed bid" procurement in the CICA). The CICA provides that agencies are to use "sealed bid" procurement only if all of the following four conditions are met:

(i) time permits the solicitation, submission, and evaluation of sealed bids;

(ii) the award.will be made on the basis of price and other pricerelated factors;

18/ Title VII of Public Law No. 98-369, the Deficit Reduction Act of 1984, amending Title III of the Federal Property and Administrative Services Act of 1949 (41 U.S.C. 251 et seq.) (hereinafter the "Property Act") and the Armed Services Procurement Act of 1947 (Public Law No. 80-413).

19/ The definition of "property" applicable to CICA's provisions, contained in section 3 of the Property Act, 40 U.S.C. 472(d), encompasses "any interest in property. . . ." 
(iii) it is not necessary to conduct discussions with the responding sources about their bids; and

(iv) there is a reasonable expectation of receiving more than one sealed bid ... (41 U.S.C. 253(a)(2)(A))

But the procuring activity, whether soliciting "sealed bids" and making contract awards without discussions with bidders, or soliciting competitive proposals and making awards after discussion (competitive negotiation), ordinarily must meet the standard of "full and open" competition by permitting all responsible sources to compete. 41 U.S.C. 253(a)(1), (a)(2).

Both before and after the enactment of the CICA, the Federal Government has used principally the negotiated procurement technique, rather than "sealed bids" (or "formally advertised" competition), $\underline{20}$ in SPR oil acquisition. As will be discussed below, this negotiated procurement approach sometimes has been used competitively, and at other times it has been used noncompetitively.

\section{c. The Act's Competition Requirement}

The CICA instructs agencies to take a number of steps to insure full and open competition in their procurement activities (whether involving "sealed bids" or negotiated procurement). In preparing for a procurement, agencies are required to: specify agency needs and solicit bids or proposals in a manner designed to achieve full and open competition; use advance procurement and planning and market research; and develop specifications so as to obtain full and open competition. See 41 U.S.C. 253(a)(1).

Solicitation restrictions may include restrictive provisions or conditions "only to the extent necessary to satisfy the needs of the executive agency or as authorized by law." 41 U.S.C. 253a(a)(2).

\section{d. Exceptions from Compctition}

The CICA specifies seven circumstances in which "other than competitive procedures" may be used:

(1) the property or services needed by the executive agency are available from only one responsible source and no other lype of property or services will satisfy the needs of the executive agency;

(2) the executive agency's need for the property or services is of such an unusual and compelling urgency that the Government would be seriously injured unless the executive agency is permitted to limit the number of sources from which its solicits bids or proposals;

The terminology can be somewhat confusing. In competitive negotiated procurements for SPR oil, "sealed bids" for oil have been called for in the first instance. However, negotiation has ensued following the opening of bids, rather than the Government's making contract awards solely on the basis of price bids. 
(3) it is necessary to award the contract to a particular source or sources in order (A) to maintain a facility, producer, manufacturer, or other supplier available for furnishing property or services in case of a national emergency or to achieve industrial mobilization, or (B) to establish or maintain an essential engineering, research, or development capability to be provided by an educational or other nonprofit institution or a federally funded research and development center;

(4) the terms of an international agreement or treaty between the United States Government and a foreign government or international organization, or the written directions of a foreign government reimbursing the executive agency for the cost of the procurement of the property or services for such government, have the effect of requiring the use of procedures other than competitive procedures;

(5) a statute expressly authorizes or requires that the procurement be made through another executive agency or from a specified source, or the agency's need is for a brand-name commercial item for authorized resale;

(6) the disclosure of the executive agency's needs would compromise the national security unless the agency is permitted to limit the number of sources from which it solicits bids or proposals; or

(7) the head of the executive agency -

(A) determines that it is necessary in the public interest to use procedures other than competitive procedures in the particular procurement concerned, and

(B) notifies the Congress in writing of such determination not less than 30 days before the award of the contract. $11 /$ (41 U.S.C. 253(c))

Except where there is unusual and compelling urgency, every use of noncompetitive procedures must be justified and certified by the contracting officer, and such justification has to be approved by higher-level agency officials. The justification is to include, among other things, a determination that the anticipated cost of the procurement will be fair and reasonable, a description of the market survey conducted or an explanation of why a market survey was not conducted, and a statement of the actions, if any, the agency may take to remove or overcome a barrier to competition before a subsequent procurement for such needs. The Act cautions that the use of other than competitive procedures may not be justified "on the basis of the lack of advance

An agency relying on the exception numbered 2 (urgency) or 6 (national security threat) is required to "request offers from as many potential sources as is practicable under the circumstances." 41 U.S.C. 253(e). 
planning or concerns related to the amount of funds available to the agency for procurement functions." 41 U.S.C. $253(\mathrm{f})(5)$. For contracts exceeding $\$ 10$ million dollars, the agency justification for use of noncompetitive procedures must be approved by the senior procurement executive, designated pursuant to section 16(3) of the Office of Federal Procurement Policy Act, 42 U.S.C. $414(3)$. 221

\section{e. Noncompetitive SPR Oil Purchases}

Until 1981, most of the SPR's oil was acquired through negotiated competitive procurements, conducted on the DOE's behalf by the Defense Fuel Supply Center of the Department of Defense. Since 1981, the DOE has used other than competitive procedures for the acquisition of sour crude oil for the SPR from Petroleos Mexicanos (PEMEX), the Mexican national oil company. The first two PEMEX contracts (PEMEX I and PEMEX II) were entered into before the enactment of the CICA.

PEMEX I, signed in August 1981, was for the purchase of approximately 110 million barrels of oil over a period of five years. The written "sole source" justification for PEMEX I, which reflected a determination similar to the first exception from competition set out in the CICA (quoted above), ciled the following: the need to develop a long-term secure source of supply for the SPR that would not be vulnerable to the kind of volatile conditions in the world oil market that, following the 1979 Iranian Revolution, had led to claims of force majeure by the traders then selling oil to the SPR, and that would give the DOE greater assurance of meeting the congressionally mandated fill rates for the SPR; PEMEX's reliability as a supplier during periods of tight oil supplies, in contrast with those other contractors who had defaulted on their contracts with the DOE; a State Department survey of producer governments indicating that PEMEX was the only oil-producing country oil company that was willing to enter into a long-term contract to supply the SPR; and State Department advice to the DOE that a contract with PEMEX would promote U.S. foreign policy and was in the national interest.

PEMEX II, a noncompetitive contract that involved the delivery of 40.2 million barrels of oil during the period of October 1982 - September 1983, had its origin in the Mexican financial crisis in the summer of 1982. It was the uutgrowth of an agreement between the U.S. and Mexican Governments to provide Mexico with a $\$ 1$ billion advance payment for oil to be delivered in the future. The DOE's written PEMEX II justification also cited the undiminished unique ability of PEMEX to meet the DOE's needs for a long-term crude oil supply arrangement, and advice not only from the Department of State but also from the Department of the Treasury that the contract would promote U.S. foreign policy and economic interests and generally would be in the public interest.

PEMEX III and IV, which were concluded following the enactment of the CICA, were based on both the CICA's "unusual and compelling circumstances" exception (exception number 1) and the "only one responsible source available" exception (exception number 2). However, the sole source justifications for both contracts stated that, as a technical matter, the first CICA exception was not being relied upon because Federal Acquisition Regulation Section 6.302-1(b) required that where

22f Within the DOE, the Director, Procurement and Assistance Management Directorate, has been designated the senior procurement executive. 
the requirements of both exceptions numbered 1 and 2 are met, only the second CICA exception should be cited.

The noncompetitive justification for PEMEX III, which covered oil deliveries from December 1986 through November 1987, documented the DOE's determination that PEMEX had a unique ability to satisfy the SPR's requirements, citing the factors relied upon in the PEMEX I and II sole source justification, as well as PEMEX's exemplary performance under those contracts. In addition, the justification cited advice from the Departments of State and the Treasury similar to that provided in connection with PEMEX I and II. With respect to the "unusual and compelling circumstances exception," the justification pointed out that the Congress, in an unanticipated action after the beginning of Fiscal Year 1987, increased the statutorily-mandated fill rate for the SPR from 35,000 harrels per day to 75,000 barrels per day (or the highest practicable fill rate, subject to the availability of funds), leaving insufficient time to conduct a competitive procurethent to meet the required fill rate. The DOE's written justification also relied upon the facts that the EPCA rengivired the shut-in of the Elk Hills, California, Naval Petroleum Reserve if the SPR fill rate was not achieved, and that, prior to the beginning of Fiscal Year 198\%, the DOE had been unly partially successful in meeting the then-applicable Fiscal Ycar 1987 fill rate of 35,000 barrels per day through a competitive solicitation that was limited to offers of domestic crude oil.

The noncompetitive justification for PEMEX IV, which anticipated oil deliveries from December 1987 through November 1989, reiterated the factors cited in the justifications for PEMEX I-III underlying the DOE's finding that PEMEX had a unique capability to meet the SPR's requirements, as well as advice from the Departments of State and the Treasury supporting the contract. With respect to the "unusual and compelling circumstances" exception, the justification pointed out that, at the beginning of Fiscal Year 1988, Congress had not appropriated funds for SPR fill for Fiscal Year 1988, and, given the uncertainty as to when Congrcssional action would occur and as to whether the appropriations would increase the fill rate above the then-applicable 75,000 barrel per day fill rate, there would be insufficient time to conduct a competitive solicitation to meet the fill rate ultimately mandated by the Cungress.

\section{f. Limited Competition in SPR Oil Purchasing}

The DOE also conducted a competitive sealed bid procurement that was limited to offers of domestic crude oil for the SPR. This limitation on competition was based on the seventh CICA exccption, which permits an agency head to determine when it is necessary in the public interest to use other than competitive procedures for a particular procurement. The head of an agency is required to notify the Congress in writing of his intention to use this exception 30 days before the contract is awardcd. The Secretary of Energy's August 29, 1988, notice to Congress provided the following rationale for limiting the procurement to domestic crude oil:

In the past, domestic crudes have been purchased for the Reserve. Thus far, domestic oil represents the third largest single source of oil for the Reserve, behind only oil from Mexico and the United Kingdom. However, there recently have been no substantial Strategic Petroleum Reserve purchases from domestic sources under the Reserve's spot market solicitations, although domestic crudes were eligible. Current market conditions represent an excellont opportunity to reestablish this important source of supply, which 
would indicate Federal Government support of the domestic oil industry.

A limitation of Reserve purchases to domestic oil would help correct a disadvantage that domestic purchasers may face in bidding to sell oil to the Reserve, as a result of the location of the Reserve's storage facilities. For technical and logistical reasons, the Reserve's storage facilities are located along the primary routes by which foreign crudes enter this country. This may give bidders offering foreign crudes an inherent advantage over bidders offering domestic crudes. This advantage can best be eliminated by use of a solicitation limited to domestic sources of crude oil only. Therefore, I have determined that it is in the public interest to issue a solicitation which is limited to domestic crude sources.

Five timely bids were received in response to the DOE's Invitation for Bids (IFB) for domestic crude oil, and Transworld Oil U.S.A. was awarded a contract for 3.65 million barrels $(10,000$ barrels per day for one year) of West Texas Sour crude oil. The other bids were determined to be either unreasonably high compared to prevailing oil prices or unresponsive to the IFB's requirements.

\section{g. Publication Requirements}

The Office of Federal Procurement Policy Act, as amended by the CICA, establishes publication requirements for procurements to promote competition. Subject to certain exceptions, advance notice of solicitations for property or services that are expected to cost in excess of $\$ 10,000$ must be published in the Commerce Business Daily. The exceptions include noncompetitive procurement justified on the basis of unusual and compelling urgency, international agreement or treaty, express statutory authorization, and a public interest determination by the agency head. If notice of a solicitation is required, an agency may not issue a solicitation until 15 days after the publication; nor may the agency establish a deadline for submission of bids or proposals which is less than 30 days after the date the solicitation is issued.

\section{The Federal Acquisition Regulation}

\section{a. Applicability}

The Federal Acquisition Regulation (FAR) $\underline{23}$ is the primary regulation for use by all Federal execulive agencies in their "acquisition" of "supplies and services" with appropriated funds. See FAR 1.103. The term "acquisition" is defined in FAR 2.101 as "the acquiring by contract ... of supplies and services (including construction) .... through purchase or lease ...." (Emphasis added). "Supplies" also is defined in FAR 2.101, as:

48 C.F.R. Chapter 1. The FAR System has been developed in accordance with the Office of Federal Procurement Policy Act of 1974, as amended, 41 U.S.C. 401 et seq. The FAR is issued under the joint authorities of the Administrator of General Services, the Secretary of Defense, and the Administrator of the National Aeronautics and Space Administration, pursuant to the broad policy guidelines of the Administrator for Federal Procurement Policy. 
.. . all property except land or interest in land. It includes (but is not limited to) public works, buildings, and facilities, .... (Emphasis added)

In view of these definitions, it seems clear that an acquisition of oil for the SPR, through leasing, is subject to the FAR.

The applicability of the FAR to the leasing of salt dome cavern or mine storage for the SPR, however, is left in some doubt inasmuch as a storage lease, which is likely to concern an "interest in land," probably also will involve "supplies" (as defined) to some extent. The FAR definition of "supplies" does not address situations of a "mixed" nature where facilities and land are being acquired.

Based on a review of the Federal Property and Management Regulations (FPMRs) and the General Services Acquisition Regulations (GSARs) $\stackrel{24 /}{ }$ and after consultation with knowledgeable sources both within the Department of Energy and in other Federal agencies, there appears to be no FAR coverage of acquisitions through leasing of real property, or of the leasing of real property with improvements. $\stackrel{25 /}{ }$ On the other hand, in light of the FAR's definition of "supplies," it appears that the FAR is applicable to the acquisition of ready-made buildings or facilities (e.g., prefabricated or so-called "Butler" buildings). By way of example, the acquisition of aboveground movable steel storage tanks as "supplies" would be subject to the FAR, but not the acquisition of salt caverns or of steel storage tanks that are affixed to, or integrated into, the land. Accordingly, it seems reasonable to conclude that the important distinguishing factor regarding the FAR's applicability to facilities is whether or not the building or facility at issue is a permanent improvement of the land, and thus realty that is not subject to the FAR.

\section{b. Deviations}

Notwithstanding its breadth in scope (see FAR 1.103), the FAR itself contains a policy statement at FAR 1.402 which indicates that "deviations" $\underline{26 /}$ are envisioned and actually are encouraged if needed to test innovative acquisition methods:

24/ FPMR Subpart 101-18 applies to the acquisition of real property by Executive Branch agencies and GSAR Part 570, which has been issued as a supplement to the FAR, applies to GSA acquisitions of real property.

25/ The question of whether the FAR applies must be distinguished from the issue of whether the Competition in Contracting Act applies, and also from the issue of whether individual statutorilymandated contract clauses or requirements apply. The FAR contains coverage of these areas, but the scope of the various statutes is not correspondingly limited to the coverage of the FAR.

The term "deviation" is defined broadly at FAR 1.401 to include the issuance or use of a policy, procedure, solicitation provision, contract clause, method, or practice of conducting acquisition actions of "any kind at any stage of the acquisition process that is inconsistent with the FAR"; the omission of required clauses; the unauthorized use of modified clauses; and the authorization of lesser or greater limitations on the use of clauses or procedures prescribed by the FAR. 
Unless precluded by law; executive order, or regulation, deviations from the FAR may be granted as specified in this subpart when necessary to meet the specific needs and requirements of each agency. The development and testing of new techniques and methods of acquisition should not be stifled simply hecause such action would require a FAR deviation. The fact that deviation authority is required should not, of itself, deter agencies in their development and testing of techniques and acquisition methods. ...

The procedure for obtaining authority to deviate from the FAR is set out in FAR 1.403, "Individual deviations"; FAR 1.404, "Class deviations"; and FAR 1.405, "Deviations pertaining to treaties and executive agreements." "Individual deviations" affect only one contracting action and may be authorized by the agency head. In the DOE, this authority has been delegated to Heads of Contracting Activities (HCAs) or their authorized designees. Department of Energy Acquisition Regulation (DEAR) 901.403, 48 C.F.R. 901.403. "Class deviations" affect more than one contracting action and may be authorized by the agency head (who may delegate that authority but not below the HCA level), following consultation with the chairperson of the Civilian Agency Acquisition Council. The DOE requires that class deviations be processed through the DOE's Procurement Executive. See DEAR 901.404. The FAR contains a blanket individual and class deviation for deviations from the FAR that are required to comply with a treaty or executive agreement to which the United States is a party, unless such deviation would be inconsistent with FAR coverage based on law.

\section{The DOE Real Estate Manual}

The Department of Energy Real Estate Manual, contained in DOE Order 4300.1B, establishes policies and procedures for planning the development and use of sites and facilities and for the acquisition, use, inventory and disposal of real property and interests therein. Chapter III of the Manual addresses the acquisition of real property and prescribes, inter alia, requirements for quantifying needs and preparing preliminary real estate plans. Acquisition through leasing is the subject of paragraph 7 of Chapter III, which treats separately the five categories of the most common leasing actions for the DOE, as those signed by: (1) the DOE under the Department of Energy Organization Acl, Public Law No. 95-91, 42 U.S.C. 7101 et seq.; (2) a DOE contractor as authorized under its contract with DOE; (3) a DOE contractor under its own corporate authority; (4) the General Services Administration (GSA) for space under its statutory authority (Section 210 of the Federal Property and Administrative Services Act of 1949, 40 U.S.C. 490), then assigned for use by DOE; and (5) the DOE under a delegation of authority from GSA. Under each category, certain policies and procedures are set forth. The DOE Real Estate Manual does not purport to address separately the policies and procedures for leasing actions under statutory authorities other than those cited therein. The Energy Policy and Conservation Act, section 159(f)(C) of which grants to the DOE the authority to lease storage facilities for the SPR, is not cited in the Manual. However, paragraph 3 of the Order, entitled "Scope," specifies that the Order applies unless otherwise provided by statute or by specific delegation from the Secretary.

While a leasing action under the DOE's EPCA authorities, as opposed to action under an authority found in the DOE Organization Act or delegated by the GSA, is not covered expressly in the Manual, the Manual nonetheless provides guidelines that could prove useful in an SPR leasing action. It addrcsscs a variety of malters that are required in leasing actions under the 
DOE Organization Act and under authority delegated by GSA, such as standards and procedures for boundary identification, advertising, competition, market surveys, solicitation of offers, cancellation clauses, and fair annual rental determinations. See pp. III-19 through III-26. For example, at page III-19, the Manual discusses multi-year leasing actions under the DOE Organization Act as follows:

DOE may lease special purpose space for more than a year provided that no-year funds are either committed for the entire amount of the firm term rent or the amount of the cancellation payment, if one is provided, plus rent to the date on which cancellation may be exercised. Using no-year funds, however ties up sums of money for long perinds, and the Office of the Controller, has advised that taking a large sum from no-year funds for long-term rent in any given year can have an adverse impact on the overall budget and that such action is generally not consistent with good financial managcment. Therefore, while this option is legally available, its use must be approved by the Controller and the Director of Real Property and Facilities Management. Such approvals will be rare.

Thus, the Manual reflects some internal institutional policies and controls that may be relevant to, but does not establish any directly applicable limitation regarding, an SPR multi-year lease of storage facilities.

\section{Evaluating Competitive Proposals}

\section{a. General Principles}

The General Accounting Office long has held that the Government's solicitation of proposals from prospective contracturs must advise offcrors of all of the evaluation factors that the Government will be applying in a procurement and that the Government's selection of the winning proposals must be made rationally and in a manner consistent with stated evaluation criteria. See e.g., Tracor, Inc., 56 Comp. Gen. 62 (1976) and Grey Advertising, Inc., 55 Comp. Gen. 1111 (1976). The Competition in Contracting Act of 1984 (CICA) essentially codified these principles. The CICA provides, inter alia, that any Federal Government solicitation must include a statement of all significant factors to be considered in evalualing proposals and "the relative importance assigned to each of these factors," 41 U.S.C. $253 \mathrm{a}$ (b)(1), and further, that proposal cvaluation must be based "solely on the factors specified." 41 U.S.C. 253b(a). Accordingly, the Federal Acquisition Regulation indicates that a solicitation "shall clearly statc the evaluation factors, including price or cost and any significant subfactors, that will be considered in making the source selection and their relative importance. . . ." 48 C.F.R. 15.605(e). As noted in this chapter's Section B(1)(b) discussion of lease-versus-purchase considerations, the CICA's competition requirements appear to be applicable to leases of oil and of storage facilities.

\section{b. Evaluating Lease Offers}

The articulation and implementation of evaluation criteria for SPR facilities and oil leasing would present difficult contracting problems. Even when a decision to lease rather than buy was made, this necessarily would remain a tentative decision pending ascertainment that satisfactory lease 
proposals were elicited by the Government's solicitation, thus suggesting a need for some minimum standard of lease acceptability. Moreover, since would-be lessors could be allowed to offer facilities with or without the oil to be stored in them, and with or without provision for operations and maintenance or security services, the criteria might have to address the evaluation of all kinds of proposals, separately and against one another. Separate contracts to supply oil, facilities, or oil and facilities, and to perform various services, might have to be awarded in combination in order to meet the Government's needs, so that an award decision on any individual contract would turn on how well that contract fitted into the overall slate of awards, which in turn must mesh with the existing SPR storage and distribution capabilities, rather than necessarily being made exclusively on the merit of a particular proposal. And the source selection outcome could be affected significantly by the relative weighting accorded such potentially inconsistent evaluation factors as SPR oil fill acceleration, total cost, near-term budget outlays, requirements for near-term budget authority, and U.S.-flag vessel utilization.

A related issue is the extent to which the terms and conditions of oil or facilities leases are to be specified in the Government's solicitations, rather than allowing offerors to propose various terms and conditions. Prespecification of contract provisions risks limiting offerors' flexibility and confining their proposals to a narrow range; on the other hand, allowing a wide range of types of leasing proposals would compound the difficulties of source selection by eliminating a common basis for comparative evaluation. Any effort to acquire oil or facilities leases competitively will need to try to strike a balance between the two extremes.

\section{c. Regional and "Noncontiguous" Storage}

Special evaluation problems are posed in connection with the Energy Policy and Conservation Act provisions authorizing the creation of Regional Petroleum Reserves (RPRs) and the establishment of oil storage in certain noncontiguous areas of the United States. The drafting of requirements and evaluation criteria for a competitive solicitation of facilities storage leases inevitably will have an effect -- which could be either positive or negative -- on the likelihood of the DOE's awarding a storage contract for facilities located in the geographic areas to which these EPCA provisions apply.

The principal RPR provision is EPCA section 157, which contemplates having an RPR in or readily accessible to each Federal Energy Administration (FEA) Region $27 /$ in which imports of residual fuel oil or any refined petroleum product, during the preceding 24 months, equalled more than 20 percent of demand for such oil or product. Section 157(a). FEA Regions 1 through 4, encompassing generally all of the East Coast and the Southeast as far as Mississippi to the west, meet this test. However, section 157(c) expressly authorizes substitution of the storage of crude oil for that of product, and the Conference Report on the EPCA interprets this provision by stating that the authority for substitution is "without express restriction on the location of substitute storage facilities." S. Rep. No. 516, 94th Cong., 1st Sess. at 135 (1975). Thus, from the outset the SPR has consisted exclusively of crude oil stored in Louisiana and Texas, the main entry point for U.S. crude oil imports, offering the best distributional access to the country's refineries. 
Section 154(d) of the EPCA also indicates that the SPR Plan should be designed to assure, to the maximum extent practicable, the location of an SPR "component" within each "noncontiguous area of the United States $\underline{28 /}$ which does not have overland access to domestic crude oil production," such as Hawaii, Puerto Rico, etc. However, the Conference Report emphasized that this is not an absolute requirement but one governed by practicability, $i d$. at 137 , and the FEA and the DOE consistently have concluded that storage in each such noncontiguous area would not be costeffective compared with centralized Gulf Coast crude oil storage.

The drafters of a solicitation for facilities leasing necessarily must confront questions that will bear upon the eligibility of and the prospects for leased SPR storage physically located within or in proximity to the relatively product import-dependent FEA Regions and the noncontiguous areas. A threshold question is what, if any, geographic limitation to put on thc lcased facilities in the solicitation, e.g., to North America, the U.S., or only designated areas of the U.S. The distribution capability of proposed storage sites is likely to be an evaluation criterion; but whereas the SPR's emphasis for distribution of its first 750 million barrels has been on reaching the greatest number of domestic refineries, it is an open question whether the distribution capability of every site comprising a final 250 million barrels in SPR storage capacity needs to be judged by that same standard. Other factors, such as minimum facility sizc requirements and whether to allow for any storage of refined product, also will affect the outcome. And if there were an actual preference for leased storage in the product import-dependent or noncontiguous areas, it would be necessary to develop standards for weighing higher costs or other disadvantages of such storage against the preference accorded.

\section{Protests Against Contract Award}

Subtitle D of CICA added a new statutory "procurement protest system," 29/ applicable to protests filed after January 14, 1985. 31 U.S.C. 3552 . The statute permits protests to be filed at the GAO $\stackrel{30 /}{ }$ concerning "an alleged violation of a procurement statute or regulation" under procedures issued by the Comptroller General. 31 U.S.C. 3552. CICA imposed statutory tıme limits for the administrative processing and deciding of protests. The GAO must notify the Federal agency of the protest within one working day. 31 U.S.C. 3553(b)(1). The agency must file its administrative report within 25 working days from its receipt of notice (unless the Comptroller General determines a longer period is required) or within 10 working days if the "express option" is

28/ EPCA section 3(5) defines "United States" to include "all of the States"; section 3(4) defines "State" to include "Puerto Rico, the Trust Tcrritory of the Pacific Islands, or any territory or possession of the United States."

The General Accounting Office (GAO) has had a protest system administratively in place since the GAO's establishment in 1921, but the system was not created expressly by statute and had been criticized over the years as largely ineffective and lacking in enforcement powers. to certain procurements for automated data processing equipment and services. See 40 U.S.C. 759. 
applicable. $31 / 31$ U.S.C. $3553(\mathrm{~b})(2)$. The protest must be decided by the GAO within 90 days unless the Comptroller General determines a longer period is required. 31 U.S.C. $3554(a) . ~ \underline{321}$

During the pendency of a protest, a contract may not be awarded unless the head of the procuring activity (HPA) determines that "urgent and compelling circumstances which significantly affect interests of the United States" will not permit delaying award for a decision on the protest. 31 U.S.C. $3553(\mathrm{c})(2) . \stackrel{33 /}{ }$ Furthermore, if notice of a protest is received within 10 days of the contract award, the Act provides that performance must be suspended unless the HPA determines that: (1) performance is in the best interests of the United States, or (2) urgent and compelling circumstances significantly affecting the interests of the United States will not permit waiting for the Cumptroller General's. decision. 31 U.S.C. 3553(d). The GAO is authorized only to recommend relief if a protest is sustained, but may declare the protester entitled to protest and bid preparation costs. $\frac{34 /}{}$

In the four years since its enactment, the procurement protest system has been utilized extensively by competing bidders to challenge agencies' acquisition actions. The system provides a mechanism by which contract award or performance could be delayed or upset.

31/ The CICA required that the Comptroller General establish an "express option" for those protests he believes can be resolved within 45 days of filing. The GAO regulations provide that the "express option $^{n}$ may be requested by any interested party and will be invoked only in those cases that the Comptrnller General, in his discretion, dctcrmines are suilable for resolution within 45 calendar days. 4 C.F.R. 21.8.

32/ Protests under the express option must be decided within 45 days. 4 C.F.R. 21.8.

33/ This finding cannot be made unless the award otherwise is likely to be made within 30 days. 31 U.S.C. 3553(c).

34/ Both prior to and following the CICA's enactment, the Executive Branch questioned the constitutionality of certain provisions of the GAO's procurement protest system relating to the suspension of contract award and performance on the basis that it violates the constitutionally mandated separation of powers. See Federal Acquisition Circular 84-6 (January 10, 1985), which issued the Attorney General's advice to Executive agencies not to implement certain features of the protest system. However, all constitutional challenges to date have been unsuccessful. See Ameron, Inc. v. U.S. Army Corps of Engineers, 809 F.2d 979 (3d Cir. 1986), cert. granted 108 S.Ct. 1218, cert. dismissed 109 S.Ct. 297 (1988); Lear Siegler, Inc. Energy Products Division v. United States, 842 F.2d 1102 (9th Cir. 1988); and Universal Shipping Co., Inc. v. United States, 652 F.Supp. 668 (D.D.C. 1987). 


\section{CONTRACT STRUCTURE}

This part deals with several legal issues that affect the design of a lease of oil or facilities. First, it sets out the principles that control the Federal Government's need for, and obligation of, appropriated funds. Next, it discusses the separate question of authority to enter into a long-term lease or other contract. It then addresses funding mechanisms through which oil lessors could recover their capital, and explains the limitations on the Government's ability to fund improvements on privately-owned storage facility property.

\section{Principles Governing the Obligation of Funds}

The availability and obligation of funds is a fundamental concept in Federal appiopiriations law, and the application of this concept is a prerequisite to all Federal contracting actions. The key provision of the Anti-Deficiency Act, 31 U.S.C. 1341(a), prohibits making expenditures or incurring obligations "in excess of" or "in advance of" available appropriations. $\underline{35}$ I

The basic issue in obligation of funds questions ordinarily is not whether funds must be obligated, but rather when and how much funds are to be obligated. This inquiry is especially important when contemplating transactions such as those being considered in the SPR Alternative Financing Study, because the answer as to when and how much to obligate can differ considerably depending on the structure of each particular transaction. The following discussion sets out general parameters relating to the obligation of funds that need to be considered in depth on a case-by-case basis.

\section{a. The General Rule}

The timing and scope of the requirement to record obligations of funds turn on whether and when an "obligation" has been incurred. $36 /$ For appropriations accounting purposes, the term includes both obligations that have matured into legal liabilities (e.g., amounts due for goods reccived) and those that are dependent on some fulure performance (e.g., the delivery of goods). See 42 Comp. Gen. Dec. 708 (1963). The obligation takes place when the definite corrmitment is made, even though the actual payment may not take place until the next fiscal year or even many fiscal years later. See 56 Comp. Gen. 351 (1977). The precise amount of the Government's liability should be recorded as the obligation, where it is known. The agency's best estimate can be used where the amount is not definite, and the basis for the estimate must be shown on the obligating document. See 56 Comp. Gen. 414, 418 (1977) and cases cited therein. Obligations based on

35/ The prohibitions in subsection (a) of the Anti-Deficiency Act in many ways parallel those in the Adequacy of Appropriations Act, 41 U.S.C. 11, which generally covers the sufficiency of funds for purchases and contracts at the time of contract award. But the fact that neither Act is violated at the time of contract award does not necessarily ensure that a violation of the Anti-Deficiency Act will not later occur, in light of the Anti-Deficiency Act's broader scope in covering expenditures and the incurrence of obligations during contract performance.

An "obligation" is viewed by the GAO as "some action that creates a liability or definite commitment on the part of the Government to make a disbursement at some later time." Principles of Federal Appropriations Law, U.S. General Accounting Office, Office of Gencral Counsel, at p. 6-4 (1982). See also OMB Circular A-34, "Instructions on Budget Execution" (August 1985), Sections 21.1 and 22. 
estimates must be adjusted periodically as more precise data becomes available. See generally Principles of Federal Appropriations Law, op. cit. p. 6-4 (1982).

The standards for the recording of obligations, set out in 31 U.S.C. 1501, indicate that both the underrecording and the overrecording of funds are improper. OMB Circular A-34 points out that "agencies should ensure that obligations are not overstated by the inclusion of obligations that are not likely to require payment." OMB Cir. A-34, Section 22.1, at page II-9. Section 1501 of Title 31, United States Code, specifying criteria for the obligation of funds, begins by stating:

a. An amount shall be recorded as an obligation of the United States Government only when supported by documentary evidence of . . . [eight criteria, a single one of which must be met].

Once one of the criteria is satisfied, the obligation must be recorded.

\section{b. Contract Renewal Options}

Application of the general rule that funds must be obligated to cover the full extent of the firm commitment (see 63 Comp. Gen. 129, 131 (1983)) is perhaps best illustrated by example. In the context of leasing oil or storage facilities, if a firm ten year lease is entered into, the rental payments for the full ten year term must be obligated upon the execution of the lease. $\frac{37 /}{}$ The result would be different, however, if the transaction were structured as a ten-year lease with ten renewal options, each of which bound the Government for only one year at a time. In a transaction of this nature, the firm commitment, and thus the amount to be obligated, would be the amount needed to cover rental payments for the initial one-year term. As each renewal option was exercised, funds to cover the renewal period would have to be obligated. See 62 Comp. Gen. 143 (1983).

OMB Circular A-34 advises: "For contracts with renewal options, include [in reports on obligations] the amount required to cover the basic period and any penalty charged for failure to exercise options." Section 23.4, at page II-10. An example is a lease with renewal options, which applies terminaliou/cancellation charges in the event the options are not exercised; in such a case, the initial lease period rental fee and the termination/cancellation charges must be obligated at the outset.

37/ Either multi-year or no-year funds are required in the absence of express statutory authority to obligate funds in advance of appropriations, because the obligation of annual appropriations is limited to the fiscal year for which they were appropriated. See 31 U.S.C. 1301(c). The SPR program historically has received no-year appropriations to fund all of its activities, including those involving both facilities and petroleum. 


\section{c. Contingent Liabilities}

The preceding paragraph introduces the subject of "contingent liabilities." In lease transactions, termination or cancellation charges often are established in the contract to protect the contractor's financing of the investment in the event that all of the options are not exercised. Termination/cancellation charges are a type of "contingent liability" $\underline{38}$ ' to which special rules apply. A "contingent liability" is a potential liability that may become an actual liability if some particular event happens or does not happen. 39 / Contingent liabilities may involve a risk that occurrence of the applicable contingency will result in an obligation in excess of available funds. Given the prohibitions contained in the Anti-Deficiency Act, an agency cannot enter into an agreement creating a contingent liability that would result in an indefinite, indeterminate, or potentially unlimited obligation. ${ }^{40}$ Those contingent liabilities that can be reasunably estimated must be recorded as obligations where their occurrence is probable. See 62 Comp. Gen. 143 (1983); UMB Cir. A-34, op. cit.

38/ The GAO recognizes the following formal definition of the term "contingent liability":

An existing condition, situation, or set of circumstances involving uncertainty as to a possible loss to an agency that will ultimately be resolved when one or more future events occur or fail to occur.

See Principles of Federal Appropriations Law, op. cit. at p. 6-41, citing Glossary of Terms Uscd in the Federal Budget Process, PAD-81-27, p. 86. See also Treasury Financial Manual, Department of the Treasury, Vol. I, Section 4190, at page 2-4100-5.

39/ It is accepted that there is a class of contingent liabilities that should be reflecied in fintamcial statements but which need not have funds obligated to cover them at the time they are incurred. Examples of such situations, which the GAO has held do not require the obligation of funds, include contract claims in litigation against the Government (37 Comp. Gen 691 (1.958)) and loan guarantees (60 Comp. Gen $700(1981))$. In principle the question of whether or not funds need to be obligated to cover a contingent liability turns on whether the cuntingency is sufficicntly probable or is little more than a mere possibility. See Principles of Federal Appropriations Law, op. cit. at p. 6-41 and p. 14-4. However, the categorizations may simply reflect accepted conventions in difficult areas, as it is not always apparent that specific other contingencies involve a higher degree of likelihood than those that are in this excepted class.

40/ This issue sometimes comes up in connection with proposed indemnification arrangements, where a contractor seeks an agreement to indemnify it from losses. Where such arrangements are of an unlimited or indeterminate nature, the obligation of sufficient funds cannot be assured. The only protection of the Government which the GAO has countenanced is an explicit contractual limitation of liability to funds available at the time the contingency occurs, coupled with the express assurance that nothing in the agreement will be viewed as binding Congress to appropriate additional funds to cover the deficiency. 63 Comp. Gen. 145, 147 (1984), citing Comp. Gen. Dec. B-202578 (Jan. 8, 1982). But cf. 63 Comp. Gen. 145, 147 (1984), citing 62 Comp. Gen. 361, 368 (1983), where the GAO reiterated its previously stated "tentative position that open-ended indemnification agreements should not be entered into regardless of the existence of such language of limitation, unless authorized by law." 


\section{d. Limiting the Government's Exposure}

A number of methods commonly are utilized by Federal contracting activities to limit the commitment of the Government, but simultaneously demonstrate to the contracting community that a longer-term project ultimately is envisioned. For example, the GAO has interposed no objection to the use, in certain circumstances, of a "subject to availability of funds" clause which expressly conditions the Government's liability, coupled with a statement that there should be no inference that Congress would appropriate additional funds. See 67 Comp. Gen. 190 (1988), citing 39 Comp. Gen. 340 (1959). This mechanism also has been employed in contracting in advance of funds for one-year contracts in limited instances, using annual appropriations. See Federal Acquisition Regulation (FAR) 32.703-2, 48 C.F.R. Chapter 1. Similar in legal effect are "Limitation of Funds" and "Limitation of Government Liability" clauses, which are used in a number of cost reimbursement situations. See FAR 32.704 and FAR 32.705-2. As an example, the DOE traditionally does not fully fund its management and operating contracts; rather, the Department "incrementally" funds such multi-year contracts and uses a standard "Limitation of Liability" clause set forth in FAR 52.246-25. The GAO has approved the use of such clauses in the circumstances for which they are designed. See, e.g., 59 Comp. Gen. 526 (1980).

These mechanisms offer a certain degree of flexibility in structuring a particular transaction. However, as a practical matter, potential contractors may be hesitant to enter into a contractual arrangement that leaves the contract's actual duration uncertain. Experienced Government contractors often are unintimidated by technical limitations of this nature because they are confident of their ability to assess the Government's commitment to the contract effort. Additionally, contracts of this type ordinarily provide for payment of some type of termination or cancellation costs, so that a contractor has a measure of protection.

\section{e. Other Forms of Budget Authority}

Two alteruatives exist to the obligation of appropriated funds in accordance with the principles described above. First, in the unusual case where a Federal agency has statutory authority to enter into a binding multi-year contract, known as "contract authority," 41 / the agency may legally commit the United States prior to the appropriation of funds in the full amount of the binding legal commitment. Such authority cuustitutes a specific form of budgetary resources and, if provided, would enable the DOE to offer assurances to lcssors in the form of fixed, long terms.

41/ "Contract authority" is to be distinguished from the authority to enter into a "multi-year contract," discussed shortly in Section D(2) of this chapter. "Contract authority" is defined in OMB Circular A-34, op. cit. Section 21.1, at page II-3, as "statutory authority under which contracts or other obligations may be entered into prior to an appropriation for the payment of such obligations." Such obligations are liquidated by later cnacted appropriations; it is the provision of the contract authority, and not the liquidating cash, which constitutes the budgetary resource available for use. In contrast, Section $\mathrm{D}(2)$ below addresses whether there are legal restrictions on entering into a "multi-ycar contract," irrespective of whethcr appropriated funds are then available for obligation against the full contractual commitment. The former is an appropriations issue, the latter an issue of procurement authorization and practice. 
However, in addition to the fact that such authority rarely has been granted, $\underline{42}$ consideration of any bill, resolution or conference report that provides for such "backdoor" authority is subject to a point of order by an individual Member in either House pursuant to 2 U.S.C. 651(a), "unless [it] also provides that such new spending authority is to be effective for any fiscal year only to such extent or in such amount as are provided in appropriation acts."

The second alternative is "borrowing authority," which consists of authority to obtain funds: (1) from the Treasury that are realized from the sale of Treasury debt securities pursuant to

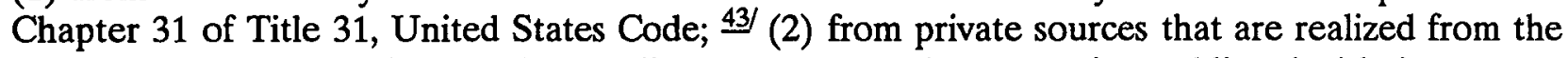
sale of agency securities to the public pursuant to the agency's enabling legislation or an appropriation act; $\underline{44 /}$ or (3) a combination of both authorities. $\frac{45 /}{}$

See generally Principles of Federal Appropriations Law, op. cit., at p. 2-4; OMB Circulaı A-34, op. cit. Sec. 21.1, at p. II-3.

\section{f. Advance Payments}

The legality of making "advance payments" is a subject that, although actually an issue concerning the outlay of appropriated funds rather than their obligation against a contractual commitmcnt, is related to the obligation of funds against a lease and therefore warrants mention at this juncture. The making of "advance payments," or payments in advance of receipt of the goods or services for which the payment is made, arises in this context because the structure of lease payments would be a central feature of any lease agreement. Several statutes bear on this issue. The question of legality is raised by 31 U.S.C. 3324, the Advance Payment Act, which in pertinent part provides:

[A] payment under a contract to provide a service or deliver an article for the United States Government may not be more than the value of the service already prơvided or the article alrcady delivered.

42) Examples of contract authority include 40 U.S.C. $490(\mathrm{~h})$, authorizing the Administrator of General Scrvices to enter into lease agreements for buildings of up to 20 years; 40 U.S.C. 481(a)(3), authorizing the Administrator of General Services to enter into public utility services contracts for periods not cxceeding 10 years; and 10 U.S.C. $2306(\mathrm{~g})(1)$, authorizing the Secretary of Defense, subject to certain limitations, to award contracts for periods of up to 5 years when acquiring certain types of services.

See e.g., 42 U.S.C. 1437(b) (Housing and Urban Development loans to finance lower income housing); 45 U.S.C. 720(e) (Department of Transportation loans to the U.S. Railway Association); 42 U.S.C. 5919(n)(4) (DOE guarantees for alternative fuel conversion facilities loans); 16 U.S.C. 838k(a) (Bonneville Power Administration); 42 U.S.C. 2414(e) and 42 U.S.C. 4016 (National Flood Insurance Revolving Fund--Federal Emergency Management Agency; 50 U.S.C. 167j (Helium Production Fund--Department of the Interior); 33 U.S.C. 985 (St. Lawrence Seaway Corporation).

44/ See e.g., 39 U.S.C. 2005 (Postal Service); 16 U.S.C. 831n-4(a) (Tennessee Valley Authority); 15 U.S.C. 713a-4 (Commodity Credit Corporation). 
The Advance Payment statute provides for advance payments where authorized by a specific appropriation or by the President or by "other law," but it otherwise serves as a general prohibition on agencies' paying for goods and services in advance of receiving them. See 64 Comp. Gen. 710 (1985).

\section{(1) Rentals}

The title 31 advance payment statute consistently has been construed as applicable to lease agreements as well as to purchases, and it applies with respect to both real and personal property. See Principles of Federal Appropriations Law, op. cit. at p. 4-29 (1982), citing 3 Comp. Gen. 542 (1924); 18 Comp. Gen. 839 (1939); and Comp. Gen. Dec. B-188166 (June 3, 1977) (unpublished). Thus, when the Government acquires land by leasing, payments must be made "in arrears" unless the applicable appropriation statute or "other law" provides contrary authority. See 57 Comp. Gen. 89 (1977); 58 Comp. Gen. 29 (1978). One of the more indirect contexts is that of a lease with option to purchase where the Government is paying a discrete amount for the option; if the option is not exercised, any amount paid for that option is forfeited by the Government. Therefore, absent statutory authority to the contrary, there at least is a question whether the purchase of an option is consistent with 31 U.S.C. 3324; there also is a question whether the payment of an earnest money deposit might be viewed differently. See 34 Comp. Gen. 659 (1955).

\section{(2) DOE's Authority}

Two "other" laws authorizing advance payments are relevant. First, 41 U.S.C. 255 authorizes any executive agency to make "advance, partial, progress, or other payments." This exception is limited, however, by the condition that adequate security is received for the advance; moreover, the agency head must determine that the advance payment would be in the public interest.

The second exception is found in the DOE Organization Act (DOE Act). Section 646(a) of the DOE Act, 42 U.S.C. 7256, says:

The Secretary is authorized to enter into and perform such contracts, leases, cooperative agreements, or other similar transactions with public agencies and private organizations and persons, and to make such payments (in lump sum or installments, and by way of advance or reimbursement) as he deems necessary and appropriate to carry out functions now or hereafter vested in the Secretary. (Emphasis added)

Thus, the DOE Act provides independent authority for advance payments, and it does not expressly impose a requirement for obtaining security such as exists under 41 U.S.C. 255 . Under generally accepted rules of statutory construction, the DOE Act, as the later-enacted, more specific statute, would control to the extent that the Secretary determines that an advance payment (without security and a public interest determination) was "necessary and appropriate" to carry out his statutory functions.

Nonetheless, the Federal Acquisition Regulation characterizes advance payments as the "least preferred method of contract financing" and generally requires the Government to receive adequate security and make a public interest determination. FAR Subpart 32.402. However, the FAR coverage is premised on the assumption that receipt of a security interest and the public interest 
determination are required under 41 U.S.C. 255 . To the extent that the 41 U.S.C. 255 statutory requirements may be inapplicable to the making of advance payments under the DOE Act, the

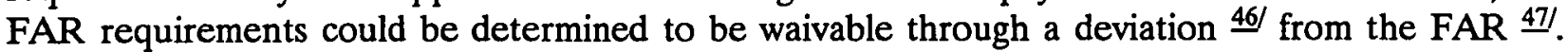

\section{Multi-year Contracting $\frac{48 /}{1}$}

This section discusses statutory and regulatory impediments or restrictions that must be considered by the DOE in leasing oil or facilities for the SPR beyond the current fiscal year's requirements. In examining this issue, a number of relevant statutory and regulatory authorities, including the Anti-Deficiency Act, the Department of Energy Organization Act, the Energy Policy and Conservation Act, the Federal Acquisition Regulation, and the Department of Energy Acquisition Regulation, were reviewed to determine what, if any, legal impediments exist to a multi-year lease contract.

\section{a. The Anti-Deficiency Act}

The Anti-Deficiency Act, 31 U.S.C. 1341, often is of concern in considering multi-year contracting because of the Federal Government's annual appropriations process. As discussed in Section $\mathrm{D}(1)$ of this chapter, the Anti-Deficiency Act sets out two basic prohibitions: (1) making expenditures or incurring obligations in excess of available appropriations; and (2) making expenditures or incurring obligations in advance of appropriations. Both the courts and the Comptroller General have held that the Anti-Deficiency Act prohibits multi-year contracts, including a procurement that obligates the United States to pay for severable services to be performed in future fiscal years, without either multi-year or no-year funding, or specific statutory authority. See Leiter v. United States, 271 U.S. 204 (1925); 67 Comp. Gen. 190 (1988); 48 Comp. Gen. 497 (1969). But, in view of the fact that the SPR program receives "no-year" appropriations to fund all of its activities, including both facilities and petroleum expenditures, the Anti-Deficiency Act should not pose a legal constraint to the term of an SPR multi-year contract, provided that there are sufficient funds available to obligate for the full amount of the firm contractual undertaking. As discussed in Section D(1)(b), (c), and (d), the firm contractual commitment can be structured so as to limit the extent of the undertaking and thereby avoid a violation of the Anti-Deficiency Act.

46/ The term "deviation" covers the issuance or use of a policy, procedure, solicitation provision, contract clause, method, or practice of conducting acquisition actions of "any kind at any stage of the acquisition process that is inconsistent with the FAR"; the omission of required clauses; the unauthorized use of modified clauses; and the authorization of lesser or greater limitations on the use of clauses or procedures prescribed by FAR. See FAR 1.401.

47/ See Section $\mathrm{C}(2)(\mathrm{b})$ of this chapter for a discussion of the policy and procedures for obtaining individual and class deviations from the FAR.

48) The term "multi-year contracting" as used herein refers to the practice of contracting for more than the current fiscal year's requirement. See FAR 17.101. As explained above in footnote 41, Section $\mathrm{D}(1)(\mathrm{b})$, this is to be distinguished from "contract authority." The distinction is important because an agency need not necessarily have "contract authority" in order to enter into a contract for goods or services in excess of its current fiscal year's needs. 


\section{b. Other Relevant Statutes}

Also relevant to this examination is whether multi-year contracting is addressed by either the Department's or the SPR's organic legislation, i.e., respectively, the Department of Energy Organization Act, Public Law No. 95-91, 42 U.S.C. 7101 et seq., as amended, and the Energy Policy and Conservation Act (EPCA), Public Law No. 94-163, 42 U.S.C. 6201 et seq., as amended. In brief, neither the DOE Organization Act nor the EPCA contains either an express grant of authority or an express prohibition regarding a limitation on the term of years for a lease where the DOE is the lessee. Both Acts contain broad and generally-worded grants of contracting authority, and thus do not impose any limitation regarding the term of years for a potential multiyear lease contract.

In this regard, a Comptroller General opinion of February 28, 1978, concerned the issue of whether a multi-year lease of SPR storage facilities that extended beyond the then-current expiration date of the EPCA would terminate by operation of law if the SPR program's authority was not extended. 57 Comp. Gen. 316 (1978). Before concluding that such a lease would not so terminate, the Comptroller General first considered whether the DOE had authority to enter into a multi-year lease for SPR storage facilities and concluded that there was no prohibition due to the grant of independent lease authority and the appropriation of no-year funds. There has been no material change during the intervening years to the substantive authorities relied on by the General Accounting Office.

\section{c. Regulations}

Based on the view that the Federal Acquisition Regulation (FAR) would apply to a lease of oil and potentially also to a lease of certain types of storage facilities as discussed above in Section C(2)(a), the FAR and Department of Energy Acquisition Regulation (DEAR) were examined for any limitations or restrictions on the term of years permissible under these authorities.

FAR Subpart 17.1 covers "multi-year contracts", defined therein to be "contracts covering more than 1-year's but not in excess of 5-year's requirements, unless otherwise authorized by statute." FAR 17.103-1(b)(2) specifies that agencies "shall not use multi-year contracts when . . . [r]equirements exceed a 5-year planned program." Additionally, although FAR 17.104-3 states that benefits may accrue by providing options in a multi-year contract, FAR 17.204(e) provides:

(e) The total of the basic and option periods shall not exceed 5 years in the case of services, and the total of the basic and option quantities shall not exceed the requirement for 5 years in the case of supplies, unless otherwise authorized by statute. (Emphasis added)

These provisions indicate, therefore, that a lease contract subject to the FAR would be limited to a five-year term, unless "otherwise authorized by statute," or unless a deviation from the five-year FAR limitation is obtained. $\frac{49}{}$ 


\section{Methods of Returning Capital to Lessors}

An oil lease may contemplate that at some point the lessor can recover its capital, either with or without participating in any increase in the oil's value since the time it was delivered to the Government. This recovery of capital could occur on the occasion of an SPR drawdown, at the end of the full lease term, upon the DOE's failure to extend the lease, or at some other point in time. It could take the form of a cash payment or of a return of the oil. The obligation of funds issues raised by such arrangements are discussed in Section $\mathrm{D}(1)$ of this chapter. This section addresses the mechanism for paying the lessor, in the case where a cash payment is due.

One way of doing so of course would be to seek appropriations, at the time a lease is entered into, to cover the full amnunt of the lessor's potential recovery of capital. Another theoretical possibility, which also obviously has major disadvantages, would be to seek an âpproprialiun upuir the occasion of each recovery of capital by a lessor.

A third possibility would be to use receipts from the sale of SPR oil to pay the lessor the amuunt due. If payments were due to the lessor during an emergency when the SPR was heing drawn down pursuant to a Presidential decision, sales proceeds would be generated in the normal course. However, if the lease entitled the lessor, absent a DUE decision to extend the lease tcrm, to receive a cash payment during a non-emergency period, new legal authority would be necessary in order for the DOE to sell SPR oil at that time for the purpose of paying the lessor out of the proceeds. In either event, but more likely under the non-emergency scenario, the amount contractually due to the lessor could exceed the sales proceeds from the oil owned by the lessor; thus, depending on the amount owed the lessor and the amount for which the lessor's oil is sold, it might be necessary to compensate the lessor in part out of the sale of additional SPR oil, over and above that owned by the lessor.

There are at least two possible methods of employing SPR sales receipts in this manner. The first would be to pay lessors out of the existing "SPR Petroleum Account" established in the Treasury of the United States pursuant to section 167 of the Energy Policy and Conservation Act. Amounts in this account may be obligated for "the acquisition, transportation, and injection of petroleum products into" the SPR, and for the "drawdown and delivery" of oil from the SPR. Section 167(b). In the absence of a drawdown and distribution of the SPR, the amount that may be obligated from the SPR Petroleum Account is limited to the aggregate amount of appropriations to the account. $\underline{50}$ However, section 167(b)(3) in effect provides that when an SPR drawdown and distribution occurs, there may be obligated from the account in any fiscal year, "an aggregate amount equal to the aggregate amount of the receipts to the United States from. the sale of petroleum products." $\underline{51}$ It can be argued that the recovery of capital by a lessor out of the SPR Petroleum Account is appropriate, either as a facet of oil "acquisition" or as an aspect of "drawdown and delivery."

Another possible approach for paying the lessor out of receipts from the sale of SPR oil is suggested by a line of Federal Appeals Court decisions, originating with Varney v. Warehine,

50/ Funds available for obligation from the account remain available without fiscal year limitation.

51/ It will be seen that, under this language, the appropriation is of an amount "equal to" the sales receipts rather than "of" the sales receipts. 
147 F.2d 238 (6th Cir.), cert. denied, 325 U.S. 882, rehearing denied, 326 U.S. 805 (1945), which have held that funds received "in trust" need not be paid into the Treasury and may be disbursed to the rightful recipient without need for an appropriation. For example, in Citronelle-Mobile Gathering, Inc. v. Edwards, 669 F.2d 717 (Temp. Emerg. Ct. App. 1982), cert. denied, 459 U.S. 877 (1982), a case involving restitution of overcharges violating DOE's petroleum price regulations, the Temporary Emergency Court of Appeals (TECA) ruled that a Congressional appropriation was not required for DOE's disbursement of overcharges to injured customers of the defendant which the defendant was required to deposit in a Treasury Department trust account:

The Treasury holds the payments in a "Deposit Fund Account" to be paid out at the direction of DOE. . . Receipts contained in those accounts are subject to a "constructive trust," . . . are treated as liabilities of the United States, . . . and for their disbursement, an appropriation is not required. (669 F.2d at 723)

Similarly, in U.S. v. Exxon Corp., 773 F.2d 1240 (Temp. Emerg. Ct. App. 1985), the TECA, citing its earlier decision in the Citronelle-Mobile Gathering, Inc. case, approved a restitution arrangement which required Exxon to pay overcharges and interest, stemming from its violation of DOE price regulations, into an interest-bearing Treasury escrow account, to be held in trust by the Department of the Treasury for ultimate distribution to the states for use in various energy programs. See also Emery v. U.S., 186 F.2d 900 (9th Cir.), cert. denied, 341 U.S. 925 (1951).

The Department of the Treasury, in Volume I of its Treasury Financial Manual prepared for the guidance of departments and agencies, provides criteria for determining which accounts are to be treated as deposit fund activity "falling outside of the budget, . . . as part of the means of financing. . . ." Section 1560.20, at page 2-1500-4. A "deposit fund (liability)" classification is proper if any one of four criteria is met. Among these criteria, the manual lists:

Deposits received from outside sources for which the government is acting solely as a banker, fiscal agent, or custodian. (Section 1560.10 , at page 2-1500-4.)

\section{Pcrmancnt Improvements on Piivaltly Owned Property}

The SPR program's drawdown and distribution system has been designed to utilize, rather than replicate, industry's logistical infrastructure. Yet the SPR's requirements sometimes have involved reversing the flow of oil within this infrastructure, for example, making preparations that would allow the DOE to move oil, during an emergency, from the interior to tankers through marine terminals which theretofore handled exclusively oil movements from the water to the interior. Not infrequently, these preparations have necessitated making physical modifications to industry facilities, and these modifications from time to time have presented questions of the propriety of utilizing appropriated funds to finance permanent improvements on privately-owned property. A similar issue could arise in connection with the leasing of oil storage and related terminalling facilities to the SPR.

In a 1986 decision, 65 Comp. Gen. 722, the Comptroller General provided an historical review of General Accounting Office (GAO) holdings on the issue. The opinion noted a longstanding GAO position that appropriated funds could not be used for permanent improvements in leased premises 
unless the lease treated such improvements as part of the consideration under the lease. However, the GAO recognized that the rule was one of public policy rather than of statutory prohibition, and that exceptions appropriately were made. $\underline{52}$

A statutory limitation on Government spending for the alteration of rental space previously was contained in section 322 of the Economy Act of 1932, formerly codified at 40 U.S.C. 278a and repealed in 1988, Public Law No. 100-678, section 7, 102 Stat. 4049. But, like the rule of public policy enunciated by the GAO, the Economy Act limitation applied only where the Government was to pay directly for the cost of improvements, and not where the lessor used the rent received under the lease to amortize such expenses. 59 Comp. Gen. 474 (1980). The statutory limitation also had been held to be inapplicable to unimproved land. 38 Comp. Gen. 143 (1958).

Even more important, the GAO has concluded that:

[T]he Department ... [of Energy's] authority ... differs significantly from the leasing authority, given many other Federal agencies, which we have held insufticient, without more, to exempt thein from the section 322 requirements. 'The statutory leasing authority granted to the Department [under the EPCA] is for the sole purpose of creating and maintaining a Strategic Petroleum Reserve. ... In contrast, the kind of leasing authority which we have considered subject to the Economy Act limitations is to carry out the general purposes of the agency, rather than, as in this case, to accomplish a specific goal mandated by statute. (57 Comp. Gen. 316, 320 (1978))

For these reasons, the GAO recognized that the DOE has authority to construct storage facilities on leased property.

However, this legal situation is complicated somewhat by the potential relevance, in some circumstances, of 40 U.S.C. 255 , which provides in pertinent part:

Unless the Attorney General gives prior written approval of the sufficiency of the title to land for the purpose for which the property is being acquired by the United States, public money may not be expended for the purchase of the land or any interest therein. (Emphasis added)

In 1979 , when the DOE was considering whether to accept a "servitude" $\underline{5} 3 /$ in real property in Louisiana, within which storage facilities were to be developed, the DOE inquired of the Department of Justice with regard to the sufficiency of this title. The Justice Department's Office

52/ The DOE's Real Estate Manual (pages III-19 and III-20), DOE Order 4300.1B, discusses the GAO's general policy concerning permanent improvements on privately owned property and the criteria the GAO considers in recognizing exceptions to that policy. 
of Legal Counsel responded on August 29, 1979, that under Justice's unpublished regulations implementing 40 U.S.C. 255, the proposed transaction must be disapproved. Opinion No. 79-63, 3 Opinions of Office of Legal Counsel 337.

The Justice Department's opinion pointed out that in administering the regulations, the Department's Lands Division "has generally taken the position that where permanent improvements of substantial value are to be erected on lands, the only interest sufficient to protect the federal investment in the property is a full fee simple title." Id. at 339. Thus, in cases where 40 U.S.C. 255 applies:

This Department has regularly refused to approve the acquisition of less than fee simple title if permanent and substantial improvements are to be constructed on the land, unless Congress has separately and explicitly approved the particular acquisition at issue. (Id. at 340)

On the other hand, it is the DOE's understanding that as a matter of practice, the Department of Justice does not review leasehold interests. 


\section{E. CONTRACTUAL REQUIREMENTS}

This part enumerates clauses required to be included in contracts with the Federal Government, and then discusses specific clauses which concern the process for resolving contractual disputes, and cargo preference requirements.

\section{Required Contract Clauses}

Pursuant to various statutes, Executive Orders, Office of. Management and Budget circulars, regulations and Executive Branch policies, there are a number of "standard" clauses that typically are required to be included in Federal Government contracts. The applicability of these clauses to a particular DOE contract will vary considerably, depending on such factors as: the nature of the contractual effort; the items or services being acquired; the dollar value of the contract; the geographic places of contract execution and of contract performance; the date of execution; and the identity of the contracting parties. Some statutes or regulations contain express exemptions or have waiver provisions. Some of those having waiver provisions allow for waiver determinations to be made within the DOE at specified levels, whereas others require concurrence, approval or notification of parties external to the Department before, or upon, implementation of the waiver action.

While no final determination of contract clause applicability can be made at this time, the "standard" contract clauses were reviewed from the viewpoint of possible inclusion in oil and storage lease agreements. A list of the areas of potential coverage is included below, with "O" and "F" respectively designating provisions that may be applicable to an oil or a facilities lease. The enumeration is divided into two segments: (i) clauses based in statute or Executive Order; and (ii) some of the more prominent clauses based in regulation that are uncharacteristic of commercial agreements. As a general rule, provisions or clauses that are based exclusively on regulation and not on a statute or Executive Order can be waived by following a prescribed procedure. 55 /

Twenty-seven clauses based in statute or Executive Order and ten clauses based in regulation were identified as potentially applicable. The former group includes labor laws, which mandate that certain wage rates, fringe benefits, working conditions and employment opportunities be maintained; environmental laws, covering clean air and water requirements and the process required to determine the environmental impacts of major Federal actions; the small business and small disadvantaged business law and women-owned small business Executive Order, specifying the actions to be taken to increase the contracting opportunities of these firms; laws reflecting Federal policies such as those covering drug-freè work places, procurement integrity, and prohibitions on kickbacks; and laws establishing preferences for U.S. firms and requiring submission of, and Government access to, certain financial records of contractors. The regulatory-based clauses selected for analysis encompass a wide range of topics, including requirements for cost accounting standards, audits, and termination rights.

Notwithstanding the diverse subject matter of these clauses, there are some common elements. Although the precise wording varies, many of the statutes contain an exemption for contracts that will be performed "entirely outside the United States." This issue bears especially on leased oil 
that, for example, might be lifted f.o.b. origin by the DOE; delivered c.i.f. or f.o.b. destination to a U.S. port by the lessor; or entered into U.S. customs territory by the lessor. $\underline{56}$ Exemptions also frequently exist for contracts with foreign governments (or agencies thereof) or for contracts pursuant to international agreements or treaties. These exemptions could come into play in arrangements made with foreign suppliers.

It would be difficult to predict what effect any particular requirement imposed by a procurement law might have on the leasing of oil or facilities. 57/ Firms accustomed to contracting with the Government may already have in place processes for meeting certain requirements such as small business and small disadvantaged subcontracting plans, drug-free workplace programs, submission of cost or pricing data, and certifications regarding procurement integrity. Other potential contractors will not.

\section{a. Clauses Based In Statute or Executive Order}

Subcontracting with Small Business and Small Disadvantaged Business Concerns (see 15 U.S.C. 631d et seq.), (O), (F).

\section{Labor Laws:}

Convict Labor Act (18 U.S.C. 4082(c)(2) and E.O. 11755), (F).

Contract Work Hours and Safety Standards Act (40 U.S.C. 327 -333), (F).

Davis - Bacon Act (40 U.S.C. 276a - 276a-7).

Miller Act (40 U.S.C. 270a -270d).

Copeland (Anti-Kickback) Act (18 U.S.C. 874 and 40 U.S.C. 276a).

Walsh-Healey Public Contracts Act (41 U.S.C. 35 - 45), (O).

Equal Employment Opportunity (E.O. 11246), (O), (F).

56/ "F.o.b." means "free on board" at a named place, which may be the place of shipment or the place of destination. "C.i.f." means that the price includes in a lump sum the cost of the goods and the insurance and freight to the named destination, but with title and risk of loss passing to the buyer upon shipment. Oil industry usage commonly refers simply to "f.o.b." origin, and employs the acronym "c.i.f." where the transaction technically is "f.o.b. destination."

57/ Agencies occasionally are expressly authorized by statute to waive otherwise applicable procurement laws and regulations in certain circumstances. For example, the Secretary of Energy is authorized to exchange the United States' share of petroleum produced from the Naval Petroleum Reserves, directly or indirectly, for other petroleum to be placed in the SPR "under such terms and conditions and by such methods as the Secretary determines to be appropriate, without regard to otherwise applicable Federal procurement statutes and regulations." (Emphasis added). 10 U.S.C. $7430(\mathrm{k})(1)(\mathrm{B})$. See also section 303(b) of the Defense Production Act of 1950, 50 U.S.C. App. 2093(b). Cf. section 633 of the Foreign Assistance Act of 1961, 22 U.S.C. 2393. 
Service Contract Act of 1965, as amended (41 U.S.C. 351 et seq.), (F).

Fair Labor Standards Act (29 U.S.C. 201 et seq.), (F).

Vietnam Era Veterans Readjustment Assistance Act of 1972, as amended (38 U.S.C. 2012) and Executive Order 11701), (O), (F).

Rehabilitation Act of 1973, as amended (29 U.S.C. 793) and Executive Order 11758, (O). Anti-Kickback Act of 1986 (41 U.S.C. 51 - 58), (O), (F).

Drug Free Workplace Act of 1988 (Public Law No. 100-690, 41 U.S.C. 701 et seq.), (O), (F).

Comptroller General Examination of Records (41 U.S.C. 254(C), 10 U.S.C. 2313(b)), (O), (F).

Cost or Pricing Data (Public Law No. 98-369, 41 U.S.C. 254(D)), (O), (F).

Procurement Integrity (41 U.S.C. 423), (O), (F).

Contract Disputes (42 U.S.C. 601 et seq.), (O), (F).

Officials not to Benefit (41 U.S.C. 22), (O), (F).

Clean Air and Water (41 U.S.C. 7401 et seq.; 33 U.S.C. 1251 et seq.), (F).

National Environmental Policy Act of 1969 (NEPA) (42 U.S.C. 4321 et seq.), (O), (F).

Cargo Preference (46 U.S.C. 1241(b)), (O).

Buy American (41 U.S.C. 10 and Executive Order 10582).

Women-Owned Small Business (Executive Order No. 12138), (O), (F).

Covenant Against Contingent Fees (41 U.S.C. 254(a), (O), (F).

Restrictions on Subcontractor Sales to the Government (Public Law 98-577 and 41 U.S.C. $253(\mathrm{~g}))$.

Sanctions for Violations of Export Controls (Public Law No. 100-418 and Executive Order 12661), (O), (F).

\section{b. Clauses Based in Regulation}

Professional Employment Compensation, (FAR 22.11; FAR 52.222-45), (F).

Cost Accounting Standards (50 U.S.C. App. 2168), (O). 
Contract Termination, (FAR 49.5; FAR 52.249-2; FAR 52.249-11), (O).

Audit Requirements, (FAR 15.106-2; FAR 52.215-2), (O).

Labor Surplus Area Concerns, (FAR Part 20; FAR 52.220-3; FAR 52.220.4; FAR 20.302), (O).

Protests Before and After Award (31 U.S.C. 3551), (O).

Prompt Payment and Interest Payments, (FAR 32.902; FAR 52.232-23; FAR 52.232-25), (O), (F).

Subcontracting with Debarred or Suspended Contractors, (FAR 9.404; FAR 52.209-6), (O).

Assignment of Claims, (FAR 32.8; FAR 52.232-23), (O).

Printing (44 U.S.C. 501), (O).

\section{Dispute Resolution}

One of the required contract clauses listed above is that concerning contract disputes. Pursuant to the Contract Disputes Act of 1978 (CDA), 41 U.S.C. 601 et seq., disputes and claims relating to most Government procurement contracts are subject to a dispute resolution process that involves: (a) a written decision by the Government Contracting Officer; (b) contractor appeal rights to either (i) the agency's board of contract appeals or (ii) the U.S. Claims Court; and (c) appeal rights to the Court of Appeals for the Federal Circuit. 41 U.S.C. 605, 606 and 607. The CDA applies to any express or implied contract entered into by an executive agency for:

(1) the procurement of property, other than real property in being;

(2) the procurement of services;

(3) the procurement of construction, alteration, repair or maintenance of real property; or,

(4) the disposal of personal property. (41 U.S.C. 602(a))

The issue of dispute resolution arose when the DOE first negotiated an oil supply agreement with Mexico's state oil company, Petroleos Mexicanos (PEMEX), in 1981. The compromise solution then arrived at, which has been contained in all four of the DOE's contracts with PEMEX since that time, was dispute resolution by the DOE's Board of Contract Appeals, but with Mexican law to be applied by the Board. In fact, it thus far has not proved necessary for any dispute arising under these four contracts to be decided by the Energy Board of Contract Appeals.

It would appear that both an oil lease and an oil storage lease would be subject to the CDA and thus should include a "Disputes" clause, which sets out the decision-making and appeal processes. The standard "Disputes" clause prescribed by the Federal Acquisition Regulation (FAR), however, being a requirement of regulation but not of law, could be altered by obtaining a deviation. See FAR Subpart 1.4. 
Among the limited exceptions $\underline{58}$ from the Act's applicability are contracts with a foreign government or agency thereof, or international organization or subsidiary body thereof, if the agency head determines that the application of the Act to the contract would not be in the "public interest." 41 U.S.C. 602 (c). "Public interest" is not defined or interpreted in the Act or the implementing regulations.

Were such a finding to be made with respect to a lease agreement with a foreign government, a question could arise whether to agree to arbitrate disputes. Commercial entities often stipulate to the submission of contractual disagreements to arbitration and agree by contract as to the method of selecting the arbitrators in an effort to avoid the time and expense of litigation or to ensure expertise in a particular field. With respect to claims against the Federal Government, the general rule historically adhered to by the Comptroller General is that, in the absence of specific statutory authority, a Federal Government agent is not free to submit to arbitration controversies to which the Government is a party. 32 Comp. Gen. 333 (1953). This prohibition has been based, in part, on the agent's lack of authority to settle or compromise certain types of disputes, the express legislative grant of arbitration authority to some agencies, and the lack of authority to settle claims against the Government for unliquidated damages. Id., citing, inter alia, 33 Op. Atty. Gen. 354 (1922). This rule did permit a contract arbitration provision where no question of legal liability was involved; where the determination was one of fact; and where the determination provided for did not have the effect of imposing additional obligations upon the Government. 22 Comp. Gen. 140 (1942); 20 Comp. Gen. 95 (1940).

The General Accounting Office's rule against binding arbitration has been criticized both before and after passage of the CDA which, for the first time, provided an express statutory basis for the administrative process of dispute resolution for Government contracts. $\underline{59}$ Furthermore, the U.S. Claims Court has stated that agreements which provide for non-binding alternative resolution proceedings, prior to a final decision by the Contracting Officer, are not inconsistent with the CDA. OSHCO-PAE-SOMC v. United States, 8 FPD 49 (Cl. Ct. 1989), citing Mayflower Construction Co. v. United States, 841 F.2d 1576, 1578 (Fed, Cir.), cert. denied, 109 S.Ct. 528 (1988).

\section{Cargo Preference Requirements}

The Cargo Preference Act (section 901(b) of the Merchant Marine Act, 1936, as amended), 46 U.S.C. 1241(b), provides that

(1) Whenever the United States shall procure, contract for, or otherwise obtain for its own account, ... any equipment, materials, or commodities, within or without the United States, . . . the appropriate agency or agencies shall take such steps as may be necessary and practicable to assure that at least 50 per centum of the

58/ Certain maritime and Tennessee Valley Authority contracts are excepted from coverage under the Act. See 41 U.S.C. 602(b) and 41 U.S.C. 603.

59/ See, e.g., Harter, "Points on a Continuum: Dispute Resolution Procedures and the Administrative Process," reprinted in, Administrative Conference of the United States, Sourcebook: Federal Agency Use of Alternative Means of Dispute Resolution 309 (1987). 
gross tonnage of such equipment, materials, or commodities . . . which may be transported on ocean vessels shall be transported on privately owned United States-flag commercial vessels, to the extent such vessels are available at fair and reasonable rates for United States-flag commercial vessels, in such manner as will insure a fair and reasonable participation of United States-flag commercial vessels in such cargoes by geographic areas: Provided, That the provisions of this subsection may be waived whenever the Congress by concurrent resolution or otherwise, or the President of the United States or the Secretary of Defense declares that an emergency exists justifying a temporary waiver of the provisions of this paragraph and so notifies the appropriate agency or agencies. ...

(2) Every department or agency having responsibility under this subsection shall administer its programs with respect to this subsection under regulations issued by the Secretary of Transportation. The Secretary of Transportation shall review such administration and shall annually report to the Congress with respect thereto.

The implementing regulations of the Maritime Administration (MarAd) of the Department of Transportation, 46 C.F.R. Part 381, require each responsible department or agency to prescribe staff instructions or regulations providing for ocean vessel cargoes to be divided "in such a manner as to yield to the U.S.-flag vessels freight revenue per long ton at least equal to the freight revenue per long ton afforded the foreign-flag vessels participating in the same ... purchase transaction." 46 C.F.R. 381.4. The regulations further provide:

Each department or agency having responsibility under the Cargo Preference Act of 1954 shall cause each full shipload of cargo subject to said act to be fixed on U.S.-flag vessels for at least that portion of all preference cargoes required by that Act to be shipped on U.S.-flag vessels, computed by purchase authorization or other quantitative unit satisfactory to the agency involved and the Maritime Administration, except where such department or agency determines, with the concurrence of the Maritime Administration, that (a) U.S.-flag vessels are not available at fair and reasonable rates for U.S.-flag commercial vessels, or (b) that there is a substantially valid reason for fixing foreign-flag vessels first. (Section 381.5)

By agreement between the DOE and the MarAd, the SPR's Cargo Preference Act compliance is measured in overall long ton miles during the course of each calendar year. Historically the Act's provision for compliance "by geographic areas" has not been strictly enforced by the MarAd in the SPR program. Generally, the transportation of oil cargoes that has occurred prior to the purchase of those cargoes on the spot market for the SPR is included in Cargo Preference Act computations. In addition, foreign-flag ton miles of transportation are included in the calculations in cases where U.S.-flag vessels were solicited but proved unavailable at fair and reasonable rates, necessitating the use of the foreign-flag vessels. 
In order to assure Cargo Preference Act compliance, competitive SPR oil solicitations issued in past years by the Defense Fuel Supply Center commonly included a provision giving preference to reasonable U.S.-flag transportation offers and f.o.b. origin supply offers over offers for foreign-flag deliveries. In recent years the DOE's offshore oil purchases have been exclusively on an f.o.b. origin basis from Mexico's state oil company Petroleos Mexicanos, thus enabling the DOE; through the Military Sealift Command, to arrange for 50 percent utilization of U:S.-flag vessels.

The Cargo Preference Act applies "whenever the United States shall procure, contract for, or otherwise obtain" goods, such as oil, "for its own account." No distinction is made between the acquisition of those goods through lease and their acquisition by purchase, nor does it matter whether the goods are for use or storage within or outside the U.S.

The application of the Cargo Preference Act's 50 percent U.S.-flag requirement magnifies differentials that exist between the costs of long-haul and short-haul oil deliveries to the SPR. The following illustrates recent cost differences between spot market U.S.- and foreign-flag tankers, for likely vessel sizes and routes from various lifting points to the existing SPR storage sites in the Gulf Coast:

\begin{tabular}{|c|c|c|}
\hline From & Foreign-FlagU.S.-Flag & \\
\hline Mexico & $\$ .39$ & $\$ .54$ \\
\hline Venezuela & .74 & 1.14 \\
\hline North Sea & 1.13 60/ & 1.78 \\
\hline West Africa & 1.24 & 1.97 \\
\hline Persian Gulf & 1.52 60/ & 2.46 \\
\hline
\end{tabular}

On the other hand, compliance with the Cargo Preference Act's 50 percent U.S.-flag standard is not an absolute requirement under all circumstances. In a September 15, 1983, legal opinion addressed to the Secretary of Energy and the Secretary of Transportation, the Assistant Attorney General, Office of Legal Counsel, Department of Justice, advised as follows:

We believe it is clear that the Act does not impose an absolute duty on federal agencies to ship the cargo of a particular program (or of the agency) in United States-flag vessels, regardless of the availability of such vessels or of unforeseen circumstances that might prevent an agency from reaching the $50 \%$ level. An early version of [the bill which became the Cargo Preference Act] would have set $50 \%$ as a mandatory minimum compliance level, by requiring that "at least 50 per centum of the gross tonnage ... which may be transported on ocean vessels shall be transported on privately-owned United States-flag vessels." S. Rep. No. 1584, supra, at 2 (emphasis added). The bill was subsequently amended, however, to require only that agencies "take such steps as may be necessary and practicable to assure that at least 50 per centum ..." Id. (emphasis added). In discussing this amendment, Representative Butler, the sponsor of 
the bill, specifically noted that the "unequivocal provision for shipment of at least $50 \%$ of all aid or federally owned or financed cargoes was softened to require only such steps as may be reasonable and practicable to insure shipment of at least 50\% in American bottoms." 100 Cong. Rec. 8228 (June 15, 1954) (remarks of Rep. Butler). Moreover, the Act by its terms requires 50\% shipment in United States-flag vessels only "to the extent such vessels are available at fair and reasonable rates for United States-flag commercial vessels." 46 U.S.C. 1241(b).

The language of the statute, particularly when read in light of its legislative history, therefore clearly contemplates that agencies may not be able to meet the $50 \%$ level -- ie., if, despite the best efforts of the agency, it could not arrange for $50 \%$ shipment of its cargo on United States-flag vessels, or if United States-flag vessels were not available for particular shipments at fair and reasonable rates for such vessels. Therefore, we do not believe that, as a matter of law, a federal agency is required to meet an absolute $50 \%$ minimum in its shipments of cargo subject to the Cargo Preference Act. (note 20) (Emphasis in original) 


\section{F. TAXES AND FEES}

A number of different tax and tax-related issues are covered in this part, including: (1) the applicability of U.S. taxes to a foreign sovereign; (2) oil import charges; (3) Federal income tax considerations; (4) state taxes; and (5) the use of a Foreign Trade Zone or in-warehouse bonding.

\section{Applicability of U.S. Tax Laws to a Foreign Government}

It is a settled principle that a foreign sovereign is immune from taxation on premises used for diplomatic purposes. In the absence of agreement, however, international law does not require tax exemption for other property or income of a foreign state related to activities of a governmental but non-diplomatic character. 61/ A foreign government lessor of oil or facilities to the U.S. Government would not be exempt from any applicable taxes on the income derived from the lease, unless: the foreign government is specifically immune from taxation as the result of a treaty with the United States; or the leasing activity is exempt from enforcement of the tax laws under the Foreign Sovereign Immunities Act, 28 U.S.C. 1602 et seq.

\section{a. Treaty Exemptions from Tax Liability}

\section{(1) Treaties of Friendship, Commerce, and Navigation}

Friendship, Commerce and Navigation (FCN) Treaties, which are comprehensive agreements intended to provide a general framework for bilateral commerce and communication, deal with many matters beyond trade and investment, such as diplomatic and consular immunity. Because of the FCN Treaty's thorough nature, the United States recently has preferred to use Bilateral Investment Treaties (BITs) or bilateral tax treaties, which focus more narrowly on investment rights and obligations, and tax liabilities, respectively.

The precise content of the FCN Treaty has varied from era to era depending on the needs of the time, the countries involved, and foreign policy objectives. Any questions about the tax treatment provided in an FCN Treaty between the United States and a particular country only can be resolved definitively by analyzing the FCN Treaty in question. 62/ FCN Treaties sometimes include reciprocal exemption for the two countries from some taxation when consular or diplomatic personnel or property is used for diplomatic or consular purposes, but specifically prohibit an enterprise of either party, including corporations and government agencies, from claiming immunity from taxation for commercial activities within the other's territory.

Some FCN Treaties promise unconditional most-favored-natıon (MFN) treatment with respect $t u$ duties and charges affecting commerce and navigation, but they do not guarantee tax immunity.

61/ The Restatement (Third) of Foreign Relations Law of the United States (1987), Introductory Note to Subpart IV, Chapter 5, Subchapter B.

621 Individual FCN Treaties that the United States has concluded with Iraq, Japan, Norway, Saudi Arabia, Venezuela, and the United Kingdom were consulted in the preparation of this discussion. There is no FCN Treaty with Kuwait, Mexico, Nigeria, or the United Arab Emirates. 
In addition, FCN Treaties frequently reserve to each government the right to impose, on such terms as it may see fit, regulations for the enforcement of police or revenue laws. $\underline{63}$

In contrast to earlier FCN Treaties which discussed diplomatic immunities, some later FCN Treaties focus primarily on the rights of nationals of either Party in commercial activities, and require national treatment and MFN treatment for commercial transactions within the territory of the other signatory. 64/ Existing FCN Treaties might protect the signatory country against discriminatory treatment with respect to the storage of leased crude oil in the United States, but would not provide tax immunity for commercial activities.

\section{(2) Bilateral Investment Treaties}

Unlike the FCN Treaty, the BIT focuses exclusively on the encouragement and protection of investments made by nationals and companies of one party in the territory of the other party. Moreover, the BIT speaks to rights and obligations with respect to investments per se, rather than to rights and obligations with respect to nationals and companies, as in the case of the FCN Treaties. The BITs include four significant articles regarding investment: nondiscrimination with respect to both establishment and operation of investments; rights with respect to transfers associated with investments; expropriation; and mandatory dispute settlement mechanisms.

Because tax-related matters typically receive comprehensive treatment in U.S. bilateral tax treaties, almost all matters relating to taxation are excepted from the coverage of the BIT. However, most of the BITs into which the U.S. has entered provide that each party agrees that, with respect to its tax policies, it will strive to accord fair and equitable treatment to investments of nationals and companies of the other party. The reference to "fair and equitable" treatment provides a noncontingent standard, without reference to any treatment provided to others. It is intended to afford a residual, but absolute minimum, standard for investment protection. None of the BITs that the United States has concluded provides immunity from taxation for commercial activities by a foreign sovereign. $\stackrel{65 /}{ }$

63/ See, e.g., the 1933 FCN Executive Agreement between the United States and Saudi Arabia, 48 Stat. 182; and the 1928 FCN Treaty between the United States and Norway, 47 Stat. 2135.

64/ See, e.g., the 1953 FCN Treaty between the United States and Japan, 4 UST 2063; TIAS 2863; 206 UNTS 143.

65) BITs are in fnrre with Rangladesh, Cameroon, Grenada and Zaire. BITs with Egypt and Turkey have been approved by the Senate, but have not yet entered into force. In addition, BITs with Haiti, Morocco, Panama, and Senegal await Senate approval. 


\section{(3) Bilateral Tax Treaties}

The United States has tax treaties with only a few of the major oil producing countries, $\underline{66}$ and the bilateral tax treaty provides benefits only to residents of those signatory countries. For the purpose of preventing "treaty shopping," recently concluded treaties contain provisions designed to prevent third-country residents from taking unwarranted advantage of the treaty. For example, the Barbados treaty denies certain benefits to any person if 50 percent or less of the beneficial interest in such person is owned by a resident or citizen of the U.S. or Barbados, or if a substantial part of the income is used, directly or indirectly, to meet liabilities to persons not covered by the treaty.

Generally, bilateral tax treaties provide rules with respect to Federal taxation of various types of income. The bilateral tax treaties typically are silent concerning state and local taxation except for a requirement that the Nondiscrimination Article also should apply to taxes of every kind imposed at the national, state, or local level. Under current law, a foreign sovereign is treated in the identical manner as a corporate resident of its country, provided that such government grants equivalent treatment to the Government of the United States.

\section{b. The Foreign Sovereign Immunities Act}

For more than a century and a half, the United States generally granted foreign sovereigns complete immunity from suit in the courts of this country. Until 1952, the State Department ordinarily requested immunity in all actions against friendly sovereigns, but in the so-called "Tate Letter," $67 /$ the State Department announced its adoption of the "restrictive" theory of foreign sovereign immunity. Under this theory, immunity is confined to suits involving the foreign sovereign's public acts, and does not extend to cases arising out of a foreign state's strictly commercial acts. The restrictive theory was not at that time enacted into law, however, and its application proved troublesome since sovereign immunity determinations still were suhject tn a variety of factors, including diplomatic. In 1976, the Congress enacted the Foreign Sovereign Immunities Act (FSIA), 28 U.S.C. 1601 et seq., which codified the restrictive theory of sovereign immunity.

Under the Act, a foreign state normally is immune from the jurisdiction of federal and state courts, subject to a set of exceptions specified in 28 U.S.C. 1605 and 1607. Those exceptions include actions in which the foreign state has explicitly or impliedly waived its immunity, and any case in which the action is based upon: a commercial activity carried on in the United States by a foreign state; an act performed in the United States in connection with a commercial activity of the foreign

The United States has tax treaties with Aruba, Australia, Austria, Barbados, Belgium, Bermuda, Canada, Cyprus, Denmark, Egypt, Finland, the Federal Republic of Germany, France, Greece, Hungary, Iceland, Ireland, Italy, Jamaica, Japan, the Republic of Korea, Luxembourg, Malta, Morocco, the Netherlands, the Netherlands Antilles, New Zealand, Norway, Pakistan, the People's Republic of China, the Philippines, Poland, Romania, Sweden, Switzerland, Trinidad and Tobago, the United Kingdom, and the U.S.S.R. A number of other treaties that have been negotiated have not entered into force, either because of the Senate's (or the other Government's) failure to ratify or because instruments of ratification have not been exchanged.

67/ Letter from Jack B. Tate, Acting Legal Adviser, Department of State, to Acting Attorney General Philip B. Perlman (May 19, 1952), reprinted in 26 Dept. of State Bulletin 984-985 (1952). 
state elsewhere; or an act outside the territory of the United States in connection with a commercial activity of a foreign state elsewhere, if that act causes a direct effect in the United States.

A foreign state is defined in 28 U.S.C. 1603(a) as a "political subdivision of a foreign state or an agency or instrumentality of a foreign state as defined in subsection (b). ${ }^{168 /}$ Federal courts have found the Organization of Petroleum Exporting Countries (OPEC), the Libyan National Oil Company, and Air France to be "foreign states" for jurisdictional immunity purposes. 69 /

\section{A "commercial activity" is defined as:}

either a regular course of commercial conduct [을 $]$ or a particular commercial transaction or act. The commercial character of an activity shall be determined by reference to the nature of the course of conduct or particular transaction or act, rather than by reference to its purpose. (28 U.S.C. 1603 (c))

The focus of the commercial activity exception to foreign sovereign immunity is not on whether the defendant generally engages in commercial enterprises or activities; rather, it is on whether the particular conduct giving rise to the claim in question actually constitutes or is in connection with commercial activity, regardless of the defendant's generally commercial or governmental character.

In discussing the definition of "commercial activity" as set forth in section 1603(d), the House Report on the bill that became the Foreign Sovereign Immunities Act concluded that:

The courts would have a great deal of latitude in determining what is a "commercial activity" for purposes of this bill. It has seemed unwise to attempl an excessively precise definition of this term, even if that were practicable. Activities such as a foreign government's sale of a service or a product, its leasing of property, its borrowing of money ... would be among those included within the definition. (H.R. Rep. No. 1487, 94th Cong. 2nd Sess. 16 (1976))

68/ An "agency or instrumentality of a foreign state" is defined as any entity that is (1) a separate legal person, corporate or otherwise, (2) an organ of a foreign state or political subdivision thereof, or a majority of whose shares or other ownership interest is owned by a foreign state or political subdivision there, and (3) neither a citizen of a State of the United States . . nor created under the laws of any third country.

International Ass'n of Machinists, etc. v. OPEC, 649 F.2d 1354 (9th Cir. 1981); Carey v. National Oil Corp., 592 F.2d 673 (2nd Cir. 1979); American Bonded Warehouse Corp. v. Compagnie Nationale Air France, 653 F.Supp. 861 (N.D.I11. 1987).

70/ The "regular course of commercial conduct" includes the carrying on of a commercial enterprise such as a mineral extraction company, an airline or a statc trading corporation. H.R. Rep. No. 1487, 94th Cong., 2nd Sess. 16 (1976). 
If a foreign government or its agent, such as a state oil company, leases oil or facilities to a private party within the United States, the leased oil and facilities potentially would be subject to taxation by state and local governments according to applicable law. Foreign sovereign immunity is unlikely to be available for such commercial activity. Similarly, it appears that under most circumstances the leasing of oil or facilities for profit by a foreign sovereign or its agent to the United States Government for placement in the Strategic Petroleum Reserve would be considered a commercial activity. $\underline{71}$

\section{Oil Import Charges}

Subject to certain exceptions, imported crude oil that was leased to the DOE for, or otherwise stored in the SPR, would be subject to U.S. customs duties, taxes to support the Hazardous Substance Superfund and the Oil Spill Liability Trust Fund, a Customs Services user fee, and a harbor maintenance fee. Throughout the history of SPR oil acquisition, all such charges, to the extent applicable, have been paid by the DOE rather than heing paid by an oil supplier and reflected in the purchase price to the DOE.

\section{a. Customs Duties}

Most crude oil imported into the "customs territory of the United States" $\underline{72}$ presently is subject to customs "column 1" duties of 5.25 cents per barrel on heavy crude oil (testing under 25 degrees A.P.I.) and 10.5 cents per barrel on lighter crude oils (testing 25 degrees A.P.I. or more), $\underline{73}$ payable by the importer of record at the time of the arrival of the importing vessel within a customs port. ${ }^{74 /}$ Customs duties are collected by Customs Service District Directors in charge of

71. Cf. Castro v. Saudi Arabia, 510 F.Supp. 309 (W.D. Tex. 1980), where the court upheld sovereign immunity, finding that a non-profit contract to train a foreign government's military personnel in the U.S. was not commercial activity.

General Note 2 to the Harmonized Tariff Schedule of the United States (HTS), 19 U.S.C. preceding 1202 note, defines the "customs territory of the United States" as "only the States, the District of Columbia, and Puerto Rico."

73/ Subheadings 2709.00.10 and 2709.00.20, respectively, of the HTS. The HTS contains two "Rates of Duty" columns, numbered 1 and 2. Column 2 rates of duty were enacted by the Tariff Act of 1930 and apply to imports from certain designated Communist countries that have been denied "Most-Favored-Nation" (MFN) status by the U.S. Column 2 rates of duty on petroleum range from 21 cents per barrel for crude oil to $\$ 1.05$ per barrel for certain refined products. Column 1 rates of duty are the lowest concessional rates of duty, which have been set through reductions of the full statutory rates in negotiations with other countries, and they are applicable to imports from countries that have been extended MFN trade treatment by the U.S., which includes most crude oil exporting countries.

74/ With the exception of a small amount of Maya crude oil from Mexico, which tests approximately 22 degrees A.P.I., all of the various types of crude oil stored in the SPR test 25 degrees A.P.I. or more. To date, all of the foreign origin crude oil in the SPR has been imported from producing countries entitled to "column 1 " rates 'of duty. 
ports of entry. There is no exemption for petroleum imports by or on behalf of the U.S. Government. $\frac{75 /}{1}$

Foreign crude oil that is brought into a Foreign Trade Zone (FTZ) established under the Foreign Trade Zones Act, 19 U.S.C. 81a et seq., for storage therein and which subsequently is transported to a foreign destination is not subject to customs duties. 19 U.S.C. 81c. But foreign crude oil sent from an FTZ into the customs territory of the United States is subject to customs duties. Foreign crude oil brought into a "deepwater port," e.g., the Louisiana Offshore Oil Port (LOOP), licensed under the Deepwater Port Act of 1974 (DPA), $76 / 33$ U.S.C. 1501 et seq., is exempt from customs duties unless it subsequently is entered into the customs territory of the United States. 33 U.S.C. 1518(d); see also Customs Service Decision 79-35, Control No. 5864 M, Oct. 13, 1978 77/. If SPR storage facilities were to be located in an FTZ, foreign crude oil that is brought into such facilities and which is not subsequently entered into the customs territory of the United States would be exempt from customs duties. However, foreign crude oil that was offloaded at the LOOP's deepwater port facilities and transported by pipeline to SPR storage located in the LOOP storage caverns would be subject to customs duties.

\section{b. Hazardous Substance Superfund and Oil Spill Liability Trust Fund Taxes}

Section 4611 of the Internal Revenue Code, 26 U.S.C. 4611, imposes separate taxes on domestic crude oil and on foreign crude oil imported into the United States or brought into an FTZ or a deepwater port, to finance the Hazardous Substance Superfund and the Oil Spill Liability Trust Fund, respectively. The Superfund tax is 9.7 cents per barrel for both imported and domestic crude oil. The Oil Spill Liability Trust Fund tax, which is effective from January 1, 1990, through December 31, 1994, is 5 cents per barrel for both domestic and foreign crude oil. $78 /$ The taxes on domestic crude oil are payable by the operator of the refinery at which it is received and the tax on imported petroleum is payable by the importer of record. Liability for the taxes is required to be reported to the Internal Revenue Service on a calendar quarter basis, and the applicable taxes are payable at the time prescribed for filing the return.

\section{c. The Customs Services User Fee}

Crude oil imported into the customs territory of the United States is subject to a Customs Service user fee of 0.17 percent ad valorem. 19 U.S.C. $58 \mathrm{c}(\mathrm{a})(9)$. The fee is payable to the Customs Service District Director in charge of the port of entry at the time of payment of customs duties.

75) Chapter 98 of the HTS does contain exemptions from customs duties for some merchandise imported by or for the U.S. Government, including, for example, emergency war material and materials procured for the Strategic and Critical Materials Stockpile.

76/ To date, the LOOP is the only deepwater port licensed under the Act.

77/ Although the LOOP's deepwater port facilities are outside the customs territory, the existing LOOP storage caverns, which are connected by pipeline to the port facility, are within the customs territory.

78/ The Oil Spill Liability Trust Fund tax is not applicable during any calendar quarter if the Secretary of the Treasury estimates that, as of the close of the preceding calendar quarter, the unobligated balance in the Trust Fund exceeds $\$ 1$ billion. 26 U.S.C. 4611(f)(2). 
Crude oil brought into an FTZ or offloaded at the LOOP's deepwater port is not subject to the fee; however, the fee would be applicable if the crude oil ultimately were transported from the FTZ or the LOOP deepwater port into the customs territory. The fee is applicable to merchandise owned by the Federal Government, unless such merchandise is listed in Chapter 98 of the HTS as being exempt from Customs duties. As noted above, petroleum imports by or on behalf of the Federal Government are subject to customs duties.

\section{d. The Harbor Maintenance Fee}

Section 4461 of Chapter 36 of the Internal Revenue Code, 26 U.S.C. 4461, imposes a harbor maintenance fee, which is administered by the U.S. Customs Service, with respect to the loading and unloading of commercial cargo (including both domestic and foreign crude oil) at most U.S. ports. The fee is 0.04 percent of the value of the cargo; in the case of imports, the fee is payable to the Customs Service District Director in charge of the port of entry at the time of payment of customs duties.

Cargo unloaded at a port covered by the regulations and admitted into an FTZ is subject to the fee. However, the fee is not applicable to bonded commercial cargo entering the United States for direct exportation to a foreign country. 26 U.S.C. 4462 (d)(i). The fee likewise is inapplicable to the loading or subsequent unloading of cargo that is loaded on vessels at ports in Alaska, Hawaii or a U.S. possession for shipment to the U.S. mainland for use or consumption therein, or to the loading or subsequent unloading of cargo shipped from the mainland to Alaska, Hawaii, or a U.S. possession; however, this exemption does not apply to Alaskan crude oil. In addition, the fee is inapplicable to the loading or unloading of cargoes owned by the Federal Government, provided the Government is identified on customs entry documents as the importer of record. And the implementing regulations promulgated by the Customs Service exclude LOOP from the definition of "port". 19 C.F.R. 24.24(b)(1).

\section{Federal Income Tax Considerations}

This section discusses the United States tax implications of the provision of crude oil and crude oil storage facilities by foreign persons, including oil producer countries, for use by the United States in its Strategic Petroleum Reserve.

\section{a. Determination of Character of Transaction}

The provision of storage facilities by lease, under a services contract, or in some other form, is unlikely to raise special problems of characterization. However, the provision of crude oil for Strategic Petroleum Reserve storage is an unprecedented and unique transaction, which raises

79/ This section is based on a letter dated November 28, 1989, from the Associate Chief Counsel (International) of the Internal Revenue Service (IRS) to the DOE Deputy Assistant Secretary for Petroleum Reserves, the purpose of which was to provide general information (as distinguished from an official ruling by the IRS) on the issue of the taxation of foreign and domestic corporations engaged in the leasing of crude oil or crude oil storage facilities to the U.S. Government for use in the SPR; and further, on subsequent informal discussions with that IRS office and with the offices of the IRS Assistant Chief Counsels for Income Tax and Accounting and for Financial Institutions and Products. 
difficult issues of characterization for Federal income tax purposes. The problem of characterization is an important one, because the United States tax implications will vary depending on whether a given transaction is determined in substance to be a conditional sale, a true lease, or an option (permitting the Government to buy the oil, or to sell it and then pay the provider a contractually agreed amount).

Since there are many different ways that an oil storage transaction can be structured, and an IRS determination would depend on the facts of a particular transaction, it is difficult to speak authoritatively as to the appropriate characterization. Nonetheless, what follows reflects the current views of IRS staff, based on the information contained in Chapter VI, as to how a contract for oil storage might be characterized for Federal income tax purposes.

\section{(1) Conditional Sale}

In Rev. Rul. 55-540, 1955-2 C.B. 39, the Internal Revenue Service published guidelines for distinguishing a lease from a conditional sales contract. Set forth in section 4 of that ruling are factors, based on United States Tax Court precedent, that would warrant a finding that, for Federal income tax purposes, a transaction be treated as a sale rather than a lease. The six factors most indicative of a sale are:

(a) Portions of the periodic payments are made specifically applicable to an equity interest to be acquired by the lessee;

(b) The lessee will acquire title upon the payment of a stated amount of "rentals" that, under the contract, it is required to make;

(c) The total amount that the lessee is required to pay for a relatively short perind of use (or possession) constitutes an inordinately large proportion of the total sum required to be paid to secure the transfer of the title;

(d) The agreed "rental" payments materially exceed the current fair rental value (this may indicate that the payments include an element other than compensation for the use of the property);

(e) The property may be acquired under a purchase option that is nominal in relation to the value of the property at the time when the option may be exercised, as determined at the time of entering into the original agreement, or that is a relatively small amount when compared with the total payments that are required to be made; and

(f) Some portion of the periodic payments is specifically designated as interest or is otherwise readily recognizable as the equivalent of interest.

Moreover, Rev. Rul. 55-540 provides that the fact that the agreement makes no provision for the transfer of title or specifically precludes the transfer of title does not, of itself, prevent the contract from being held to be a sale of an equitable interest in the property. Further, a 
conditional sales contract will be presumed if the total of the rental payments and any option price payable approximates the price at which the property could have been acquired by purchase at the time of entering into the agreement, plus interest and carrying charges. In addition, if the sum of the specified "rentals" over a relatively short part of the expected useful life of the property approximates the price at which the property could have been acquired by purchase at the time of entering into the agreement, plus interest and carrying charges on that amount, and the lessee may continue to use the property for an additional period or periods approximating its remaining useful life for relatively nominal or token payments, the parties are assumed (but not presumed) to have entered into a conditional sales contract (even if the agreement is silent as to the passage of title). Even if the six specific factors set out in Rev. Rul. 55-540 were not satisfied, the latter tests could suggest that a given transaction was a conditional sale.

Additional guidance as to whether a transaction is a sale or lease has been provided by the Tax Court. Among the factors considered to be relevant by the Tax Court are: whether legal title has passed; whether an equity. interest in the property was acquired as a result of the periodic payments; whether the contract creates present obligations on the part of the purchaser to make payments and on the part of the seller to deliver a deed; who has a right of possession to the property; which party pays taxes on the property; which party bears the risk of loss or damage to the property; and which party receives the profit from the sale, operation, or retention of the property. See Grott \& McKay Realty, Inc. v. Commissioner, 77 T.C. 1221 (1981).

\section{(2) Lease}

Under the general tax principles of Rev. Rul. 55-540, and its progeny, in order for a transaction to be considered a true lease, the lessor must have an equity investment, based on a percentage of the cost of the property, at the time the transaction was entered into and at all times throughout the life of the agreement. Additionally, the lessor must demonstrate that the property has a residual value at the end of the lease in relation to the cost of the property (without adjustment for inflation or deflation) at the beginning of the lease term, and must show a remaining useful life of the property. The lease term includes all renewal or extension periods, except renewals or extensions at the option of the lessee at fair rental value at the time of such renewal or extension.

A lease implies that the leased property is capable, at a minimum, of use during the period of possession, without change or destruction of the essential character of the property. In the case of a consumable commodity such as petroleum, if it is actually used during the period of possession (for example, by refining or consumption), the petroleum changes its physical characteristics so greatly that it would have neither a useful life nor a residual vale at the end of the lease. A further characteristic of a lease is that the lessee must not have a contractual right to purchase the property from the lessor at a price less than its fair market value at the time the right is exercised (that is, there can be no cap or ceiling in the purchase price option).

The oil "lease" discussed in Chapter VI thus does not seem, in most of the forms conceptualized there, to be a true lease for Federal income tax purposes. 


\section{(3) Option}

An option is a contract sold for a price, that gives the holder the right to buy or sell from or to the writer of the option, over a specified period, a specified property at a specified price. See Rev. Rul. 58-234, 1958-1 C.B. 279, 280-81. Central to classification as an option is the element of future performance: here, the future purchase of the oil by the United States (or, what in substance amounts to the same thing, the Government's sale of the oil, using the sales proceeds to liquidate the contract). In a lease, payments represent the value of the current use of the property. An option payment, by contrast, is made in consideration of the right to purchase the property at a future date. In this instance, the United States would be paying for the right, should it so choose, to purchase the oil at a future date. The concept would not contemplate current use of the oil while in storage, nor need it include an obligation to purchase the oil in the future.

Because of the absence of current use, many forms of the conceptualized "lease" structure appear to resemble more closely an option than a true lease, for Federal income tax purposes. Although the oil is in the physical custody of the United States, this custody confers no right of current use, but rather appears only to assure that the right to purchase the oil by the United States, should the option be exercised, will not be jeopardized.

Serious consideration also must be given to the transaction's possible status as an option rather than as a conditional sale. As described in Chapter VI, many of the conceptualized "lease" structures do not provide for the transfer of any equity interest in the crude oil or the creation of an obligation on the part of the United States to purchase such oil, as would occur in a conditional sale. Such arrangements are instead typical of an option, whereby the equity interest is transferred only after payment of the purchase price, and the grantee is under no obligation to exercise the option to purchase the commodity.

\section{b. United States Taxation of a Domestic Corporation}

Any United States domestic corporation (including a domestic subsidiary of a foreign corporation) that sells crude oil, regardless of the country of extraction, to the United States Government will be subject to United States income tax on the net income from the sale at the general corporate income tax rates set forth in section 11 of the Internal Revenue Code (as augmented by the alternative minimum tax of section 55 of the Code or the alternative tax for corporations of section 1201(a), if applicable) ("net basis taxation"). In addition, pursuant to section 59A, the United States imposes an environmental tax equal to 0.12 percent of the excess of the modified alternative minimum taxable income of the corporation for the taxable year over $\$ 2,000,000$. Both the alternative minimum tax of section 55 and the environmental tax of section 59A apply, generally, to taxable years beginning after December 31, 1986.

Part of the proceeds from the sale of crude oil will be recharacterized as an interest equivalent amount called original issue discount (OID), if the obligation issued in the sale does not bear stated interest at least equal to a market measure of interest called the applicable Federal rate (AFR). See sections 483(d)(1) and 1274 of the Code. There are three AFRs, for short-tcrm (i.e., not over three years), mid-term, and long-term (ie., over nine years) obligations. Each of the AFRs is an average of the original yields of recent Federal borrowings of comparable terms. See section 1274(d) of the Code. The OID rules are not applicable to lease or option transactions. 
In the case of a sale, the imputed OID amount, in addition to any gain on the sale, will also be subject to net basis taxation.

Domestic corporations will be subject to the same net basis taxation if they lease crude oil and crude oil storage facilities to the United States Government.

Under section 1234(b) of the Code, the grantor of an option to buy a commodity is not taxed on the premium paid by the purchaser of the option at the time of the premium's receipt by the grantor. Instead, the premium is accounted for when the option lapses, is repurchased by the grantor, or is exercised. If the option lapses, the premium is taken into income by the grantor on the date of the lapse, generally as short-term capital gain. If the option is repurchased by the grantor, the difference between the repurchase price and the premium received is taken into income at the time of the repurchase, generally as short-term capital gain or loss. If the option is exercised, resulting in a sale by the grantor of the underlying commodity, the premium increases the amount realized by the grantor upon the sale of the commodity in determining gain or loss.

\section{c. United States Taxation of a Foreign Corporation}

The income earned by a foreign corporation within the United States, depending on the type and characteristics of the income earned and the means which the foreign corporation uses to earn that income, may be entirely exempt from United States tax or subject:

(1) To a withholding tax on the gross income earned in the United States;

(2) To a tax on the net income effectively connected to the foreign corporation's United States trade or business; or

(3) To a tax on the net income attributable to the foreign corporation's permanent establishment within the United States.

\section{(1) Withholding Tax}

If the foreign corporation's only contact with the United States is the earning of investment type income from United States sources, that income will be subject to a 30 percent withholding tax when it is paid to the foreign corporation. This investment type income is referred to as "fixed or determinable annual or periodical income" (FDAP). See sections 881(a)(1) and 1442 of the Code. The 30 percent withholding rate may be reduced or eliminated by a bilateral income tax treaty between the United States and a foreign country if the foreign corporation is a resident of that foreign country.

The principal payments derived from the sale of crude oil are not subject to the United States 30 percent withholding tax since the income is not FDAP. See Treas. Reg. Section 1.1441-2(a)(3). Any OID is, however, although not FDAP, subject to the 30 percent withholding tax when paid since it will be U.S. source. See sections 861(a)(1), 881(a)(3) and 1442 of the Code.

The 30 percent withholding tax on OID will be eliminated if the sales instrument is a qualified portfolio debt instrument under section $881(\mathrm{c})$ of the Code or, as discussed below, if the OID is effectively connected income. 
Option lapse income, and income or loss from closing transactions (ie., from exercise of the option), are treated as short-term capital gain or loss. This is not FDAP income, and the OID rules do not apply. Thus, a foreign corporation granting a commodity option to the U.S. Government would not be subject to the 30 percent withholding of tax at source, on the gain from the lapse of an option or from a closing transaction involving options.

Rental income from the lease of crude oil and crude oil storage facilities, assuming that the crude oil is located within the United States during the term of the lease, will generally be subject to the 30 percent withholding tax since rental income is FDAP. The United States Government, as the lessee, will be required to withhold the 30 percent tax from the lease payments. See sections 861(a)(4) and 881(a)(1) of the Code and Treas. Reg. Section 1.1441-2(a)(1).

If a bilateral income tax treaty applies, the rental income from the lease of the crude oil, but not the crude oil storage facilities, and the OID, if any, on the sale of the crude oil may be subject to a reduced withholding rate. Treaties do not reduce the withholding rate with regard to rental income from the lease of real property, such as the storage facilities. Such a treaty will apply only if the foreign corporation is a resident of the foreign country that is a signatory of the treaty, and only if the corporation is not disqualified under the treaty by a limitation of benefits provision.

If the rental income is either effectively connected to the foreign corporation's United States trade or business or, if a bilateral income tax treaty applies, attributable to the foreign corporation's permanent establishment within the United States, it will not be subject to the withholding tax, but to a United States tax on the foreign corporation's net income derived from the lease. The same rules will apply to the OID.

Finally, the rental income from the lease of the crude oil may be entirely exempt from both the withholding tax and the tax on net income if that income is considered under a bilateral income tax treaty to be business profits and if the foreign corporation does not have a permanent establishment to which the income is attributable. See Rev. Rul. 86-156, 1986-2 C.B. 297.

The concepts of effectively connected income, permanent establishment and business profits will be discussed more thoroughly below.

\section{(2) Net Income Effectively Connected to a United States Trade or Business}

\section{(a) General provisions}

Although not subject to a withholding tax, the income earned by a foreign corporation from the sale of, or an option on, the crude oil may be subject to the same net basis taxation and income tax rates that apply to United States domestic corporations if that income is effectively connected to the foreign corporation's trade or business within the United States. See section 882 of the Code.

The phrase "trade or business within the United States" is defined, in part, in section 864(b) of the Code and in Treas. Reg. Section 1.864-2. Determination of what constitutes a trade or business is a question of fact and turns generally on whether the foreign corporation is engaged in regular commercial activities. The exception at section $864(\mathrm{~b})(2)(\mathrm{B})$ of the Code that trading in 
commodities through a resident broker, commission agent, custodian, or other independent agent or trading for the foreign corporation's own account, will not constitute a trade or business within the United States does not apply to the sale of crude oil held in inventory. See Treas. Reg. Section 1.864-2(d)(3).

The phrase "effectively connected income" is defined in section 864 (c) of the Code and in Treas. Reg. Sections 1.864-3 through 1.864-7. All income earned by a foreign corporation that has a trade or business in the United States that is sourced within the United States, other than FDAP and OID, will be considered to be effectively connected to the foreign corporation's United States trade or business. United States source FDAP and OID will also be considered to be effectively connected to the foreign corporation's United States trade or business if that income is derived from assets used in or held for use in the conduct of the trade or business or if the activities of the trade or business are a material factor in the realization of the income. See section 864(c)(2). In addition, foreign source income from the sale of inventory property will be considered to be effectively connected to a foreign corporation's United States trade or business if that foreign corporation has an office or other fixed place of business within the United States that participates materially in the production of the income and the office or fixed place of business regularly carries on activities of the type from which such income is derived. See section 864(c)(4)(B)(iii) and (5)(B). An office of an agent will not be considered an office of the foreign corporation unless the agent is a dependent agent with authority to negotiate and conclude contracts in the name of the foreign corporation. See section 864 (c)(5).

In the case of affiliated or otherwise related corporations, where one corporation clearly is engaged in a trade or business within the United States, but an affiliated corporation is not, the IRS does not consider the income of the second corporation to be effectively connected income simply by virtue of its relation to the first corporation, as long as the corporate entities are kept separate.

All of the income from the sale consummated within the United States of crude oil held in inventory by a foreign corporation will be considered United States source income unless the foreign corporation was also involved in the extraction of that crude oil. See section 861(a)(6) of the Code and Treas. Reg. Section 1.861-7. The sale will be consummated within the United States if the rights, title, and interest of the foreign corporation in the crude oil are transferred to the United States Government in the United States or if the substance of the sale occurs in the United States. See Treas. Reg. Section 1.861-7(c). If, however, the foreign corporation has extracted the crude oil in a foreign country and merely sold the crude oil to the United States Government in the United States, the current regulations provide that all or a portion of the income earned on the sale will not be United States source income. See Treas. Reg. Section 1.863-6 and Rev. Rul. 67-194, 1967-1 C.B. 183. This exception probably would not be available to a wholly owned subsidiary of the foreign corporation which extracted the crude oil.

If a crude oil supply option ultimately is exercised, resulting in a sale by the grantor of the underlying commodity, payments for the option will be sourced in the same country as the income from sale of the crude oil. If, however, the option lapses without exercise, the rules governing the source of the option payments are not necessarily the same for the case where a foreign corporation extracted, in a foreign country, the crude oil subject to the option, and the case where a foreign corporation did not so extract the oil. In the former case, the option payments are unlikely to be United States source income. But it is unclear whether or not the option payments would be United States income in the latter case. 
If income derived by a foreign corporation from real property located in the United States, or from any interest in that real property, is not income effectively connected with the conduct of a trade or business within the United States under the statutory rules discussed above, the foreign corporation may, nonetheless, elect such treatment. See section 882(d) of the Code. This election may be revoked only with the consent of the Internal Revenue Service. The election will be beneficial if the applicable deductions (for example, the depreciation deduction) exceed the gross income from the rental or substantially reduce the income that would be subject to net basis taxation.

Finally, if property used by a foreign corporation in its United States trade or business is disposed of within ten years from the last date on which the property was used in the trade or business, income realized from that disposition will be income effectively connected to the foreign corporation's United States trade or business even if the foreign corporation is not engaged in such a trade or business during the year of disposition. See section 864(c)(7) of the Code. Section 897 provides, further, that the income from the sale of a real property interest, such as the crude oil storage facilities, will always be income effectively connected to a United States trade or business. See Treas. Reg. Section 1.897-1(b)(3).

If a foreign corporation is determined to be engaged in a trade or business within the United States, in addition to the net income tax on the foreign corporation's effectively connected income, the United States imposes, pursuant to section 884(a) of the Code, a 30 percent branch profits tax on all of the foreign corporation's effectively connected income to the extent that the income is not reinvested in the foreign corporation's United States trade or business. Also, a 30 percent branch level interest tax is imposed by section 884(f) on interest paid (or treated as having been paid) by the branch to foreign recipients. Certain types of interest are exempt under the Code. In addition, nearly all bilateral income tax treaties to which the United States is a signatory reduce the rate of the branch-level interest tax and exempt qualified residents of the other signatory country from the branch profits tax. A foreign corporation will be a qualified resident of a foreign country if it meets both a stock ownership test and an income use test. Congress has directed that the Department of the Treasury seek to renegotiate treaties to permit imposition of the branch profits tax.

A further consequence to a foreign corporation if its income is determined to be income effectively connected to its trade or business in the United States is that the alternative minimum tax of section 55 of the Code will apply to that effectively connected income. The environmental tax of section 59A will also apply to the effectively connected income of the foreign corporation.

\section{(b) Sale of Crude Oil}

From the preceding discussion, it is apparent that the determination of whether a foreign corporation's income from the sale of crude oil (including OID) will be subject to a United States tax on a net basis because it is income effectively connected to a United States trade or business is a multiple step process. If it is determined that the foreign corporation is not engaged in a United States trade or business, none of the income from the crude oil sale will be subject to net United States taxation (or, as explained above, other than imputed OID, to the United States withholding tax). If the foreign corporation is so engaged, however, income (including any OID) from the sale of the crude oil that is effectively connected to the United States trade or business 
will be subject to the United States net taxation (and, in addition, if applicable, to the branch tax, the branch-level interest tax and the environmental tax).

Whether the income from the sale of the crude oil is effectively connected income turns, in large part, on the source of the income. If the foreign corporation is selling crude oil that it purchased, the income from the sale will be effectively connected income if the substance of the sale takes place within the United States since that income will be United States source. If the foreign corporation is selling crude oil that it extracted in a foreign country, a portion and possibly all of the income from the sale will likely be foreign source income and will not be effectively connected income unless an office of the foreign corporation located in the United States participated materially in the production of the income from the sale. This is true even if the foreign corporation is otherwise engaged in a United States trade or business, such as providing, in the United States, crude oil storage facilities to others. Finally, any OID on the sale will be effectively connected income only if it is derived from assets used in or held for use in the conduct of the foreign corporation's U.S. trade or business, or if the activities of that trade or business are a material factor in the realization of that OID income.

\section{(c) Option to Purchase Crude Oil}

Much of what has been said above concerning the sale of crude oil applies here also. The determination of whether option payments are subject to a United States tax on a net hasis depends on whether that income is effectively connected to a United States trade or business. Unless a foreign corporation is in the business of selling options in the U.S., the option income of that corporation from crude oil extracted by it in a foreign country probably will be foreign source income and not effectively connected income, unless a U.S. office of the foreign corporation participated materially in the production of the income.

Should the foreign corporation be engaged in a U.S. trade or business, however, through a lease of crude oil facilities or other activities, the net tax (and, potentially, the branch tax, the branchlevel interest tax and the environmental tax) will apply to option payment income if it is effectively connected to the trade or business.

Nonetheless, as pointed out earlier, qualifying sales income of a corporation that extracted crude oil in a foreign country will not be U.S. source income, and option payments would be similarly treated. This likewise is true even if the foreign corporation is otherwise engaged in a United States trade or business, such as providing, in the United States, crude oil storage facilities to others.

\section{(d) Lease of Crude Oil}

A multi-step analysis is required to determine whether the rental income from the lease of crude oil will be subject to a United States tax on a net basis. The first step is to determine whether the lease by the foreign corporation of the crude oil, alone or in conjunction with the lease of crude oil storage facilities or other activities of the foreign corporation, constitutes a trade or business of the foreign corporation within the United States.

If the foreign corporation does not have an office in the United States and does not have employees in the United States who will negotiate the lease of the crude oil, it is unlikely that the 
lease of the crude oil itself will constitute a trade or business within the United States. The gross rental income from the lease of the crude oil will be subject, therefore, assuming no treaty applies, to the United States 30 percent withholding tax.

If the foreign corporation is engaged in a United States trade or business either through the lease of the crude oil storage facilities or through other activities, the rental income derived from the lease of the crude oil may be subject to the net tax (and, if applicable, to the branch tax, the branch-level interest tax and the environmental tax) if it is income effectively connected to that trade or business. Since the rental income will be FDAP, it will be income effectively connected to the trade or business of the foreign corporation only if it is derived from assets used in or held for use in the conduct of the trade or business or if the activities of the trade or business are a material factor in the realization of that rental income.

Should the income from the lease be income effectively connected to a United States trade or business, income from its subsequent sale will be effectively connected if the sale takes place within ten years from the date the crude oil ceased being used in the trade or business.

\section{(e) Lease of Crude Oil Storage Facilities}

The same analysis applies with respect to the rental income from the lease of the crude oil storage facilities except that it is more likely that the lease itself may constitute a trade or business. It will not constitute a trade or business, however, if the responsibility for the management, operation, and maintenance of the storage facilities are assumed by the lessee, the United States Government. Cf. Rev. Rul. 73-522, 1973-2 C.B. 228. In addition, since the crude oil storage facilities will be a real property interest, income from the disposition of that interest will be, pursuant to section 897 , income effectively connected to a United States trade or business regardless of whether the foreign corporation is so determined during the term of the lease.

\section{(3) Net Income Attributable to the Foreign Corporation's Permanent Establishment within the United States}

If the foreign corporation is a resident of a country that is a signatory to a bilateral income tax treaty with the United States, the net taxation scheme of section 882 will be replaced by a similar net taxation scheme set forth in the treaty. This variation will apply to the business profits (in older treaties, industrial or commercial profits) of the foreign corporation that are attributable to that corporation's permanent establishment in the United States.

The term "permanent establishment" ordinarily includes a place of management, a branch, an office, a factory or a mine or other similar fixed place of business. However, a permanent establishment may also exist if a foreign corporation engages a dependent agent and if the agent has and habitually exercises a general authority to negotiate and conclude contracts on behalf of the foreign corporation. A permanent establishment will not exist if a foreign corporation carries on business in the United States through an independent agent acting in the ordinary course of its business.

The term "business profits" is defined in most treaties to mean income derived from a trade or business. Many treaties specifically include as business profits income from the rental of tangible personal property. Rental of crude oil would presumably be included. 
The term "attributable to" is similar to but not as inclusive as the "effectively connected" concept in section 864(c). As discussed above, under section 864(c)(3), any United States source income of the foreign corporation, other than FDAP, will be income effectively connected to the foreign corporation's United States trade or business (and therefore, subject to a United States tax on the net income). Many treaties provide, on the other hand, that business profits with a United States source will not be attributable to the foreign corporation's permanent establishment if the permanent establishment was not engaged in the type of activity that generated that income. Accordingly, under those treaties, a foreign corporation which sells, options or leases crude oil, income from which will generally be business profits, may have a permanent establishment in the United States with regard to certain of its other business profits yet avoid net taxation on the income from the sale, option or lease of crude oil if the sale, option or lease activities of the foreign corporation are not engaged in through that permanent establishment. If business profits avoid net taxation they generally will also be exempt from the United States withholding tax. See Rev. Rul. 86-156, 1986-2 C.B. 297.

Most treaties provide that if a treaty article sets forth specific rules for the taxation of a particular type of income the specific article, and not the article dealing with business profits, will apply. One such article contained in all comprehensive income tax treaties is an article affirming the right of the source country to tax the income from immovable property or real property. Unless the treaty sets forth the taxing scheme, the Code provisions discussed above will apply to that income. Accordingly, with regard to the income earned from the lease of the crude oil storage facilities, assuming the facilities are immovable, that income will be subject to either a gross 30 percent withholding tax if a net lease or a tax on the net income if the foreign corporation is involved in the actual operation of the facilities. Treaties generally do not reduce the withholding rate on income from a net lease rental of real property. In addition, many treaties have a special provision that will allow the foreign corporation to elect (either annually or permanently) to compute the tax on a net basis even if the lease is a net lease. This election will be beneficial if the applicable deductions (for example, the depreciation deduction) exceed or substantially reduce the gross income from the rental.

\section{d. United States Taxation of a Foreign Government (Including a Controlled Entity)}

Most income earned by a foreign government (including a controlled entity) will be subject to the same United States tax treatment, both under the Internal Revenue Code and any applicable treaty, as if the income had been earned by a foreign corporation. A foreign government (including a controlled entity) will be treated as a corporate resident of its country, and therefore the treaty will apply to its income only if the foreign government grants equivalent treatment to the United States Government. See section $892(a)(3)$ of the Code.

Under the Code, certain types of income received by the foreign government (including a controlled entity) from United States sources will be exempt, however, from United States taxation. The income exempt from United States taxation is limited to the income from investments in the United States in stock, bonds, or other domestic securities or in financial instruments held in the execution of governmental financial or monetary policy or interest on deposits in banks in the United States of monies belonging to the foreign government. See section $892(\mathrm{a})(1)$. 
A "controlled entity" means any separate entity that is wholly owned and controlled by a foreign government and is organized under its laws, the income of which does not inure to the benefit of any private person and the assets of which vest in the foreign government upon dissolution. See Treas. Reg. Section 1.892-2T(a)(3).

The term "financial instruments" is defined in Treas. Reg. Section 1.892-3T(a)(4) to include any forward, futures, or options contract, swap agreement or similar instrument in a functional or nonfunctional currency or in precious metals when held by a foreign government or central bank of issue (as defined in Treas. Reg. Section 1.895-1(b)). Gold is treated as a financial instrument when it is physically held by a central bank of issue. The exception for gold is included to deal with central bank currency-management and similar financial concerns. Other physical commodities, including crude oil, do not qualify as financial instruments. In addition, the exception for gold is extremely limited. Income earned by a gold-producing country from sales of gold held in its inventory would not be exempt under section 892 since the gold would not be held in the execution of the country's financial or monetary policies.

Since the income to be earned from the option, sale or lease of the crude oil and lease of the crude oil storage facilities will not be one of the exempt types of income listed in section 892(a)(1), that income will be subject to United States taxation to the same extent as if it had been earned by a foreign corporation. With regard to the OID earned on the sale of the crude oil, several treaties will exempt that income from U.S. tax, if it is earned by the foreign government (including a controlled entity) signatory.

\section{State Tax Considerations}

Absent the United States' consent, any attempt by a state to tax the United States for property owned by or contractually provided to the United States would be unconstitutional as a violation of the Supremacy Clause of the Constitution. Thus, the United States would not be liable for state and local taxes on oil purchased or otherwise acquired (e.g., leased) by the United States and stored in the SPR. However, the lessor, option grantor, or conditional seller of that crude oil may be liable for such taxes. Leasing or conditionally selling oil to the U.S. Government, or granting it purchase options, may be considered in some states to be doing business there, which might trigger additional tax liability, such as the corporate franchise tax. In addition, states may impose a sales tax, a use tax, or a severance tax, depending upon the nature of the transaction.

With two exceptions, a person leasing or optioning crude oil or facilities to the U.S. Government would appear to be subject to applicable state and local income and property taxes. The exceptions are a lease in perpetuity, as to which the liability for property taxes would shift to the lessce, and the case where there is a particular state or Federal exemption from taxation.

This section summarizes only the tax laws of Louisiana and Texas, where the existing SPR sites are located, even though it is possible that in the future SPR oil might be stored in states other than these two.

\section{a. Louisiana}

Louisiana residents are taxed on net income from whatever source derived; corporations and nonresidents are liable for taxes on net income from sources within the state. Persons leasing 
crude oil or facilities to the U.S. Government in Louisiana, or experiencing sales of their oil stored in the state, might be liable for taxes on the income received from such transactions, even if the U.S. took possession of the leased oil outside the United States and the lessor never entered the state.

Louisiana income taxation of corporations generally conforms to Federal income tax law. "Gross income" of a corporation is defined to include the same items and the same dollar amount required by Federal law to be reported as gross income on the corporation's Federal income tax return for the same taxable year, whether or not a Federal income tax return actually is filed. La. Rev. Stat. Ann. 47:287.61 (West). Accordingly, income that is not required by Federal law to be reported as gross income on a corporation's Federal income tax return is not gross income for state income tax purposes. Any gains derived from the sale of crude oil that are exempt from Federal taxation also would be exempt from the Louisiana corporate income tax. As discussed above in Section F(3) of this chapter concerning Federal taxation, income from the rental of crude oil or facilities, or from option premiums on oil, would be reported as Federal gross income and therefore also would be subject to the Louisiana corporate income tax.

Even if the gain enjoyed by a corporation on the sale of leased crude oil is reported as Federal gross income, it will be exempt from state corporate taxation in Louisiana if the crude oil is stored in a customs-bonded warehouse or foreign trade zone (FTZ) and the sale is judged to be made "in the regular course of business." $80 /$ Then the crude oil would not be considered to be located in the State of Louisiana for purposes of taxation, $\underline{81 /}$ and would be immune from corporate taxation. There is no comparable exemption for rental or option premium income from oil stored in an FTZ.

Option premiums are not taxed by the State of Louisiana until such income is reported as gross income on a corporation's Federal income tax return. To the extent that the exercise, lapse, nr repurchase of an option results in income reported as gross income nn a corporation's Federal tax return for the same taxable year, such income will be treated as gross income for purpnses of Louisiana taxation.

If the payments on a conditional sale include OID payments which are taxed by the federal Government, such payments also may be taxed by the State of Louisiana as income allocable to Louisiana, if the payments derive from the sale, in the regular course of business, of inventory located in Louisiana.

The sale of leased or optioned crude oil from the SPR, or of SPR oil that is subject to a conditional sale contract, even if not otherwise exempt, would appear to be exempt from the state

80/ "Whether a sale or exchange is a sale 'not made in the regular course of business' is a factual determination required to be made with respect to each property sold which will take into consideration such factors as the frequency of sales of similar properties and the relationship of the particular sale to other business transacted by the taxpayer." La. Corporation Income Tax Reg. Section $1130(3)$.

81/ La. Rev. Stat. Ann. \$47:287.95H (West) provides that corporeal movable property located in Louisiana in United States customs-bonded warehouses or foreign trade zones is considered as located outside of Louisiana for purposes of computing applicable corporate taxes. 
retail sales tax: (1) under the Supremacy Clause if sold to the United States Government; or (2) as not being a "retail sale" if sold to a third party for refining. Nonetheless, leased crude oil stored in Louisiana may be subject to the state's four percent use tax, plus the local use tax (which may be as high as one and a half percent, depending upon location), which is imposed upon the use, and storage for use in the state, of tangible personal property (provided that there is no overlap with the four percent sales tax). A lessee ordinarily also is liable for a state tax on the gross proceeds of leases and rentals of tangible personal property, where the lease or rental of such property is an established business, or the same is incidental to the business; the United States Government, however, would be exempt from the tax under the Supremacy Clause of the Constitution.

It appears that the storage of crude oil that is not leased to the U.S. Government, but instead is held in inventory for potential sale, subject to an option contract, might not be considered a taxable use, since holding inventory for potential sale is not a taxable use. However, it also appears possible that crude oil subject to an option contract might be taxed if it was considered to have been withdrawn from interstate commerce and to have become a part of the mass of property within the State of Louisiana as a result of the length of the term of its storage within the state.

Oil subject to a conditional sale to the United States Government would be exempt from the use tax, because a conditional sale is considered to be a completed sale for purposes of Louisiana tax law, where title passes to the buyer at the beginning of the transaction while the seller holds a secured interest in the sale property. In the case of a conditional sale to the U.S. Government, such property would be exempt from taxation under the Supremacy Clause of the Constitution.

All privately-owned property in Louisiana is subject to an ad valorem tax based upon a percentage of the property's fair market value. The ad valorem tax would apply to storage facilities and crude oil in Louisiana that are leased to the United States Government, $\underline{82 /}$ unless the storage site is classified as an FTZ, in which case the crude oil, but not the storage facilities, would be exempt from taxation. $\frac{83 /}{}$ The ad valorem tax also does not apply to property subject to a conditional sale to the U.S. Government. As noted above, for purposes of Louisiana tax law, title is considered to pass to the purchaser at the beginning of the conditional sale transaction, so that property subject to a conditional sale to the U.S. Government would be exempt from taxation under the Supremacy Clause.

All crude oil produced in Louisiana, including that leased for storage in the SPR, is subject to a state severance tax. La. Rev. Stat. Ann. $\$ 47: 631$ et seq. (West). Payment of the severance tax on Louisiana crude oil does not exempt that crude oil from the ad valorem tax while the oil is in

821 A June 9, 1938, Opinion of the Louisiana Attorney General to the Louisiana Tax Commission, $\mathrm{CCH}$ ๆ20-203.25, OAG 1938-40, p.1224, apparently holds that property leased to the U.S. is not exempt from ad valorem taxation.

83/ Section 810 (e) of the Foreign Trade Zones Act, 19 U.S.C. $810(e)$, specifically exempts from state and local ad valorem taxes, tangible personal property imported from outside the United States and held in an FTZ zone and tangible personal property produced in the United States and held in a zone for exportation. 
storage. La. Rev. Stat. Ann. \$47:643 (West). Domestic and foreign corporations $\stackrel{84 /}{\text { leasing crude }}$ oil to or operating storage facilities for the U.S. Government, granting it oil purchase options, or conditionally selling it crude oil, would be subject to the state corporation franchise tax. La. Rev. Stat. Ann. $\$ 47.601$ (West).

In summary, the following Louisiana taxes would seem potentially applicable to an SPR oil or facility lease transaction: an income tax, either personal or corporate; a use or storage tax; an ad valorem tax on the leased crude oil while in storage; a severance tax on crude oil produced in Louisiana; and a corporation franchise tax. A Louisiana income tax, either personal or corporate; an ad valorem tax; a severance tax on crude oil produced in Louisiana; and a corporation franchise tax potentially may be applicable to an option to purchase crude oil, but it appears that the crude oil subject to such an option may be exempt from the use tax. It also appears that a conditional sale contract to the U.S. Government would be subject to an income tax, either personal or corporate, to a severance tax on crude oil produced in Louisiana, and to a corporate franchise tax, but that it probably would be exempt from the state ad valorem tax and the use tax. There also may be general levies for parish governments and special assessments for particular projects, such as schools, that are applicable to each type of transaction.

\section{b. Texas}

All real property located in Texas is taxable unless exempt by law. $85 /$ Tangible personal property is taxable if the property is: located in Texas for longer than a temporary period; temporarily located outside of Texas while the owner resides in Texas; or used continually in Texas. Crude oil leased to the U.S. Government for the SPR and crude oil subject to an option both would be subject to the Texas property tax. However, in the case of property subject to a conditional sale, Texas appears to hold the beneficial owner of the property liable for all property taxes. In this case, the beneficial owner would be the U.S. Government, which is exempt from taxation under the Supremacy Clause; however, this issue reportedly has not been addressed in Texas, and it may not be clear that the tax liability would shift from the seller to the U.S. Government.

All crude oil produced in Texas, including crude oil leased to the U.S. Government for the SPR, is potentially subject to a severance tax under Chapter 202 of the Texas Tax Code. Oil thus taxed is exempt from the sales, excise, and use tax imposed by Chapter 151 of the Tax Code.

The Texas sales tax would not appear to apply to sales of leased, optioned, or conditionally sold SPR crude oil because sales for resale and sales in interstate commerce are exempt from the tax. Such optioned, or conditionally sold SPR crude oil also would appear to be exempt from the Texas use tax, which only applies to the storage or use of personal property purchased from a retailer.

The term "foreign corporation" is defined to include all such business organizations, including corporations, joint stock companies or associations, that are organized under the laws of any other state than Louisiana, any territory or district, or foreign country. La. Rev. Stat. Ann. 47:601C(2)(West).

85/ "Real property" is defined by section 1.04 of the Texas Tax Code to include land, an improvement, a mine or quarry, a mineral in place, standing timber, or an estate or interest, other than a mortgage or deed of trust creating a lien on the property or an interest securing payment or performance of an obligation, in property enumerated previously. 
\$151.101. In addition, any taxable item sold, leased, or rented to, or stored, used, or consumed by the United States is exempt from the end use taxes imposed by Chapter 151.

Any corporation with property in the State of Texas is subject to the corporate franchise tax under Chapter 171 of the Tax Code; the extent of the tax depends upon the ratio of the corporation's business in Texas to the corporation's total business worldwide. Income received from option premium payments, from periodic payments on a conditional sale, or from a lease of crude oil or storage facilities would be subject to the corporate franchise tax.

In summary, the following Texas taxes would seem potentially applicable to an SPR oil or facility lease transaction, or to an oil purchase option: an ad valorem property tax, a severance tax on leased Texas crude oil placed in storage, and a corporation franchise tax. The following Texas taxes would seem potentially applicable to a conditional sale contract to the U.S. Government: a severance tax on Texas crude oil subject to the conditional sale, and a corporation franchise tax; it appears that the ad valorem property tax may not apply. There is no state income tax in Texas.

\section{Use of In-Warehouse Bonding or a Foreign Trade Zone}

This section describes advantages and disadvantages of storing leased or other SPR oil in bond or of locating an SPR storage site in a Foreign Trade Zone (FTZ).

\section{a. Storage in a Customs-Bonded Warehouse}

Various types of facilities, including SPR oil storage sites, may be designated as customs-bonded warehouses for the purpose of storing imported goods. Payment of applicable customs duties and of the Customs Services user fee is delayed until goods are withdrawn from the warehouse for importation into the U.S.; however, goods may remain in a customs-bonded warehouse for no more

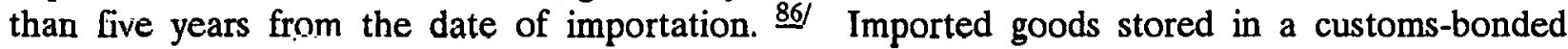
warehouse and destined for domestic manufacture and sale remain subject to state and local property taxes, and income derived from the leasing or sale of goods, while the goods are in the warehouse, is not exempted from Federal income taxation. Payment of and liability for the Hazardous Substance Superfund and Oil Spill Liability Trust Fund taxes and the harbor maintenance fee would be applicable to crude oil stored in a customs-bonded warehouse, irrespective of whether the oil is reexported or entered into the U.S. customs territory. With respect to liability for state taxes other than property taxes, at least one state, Louisiana, exempts from its corporate income tax income derived by a corporation from sales in the regular course of business of personal property located in a customs-bonded warehouse; however, rental income derived from such property is subject to the corporation income tax. Additionally, property located in a customs-bonded warehouse does not acquire a Louisiana situs for purposes of computing Louisiana revenue or property in connection with the application of the Louisiana corporate franchise tax. Texas law does not contain such an exemption; other states' laws have not been surveyed on this point.

86) At the end of five years, the goods either must be imported and the duty paid, or exported; otherwise, they are considered abandoned and will be auctioned by the Customs Service. 


\section{b. Storage in a Foreign Trade Zone}

The Foreign Trade Zones Act, 19 U.S.C. 81a et seq., authorizes the establishment of processing activities in domestic areas which are considered, under U.S. customs law, to be foreign territory. The purpose of the Act was to expedite and encourage foreign commerce. Section 3 of the Act provides that raw materials are allowed to enter a Foreign Trade Zone (FTZ) free of any quotas or customs duties, and the finished products may be imported into the U.S. subject to the same restrictions as would apply to products manufactured outside of the U.S. Similarly, when the finished products are imported from the FTZ into the U.S. customs territory, the importer of record is liable for the Customs Service user fee, which previously had been deferred. Other potentially applicable Federal taxes, including the harbor maintenance fee and the Hazardous Substance Superfund and Oil Spill I iahility Tnust Fund taxes, are assessed regardless of whelher the crude oil first is placed in an FTZ or enters the U.S. customs tcrritory immediately. Use of an FTZ for processing or manufacturing activities does not provide an exemption from federal income tax liability. Under the Act, tangible personal property cntered into an FTZ for proccssing is exempt from all state and local ad valorem (property) taxes. With respect to liability for state taxes other than personal property taxes, at least one state, Louisiana, exempts from its corporate income tax income derived by a corporation from sales in the regular course of business of personal property located in an FTZ; however, rental income derived from such property is subject to the corporate income tax. Additionally, property located in an FTZ does not acquire a Louisiana situs for purposes of computing Louisiana revenue or property in connection with the application of the Louisiana corporate franchise tax. On the other hand, Texas, which has no state income tax, does not provide such an exemption from its state corporate franchise tax. Ncither Louisiana nor Texas exempts property stored in an FTZ from the use tax. Other states' laws have not been surveyed.

Several refineries and oil storage facilities enjoy or have applied for FTZ status hecause of the advantages such status provides. s' $^{\prime \prime}$ The refineries currently can bring blending stocks into the FTZ duty-free, process them into gasoline, and pay the lower duty on the gasoline when importing it into U.S. customs territory. In addition, avoiding customs duties by never entering the product into the U.S. customs territory permits a refiner to reduce inventory carrying costs for a product slated for export.

If an SPR site were designated as an FTZ, it would be necessary to pay the U.S. Customs Service for the cost of maintaining the additional Customs Service support necessary to opcrate the zone. In addition, some method would have to be established to monitor the quantity of oil in salt cavern or other storage in such a manner as to satisfy the Customs Service that the oil has not reentered the U.S. customs territory. In the event that an SPR site desigualed as an FTZ did not include terminalling facilities with direct delivery capacity to an SPR storage site, the crude oil might be placed under a "cartage bond" for shipment through a pipeline to the SPR site. The cartage bond protects the crude oil from being considered as having entered the U.S. customs

Four refineries (one in Hawaii and three in Corpus Christi, Texas) are operational. Another, Champlain Refining in Corpus Christi, has received all necessary approvals but has not begun actual operations. In addition, five refineries have received approval to commence refinery operations in FTZs but are awaiting approval from the U.S. Customs Service to begin operations. Three Houston blending companies also have received restricted FTZ status but are awaiting Customs Service approval to begin operations. 
territory, which would make the crude oil dutiable and might trigger liability for state and local ad valorem taxes. 


\section{G. OTHER ISSUES}

Issues covered in this part include: (1) the use of SPR facilities for commercial purposes; (2) the question of whether commercial use of SPR pipelines would cause them to become "common carriers"; (3) U.S. oil export controls; (4) the scope of Federal condemnation authority; (5) the applicability of state powers to condemn or allocate leased oil or facilities; and (6) the assignment of rights or benefits under a Federal Government lease or other contract.

\section{Commercial and Other Non-SPR-Related Uses of SPR Storage Facilities}

The question occasionally has arisen of DOE's authority to allow the commercial or other nonSHK-connected use of SPR storage and "related" facilities. There are several ways this issue could surface in the context of SPR alternative financing. For example, a private firm or a foreign oil producer government might condition its offer to lease or otherwise supply oil to the SPR upon some additional use of SPR storage and related facilities for its own commercial purposes; dual U.S. Government and supplier access to the same oil, under different circumstances, could be proposed by an oil supplier; or another International Energy Agency country might become interested in storing its own strategic stocks in the SPR. DOE's view is that authority to permit such arrangements presently exists under the EPCA, subject to certain limitations.

Section 159(f)(D) of the EPCA authorizes the Secretary of Energy to "use, lease, maintain, sell, or otherwise dispose of" SPR storage and "related" facilities (defined in section 152(8) as including necessary appurtenances, among them pipelines). Leases are expressly authorized; the authorizing language also seems sufficiently broad to permit the DOE to contract to perform services in SPR facilities on behalf of other persons. This authority is granted, however, "to the extent necessary or appropriate to implement" the SPR Plan, suggesting an intent that any significant program for the commercial or otherwise non-SPR-related use of the SPR be detailed in a Plan Amendment.

In addition, pursuant to section 649(b) of the Department of Energy Organization Act, the Secretary of Energy is authorized to permit private use of any real property, or any facility, under the custody of the Secretary for Department purposes. The Conference Report on this provision indicates that there must be a Departmental function which would be facilitated by the proposcd private use. See H.R. Conference Report No. 539, 95th Cong., 1st Sess. 97 (1977). An example might be a private use which assisted in maintaining SPR facilities in a state of readiness. Section 646(a) further empowers the Secretary to enter into and perform such contracts, leases or other similar transactions as he may deem necessary or appropriate to carry out functions vested in him.

A potential limitation on the DOE's ability to allow commercial or other use of storage space in the SPR's facilities is the DOE's need to dedicate, each fiscal year, sufficient capacity to accommodate the statutorily-mandated fill rate for the SPR. Section 160(c) of the EPCA presently requires that the SPR be filled "at the highest practicable rate achievable" using available appropriations; and EPCA section 160(d) provides that, with limited exceptions, the U.S. Government share of crude oil produced from Naval Petroleum Reserve No. 1 (Elk Hills, California) may not be sold or otherwise disposed of except to the SPR (directly or by exchange), 
if there is less than 750 million barrels of oil in the SPR or if SPR fill is less than an average 75,000 barrels per day in a fiscal year. ${ }^{.99}$ Use of SPR storage facilities could be permitted only to the extent such use did not impinge upon achievement of the statutory fill mandates.

There could be environmental considerations, including the question of the need for an environmental Policy Act, that would have to be taken into account before SPR facilities are used for commercial or other non-SPR-related purposes. $\underline{90}$ The programmatic and site-specific environmental impact statements heretofore prepared for the SPR have addressed construction and operation of SPR facilities based on an assumption of intermittent use of those facilities during fill and drawdown. More extensive use of the facilities by others could mean increased hydrocarbon emissions or an increased risk of oil spills. An assessment of these impacts thus might have to be undertaken to determine whether a supplement to the original impact statement is required.

In addition, the same assumption of intermittent use was made in applying for the permits necessary to operate SPR facilities under the Clean Air Act and the Federal Water Pollution Control Act. Greater use of the existing and currently planned SPR facilities could mean increased hydrocarbon emissions within areas in which hydrocarbon emissions exceed the national ambient air quality standards and which the Environmental Protection Agency and the States of Texas and Louisiana have designated as non-attainment areas. Expanded use of these facilities might require new permits and offsetting decreases in other emissions in order to avoid further deterioration of the local air quality.

Use by others of Government-owned or Government-leased oil pipelines that are dedicated to SPR use also could raise a question of whether the pipelines, by virtue of such use, have become "common carriers," subject to the requirements of the Interstate Commerce Act. This issue is discussed in Section $\mathrm{G}(2)$ below.

\section{Common Carrier Status of SPR Pipelines}

The shipment of leased or other privately-owned oil through Government-owned oil or Government-leased pipelines that are dedicated to SPR use could, under some circumstances, raise a question of whether the Interstate Commerce Act, 49 U.S.C. 1 et seq. (IC Act), is applicable to the SPR's pipelines -- ie., whether by virtue of such shipment those pipelines have become "common carriers." This question might arise in oil leasing transactions, or if someone outside the Government was allowed to hold oil for his own account in SPR facilities or in adjacent private facilities.

Should it be concluded that the SPR pipelines are common carriers, they would be subject to the rules and regulations of the Federal Energy Regulatory Commission (FERC) which, under section 402 of the Department of Energy Organization Act, 42 U.S.C. 7172, is charged with regulating pipelines subject to the IC Act. These regulations would require, among other things, compliance with reporting requirements, and arguably could require the SPR to serve private firms (possibly

89/ The Congress has enacted waivers of this sanction for Fiscal Years 1988, 1989 and 1990. The SPR fill rates for Fiscal Years 1988 and 1989 were approximately 57,000 barrels per day and 61,000 barrels per day, respectively.

90/ The NEPA's requirements are discussed in Section $\mathrm{B}(2)$ of this chapter. 
including requiring the SPR to allow private firms to tie in their pipelines to the SPR's pipelines), thereby hampering fill of the SPR's storage facilities and conceivably denying the SPR full access to its pipelines in the event of drawdown of the SPR. The DOE is of the view that SPR pipelines are not and, under most if not all hypothetical scenarios, would not become subject to the IC Act. Nonetheless, the potential issue would be subject to resolution by the FERC, in the context of a particular set of facts and circumstances.

\section{Restrictions on U.S. Crude Oil Exports}

It is possible to imagine circumstances in which an owner of oil leased to the DOE for, or otherwise stored in, the SPR might propose to export that oil from the U.S. This might be contemplated, for example, upon the expiration of a lease or in case of a U.S. Government decision not to exercise an option to extend a lease. The issue also could arise if other International Energy Agency (IEA) member countries were allowed to hold oil in any otherwise underutilized SPR storage facility. However, under current law, the export of such oil would remain subject to existing or potential U.S. restrictions on crude oil exports.

There are relatively stringent statutory tests governing the export of certain domestic crude oils, the application of which varies according the origin of the oil, the mode if its transportation, and the specifics of the export transaction. The most stringent provisions are those that apply to Alaska North Slope (ANS) oil (see section 7(d) of the Export Administration Act (EAA), 50 U.S.C. App. 2406(d)), but there are separate restrictions on oil shipped through pipelines across rightsof-way granted under the Mineral Leasing Act (section 28(u) of the Act, 30 U.S.C. 185(u)); Naval Petroleum Reserves (NPR) oil (10 U.S.C. 7430(e)); and Outer Continental Shelf oil (43 U.S.C. 1354(a). $\underline{\text { ㄴ }}$ !

In addition, the export of any crude oil from the United States, including not only domestic oil by also imported oil, is subject to the Department of Commerce "Short Supply Controls," 15 C.F.R. Part 777, promulgated pursuant to section 7(a) of the EAA, and section 103(b) of the Energy Policy and Conservation Act (EPCA), 42 U.S.C. 6212(b). All crude oil exports must be licensed by the Commerce Department, on a basis prescribed in that Department's Export Administration Regulations (EARs). There is no exception for domestic or imported oil stored in the SPR.

Although there are no statutory restrictions on the export of previously imported crude oil, the EARs presently would permit the export of such oil to countries other than Canada only if the

91/ There is a notable exception with regard to exports to Canada. In June 1985 the President determined that the export of crude oil (other than ANS and NPR oils) to Canada for use or consumption in Canada is in the national interest and made the necessary findings under several applicable statutes to permit such exports. Subsequently, the U.S. agreed in the U.S.-Canada FreeTrade Agreement, which went into force January 1, 1989, to allow the export to Canada of up to 50,000 barrels per day of ANS crude oil, subject to a requirement of ocean carriage on U.S.-flag vessels. The U.S. implementing legislation for the Agreement, Public Law No. 100-449 (Sept. 28, 1988), authorizes these exports in section 305(a), amending the Export Administration Act. 
export is pursuant to one of three types of exchange transactions specified in the regulations. .21 The least restrictive of the provisions authorizing those exchange transaction requires, inter alia, that: the export will result "directly" in the importation of a "quantity and quality" of certain types of refined products that are "not less" than what would be derived by their refining; the imported products would be sold at no more than "the lowest price at which they could have been sold" if the exported crude oil had been refined at the "nearest U.S. refinery capable of processing it within a reasonable period of time"; and for "compelling economic or technological reasons beyond the control of the applicant," the exported crude oil "cannot reasonably be processed within" the U.S. (section $777.6(\mathrm{~d})(1)($ viii) $) . \stackrel{93 /}{ }$

Moreover, the application of the EARs to crude oil stored in the SPR is complicated by the fact that different crude oils subject to the disparate legal export criteria are to some extent commingled in storage. The SPR consists mainly of imported oil, but it also contains ANS oil, NPR oil, and other domestic oils that may or may not be subject to the Mineral Leasing Act section 28(u) restriction. These various oils generally are commingled in storage. It is possible that future oil acquisitions, whether through purchase, leasing or other means, will perpetuate or aggravate this commingling. And the various oils may.become further commingled during a drawdown of the SPR at a time of emergency. Thus, depending on the particulars of a storage arrangement, it may be difficult to determine which export control laws particular quantities of SPR crude oil are subject to. Where this is ascertainable, the EARs nonetheless do not currently address the export of imported oil such as oil that has been leased to the SPR or stored in the SPR by an IEA country. Even assuming that the EARs were amended to address these subjects in a suitable manner, the potential could exist that available statutory authority might be exercised in the future to preclude such export.

92/ The EAR restrictions on the export of previously imported crude oil from the customs territory of the United States also apply to the export of foreign crude oil that is brought into a Foreign Trade Zone established under the Foreign Trade Zones Act, 19 U.S.C. 81a et seq., 15 C.F.R. 777.6(e).

The two remaining permissible exchange transactions are described in subparagraphs (iii) and (vi) of section 777.6(d)(1). Subparagraph (iii), entitled "Equivalent importation," would permit exchanges with persons or the government of an "adjacent" foreign state, but only for exchanges that will result "directly" in "equal or greater quantity" imports of "that same commodity." Subparagraph (vi), entitled, "Corresponding importation of the same commodity," would permit the export of imported crude oil to other than adjacent foreign countries, but only if, inter alia: an "equal or greater quantity" and "an equal or better quality" of "the same commodity" will result "directly"; the transaction will decrease average refiner crude acquisition costs and benefit consumer oil prices; the contract is terminable if U.S. petroleum supplies are interrupted or seriously threatened; the imported commodity otherwise would not be available for import; and "[f]or compelling economic or technological reasons that are beyond the control of the applicant, the commodity cannot reasonably be processed within the United States." 


\section{Federal Condemnation Authority}

Multiple ownership of diverse kinds of real property estates, and competing uses of salt domes, have contributed to the need for the DOE to use condemnation authority provided by the EPCA to acquire all of the SPR's existing underground storage sites. A program for leasing oil and/or oil storage facilities for the SPR similarly might necessitate use of the DOE's condemnation authority. This authority, described below, clearly authorizes the DOE to condemn private property for the location of SPR storage and related facilities. Questions might arise, however, about the appropriateness of using the condemnation authority to: acquire facilities that were intended to store both leased oil and oil held by the lessor for its own commercial purposes; acquire storage capacity on behalf of another International Energy Agency member country; or enable a facilities lease contractor to acquire necessary title to a site or to pipeline rights-of-way.

Section 159(f) of the EPCA authorizes the DOE, "[t]o the extent necessary or appropriate to implement" the SPR Plan, to:

(B) acquire by ... condemnation ... land or interest in land for the location of storage and related facilities;

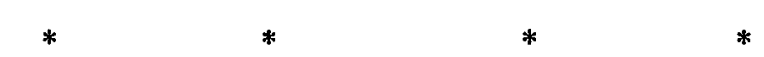

(L) bring an action, whenever [the Secretary] deems it necessary to implement the Strategic Petroleum Reserve Plan, in any court having jurisdiction of such proceedings, to acquire by condemnation any real or personal property, including facilities, temporary use of facilities, or other interests in land, together with any personal property located thereon or used therewith.

The scope of the DOE's condemnation authority under the EPCA in part depends on whether a proposed condemnation satisfies the "public use" requirement of the Fifth Amendment to the U.S. Constitution. ${ }^{94 / /}$ The Supreme Court has adopted a deferential approach toward Federal exercise of condemnation power. In United States ex rel. TVA v. Welch, 327 U.S. 546, 552 (1946), a decision upholding the TVA's condemnation of property near a dam, the Court emphasized that "[a]ny departure from .... judicial restraint would result in courts deciding on what is and is not a governmental function and in their invalidating legislation on the basis of their view on that question at the moment of decision, a practice which has proved to be impractical in other tields." In Berman v. Parker, 348 U.S. 26 (1954), holding constitutional the District of Columbia Redevelopment Act of 1945, the Court expanded the general substantive definition of "public use" by establishing that reconveyance of condemned property to private parties for redevelopment is acceptable where an overall public purpose is being served. In short, "public use" does not mean public ownership; if, despite the commingling of private and public uses, the condemnation will serve some controlling governmental purpose, the courts are disposed to ignore the private element

94/... nor shall private property be taken for public use, without just compensation." 
as purely incidental. See Hawaii Housing Authority v. Midkiff, 467 U.S. 229 (1984); United States ex rel. T.V.A. v. Two Tracts of Land, etc., 532 F.2d 1083 (1976); see also 1 Nichols Law of Eminent Domain, section 2.136 (Rev. 3d ed. 1988).

\section{Applicability of State Condemnation Power/Oil Allocation Authority}

It is possible to imagine circumstances in which a state might attempt to condemn oil storage facilities leased to the DOE for the SPR program. It also is conceivable that a state, in responding to a shortage or potential shortage of petroleum products, might attempt either to condemn or to allocate oil leased to the DOE for the SPR. Little directly relevant legal authority has been found on the issues such actions would raise.

Concerning state condemnation authority, it is well settled that a state may not exercise its right of eminent domain with respect to Federal property, including leasehold interests in real and personal property. .5 s state could condemn the property interests of the owner of a storage facility or of oil leased to the DOE, possibly subject to the limitation that the Federal Government's interest in and use of the property may not be affected by the taking. $96 /$ If the lessor of the oil and/or storage facility was a foreign government, and the leasing arrangement was pursuant to a bilateral agreement between the United States and the foreign government, a state might be precluded from taking the oil or storage facility, because its action could invade the President's constitutional power over foreign affairs. See U.S. Constitution, Article II, section 2, clause 3.

Since the Federal Government has the authority to condemn state property, 97/ if a state condemned the property interest in land or oil owned by the DOE's lessor, the Federal Government could effectively preclude ultimate state ownership by condemning any interest a state might acquire by condemnation.

With respect to the question of state allocation authority, state action to allocate oil that is leased to the DOE and that is held as part of the SPR should be subject to Federal preemption under the Supremacy Clause of the Constitution. As noted above, the EPCA, which authorizes the leasing of oil for the SPR, stipulates in section 161(d) that no drawdown and distribution of the SPR may be made unless the President finds that such actions are "required by a severe energy supply interruption or by obligations of the United States under the international energy program." State action to allocate leased oil that is in the $S P R$ would be in direct conflict with this requirement.

95/ See 1 Nichols, Law of Eminent Domain, sec. 2.22 (Rev. 3d ed. 1988); U.S. Dept. of Justice, Federal Eminent Domain at 15-16 (GPO 1940).

96/ City of Anandarko v. Caddo Electric Cooperative, 258 F. Supp. 441, 443 (N.D. Okla. 1966); but see Kosciusko County R.E.M. Corp. v. Northern Indiana P.S. Co., 248 Ind. 482, 229 N.E.2d 811 (1967). 


\section{The Assignment of Claims Act of $\mathbf{1 9 4 0}$}

An owner of oil and/or storage facilities leased to the DOE for the SPR program might propose to assign to a third party its rights under the lease to rental and other payments from the DOE as security in obtaining private financing for the oil and/or storage facilities. Potential financing mechanisms could include the issuance of securities backed by the lease. Use of the proceeds of government contracts as security in private financing arrangements is subject to the Assignment of Claims Act of 1940, as amended, 31 U.S.C. 3727; 41 U.S.C. 15, $\underline{\text {, }}$ which was enacted to induce financial institutions to lend money to contractors to finance their performance of contracts with the Government.

The Assignment of Claims Act permits a contractor to assign to specified third parties its right to payment from the Government, ${ }^{9}$ / provided that the following conditions are met:

2. [N]o claim shall be assigned if it arises under a contract which forbids such assignment;

3. [U]nless otherwise expressly permitted by such contract any such assignment shall cover all amounts payable under such contract and not already paid, shall not be made to more than one party, and shall not be subject to further assignment, except that any such assignment may be made to one party as agent or trustee for two or more parties participating in such financing;

4. [I]n the event of any such assignment, the assignee thereof shall file written notice of the assignment together with a true copy of the instrument of assignment with (a) the contracting officer or the head of his department or agency; (b) the surety or sureties upon the bond or bonds, if any, in connection with such contract; and (c) the disbursing officer, if any, designated in such contract to make payment. (41 U.S.C. 15) 100 /

98 The Assignment of Claims Act of 1940 amended existing statutory restrictions on the assignment of government contract claims (Revised Statutes, section 3477) and on the assignment of government contracts (Revised Statutes, section 3737).

99/ Read literally, 41 U.S.C. 15 prohibits a contractor from assigning its obligations under a contract with the Government. However, the Court of Claims has held that the Government may recognize an assignment of obligations if it chooses to do so, notwithstanding the Act, Tuftco v. United States, $222 \mathrm{Ct}$. Cl. 277, 614 F.2d. 740 (1980). A novation agreement is the appropriate method by which the Government recognizes a successor in interest to a contractor.

100/ 31 U.S.C. 3727 (c), which is given similar construction to 41 U.S.C. 15 , permits an assignment to a financing institution of money due or to become due under a contract when:

(1) the contract does not forbid an assignment;

(2) unless the contract expressly provides otherwise, the assignment -- 
Financing institutions that are entitled to be assignees within the meaning of the Act include banks or trust companies and those persons whose primary business is that of engaging in financial activities, such as financing in connection with accounts receivable. A pension trust also has been held to be a "financing institution." $\underline{101 /}$ However, "financing institution" does not include entities that, as an incident to their other major business, lend money to contractors to assist them in their business. $\underline{102 /}$ Payments under an assignment are made directly by the Government to the assignee.

Multiple-party financing transactions are permissible, in that an assignment may be made to one party as agent or trustee for two or more parties participating in the financing. However, the trustee or agent must qualify as a "financing institution."103/

The transactions most clearly within the purpose of the Act are those that provide money for the contractor to use in performing a single contract, the proceeds of which are assigned as security. The modern trend against tying particular loans to particular security has been recognized, however, in decisions approving revolving credit arrangements in which loans are intended to be secured by a succession of contracts. $104 /$ What is crucial, is whether the lender/assignee has reason to know in advance that the loan proceeds cannot be used in completing the contract. Where the contract has been fully performed before a loan is made the assignment is invalid. $105 /$ If the financing institution's advances are at least available for the performance of a particular contract, they may be secured by the proceeds of that contract.

(A) is for the entire amount not already paid;

(B) is made to only one party, except that it may be made to a party as agent or trustee for more than one party participating in the financing; and

(C) may not be reassigned; and

(3) The assignee files a written notice of the assignment and a copy of the assignment with thc contracting official or the head of the agency, the surety on a bond on the contract, and any disbursing official for the contracl.

101/ 40 Comp. Gen. 174 (1960).

102/ 22 Comp Gen. 44 (1942).

103/ The Comptroller General has held that a transfer of rents by a government contractor to a bank acting as trustee for bondholders, financing the construction of a Social Security Administration building, was proper because the trustee was a "financing institution" within the meaning of the Assignment of Claims Act. As the bank was acting as an agent, the Comptroller General looked to the individuals represented by the bank, the bondholders, and determined that they had a group function as a lender and as a financing institution under the Act. 52 Comp. Gen. 462 (1973).

104/ Continental Bank \& Trust Co. v. United States, 189 Ct. Cl. 99, 416 F.2d. 1296 (1969).

105/ First National City Bank v. United States, 212 Ct. Cl. 357, 548 F.2d. 928 (1977). 


\section{CHAPTER IV. MAJOR ISSUES}

There are a number of issues that are associated with changes in the method of financing SPR oil acquisition and facilities development. These issues are discussed in depth in the analyses of the separate options in later chapters. The purpose of this chapter is to provide an overview of the following major issues which arise in conjunction with most of the policy alternatives:

- Effects of alternative financing on the flexibility of the Federal Government to draw down and distribute SPR oil during a severe energy supply disruption.

- $\quad$ Risk and rate of return.

- $\quad$ Size of market for voluntary third-party investment in SPR.

\section{A. EFFECTS ON DRAWDOWN AND DISTRIBUTION}

The current legislation and policy framework for the Strategic Petroleum Reserve provide the President and the Secretary of Energy with broad discretion on whether, when, and how to deploy the SPR inventory during a severe energy supply interruption. Direct Federal ownership of the storage facilities and oil supports this flexibility because the Government is in a position to exercise market power as a full equity participant in business transactions along with any government powers it may also choose to exercise.

Depending on how the alternative financing mechanisms are structured, there is clear potential for having third party interests affected by the manner in which the SPR is drawn down and distributed. Under some approaches to oil leasing or oil denominated bonds, for example, investors who have supplied funds to acquire oil for the SPR might be permitted to receive a return of capital based in part on the future value of oil at the time of a major energy supply interruption.

Similarly, under some variations of the mandatory private contributions concepts discussed in Chapter IX, the private sector could retain ownership interests in oil stored in, or in conjunction with, the SPR. As with lessors or owners of oil denominated bonds, private parties required to hold oil inventories would have interests in the timing and circumstances associated with an emergency release of those inventories into the market.

Under current policy, as set forth in Strategic Petroleum Reserve Plan Amendment No. 4 (1982), the Government has not specified, in quantitative terms, the circumstances under which the Reserve inventory will be drawn down. There has been a general policy that emergency oil stockpiles represent the first line of defense against disruptions in foreign oil supply and that substantial SPR deployment should occur early in a disruption. However, the President retains the prerogative to authorize the use of the SPR under the general guidance of the EPCA.

Current policy also calls for not imposing price and allocation controls on U.S. oil markets during a disruption, and the principal method of SPR distribution is expected to be through pricecompetitive sales to the private sector. 
In general, therefore, an investor in the oil lease or oil bond options could expect that, to the extent that its contract with the Government provided for partial or full repayment of capital upon liquidation of the SPR oil inventory, the Government would be selling some SPR oil during the early months of a disruption. Furthermore, the investor could expect that SPR oil would be sold at competitive prices in the free market environment.

Nevertheless, an investor would face the following forms of uncertainty:

- There is the potential for the Congress to enact legislation that would change cither the general free market environment for supply disruption periods or the manner in which the SPR is authorized to be sold.

- Within existing law, there is a possibility of future changes in the SPR policy framework, including decisions to distribute SPR oil through means other than competitive sale.

- Within existing law and policy, there remains uncertainty as to the timing and rate of SPR drawdown.

- Even if a portion of the SPR is drawn down in an emergency, an investor may face uncertainty as to whether its capital will be recovered at that point.

- The release of oil from the SPR during an emergency is intended to mitigate the adverse economic effects of a major energy supply interruption. One important form of such mitigation would be to dampen the upward pressure on oil prices. Since the SPR has never been drawn down during a supply interruption, there is uncertainty as to the extent to which the drawdown would have feedback effects on SPR sales prices.

Some but not all of these uncertainties could be remedied by provisions in the contractual instrument accompanying the investment. As discussed in more detail in the chapters on oil leases and oil bonds, it would be possible to stipulate in the investment contract how the investor's capital recovery would relate to a drawdown. The contract would likely provide for a process reflecting some or all of the following:

- Methodology for deeming whether a particular investor's capital would be recovered in whole or in part.

- Allocating between the Government and the investor a series of choices on method of capital recovery, including one or more of the following: 
- $\quad$ Direct provision of "wet barrels" from the SPR;

- Pass-through of payments received by the Government for sales of a particular grade of crude oil;

- Payment to the investor based on a market price index;

- Payment to the investor based on a pre-specified schedule; or

- Use of the investment instrument as a means to pay for oil acquired at the time of an SPR drawdown.

- Allocating between the Government and the investor a set of rights to renewals of the investment arrangement.

- Allocating to the investor some rights, possibly subject to U.S. Government approvals, to transfer title to the investment instrument to other parties.

These possibilities are discussed further in the chapters dealing with various options. The general issue discussed here, however, is that the more rights that are allocated to the investor, the less flexibility the Government will retain. But the more rights that the Government decides to retain, the more the uncertainty created for the investor.

Similar forms of uncertainty would be associated with mandatory storage options, as discussed in Chapter IX. In those cases in which a private entity would, by law or regulation, be required to invest in strategic oil inventories, provisions would be required for coordinating the drawdown of such inventories with use of the Government-owned stockpile.

This allocation of rights also affects the other issues discussed further below: risk and rate of return, and market size. There may be trade-offs between the retention of drawdown flexibility and the objective of minimizing costs. As discussed above, some forms of Federal Government distribution flexibility translate into financial uncertainty for possible participants. Therefore, over and above the financial risks inherent in oil ownership, as discussed in the following section, there would be risks created for oil owners by the nature of their association with the SPR program.

A key criterion for evaluating alternative SPR financing proposals is the need to minimize the vulnerability of the United States to oil supply disruptions. During consultations with producing nations regarding the possibility of their leasing oil to the SPR, U.S. representatives stressed the need to maintain the strategic character of the Reserve, including the President's flexibility in making decisions regarding SPR deployment. The individual SPR financing alternatives discussed in this study have been designed in accordance with this policy objective. 


\section{B. RISK AND RATE OF RETURN}

As discussed in Chapter $I$ in the context of evaluation criteria, a major element of the cost of strategic stockpiling is the "holding cost," which reflects the time-value-of-money for the capital which is invested in the Reserve, adjusted for any change in the value of the oil while it is held in storage. The physical attributes of the oil stored in the SPR are not expected to change during the period of storage, and no income from the investment is generated until resale of the oil. In this sense, the SPR has been characterized as a "sterile asset," for which the return to the investor becomes dependent substantially on the relationship between the holding cost, or the cost of the capital employed, and any appreciation which may occur in the value of the oil itself.

Over time, the holding cost on the Reserve may actually exceed the initial capital cost. Using Treasury borrowing rates, if all Federal funds now invested in the Reserve oil inventory were derived from Federal issuance of debt securities, the compound interest on such dcbt through fiscual year 1988 would be approximately the same as the direct purchase cost of the oil.

In analyzing alternative financing methods, it is important to understand whether and how the holding costs of the Reserve, to the U.S. economy overall and to the Federal Government, would be affected by the financing method. The purpose of this section is to explore some of the underlying issues in the selection of discount rates or interest rates for purposes of comparing financing methods. Current Federal standards for making these judgements, such as those in Office of Management and Budget (OMB) Circulars A-94 Revised, "Discount rates to be used in evaluating time-distributed costs and benefits," and A-104 Revised, "Evaluating Leases of Capital Assets," are explained, and their applicability to the financing methods under consideration is discussed.

\section{Financing Criteria in OMB Circulars}

There are a number of OMB circulars that establish policies for evaluating different forms of Federal financing methods. Two of those Circulars appear to be the most relevant for evaluating alternative methods of financing the Strategic Petroleum Reserve, and the primary provisions of those circulars are discussed in turn below.

\section{a. Circular A-94}

OMB Circular A-94 describes methods which are to be used by Federal agencies in the conduct of benefit/cost analyses of program and policy proposals. It prescribcs the use of a real (before inflation) discount rate of 10 percent in comparing the present value of costs and benefits for Government activities. The 10 percent real rate was derived from studies in the late 1960's of the long-term pre-tax real rate of return on both debt and equity investments in the private sector. The presumption is that a new Government activity that withdrew resources from the private economy would reduce the capital available for private investment, thereby creating a loss to the private economy equivalent to this average pre-tax rate of return.

Circular A-94 applies "to the evaluation of Government decisions concerning the initiation, renewal, or expansion of all programs or project." However, as stated in Section 3(c), Circular A-94 does not apply to certain program implementation decisions, such as lease/purchase decisions, 
that are made after the basic decision has been taken on whether to proceed with the program or project.

Circular A-94 requires consideration of all economic costs, whether or not they are borne by the Federal Government. Thus proposals to use regulatory methods to cause the private sector to create emergency reserves would need to be evaluated in parallel with consideration of alternative ways of financing a Government stockpile.

Throughout this study, a range of discount rates is used to assess program costs. This range will include the 10 percent real rate of return prescribed in Circular A-94.

\section{b. Circular A-104}

OMB Circular A-104 requires an economic analysis of decisions whether to purchase or lease capital assets for Federal agency use. It also provides a methodology for the conduct of such analysis, and prescribes the use of the interest rate on Treasury securities (plus one-eighth of a percent) as the discount rate for comparing the costs of leasing versus outright purchase.

The methodology set forth in the circular is intended to ensure that the analysis accounts for all Government costs for the lease and purchase alternatives, including any special tax benefits that could accrue to the lessor. Further, it is intended to provide for an accurate comparison of the lease to a purchase. Specifically, when the lease contract requires the lessor to provide some ongoing services, such as building maintenance, the costs of the purchase alternative are to be adjusted likewise to include the costs for such services.

In analyzing alternative SPR financing methods, two fundamental issues arise in the selection of a discount rate for calculating holding costs. First, there is a question as to whether the choice of financing methods would have an effect on the amount of oil acquired for the Reserve. The answer to this question is important in selecting between the discount rate called for in OMB Circular A-94 and the rate prescribed in Circular A-104. Second, there is a question as to whether, in making lease/purchase decisions under Circular A-104 for the oil leasing alternative, it would be appropriate to reflect that the private lessor is bearing a certain amount of price risk which the Government would have borne if it had purchased the oil.

The remainder of this section is devoted to a discussion of these two issues.

\section{Effects of Financing on Oil Fill Rates}

There are two possible approaches to the analysis of alternative SPR financing methods. The first is to assume that decisions have been made, independent of the financing decision, to achieve a particular level of SPR fill over a defined period of time. The financing method choice therefore could focus on ways of minimizing the overall economic costs or the Federal financial costs of achieving that fill level.

Accordingly, one benchmark for comparing the effects of alternative SPR financing methods is the rate of interest being paid by the Treasury on debt securities of maturities comparable to those of the alternative financing instrument. This is the basic comparison that is called for in OMB 
Circular A-104, wherein the Treasury borrowing rate is a factor in making lease-versus-purchase decisions for Federal programs.

In general, apart from the risk that actual inflation rates may vary from expected inflation at the time the loan is made, U.S. Treasury debt is considered to be "risk-free." This is because of the high degree of confidence that investors have that the Federal Government will not default on its financial obligations. In contrast, other borrowers are, to varying degrees, more likely to default and are likely to be charged a higher rate of interest than the U.S. Treasury. This phenomenon has led some to conclude that there can be no lower-cost method of financing the SPR than Treasury borrowing.

Alternatively, it is possible that there would be feedback effects of an alternative SPR financing method, such that a new financing method would result in a different pace of SPR development than that associated with current tınancing from a mix of tax revenues and dèbt säle proceeds.

Figure IV-1 describes two different simple models of the decision process. The top half of the figure assumes that budget allowances are the result of fill rate and financing decisions, whereas the bottom half of the figure assumes that fill rates are the result of the interaction between budget allowances and financing methods.

Figure IV-1

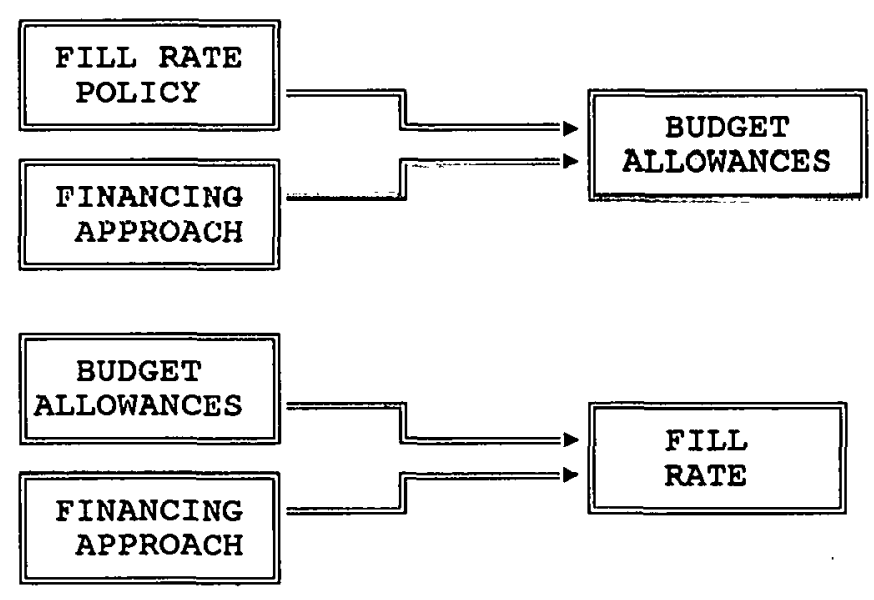

If fill rate decisions are affected by the choice of financing methods, then there is reason to use the economic analysis methods called for in OMB Circular A-94, including the ten percent real discount rate.

In order to reflect these two different perspectives, the Department has undertaken sensitivity analysis in evaluating alternatives, incorporating both the discount rate called for in A-94 and the rate prescribed in A-104. Furthermore, sensitivity analysis is undertaken to indicate how reliance on certain financing methods could affect the rate of SPR fill. Since budget allowances and 
scorekeeping conventions represent decisions by the Congress and the President, these sensitivity tests are only examples of a broad range of plausible outcomes.

\section{Business Risk}

The direct financial risks of owning a barrel of oil are considerable. Over the past decade, oil prices have been as high as approximately double the mid-1989 levels, but they have also been as low as approximately half the current level. The price cases presented in Chapter V likewise provide a broad range of possible market conditions over the coming decade. Using either recent history or current projections, the owner of a barrel of oil faces considerable uncertainty as to its future value.

All other things being equal, in a private market context an investment with a higher degree of perceived risk will command a higher rate of return, to compensate the investor for bearing the risk. Faced with a choice between investing funds in Treasury securities, where there is essentially no default risk to the lender, and investing in oil, a private sector party would only choose the oil investment if the rate of return exceeded that on the Treasury securities.

Some SPR financing methods entail sharing the financial risk and reward of oil ownership with participants outside the Federal Government. The purpose of this section is to discuss the return of these risks, based on historical experience.

Four historical examples are provided:

- Ownership of oil versus debt instruments;

- $\quad$ Ownership of oil versus stock market instruments;

- Federal experience in SPR oil ownership; and

- $\quad$ Portfolio effects of oil ownership.

\section{a. Oil Ownership Versus Debt Instruments}

To analyze the historical business risk that would have been associated with owning a barrel of oil rather than debit instruments, the Department used a methodology as follows:

- Actual oil price trends, in nominal dollars per barrel, were identified for the period 1960 through 1988.

- Average yields for three different investments were collected for each year:

- 3-year Treasury securities

- 10-year Treasury securities 
- The Moody's Aaa corporate bond yield for high quality private debt instruments with maturities of fifteen to twenty-five years.

- Using this data, the Department determined estimates of what the oil price would have to have been in each year from 1970 to 1988 for an investor to have broken even, at each of the above interest rates, after having bought a barrel of oil 5 or 10 years earlier at market prices. $\underline{1}$. These break-even prices were then compared to actual oil prices in the years in question.

Exhibit A-1 provides the input data for this analysis and Exhibit A-2 provides the results.

The results can be summarized as follows:

- In 8 of the 19 years tested, an investor would have lost money by investing in a barrel of oil rather than buying and holding 10-year Treasury securities. Gains would have been realized only in the middle years, 1974-1984, for oil acquired in the 1964-1974 period.

- In 9 of the 19 years tested, an investor would have lost money by investing in a barrel of oil held for five years.

- In 8 of the 19 years tested, an investor would have lost money by investing in a barrel of oil rather than buying and holding high quality corporate bonds.

Figure IV-2 presents a frequency distribution for gains and losses, using the 10 -year Treasury bond comparison cited above.

In sum, there would have been gains from holding oil, rather than conventional financial instruments, but there would have been very significant losses in some years.

\section{b. Oil Ownership versus Equity Insitiüments}

Another investment comparison which could be made is between performance of oil prices and the stock market. To undertake this analysis, the annhual change in vil prices (which would be the annual rate of return from a pure oil-denominated investment) was compared to the performance of the stocks constituting the Standard and Poor 500 index.

Over the entire period 1960-1988, the simple average annual pre-tax nominal total return (dividend payments plus price appreciation) on the Standard \& Poor's Corporate Index was 10.4 percent

1/ The three-year Treasury rate is used as a proxy for the five-year rate to represent the opportunity cost in the five-year scenarios. 
Figure IV-2

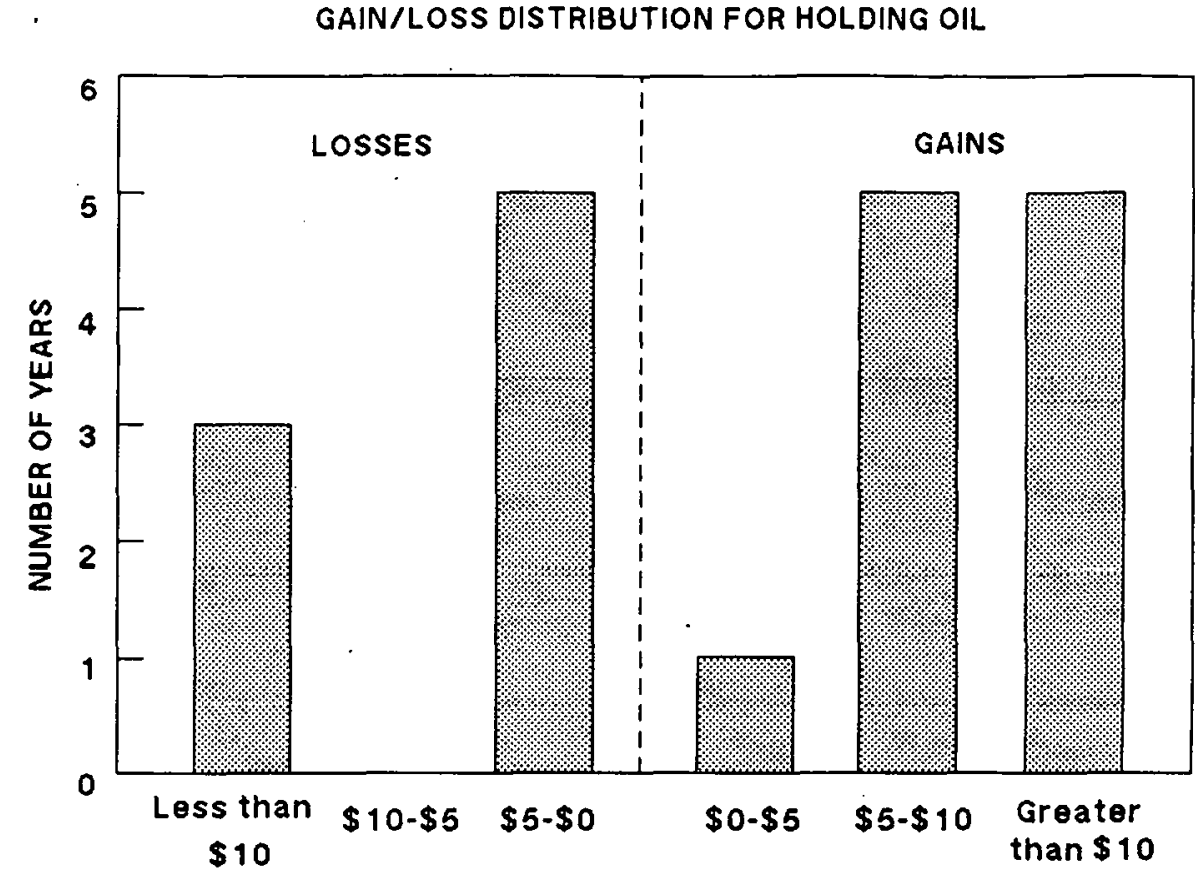

whereas the average rate of return on oil was 10.1 percent. However, around those average points, there has been much more variation in oil price returns than in stock market returns. Exhibit A-3 presents the data series used in this analysis.

In general, the rates of return on the overall Standard \& Poor index (though not necessarily on individual stocks) have been clustered rather tightly around the 10.4 percent annual average. Of the 29 years, only five reflected any overall stock market losses and two (1983 and 1986) reflected gains in excess of 25 percent. In contrast, oil prices declined in 11 of the 29 years, but increased by more than 25 percent in four other years.

One measure of the dispersion of outcomes relative to the average is the standard deviation, which was 12.4 percent for the Standard and Poor 500 returns, but 42.1 percent for oil price returns.

While there are a number of simplifying assumptions embodied in this analysis, it illustrates that if history is an accurate guide, then investors in oil-denominated investments (such as SPR oil leases or oil-denominated bonds) face a high degree of uncertainty regarding returns from the oilprice-appreciation component of the security. Even when average returns are similar, oil investment creates the possibility of higher gains and higher losses in a larger number of years. 


\section{c. Federal Experience}

While lenders to the Federal Government do not face default risk, this does not mean that investments by the Federal Government are risk free. In particular, the Federal Government has incurred risks and from a purely financial perspective, ownership losses from its investment in the SPR. Exhibit A-4 compares the average cumulative cost of SPR oil to the current market price of oil as reflected by the average refiner acquisition cost for each calendar year. By the end of 1988 , the resale value of the SPR oil inventory was only slightly over half the purchase costs.

If the Treasury borrowing rates are applied to the direct SPR costs, the cumulative total cost of the SPR oil inventory through the end of FY 1988 would be an estimated $\$ 31$ billion, or approximately $\$ 56$ per barrel of oil stored. This per barrel total investment cost is several times higher than the average market price at the end of 1988.

\section{d. Portfolio Effects}

The foregoing discussion focuses exclusively on the direct benefits and risks of ownership of oil and does not reflect the effects of holding oil as a part of an overall set, or portfolio, of investments. For the broader national security and economic context, the SPR has been considered an "insurance policy" that protects the nation against a particular type of low-probability, highconsequence event -- a severe energy supply interruption. Some also have argued that the SPR can deter certain types of energy supply interruptions, while others have argued that the existence of the SPR serves to dampen market reactions to events in oil producing regions of the world. For all of these reasons, SPR development to date could have yielded net economic benefits to the United States even if there have been financial net losses to the Government.

The private sector analogy to these arguments could include investment portfolio theory. Specifically there may be certain types of investments that, while yielding low or even negative direct profits, may serve to reduce the risk (and hence increase the value) of the investor's total portfolio of investments. One response to the Notice of Inquiry regarding alternative SPR financing drew an analogy between ownership of oil and ownership of gold, as inflation hedges within overall investment portfolios.

Under this concept, the question becomes not just whether an oil price instrument has more or less risk than a lireasury bond or the average stock market porttolio, but how the rates of return on oil instruments would relate to stock market returns. If it could be demonstrated that oil price returns varied inversely with stock market returns and that this was a strong relationship, it could be argued that investors would be interested in investing in oil as a hedge against fluctuation in the costs of return on other assets.

A regression analysis was undertaken to examine this possibility. The conclusion was that over the entire period 1960-88, there was a weak negative correlation between stock market returns and oil price changes. When the dramatic shifts of 1974 were removed from the data base, the correlation between the two sets of returns approached zero. 
Within this period of three decades, there were significant shifts in the relative changes in stock market and oil returns, as shown in Table IV-1.

Table IV-1

Subperiod Patterns in Investment Returns

\begin{tabular}{lccccccc} 
Subperiod & Mean & & \multicolumn{2}{c}{ Standard Deviation } & & \multicolumn{2}{c}{ Covariance } \\
\cline { 5 - 7 } & & & $\frac{\text { S\&P }}{.51}$ & $\frac{\text { Oil }}{8.01}$ & & $\frac{\text { S\&P }}{1.77}$ & $\frac{\text { Oil }}{-.10}$ \\
$1960-69$ & 8.99 & & 27.76 & 12.44 & & 61.45 & -.60 \\
$1970-79$ & 5.43 & & -.23 & 12.70 & & 26.77 & +.01
\end{tabular}

During the 1960's, the average return on oil was low, and the relationship between the two markets was a very weak negative.

During the 1970's, both the average annual rate of return on oil and oil return volatility increased, and there appears to have been a moderately strong negative covariance between the markets. However, much of this intermarket relationship was attributable to 1974, when the oil price increased by over 200 percent and the stock market had a negative return of nearly 20 percent. Both of these effects are linked to the 1973-74 oil embargo. When 1974 is removed from the data series, there is little or no remaining statistical relationship between markets.

During the 1980's, there has been no measurable statistical relationship between the markets. In the nine years analyzed, there were four years in which the stock market and oil returns had the same sign (both positive or both negative) and five years in which they had the opposite sign (one negative and the other positive).

A market analyst considering the use of an oil investment as a part of a portfolio would consider not only the historical trends between the two markets but also the theoretical relationships. In this regard, there are two somewhat contradictory theoretical arguments which could be made. First, it could be argued that general economic growth tends to put upward pressure on oil demand and prices, while at the same time fostering increased corporate profits and stock market returns. On this basis, one would suppose that oil prices and stock market returns would be positively correlated.

A second argument would be that a dramatic increase in oil prices, due to a severe energy supply disruption, would curtail economic growth and create the potential for stock market losses. This would suggest a negative correlation of the returns between the markets, at least under conditions of rapid, rather than gradual change. 


\section{Policy-Created Risk}

The discussion thus far has addressed risk as a general characteristic of the oil market and of other investment markets, independent of the structure of an SPR financing policy. However, there may be some forms of risk that are affected by the design of a particular policy alternative. Under current practice, the Federal Government acts in both a sovereign and an ownership capacity during a deployment of the SPR. Since all of the Reserve inventory is Government-owned, decisions about which oil is sold at which point during a drawdown are principally of a technical nature. Issues regarding the taxability of sales proceeds under current or future legislation are of no immediate interest, because of the tax-exempt status of the Reserve.

Under financing alternatives that created a distinction between ownership of and control over the oil, there would be the potential for concern by investors that the Government's actions in a sovereign capacity, whether through taxation or through decisions on SPR deployment, would conflict with the interests of investors. In this regard, the Government is an unusual business partner, and it is reasonable to suppose that investors would foresee some risks from this business relationship that are different than normal private business risks.

There may also be ways in which a private investor would attribute a reduction in risk to a business relationship with the Government. Specifically, the risk of a default in financial obligations is eliminated in contract relations with the Government. Furthermore, there is added physical security for oil storage under Government control.

\section{Conclusions}

There are a number of different -- and somewhat contradictory -- perspectives regarding the relationship of risk and rate of return for the types of SPR financing alternatives that are being considered in this study. In general, it appears reasonable to conclude as follows:

- In selecting among Federal standards for rates of return, it is necessary to make assumptions about the extent to which the method of financing may affect the magnitude of the investment. If the level of SPR fill is determined irrespective of the financing method, current Federal practices would use the Treasury borrowing rate as the standard for comparison, but higher rates might be warranted if SPR fill levels were affected by financing methods.

- There is a substantial body of evidence that an investment in oil would have exposed investors to a high degree of risk over recent decades, when compared to alternative forms of investments in bond and stock markets. The Federal Government has been exposed to this risk in its past SPR expenditures. There could be a justification for using higher rates of return in evaluating financing methods that transfer this risk to the private sector.

- There is not strong evidence that this high degree of direct financial risk is offset by the effects of portfolio diversification under normal, 
undisrupted market conditions. There may be a beneficial portfolio effect associated with a severe energy supply disruption such as the 1973-74 embargo, but evidence of this is very limited.

- A consideration in the design of a financing alternative should be the degree to which design features may expose investors to added risks as a result of the broader roles of the Federal Government.

In evaluating certain financing alternatives in subsequent chapters, the Department's approach to the question of risk and rate of return is to undertake sensitivity analysis to illustrate both the potential variability in returns to the Government and investors and the effects of using different target rates of return.

\section{MARKET FOR STRATEGIC PETROLEUM RESERVE INVESTMENT}

\section{Introduction}

Two of the financing alternatives analyzed in this study -- oil leasing and oil-denominated bonds -- entail voluntary investment in the Strategic Petroleum Reserve by parties outside the Federal Government. The two alternatives have in common the idea that an investor or a group of investors would be willing to defer alternative uses of their capital -- whether in the form of oil (through leasing) or money (through purchase of oil bonds) -- in order to invest in the SPR, in return for some combination of current financial payments and capital recovery related to trends in the market price of oil.

In efficient markets, it would be doubtful that the Government could expect to gain from shifting from one form of financing to another. Faced with high demand for oil-based financial instruments, other market participants would presumably decide to issue such securities.

This part provides a preliminary assessment of the potential for obtaining voluntary investment in the SPR under acceptable or break-even terms, and discusses approaches for dealing with uncertainties regarding market responses to Federal initiatives.

\section{Public Versus Private Ownership}

The financial benefits of SPR oil to the owner are derived from the potential for appreciation in the value of the oil during the period in storage. However, the benefits of the SPR to the nation as a whole would include not only these "ownership" benefits but also the indirect benefits associated with the ability of the SPR to mitigate the effects of a major energy supply interruption on the U.S. economy. For example, the deployment of the Reserve inventory is expected to reduce the market price of oil in comparison to the price that would be obtained during a supply disruption if there were no SPR use. Accordingly, the SPR provides benefits to all U.S. oil consumers, not just to the owner.

If a private owner only could obtain a portion of the overall benefits of the Reserve, but the Government reflected total economic benefits in its decision making, then one would expect that the private economy would be less likely to acquire and hold strategic oil stocks than would the 
Government. This effect is demonstrated in a modelling experiment carried out by the Oak Ridge National Laboratory, using the Teisberg model, a dynamic programming computer simulation model that has been used to analyze a number of aspects of SPR policy. In this experiment, the same oil price, disruption probability, and discount rate assumptions were used for a private owner -interested only in the direct financial benefits of oil ownership -- and a public agency which is concerned by the direct and the broader economic effects of stockpiling.

The results of this experiment can be summarized as follows:

- When the model was run to optimize SPR fill decisions in accordance with the broader economic effects recognized by a public agency, there were net financial losses to a private owner.

- When the model was run to optimize SPR fill decisions in accordance with the direct financial effects on a private owner, the result was a net loss of economic benefits viewed from the broader Government perspective.

- In the year 2000 , the gap between the two different perspectives was quite wide: while the "public" agency would be seeking a stockpile of one billion barrels, the optimal size from a private perspective would be about 350 million barrels.

It should be noted that this experiment was oriented explicitly toward the expansion of the Reserve from $750 \mathrm{MMB}$ to $1000 \mathrm{MMB}$. It is possible to identify circumstances under which this expansion would not yield net benefits from even a broader economic perspective. The question of whether to expand the Reserve is not dealt with in this study. However, the issue raised is that even under circumstances in which such expansion was warranted from the broad public perspective, a narrower ownership perspective might not appear profitable. This suggests that there are questions as to whether, without some form of public sector subsidy, it is reasonable to expect the appropriate level of stockpiling to be achieved through voluntary private investment.

This question has been addressed on several occasions by the National Petroleum Council (NPC) and by industry groups. In general, the NPC has concluded that the private sector develops and maintains petroleum inventories primarily to satisfy its operational requirements, including seasonal stocks, rather than to protect against the possibility of a major energy supply interruption.

One private sector representative commenting on the potential for attracting private investment in the SPR noted the unique role being played by the SPR in managing market risk. Specifically, he remarked that investment in the SPR would be less profitable when oil prices remained low, even though lower oil prices tended to provide net benefits to the U.S. as a net importer of oil. Conversely, the SPR would be most profitable when oil prices increased dramatically, yet such rapid price increase would be damaging to the overall economy.

Therefore, SPR financial success would be contrary to overall U.S. economic well being, and investors in the SPR would be in a position of basing their financial returns on the potential for national problems. 


\section{Market Size}

The Reference Case (Table V-6) suggests the need to finance in the capital markets as much as $\$ 18.8$ billion over a 15 year period to complete a one billion barrel SPR at a fill rate of 75,000 barrels per day (27 million barrels per year). This includes SPR facilities costs, so that the funds needed for oil fill alone would be in the range of only $\$ 14-15$ billion, or around $\$ 1$ billion per year. The question arises as to whether such financing would be difficult to accomplish either directly in the financial markets thorough oil-index bond sales or indirectly through competitively bid oil-leasing arrangements, which in turn could lead to secondary financings of oil-indexed securities by the initial investors.

As discussed in later chapters, it would be possible to enter into voluntary investment agreements in one of two ways. First, the U.S. Government would conduct a competitive solicitation, based on a set of terms and conditions defined by the Government and applicable to all participants. This is the preferred approach in normal Federal procurements and also in Treasury issues of Federal debt securities. Each contract, whether an oil lease or an oil-denominated bond, would represent a financial instrument that could be traded in private capital markets.

An alternative approach would be to enter into a non-competitive contract, possibly a governmentto-government arrangement with a major oil-producing country. In this case, an agreement could be tailored to the individual needs of the participants. The most likely participants in such arrangements would be nations with excess production capacity.

Chaptcr VI discusses, in more depth, the possibility of agreements with oil-producing countries. The remainder of this section addresses the competitive approach toward issuing oil-related financial instruments.

In the broadest terms, of course, the additional financial requirement of $\$ 1$ billion per year is small in comparison to current levels of new U.S. Government debt issues. So, too, is the incremental demand of 27 million barrels per year in relation to the 18 billion barrels of oil consumed each year in the non-communist world. In addition, worldwide investment in the petroleum industry approximates $\$ 200$ billion annually.

These broad figures, however, conceal a number of specialized sub-markets where either the lease or the bond would likely compete for investor financing. The history of oil-index bonds is limited to only about $\$ 500$ million raised over the past decade. Such bonds were issued by both oil producing countrics in need of funds (e.g., Mexicn, Nigeria) and by private oil companies (e.g., British Petroleum/Sohio). None, however, were issued by the U.S. Government or other major industrial countries, where thc risk of default is virtually zern.

As to the competition for funds related to oil leasing, the most analogous sub-markets would appear to be either the New York Mercantile Exchange's traded crude oil operations or the overthe-counter market in long term oil swaps. The number of outstanding crude oil options contracts is around 200,000, or the equivalent of 200 million barrels. These are typically two to three month options, with premiums of around $\$ 1$ per barrel. As a result, investors are paying somewhere in the range of $\$ 1$ billion per year, approximately the SPR oil financing requirement. Also, it has 
been estimated that the size of the oil swap market is around $\$ 3$ billion per year. Given the very rapid growth of these markets over the past five years, prior to which time they were virtually nonexistent, it is possible that the introduction of an SPR Government-sponsored oil-related financial instrument could be accommodated by the current and growing investor interest in these types of securities.

The receptivity of investors to these U.S. Government backed oil-related securities would, in part, be determined by their design features. While the lease and the bond may be similar in some respects, they would differ in at least two important ways. First, the lease size at a minimum of 5 million barrels would be worth around $\$ 100$ million, while a single bond would have only a $\$ 1000$ denomination. This difference clearly affects the number of interested investors. As a result, the initial market for the lease would not likely encompass more than 100 individual investor entities, such as oil exporting countries, oil companies, and large banks or investment firms.

Second, with the investor call feature, the bond could be traded in the short-term oil-related financial markets, because the bond would have on-going value commensurate with the price of oil. To the extent that the Government-sponsored oil lease did not have a value commensurate with the on-going price of oil, the initial lessors could resell a "strip" version of the lease security in smaller denominations, and offer the secondary investor the equivalent of the bond's call feature. Consequently, both securities could have a similar marketability to a wide group of institutional investors.

Listed below are six investor groups that would likely be interested in either of these securities, based on such incentives as oil price hedging, investment diversification, speculation, or ease of access to crude oil in a disruption. These investor groups are:

\section{Oil Importing Industrial Countries}

Governments of certain major oil-consuming countries, especially those with substantial balance of payments surpluses, would view an oil index security as a hedge against rising oil prices. This is especially true of Germany and Japan where there is a high degree nf vilnerability to an oil supply disruption. While not providing physical oil in a disruption, an element of financial protection could be achieved by owning these securities.

\section{Private Sector Oil-Consuming Companies}

Ownership of U.S. Government-backed oil securities would present a relatively risk-free financial hedge to industrial companies that consume large amounts of petroleum products. This is true both for U.S. companies and for foreign companies. Airlines, shipping companies, railroads, utilities, and energy-intensive manufacturing companies all represent potential purchasers. While the minimum rate of return might not equal that of conventional U.S. Treasury bonds, the financial risk associated with a large increase in oil prices may be sufficient offsetting compensation. Purchases of these securities would be only incremental to other financial investments and could also qualify for pension fund investments. Finally, overseas companies might well view the dollar interest rate as attractive relative to rates in their own countries. 


\section{Oil Refining Companies}

Ease of access to SPR oil in the event of a disruption would likely be the major motivating factor for oil refining companies. In addition, the financial gain in the event of disruption might well offset the loss in rate of return relative to other low risk investments.

\section{Financial Institutions}

Equity incentives in real estate, project finance, and corporate takeovers are by now commonplace in pension fund, insurance company, and other large investment portfolios. Purchase of these U.S. Government-backed securities would represent a low risk diversification with an equity incentive and could play a role in the investment portfolios of these financial institutions. Here, again, the attraction might even be greater for foreign financial institutions, because of the dollar exchange rate, relative interest rates, and U.S. Government guarantees.

\section{Current U.S. Government Bond Investors}

Some current Government bond investors might be attracted to the potential reward from the oil price link and be willing to accept a lower minimum yield-to-maturity than with a conventional Treasury bond. The oil security would represent only a very small increase in their risk/return profile and could be done on a relatively small scale.

\section{Oil Trading Companies and Banks}

Participants in both the short- and long-term "wet" and "paper" barrel oil markets would be attracted to these oil securities. While not likely to be long-term investors, they could provide a high degree of liquidity to a secondary market. With a timely link to oil prices and an investor call feature, the security could be traded against the oil futures and options markets. That is, the SPR oil security could be used for hedging or speculation, and as such would be arbitraged against the oil futures market. This is analogous to current commercial practice in the Treasury bill and Treasury bond markets, where there is constant arbitrage against other similar money market instruments. An oil trader, for example, could hold these securities against a short commitment to deliver oil under a several month price-reference contract. This would be similar to a long futures position or the purchase of a call option. Banks, making long-term sway markets in oil, could hold these securities during the period of matching the different volume and timing needs of buyers and sellers. Because the oil trading markets today are so closely linked to the financial markets, these securities would represent a useful supplement to the trader's tool kit for both short-term risk reduction and short-term profit enhancement.

While the above list is not meant to be exhaustive, it suggest the types of investors likely to be attracted to U.S. Government-backed oil index securities.

The Interagency Working Group met with a panel of representatives from the private sector to learn more about the growing market for oil-backed securities: In addition, a number of companies were asked about prevailing market terms and conditions for such instruments. While this market segment is still developing and there is not yet a high degree of price transparency, there are a number of broad conclusions which can be drawn: 
- In general, the market participants are not now willing to accept the current Federal Government assumptions, as presented in Chapter $\mathrm{V}$, concerning significant future increases in real and nominal oil price levels. This does not mean that they necessarily disagree with Government price projections; rather, it means that they are not willing to assume such prices as the basis for making financial commitments. For example, a recent survey by the Society of Petroleum Engineers entitled "Review of Parameters Used in Property Evaluation" indicated that private participants in oil production investments are assuming prices in 1998 in the range of $\$ 26$ per barrel, in nominal dollars. This is approximately equal to the Low Case oil price projections presented in Chapter V and is approximately 25 percent below the Base Case oil price projections.

- The market is concerned about the "downside" potential for oil investments, based on its experience in the mid-1980's. As an example, one estimate was received that a private company would charge $\$ 3.25$ per barrel for the right to be able to sell oil at $\$ 20$ (a "put" option) in 10 years. A larger fee of. $\$ 6.50$ per barrel would be charged for the right to sell a barrel at $\$ 20$ at any time within the 10 -year period. Since the party selling the "put" option could invest the $\$ 3.25$ for the 10-year period, for a future value of approximately $\$ 7$ at a rate of 8 percent, the seller of the "put" would break even at prices above approximately $\$ 13$ per barrel.

- The pre-tax discount rates used in the oil market appear to be higher than the 8-13 percent range used in this study. One set of estimates entailed a 12 percent after-tax cost of capital. This could translate into pre-tax rates of return of approximately 17 percent.

- The SPR program time horizon is generally longer than the maturities of current market instruments for oil-backed investments.

- A large proportion of the current market, such as the oil price "swap" market, does not result in remaining immediate cash for new investment. Rather, it involves commitments by oil buyers and sellers, working through intermediaries, to. make purchases or sales at future dates at particular prices.

Accordingly, there is reason to believe that the private capital markets would require compensation for the types of risk inherent in an SPR oil lease or oil denominated bond, and it is uncertain whether the Federal Government could raise all of the capital regained for future SPR development, at an acceptable cost. 


\section{Dealing with Market Uncertainty}

There are three approaches that the Government could adopt in the face of uncertainty about market conditions for voluntary private investment in the SPR. The first approach would be to let the Government decide on a particular SPR fill rate and offer the investment opportunity to the private sector with the intent to accept all private bids up to the volume desired, with indefinite budget authority to cover the resulting financial obligations. In this case, all uncertainty would be reflected in the financing requirements, and none would be reflected in the fill rate. In some respects, this would parallel the Treasury auction of U.S. debt instruments, wherein the effective financing charge adjustments with market conditions and Congress has provided permanent indefinite authority to pay the interest on the debt incurred.

A second approach would be to set a reservation price or some other financing cost criterion to reflect the Government's view of the appropriate terms and conditions for the financing arrangement. For example, this could be expressed as a rate of return linked to Treasury borrowing experience. In this case, the volume of oil (in the case of leases) or the amount of financing (in the case of bonds) would fluctuate with the results of the public sale. In general, to the extent that the investment return was linked to the future price of oil, this approach would permit the Government to acquire more oil when the private market had the highest expectations for future price appreciation, but would permit the Government to acquire less oil when private expectations were for softer future markets. If the private expectations turned out to be accurate, this approach would have the benefit of increasing SPR fill rates during periods of slack markets, in anticipation of future price growth, but decreasing SPR purchases in tight markets, in anticipation of future softening.

This second approach would not, by itself, be compatible with establishing a firm SPR fill rate criterion, such as the minimum average daily fill rate which has been employed by Congress in different ways since 1980 .

A third approach would be a combination of the first two, under which the Congress would provide an appropriation of SPR oil acquisition that could be used either for direct purchase of oil or for meeting Federal obligations under one of the alternative financing approaches. The expected degree of succcss in acquiring oil through private investment could be reflected in the budget as an estimated offset to the use of appropriated funds, but if the investment could not be attracted within the reservation price criteria, the amount of the offset would be reduced. A variation of this approach would entail permitting the Department to use a portion of the appropriations for direct purchases to achieve some minimum fill rate. Thus, Congress might set an appropriation level sufficient to achieve 50,000 barrels per day under the direct purchase method, with a higher target rate such as 75,000 barrels per day if alternative financing proves successful.

In sum, at least one of the following variables needs to be left flexible in the face of market uncertainty: (1) the SPR financing cost and appropriation requirement, (2) the SPR fill rate, or (3) a combination of the two. 


\section{Conclusions}

There is reason to question, on theoretical grounds, whether the Federal Government could expect to gain by adopting a new financing method. Moreover, while there is a large and growing market for oil-backed securities, such as those which could be issued for the SPR, there would be obstacles to the issuance of such securities. Specifically, it appears that the Federal Government's oil price projections are significantly above those of private investors, making it less likely that mutually acceptable terms could be arranged.

Consideration would need to be given to ways of dealing with uncertainty in market response to SPR financing initiatives. 


\section{EXHIBIT A}

Source Data For Debt Calculations

Exhibit A-1

Interest Rates

\begin{tabular}{|c|c|c|c|c|}
\hline $\begin{array}{l}\text { Calendar } \\
\text { Year } \\
\end{array}$ & $\begin{array}{l}\text { 3-Year } \\
\text { Treasury }^{2 /}\end{array}$ & $\begin{array}{l}\text { 10-Year } \\
\text { Treasury }\end{array}$ & $\begin{array}{l}\text { Moody's } \\
\text { Aaa b/ }\end{array}$ & $\begin{array}{l}\text { Oil Price }{ }^{\prime} \\
(\$ / \mathrm{bbl})\end{array}$ \\
\hline 1960 & 3.98 & 4.12 & $4.41 \%$ & 3.57 \\
\hline 1961 & 3.54 & 3.88 & $4.35 \%$ & 3.59 \\
\hline 1962 & 3.47 & 3.95 & $4.33 \%$ & 3.60 \\
\hline 1963 & 3.67 & 4.00 & $4.26 \%$ & 3.60 \\
\hline 1964 & 4.03 & 4.19 & $4.40 \%$ & 3.59 \\
\hline 1965 & 4.22 & 4.28 & $4.49 \%$ & 3.61 \\
\hline 1966 & 5.23 & 4.92 & $5.13 \%$ & 3.63 \\
\hline 1967 & 5.03 & 5.07 & $5.51 \%$ & 3.65 \\
\hline 1968 & 5.68 & 5.65 & $6.18 \%$ & 3.68 \\
\hline 1969 & 7.02 & 6.67 & $7.03 \%$ & 3.86 \\
\hline 1970 & 7.29 & 7.35 & $8.04 \%$ & 4.04 \\
\hline 1971 & 5.65 & 6.16 & $7.39 \%$ & 4.20 \\
\hline 1972 & 5.72 & 6.21 & $7.21 \%$ & 4.36 \\
\hline 1973 & 6.95 & 6.84 & $7.44 \%$ & 4.08 \\
\hline 1974 & 7.82 & 7.56 & $8.57 \%$ & 12.52 \\
\hline 1975 & 7.49 & 7.99 & $8.83 \%$ & 13.93 \\
\hline 1976 & 6.77 & 7.61 & $8.43 \%$ & 13.48 \\
\hline 1977 & 6.69 & 7.42 & $8.02 \%$ & 14.53 \\
\hline 1978 & 8.29 & 8.41 & $8.73 \%$ & 14.57 \\
\hline 1979 & 9.71 & 9.44 & $9.63 \%$ & 21.67 \\
\hline 1980 & 11.55 & 11.46 & $11.94 \%$ & 33.89 \\
\hline 1981 & 14.44 & 13.91 & $14.17 \%$ & 37.05 \\
\hline 1982 & 12.92 & 13.00 & $13.79 \%$ & 33.55 \\
\hline 1983 & 10.45 & 11.10 & $12.04 \%$ & 29.30 \\
\hline 1984 & 11.89 & 12.44 & $12.71 \%$ & 28.88 \\
\hline 1985 & 9.64 & 10.62 & $11.37 \%$ & 26.99 \\
\hline 1986 & 7.06 & 7.68 & $9.02 \%$ & 14.00 \\
\hline 1987 & 7.68 & 8.39 & $9.38 \%$ & 18.13 \\
\hline 1988 & 8.26 & 8.85 & $9.71 \%$ & 14.64 \\
\hline
\end{tabular}

Sources:

a/ Treasury yield data were taken from Economic Report of the President January 1989 p. 390.

b/ Moody's Aaa Corporate Bond yields were derived from Economic Report of the President January 1989 , p. 390.

s/ 1960-1972 average refiner acquisition cost for imported oil, from Arlon R. Tussing, "Reflections on the End of the OPEC Era," Alaska Review of Social and Economic Conditions. XIX No. 4 (Dec. 1982), pp. 1-16. 1973-1988 ELA Monthly Energy Review, May 1989, p. 97. 
Exhibit A-2

Results of Break-even Oil Price Analysis

\begin{tabular}{|c|c|c|c|c|}
\hline \multirow{3}{*}{$\begin{array}{l}\text { Calendar } \\
\text { Year }\end{array}$} & \multirow{3}{*}{$\begin{array}{l}\text { Actual } \\
\text { Oil Price }\end{array}$} & \multicolumn{3}{|c|}{ Break-even Oil Price } \\
\hline & & 3-Year & 10-Year & Moody's Aaa \\
\hline & & Treasury & Treasury & Corporate \\
\hline 1970 & 4.04 & 4.44 & 5.35 & 5.49 \\
\hline 1971 & 4.20 & 4.68 & 5.25 & 5.49 \\
\hline 1972 & 4.36 & 4.67 & 5.30 & 5.51 \\
\hline 1973 & 4.08 & 4.85 & 5.33 & 5.46 \\
\hline 1974 & 12.52 & 5.42 & 5.41 & 5.52 \\
\hline 1975 & 13.93 & 5.75 & 5.49 & 5.60 \\
\hline 1976 & 13.48 & 5.53 & 5.83 & 5.98 \\
\hline 1977 & 14.53 & 5.75 & 5.99 & 6.25 \\
\hline 1978 & 14.57 & 5.71 & 6.38 & 6.70 \\
\hline 1979 & 21.67 & 18.24 & 7.36 & 7.62 \\
\hline 1980 & 33.89 & 19.99 & 8.21 & 8.76 \\
\hline 1981 & 37.05 & 18.70 & 7.64 & 8.36 \\
\hline 1982 & 33.55 & 20.09 & 7.96 & 8.74 \\
\hline 1983 & 29.30 & 21.70 & 7.91 & 8.36 \\
\hline 1984 & 28.88 & 34.44 & 25.95 & 28.49 \\
\hline 1985 & 26.99 & 58.54 & 30.05 & 32.47 \\
\hline 1986 & 14.00 & 72.72 & 28.07 & 30.28 \\
\hline 1987 & 18.13 & 61.60 & 29.72 & 31.43 \\
\hline 1988 & 14.64 & 48.16 & 32.67 & 33.65 \\
\hline
\end{tabular}

Source:

a) 1970-1972 average refiner acquisition cost for imported oil, from Arlon R. Tussing, "Reflections on the End of the OPEC Era," Alaska Review of Social and Economic Conditions. XIX No. 4 (Dec. 1982), pp. 1-16. 1973-1988 ELA Monthly Energy Review, May 1989, p. 97. 


\section{Exhibit A-3}

Comparison of Equity Returns and Oil Price Changes

Calendar

\begin{tabular}{l} 
Year \\
\hline 1960 \\
1961 \\
1962 \\
1963 \\
1964 \\
1965 \\
1966 \\
1967 \\
1968 \\
1969 \\
1970 \\
1971 \\
1972 \\
1973 \\
1974 \\
1975 \\
1976 \\
1977 \\
1978 \\
1979 \\
1980 \\
1981 \\
1982 \\
1983 \\
1984 \\
1985 \\
1986 \\
1987 \\
1988 \\
\end{tabular}

\begin{tabular}{r} 
S\&P Return \\
\hline $0.8 \%$ \\
$21.6 \%$ \\
$-2.5 \%$ \\
$15.2 \%$ \\
$19.5 \%$ \\
$11.4 \%$ \\
$0.1 \%$ \\
$11.0 \%$ \\
$10.4 \%$
\end{tabular}

Oil Return

$2.4 \%$

$-11.1 \%$

$21.2 \%$

$13.9 \%$

$1.4 \%$

$-18.4 \%$

$8.3 \%$

$22.2 \%$

$0.9 \%$

$3.1 \%$

$12.8 \%$

$20.6 \%$

$13.0 \%$

$-0.7 \%$

$38.4 \%$

$4.7 \%$

$20.7 \%$

$30.0 \%$

$24.4 \%$

$-3.7 \%$

$-2.7 \%$

$0.5 \%$

$0.5 \%$

$-0.2 \%$

$-0.2 \%$

$0.5 \%$

$0.5 \%$

$0.6 \%$

$0.6 \%$

$5.0 \%$

$4.7 \%$

$3.9 \%$

$3.6 \%$

$-6.4 \%$

$206.9 \%$

$11.3 \%$

$-3.2 \%$

$7.8 \%$

$0.3 \%$

$48.7 \%$

$56.4 \%$

$9.3 \%$

$-9.4 \%$

$-12.7 \%$

$-1.4 \%$

$-6.5 \%$

$-48.1 \%$

$29.5 \%$

$-19.2 \%$

Std Errors

$12.4 \%$

$42.1 \%$

Means

$10.4 \%$

$10.1 \%$ 
Exhibit A-4

\begin{tabular}{|c|c|c|c|c|}
\hline Fiscal Year & $\begin{array}{l}\text { Cumulative } \\
\text { SPR Oil } \\
\text { Costs } \\
\text { (\$ Millions) }\end{array}$ & $\begin{array}{l}\text { Cumulative } \\
\text { SPR } \\
\frac{\text { Inventory }}{(\mathrm{MMB})}\end{array}$ & $\begin{array}{l}\text { Average } \\
\text { Cost Per } \\
\text { Barrel } \\
\end{array}$ & $\begin{array}{l}\text { Market } \\
\text { Price }\end{array}$ \\
\hline 1977 & 16 & 1.3 & 12.58 & 14.53 \\
\hline 1978 & 615 & $15: 9$ & 13.10 & 14.57 \\
\hline 1979 & 1,285 & 91.2 & 14.09 & 21.67 \\
\hline 1980 & 1,341 & 92.8 & 14.45 & 33.89 \\
\hline 1981. & 5,247 & 199.2 & 26.42 & 37.05 \\
\hline 1982 & 7,952 & 277.9 & 28.62 & 33.55 \\
\hline 1983 & 10,397 & 361.0 & 28.80 & 29.30 \\
\hline 1984 & 12,559 & 431.1 & 29.13 & 28.88 \\
\hline 1985 & 14,257 & 489.3 & 29.14 & 26.99 \\
\hline 1986 & 14,557 & 506.4 & 28.75 & 14.00 \\
\hline 1987 & 15,061 & 533.9 & 28.21 & 18.13 \\
\hline 1988 & 15,397 & 554.7 & 27.76 & 14.64 \\
\hline
\end{tabular}

a/ Average Refiner Acquisition Cost for Imported Oil for calendar year. 


\section{CHAPTER V. REFERENCE CASE}

\section{A. INTRODUCTION}

The purpose of Chapter $\mathrm{V}$ is to describe SPR development and fill alternatives and associated costs, assuming that the program is financed according to existing practice. It is against this backdrop of existing SPR practices that alternative methods of finance and development are compared and assessed in later chapters.

\section{Variables and Sensitivities}

For comparison purposes, a Reference Case has been constructed, involving three sets of variables, as follows:

- Three SPR size increments:

1) 600 to 750 million barrels

2) 750 to 850 million barrels

3) 850 million barrels to one billion barrels

- An average annual fill rate of 75,000 barrels per day (75 MB/D) or 27 million barrels per year; and

- The Base Case oil price projection from the Energy Information Administration's Annual Energy Outlook, 1989, through the year 2000 , extended beyond 2000 through the use of an oil market simulation model.

The storage capacity development schedules for the three SPR size increments are based on a continuation of current practices regarding the oil commodity type, storage facility type and storage facility location, as described more fully below.

The Reference Case is supplemented by two sensitivity analyses. First, oil price assumptions are varied, using High and Low oil price paths, which bracket the Base Case trend.

Second, the Reference Case is compared to other scenarios by varying the SPR fill rates. In addition to the Reference Case assumption of a $75 \mathrm{MB} / \mathrm{D}$ fill rate, the sensitivity analysis examines the effects of 50 and $100 \mathrm{MB} / \mathrm{D}$ fill rates, along with a case that assumes filling the SPR each year to full storage capacity.

\section{Financial Measures}

The Reference Case and the sensitivity cases are reviewed in terms of a number of financial measures, as follows. 


\section{a. Direct SPR Budget Outlays}

Under current practice, the Department of Energy budget provides for the direct capital cost for SPR development and fill, as well as the cost of operating and maintaining the SPR storage complexes after fill. Thus, this measure represents the future budget outlay requirements of the Department associated with each option.

Interest costs for any debt-financed expenditures are paid from the Department of the Treasury budget, and such interest costs are covered in "Total Treasury Costs", discussed below.

\section{b. Average Annual Outlays by Time Period}

For this analysis, the average annual direct SPR budget outlays are presented for successive fiveyear fiscal periods, starting in FY 1991. The purpose of this presentation is to illustrate when the direct outlays would be required under current practice. As discussed further below, there is a relationship between decisions on the size of the Reserve and the timing of financing requirements, and this analysis permits a better understanding of the relationship than would the total budget outlays as presented above.

\section{c. Real Dollar Costs through Completion}

This measure backs out the inflation assumed to occur in the calculation of nominal dollar costs for either of the two preceding measures. It permits one to interpret the data presented above in terms of constant price levels and to understand the effects of inflation assumptions on the budget requirements.

\section{d. Present Value Costs}

Under OMB Circular A-94, agencies are directed to evaluate investment proposals in terms of the present value of costs and benefits, using a discount rate of ten percent plus inflation. The present value costs discussed below are derived from taking real dollar costs and discounting at a rate of 10 percent per year to 1991 .

\section{e. Total Treasury Costs}

For this analysis, it is assumed that all SPR spending requirements are met through Treasury borrowing. Thus the total cost of future development increments of the SPR can be portrayed as the sum of the direct budget costs to the Department of Energy plus the cumulative interest costs incurred if SPR budget requirements are financed through public debt. The analysis assumes that the Treasury borrowing costs would average approximately 5 percent above the rate of inflation, with an eventual average of 8 percent per year by the mid-1990's.

\section{f. Market Value of SPR Oil at Completion}

This measure is simply the product of the number of barrels over 600 million barrels, associated with a particular size increment, times the nominal dollar price of oil in 2005 , the last year of fill 
under the Reference Case. In calculating this market price, the costs for Cargo Preference Act compliance have been deducted from the SPR oil cost data series to reflect the fact that some or all of this "add-on" would not increase the resale value of the oil." 1 '

This part combines two stages of analysis. The first stage of analysis is to describe the financial implications of the Reference Case. The second stage of analysis is to compare the financial implications of the Reference Case to those of the other sensitivity cases.

\section{B. ASSUMPTIONS}

This part describes three SPR development and analytical assumptions as listed below:

- $\quad$ Program design criteria;

- Capacity development and oil fill schedules;

- $\quad$ Oil price projections.

\section{Design Criteria}

The major design variables that define a particular SPR development plan are as follows:

\section{a. Type of Commodity Stored}

The current SPR consists entirely of crude oil, rather than refined products. The primary reasons for this choice have been:

- The majority of U.S. petroleum imports are in the form of crude oil;

- Crude oil can be refined into a broad slate of products;

- Crude oil acquisition is less expensive than gasoline or middle distillate, though somewhat more expensive than residual fuel oil; and

- $\quad$ Crude oil can be stored in salt caverns for long periods of time without deterioration.

1I There are questions regarding the reference of SPR resale values under normal market conditions when current law restricts SPR drawdown to emergency conditions. However, as discussed is Chapter VI, OMB Circular A-104 requires that the market value of Federal assets be deducted in comparing outright purchases to leases. This market value of the inventory is included here both as a prelude to A-104 analysis and to demonstrate the relationship of the net Federal financial position to changes in oil price assumptions. 


\section{b. Type of Storage Facility}

The two major types of crude oil storage facilities are solution mined caverns in salt dome formations (the current method) and above ground steel tanks. Salt caverns were selected for the SPR in the 1970's because, for large volumes, they are less expensive than steel tanks.

Table V-1 provides the unit costs of salt cavern storage and new steel tank storage as calculated previously in the April 1989 Report to Congress. Use of existing steel tank storage, if available, could be less expensive.

Table V-1

Facilities Development Cost per Barrel

(1989 Dollars)

Salt Caverns

Sleel Tank
$\$ 3.50-\$ 7.50$

$\$ 15.00$

Despite the favorable cost advantage of salt cavern storage, three other kinds of advantages that steel tanks have over salt caverns are the following:

(1) Salt caverns generally need to be located in the Gulf Coast area where salt dome formations are found, whereas steel tanks may be sited at decentralized locations.

(2) Steel tanks can be built somewhat faster.

(3) Steel tanks can be used for frequent drawdown and refill cycles, whereas most SPR salt caverns have been designed for only four or five complete drawdown/refill cycles.

This study assumes the continued use of salt caverns as the only storage medium for SPR crude oil.

\section{c. Location of Storage Facility}

Salt caverns could be developed at either a new SPR site in the Gulf Coast area or added to existing SPR sites. The principal trade-offs involved in this choice are that the expansion of existing sites would be less expensive because the solution mining infrastructure already exists, but such an expansion would not necessarily increase SPR distribution capability.

This paper assumes that the first 100 million barrels (MMB) of SPR expansion beyond 750 MMB would be through an expansion of an existing site, that at Big Hill, Texas, for a total of $850 \mathrm{MMB}$. The next $150 \mathrm{MMB}$ (to achieve one billion barrels, or 1,000 MMB) would entail the acquisition and development of a new site, probably also in the Gulf Coast area. 


\section{Capacity Development Schedule}

Either expansion of an existing SPR site or development of a new site would involve time requirements for environmental studies, permits, land acquisition, design, and drilling. A new site would require additional lead time for installing pipelines for transporting crude oil, fresh water and brine.

Figure V-1 depicts the major stages of development for new underground storage. Up to two years for advance planning and compliance with the National Environmental Policy Act (NEPA) are assumed before the start of land acquisition, and, up to approximately five more years to elapse before oil fill could commence. On these assumptions, if work started in FY 1991, fill of a new site could commence in FY 1998.

The profile for an expansion of an existing site would be somewhat different. Table V-2 indicates how capacity from both increments would be phased in if work started in FY 1991.

Table V-2

SPR Capacity Schedule (Cumulative Millions of Barrels)

\begin{tabular}{|c|c|c|c|c|c|}
\hline & 750 & 100 & 850 & & 1,000 \\
\hline Fiscal & MMB & MMB & MMB & New & MMB \\
\hline Year & System & Expansion & System & Site & System \\
\hline 1990 & 627 & - & 627 & - & 627 \\
\hline 1991 & 655 & - & 665 & - & 665 \\
\hline 1992 & 750 & $\therefore$ & 750 & - & 750 \\
\hline 1993 & 750 & - & 750 & - & 750 \\
\hline 1994 & 750 & - & 750 & - & 750 \\
\hline 1995 & 750 & - & 750 & - & 750 \\
\hline 1996 & 750 & 10 & 760 & - & 760 \\
\hline 1997 & 750 & 50 & 800 & - & 800 \\
\hline 1998 & 750 & 100 & 850 & 50 & 900 \\
\hline 1999 & 750 & 100 & 850 & 125 & 975 \\
\hline 2000 & 750 & 100 & 850 & 150 & 1000 \\
\hline
\end{tabular}

Figure V-2 illustrates the relationships between the permanent capacity profile and alternative fill rate schedules. Fill rates of $75 \mathrm{MB} / \mathrm{D}$ or less could be sustained for all three sizes. A higher fill rate of $100 \mathrm{MB} / \mathrm{D}$ could be sustained only if interim storage could be acquired for varying volumes over a three year period in the mid-1990's, while permanent storage were being created. 


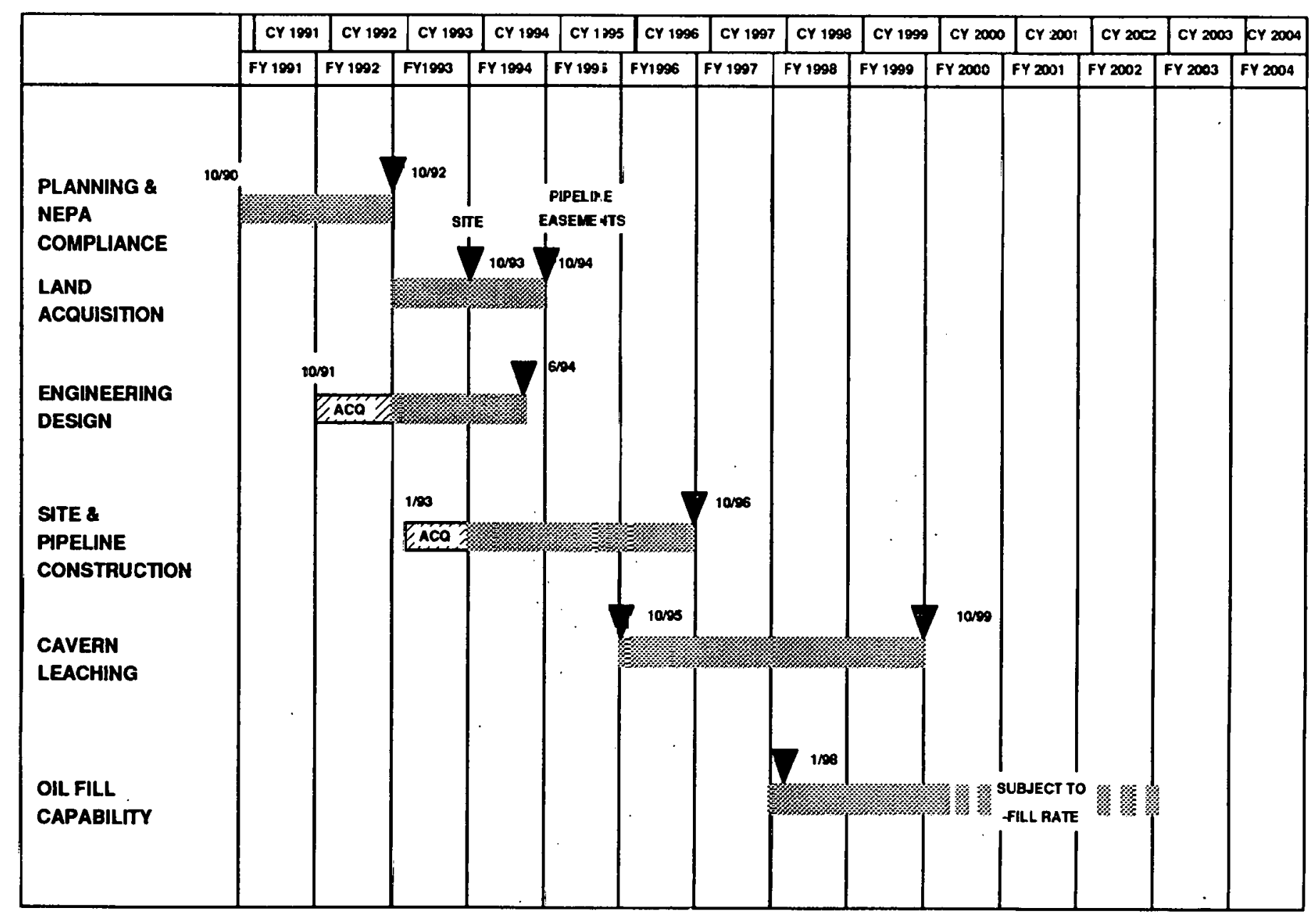


Figure V-2

STRATEGIC PETROLEUM RESERVE STORAGE CAPACITY DEVELOPMENT VS. OIL FILL 250-MMD EXPANSION

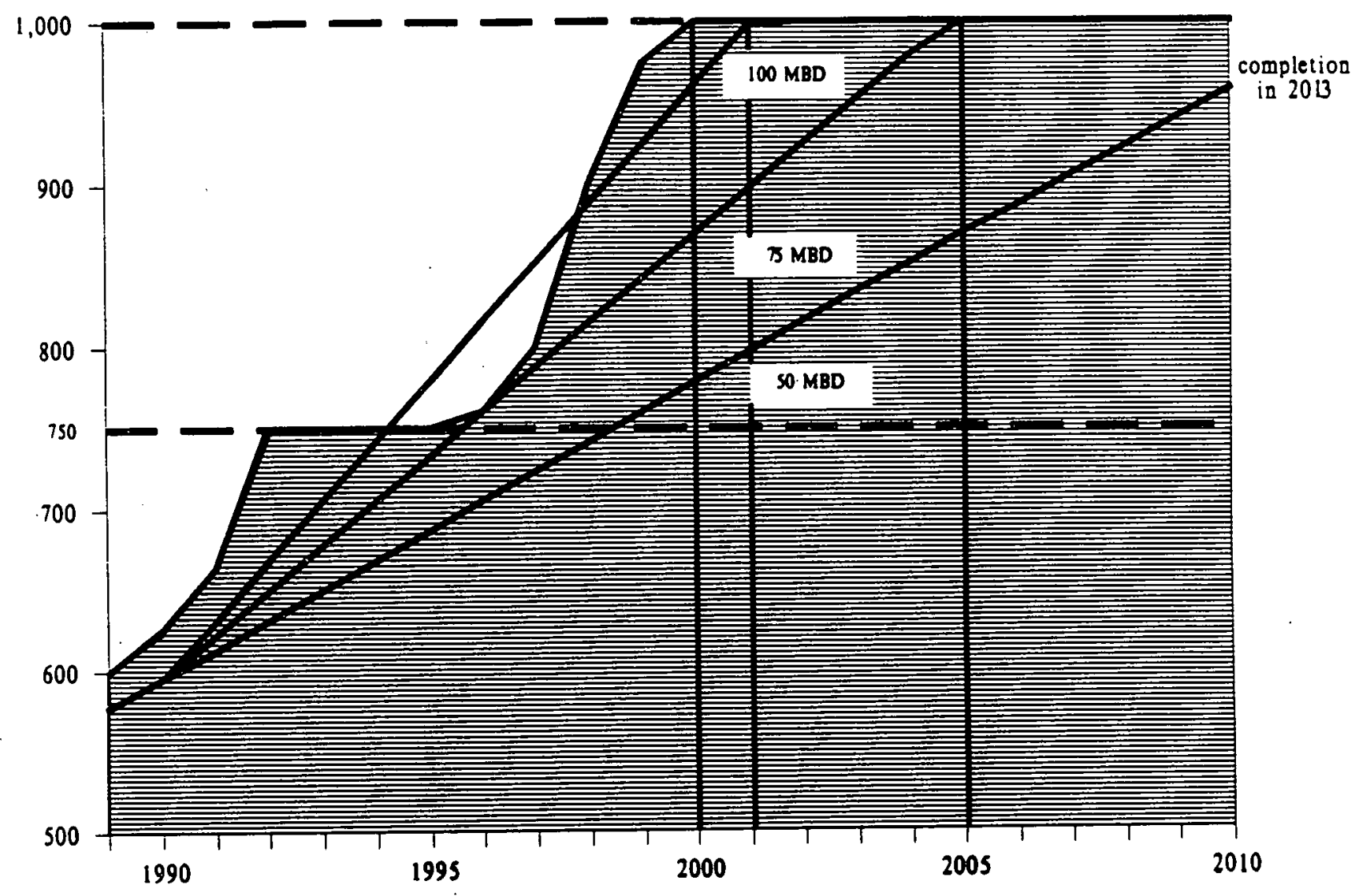


Table V-3 provides the completion dates for different sizes under different fill rate policy decisions.

Table V-3

Completion Dates for Alternative SPR Size Increments

(Fiscal Year of Last Fill)

Fill Rate

$750 \mathrm{MMB} \quad \underline{850 \mathrm{MMB}} \quad \underline{1000 \mathrm{MMB}}$

$50 \mathrm{MB} / \mathrm{D}$

1999

2004

2013

$75 \mathrm{MB} / \mathrm{D}$

1996

2000

2005

$100 \mathrm{MB} / \mathrm{D}$

1995

1998

2002

Fill to Capacity

1993

1997

2000

\section{Oil Price Projections}

As discussed earlier, Reference Case oil prices were derived by using the Annual Energy Outlook, 1989 real dollar Base Case price projections through the year 2000. Beyond 2000, the Department's Oil Market Simulation Model (OMS) was used to derive estimatcs. For sensitivity cases, the High and Low Price examples were similarly derived. Panel (a) in Figure V-3 provides the information in graphic form. 
Figure V-3

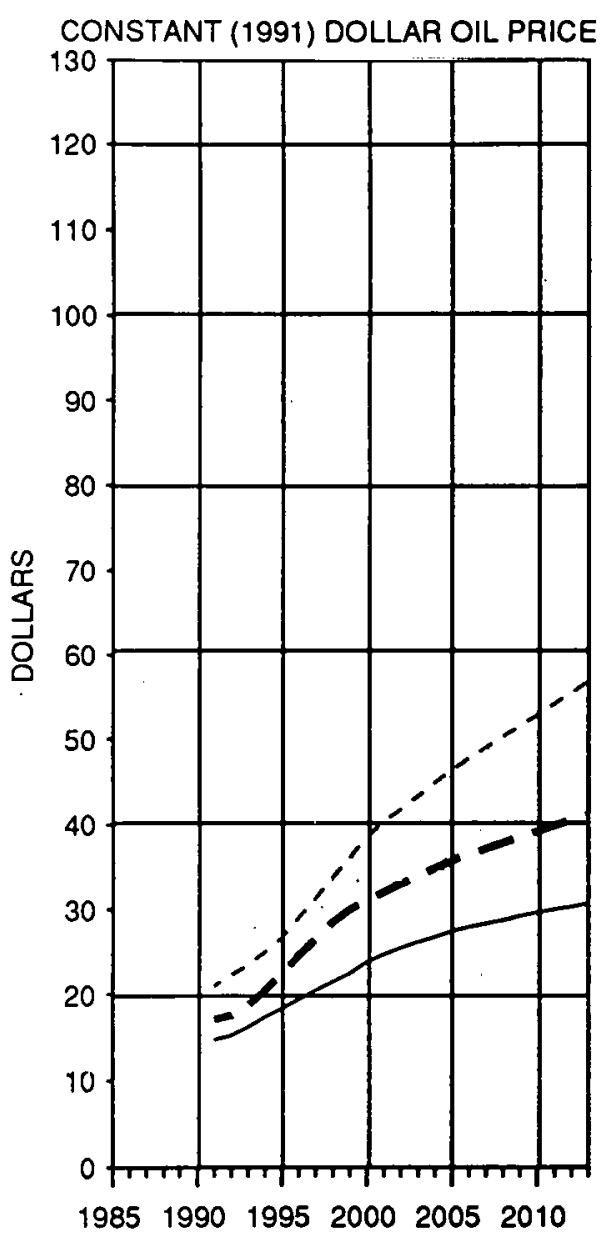

(a)

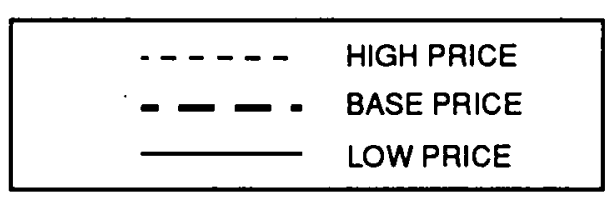

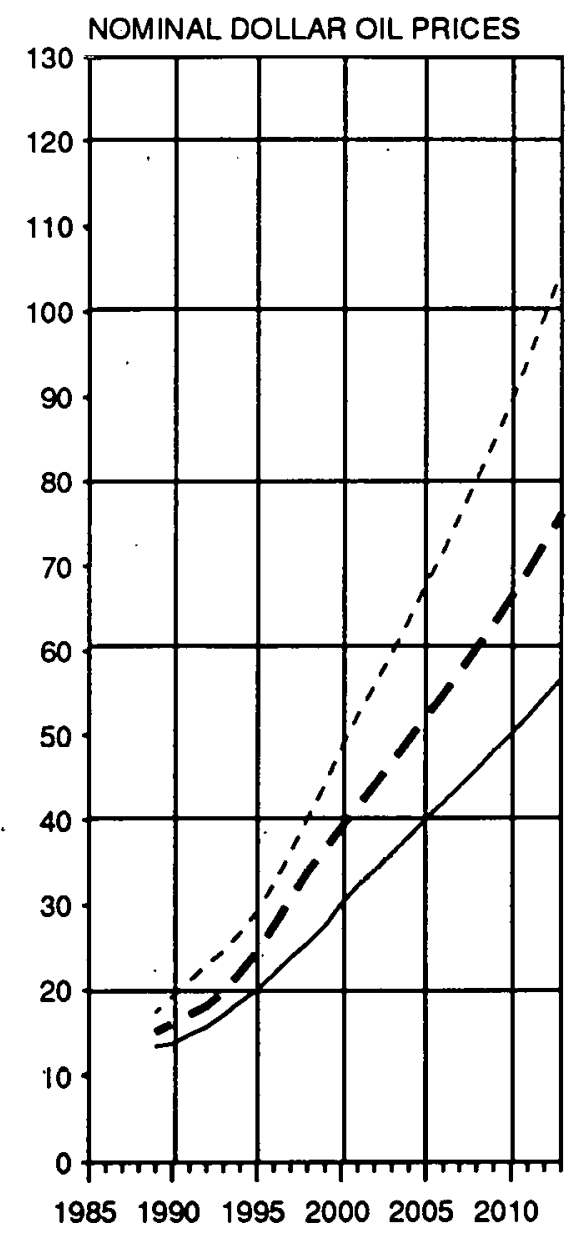

(b)

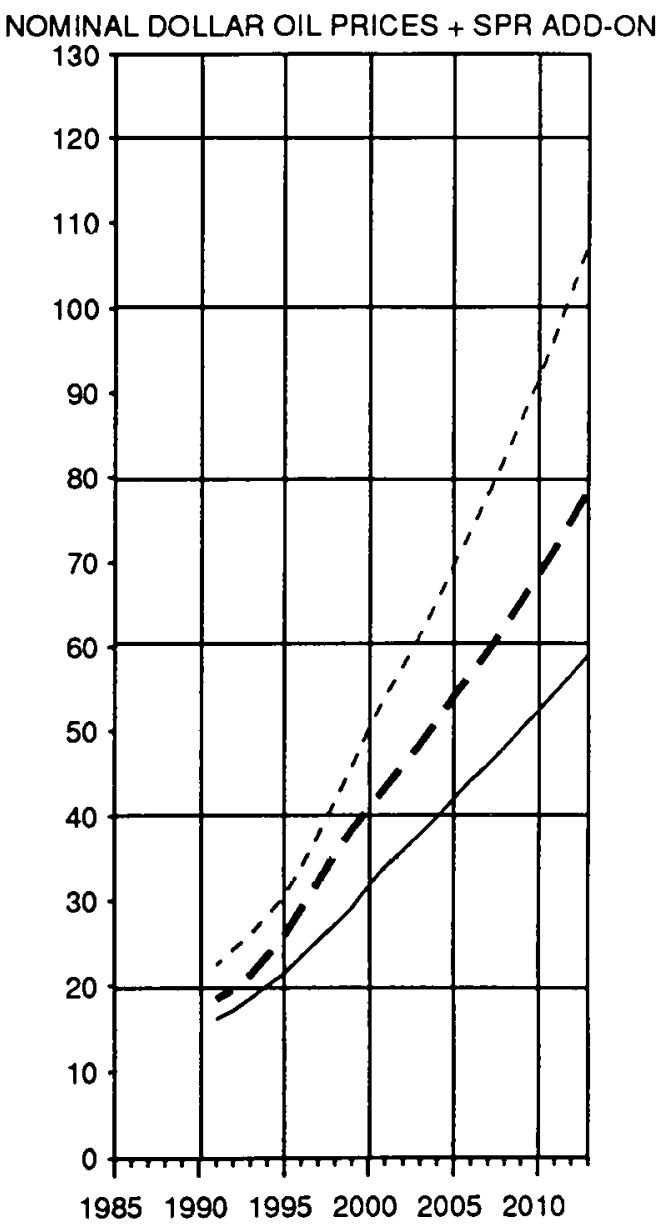

(c) 
Nominal dollar oil prices are the result of applying inflation rates to constant dollar prices. In developing the above nominal dollar estimates, inflation was applied through the year 1995 at the annual rates of inflation assumed by the Office of Management and Budget for the FY 1990 budget Mid-Session Review. Beyond 1995, an annual inflation rate of 3 percent was assumed, reflecting an approximate average for the FY 1989-94 assumptions. The following are the inflation rates assumed:

Table V-4

Inflation Projection

\section{Eiscal Years}

1989

1990

1991

1992

1993

1994

1995

Future Years

\section{Annual Change in GNP Inflation (Percent)}

4.0

3.6

3.3

2.8

2.3

1.8

1.8

3.0

Panel (b) of Figure V-3 illustrates the resulting pattern in nominal dollar prices.

The SPR program is subject to requirements of the Cargo Preference Act, under which half of SPR oil transportation needs to involve U.S. flag tankers (See Section E(3) of Chapter III). For this and other reasons, a further price increment, termed the "SPR add-on" is added to nominal dollar prices. Panel (c) of Figure V-3 provides the results of this price adjustments.

Table V-5 presents the nominal dollar SPR acquisition cost for each of the three price cases, along with SPR "add-on" which is included therein. 
Table V-5

Strategic Petroleum Reserve

Oil Price Assumptions Using AEO/OMS Projections

(Nominal Dollars per Barrel)

$\begin{array}{llllc}\begin{array}{l}\text { Fiscal } \\ \text { Year }\end{array} & \begin{array}{l}\text { Base } \\ \text { Case }\end{array} & \begin{array}{l}\text { Low } \\ \text { Case }\end{array} & \begin{array}{l}\text { High } \\ \text { Case }\end{array} & \begin{array}{c}\text { SPR } \\ \text { Add-Onal/ }\end{array} \\ 1990 & \$ 17.35 & \$ 15.11 & \$ 20.52 & \$ 1.28 \\ 1991 & \$ 18.51 & \$ 16.16 & \$ 22.37 & 1.32 \\ 1992 & \$ 19.52 & \$ 17.11 & \$ 24.27 & 1.36 \\ 1993 & \$ 21.15 & \$ 18.50 & \$ 26.03 & 1.39 \\ 1994 & \$ 23.51 & \$ 20.04 & \$ 28.24 & 1.42 \\ 1995 & \$ 25.91 & \$ 21.42 & \$ 30.55 & 1.44 \\ 1996 & \$ 29.00 & \$ 23.28 & \$ 33.93 & 1.48 \\ 1997 & \$ 32.22 & \$ 25.27 & \$ 37.66 & 1.53 \\ 1998 & \$ 35.47 & \$ 27.15 & \$ 41.67 & 1.57 \\ 1999 & \$ 38.24 & \$ 29.16 & \$ 45.82 & 1.62 \\ 2000 & \$ 40.73 & \$ 31.73 & \$ 50.15 & 1.67 \\ 2001 & \$ 43.69 & \$ 33.91 & \$ 54.04 & 1.72 \\ 2002 & \$ 46.82 & \$ 35.97 & \$ 57.83 & 1.77 \\ 2003 & \$ 49.84 & \$ 38.01 & \$ 61.67 & 1.82 \\ 2004 & \$ 52.80 & \$ 39.98 & \$ 65.52 & 1.88 \\ 2005 & \$ 55.98 & \$ 42.12 & \$ 69.64 & 1.94 \\ 2006 & \$ 59.08 & \$ 44.14 & \$ 73.90 & 1.99 \\ 2007 & \$ 62.11 & \$ 46.02 & \$ 78.15 & 2.05 \\ 2008 & \$ 65.35 & \$ 48.20 & \$ 82.49 & 2.11 \\ 2009 & \$ 68.65 & \$ 50.44 & \$ 86.99 & 2.18 \\ 2010 & \$ 72.17 & \$ 52.56 & \$ 91.96 & 2.24 \\ 2011 & \$ 75.74 & \$ 54.87 & \$ 96.67 & 2.31 \\ 2012 & \$ 79.27 & \$ 57.34 & \$ 101.07 & 2.38 \\ 2013 & \$ 82.73 & \$ 59.86 & \$ 105.55 & 2.45 \\ \text { a/ } & & & & \end{array}$




\section{REFERENCE SCENARIO}

The purpose of this part is to define a Reference Case which provides a starting point for the analysis.

In the Reference Scenario, the average annual fill rate is $75 \mathrm{MB} / \mathrm{D}$. This fill rate reflects the Administration's budget proposal for FY 1990 and the guidance provided by the Congress for this study in Public Law No. 101-46. The assumed fill rate is important for both the length of time in years to attain a certain SPR size and concomitantly, average annual budget outlays. The lower the fill rate, the longer the time to attain a certain SPR size, but the lower the near term annual outlays. However, at the same time, lower fill rates increase the ultimate cost of the Reserve by deferring the purchase of SPR oil to a future of when oil prices are assumed to be higher.

The Base Case oil price projection; presented previously in the Background Section, is used here for the Reference Case. The SPR oil acquisition cost includes crude oil purchases, transportation, terminalling, customs fees, environmental taxes and associated costs. Because the SPR is subject to Cargo Preference Act requirements, the forecasts of oil prices are adjusted by the "SPR addon" to reflect the added costs of transporting part of the oil in the U.S.-flag tankers. After applying OMB inflation assumptions, the SPR add-on increases SPR purchase prices slightly.

Table V-6 below provides six sets of financial measures for the Reference Case assumptions. All information on this table is carried through the year 2005, when a one billion barrel SPR would be completed at a fill rate of $75 \mathrm{MB} / \mathrm{D}$.

\section{Direct SPR Budget Outlays}

As presented in Table V-6, future budget outlays for completing a one billion barrel reserve would be $\$ 18.8$ billion. Three-fourths of this total is for acquiring 400 million barrels in oil; the remainder is for storage facility development and for the operation and maintenance of the SPR system through FY 2005.

For the 750 MMB system, it should be noted that a large proportion of the non-oil costs of $\$ 2.8$ billion are essentially sunk costs associated with operation and maintenance of the first $600 \mathrm{MMB}$ for 15 years (FY 1991 thru FY 2005), whether or not there is significant further fill.

\section{Average Annual Budget Outlays}

For development of the full one billion barrels, average annual outlays would increase steadily during the period from $\$ 1.0$ billion per year in the first five years to $\$ 1.5$ billion per year for the last five years. During the first five-year period, most of the annual outlays would be associated with fill of the 600-750 MMB increment, with some additional costs for the development of storage facilities for further size increments. During the second five-year period, most of the costs would be associated with the 750-850 MMB expansion.

During the last five years of the 15 -year period of analysis, nearly all of the financing requirements, except for continued operation and maintenance of existing SPR sites, would be associated with fill of the $850-1,000 \mathrm{MMB}$ increment. This illustrates that, in the near term, the primary financial 
manifestation of a decision to increase the ultimate size of the Reserve would be in terms of facility construction costs. The actual oil fill financial requirements would occur in future years, possibly under different market conditions than those now projected.

\section{Real Dollar Costs}

The real dollar costs shown in Table V-6 are direct budget outlays with inflation removed from the estimates. At constant 1991 prices, a total of $\$ 15.4$ billion would be required for development, fill, and standby operation of a one-billion barrel program through FY 2005 . Comparing these real dollar costs to direct budget outlays illustrates that approximately one-sixth of the total future budget costs of the Reserve would reflect inflation beyond .1991. The larger the size, the further into the future it will be developed, hence the larger the inflation impact.

Table V-6

Financial Summary

Reference Case

(billions of dollars)

Financial Measures

Direct Budget Outlays

(Oil only)

Average Annual Outlays

FY 1991-1996

FY $1997-200$

FY 2001-2005

Real Dollar Costs (\$1991)

Present Value Costs

Total Treasury Costs

(Interest)

Market Value at Completion ${ }^{\mathrm{a} /}$

Completion Year

a/ Based on oil prices in 2005.
Size Increments (MMB)

$\begin{array}{lll}600-750 & \mathbf{7 5 0 - 8 5 0} \quad \underline{850-1000}\end{array}$

6.3

(3.5)

3.9

(3.5)

8.5

(7.3)

0.8

0.2

0.1

0.2

1.0

0.2

0.8

0.2

1.2

1.3

1.5

5.6

3.3

6.5

15,4

3.9

1.8

2.5

13.7

(7.4)

7.2

11.8

(3.2)

8.1

5.4

8.1

21.6

1996

2000

2005

2005 


\section{Present Value Costs}

When the real dollar costs are discounted at a rate of 10 percent per year, the result is the set of "present value" costs. Overall, the present value in 1991 of the $\$ 15$ billion in real costs to complete a one billion barrel system would be $\$ 8.2$ billion. Nearly one-half of these present value costs are for the completion of the $750 \mathrm{MMB}$ system and its maintenance through 2005. Taken together, the two expansion increments have a present value cost of approximately $\$ 4.3$ billion.

Thus in nominal dollars, shown as direct budget outlays, the $850-1000 \mathrm{MMB}$ increment is more expensive than the $600-750 \mathrm{MMB}$ increment, but in present value terms, the $850-1000 \mathrm{MMB}$ increment is far less costly than the completion of the $750 \mathrm{MMB}$ systeru.

\section{Total Treasury Costs}

Direct budget outlays, expressed in nominal dollars, have been used as the basis for calculating the interest costs to Treasury if all SPR costs were borne by additional Treasury borrowing. When the interest and the principal are accumulated, the result is an estimate of the total effect of the SPR on the Federal budget.

Table V-6 illustrates that the total budget effect of future SPR development through 2005 could be as high as $\$ 32.6$ billion, reflecting $\$ 18.8$ billion in principal (for direct budget outlays) and nearly $\$ 14$ billion in interest. Interest costs are highest, in proportional terms, for the first $750 \mathrm{MMB}$ because the principal costs are borne earlier in the 1991-2005 period.

\section{Market Value in 2005}

The market value of the $400 \mathrm{MMB}$ added to the SPR by the year 2005 would be approximately $\$ 22$ billion under base case oil prices. This is higher than the cumulative direct budget cost, but lower than the total Treasury cost. From a total budget perspective, the Government would incur net financial losses of approximately $\$ 11$ billion from developing a one-billion-barrel reserve and then liquidating its investment under non-disruption conditions in the year 2005. The disparity between market value at completion and total Treasury costs is largest for the $750 \mathrm{MMB}$ systcm, both because it involves the longest period of interest accrual and because of the continuing standby operation and maintenance through 2005. 


\section{PRICE SENSITIVITY ANALYSIS}

Tables V-7 and V-8 below present comparable financial summaries for the Reference Case oil fill rate, but under Low Oil Price and High Oil Price cases respectively. Table V-9 presents the differences between the Reference Case and both the Low and High Oil Price Cases.

\section{Table V-7}

Financial Summary

Low Oil Price Case

(billions of dollars)

Financial Measures

Direct Budget Outlays

(Oil Only)

Average Annual Outlays

FY 1991-1996

FY 1997-2000

FY 2001-2005

Real Dollar Costs (\$1991)

Present Value Costs

Total Treasury Costs (Interest)

Market Value at Completion ${ }^{\mathrm{a} /}$

Completion Year

a/ Based on oil prices in 2005 .
Size Increments (MMB)

$\underline{600-750}$
$\underline{750-850}$

3.1

(2.7)

(3.0)

0.7

0.2

0.2

0.1

0.6

0.0

0.2

0.9

1.0

1.2

5.1

2.7

5.2

13.0

3.6

1.4

2.1

7.1

12.4

(6.6)

5.8

(2.6)

9.6

(2.8)

6.0

4.0

6.0

16.1

1996

2000

2005

2005

Total

15.8

\section{9} 1.2

600-1000 


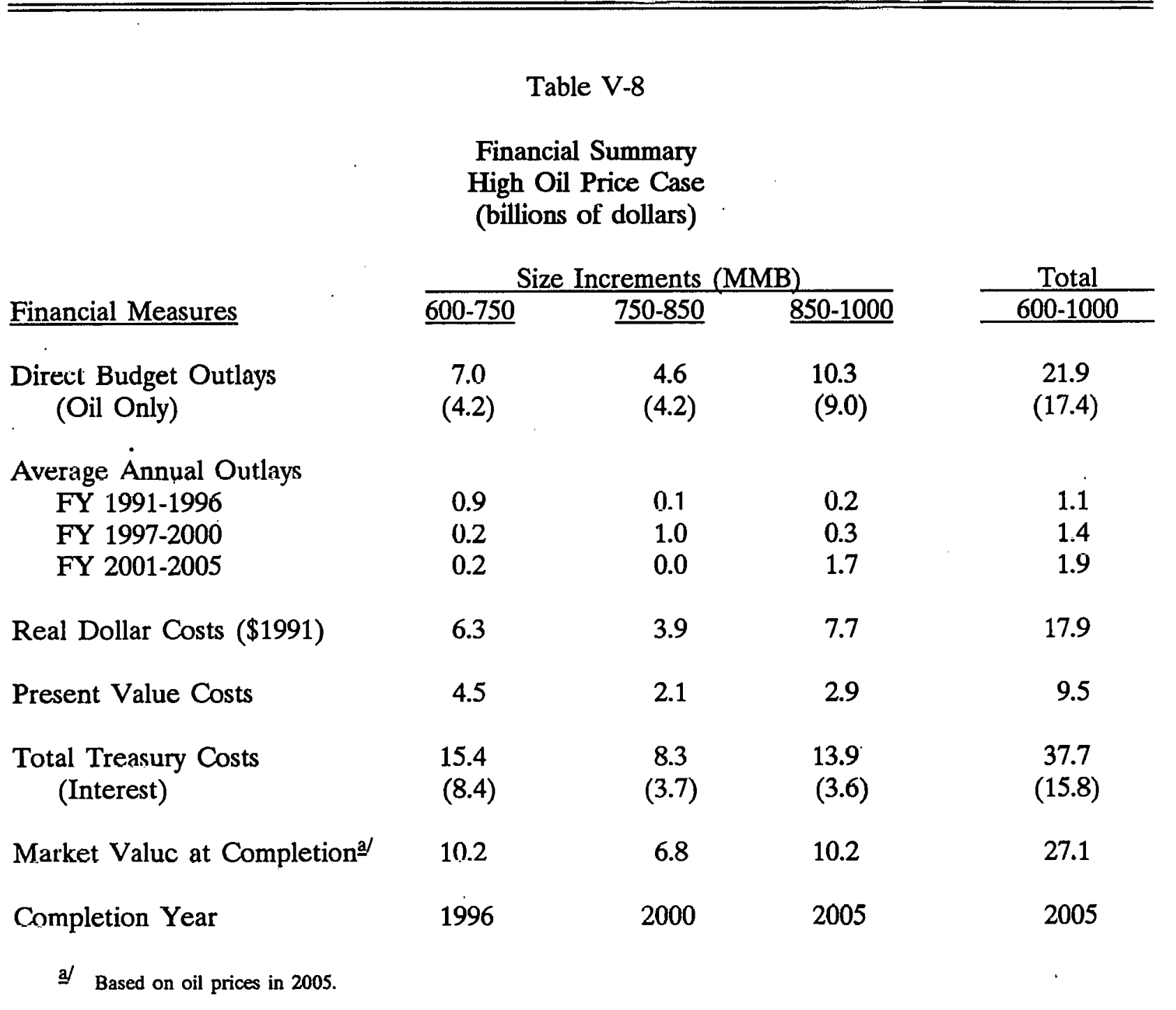


Table V-9

Financial Summary

Low and High Oil Price Cases: Differences from Reference Case

(billions of dollars)

\begin{tabular}{|c|c|c|c|c|c|c|c|c|}
\hline \multirow[b]{3}{*}{ Financial Measures } & \multicolumn{6}{|c|}{ Size Increments (MMB) } & \multirow{2}{*}{\multicolumn{2}{|c|}{$\frac{\text { Total }}{600-1000}$}} \\
\hline & \multicolumn{2}{|c|}{$600-750$} & \multicolumn{2}{|c|}{ 750-850 } & \multicolumn{2}{|c|}{$\underline{850-1000}$} & & \\
\hline & Low & High & Low & High & Low & $\underline{\text { High }}$ & Low & High \\
\hline $\begin{array}{l}\text { Direct Budget Outlays } \\
\quad \text { (Oil Only) }\end{array}$ & $\begin{array}{c}-0.5 \\
(-0.5)\end{array}$ & $\begin{array}{c}0.7 \\
(0.7)\end{array}$ & $\begin{array}{c}-0.8 \\
(-0.8)\end{array}$ & $\begin{array}{c}0.6 \\
(0.6)\end{array}$ & $\begin{array}{c}-1.7 \\
(-1.7)\end{array}$ & $\begin{array}{c}1.7 \\
(1.7)\end{array}$ & $\begin{array}{l}-3.0 \\
(-3.0)\end{array}$ & $\begin{array}{c}3.1 \\
(3.1)\end{array}$ \\
\hline \multicolumn{9}{|l|}{ Average Annual Outlays } \\
\hline FY 1991-1996 & -0.1 & 0.1 & 0.0 & 0.0 & 0.0 & 0.0 & -0.1 & 0.1 \\
\hline FY $1997-2000$ & 0.0 & 0.0 & -0.2 & 0.2 & 0.0 & 0.0 & -0.2 & 0.2 \\
\hline FY 2001-2005 & 0.0 & 0.0 & 0.0 & 0.0 & -0.3 & 0.3 & -0.3 & 0.3 \\
\hline $\begin{array}{l}\text { Real Dollar Costs } \\
\quad(\$ 1991)\end{array}$ & -0.5 & 0.7 & -0.7 & 0.5 & -1.2 & 1.3 & -2.4 & 2.5 \\
\hline Present Value Costs & -0.4 & 0.5 & -0.3 & 0.3 & -0.4 & 0.4 & -1.1 & 1.2 \\
\hline $\begin{array}{l}\text { Total Treasury Costs } \\
\text { (Interest) }\end{array}$ & $\begin{array}{c}-1.3 \\
(-0.8)\end{array}$ & $\begin{array}{c}1.8 \\
(1.0)\end{array}$ & $\begin{array}{c}-1.4 \\
(-0.6)\end{array}$ & $\begin{array}{c}1.1 \\
(0.4)\end{array}$ & $\begin{array}{c}-2.1 \\
(-0.5)\end{array}$ & $\begin{array}{c}2.2 \\
(0.3)\end{array}$ & $\begin{array}{l}-4.8 \\
(-1.8)\end{array}$ & $\begin{array}{c}5.1 \\
(2.0)\end{array}$ \\
\hline Market Value at Completion ${ }^{\text {a/ }}$ & -2.1 & 2.1 & -1.4 & 1.4 & -2.1 & 2.1 & -5.5 & 5.6 \\
\hline
\end{tabular}

The following text describes the effects of these price differentials on the financial measures previously discussed in the context of the Reference Case.

\section{Direct Budget Outlays}

The direct budget outlays for completion of a one-billion-barrel system would be $\$ 15.8$ billion and $\$ 21.9$ billion for the Low Price and High Price cases respectively. Overall, the variation of these cases from the Reference Case is approximately $\$ 3$ billion, all attributable to oil prices. The variation, positive and negative, is substantially higher for the last increment to be developed because of the widening range between the different price cases toward the end of the period.

\section{Average Annual Outlays}

The variation in average annual outlays likewise increases over the time period of development, in both absolute and proportionate terms. During the first five years, the variation due to price 
would be approximately $\$ .1$ billion per year or 10 percent of the Reference Case estimate. By the last five years, the variation will have increased to $\$ .3$ billion or approximately 20 percent of the Reference Case.

\section{Real Dollar Cost}

With respect to the three size increments, the greatest variance in real dollar costs pertains to the 850-1,000 million barrel size increment because the low/high oil price spread widens, the further into the future that real oil prices are projected. Since real oil prices exclude inflation, the increasing spread in real dollar costs between the low and high cases is due solely to differences in the projected rate of growth in real oil prices and not the effects of inflation.

\section{Present Value Costs}

Effects of price variation on present value costs range from $-\$ 1.1$ billion to $+\$ 1.2$ billion around the Reference Case of $\$ 8.2$ billion for a one-billion-barrel system, a variation of approximately 15 percent. This present value cost change is distributed in approximately equal amounts across the three size options. While the absolute value of the price effects on costs increases in the future, this effect is counteracted by the effects of discounting.

\section{Total Treasury Costs}

Total Treasury costs could decline by $\$ 4.8$ billion or increase by $\$ 5.1$ billion, depending on the oil price projection. This reflects the price-related change of approximately $\$ 3$ billion plus the effects of compound interest.

\section{Market Value in 2005}

The market value of the last $400 \mathrm{MMB}$ of a one-billion-barrel system would vary by approximately one-fourth up or down from the Reference Case, depending on the selection between the High or Low oil price cases. In absolute terms, this variability is approximately equivalent to the variability of the Total Treasury Costs described above. Accordingly, as with the Reference Case, the net financial cost of future Reserve additions, through the year 2005, would be approximately $\$ 10$ billion. The additional costs associated with the High Price Case are offset by the additional value of the Reserve at completion, whereas the savings from the Low Price Case are substantially offset by a reduced market value at completion. 


\section{E. FILL RATE SENSITIVITY ANALYSIS}

The next four tables compare financial summary measures for the Reference Case oil price, but under a lower and a higher oil fill rate at 50,000 barrels per day and 100,000 barrels per day, respectively. The first three tables (V-10, V-11, and V-12) hold the year of completion the same as the Reference Case at 2005. In this way, the fixed time period allows for a comparison between the two fill rate sensitivities and the Reference Case. However, the fourth table (V-13) compares the Reference Case to each of the two fill rate sensitivities in their respective year of completion, i.e., 2013 for the 50,000 barrel per day fill rate and 2002 for the 100,000 barrel per day fill rate.

Tables V-10 and V-11, below, present financial summary figures for the two fill rate sensitivity cases through 2005. Table V-12 presents the differences between the Reference Case and the low and high fill rate cases.

The following section describes the effects, through the year 2005 , of these two fill rate differences from the Reference Case for the six financial measures.

\section{Financial Analysis Through 2005}

\section{a. Direct Budget Outlays through 2005}

The direct budget outlays for the fill rates of $50 \mathrm{MB} / \mathrm{D}$ and $100 \mathrm{MB} / \mathrm{D}$ through FY 2005 would be $\$ 14.3$ billion and $\$ 17.0$ billion respectively. The lower fill rate, $50 \mathrm{MB} / \mathrm{D}$, reflects reduced outlays of $\$ 4.5$ billion compared to the $75 \mathrm{MB} / \mathrm{D}$ case. Lower outlays for the $50 \mathrm{MB} / \mathrm{D}$ fill rate are solely because in 2005 only 869 million barrels of oil have been purchased compared to the purchase of 1,000 million barrels under the Reference Case. The outlays for the higher fill rate, $100 \mathrm{MB} / \mathrm{D}$, would be $\$ 1.8$ billion lower than the Reference Case because the oil was purchased sooner when oil prices were lower. These differences in outlays due to fill rate variation are due to different rates of oil acquisition over a period of rapidly increasing oil prices, as projected by EIA.

\section{b. Average Annual Outlays}

The lower oil fill rate of $50 \mathrm{MB} / \mathrm{D}$ reduces average annual outlays across each of the three time periods by only about 25 percent, but the comparable dollar savings results in a substantially lower SPR stockpile or 131 million barrels less than the Reference Case by 2005 . The higher fill rate, on the other hand, maintains the same average annual outlays as the Reference Case during the first time frame, 1991-1996, because both fill rates include the same facility expansion costs and, in 1996, there is no storagc capacity available for the $100 \mathrm{MB} / \mathrm{D}$ fill rate which attains the 750 million barrel fill in 1995.

However, during the second period, 1997-2000, average annual outlays increase over the Reference Case by $\$ 1.0$ billion for the $100 \mathrm{MB} / \mathrm{D}$ fill rate and then decrease by $\$ 1.0$ billion during the last period, 2001-2005. The reason for the extreme differential in average annual outlays is because over 200 million barrels of oil is purchased during the $1997-2000$ period at the $100 \mathrm{MB} / \mathrm{D}$ fill rate compared to just over 100 million barrels of oil purchased for the $75 \mathrm{MB} / \mathrm{D}$ fill rate. These 
Table V-10

Financial Summary

Fill Rate of $50 \mathrm{MB} / \mathrm{D}$

(billions of dollars)

Financial Measures

$$
\text { 600-750 }
$$

Size Increments (MMB)

Direct Budget Uutlays

$$
6.9
$$

(Oil Only)

$\underline{750-850}$

5.0

$\underline{850-1000}$

Total

$600-1000$

Average Annual Outlays

FY 1991-1996

0.6

0.1

0.2

0.0

0.8

FY 1997-2000

0.6

0.3

0.2

0.9

FY 2001-2005

0.2

0.7

1.9

11.8

Real Dollar Costs (\$1991)

6.0

3.8

0.9

6.3

Present Value Costs

1.5

14.3

(9.7)

in 1991

Total Treasury Costs

(Interest)

7.1

(2.0)

3.8

24.9

Market Value at Completion ${ }^{\mathrm{a} /}$

8.1

5.4

1.0

14.5

a/ Based on oil prices in 2005.

relative quantities of oil purchases are reversed during the 2001-2005 period as reflected in the respective annual outlays.

\section{c. Real Dollar Costs}

For the first two size increments, real dollar costs are larger than the Referencc Case by $\$ 0.4$ billion and $\$ 0.5$ billion for the lower fill rate, $50 \mathrm{MB} / \mathrm{D}$, because oil would be purchased at higher real oil prices even though the total quantity of oil bought at this lower fill rate is only $178 \mathrm{MMB}$ by 2000 , compared to $250 \mathrm{MMB}$ for the Reference Case. Real dollar costs for the higher fill rate, $100 \mathrm{MB} / \mathrm{D}$, would be $\$ 0.8$ lower than the Reference Case for the whole $400 \mathrm{MMB}$ due to lower real oil prices before 2000 . 
Table V-11

Financial Summary

Fill Rate of $100 \mathrm{MB} / \mathrm{D}$

(billions of dollars)

Financial Measures

Size Increments (MMB)

\begin{tabular}{lll}
\hline $600-750$ & $750-850$ & $850-1000$
\end{tabular}

Total

$600-1000$

Direct Budget Outlays

(Oil Only)

Average Annual Outlays

FY 1991-1996

FY 1997-2000

FY 2001-2005

Real Dollar Costs (\$1991)

Present Value Costs in 1991

Total Treasury Costs

(Interest)

Market Value at Completion ${ }^{\mathrm{a} /}$
6.1

(3.2)

3.8

(3.4)

0.7

0.2

0.2

5.4

4.0

13.4

(7.3)

8.1
0.1

0.8

0.0

3.3

1.8

7.2

(3.5)

5.4
7.2

(5.9)

17.0

1.0

2.0

0.6

14.6

8.6

32.7

(4.8)

8.1

21.6

\section{d. Present Value Costs}

Present value costs of $\$ 3.9$ billion and $\$ 1.5$ billion for the first two size increments for the lower fill rate are only marginally lower than for the Reference Case. Again, for the 2001-05 period, the only reason that present value costs of $\$ 0.9$ billion for the lower fill rate are substantially lower than $\$ 2.5$ billion for the Reference Case is due to the 131 million barrel lower SPR stockpile for the $50 \mathrm{MB} / \mathrm{D}$ fill rate.

Present value costs for the higher fill rate are $\$ 0.4$ billion higher than the Reference Case because the savings from buying lower priced oil sooner for the $100 \mathrm{MB} / \mathrm{D}$ fill rate is more than offset by the present value affects of earlier spending. 
Table V-12

Financial Summary

Low and High Fill Rate Cases: Differences from Reference Case

(billions of dollars)

Financial Measures

Direct Budget Outlays

(Oil Only)

Average Annual Outlays

FY 1991.1996

FY 1997-2000

FY 2001-2005

Real Dollar Costs (\$1991)

Present Value Costs in 1991

Total Treasury Costs (Interest)

Market Value at Completion ${ }^{\mathrm{a} /}$

a/ Based on oil prices in 2005 .
Size Increments (MMB)

\begin{tabular}{|c|c|c|}
\hline $600-750$ & $750-850$ & $850-1000$ \\
\hline Low High & Low High & Low Hig \\
\hline
\end{tabular}

$\begin{array}{llllll}0.6 & -0.2 & 1.1 & -0.2 & -6.2 & -1.3\end{array}$

$\begin{array}{llllll}-0.6 & 0.2 & -1.1 & 0.2 & 6.2 & 1.3\end{array}$

$-0.3 \quad 0.0$

$0.4 \quad 0.0$

$0.0 \quad 0.0$

0.1

$-0.5$

0.7

0.0

$0.0-0.2$

$0.0-1.1$

0.2

1.0

$-1.0$

$-0.2$

$-0.3$

$-0.4$

0.0

1.0

$-1.0$

$\begin{array}{llllll}-0.4 & -0.2 & 0.5 & -0.1 & -4.6 & -0.5\end{array}$

$\begin{array}{llllll}-0.1 & 0.0 & -0.3 & 0.0 & -1.6 & 0.3\end{array}$

$-1.9$

0.4

$\begin{array}{llllll}0.4 & -0.2 & -0.1 & 0.0 & -7.9 & 0.3\end{array}$

$\begin{array}{llllll}0.0 & 0.0 & 0.0 & 0.0 & 0.0 & 0.0\end{array}$

$\begin{array}{llllll}0.0 & 0.0 & 0.0 & 0.0 & -7.1 & 0.0\end{array}$

$\begin{array}{ll}-7.1 & 0.0\end{array}$

$-7.7$

0.1

$0.0 \quad 0.0$

\section{e. Total Treasury Costs}

Total treasury costs through 2005 for the lower fill rate could be $\$ 7.7$ billion lower than the Reference Case because the total stockpile would be only $869 \mathrm{MMB}$ instead of 1,000 MMB for the Reference Case. However, total treasury costs for the higher fill rate are about the same as for the Reference Case because the lower outlay savings of $\$ 1.7$ billion for the $100 \mathrm{MB} / \mathrm{D}$ fill rate are canceled by the increase in debt rollover from 2002 through 2005 after this higher fill rate has attained the 1,000 MMB stockpile size. 


\section{f. Market Value in 2005}

Market value in 2005 reveals the other side of the above lower cost figures for the $50 \mathrm{MB} / \mathrm{D}$ fill rate. The market value for the $269 \mathrm{MMB}$ of oil in 2005 purchased under the $50 \mathrm{MB} / \mathrm{D}$ fill rate is $\$ 7.1$ billion lower than the $\$ 21.6$ billion market value of the $400 \mathrm{MMB}$ for both the other two fill rates for $400 \mathrm{MMB}$. After comparing total treasury costs to market value, the difference is $\$ 10.4$ billion for the $50 \mathrm{MB} / \mathrm{D}$ fill rate and only marginally higher (about $\$ 11$ billion) for the other two fill rates even though the SPR size is 131 MMB greater for these two higher fill rates.

\section{Financial Analysis Through Completion}

The above tables held the time period constant at 2005 to compare the financial measures for the lower and higher fill rates with respect to the completion date of the Reference Case. For the following analysis, the time period is allowed to vary, but the ultimate fill is held constant at one billion barrels for each of the three fill rates.

Table V-13 presents the financial measures for the three fill rates through completion for each respective fill rate. The purpose of this comparison is to observe how the financial measures change among the $50 \mathrm{MB} / \mathrm{D}$ fill rate completed in 2013 , the $75 \mathrm{MB} / \mathrm{D}$ fill rate completed in 2005 , and the $100 \mathrm{MB} / \mathrm{D}$ fill rate completed in 2002 .

\section{a. Direct Budget Outlays}

Higher fill rates reduce the direct budget cost to achieve a 1-billion-barrel inventory.

The direct budget outlays decline from $\$ 25.5$ billion to $\$ 18.8$ billion and, finally, to $\$ 16.3$ billion for the lowest, Reference Case, and highest fill rates, respectively. The primary difference in outlays among the three fill rates is the difference in oil costs, which increase as the fill rate declines because oil is purchased later at higher oil prices. However, a large part of the outlay differential between the $50 \mathrm{MB} / \mathrm{D}$ and $75 \mathrm{MB} / \mathrm{D}$ fill rates is due to the approximately $\$ 200$ million a year in standby cost overhead that is accumulated over the 2006 through 2013 period, when the 50 MB/D fill rate is still building luwards the une-billiun-barrel inventury.

\section{b. Average Annual Outlays}

The average annual outlays denote government expenditures over the three periods of time that it takes to attain each of the three size increments. One important point to note is that for the first two size increments for all three fill rates, average annual outlays are almost equal at about $\$ 0.8$ billion and $\$ 1.2$ billion; in other words, a substantially slower fill rate does not achieve annual savings in outlays because the longer time period to attain the 750- and 850-million barrel stockpiles means higher oil purchases at higher oil prices.

Only with respect to the last size increment from 850 million barrels to one billion barrels is there a notable difference in annual outlays. In this case, annual outlays are $\$ 1.5$ billion for the low fill rate $(50 \mathrm{MB} / \mathrm{D})$ as compared to $\$ 1.9$ and $\$ 2.0$ billion for the two respective higher fill rates. But this is because the two higher fill rates take only four and five years to complete the last 150 
million barrels, whereas with a fill rate of $50 \mathrm{MB} / \mathrm{D}$ it takes nine years to complete the same size increment.

\section{c. Real Dollar Costs}

After inflation has been removed from outlays, the real dollar cost of the $50 \mathrm{MB} / \mathrm{D}$ fill rate at $\$ 18.3$ billion remains higher than the real dollar cost for either of the two other fill rates. The projected steady increase of real oil prices of about 3 percent per year after 2005 adds substantially to the real cost of the slowest fill rate. Real dollar costs for the two higher fill rates are $\$ 15.4$ billion and $\$ 14.1$ billion.

\section{Table V-13 \\ Financial Summary \\ Through Fill Rates at Respective Completion Date \\ (billion of dollars)}

\begin{tabular}{|c|c|c|c|}
\hline Fill Rate & $\begin{array}{l}50,000 \mathrm{bbl} / \mathrm{d} \\
\text { at } 2013 \\
\end{array}$ & $\begin{array}{c}75,000 \mathrm{bbl} / \mathrm{d} \\
\text { at } 2005 \\
\end{array}$ & $\begin{array}{c}100,000 \mathrm{bbl} / \mathrm{d} \\
\text { at } 2002 \\
\end{array}$ \\
\hline Direct Budget Outlays & 25.5 & 18.8 & 16.3 \\
\hline (Oil Only) & (18.8) & $(14.3)$ & (12.5) \\
\hline Avg. Annual Outlays & ( & & \\
\hline to 750 & 0.6 & 0.8 & 0.8 \\
\hline to 850 & 1.2 & 1.2 & 1.4 \\
\hline to 1000 & 1.5 & 1.9 & 2.0 \\
\hline Total Real Costs (1991\$) & $\$ 18.3$ & 15.4 & 14.1 \\
\hline Present Value Cost in 1991 & 7.5 & 8.2 & 8.5 \\
\hline $\begin{array}{l}\text { Total Treasury Cost } \\
\text { (Interest) }\end{array}$ & $\begin{array}{c}61.7 \\
(36.2)\end{array}$ & $\begin{array}{c}32.6 \\
(13.8)\end{array}$ & $\begin{array}{l}25.3 \\
(9.0)\end{array}$ \\
\hline Market Value at Completion ${ }^{2} /$ & 32.1 & 21.6 & 18.0 \\
\hline Completion Year & 2013 & 2005 & 2002 \\
\hline
\end{tabular}




\section{d. Present Value Cost}

Applying the 10 percent discount rate to adjust for the time value of money results in a present value cost of $\$ 7.5$ billion for the $50 \mathrm{MB} / \mathrm{D}$ fill rate which is $\$ 0.7$ billion and $\$ 1.0$ billion lower than the two respectively higher fill rates. In this case, the time value of money at 10 percent discounts the higher nominal and real dollar costs of the $50 \mathrm{MB} / \mathrm{D}$ fill rate more rapidly than for the two faster fill rates.

\section{e. Total Treasury Cost}

The slower fill rate accumulates an higher ultimate debt burden compared to the two higher fill rates because of the longer period of compounding interest. For the $50 \mathrm{MB} / \mathrm{D}$ fill rate, total Treasury cost is $\$ 61.7$ billion, of which more than half, $\$ 36.2$ billion, consists of interest. In comparison, total Treasury costs of $\$ 32.6$ for the $75 \mathrm{MB} / \mathrm{D}$ fill rate is almost half that of the slower fill rate. Also, interest cost for the $75 \mathrm{MB} / \mathrm{D}$ fill rate at $\$ 13.8$ billion is less than half total Treasury costs. The lowest Treasury costs, $\$ 25.3$ billion, is associated with the fastest fill rate of $100 \mathrm{MB} / \mathrm{D}$; in this case, interest cost, at $\$ 9.0$ billion, is close to one third total Treasury cost.

\section{f. Market Value in the Year of Completion}

The market value for the 400 million barrels in 2013 is the highest at $\$ 32.1$ billion for the 50 $\mathrm{MB} / \mathrm{D}$ fill rate. The market value declines to $\$ 21.6$ billion and $\$ 18.0$ billion for the $75 \mathrm{MB} / \mathrm{D}$ and $100 \mathrm{MB} / \mathrm{D}$ fill rates, respectively.

However, the relationship between Treasury cost and market value reveals one measure of the net financial position for the three fill rates. Treasury cost less market value for the $50 \mathrm{MB} / \mathrm{D}$ fill rate is $\$ 29.6$ billion, compared with $\$ 11.0$ billion and $\$ 7.3$ billion for the $75 \mathrm{MB} / \mathrm{D}$ and $100 \mathrm{MB} / \mathrm{D}$ fill rates, respectively. 


\section{EXHIBIT A}

Fill Rate, Oil Price, and Size Sensitives

Exhibit A presents fifteen tables of detailed annual figures that were summarized earlier in Tables V-6 through V-13. The figures are categorized as follows:

- A-1 through A-3: Reference Case fill rate of $75 \mathrm{MB} / \mathrm{D}$ for the three oil price scenarios through 2005.

- A-4 through A-6; Four fill rates at base case oil prices for each of the three size increments through 2005.

- A-7 through A-9: Four fill rates for a 750 MMB SPR for each of the three oil price paths through their respective periods of completion.

- A-10 through A-12: Four fill rates for an 850 MMB SPR for each of the three oil price paths through their respective periods of completion.

- $\quad$ A-13 through A-15: Four fill rates for a 1,000 MMB SPR for each of the three oil price paths through their respective periods of completion. 
EXHIBIT A-1

STRATEGIC PETROLEUM RESERVE

Funding Prof i les For Alternative Size Programs

75 MBD Fill Rate/ Base Case 0 il Price Assumptions

(Dollars in Millions)

$1995 \quad 1996$

1997

1998

$1999 \quad 2000$

2001

2002

2003

2004

2005

2006

Total

$\begin{array}{lrrrr}\text { Facilities and Management } & 196 & 177 & 169 & 167 \\ \text { Oil Aquisition } & 50 ? & 536 & 579 & 643 \\ \text { Total New BA } & 703 & 713 & 748 & 810 \\ \text { Out lays from New BA } & 644 & 712 & 745 & 806 \\ \text { Constant FY1991 \$ } & 644 & 693 & 709 & 753 \\ \text { Present Value * } & 644 & 630 & 586 & 565 \\ \text { USG Borrowing Cost } \star \star & 27 & 80 & 134 & 187\end{array}$

750 MMB Program - 0il Fill Complete in FY 1996

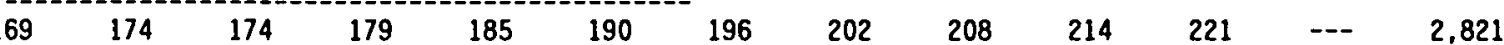

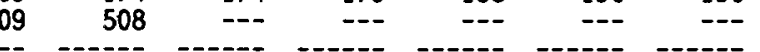

$\begin{array}{llll}582 & 174 & 179\end{array}$

$873 \quad 740$

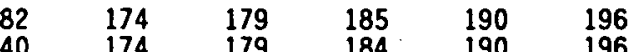

850

411

174
151
85

151
77

184
151
71
558

$\begin{array}{ll}190 & 196 \\ 190 & 196 \\ 151 & 151\end{array}$

850 MMB Program - 011 F 111 Complete in FY 2000

Facilities and Management Dil Aquisition

Total New BA

Out lays from New BA

Constant FY1991

Present Value

USG Borrowing Cost **

\begin{tabular}{rr}
202 & 179 \\
507 & 536 \\
\hdashline 709 & 715 \\
649 & 714 \\
649 & 695 \\
649 & 632 \\
27 & 81
\end{tabular}

Facilities and Management 0 il Aquisition

Tota I New BA

Out lays from New BA

Constant FY1991 \$

USG Borrowing Cost $\star \star$

$\begin{array}{rrrr}202 & 185 & 354 & 905 \\ 507 & 536 & 579 & 643 \\ -709 & 721 & 933 & 1,548 \\ 649 & 720 & 913 & 1.371 \\ 649 & 701 & 868 & 1.280 \\ 649 & 637 & 717 & 962 \\ 27 & 81 & 141 & 219\end{array}$

192
709
90
97
59
258

\begin{tabular}{rrrrrr}
193 & 194 & 184 & 189 & 194 & 198 \\
796 & 882 & 971 & 1,047 & 323 & -- \\
\hline 989 & 1,076 & 1,155 & 1,236 & 517 & 198 \\
986 & 1,069 & 1,148 & 1,229 & 604 & 197 \\
882 & 929 & 969 & 1,007 & 480 & 153 \\
548 & 524 & 497 & 470 & 204 & 59 \\
426 & 542 & 674 & 823 & 963 & 1,072
\end{tabular}

\begin{tabular}{rr}
204 \\
\hline \\
\hline
\end{tabular}

$\begin{array}{rr}202 & 208 \\ --- & - \\ -202 & 208 \\ 201 & 207 \\ 150 & 151 \\ 53 & 48 \\ 752 & 829\end{array}$

208
208
207
151
48
829

214
---
214
214
151
44

\begin{tabular}{rrr}
221 & --- & 2,821 \\
--- & 3,482 \\
\hline 221 & --- & --303 \\
220 & 18 & 6,303 \\
151 & 12 & 5.637 \\
40 & 2 & 3,928 \\
1.003 & $\star \star \star$ & 7,360
\end{tabular}

1000 MMB Program - 011 Fill Complete in FY 2005

\begin{tabular}{|c|c|c|c|c|c|c|c|c|c|c|c|c|}
\hline $\begin{array}{l}512 \\
709\end{array}$ & $\begin{array}{l}256 \\
796\end{array}$ & $\begin{array}{l}250 \\
882\end{array}$ & $\begin{array}{l}241 \\
971\end{array}$ & $\begin{array}{r}247 \\
1.047\end{array}$ & $\begin{array}{r}213 \\
1.115\end{array}$ & $\begin{array}{r}218 \\
1,196\end{array}$ & $\begin{array}{r}225 \\
1,282\end{array}$ & $\begin{array}{r}231 \\
1,364\end{array}$ & $\begin{array}{r}238 \\
1,449\end{array}$ & $\begin{array}{r}246 \\
1,175\end{array}$ & $\begin{array}{l}--- \\
---\end{array}$ & $\begin{array}{r}4,523 \\
14,251\end{array}$ \\
\hline 835 & $\begin{array}{r}1.052 \\
1.115 \\
998 \\
520 \\
504\end{array}$ & $\begin{array}{r}1,132 \\
1,129 \\
982 \\
554 \\
634\end{array}$ & $\begin{array}{r}1.212 \\
1.205 \\
1.017 \\
522 \\
779\end{array}$ & $\begin{array}{r}1,294 \\
1,287 \\
1,054 \\
492 \\
941\end{array}$ & $\begin{array}{r}1.328 \\
1.325 \\
1.054 \\
447 \\
1.120\end{array}$ & $\begin{array}{r}1,407 \\
1,087 \\
419 \\
1,319\end{array}$ & $\begin{array}{r}1,499 \\
1,120 \\
393 \\
1,541\end{array}$ & $\begin{array}{r}1,588 \\
1,153 \\
367 \\
1,788\end{array}$ & $\begin{array}{r}1,687 \\
1,680 \\
1,184 \\
343 \\
2,062\end{array}$ & $\begin{array}{l}1.5 \\
1.5\end{array}$ & $\begin{array}{r}--- \\
20 \\
14 \\
3 \\
\star \star \star\end{array}$ & $\begin{array}{r}18,774 \\
18,774 \\
15,437 \\
8,238 \\
13,813\end{array}$ \\
\hline
\end{tabular}

* Constant FY1991 dollars discounted at $10 \%$ to FY1991.

** Using projected interest rates for 10-year Treasury bonds; interest applied at mid-year to annual investment (out lays).

$\star \star *$ Interest on annual investment included in total for FY 2005 
EXHIBIT A-2

STRATEGIC PETROLEUM RESERVE

Funding Profiles For Alternative Size Programs

FY 1991 to FY 2005

te/ High Case 011 Price Assumptions

(Dollars in Millions)

FISCAL YEAR

$\begin{array}{cccc}1991 & 1992 & 1993 & 1994 \\ - & & & \end{array}$

1995

1997

1998

1999

2000

2001

$2002 \quad 2003$

2004

2005

2006

Tota 1

750 MMB Program - $0 i 1 \mathrm{Fill}$ Complete in FY 1996

Facilities and Management
Oil Aquisition

Total New BA

$\begin{array}{rrrr}196 & 177 & 169 & 167 \\ 612 & 666 & 713 & 773 \\ -808 & 843 & 882 & 940 \\ 741 & 841 & 879 & 936 \\ 741 & 818 & 835 & 874 \\ 741 & 743 & 690 & 657 \\ 31 & 93 & 157 & 218\end{array}$

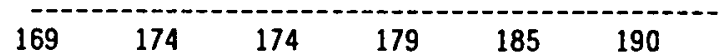

Out lays from New BA

Constant FY1991 \$

Present Value $\star$
uSG Borrowing Cost $\star \star$

$\begin{array}{llll}31 & 93 & 157 & 218\end{array}$

\begin{tabular}{rrr}
836 & 595 & --- \\
\hline 005 & 769 & 174
\end{tabular}

1.005

$\begin{array}{llllll}922 & 837 & 174 & 179 & 185 & 190 \\ 184 & 749 & 151 & 151 & 151 & 150\end{array}$

$\begin{array}{rrr}630 & 465 & 151 \\ 277 & 447 & 823\end{array}$

151
77
579

151
70
640

$190 \quad 196$

850 MMB Program - $011 \mathrm{~F} 111$ Complete in FY 2000

Facilities and Management

$\begin{array}{lrrrr}\text { Facilities and Management } & 202 & 179 & 236 & 427 \\ \text { Oil Aquisition } & 612 & 666 & 713 & 773 \\ \text { Total New BA Now BA } & 814 & 845 & 949 & 1.200 \\ \text { Out lays from New } & 746 & 843 & 939 & 1.142 \\ \text { Constant FY1991 \$ } & 746 & 820 & 892 & 1.067 \\ \text { Present Value } \star & 746 & 745 & 738 & 802 \\ \text { USG Borrowing Cost } \star \star & 31 & 93 & 160 & 230\end{array}$

\begin{tabular}{rrr}
192 & 193 & 194 \\
836 & 932 & 1,03 \\
\hdashline 1,028 & 1,125 & 1,225 \\
1,077 & 1,120 & 1,217 \\
993 & 1.003 & 1,058 \\
678 & 623 & 597 \\
297 & 490 & 622
\end{tabular}

\begin{tabular}{rrrrr}
1 & 1.144 & 189 & 194 & 198 \\
\hline$-1,254$ & 398 & - \\
\hline 7 & 1,325 & 1,443 & 592 & 198 \\
8 & 1,316 & 1,434 & 696 & 197 \\
7 & 1.111 & 1.174 & 554 & 152 \\
570 & 547 & 235 & 59 \\
6 & 773 & 945 & 1,106 & 1,230
\end{tabular}

\begin{tabular}{rr}
202 \\
-202 \\
\hline 1 & 201 \\
\hline 8 & 53 \\
\hline 8 & 85
\end{tabular}

$\begin{array}{rr}202 & 208 \\ 202 & 208 \\ 201 & 207 \\ 151 & 150 \\ 53 & 48 \\ 857 & 94\end{array}$

$\begin{array}{rrr}214 & 221 & -- \\ --- & --- & -- \\ 214 & 221 & -- \\ 214 & 220 & 18 \\ 151 & 151 & 12 \\ 44 & 40 & 3 \\ 1,033 & 1,134 & \star \star \star\end{array}$

2.821

7.016

1000 MMB Program - $0 i 1$ Fill Complete in FY 2005

Facilities and Management 011 Aquisition

$\begin{array}{rrrr}202 & 185 & 354 & 905 \\ 612 & 666 & 713 & 773 \\ -814 & 851 & 1,067 & 1,678 \\ 746 & 849 & 1,046 & 1.501 \\ 746 & 826 & 995 & 1,401 \\ 746 & 751 & 822 & 1,053 \\ 31 & 94 & 164 & 250\end{array}$

$\begin{array}{rrrrrrr}512 & 256 & 250 & 241 & 247 & 213 & 218 \\ 836 & 932 & 1.031 & 1.141 & 1,254 & 1,373 & 1,482 \\ -1.348 & 1.188 & 1.281 & 1.382 & 1,-501 & 1,586 & -1,700 \\ 1.452 & 1.250 & 1.277 & 1.373 & 1,491 & 1,579 & 1,691 \\ 1.339 & 1.119 & 1.110 & 1,159 & 1,222 & 1.256 & 1,306 \\ 915 & 695 & 627 & 595 & 570 & 532 & 503 \\ 341 & 568 & 714 & 877 & 1,062 & 1,270 & 1,502\end{array}$

$\begin{array}{rrr}204 & 210 \\ -- \\ -204 & - \\ 203 & 210 \\ 152 & 152 \\ 53 & 49 \\ 1,344 & 1,469\end{array}$

\begin{tabular}{rr}
0 & 216 \\
\hline & 216 \\
\hline 9 & 216 \\
\hline & 152 \\
\hline & 44
\end{tabular}

\begin{tabular}{|c|c|c|}
\hline 222 & $\ldots$ & 3.240 \\
\hline & & 8,35 \\
\hline $\begin{array}{r}222 \\
222 \\
152 \\
40 \\
1.749\end{array}$ & $\begin{array}{r}19 \\
12 \\
3 \\
\star \star \star \star\end{array}$ & $\begin{array}{r}11.596 \\
11.596 \\
10,190 \\
6,529 \\
12.142\end{array}$ \\
\hline
\end{tabular}

\section{Total New BA}

Out lays from New $B A$

Constant FY1991

USG Borrowing Cost $\star \star$

* Constant FY1991 dollars discounted at $10 \%$ to FY1991.

** Using projected interest rates for 10-year Ireasury bonds; interest applied at mid-year to annual investment (outlays). 
EXHIBIT. A-3

STRATEGIC PETROLEUM RESERVE

Funding Prof $i$ les For Alternative Size Programs

FY 1991 to FY 2005

75 MBD Fill Rate/ Low Case 0 il Price Assumptions

(Dollars in Millions)

FISCAL YEAR

$1991 \quad 1992 \quad 1993 \quad 1994$

$1995 \quad 1996$

1997

$1998 \quad 1999$

$2000 \quad 2001$

2002

2003

2004

2005

2006

Total

750 MMB Program - Oil Fill Complete in FY 1996 Facilities and Management
0 il Aquisition

Total New BA

Out lays from Hew BA

Cons:ant FY1991 \$

Present Value * $\star *$

\begin{tabular}{rrrr}
196 & 177 & 169 & 167 \\
442 & 470 & 506 & 549 \\
\hline 638 & 647 & 675 & 716 \\
58.5 & 646 & 673 & 713 \\
58.5 & 629 & 640 & 666 \\
58.5 & 572 & 529 & 500 \\
64 & 73 & 121 & 169
\end{tabular}

$169-174 \quad 174 \quad 179 \quad 185-190$

USG Borrowing Cost $\star \star$

$\begin{array}{rrrrrrr}169 & 174 & 174 & 179 & 185 & 190 & 196 \\ \mathbf{5 8 6} & \mathbf{4 0 8} & --- & --- & --- & -- & -- \\ -755 & 582 & 174 & 179 & 185 & 190 & 196 \\ 752 & 630 & 174 & 179 & 184 & 190 & 196 \\ 693 & 564 & 151 & 151 & 151 & 151 & 151 \\ 474 & 350 & 85 & 77 & 70 & 64 & 58 \\ 213 & 343 & 402 & 449 & 499 & 554 & 614\end{array}$

\begin{tabular}{rr}
202 \\
6 & 202 \\
1 & 150 \\
\hline & 53 \\
\hline & 678
\end{tabular}

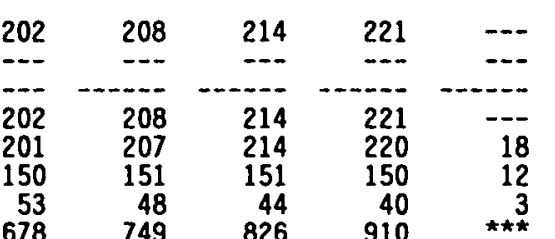

2.821
2.961

5,782

5,782

5,146

3,552

850 MMB Program - 0 il Fill Complete in FY 2000

Facilities and Management

Aquisition

Total New BA

Out lays from Hew $B A$

Constant FY1991 \$

Present Value $\star$

$\begin{array}{rrrr}262 & 179 & 236 & 42 \\ 442 & 470 & 506 & 549 \\ -644 & 649 & 742 & 97 \\ 550 & 648 & 733 & 91 \\ 590 & 631 & 697 & 85 \\ 590 & 573 & 576 & 645 \\ 24 & 73 & 124 & 180\end{array}$

850 MMB Program - 011 Fill Complete in FY 2000

\begin{tabular}{|c|c|c|c|c|c|}
\hline $\begin{array}{l}192 \\
586\end{array}$ & $\begin{array}{l}193 \\
639\end{array}$ & $\begin{array}{l}194 \\
692\end{array}$ & $\begin{array}{l}184 \\
743\end{array}$ & $\begin{array}{l}189 \\
798\end{array}$ & $\begin{array}{l}194 \\
252\end{array}$ \\
\hline $\begin{array}{l}778 \\
829 \\
765 \\
522 \\
234\end{array}$ & $\begin{array}{l}832 \\
831 \\
744 \\
462 \\
382\end{array}$ & $\begin{array}{l}886 \\
882 \\
766 \\
433 \\
481\end{array}$ & $\begin{array}{l}927 \\
924 \\
780 \\
400 \\
592\end{array}$ & $\begin{array}{l}987 \\
983 \\
805 \\
376 \\
715\end{array}$ & $\begin{array}{l}446 \\
512 \\
407 \\
173 \\
832\end{array}$ \\
\hline
\end{tabular}

\begin{tabular}{rrr}
204 & 210 \\
--- & - \\
\hline 204 & 210 \\
203 & 209 \\
152 & 152 \\
53 & 1,017 & 1,115
\end{tabular}

1000 MMB Progran - $0 i 1$ F 111 Complete in FY 2005

Facilities and Management 0 il Aquisition

\section{Total New BA}

Out lays from New BA

Consiant FY1991

USG Borrowing Cost **

$\begin{array}{rrrr}202 & 185 & 354 & 905 \\ 442 & 470 & 506 & 549 \\ -644 & 655 & 860 & 1.454 \\ 590 & 654 & 841 & 1.278 \\ 590 & 637 & 799 & 1.193 \\ 590 & 579 & 661 & 896 \\ 24 & 73 & 129 & 20:\end{array}$

$\begin{array}{rrr}512 & 256 & 250 \\ 586 & 639 & 692 \\ -1.098 & 895 & 942 \\ 1.204 & 961 & 942 \\ 1.111 & 860 & 819 \\ 759 & 534 & 462 \\ 277 & 460 & 573\end{array}$

* Constant FY1991 dollars discounted at $10 \%$ to FY199:.

$\star \star$
$\star$ Using projected interest rates or 10 -year Treasury bonds; interest applied at mid-year to annual investment (out lays).
Interest on annual investraent inc luded in total for FY 2005 . 
EXHI8IT A-4

STRATEGIC PETROLEUM RESERVE

Funding Prof $i$ les For 750 MMB Program

FY 1991 to FY 2005

Alternative 0 il Fill Rates/Base Case 0il Price Assumptions

(Dollars in Millions)

FISCAL YEAR

199

1992

1993

1994

1995

1996

1997

1998

1999

2000

2001

2002

2003

2004

2005

2006

Total

50 MBD Fill Rate - $011 \mathrm{~F}$ ill Complete in FY 1999

Facilities and Management
Oil Aquisition

Total New BA

Out lays from New BA

Constant FY1991 \$

Present Value *

\begin{tabular}{rrrr}
195 & 177 & 169 & 167 \\
338 & 357 & 386 & 429 \\
--- & -- & -- & - \\
\hline 533 & 534 & 555 & 59 \\
489 & 534 & 553 & 593 \\
489 & 520 & 526 & 55 \\
489 & 472 & 435 & 41 \\
20 & 61 & 101 & 14
\end{tabular}

\begin{tabular}{l}
169 \\
473 \\
\hline 642 \\
638 \\
588 \\
402 \\
177
\end{tabular}

\begin{tabular}{rr}
174 & 179 \\
531 & 588 \\
\hdashline 705 & 767 \\
699 & 762 \\
626 & 662 \\
389 & 374 \\
292 & 374
\end{tabular}

184
647
-831
826
697
358
468

189
320
-509
563
461
215
561

$\begin{array}{rr}190 & 196 \\ -190 & 196 \\ 190 & 196 \\ 151 & 15 \\ 64 & 58 \\ 636 & 702\end{array}$

$\begin{array}{rr}96 & 202 \\ 96 & - \\ 96 & 202 \\ 51 & \vdots 50 \\ 58 & ? 53 \\ 02 & ? 74\end{array}$

75 ABD Fill Rate - $0 i 1$ Fill Complete in FY 1996

$\begin{array}{lrrrrr}\text { Facilities and Management } & 196 & 177 & 169 & 167 \\ \text { Oil Aquisition } & 507 & 536 & 579 & 643 & \\ \text { Total New BA } & 703 & 713 & 748 & 810 & 878 \\ \text { Out lays from New BA } & 644 & 712 & 745 & 806 & 875 \\ \text { Constant FY1991 \$ } & 644 & 693 & 709 & 753 & 805 \\ \text { Present Value } \star & 644 & 630 & 586 & 565 & 550 \\ \text { USG Borrowing Cost } \star \star & 27 & 80 & 134 & 187\end{array}$

\begin{tabular}{|c|c|c|c|c|}
\hline $\begin{array}{l}174 \\
508\end{array}$ & $\begin{array}{l}174 \\
--\end{array}$ & 179 & 185 & 190 \\
\hline $\begin{array}{l}682 \\
740 \\
663 \\
411 \\
385\end{array}$ & $\begin{array}{r}174 \\
174 \\
151 \\
85 \\
453\end{array}$ & $\begin{array}{r}179 \\
179 \\
151 \\
77 \\
503\end{array}$ & $\begin{array}{r}185 \\
184 \\
151 \\
71 \\
558\end{array}$ & $\begin{array}{r}190 \\
190 \\
151 \\
64 \\
617\end{array}$ \\
\hline
\end{tabular}

\begin{tabular}{rrr}
96 & 202 & 208 \\
\hline 96 & 202 & 208 \\
96 & 201 & 207 \\
51 & 250 & 151 \\
58 & 53 & 48
\end{tabular}

100 MBD Fill Rate - 0il Fill Complete in FY 1995

Facilities and Management 0 il Aquisition

Total New BA

Out lays from New $B A$

Constant FY1991

Present Value

USG Borrowing Cost **

\begin{tabular}{rrrr}
196 & 178 & 169 & 167 \\
676 & 714 & 772 & 858 \\
\hline 872 & 892 & 941 & 1.025 \\
799 & 890 & 937 & 1.019 \\
799 & 866 & 891 & 951 \\
799 & 787 & 737 & 715 \\
33 & 100 & 167 & 234
\end{tabular}

Maximum OII FIII - 011 Fill Complete in FY 1992

$\begin{array}{lrrrr}\text { Facilities and Management } & 197 & 179 & 165 & 162 \\ \text { 0il Aquisition } & 1,286 & 1,659 & --- & - \\ \text { Total New BA } & 1,483 & 1,838 & 165 & 162 \\ \text { Out lays from New BA } & 1,359 & 1,809 & 304 & 163 \\ \text { Constant FY1991 \$ } & 1,359 & 1,760 & 289 & 152 \\ \text { Present Value * } & 1,359 & 1,599 & 239 & 11 \\ \text { USG Borrowing Cost ** } & 56 & 181 & 256 & 259\end{array}$

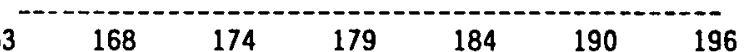

$\begin{array}{rrrrrrr}163 & 168 & 174 & 179 & 184 & 190 & 196 \\ --- & --- & --- & --- & --- & --- & --- \\ 163 & 168 & 174 & 179 & 184 & 190 & 196 \\ 164 & 168 & 173 & 178 & 184 & 189 & 196 \\ 151 & 150 & 150 & 151 & 150 & 150 & 151 \\ 103 & 93 & 85 & 77 & 70 & 64 & 58\end{array}$

$\begin{array}{rrr}96 & 202 & 208 \\ 96 & 202 & 208 \\ 96 & 201 & 207 \\ 51 & 150 & 151 \\ 58 & 53 & 4\end{array}$

* Constant FY1991 dollars discounted at $10 \%$ to FY19g1.

** Using projected interest rates for 10-year Treasury bonds: interest applied at mid-year to annual investment (out lays).

$\star \star \star *$ Interest on annual investment inc Juded in total for FY. 2005. 
EXHIBIT A-5

STRATEGIC PETROLEUM RESERVE

Funding Profiles For 850 MMB Program

Alternative 0 il Fill Rates/Base Case 0il Price Assumptions

(Dollars in Millions)

\section{FISCAL YEAR}

1991

1993

1994

$1995 \quad 1996$

1997

1998

1999

2000

2001

2002

2003

2004

2005

2006

Total

50 MBD Fill Rate - 0 il Fill Complete in FY 2004

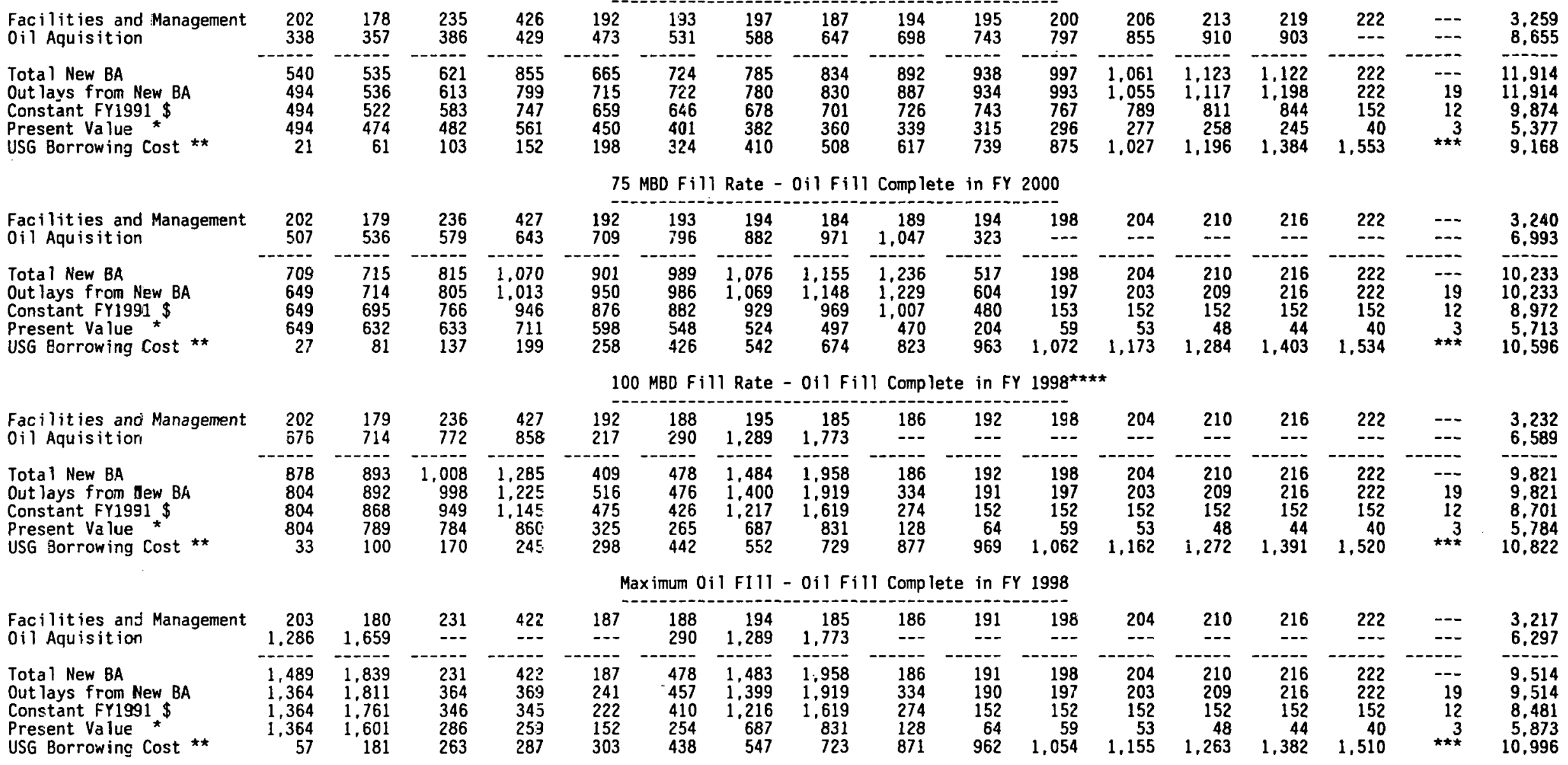

* Constant FY1991 dollars discounted at $10 \%$ to FY1991

\#* Using projected interest rates for 10-year Treasury bonds; interest applied at mid-year to annual investment (outlays).

$\star \star \star \star$
$* \star \star$ Fill constrained to less than $100 \mathrm{MBD}$ in FY1995 and FY1996 by capacity limitations; shortfall recovered by increased $\mathrm{fill}$ in FY1997 and FY1998. 
EXHIBIT A-6

STRATEGIC PETROLEUM RESERYE

Funding Prof $\mathfrak{i}$ les For 1000 MMB Program

FY 1991 to FY 2005

Alternative 0il Fill Rates/Base Case 0il Price Assumptions

(Dollars in Millions)

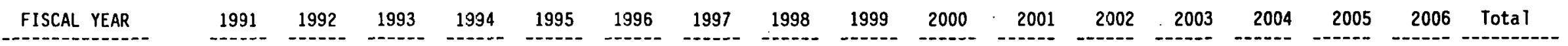

50 MBD Fill Rate - Dil Fill Complete in FY 2013

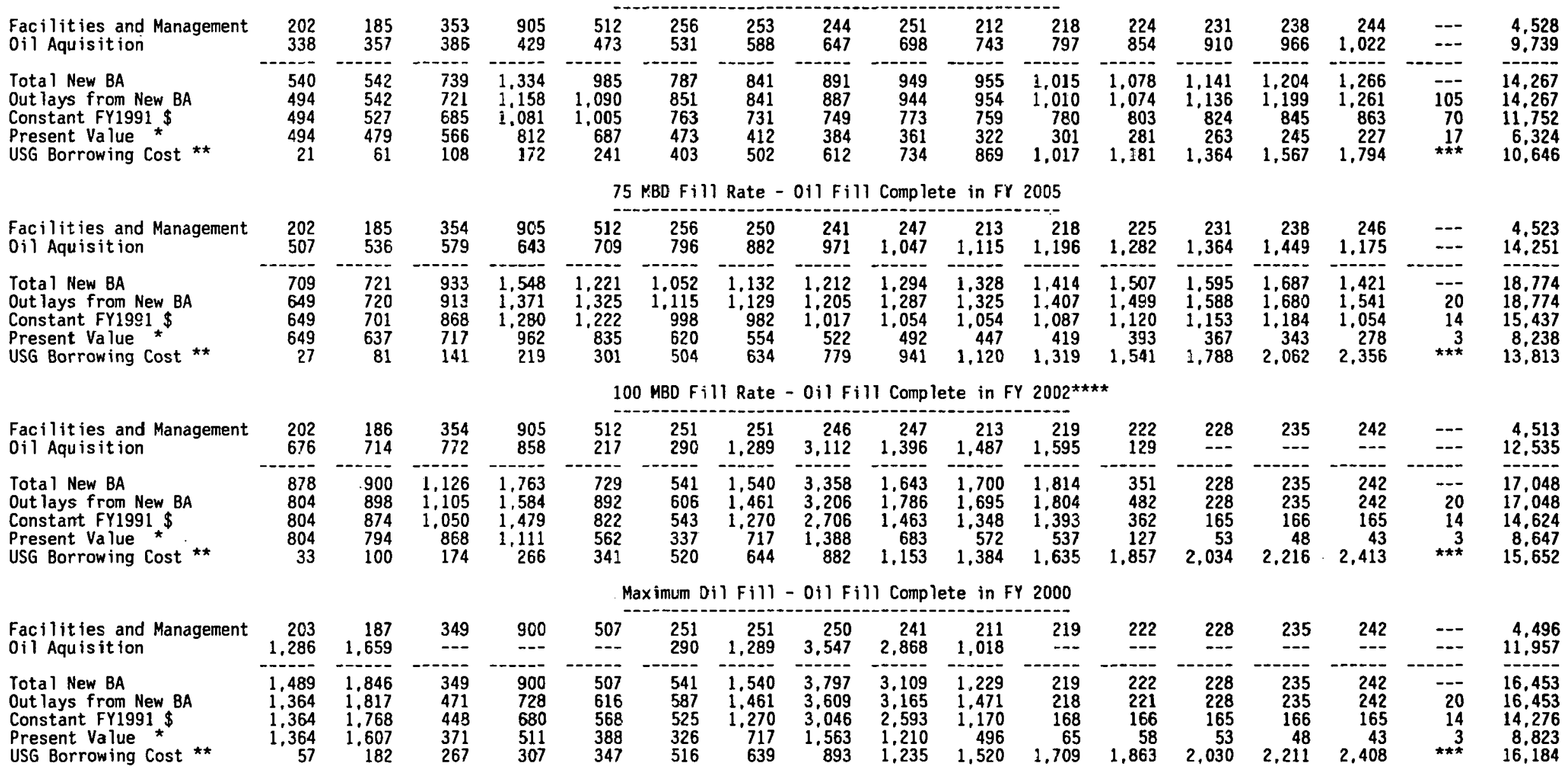

* Constant FY1991 dollars discounted at $10 \%$ to FY1991.

** Using projected interest rates for 10-year Treasury bonds; interest applied at mid-year to annual investment (out lays).

$\star \star \star *$ Interest on annual investment included in total for FY 2005.

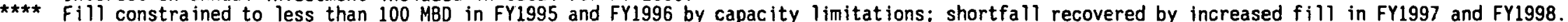


EXHIBIT $A-7$

STRATEGIC PETROLEUM RESERVE

Funding Prof iles for 750 MMB Program

Base Case Oil Price Assumptions

(Dollars in Millions)

$\begin{array}{ccccccccccc}\text { FISCAL YEAR } & 1991 & 1992 & 1993 & 1994 & 1995 & 1996 & 1997 & 1998 & 1999 & 2000 \quad \text { Total to } \\ - & - & & \end{array}$

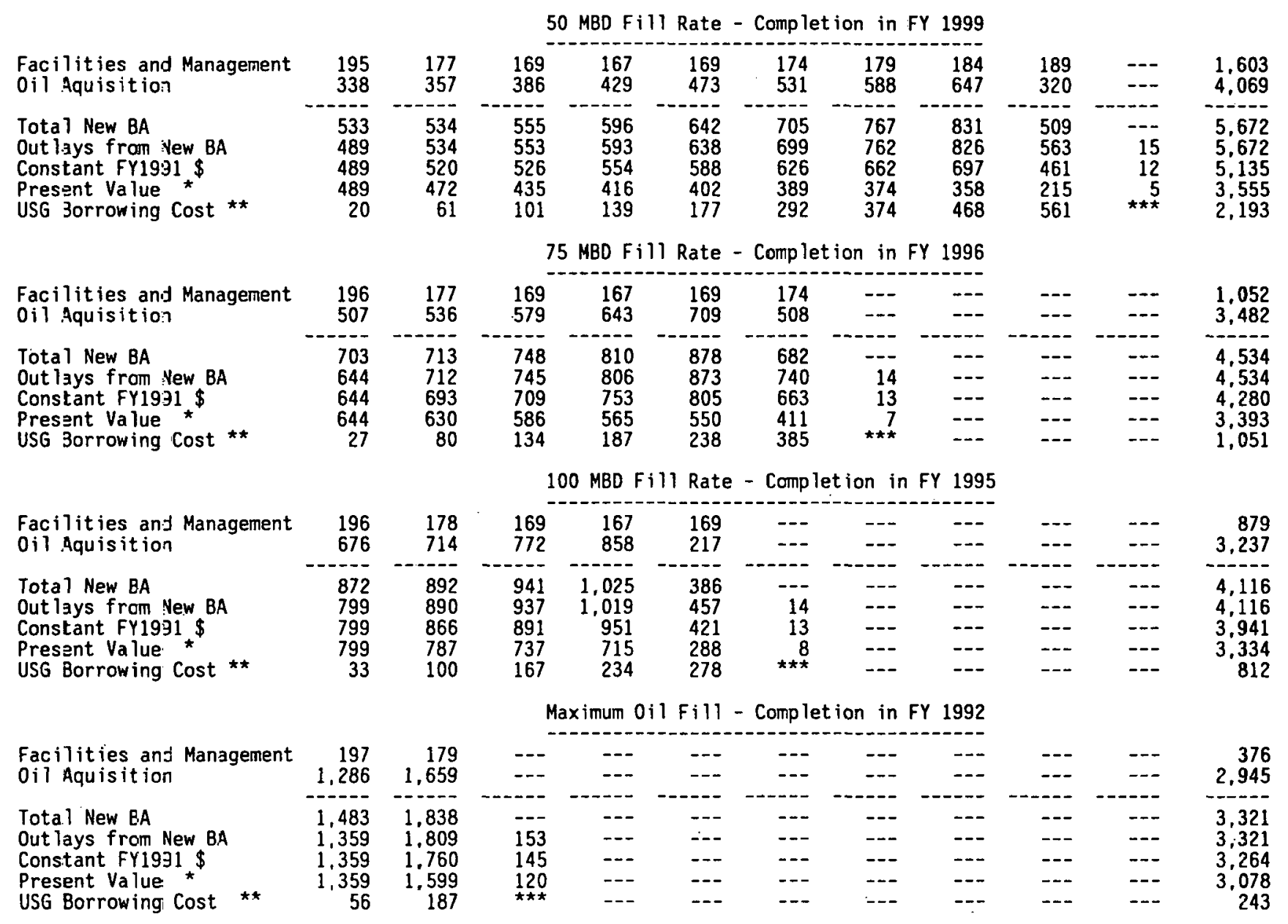

* Constant. FY1991 dollars discounted at $10 \%$ to FY1991.

** Using projected interest rates for 10-year Treasury bonds; interest applied at mid-year to anrual investment (out lays).

$\star \star \star$ Interest on annul investment included in total for complet ion year. 
EXHIBIT $A-8$

STRATEGIC PETROLEUM RESERVE

Funding Profiles for 750 MMB Program

FY 1991 to Completion

High Case 0 il Price Assumptions

(Dollars in Millions)

\begin{tabular}{|c|c|c|c|c|c|c|c|c|c|c|c|}
\hline FISCAL YEAR & 1991 & 1992 & 1993 & 1994 & 1995 & 1996 & 1997 & 1998 & 1999 & 2000 & $\begin{array}{l}\text { Total to } \\
\text { Complet ion }\end{array}$ \\
\hline 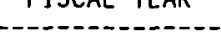 & & $-\ldots$ & 1000 & - & ---- & ---- & - & $-130-$ & -100 & & \\
\hline
\end{tabular}

50 MBD Fill Rate - Completion in FY 1999

Facilities and Management 0 il Aquisition

Total New 8A

Out lays from Wew BA

Constant FY1991

Present Value

USG Borrowing Cost $\star \star$

\begin{tabular}{rr}
195 & 177 \\
408 & 444 \\
\hline 603 & 621 \\
553 & 620 \\
553 & 603 \\
553 & 548 \\
23 & 69
\end{tabular}

$169 \quad 167 \quad 169 \quad 174 \quad 179$

$\begin{array}{rrrrrrrrr}169 & 167 & 169 & 174 & 179 & 184 & 189 & -- & 1.603 \\ 475 & 515 & 558 & 621 & 687 & 761 & 383 & -- & 4.852 \\ -644 & 682 & 727 & 795 & 866 & 945 & 572 & -- & --.455 \\ 642 & 679 & 723 & 789 & 860 & 938 & 636 & 15 & 6.455 \\ 611 & 634 & 666 & 706 & 748 & 792 & 521 & 12 & 5.846 \\ 504 & 476 & 455 & 438 & 423 & 407 & 244 & 5 & 4.053 \\ 116 & 160 & 203 & 335 & 427 & 533 & 640 & \star \star \star & 2,506\end{array}$

Facilities and Management 0 il Aquisition

75 MBD Fill Rate - Completion in FY 1996

Total New BA

Out lays from New BA

Constant FY1991 \$

Present Value

USG Borrowing Cost $\star \star$

\begin{tabular}{rr}
196 & 177 \\
612 & 666 \\
\hline 808 & 843 \\
741 & 841 \\
741 & 818 \\
741 & 743 \\
31 & 93
\end{tabular}

$169-167-169 \quad 174 \quad--$

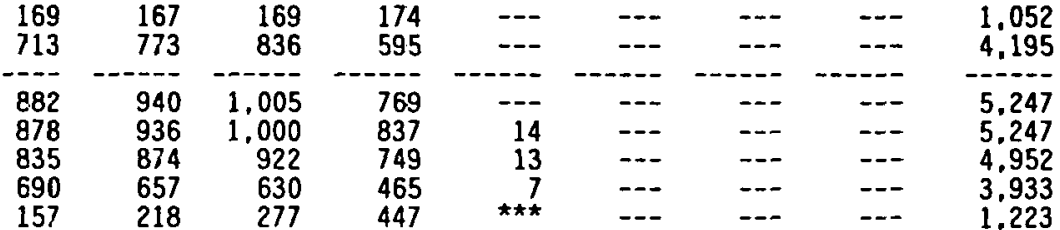

100 MBD Fill Rate - Completion in FY 1995

Facilities and Management 0 il Aquisition

Tota) New BA

Out lays from Hew BA

Constant FY1991 \$

USG Borrowing Cost $\star \star$

\begin{tabular}{rr}
196 & 178 \\
817 & 888 \\
\hline 1,013 & 1.066 \\
928 & 1.061 \\
928 & 1.033 \\
928 & 939 \\
38 & 117
\end{tabular}

\begin{tabular}{|c|c|c|c|c|c|c|c|c|}
\hline $\begin{array}{l}169 \\
950\end{array}$ & $\begin{array}{r}167 \\
1,031\end{array}$ & $\begin{array}{l}169 \\
255\end{array}$ & $\begin{array}{l}--- \\
---\end{array}$ & --- & -- & -- & --- & $\begin{array}{r}879 \\
3,941\end{array}$ \\
\hline $\begin{array}{r}.060 \\
876 \\
197\end{array}$ & $\begin{array}{r}1,198 \\
1,192 \\
1.113 \\
836 \\
276\end{array}$ & $\begin{array}{l}424 \\
510 \\
470 \\
321 \\
327\end{array}$ & $\begin{array}{r}-- \\
14 \\
13 \\
8 \\
\star \star \star \star\end{array}$ & $\begin{array}{l}--- \\
--- \\
--- \\
---\end{array}$ & $\begin{array}{l}--- \\
--- \\
--- \\
---\end{array}$ & $\begin{array}{l}-- \\
\because- \\
-- \\
--\end{array}$ & $\begin{array}{l}--- \\
--- \\
--- \\
--- \\
---\end{array}$ & $\begin{array}{r}4,820 \\
4,820 \\
4,617 \\
3,908 \\
955\end{array}$ \\
\hline
\end{tabular}

Facilities and Management

Maximum Oil Fill - Completion in FY 1992

0 il Aquisition

Total New BA

Out lays from New BA

Constant FY1991 \$

Present Value $\star$
USG Borrowing Cost $\star \star$

\begin{tabular}{|c|c|c|c|c|c|c|c|c|c|c|}
\hline $\begin{array}{r}197 \\
1,554\end{array}$ & $\begin{array}{r}179 \\
2,063\end{array}$ & -- & -- & --- & -- & --- & --- & --- & --- & $\begin{array}{r}376 \\
3,617\end{array}$ \\
\hline $\begin{array}{r}1,751 \\
1,605 \\
1,605 \\
1,605 \\
67\end{array}$ & $\begin{array}{r}2.242 \\
2.201 \\
2.141 \\
1.947 \\
223\end{array}$ & $\begin{array}{l}--- \\
187 \\
178 \\
147 \\
\star \star \star\end{array}$ & $\begin{array}{l}--- \\
--- \\
--- \\
---\end{array}$ & $\begin{array}{l}--- \\
-- \\
--- \\
---\end{array}$ & $\begin{array}{l}--- \\
--- \\
--- \\
---\end{array}$ & $\begin{array}{l}--- \\
--- \\
--- \\
---\end{array}$ & $\begin{array}{l}--- \\
--- \\
--- \\
---\end{array}$ & $\begin{array}{l}--- \\
--- \\
--- \\
--\end{array}$ & $\begin{array}{l}-- \\
--- \\
--- \\
---\end{array}$ & $\begin{array}{r}3,993 \\
3,993 \\
3,924 \\
3,699 \\
290\end{array}$ \\
\hline
\end{tabular}

* Constant FY1991 dollars discounted at $10 \%$ to FY1991.

** Using projected interest rates for 10-year Treasury bonds; interest applied at mid-year to annual invostment (outlays).

$\star \star \star *$ Interest on annual investment included in total for complet ion year. 
EXHIBIT $a-9$

STRATEGIC PETROL EUM RESERVE

Funding Profiles for 750 MMB Program

$=y 1991$ to Completion

Low Case 0 il Price Assumptions

(Dollars in Millions)

\section{FISCAL YEAR}

1991

1992

1993

1994

1995

1996

1997

1998

1999

50 MBD Fill Rate - Completion in FY 1999

\begin{tabular}{|c|c|c|c|c|c|c|c|c|c|c|c|}
\hline \multirow[b]{2}{*}{$\begin{array}{l}\text { Facilities and Management } \\
\text { Oil Aquisition }\end{array}$} & \\
\hline & $\begin{array}{l}195 \\
295\end{array}$ & $\frac{177}{313}$ & $\begin{array}{l}169 \\
338\end{array}$ & $\begin{array}{l}167 \\
366\end{array}$ & $\begin{array}{l}169 \\
391\end{array}$ & $\begin{array}{l}174 \\
426\end{array}$ & $\begin{array}{l}179 \\
461\end{array}$ & $\begin{array}{l}184 \\
495\end{array}$ & $\begin{array}{l}189 \\
244\end{array}$ & --- & $\begin{array}{l}1,603 \\
3,329\end{array}$ \\
\hline \multirow[t]{2}{*}{$\begin{array}{l}\text { Total New BA } \\
\text { Out lays from New BA } \\
\text { Constant FY1991 } \$ \\
\text { Present Va lue } \star \\
\text { USG Borrowing Cost }\end{array}$} & $\begin{array}{r}490 \\
449 \\
449 \\
449 \\
19\end{array}$ & $\begin{array}{r}490 \\
490 \\
477 \\
434 \\
55\end{array}$ & $\begin{array}{r}507 \\
505 \\
480 \\
397 \\
92\end{array}$ & $\begin{array}{l}533 \\
531 \\
496 \\
372 \\
128\end{array}$ & $\begin{array}{l}560 \\
558 \\
514 \\
351 \\
161\end{array}$ & $\begin{array}{l}600 \\
596 \\
534 \\
332 \\
263\end{array}$ & $\begin{array}{l}640 \\
637 \\
554 \\
312 \\
333\end{array}$ & $\begin{array}{l}679 \\
676 \\
571 \\
293 \\
412\end{array}$ & $\begin{array}{l}433 \\
475 \\
388 \\
182 \\
492\end{array}$ & $\begin{array}{r}-15 \\
12 \\
5 \\
\star \star \star \star *\end{array}$ & $\begin{array}{l}4.932 \\
4.932 \\
4.475 \\
3.127 \\
1.955\end{array}$ \\
\hline & \multicolumn{11}{|c|}{75 MBD Fi.ll Rate - Completion in FY 1996} \\
\hline $\begin{array}{l}\text { cilities and Management } \\
\text { il Aquis ition }\end{array}$ & $\begin{array}{r}196 \\
442 \\
-\end{array}$ & $\begin{array}{r}177 \\
470 \\
---\end{array}$ & $\begin{array}{l}169 \\
506\end{array}$ & $\begin{array}{l}167 \\
549 \\
\end{array}$ & $\begin{array}{l}169 \\
586\end{array}$ & $\begin{array}{l}174 \\
408\end{array}$ & -- & $\begin{array}{l}--- \\
---\end{array}$ & 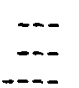 & $\begin{array}{l}--- \\
---\end{array}$ & $\begin{array}{l}1,052 \\
2,961 \\
\end{array}$ \\
\hline \multirow[t]{2}{*}{$\begin{array}{l}\text { Total New BA } \\
\text { Out lays from New BA } \\
\text { Constant FY199: \$\$ } \\
\text { Present Va lue } \\
\text { USG Borrowing Cost }\end{array}$} & $\begin{array}{r}638 \\
585 \\
585 \\
585 \\
24\end{array}$ & $\begin{array}{r}647 \\
646 \\
629 \\
572 \\
73\end{array}$ & $\begin{array}{l}675 \\
673 \\
640 \\
529 \\
121\end{array}$ & $\begin{array}{l}716 \\
713 \\
666 \\
500 \\
169\end{array}$ & $\begin{array}{l}755 \\
752 \\
693 \\
474 \\
213\end{array}$ & $\begin{array}{l}582 . \\
630 \\
564 \\
350 \\
343\end{array}$ & $\begin{array}{r}--- \\
14 \\
13 \\
7 \\
\star \star \star\end{array}$ & $\begin{array}{l}--- \\
--- \\
--- \\
---\end{array}$ & $\begin{array}{l}--- \\
-\cdots \\
-\cdots \\
-\cdots \\
---\end{array}$ & $\begin{array}{l}--- \\
--- \\
--- \\
---\end{array}$ & $\begin{array}{r}4.013 \\
4,013 \\
3,790 \\
3,017 \\
943\end{array}$ \\
\hline & \multicolumn{11}{|c|}{100 MBD Fill Rate - Completion in FY 1995} \\
\hline $\begin{array}{l}\text { Facilities and Management } \\
0 \text { il Aquisition }\end{array}$ & $\begin{array}{r}196 \\
590\end{array}$ & $\begin{array}{l}178 \\
626\end{array}$ & $\begin{array}{l}169 \\
675\end{array}$ & $\begin{array}{l}167 \\
732\end{array}$ & $\begin{array}{l}169 \\
179\end{array}$ & $\begin{array}{ll}-- \\
---\end{array}$ & 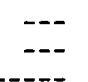 & --- & 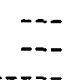 & 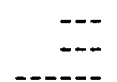 & $\begin{array}{r}879 \\
2,802 \\
\end{array}$ \\
\hline \multirow[t]{2}{*}{$\begin{array}{l}\text { Total New BA } \\
\text { Out lays from New BA } \\
\text { Constant FY199I } \$ \\
\text { Present Value } \star \\
\text { USG Borrowing cost }\end{array}$} & $\begin{array}{r}786 \\
720 \\
720 \\
720 \\
30\end{array}$ & $\begin{array}{r}804 \\
802 \\
781 \\
710 \\
90\end{array}$ & $\begin{array}{l}844 \\
841 \\
800 \\
661 \\
150\end{array}$ & $\begin{array}{l}899 \\
895 \\
835 \\
628 \\
210\end{array}$ & $\begin{array}{l}348 \\
409 \\
377 \\
257 \\
248\end{array}$ & $\begin{array}{r}14 \\
13 \\
8 \\
\times * \star\end{array}$ & $\begin{array}{l}--- \\
--- \\
--- \\
---\end{array}$ & $\begin{array}{l}-- \\
--- \\
--- \\
---\end{array}$ & $\begin{array}{l}--- \\
-- \\
-- \\
-- \\
--\end{array}$ & $\begin{array}{l}-- \\
\cdots- \\
-- \\
-\cdots\end{array}$ & $\begin{array}{r}3,681 \\
3,681 \\
3,526 \\
2,984 \\
728\end{array}$ \\
\hline & \multicolumn{11}{|c|}{ Maximum 0il Fill - Completion in FY 1992} \\
\hline $\begin{array}{l}\text { Facilities and: Management } \\
0 \text { il Aquisition }\end{array}$ & $\begin{array}{r}197 \\
1.123 \\
\end{array}$ & $\begin{array}{r}179 \\
1,454 \\
\end{array}$ & --- & -- & --- & --- & --- & --- & $\cdots$ & --- & $\begin{array}{r}376 \\
2,577 \\
\end{array}$ \\
\hline $\begin{array}{l}\text { Total New BA } \\
\text { Out lays from Now BA } \\
\text { Constant FY1991 } \$ \\
\text { Present Value * } \\
\text { USG Borrowing Cost } \star \star\end{array}$ & $\begin{array}{r}1.320 \\
1.209 \\
1.209 \\
1.209 \\
50\end{array}$ & $\begin{array}{l}1,633 \\
1,608 \\
1,564 \\
1,422 \\
166\end{array}$ & $\begin{array}{l}-1- \\
136 \\
130 \\
107 \\
\star \star \star\end{array}$ & $\begin{array}{l}-- \\
-- \\
-- \\
--\end{array}$ & $\begin{array}{l}--- \\
--- \\
--- \\
---\end{array}$ & $\begin{array}{l}--. \\
--- \\
---\end{array}$ & $\begin{array}{l}--- \\
--- \\
--- \\
---\end{array}$ & $\begin{array}{l}--- \\
--- \\
--- \\
---\end{array}$ & $\begin{array}{l}\cdots- \\
\cdots- \\
\cdots- \\
\cdots-\end{array}$ & $\begin{array}{l}--- \\
-- \\
-- \\
--\end{array}$ & $\begin{array}{r}2.953 \\
2.953 \\
2,903 \\
2.738 \\
216\end{array}$ \\
\hline
\end{tabular}

* Constant FY1991 dollars discounted at $10 \%$ to FY1991

** Using prajected interest rates for 10-year Treasury bonds; interest applied at mid-year to annual investment (out lays).

$\star \star \star *$ Interest on annual investment included in total for complet ion year. 
EXHIBIT A-10

STRATEGIC PETROLEUM RESERVE

Funding Profiles for 850 MMB Program

FY 1991 to Completion

Base Case Oil Price Assumptions

(Dollars in Millions)

\section{FISCAL YEAR}

Facilities and Management 0 il Aquisition

Total New BA

Out lays from New BA

Constant FY1991 \$

Present Value

USG Borrowing Cost **

Facilities and Management o 11 Aquisition

\section{Total New BA}

Out lays from New BA

Constant FY1991 \$

Present Value *

USG Borrowing Cost $\star \star$

Facilities and Management

0 il Aquisition

Total New BA

Out lays from New BA

Constant FY1991 \$

Present

USG Borrawing Cost **

Facilities and Management 0 i) Aquisition

\section{Total New BA}

Out lays from New BA

Constant FY1991

USG Borrowing Cost *

$\begin{array}{rrrr}1991 & 1992 & 1993 & 1994 \\ - & & & \\ 202 & 178 & 235 & 425 \\ 338 & 357 & 386 & 423 \\ -540 & 535 & 621 & 855 \\ 494 & 536 & 613 & 793 \\ 494 & 522 & 583 & 747 \\ 494 & 474 & 482 & 561 \\ 21 & 61 & 103 & 15 ?\end{array}$

1995

50 MBD Fill Rate - Completion in FY 2004
Total to

Completion
- 19201930197

$\begin{array}{rrrrrrrrrrrr}192 & 193 & 197 & 187 & 194 & 195 & 200 & 206 & 213 & 219 & -- & 3.037 \\ 473 & 531 & 588 & 647 & 698 & 743 & 797 & 855 & 910 & 903 & -- & 8.655 \\ -665 & 724 & 785 & 834 & 892 & 938 & 997 & 1.061 & 1.123 & 1.122 & -1 .- & 11.692 \\ 715 & 722 & 780 & 830 & 887 & 934 & 993 & 1.055 & 1.117 & 1.198 & 19 & 11.692 \\ 659 & 646 & 678 & 701 & 726 & 743 & 767 & 789 & 811 & 844 & 12 & 9.722 \\ 450 & 401 & 382 & 360 & 339 & 315 & 296 & 277 & 258 & 245 & 3 & 5.337 \\ 198 & 324 & 410 & 508 & 617 & 739 & 875 & 1.027 & 1.196 & 1.385 & \star \star \star & 7.616\end{array}$

75 MBD Fill Rate - Completion in FY 2000

\begin{tabular}{|c|c|c|c|c|c|c|c|c|c|c|c|c|c|c|c|}
\hline $\begin{array}{l}202 \\
507\end{array}$ & $\begin{array}{l}179 \\
536\end{array}$ & $\begin{array}{l}236 \\
579\end{array}$ & $\begin{array}{l}427 \\
643\end{array}$ & $\begin{array}{l}192 \\
709\end{array}$ & $\begin{array}{l}193 \\
796\end{array}$ & $\begin{array}{l}194 \\
882\end{array}$ & $\begin{array}{l}184 \\
971\end{array}$ & $\begin{array}{r}189 \\
1,047\end{array}$ & $\begin{array}{l}194 \\
323\end{array}$ & --- & --- & --- & --- & -- & $\begin{array}{l}2,190 \\
6,993\end{array}$ \\
\hline $\begin{array}{r}709 \\
649 \\
649 \\
649 \\
27\end{array}$ & $\begin{array}{r}715 \\
714 \\
695 \\
632 \\
81\end{array}$ & $\begin{array}{l}815 \\
805 \\
766 \\
633 \\
137\end{array}$ & $\begin{array}{r}1.070 \\
1.013 \\
946 \\
71 \\
199\end{array}$ & $\begin{array}{l}901 \\
950 \\
876 \\
598 \\
258\end{array}$ & $\begin{array}{l}989 \\
986 \\
882 \\
548 \\
426\end{array}$ & $\begin{array}{r}1.076 \\
1.069 \\
929 \\
524 \\
542\end{array}$ & $\begin{array}{r}1,155 \\
1,148 \\
969 \\
497 \\
674\end{array}$ & $\begin{array}{r}1.236 \\
1.229 \\
1.007 \\
470 \\
823\end{array}$ & $\begin{array}{l}517 \\
604 \\
480 \\
204 \\
964\end{array}$ & $\begin{array}{r}-\cdots \\
16 \\
13 \\
5 \\
\star \star \star\end{array}$ & $\begin{array}{l}--- \\
--- \\
--- \\
---\end{array}$ & $\begin{array}{l}-- \\
--- \\
--\end{array}$ & $\begin{array}{l}--- \\
--- \\
--- \\
--- \\
--\end{array}$ & $\begin{array}{l}--- \\
--- \\
--- \\
---\end{array}$ & $\begin{array}{l}9,1 \\
9.1 \\
8.2 \\
5,4 \\
4.1\end{array}$ \\
\hline
\end{tabular}

100 MBD Fill Rate - Completion in FY $1998 * \pi \star *$

\begin{tabular}{|c|c|c|c|c|c|c|c|c|c|c|c|c|c|c|c|}
\hline $\begin{array}{l}202 \\
676\end{array}$ & $\begin{array}{l}179 \\
714\end{array}$ & $\begin{array}{l}236 \\
772\end{array}$ & $\begin{array}{l}42: \\
858\end{array}$ & $\begin{array}{l}192 \\
217\end{array}$ & $\begin{array}{l}188 \\
290\end{array}$ & $\begin{array}{r}195 \\
1.289\end{array}$ & $\begin{array}{r}185 \\
1.773\end{array}$ & -- & --- & --- & $-\cdots$ & --- & --- & --- & $\begin{array}{l}1,804 \\
6,589\end{array}$ \\
\hline $\begin{array}{r}878 \\
804 \\
804 \\
804 \\
33\end{array}$ & $\begin{array}{l}893 \\
892 \\
868 \\
789 \\
100\end{array}$ & $\begin{array}{r}1,008 \\
998 \\
949 \\
784 \\
170\end{array}$ & $\begin{array}{r}1,285 \\
1,225 \\
1,145 \\
860 \\
245\end{array}$ & $\begin{array}{l}409 \\
516 \\
475 \\
325 \\
298\end{array}$ & $\begin{array}{l}478 \\
476 \\
426 \\
265 \\
442\end{array}$ & $\begin{array}{r}1.484 \\
1.400 \\
1.217 \\
687 \\
552\end{array}$ & $\begin{array}{r}1,958 \\
1,919 \\
1,619 \\
831 \\
736\end{array}$ & $\begin{array}{r}163 \\
134 \\
62 \\
\star \star \star\end{array}$ & $\begin{array}{l}--- \\
--- \\
--- \\
---\end{array}$ & $\begin{array}{l}-- \\
--- \\
-\cdots \\
--\end{array}$ & $\begin{array}{l}--- \\
--- \\
--- \\
---\end{array}$ & 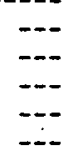 & $\begin{array}{l}--- \\
--- \\
--- \\
---\end{array}$ & $\overline{-}$ & $\begin{array}{l}8, \\
8, \\
7, \\
5,\end{array}$ \\
\hline
\end{tabular}

Maximum 0 il Fill - Completion in FY 1998

\begin{tabular}{|c|c|c|c|c|c|c|c|}
\hline $\begin{array}{r}203 \\
1.286\end{array}$ & $\begin{array}{r}180 \\
1,659\end{array}$ & $\begin{array}{r}231 \\
0\end{array}$ & $42 \hat{c}$ & $\begin{array}{r}187 \\
0\end{array}$ & $\begin{array}{l}188 \\
290\end{array}$ & $\begin{array}{r}194 \\
1,289\end{array}$ & $\begin{array}{r}185 \\
1,773\end{array}$ \\
\hline $\begin{array}{r}1,489 \\
1,364 \\
1,364 \\
1,364 \\
57\end{array}$ & $\begin{array}{l}1.839 \\
1.811 \\
1.761 \\
1.601 \\
181\end{array}$ & $\begin{array}{l}231 \\
364 \\
346 \\
286 \\
263\end{array}$ & $\begin{array}{l}42 \hat{c} \\
369 \\
345 \\
25 \mathrm{E} \\
28 \bar{t}\end{array}$ & $\begin{array}{l}187 \\
241 \\
222 \\
152 \\
303\end{array}$ & $\begin{array}{l}478 \\
457 \\
410 \\
254 \\
438\end{array}$ & $\begin{array}{r}1,483 \\
1,399 \\
1,216 \\
687 \\
547\end{array}$ & $\begin{array}{l}1,0 \\
1,9 \\
1,6\end{array}$ \\
\hline
\end{tabular}

* Constant FY1991 dollars discounted at $10 \%$ to FY1991.

$\star \star$ Using projected interest rates for 10-year Treasury bonds; irterest applied at mid-year to annual investment (outlays).

$\star \star \star$ Interest on annual investment included in total for complet ian year.

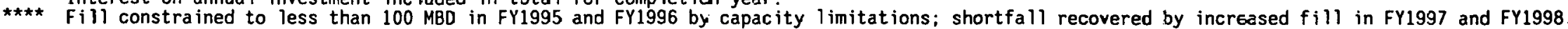


Low Case 011 Price Assumptions

(Dollars in Millions)

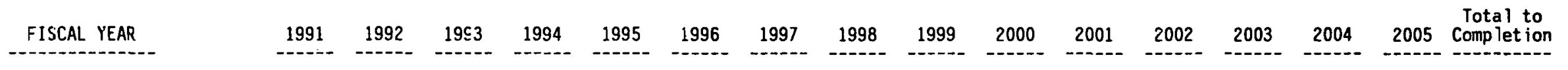

Facilities and Management oil Aquisition

Total New BA

Out lays from New BA

Constant FY1991 \$

Present Value *
USG Borrowing Cost **

Facilities and Management Dil Aquisition

\section{Total New BA}

Out lays from New BA

Constant FY1991 $\$$

USG Borrowing cost **

Facilities and Management 0 il Aquisition

\section{Total New BA}

Out lays from New BA

Constant FY19C1

Present Value $\star$
USG Borrowing Cost $\star \star$

Facilities and Management 0i) Aquisition

\section{Total New BA}

Out lays from $B$ lew $B A$

Constzant FY1991 \$

USG Borrowing Cost **
50 MBD Fill Rate - Completion in FY 2004

\begin{tabular}{|c|c|c|c|c|c|c|c|c|c|c|c|c|c|c|c|}
\hline $\begin{array}{l}202 \\
295\end{array}$ & $\begin{array}{l}178 \\
313\end{array}$ & $\begin{array}{l}235 \\
338\end{array}$ & $\begin{array}{l}426 \\
366\end{array}$ & $\begin{array}{l}192 \\
391\end{array}$ & $\begin{array}{l}193 \\
426\end{array}$ & $\begin{array}{l}197 \\
461\end{array}$ & $\begin{array}{l}187 \\
495\end{array}$ & $\begin{array}{l}194 \\
532\end{array}$ & $\begin{array}{l}195 \\
579\end{array}$ & $\begin{array}{l}200 \\
619\end{array}$ & $\begin{array}{l}206 \\
656\end{array}$ & $\begin{array}{l}213 \\
694\end{array}$ & $\begin{array}{l}219 \\
684\end{array}$ & -- & $\begin{array}{l}3.037 \\
6,849\end{array}$ \\
\hline $\begin{array}{r}497 \\
455 \\
455 \\
455 \\
19\end{array}$ & $\begin{array}{r}491 \\
492 \\
479 \\
435 \\
56\end{array}$ & $\begin{array}{r}573 \\
565 \\
538 \\
444 \\
95\end{array}$ & $\begin{array}{l}792 \\
738 \\
689 \\
517 \\
140\end{array}$ & $\begin{array}{l}583 \\
634 \\
585 \\
400 \\
181\end{array}$ & $\begin{array}{l}619 \\
619 \\
554 \\
344 \\
295\end{array}$ & $\begin{array}{l}658 \\
655 \\
569 \\
321 \\
369\end{array}$ & $\begin{array}{l}682 \\
681 \\
574 \\
295 \\
452\end{array}$ & $\begin{array}{l}726 \\
722 \\
592 \\
276 \\
545\end{array}$ & $\begin{array}{l}774 \\
770 \\
612 \\
260 \\
648\end{array}$ & $\begin{array}{l}819 \\
815 \\
630 \\
243 \\
763\end{array}$ & $\begin{array}{l}862 \\
859 \\
642 \\
225 \\
891\end{array}$ & $\begin{array}{r}907 \\
903 \\
655 \\
209 \\
033\end{array}$ & $\begin{array}{r}903 \\
960 \\
677 \\
196 \\
191\end{array}$ & $\begin{array}{r}18 \\
12 \\
3 \\
\star \star \star\end{array}$ & $\begin{array}{l}9,886 \\
9,886 \\
8.263 \\
4,623 \\
6.678\end{array}$ \\
\hline
\end{tabular}

75 MBD Fill Rate - Completion in FY 2000

\begin{tabular}{|c|c|c|c|c|c|c|c|c|c|c|c|c|c|c|c|}
\hline $\begin{array}{l}202 \\
442\end{array}$ & $\begin{array}{l}179 \\
470\end{array}$ & $\begin{array}{l}236 \\
506\end{array}$ & $\begin{array}{l}427 \\
549\end{array}$ & $\begin{array}{l}192 \\
586\end{array}$ & $\begin{array}{l}193 \\
639\end{array}$ & $\begin{array}{l}194 \\
692\end{array}$ & $\begin{array}{l}184 \\
743\end{array}$ & $\begin{array}{l}189 \\
798\end{array}$ & $\begin{array}{l}194 \\
252\end{array}$ & --- & --- & --- & --- & --- & $\begin{array}{l}2,190 \\
5,677\end{array}$ \\
\hline $\begin{array}{r}644 \\
590 \\
590 \\
590 \\
24\end{array}$ & $\begin{array}{r}649 \\
648 \\
631 \\
573 \\
73\end{array}$ & $\begin{array}{l}742 \\
733 \\
597 \\
576 \\
124\end{array}$ & $\begin{array}{l}976 \\
919 \\
859 \\
645 \\
180\end{array}$ & $\begin{array}{l}778 \\
829 \\
765 \\
522 \\
234\end{array}$ & $\begin{array}{l}832 \\
831 \\
744 \\
462 \\
382\end{array}$ & $\begin{array}{l}886 \\
882 \\
766 \\
433 \\
481\end{array}$ & $\begin{array}{l}927 \\
924 \\
780 \\
400 \\
592\end{array}$ & $\begin{array}{l}987 \\
983 \\
805 \\
376 \\
715\end{array}$ & $\begin{array}{l}446 \\
512 \\
407 \\
173 \\
833\end{array}$ & $\begin{array}{r}--- \\
16 \\
13 \\
5 \\
\star \star \star\end{array}$ & $\begin{array}{l}--- \\
-- \\
-- \\
--\end{array}$ & $\begin{array}{l}--- \\
--- \\
--- \\
--- \\
---\end{array}$ & $\begin{array}{l}--- \\
--- \\
--- \\
--- \\
---\end{array}$ & $\begin{array}{l}--- \\
--- \\
--- \\
---\end{array}$ & $\begin{array}{l}7,867 \\
7,867 \\
7,057 \\
4.755 \\
3,638\end{array}$ \\
\hline
\end{tabular}

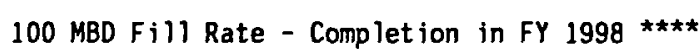

\begin{tabular}{rrrr}
202 & 179 & 236 & 427 \\
590 & 626 & 675 & 731 \\
\hline 792 & 805 & 911 & 1,158 \\
726 & 804 & 901 & 1,101 \\
726 & 782 & 857 & 1,029 \\
726 & 711 & 708 & 773 \\
30 & 90 & 154 & 221
\end{tabular}

-

\begin{tabular}{|c|c|c|c|c|c|c|c|c|c|c|c|}
\hline $\begin{array}{l}192 \\
179\end{array}$ & $\begin{array}{l}188 \\
233\end{array}$ & $\begin{array}{r}195 \\
1,011\end{array}$ & $\begin{array}{r}185 \\
1,358\end{array}$ & $\cdots$ & $=--$ & $\cdots$ & --- & $=-$ & --- & $\cdots$ & $\begin{array}{l}1,804 \\
5,403\end{array}$ \\
\hline $\begin{array}{l}371 \\
471 \\
434 \\
296 \\
269\end{array}$ & $\begin{array}{l}421 \\
421 \\
377 \\
234 \\
398\end{array}$ & $\begin{array}{r}1.206 \\
1.140 \\
991 \\
560 \\
493\end{array}$ & $\begin{array}{r}1.543 \\
1,515 \\
1.278 \\
656 \\
643\end{array}$ & $\begin{array}{r}128 \\
106 \\
50 \\
\star \star \star\end{array}$ & $\begin{array}{l}--- \\
--- \\
--- \\
---\end{array}$ & $\begin{array}{l}--- \\
--- \\
--- \\
---\end{array}$ & $\begin{array}{l}--- \\
--- \\
--- \\
--- \\
\end{array}$ & $\begin{array}{l}--- \\
--- \\
--- \\
---\end{array}$ & $\begin{array}{l}-- \\
-- \\
-- \\
--\end{array}$ & $\begin{array}{l}--- \\
--- \\
--- \\
---\end{array}$ & $\begin{array}{l}7,207 \\
7,207 \\
6,580 \\
4,714 \\
2,298\end{array}$ \\
\hline
\end{tabular}

Maximum Oil Fill - Completion in FY 1998

\begin{tabular}{|c|c|c|c|c|c|c|c|c|c|c|c|c|c|c|c|}
\hline $\begin{array}{r}203 \\
1,122\end{array}$ & $\begin{array}{r}180 \\
1,454\end{array}$ & $\begin{array}{r}231 \\
0\end{array}$ & $\begin{array}{r}422 \\
0\end{array}$ & $\begin{array}{r}187 \\
0\end{array}$ & $\begin{array}{l}188 \\
233\end{array}$ & $\begin{array}{r}194 \\
1.011\end{array}$ & $\begin{array}{r}185 \\
1,358\end{array}$ & -.. & --- & --- & --- & --- & --- & -- & $\begin{array}{l}1.790 \\
5,178\end{array}$ \\
\hline $\begin{array}{r}1.325 \\
1.215 \\
1.215 \\
1.215 \\
50\end{array}$ & $\begin{array}{r}1,634 \\
1,609 \\
1,565 \\
1,423 \\
162\end{array}$ & $\begin{array}{l}231 \\
347 \\
330 \\
273 \\
234\end{array}$ & $\begin{array}{l}422 \\
369 \\
345 \\
259 \\
259\end{array}$ & $\begin{array}{l}187 \\
241 \\
222 \\
152 \\
275\end{array}$ & $\begin{array}{l}421 \\
405 \\
362 \\
225 \\
397\end{array}$ & $\begin{array}{r}1,205 \\
1,140 \\
991 \\
559 \\
491\end{array}$ & $\begin{array}{r}1.543 \\
1.514 \\
1.278 \\
656 \\
641\end{array}$ & $\begin{array}{r}128 \\
106 \\
49 \\
\star \star \star\end{array}$ & $\begin{array}{l}--- \\
--- \\
--- \\
---\end{array}$ & $\begin{array}{l}--- \\
--- \\
--- \\
---\end{array}$ & $\begin{array}{l}--- \\
--- \\
--- \\
---\end{array}$ & $\begin{array}{l}--- \\
--- \\
--- \\
---\end{array}$ & $\begin{array}{l}--- \\
--- \\
---\end{array}$ & $\begin{array}{l}--- \\
--- \\
--- \\
--- \\
--\end{array}$ & $\begin{array}{l}6,968 \\
6,968 \\
6,414 \\
4,811 \\
2,509\end{array}$ \\
\hline
\end{tabular}

* Constan FY1991 dollars discounted at $10 \%$ to FY1991.

** Using projected interest rates for 10 -year Treasury bonds; interest applied at mid-year to annual investment (out lays).

*** Interes

$\star \star \star \star ~ F i l l$ constrained to less than $\$ 00$ MBD in FY1995 and FY1996 by capacity limitations; shortfall recovered by increased fill in FY1997 and FY1998. 
EXHIBIT A-12

STRATEGIC PETROLEUM RESERVE

Funding Profiles for 850 MMB Program

FY 1991 to Completion

High Case 0il Price Assumptions

(Dollars in Millions)

\section{FISCAL YEAR}

Facilities and Management oi) Aquis ition

Total New BA

Out lays from New BA

Constant FY1991

Present Value

USG Borrowing cost **

Facilities and Management

0 il Aquisition

\section{Total New BA}

Constant FY1991 \$

USG Borrowing Cost $\star \star$

Facilities and Management

Oil Aquisition

Total New BA

Constant FY1991 \$

USG Borrowing Cost **

Facilities and Management

0 il Aquisition

Total New BA

Constant FY1991 \$

Present Value

USG Borrowing Cost **
Out lays from New BA

Present Value *

Out lays from New BA

Out lays from New BA

\begin{tabular}{|c|c|c|}
\hline 1991 & 1992 & 1993 \\
\hline $\begin{array}{l}202 \\
408\end{array}$ & $\begin{array}{l}178 \\
444\end{array}$ & $\begin{array}{l}235 \\
475\end{array}$ \\
\hline $\begin{array}{r}610 \\
559 \\
559 \\
559 \\
23\end{array}$ & $\begin{array}{r}622 \\
621 \\
605 \\
550 \\
70\end{array}$ & $\begin{array}{l}710 \\
702 \\
668 \\
552 \\
119\end{array}$ \\
\hline
\end{tabular}

$1995 \quad 1996$

1997

1998

1999

2000

2001

2002

2003

2004

2005 Complet to

50 MBD Fill Rate - Completion in FY 2004

$192 \quad 193 \quad 197 \quad 187$

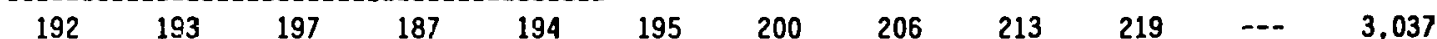

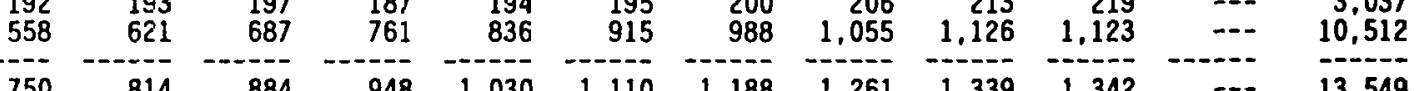

$\begin{array}{llllrrrrrr}750 & 814 & 884 & 948 & 1.030 & 1.110 & 1.188 & 1.261 & 1.339 & 1.342 \\ 800 & 812 & 879 & 942 & 1.023 & 1.103 & 1.182 & 1.255 & 1.332 & 1.435 \\ 737 & 727 & 764 & 795 & 838 & 877 & 913 & 939 & 967 & 1.011\end{array}$

504
224

451
367

75 MBD Fill Rate - Completion in FY 2000

\begin{tabular}{|c|c|c|c|c|c|c|c|c|c|c|c|c|c|c|c|}
\hline $\begin{array}{l}202 \\
612\end{array}$ & $\begin{array}{l}179 \\
666\end{array}$ & $\begin{array}{l}236 \\
713\end{array}$ & $\begin{array}{l}427 \\
773\end{array}$ & $\begin{array}{l}192 \\
836\end{array}$ & $\begin{array}{l}193 \\
932\end{array}$ & $\begin{array}{r}194 \\
1,031\end{array}$ & $\begin{array}{r}184 \\
1,141\end{array}$ & $\begin{array}{r}189 \\
1.254\end{array}$ & $\begin{array}{l}194 \\
398\end{array}$ & $\ddot{--}$ & --- & $\cdots$ & -- & --- & $\begin{array}{l}2,190 \\
8,356\end{array}$ \\
\hline $\begin{array}{r}814 \\
\cdot 746 \\
746 \\
746 \\
31\end{array}$ & $\begin{array}{r}845 \\
843 \\
820 \\
745 \\
93\end{array}$ & $\begin{array}{l}949 \\
939 \\
892 \\
738 \\
160\end{array}$ & $\begin{array}{r}1.207 \\
1.14 ? \\
1.06 ? \\
80 ? \\
23 \%\end{array}$ & $\begin{array}{r}1.028 \\
1.077 \\
993 \\
678 \\
297\end{array}$ & $\begin{array}{r}1.125 \\
1.120 \\
1.003 \\
623 \\
490\end{array}$ & $\begin{array}{r}1.225 \\
1.217 \\
1.058 \\
597 \\
627\end{array}$ & $\begin{array}{r}1,325 \\
1,316 \\
1,111 \\
570 \\
773\end{array}$ & $\begin{array}{r}1,443 \\
1.434 \\
1.174 \\
547 \\
945\end{array}$ & $\begin{array}{l}592 \\
696 \\
554 \\
235 \\
\end{array}$ & $\begin{array}{r}16 \\
13 \\
5 \\
\star \star \star\end{array}$ & $\begin{array}{l}--- \\
--- \\
--- \\
---\end{array}$ & $\begin{array}{l}--- \\
--- \\
--- \\
--\end{array}$ & $\begin{array}{l}--- \\
--- \\
--- \\
--\end{array}$ & $\begin{array}{l}--- \\
--- \\
--- \\
---\end{array}$ & $\begin{array}{r}10,546 \\
10,546 \\
9,431 \\
6,286 \\
4,748\end{array}$ \\
\hline
\end{tabular}

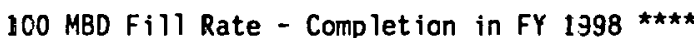

\begin{tabular}{|c|c|c|c|c|c|c|c|c|c|c|c|c|c|c|c|}
\hline $\begin{array}{l}202 \\
817\end{array}$ & $\begin{array}{l}179 \\
888\end{array}$ & $\begin{array}{l}236 \\
950\end{array}$ & $\begin{array}{r}42 ? \\
1,03 ?\end{array}$ & $\begin{array}{l}192 \\
256\end{array}$ & $\begin{array}{l}188 \\
339\end{array}$ & $\begin{array}{r}195 \\
1,506\end{array}$ & $\begin{array}{r}185 \\
2,084\end{array}$ & -- & --- & -- & --- & --- & --- & -- & $\begin{array}{l}1.804 \\
7.871\end{array}$ \\
\hline $\begin{array}{r}1.019 \\
934 \\
934 \\
934 \\
39\end{array}$ & $\begin{array}{r}1,067 \\
1,063 \\
1,034 \\
940 \\
117\end{array}$ & $\begin{array}{r}1.186 \\
1,175 \\
1,117 \\
923 \\
200\end{array}$ & $\begin{array}{r}1,458 \\
1,398 \\
1,30 i \\
982 \\
288\end{array}$ & $\begin{array}{l}448 \\
566 \\
521 \\
356 \\
346\end{array}$ & $\begin{array}{l}527 \\
525 \\
470 \\
292 \\
511\end{array}$ & $\begin{array}{r}1,701 \\
1,604 \\
1,394 \\
786 \\
637\end{array}$ & $\begin{array}{r}2.269 \\
2.221 \\
1.874 \\
962 \\
849\end{array}$ & $\begin{array}{r}--- \\
189 \\
155 \\
72 \\
\star \star \star\end{array}$ & $\begin{array}{l}--- \\
--- \\
--- \\
--- \\
---\end{array}$ & $\begin{array}{l}--- \\
--- \\
--- \\
---\end{array}$ & $\begin{array}{l}--- \\
--- \\
-\cdots\end{array}$ & $\begin{array}{l}-- \\
-- \\
-- \\
---\end{array}$ & $\begin{array}{l}-\ldots \\
-\ldots \\
-\cdots\end{array}$ & $\begin{array}{l}-\cdots \\
\cdots- \\
-- \\
--\end{array}$ & $\begin{array}{l}9,675 \\
9,675 \\
8,806 \\
6,247 \\
2,987\end{array}$ \\
\hline
\end{tabular}

Maximum 0 il Fill - Completion in FY 1998

\begin{tabular}{|c|c|c|c|c|c|c|c|c|c|c|c|c|c|c|c|}
\hline $\begin{array}{r}203 \\
1.554\end{array}$ & $\begin{array}{r}180 \\
2.063\end{array}$ & $\begin{array}{r}231 \\
0\end{array}$ & $\begin{array}{r}42 \varepsilon \\
\quad .\end{array}$ & $\begin{array}{r}187 \\
0\end{array}$ & $\begin{array}{l}188 \\
339\end{array}$ & $\begin{array}{r}194 \\
1,507\end{array}$ & $\begin{array}{r}185 \\
2,083\end{array}$ & --- & --- & --- & --- & -- & $-\cdots$ & -- & $\begin{array}{l}1.790 \\
7,546\end{array}$ \\
\hline $\begin{array}{r}1.757 \\
1.610 \\
1.610 \\
1.610 \\
67\end{array}$ & $\begin{array}{r}2.243 \\
2.203 \\
2.143 \\
1.949 \\
217\end{array}$ & $\begin{array}{l}231 \\
398 \\
379 \\
312 \\
314\end{array}$ & $\begin{array}{l}42 C \\
36 C \\
34 \bar{C} \\
25 C \\
33 \mathrm{C}\end{array}$ & $\begin{array}{l}187 \\
241 \\
222 \\
152 \\
355\end{array}$ & $\begin{array}{l}527 \\
502 \\
450 \\
279 \\
509\end{array}$ & $\begin{array}{r}1,701 \\
1,603 \\
1,393 \\
787 \\
634\end{array}$ & $\begin{array}{r}2.268 \\
2.221 \\
1,874 \\
962 \\
845\end{array}$ & $\begin{array}{r}189 \\
155 \\
72 \\
* \star \star\end{array}$ & $\begin{array}{l}--- \\
--- \\
--- \\
---\end{array}$ & $\begin{array}{l}--- \\
--- \\
--- \\
---\end{array}$ & $\begin{array}{l}--- \\
--- \\
--- \\
---\end{array}$ & $\begin{array}{l}-- \\
-- \\
--- \\
---\end{array}$ & $\begin{array}{l}--- \\
--- \\
--- \\
---\end{array}$ & $\begin{array}{l}--- \\
--- \\
---\end{array}$ & $\begin{array}{l}9 \\
9 \\
8 \\
6 \\
3\end{array}$ \\
\hline
\end{tabular}

* Constant FY1991 dollars discounted at $10 \%$ to FY1991.

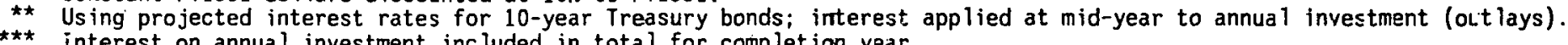

$\star * *$ interest on annual investment included in total for completion year.

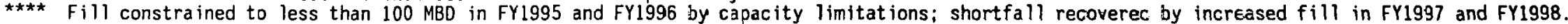


EXHIBIT A-13

STRATEGIC PETROLEUM RESERVE

Funding Profiles for 1000 MMB Program FY 1991 to Completion

Base Case 0 i) Price Assumptions

(Dollars in Millions)

FISCAL YEAR

1991 1992

1993

1994

1995

1996

1997

1998

1999

2000

2001 2002

50 MBD Fill Rate - Completion in FY 2013

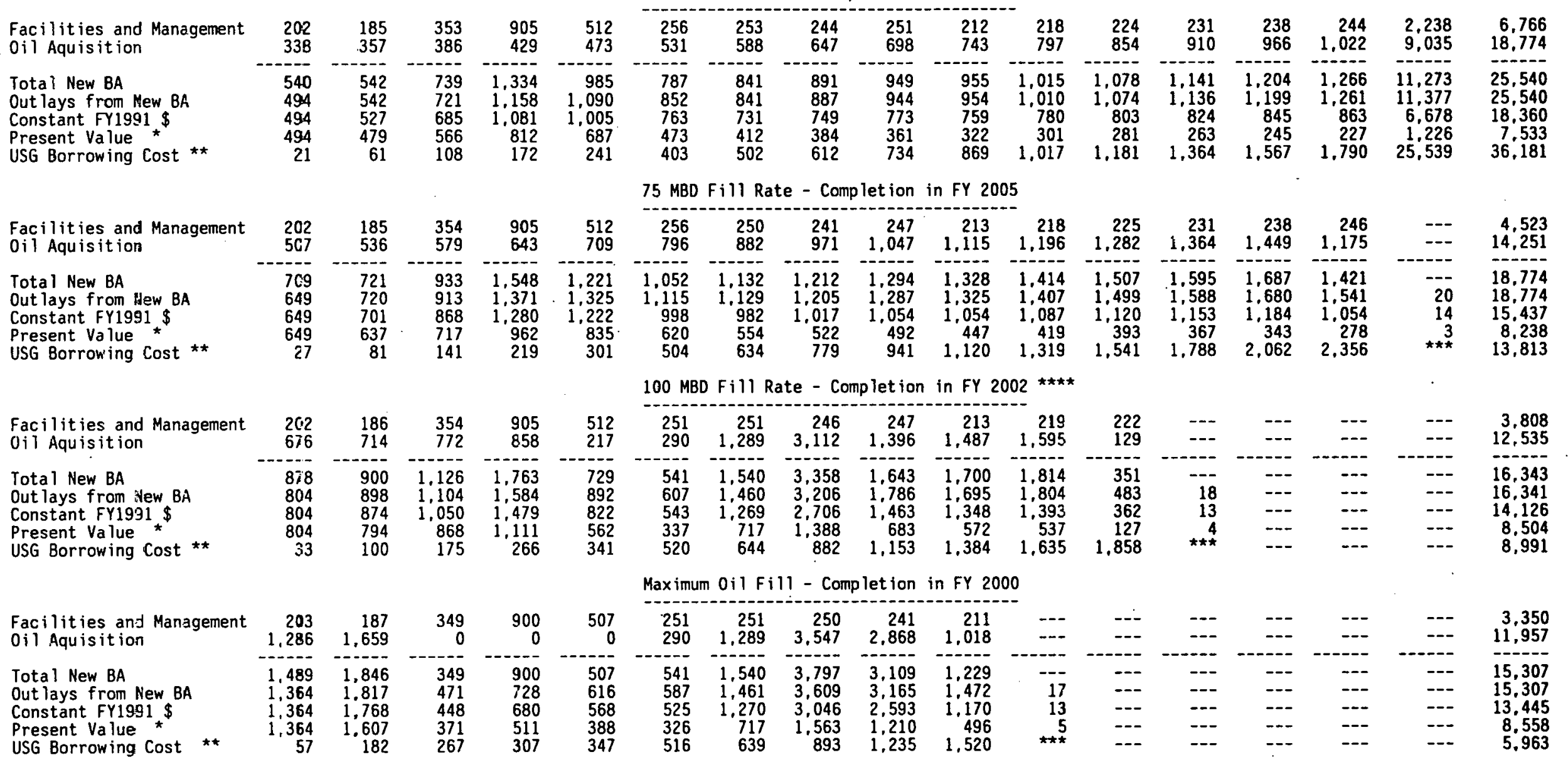

* Constant Fyigg1 dollars discounted at $10 \%$ to FY1991

** Using projected interest rates for 10-year Ireasury bonds; interest applied at mid-year to annual investment (out lays).

$\star \star \star$
$\star \star \star \star$
Total to Completion

766 540 -5
18.560 7.533 6,181

.523

774 8.774 8.438 3,813

.808

6.343

6.341
4.126

8.504

991

5, 307

4,307

5.558 
EXHIBIT A-14

STRATEGIC PETROLEUM RESERVE

Funding Prof $i$ les for 1000 MMB Program

FY 1991 to Completion

Low Case 0 i1 Price Assumptions

(Dollars in Millions)

FISCAL YEAR

1991

1992

1993

1994

1995

1996

1997

1998

1999

2000

$20 \mathrm{C} 2$

2003

2004

2005

Future Completion

50 MBD Fill Rate - Completion in FY 2013

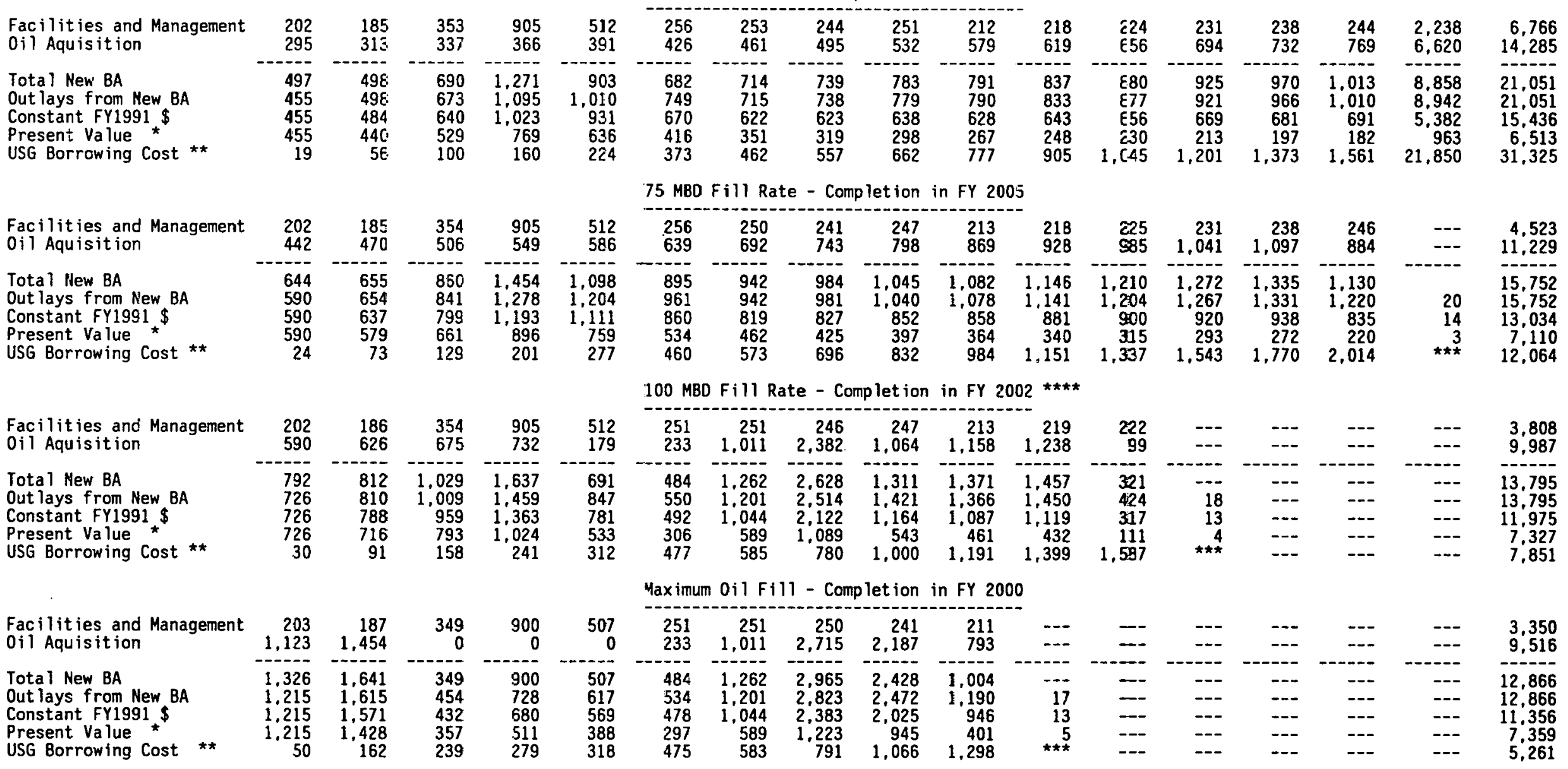

* Constant FY1991 dollars discounted at $10 \%$ to FY 1991

** Using projected interest rates for 10-year Treasury bonds; interest applied at mid-year to annual investment (outlays).

$\star \star \star \star *$ Fill constrained to less than $100 \mathrm{MBD}$ in FY1995 and FY1996 by capacity limitations; shortfall recovered by increased fill in FY1997 and FY1998. 
EXHIBIT A-15

STRATEGIC PETROLEUM RESERVE

Funding Profiles for 1000 MMB Program

FY 1991 to Completion

High Case Oi? Price Assumptions

(Dollars in Millions)

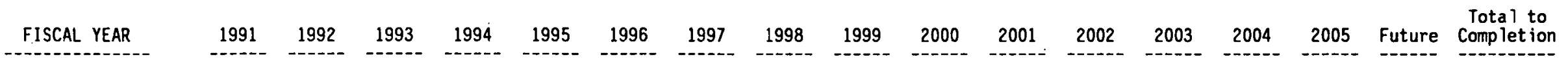

50 MBD Fill Rate - Completion in FY 2013

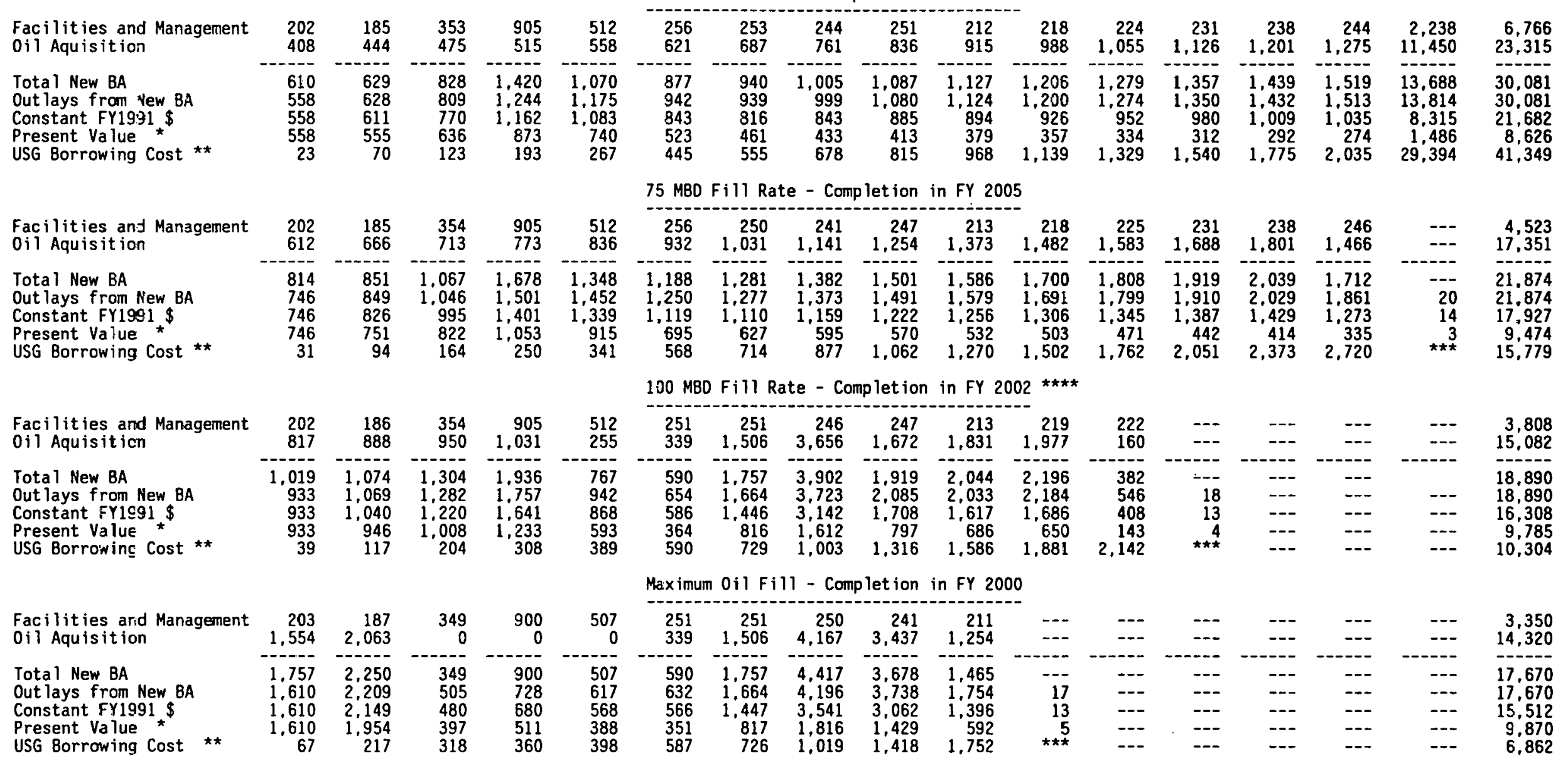

* Constant FY1991 dollars discounted at 10\% to FY1991.

$\star \star$ Using projected interest rates for 10-year Treasury bonds; interest applied at mid-year to annual investment (out lays).

$\star \star \star$
$\star \star \star \star$ 


\section{CHAPTER VI. OIL LEASING}

\section{A. GENERAL}

\section{Leasing as a General Financing Method}

Leasing is a widely used approach for financing capital assets, wherein the lessor makes the asset available for the lessee's use under defined terms and conditions in return for periodic financial payments which reflect both the lessor's costs for financing and making the asset available, and the extent to which the economic value of the asset is expected to decline over the period of its use by the lessee. Under economic conditions of perfect competition (including complete markets, no entry barriers, free information, and the like) one would not expect net gains or losses from leasing as opposed to outright purchase of a commodity. However, leasing can be advantageous in a private sector context under one or more of the following conditions:

- $\quad$ Economies to scale: The lessor can achieve efficiencies by providing facilities or equipment that can be used by more than one lessee.

- Temporary use: The lessee wants the use of the asset for only a portion of its economic life but does not want to bear the fixed costs of acquiring and disposing of the asset. Alternatively, a lessor may have unique access to the capital good in the present but wish to defer its own use until a future period.

- $\quad$ Associated service: The lessor can provide not only the use of the asset but also specialized services needed by the lessee.

- Tax advantages: The lessor may be in a position to take advantage of tax provisions relative to the asset, provisions which may not be of equal value to the lessee.

- Financing costs: The lessor is in a position to make the capital available at a lower financing cost than would be incurred by the lessee if it had to borrow the funds to acquire the asset.

\section{Oil Leasing for the Strategic Petroleum Reserve}

Oil leasing for the SPR would be a somewhat specialized use of this general financing method, both because leasing by the Federal Government entails special considerations and because leasing of a commodity, as opposed to real property or equipment, is an unusual application of this method.

Some have argued that the term lease may be misapplied in this circumstance. Others point out that the terminology is not misapplied to the extent that this financing method provides the Government with possession of the oil and some ownership rights during a defined time period 
without full purchase of the oil. In any event, oil "leasing," as used here, encompasses a range of transactions involving access to and storage of oil not owned by the U.S. Government, but subject to its control.

There are a number of possible approaches to oil leasing. The primary method considered in the study could be termed the "lease/option" method; an alternative approach would be the "lease/purchase" method.

As used in this study, a lease/option of oil for the Strategic Petroleum Reserve would have the follnwing basic features:

- The form of the lessor's investment is crude oil delivered to the Strategic Petroleum Reserve (at origin or destination). This has immediate implications for the minimum size investment required, because at current prices a tanker load of crude oil delivered to the SPR would be worth approximately $\$ 7$ million. $\stackrel{1 /}{ }$

- The lessor and the Federal Government would enter into a voluntary contractual arrangement which defines the rights and responsibilities of the parties over the term of the lease.

- The Government would not have an obligation to purchase the oil at a date certain, and title would not necessarily transfer to the Government. This feature distinguishes a lease/option from a lease/purchase and has implications for the amount and the form of the budget authority required at the time the lease is signed.

- The lease agreement would define the Government's rights to the oil during the term of the lease, as well as the rights of both parties to make decisions about the manner in which the lessor would recover its capital at the end of the lease or at defined points during the lease term, such as in the event of an SPR drawdown and distribution.

- $\quad$ One of the rights that would be reserved for the Government would be the right to cause the leased crude oil to be sold during an emergency drawdown of the SPR in accordance with the procedures established for sale of Government-owned oil in the SPR.

- During the term of the lease, the Government could agree to pay certain ancillary costs, such as the added costs of transportation due to the use of U.S.-flag tankers under the Cargo Preference Act,

$\underline{1}^{\circ}$ Due to vessel draft and length limitations, SPR cargoes are in the range of 250,000 barrels to 500,000 barrels. The example assumes a 350,000 barrel cargo at $\$ 20$ per barrel. 
customs duties and other import charges, commercial terminalling charges, and operation and management costs of storage facilities. The Government may also agree to pay a periodic fee to the lessor for making the crude oil available for storage in the SPR.

\section{Leasing Potential for the SPR}

As stated in Section $A(1)$ above, special circumstances would be required for leasing to be advantageous relative to outright purchase. The following are some of the ways in which SPR oil leasing could be attractive to either the lessor, or the Federal Government, or both:

- It is possible that a lessor would have access to oil in the present but would wish to defer full conversion of that oil to cash until some future date. Under these circumstances, it would be possible for the lessor, whether a domestic or foreign producer, to remove the oil from its natural geolngical setting and deliver it to the SPR. The Federal Government would obtain the use of the oil in the present, and the oil, or an equivalent amount of financial wealth, would be returned to the lessor at a future date. In this manner, the lessor would obtain a current financial return on assets it otherwise would not convert to cash for an extended period of time.

- Oil stockpiling has been characterized as a form of transportation between two markets -- the present and the future. In this sense, an oil producer would be interested in minimizing the transportation [storage] cost. The SPR provides a cost-effective form of oil storage in comparison to storage techniques employed elsewhere in the world. An oil lease provides the lessor with access to the economies of scale of the lessee. To the extent that the Federal Government does not charge oil lessors for the use of its storage facilities, it is confcrring a benefit in the form of a no-cost or low-cost facility use to the oil lessor.

- For reasons discussed in Chapter IV, it is difficult to foresee how the net financing cost would be lower for a lessor than for the Federal Government unless risk is taken into account. However, a leasing arrangement could be attractive to a lessor who believes that oil prices would increase substantially in the future. If such a lessor reflected its high oil price expectations and the availability of low-cost storage in its leasing offer to the Federal Government, the net financing cost could be attractive.

There is no guarantee that lessors will be found who will consider these possible advantages to be sufficiently valuable. This paper focusses on describing and evaluating lease approaches which would meet the Government's policy and management criteria while attempting to make a lease arrangement attractive to potential lessors. 


\section{Leasing Process}

There are two basic ways in which the Federal Government could enter into such a lease arrangement. First, the Government could develop a procurement solicitation that specifies most of the terms of the lease agreement, inviting potential lessors to bid for the right to enter into such an agreement, possibly using the periodic lease fee as the bidding variable. This approach is compatible with general Federal policies requiring competitive procedures and would open the door to proposals from a broad range of domestic and foreign firms.

I' he prelıminary written solicitation for the leasing of oil for the SPR contained in Volume II was prepared by the DOE in order to comply with Public Law No. 101-46, which requires in section 2(a)(5) that the Secretary of Energy:

produce [and submit to Congress by February 1, 1990] preliminary written solicitations for proposed alternative financial arrangements (including long-term leasing of crude oil and storage facilities) to assist in filling the Strategic Petroleum Reserve to one billion barrels. (Emphasis added)

The Department's understanding of the Congressional intent is that leasing solicitations should be produced and submitted to the Congress without regard to whether such arrangements are "proposed." The draft oil leasing solicitation enclosed in Volume II is preliminary in nature; it is not necessarily the solicitation that would be issued in the event that a decision was made to pursue an oil leasing arrangement. In the even of such a decision, further attention would need to be given to this solicitation within the specific context of that decision.

A second method would be to enter into a lease agreement on a non-competitive basis, with the agreement tailored to meet the needs of a particular lessor. This approach might be especially relevant in the case of a major crude oil producing nation capable of meeting a substantial portion of SPR oil requirements, but only if particular terms and conditions could be employed.

This study assumes that a competitive approach would be undertaken to leasing and analyzes lease design features in this context. However, many of the design concepts discussed might be applicable to non-competitive lease approaches as well.

\section{Results of Foreign Consultations}

Pursuant to the Congressional direction in Public Law No. 101-46, the Department of Energy, in cooperation with the Department of State, undertook consultations with representatives of foreign governments and state-owned oil companies concerning the potential for leasing oil for storage in the Strategic Petroleum Reserve. The purpose of this section is to provide an overview of the results of such consultations.

Officials of the Departments of Energy and State met with representatives of Kuwait, Mexico, Norway, Saudi Arabia, and the United Arab Emirates for in-depth discussions on leasing oil for the SPR. Other producing nations also indicated an interest in leasing oil for the SPR, and the subject 
was broached with Nigeria, Venezuela, and the United Kingdom; however, extensive discussions were not held with such other nations within the time allowed for study preparation. With the exception of Norway, the in-depth discussions were held in the producing countries within a context of bilateral discussions on a broad range of energy topics.

In all cases, the U.S. representatives in such discussions carefully explained that no final decisions had been made by the U.S. Government on whether or how to pursue the leasing alternative. The discussions were characterized as exploratory in nature, with the view toward reporting back to the Administration and the Congress on the types of arrangements that producing nations might find attractive. Officials of producing nations expressed similar views as to the preliminary nature of their own participation in the discussions. Producing nation representatives were uniformly courteous toward and cooperative with their United States counterparts.

The producing nations varied in a number of respects. In some cases, state-owned oil companies were identified as the principal contacts, whereas, in other cases, it would appear that any followon negotiations would be conducted with senior government officials. Nations also varied in terms of the types of their oil available for storage in the SPR, the extent of their current involvement in "downstream" petroleum activities such as refining and marketing in the United States, and -perhaps most importantly -- with regard to whether and how it would be feasible to depart, for SPR purposes, from their current practice of receiving full cash payment for any oil which might be produced.

With these variations among nations in mind, the following are some of the general conclusions which can be drawn from these consultations:

- The existence of the SPR and its role in U.S. energy policy was generally understood and seemingly accepted. It is believed that the strategic character of the Reserve and the U.S. desire to maintain the flexibility of the President to deploy the SPR inventory were appreciated. The hypothetical potential for cooperation with the U.S. Goveninent in the filling of the SPR was in no instance rejected; indeed, there were indications that this form of cooperation might be viewed as a "value-added" feature of oil leasing.

- It appears that at least certain of the countries consulted might be willing and able to enter into some form of "leasing" or comparable arrangement with the DOF for the SPR. For countries that appear more willing and able to undertake oil leasing, it would be necessary to resolve certain issues through legislative change, international agreement, or contractual provisions. Issues most frequently cited in discussions included the following:

(1) Taxes. The potential applicability of Federal, state and local taxes to either periodic "rental" income or to gain on the assets employed was viewed as a major obstacle. Forelgn oll producers, which generally arc not now subject to Federal or state taxes on 
income from their exports of crude oil to the U.S., are unlikely to lease oil to the DOE for the SPR unless they are either compensated for (e.g., by sufficiently higher "lease" payments) or excused from Federal or state taxes connected with such a lease. Even if a foreign producer country was exempted from existing Federal and state taxes in connection with oil "leased" to the SPR, there would be a desire on that country's part for contractual protection against any taxes that might be imposed in the future. It should be noted that Norway has a reciprocal tax treaty with the U.S.; at least one other of these countries would like to conclude such a treaty.

(2) Cargo Preference. Foreign producer governments reflect varying degrees of dissatisfaction with the U.S. Cargo Preference Act 50 percent U.S.-flag shipping requirement. Some countries have a strong preference for arranging their own shipping. But even among those governments that do not indicate that strong preference for arranging their own shipping, it is clear that prospective lessors would prefer the U.S. Government to absorb the extra costs associated with use of U.S-flag vessels.

(3) Competitive Bidding. Producer governments generally seem unlikely to bid for an oil lease in an open competitive environment. This is not the way they typically do business, and could make it more difficult to tailor an agreement to meet the producer country's particular needs.

(4) Return of Capital. Some nations were particularly concerned about the potential for leased oil to be returned to them. Their specific concern is that allowing the U.S. Grovernment to have an option to return their oil to them rather than pay cash for it or extend the lease at the end of a rental period, could force them to dispose of the oil at a time of low prices or under other unfavorable circumstances.

(5) Commercial Uses of Oil. There is a definite interest on the part of some producer countries in storing oil in, or near, the U.S. market. It is possible that this oil could be stored on a basis that supports U.S. strategic reserve purposes, even though a significant motive is to serve these countries' own commercial purposes, variously defined. This might take the form of collocating commercial stocks in facilities also storing SPR oil, or of at least limited producer country access to oil leased to the SPR.

(6) Other U.S. Uses of Leased Oil. Foreign producer countries would be concerned about leasing oil to the SPR if the SPR could be 
drawn down in non-emergency circumstances. There also was at least some suggestion that producers might be embarrassed by a use of SPR oil during drawdown which is perceived to be contrary to their own national interest.

The U.S. representatives were not in a position to indicate the manner in which the Federal Government would deal with these and other issues, and the foreign representatives typically indicated that they would not be in a position to consider making firm proposals until such issues were clarified.

- In general, the consultations confirmed the hypothesis that there is a correspondence between the ability of oil-producing nations to make attractive offers to the United States, and the availability of excess oil production capacity in those countries. Specifically, where a country is producing at capacity and is dependent on oil export revenues to satisfy current financial needs, it would be considerably less likely to lease oil for the SPR unless it were able to involve financial partners, whether other governments or private sector financial institutions. In such cases, the financial terms and conditions would likely be similar to those associated with the competitive lease options discussed further in this chapter, with financing costs being passed through to the United States in one form or another.

- Commercial Interests: A number of the producing nations -- even those not presently involved in downstream activities in the U.S. -reflected a desire to be participants in the large U.S. oil market. This desire would give an oil leasing transaction a broader "commercial" character than the narrow lease approach taken in the draft solicitation.

- Because of the complexity of the leasing approach and differences among countries, and because significant government decisions would be required in both producing countries and in the U.S., the U.S. representatives in these discussions came to the conclusion that the use of conventional competitive leasing methods would be very unlikely to attract participation by the oil-producing countries. Rather, the most feasible approach to attracting oil-producing country interest appears to be negotiating bilaterally on a country-by-country basis, tailoring each agreement to the specific interests of the participants. This approach would not preclude negotiations with more than one producing country to arrive at the most attractive agreement for the U.S. 
- A factor that would need to be taken into account is the DOE's current plan to acquire both sweet and sour crude oils, in certain desired proportions, in completing a $750 \mathrm{MMB}$ level of SPR storage. This factor becomes pertinent because those countries that have excess productive capacity have either sweet crude or sour crude but not both. The question could arise whether to maintain the DOE's sweet/sour goals in bilateral negotiations or adjust it to achieve other objectives, such as accelerating SPR storage.

In sum, there is a clear potential for the Federal Government to acquire oil directly from producing nations or state-owned oil companies if a policy decision is made to pursue this approach and the issues identified above can be addressed. 


\section{B. LEASE DESIGN FEATURES}

The purpose of this part is to discuss the alternatives identified by the Department for basic design features of an oil lease. The following is a summary listing of these features.

1. Lease Term

2. Minimum Lease Size

3. Delivery Period

4. Establishing Delivery and Maturity Dates

5. Capital Recovery Methods

6. Lease extension

7. Lease transferability

8. Ancillary costs

The focus of this discussion is on the lease/option concept introduced in Part A of this chapter. A lease/purchase concept would involve different terms, most especially for capital recovery.

\section{Lease Term}

By its nature, a lease agreement confers upon the lessee certain rights to the possession and use of property over a definable period of time. While it is possible for a lease agreement to include extension possibilities, with rights vested in one or the other of the parties, an initial term would need to be defined.

The Department's approach in structuring a lease has been to define an initial minimum term, subject to an opportunity for the Government to liquidate the lease earlier if there is an emergency drawdown of the SPR which requires the sale of the leased crude oil. There are budgetary, strategic, managerial and market implications to the definition of an initial term.

\section{a. Budget Faciluis}

From a budgetary perspective, a firm obligation of the Government to make lease payments over a minimum period of time creates the need to obligate budget authority in advance, for the total amount of such payments. The longer the initial term of the lease, the higher the amount of budget authority required at the time the Department would enter into the lease. For example, if one assumed that the oil price at the time the lease was entered into was $\$ 20$ per barrel and that the lessor would require an annual lease payment of $\$ 1$ per barrel per year, a 20-year minimum lease term could require initial budget authority of $\$ 20$ for each barrel leased, even though the Government would not own the oil, and even though only $\$ 1$ would be paid in cash in the first full fiscal year.

\section{b. Strategic Factors}

From a strategic perspective, the time horizon for energy policy analysis should extend into the next century. While major changes are possible in energy market conditions during the coming decades, 
current projections imply that the conditions which warrant the establishment of an emergency oil stockpile are likely to continue beyond the year 2000. Longer (20-30 year) terms are more compatible with the long-term strategic character of the Reserve.

\section{c. Management Factors}

If fill of the SPR were set at a minimum rate of 75,000 barrels per day through achievement of a one billion barrel inventory, the SPR would be completed in the year 2005. From a managerial perspective, there could be complexities associated with having some SPR leases expire before all the oil for the SPR is acquired, since the Department could be called on to refinance a portion of the SPR (due to expiring leases) concurrent with financing additional fill. Furthermure, to the extent that any rights would be conferred on the lessor relative to priorities for oil drawn down from the Reserve, it would complicate the drawdown management process to have the portfolio of leases constantly changing, with new ones being added as older ones expire. In fact, under most plausible storage and logistics scenarios, frequent oil turnover under multiple leases cuuld be even more complex and burdensome than suggested by the foregoing. Thus managerial considerations argue for longer rather than shorter lease terms.

\section{d. Market Factors}

From a marketability perspective, longer term leases of 20-30 years may not stimulate as much commercial market response as shorter-term leases of 3-5 years. As discussed in more depth in Chapter II, oil prices have fluctuated widely over the past two decades and an investor faces considerable risk of future fluctuations, at least to the extent that the capital recovery is linked to the market price of oil. Longer terms increase this risk. Furthermore, depending on the other conditions in the lease agreement affecting the ability of the investor to transfer his or her rights to other parties, longer-term leases would tend to reduce the liquidity of the investment. Of course, an investor that was primarily interested in the SPR because of the potential for a petroleum supply disruption accompanied by a significant increase in market prices might prefer longer-term leases because of the increased likelihood that a disruption would occur within the term. In general, however, the Department believes that private investors would not place that high a value on the possibility of a disruption occurring during the lease term and therefore that the market would favor shorter-term, rather than longer-term investments.

\section{e. Conclusions}

For purposes of drafting preliminary solicitation materials, the Department has assumed an intermediate term of 10 years. This reflects a balance between the strategic and managerial benefits of longer-term leases and the budgetary and market advantages of shorter-term leases.

\section{Minimum Size}

A public solicitation for offers for oil to be leased to the SPR will need to include a minimum amount of oil to be tendered in each offer. The factors that bear on this decision include oil delivery logistics, drawdown and distribution management, and market response. 


\section{a. Oil Delivery Logistics}

Nearly all SPR oil deliveries have been by marine transportation, in tankers ranging in size from 250,000 to 500,000 barrels. Any smaller minimum size for leasing oil to the SPR would entail inefficient use of the logistics system and could be particularly costly to the Government for those leases that, due to the need to comply with the Cargo Preference Act, the Government entered into on an f.o.b. origin basis.

\section{b. Contract Management}

Assuming an average delivery of 350,000 barrels, it would require over 400 tanker deliveries to achieve 750 million barrels, starting at a 1990 inventory level of approximately 600 million barrels. To increase the SPR to one billion barrels would require over 1000 tanker deliveries. If total permissible contract sizes were no more than a single tanker, the Department would be faced with a major contract administration challenge. In this regard, it should be noted that whereas oil purchase contracts are of a one-time nature, the oil lease contracts would entail recurring payments, possibly on a semi-annual or even quarterly basis, over the term of the contract. Accordingly, the contract management burden is cumulative in nature.

Through mid-1989, the SPR had 44 different suppliers for a total acquisition of 573 million barrels, an average of 13 million barrels per supplier. One major supplier, Petroleos Mexicanos, Mexico's national oil company, accounted for over 40 percent of the total deliveries (all on an f.o.b. origin basis), and the remaining suppliers provided an average of approximately 8 million barrels each, under one or more contracts. Most of these contracts were administered through the Defense Fuel Supply Center (DFSC) rather than the Department of Energy. During a peak period in the early 1980 's, the DOE reimbursement to DFSC for administrative costs was $\$ 4$ million per year.

With an average of 8 million barrels of oil per contract, the Department would have approximately 4 lease contracts to negotiate and award each year, increasing cumulatively to 20 lease contracts if leasing were used for the remainder of the 750-million-barrel system, and 50 contracts if leasing were used for the entire future fill of a one-billion-barrel SPR. The contract administration task would require additional resources for the Department.

\section{c. Drawdown and Distribution Management}

As discussed further below, there are variations on the lease concept which would permit capital recovery at the time of an emergency drawdown of the SPR. Apart from the policy and financial implications of such approaches, there would also be managerial considerations which would bear on the question of the target size for the average lease. Depending on the specific provisions of the leases, the following types of transactions could be required between the Government and the lessors:

- Notifying lessors of the drawdown authorization by the President, if such notification triggered exercise of any rights by one or more of the parties to makc decisions. 
- Possibly providing lessors with certain defined opportunities to withdraw oil from the Reserve, allocating delivery windows and crude types among multiple lessors choosing to exercise such options, and adjusting the Reserve's oil sales to accommodate the lease withdrawals.

- If the Government were to act as an "agent" in the sale of lessors' oil in accordance with SPR sales procedures (rather than buying and then reselling leased oil), lessors would need to be notified when their oil $=$ or nil that was "desmed" to have been their oil -- had been sold on their behalf.

- Making payments to lessors from SPR sales proceeds, including making calculations of any ceilings which may be established for such payments.

- Informing lessors of the disposition of any of their oil which was not subject to either direct distribution or sale by the Government, including any quality and quantity adjustments that would create balances owed between the parties.

All of these transactions would be in addition to the emergency operations being undertaken by the SPR field and headquarters elements at the time of a severe vil supply imtenuplioni and would require different numbers of personnel and skill mixes in comparison to the current staffing complement. The higher the number of leases, and the more diverse the provisions in different leases, the greater the burden of administering the leases at the time of a drawdown. This argues, to the extent possible, for large minimum and average size leasts.

\section{d. Market Considerations}

An 8 million barrel lease contract would represent, at current oil prices, an investment of approximately $\$ 150$ million dollars. This is much larger than the average size oil-backed security in the sample of such securities reviewed by the Department. While it would be possible for consortia to be formed to enter into such leases, or for lessors to obtain secondary financing backed by the lease agreements, it would be very difficult to create an cffectivc degree of competition in the public market for single investments of this scale and to do so several times a year until the SPR would be filled. Preliminary discussions with a limited number of industry representatives indicate that smaller leases of not more that 5 million barrels (equivalent to nearly $\$ 100$ million) might be feasible, but even at that level, competition would be limited.

By way of reference, the average-size public offering of an oil-denominated security reviewed by the Department was approximately $\$ 60$ million, which would represent the delivery of approximately 3 million barrels. At this average, there would be over 100 lease contracts in place if the lease methods were employed to fill the SPR to one billion barrels. An even smaller lease would be required to obtain participation by individual investors. 


\section{e. Conclusions}

In general, therefore, there is a difficult tradeoff between the desirability of large minimum lease sizes, to alleviate the various forms of administrative burdens which are discussed above, and smaller minimum sizes that would stimulate competition. For purposes of drafting the preliminary solicitation materials, the Department has assumed a minimum lease size of 5 million barrels, which is below the average historical amount of SPR purchases from individual oil companies but above the scale of oil-backed securities in the public market.

\section{Minimum Delivery Period}

With a minimum lease size of 5 million barrels and a tanker delivery size in the range of 250,000 to 500,000 barrels, a minimum number of 10 tanker deliveries is implied. At 75,000 barrels per day (27.4 million barrels per year) the Department would enter into up to five or six leases per year if the leasing method were to satisfy all SPR oil acquisition requirements. The Department would need to decide how frequently to solicit for leases and how fast to require the oil to be delivered.

At one extreme, the Department could award one lease in each of six bi-monthly solicitations, with each successful lessor having to deliver oil over a two-month period at greater frequency than a tanker delivery per week. At another extreme, the Department could award all five or six lease contracts at a single point in the year and then permit lessors to deliver over the course of the year.

In general, the advantage of multiple lease awards with near-term delivery would be that lessors would have the ability to lock in their crude acquisition costs through the use of hedging transactions. Furthermore, the Department could deal with a single lessor at a time in terms of transportation sçheduling.

However, for lessors seeking to use their own tankers for a portion of the deliveries, a short delivery periud could place a significant burden on some tanker fleets. Also, running six competitions per year would increase transaction costs for both parties.

At the other extreme, single annual awards followed by annual delivery periods would reduce transportation costs and maximize transportation flexibility. However, this practice would increase the risk to the purchaser that the crude oil price might change after the contract award but before delivery.

For purposes of planning a competitive oil leasing effort, the Department proposes to assume lease solicitations on a semiannual basis, but permit lessors up to a year to deliver the oil in question. This would limit the administrative burden of soliciting lease proposals while retaining some flexibility for lessors in establishing transportation schedules. However, within these extended delivery periods, individual delivery windows would need to be defined by the Department to avoid logistics bottlenecks and minimize demurrage costs. 


\section{Establishing Delivery and Maturity Dates}

It would be important to be able to define the start and end dates of a lease, for the purpose of calculating and making any monetary payments due to the lessor. Since the minimum delivery size would be well below the minimum lease size, there would be multiple physical deliveries to the SPR at the start of a lease, possibly a dozen or more. The question becomes when, within the delivery period, one establishes a date for the start of the lease.

\section{a. Multiple or Single Start Dates}

One possibility is to start a separate lease calculation upon the arrival of each cargo. While this would provide a precise way of measuring the timing of the overall lease, it would create a great deal of complexity. Indeed, it would have the effect of creating multiple leases with one given lessor, and defeats the purposes of the minimum lease size in terms of reducing administrative burdens.

The alternative that has been adopted by the Department for the purpose of preparing draft solicitation materials is to establish one particular date as the effective start date for each lease.

\section{b. Calculation of Single Start Date}

There are a number of alternative ways the Department could establish a start date for each lease, including the following:

(1) the date of contract award;

(2) the date of the first delivery;

(3) the date of the last delivery;

(4) the month representing the weighted average of the deliveries.

For some of the capital recovery options discussed below, it would be possible for the Government to satisfy the lease obligations with a cash payment that could be termed a redemption value. If the redemption value (along with any annual payment) were to be set at the time of the lease contract award, lessors might have the incentive to accelerate delivery in periods of comparatively low prices and defer deliveries in periods of higher prices, to achieve the lowest weighted average cost of the oil. By itself, this may not be counterproductive in terms of the evaluation criterion of minimizing the impact of SPR oil acquisition on market forces.

However, if multiple lessors sought to deliver a disproportionate amount of oil during periods of apparently lower oil prices, there would be a risk of creating logistical bottlenecks. Furthermore, if the date of contract award or first delivery. [(1) and (2) above] was used as the start date, but a lessor thereafter created delays in the delivery pattern, the Federal Government could end up effectively making lease payments for periods in which relatively little oil had been made available by the lessor.

Conversely, using the last date of delivery [(3) above] as the start date for calculating lease payments could penalize a lessor who made a good faith effort to deliver the preponderance of the 
lease amount promptly after contract award. Furthermore, there may be some question as to when final delivery has occurred because the actual amount delivered will vary from the amount in the original contract.

Accordingly, the Department has adopted approach (4) for purposes of drafting solicitation materials. Under this approach, each calendar month following the month of contract award is assigned a sequential number, and the amount of oil delivered in each month is multiplied by that number. Any deliveries which occurred, for the convenience of the lessor, in months earlier than those originally agreed to, shall be deemed to have been delivered in the month in which they were planned, but any deliveries made later than planned, for the convenience of the Government, also shall be deemed to have been delivered in the month originally planned. When deliveries are completed, the sum of these products is divided by the total number of barrels delivered, and this quotient is rounded to the nearest whole number.

The resulting month becomes the start date of the lease for purposes of the various time calculations required under the lease approach.

\section{Capital Recovery Provisions}

Much of the complexity of an oil lease for the SPR is associated with the terms and conditions under which the lessor's capital would be returned. It was concluded in Sections B (1) and (2), above, that a minimum term might be 10 years and a minimum size might be 5 million barrels, valued at approximately $\$ 100$ million. It is clear that a major consideration by private investors would be the structure of the arrangements for recovery of their investment capital.

In a normal lease, recovery would occur in the form of return of the original assets. To the extent that the usability or economic life of the assets had been reduced during the period of the lease, this would be reflected as a depreciation charge included within the lease fee. Oil leasing for the SPR is different in a number of ways. First, SPR crude oils are commingled in storage caverns; with an average cavern size at the Big Hill, Texas site of 12 million barrels and a minimum lease size of 5 million barrels, a lessor's oil almost certainly will be commingled with that of other lessors or with "equity uil" owned by the Federal Government. The physical ramifications of commingling on quality and quantity characteristics are discussed further below. What is important for consideration of capital recovery methods is that what the lessor will recover is not what he or she delivered to the SPR. Rather, capital recovery will occur in the form of a contractually defined substitute for the commodity provided.

A second characteristic unique to SPR oil leasing is that the physical attributes of the commodity are not expected to deteriorate during the period of the lease. Indeed, a major potential attraction of oil leasing is the potential for the commodity, through real price growth, to increase in value relative to other goods and services during the period of the lease term.

Finally, the primary method chosen by the United States for distribution of strategic oil supplies during an emergency has been price-competitive sales by the Government to the private sector. If this policy is continued and extended to leased oil, it means that, depending on the terms of the 
lease agreement, the lessee could have control over the timing and conditions under which the lessor's investment will be liquidated and its capital recovered.

With a minimum term of 10 years, there are at least two, and possibly more, decision points at which either the lessor or the lessee will trigger actions that will cause the lessor's capital to be recovered: the end of the 10-year term or, if sooner, an emergency drawdown of the SPR. Other specialized cases would include those two events occurring simultaneously, as would be possible if the SPR entered into new leases continuously over the next 15 years. Another specialized case would be a partial drawdown of the Reserve followed by a second partial drawdown before the term of the lease has expired. To simplify the exposition of the key issues, these two further possibilities have been ignored.

At each of the two major decision points, there are four hypothetical outcomes:

(1) Return of "wet barrels" to the lessor to liquidate the lease obligation;

(2) Payment to the lessee of a specific dollar amount, linked to the market price of oil;

(3) Payment of a dollar amount to the lessor which is not directly linked to the market price of oil; and

(4) Extension or renewal of the lease.

Figure VI-1 provides a schematic overview of these outcomes. There are in fact seven separate outcomes, rather than the eight implied, because the fourth outcome -- lease extension or renewal -- at the time of an emergency drawdown, is the equivalent of simply running the lease to its full term, as though there had been no disruption. The ramifications of each of these three forms of capital recovery are discussed below -- first, assuming the lease runs to term (liquidation at maturity) and second, assuming an emergency drawdown (liquidation at disruption). The implications of lease extension are discussed in Section $B(6)$, which follows this discussion on capital recovery.

\section{a. Liquidation at Maturity}

\section{(1) Return of Wet Barrels}

Under a conventional private lease, return of the leased assets to the lessor is the normal method of liquidating the lease obligation. There are, however, a number of special considerations relating to the use of this approach for SPR oil leasing:

- As discussed above, the Department's preliminary judgment is that a lease term of approximately 10 years reflects an appropriate balance between the needs of the Department and the needs of potential investors. Some leases awarded in the early 1990's could mature while the SPR was still under way. 
Figure VI-1

SPR Leasing: Capital Recovery Options

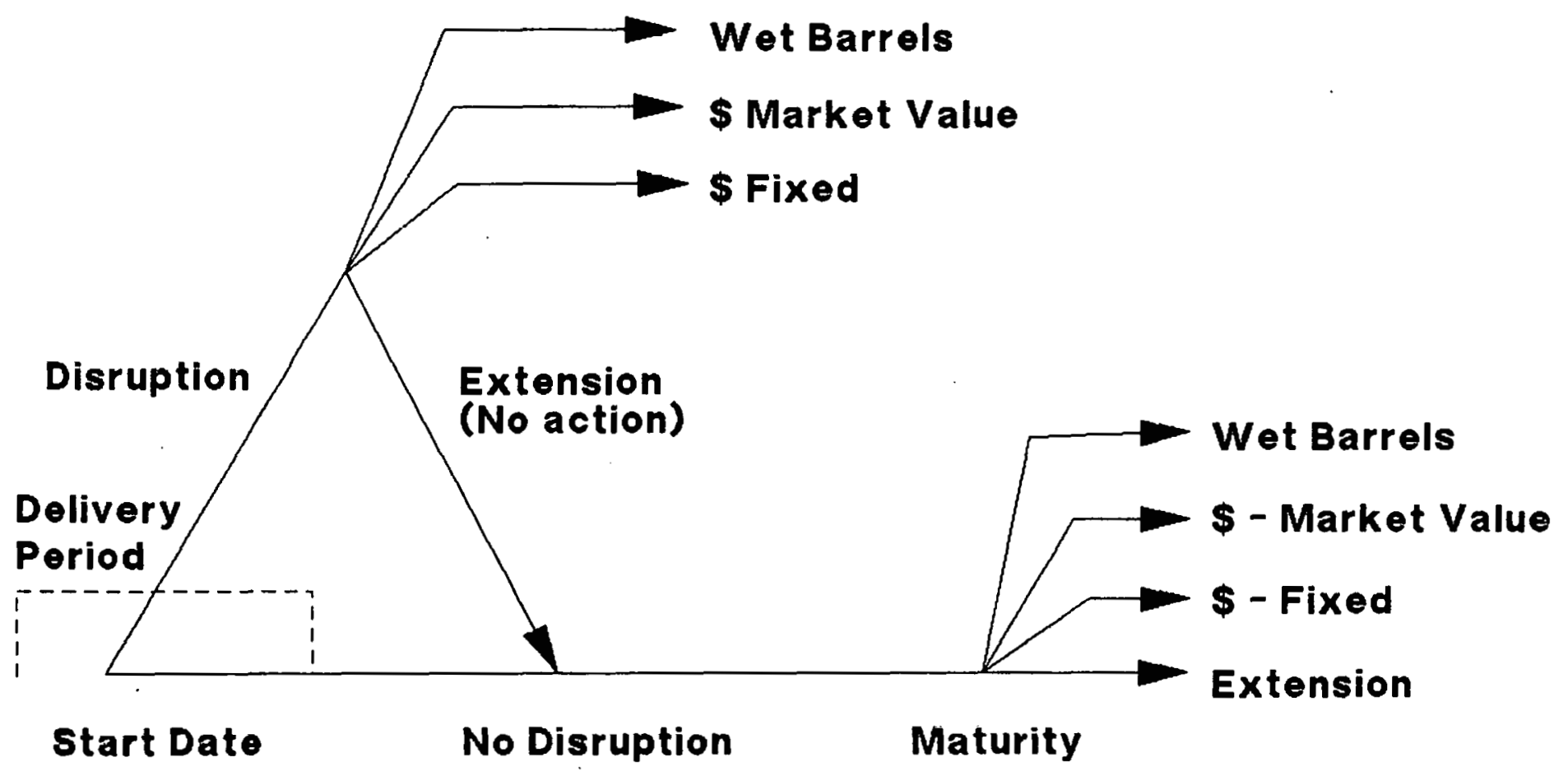


- From a logistics perspective, actual deliveries to lessees from SPR sites during non-emergency periods would create the potential for the SPR to be receiving and delivering oil simultaneously. However, commercial terminalling agreements for the handling of SPR oil do not contain any provision for recurrent non-emergency oil distribution, and this might not be easy to arrange at terminals whose normal business consists of bringing oil in from the water. Thus, the lease contracts probably would have to permit crude oil exchanges so that incoming deliveries--or oil that is in the two existing SPR sitcs from which oil can be delivered across the Government-owned St. James docks on the Mississippi River--could be directed to the lessor in lieu of withdrawal of crude oil from other SPR caverns. Bccause of the likelihood of quality and quantity differentials between leased oil and exchanged oil, provision would need to be made for cash settlement payments to or from the lessor.

- A related problem is that fact that, with one exception, the current SPR storage sites have been designed for use in a limited number of serious energy supply situations, rather than for repetitive, largescale drawdowns. Five of the six existing sites are leached salt caverns that would use fresh water injection to withdraw oil in an emergency, and each full withdrawal cycle will have the effect of further leaching the site's caverns. SPR caverns have been designed to withstand at least four or five full withdrawal cycles; however, depending on the size and frequency of the withdrawals, a requirement for the periodic return of leased oil from these caverns could risk shortening the caverns' useful lives. The single exception is the Weeks Island, Louisiana, storage facility, a conventional salt mine that employees pumps rather than water injection for oil withdrawal, and thus is capable of frequent oil withdrawal. The Weeks Island site has both pipeline access to a large number of refineries, and access to the Government-owned St. James docks.

- From a legal perspective, the Department would need relief from statutory fill goals which traditionally have been expressed as net increases in aggregate inventory levels. Furthermore, if the leased oil was placed in the Reserve, the Department would need to have the authority to deliver oil from the Reserve under non-emergency conditions.

- Since the lcssor's oil may be commingled in storage caverns with oil owned either by other lessors or by the Government, quality differentials might need to be established to compensate the lessor or the Government for actual oil deliveries of a quality lower or higher than that originally provided to the SPR by the lessor. 
- Location differentials may also be required to permit the SPR to choose a delivery point different than the place at which the original oil delivery occurred.

- A minimum and a maximum delivery rate would need to be established. The purpose of the minimum would be to ensure the removal of the lessor's oil in economic quantities, while the maximum would be established to avoid letting the return of the lessor's oil have an undue effect on market conditions.

- The effective date of the return of the lessor's oil would need to be established in conjunction with the types of procedures discussed earlier with respect to the original delivery period. Since the lessor's oil would arrive over the course of a year, with the mid-point reflecting the start date of the lease term, one approach would be to make the oil available to the lessor over a period whose midpoint corresponded to 10 years from the deemed mid-point to the original delivery.

An alternative would be to start the return of the oil at the official end of the lease term, even though this would result in having the average barrel in storage for somewhat in excess of the 10-year term. The logic behind this method is that, subject to the drawdown rate minimum and maximum, the Department effectively would be making all the oil available to the lessor at the date the drawdown commenced. The lessor might be in a position to engage in time exchanges or resales to third parties for oil which the Government had guaranteed to deliver, even if not all deliveries could be accomplished immediately. The Department has adopted this latter approach for purposes of drafting solicitation materials.

- The Government would need to provide advance notice to the lessor of its intent to return the oil. Such advance notice would be required to permit the lessor to arrange for transportation and other services.

- The lessor would be required to comply with applicable Jones Act requirements for the use of U.S.-flag tankers, which must be used for transportation from one U.S. port to another.

- The Department would have to establish a procedure for setting priorities among lessors as to delivery timing and other arrangements. Any such scheduling would need to be coordinated with the commercial terminals serving the SPR, if there was a possibility for oil to be returned through those terminals under the lease contracts. 
Since the Department's current inclination would be to award competitive lease contracts twice a year, there is the potential for overlap between the delivery periods of lessors from more than one award period. In this instance, priority could be given to the lessor from the earlier award period, thereby creating, subject to the bidbased approach above, an overall first in/first out (FIFO) approach.

- The lease contract would need to include provisions for monetary adjustments to reflect the clear likelihood that the lessor would not receive a quantity or quality identical to that which was originally delivered to the SPR. To the cxtent that, at time of lease expiration, the Department had appropriations for direct SPR purchase, such appropriations should be available to make payments to the lessor to reflect a deficit between oil delivercd to and oil removed from the SPR. Conversely, it would be advisable to permit the SPR appropriation account to receive payments from lessors for overreturn of oil. In this manner, an overall material balance could be maintained between SPR funds and oil inventory funds.

To make such quantity adjustments, an oil price indicator, or system of indicators, would need to be employed. The following section addresses options for the establishment of such indicator systems.

- Some potential lessors may be concerned that their ability to sell oil returned from the SPR at market prices would be constrained by the limited number of refiners who would be appropriately situated to bid for deliveries from a particular SPR complex, or by contractual or other logistical limitations on DOE's ability to distribute oil during non-emergency periods.

It may be questioned why, given the complexities outlined above, the Government ever would agree to have a "wet barrel" return to close out a lease. First, the possibility of a return of the lessor's property is inherent in a lease. Second, without such a return pussibility, the Department would be required to pay the lessor in cash at the end of the lease, using one or the other of the options described in the following sections. If the original lease contract required such a cash payment by a date certain and if the contract did not permit a "wet barrel" return along the above lines, then the Department would require budget authority prior to awarding the lease contract sufficient to pay not only the periodic fees but also the ultimate capital cost. This could increase SPR appropriation requirements substantially. If the objective was simply to reduce budget outlays but not reduce the need for budget authority--the need for which might, indeed, increase--a "wet barrel" return option would be less important from the Government's standpoint.

\section{(2) Oil-Price-Based Payment}

In lieu of returning oil to the lessor, the lease contract could permit the Government to make a cash payment to the investor that would be based upon sale of that oil or tied to oil market 
conditions at the time of lease maturity. This could alleviate many of the logistics problems associated with return of wet barrels, as previously discussed. Assuming such a contract, there are a number of important considerations that would bear on the manner in which oil values would be established at the time of lease maturity.

The most straightforward method for establishing the value of the leased oil would be to have the oil sold, with the proceeds returned to the lessor; this would raise some of the same issues as the return of "wet barrels," discussed above. In fact, from a programmatic perspective, this would be equivalent to a "wet barrel" return as discussed above, with the added feature of having the Government involved in the sale process under non-emergency conditions. It could also involve the Government's sale of the leased oil and, if the proceeds proved insufficient to make payment to the lessors, the sale of sufficient additional oil to make up the difference. The following sections address issues involved in establishing market value.

\section{(a) Domestic Versus Foreign Oil}

Under current policy, the United States does not impose price and allocation controls on oil, so that apart from quality differentials and other commercial factors, there generally is no reason to differentiate between the value of domestic crude versus imported crude, when delivered to a given point within the United States. Exceptions to this principle are relatively rare, including the current customs fee of $\$ .105$ per barrel. (See Section F(2) of Chapter III.)

However, some lessors could be concerned that a future Administration and Congress might impose such price and allocation controls, possibly along the lines of the regulatory regime of the 1970s. Under those regulations, a differential was created between the permissible sales price of domestic crude and the market price of equivalent foreign crude oil. Selection between a domestic and a foreign price reference could have a significant effect on the financial outcomes to an investor if similar price controls were imposed in the future.

The current Administration has expressed no intention to have the Government impose price or allocation controls on domemstic oil. To the contrary, both the Administration and the Congress have affirmed a belief in the value of a free market for energy commodities, such as the support of natural gas price decontrol. Nevertheless, a lessor could not be guaranteed that an extraordinary differential would not be created between domestic and foreign prices in the future. As noted in Chapter IV, one distinction between a commercial lease and an SPR oil lease is the ability of the lessee, acting in a sovereign rather than contractual capacity, to change the market context in which the leased asset would be valued. The potential for price regulation is the primary example of this phenomenon.

One way to deal with concerns of potential lessors would be to establish one or more backup price references to accompany the primary price reference. As discussed further below, there are practical reasons why such backup references would be required in any event. 


\section{(b) Basis Risk}

Unless the leased oil is actually sold, with the sales price used as the exclusive basis for cash payment to the lessor, the liquidation reference price would of necessity be linked to information about market prices for other oil, possibly of somewhat different quality and/or sold at a different location. In futures markets this is known as "basis risk," referring to the possibility of a divergence of uncertain magnitude and direction between the value of the physical commodity for which hedging transactions are undertaken and the price reflected in the commodity market contracts.

In the case of the SPR oil leases, a number of possible price indicators are identified and are discussed below. In each case, it would be possible to estimate quality and location ditferentials which obtained at the time the leased oil was delivered to the SPR. However, a lessor faces the risk that during the term of the lease such differentials could change in magnitude.

\section{(c) Alternative Indicators}

Most of the oil-indexed securities reviewed by the Department included a primary price index with several backup indices. The purpose of the backup indices is to accommodate the possibility that the primary index would not exist at the time of a disruption. This would be particularly important for longer-term leases.

The Department's study effort included a review of possible price indices. Five possible price indices are identified below, along with the advantages and disadvantages of each.

\section{(i) NYMEX Crude Futures Prices}

The New York Mercantile Exchange (NYMEX) sponsors trading in crude oil futures contracts with a single contract representing 1000 barrels of West Texas Intermediate (WTI) crude oil delivered in Cushing, Oklahoma, on particular dates. Considerations in the use of NYMEX price quotations for indexing SPR crude values are as follows:

\section{- Advantages}

- The NYMEX market is a very large market; 19 million contracts (each 1,000 barrels) traded during 1988, with an average of 200 million barrels in open interest during that period.

- NYMEX transaction procedures are regulated by the Commodity Futures Trading Commission (CFTC). All transactions are with the exchange as the intermediary and are reported.

- The reports of NYMEX transactions are widely quoted in the business press and are used as price indicators in a number of commercial transactions. 
While few contracts are settled with actual physical deliveries, the NYMEX prices have tracked very closely with reports of actual spot market transactions of WTI crude oil.

- $\quad$ Price data are reported for each trading day and are available in print for the following day, providing the maximum responsiveness and availability as the SPR lease indicator.

- The Department used NYMEX prices, with quality and location adjustments, in the conduct of an actual test sale in November 1985 - January 1986 pursuant to Congressional directive, and this method was found appropriate.

\section{- Disadvantages}

The underlying crude oil for the NYMEX contract is West Texas Intermediate, an important benchmark crude type for price trend analysis. There is the possibility that, at some future point in time, the oil trading community may search for an alternative to WTI. This may not be an immediate concern, but the length of time for future SPR oil acquisition, coupled with the 10-year lease term, create the possibility that some SPR leases would expire after a shift from the WTI contract to some alternative.

As noted above, there would be the need to adjust for quality and location differentials between WTI and the SPR. WTI is a light "sweet" crude type of oil, a higher quality than most SPR crude types, and the delivery location is different. As noted earlier, these differentials could shift over time, creating basis risk for both the lessor and the Federal Government.

How the NYMEX trading would be affected by a major supply interruption is an open question and there is the theoretical possibility that the CFTC would impose limits on daily price changes or even close the exchange. 


\section{(ii) Energy Information Administration/ARAC}

The Department's Energy Information Administration (EIA) publishes monthly crude oil price data, with these major series: the average refiner acquisition cost for imported oil (IRAC), the average refiner acquisition cost for domestic oil (DRAC) and the average refiner acquisition cost for all oil (ARAC), which is the weighted average of the IRAC and the DRAC. Data are collected monthly from 122 refiners on EIA form 14 and are published in the Monthly Energy Review.

- Advantages

- The reported data are collected by the Government from private firms who face penalties for misreporting information. This mitigates the risk that major lessors would attempt to distort results to their advantage at the time of lease liquidation.

- The data include transportation and other costs relevant to receipt of the oil by all U. S. refineries, and approximately $40 \%$ of the distillation capacity in the U.S. is concentrated on the Gulf Coast area (PADD III) where all SPR storage sites currently are located.

- Disadvantages

The data are not reported for 3 months after the month for which the information is relevant.

- A lessor could be concerned that the Government as lessee would have undue control over the data base for lease liquidation values.

The data include all crude types delivered to refineries. Over time, one could have each separate crude type increase in price by, for example, $10 \%$ but the ARAC might increase by a greater amount due to a trend toward higher quality crudes being sold to U.S. refiners. Conversely, the average type of crude sold in the U.S. could decrease in quality, causing the ARAC to increase by less than the percent growth in underlying crude prices. As U.S. crude production declines and refinery configurations change, the crude slate of the U.S. refining industry is likely to shift, and this creates "basis risk" for the Government and the lessor. 


\begin{abstract}
A decision would need to be made between the IRAC, DRAC, and ARAC. The Department's current judgment would be that the IRAC would be most relevant, in part because it would alleviate the problems associated with imposition of domestic oil price controls.
\end{abstract}

\title{
(iii) Energy Information Administration Cargo Crude Prices
}

On Form 856, the Energy Information Administration collects data on the quantity, quality and price of individual cargoes of imported oil. The data are collected monthly from all corporations importing more than 500,000 barrels of oil in a month, plus other companies who previously reported to the EIA. The data include country of origin, crude type and gravity, date of loading, and the like. Aggregated data are used in a number of EIA publications.

- Advantages

- Unlike the IRAC data, the EIA form 856 data indicate crude oil quality. This would permit the SPR to use a "basket" of crude qualities relevant to the leased oil, and avoid the problem cited above with respect to the possibility of changes in the overall mix of crude types which comprise the IRAC.

- $\quad$ As with the IRAC, the data are collected by a U.S. Government agency from a broad range of sources.

- Disadvantages

- A specialized report would need to be developed and published, because the EIA data relating to quality are not now published. Individual transactions reported to EIA are usually considered proprietary data.

- As with the IRAC, there would be time lags (estimated to be 3 months) and there could be concern over the involvement of the lessee in developing this information.

\section{(iv) Domestic Crude Postings}

Postings typically are offers to buy crude oil at the wellhead, as published by refiners or traders, and are specific to different oil field locations. In some portions of the country, postings are considered fair market prices, but there is no guarantee that actual transactions occur at the posted prices. 
Postings are unique to a particular type of crude oil, so a set of postings can be defined to achieve a backup for other indices.

- $\quad$ Postings are widely published in the trade press. They can be averaged or a specific subset (such as the highest three) can be identified for averaging purposes.

\section{- Disadvantages}

Postings do not necessarily reflect actual transactions. Starting in 1986, the Department moved away from postings as the basis for pricing crude oil from the Elk Hills, California, Naval Petroleum Reserve.

- It would be difficult to prevent the issuance of a posting for the sole purpose of affecting third party contract prices.

There is considerable basis risk in postings because terms such as delivery location can be changed without notice.

If postings are used as a backup to a primary index, such as NYMEX, the same problems which could reduce WTI trading could affect the availability of relevant postings.

Postings represent only an offer to buy. They do not reflect the asking price; postings often will be adjusted for specific buyers.

Since each posting is for a different location, unlike the standardized Cushing, Oklahoma, settlement point for NYMEX/WTI, location differentials would be required.

Postings are a U.S. market phenomenon and do not have a counterpart in the international market. Imposition of price controls would affect the relevance of posted prices to the market value of SPR crude. 


\section{(v) Spot Price Reports}

It would be possible to use published reports of spot purchase transactions for a "basket" of crude types to be the valuation index. This approach was adopted in 1986 through 1989 for the SPR crude purchases from Petroleos Mexicanos (PEMEX), and was based on Houston, Texas, spot prices for West Texas Intermediate and Alaskan North Slope in the Gulf of Mexico, in a ratio defined by the contract. The data are extracted from Platt's Oilgram Price Reports.

The Department has also used spot price reports as the index for price adjustments for sales of Elk Hills (Naval Petroleum Reserve No.1) crude oil in California. For this purpose the index is the average of eight separate prices for each of the 10 working days before and including the 25th of each month, as follows:

Two publications (Reuters and Telerate)

Two crude types (Alaskan North Slope and the common stream in the ARCO Four Corners Pipeline in Los Angeles).

High and low prices for each oil reported.

In the context of SPR leasing, a new set of spot price indices would need to be selected for use.

- Advantages

- Use of published data would permit the parties (lessor and Government) to obtain current estimates of value, without the delays associated with EIA data.

- Use of such indices has been_accepted by both the Government and the private sector for commercial dcalings.

- Disadvantages

- It is not possible to verify that actual transactions have occurred at published prices. This problem could he particularly acute during an oil supply disruption.

- The data collectors can be swayed by false reports.

- As with the NYMEX, the crude prices may be reported on physically declining volumes of oil. 


\section{(3) Fixed Dollar Payment}

A fixed dollar payment could be established as one alternative to the parties for liquidation of the lease obligation. If it is provided as an option to the lessor as a substitute for wet barrel return, the fixed dollar amount would become the floor for capital recovery. If the fixed payment approach is an option available to the Government as lessee, it would become the effective ceiling for capital recovery.

If, upon contract maturity, the choice between a dollar payment and wet barrel return resides with the lessor, then the Government would need to have sufficient funds appropriated prior to the lease commitment to meet the potential dollar obligation. The source could be appropriated funds, or DOE might also be authorized to sell the lessor's oil and sufficient other SPR or leased oil to satisfy such financial contingencies as they arose. In the following discussion we are treating a fixed dollar payment as an option available exclusively to the Government as lessee to liquidate its leasc obligation.

The fixed dollar payment, coupled with any lease fees, could establish the upper bound of the total return to the lessor. Another way of characterizing this upper bound is as an option for the Government to acquire the leased oil. Under this conceptualization, the lease fee can be viewed as being in part a payment for an option to buy.

Because the fixed payment establishes an upper bound on the portion of the rate of return which is reflected as capital recovery, it interacts with the lease fees, the lessor's expectations of future price trends, and the lessor's required rate of return to establish the financial characteristics of the lease investment. In general:

- The lower the lease fee, the more an investor will want in terms of upside potential for capital recovery.

- The higher the oil price expectations of the lessor, the more likely the lessor would believe that the option will be exercised by the Government, resulting in conveyance of title to the oil to the U.S. Government at below-market prices.

- Conversely, the lower the oil price expectations of the lessor, the less concerned would be the investor about a particular cap on upside gain.

- The higher the rate of return required by the investor, the higher the upside potential needs to be, given any particular lease fee rate.

- The higher the rate of return required by the investor, the higher the lease fee desired by the investor for any given cap on price appreciation. 
There are essentially three ways to establish the fixed dollar payment:

(a) Specify the payment in nominal dollars for the end of the lease.

(b) Specify a fixed payment in real dollars with adjustments based on inflation.

(c) Permit the lessor to bid this value either in conjunction with, or in lieu of, a lease fee.

The following are the advantages and disadvantages of each approach:

.(a) Fixed Nominal Dollar Payment Per Barrel

- Advantages

Easiest to define in the contract.

- Disadvantages

- $\quad$ If set too low, potential bidders may be dissuaded from bidding.

Leaves the investor with possible gain or loss of purchasing power based on actual trends in inflation.

(b) Establish a Real Dollar Per Barrel Payment, Subject to Inflation Adjustment

- $\quad$ Advantages

Offcrs the investor an inflation hedge not provided by either a fixed nominal payment or a Treasury security.

- Disadvantages

While the approach has been applied to the revenue-sharing provisions of the Department's 1988 sale of the Great Plains Coal Gasification Project, it is not customary for Federal tinancing to adjust effective rates of return for inflation. 
(c) Permit the Lessor to Bid the Payment

- Advantages

- Permits the market, rather than the Government, to express the upperbound financial payment.

- $\quad$ Since, as discussed below, the fixed financial payment has some of the characteristics of a disruption "trigger," Istting the market establish this price avoids a Government expression of expectations.

- Disadvantages

Requires a complex mathematical formula for weighing multidimensional features of offers to lease, if both the annual lease fee payment and the maturity payment are subject to bidding.

\section{b. Liquidation at Disruption}

Each of the capital recovery alternatives described above for liquidation at maturity creates a possible approach for any contractual provisions which might provide the lessor or the lessee the opportunity to liquidate the lease contract in the event of an SPR drawdown during a severe energy supply interruption. However, due to the emergency nature of a disruption, some of the alternatives would have a different character than at maturity.

\section{(1) Return of Wet Barrels}

It would be possible to use the return of wet barrels to the lessor as a means for distributing SPR oil into the economy during an emergency drawdown. For the Government, this would avoid some of the possible complications of arranging the sale of oil which was owned by a third party. For some potential lessors, access to the oil during an emergency could have commercial advantages that would make the lease approach attractive. However, as in the case of return of wet barrels during non-emergency periods (see Section $\mathrm{B}(5)(\mathrm{a})$ of this chapter, above), there are a number of issues associated with returning wet barrels that would need to be addressed.

\section{(a) Compressed Time Period}

The SPR is currently capable of distributing over 100 million barrels per month during the first part of a drawdown. When distribution systems and oil fill are complete for a 750 million barrel system, it is planned that the SPR will be able to distribute up to 400 million barrels in the first three months of a disruption at rates of 4.5 million barrels per day. Thus, drawdown could occur at rates which were 40 to 60 times higher than these delivery rates. For individual lessors, the differential would be higher still. 
Consequently, a lessor would need to have the organizational and physical capabilities to undertake receipt of "its" oil (or other oil supplied in lieu of the lessor's oil) under very challenging circumstances. This would include not only the capability to arrange for receipt of oil at SPR loading terminals, but also the disposition of the oil either to the lessor's own refineries or through resale to other parties for refining.

\section{(b) Sequencing}

If wet barrels were returned during a disruption, a methodology would have to be developed for determining the order in which each lessor's barrels (or "deemed" barrels) would be deployed in relation to those of other lessors, and in relation to the sale of DOE-owned barrels in the Reserve. Lessors would need to be contacted in advance to ensure time to arrange transportation and ultimate disposition of the crude oil.

There are a number of different ways in which oil price changes could occur during a disruption, so this methodology could have significant consequences for the effective value to the lessor of this form of capital recovery. One pattern might involve an immediate sharp increase in prices, sometimes termed a "price spike," followed by a prompt decline in prices either as the circumstances causing the disruption abated or because of the added supplies associated with an SPR drawdown. Under these circumstances, it would be valuable for an investor to recover his or her investment at the earliest possible date.

A second pattern could involve a more gradual, but nevertheless significant, escalation in prices over a period of several months, as the conditions causing the interruption in supplies worsened. In this case, an investor might prefer having wet barrels returned at a later date in the interruption.

In addition to differences between expectations regarding oil market patterns, there may be differences in terms of expectations about when, during a disruption, the Federal Government would choose to deploy the SPR and at what rates. Furthermore, there may be differences among lessors and between lessors as a group and the Government, in tcrms of objectives.

Such differences in objectives and expectations could create the basis for significant operational problems and for contractual disputes at the time of the disruption. Contractual provisions would need to be developed to ensure the performance by lessors in arranging the receipt of SPR oil, to avoid the potential for logistics bottlenecks and to integrate provisions for leased oil with procedures for delivering Government-owned oil. These provisions could be very complicated, because the existing scheme for SPR drawdown involves giving high price bidders for SPR oil the choice of delivery times, in the order of their price bids. To avoid disruption of this system, oil deliveries to lessors would have to be fitted in around the SPR's competitive sale oil delivery schedule.

If, on the other hand, there were no wet barrel return, but oil instead was "deemed" to be that of the lessors, then sequencing between the lessors' oil and the Government-owned oil, in terms of the timing of drawdown, could follow one of three general decision rules: 
(i) All leased oil could be considered to be distributed before all Government-owned oil;

(ii) All Government-owned oil could be considered to be distributed before all leased oil;

(iii) Government-owned oil and leased oil could be considered to be distributed in proportionate amounts according to the percentage of each class of oil ownership in inventory during some base period.

Sequencing between lessors could follow the procedures discussed earlier with respect to return of wet barrels at maturity.

\section{(c) Commingling}

Most of the storage capacity for the 750-million-barrel system which has not yet been filled is at the SPR's Big Hill (Texas) site, from which the Department plans to be able to draw down and distribute oil at a rate of approximately 935,000 barrels per day through commercial facilities in the Nederland, Texas, area. When the 750-million-barrel system is complete, Big Hill would represent approximately 20 percent of the distribution capability for the SPR system, yet virtually all leased oil would be located at Big Hill.

Both sweet and sour crude oils currently are planned for storage at Big Hill, but the Department plans to draw down only one type at a time.

Because of these logistics factors and for the reasons given in the preceding discussions of sequencing, the return of wet barrels to lessors during a disruption would almost certainly require substituting oil of different types and from different delivery points than the initial delivery from the lessor. In addition to providing for a method to sequence deliveries to the lessor, the contract would need to provide a method for determining which lessors received which types of crude oil at different SPR sites.

In sum, there would be numerous technical issues which would need to be resolved if the Government chose to include the potential for wet barrel delivery during a disruption as a method for capital recovery under oil leasing.

\section{(2) Oil-Price-Based Payment}

If the Government as lessee returned to the lessor a cash payment linked to oil price conditions at the time of a disruption, then an oil lease would offer an investor, such as a major oil consumer, a hedge against the financial losses which it otherwise would experience during a major energy supply interruption. In designing such a payment plan, there would be considerations similar to those which are discussed above in the context of making an oil-price-based payment at maturity. There are, however, some further considerations relative to the use of this method at the time of a drawdown. 
- The possibility exists that the price that would be used for the lease redemption payment would be tied directly to the sales proceeds received by the Federal Government as the result of the sale of SPR oil. In this case, it would be necessary to make clear which SPR sales would be used as the basis for such a financial distribution. For example, if all leased oil were stored at Big Hill and that site was not fully drawn down and distributed, it might be necessary to rely on the prices for other SPR crudes to establish the redemption payment for the lease.

- The lease contract would need to allow for the possibility that less oil might be drawn down and sold from the SPR than the aggregate quantity which had been leased. Choices would include paying some lessors, possibly those who had first delivered to the SPR, in full, while continuing leases with other lessors, or paying all lessors for the proportion of their leased volumes represented by the amount sold in relation to the aggregate quantity leased.

- If this redemption possibility were provided as an option to the lessor rather than to the Government, then a decision would need to be made on whether the Government would act as an agent for the lessor in a sale to some third party (but without creating any privity of contract between the lessor and the Government's buyer). Alternatively, the redemption payment to the lessor could be made subject to the availability of appropriated funds. In either event, unless some reference were made to the market price of an oil other than the SPR oil, the lessor would be relying on the Government's business and policy judgments in establishing the basis for capital recovery.

- Use of price indicators other than those linked directly to the SPR sales process could create problems during a disruption. This is because one characteristic of a disruption is a high degree of uncertainty in the market as to the current clearing price for oil supplies. As a result, widely disparate prices may be reported in different publications, giving rise to the potential for disputes over which data series to use for redemption purposes. Furthermore, due to the instability of prices over short periods of time during a disruption, the contracts would need to identify a time period, possibly two weeks or longer, over which published price indicators would be averaged.

\section{(3) Fixed-Dollar Payment}

Use of a fixed-dollar payment method to provide for redemption of the lease during a disruption could provide the Government with an interesting set of business and policy options during a 
disruption. The Government could, for example, structure the contract to give the Government this choice, in which case the fixed dollar payments presumably would only be made if the Government was able to sell the leased oil at a higher price. In this usage, the fixed dollar approach acts as a cap on the ability of the lessor to profit from the increase in oil prices during a disruption.

If the Government retained this option, it would be in a position to wait until after SPR sales proceeds had become available before exercising its rights under the contract. For some, the fixeddollar price becomes an indicator of the price and market conditions under which the Government would choose to draw down leased oil. This can be conceptualized as the sale of a "call" option from the lessor to the Government.

A different approach would permit the lessor to decide whether this option was to be exercised. Coupling this option with a "wet barrel" option would permit the lessor to choose whether to take the oil or be paid the fixed amount. In this case, the fixed price becomes an effective floor under the profitability of the investor. Specifically, this can be conceptualized as a "put" option that the lessor has bought from the Government.

\section{c. Combining Capital Recovery Options}

There are numerous ways in which the capital recovery options can be combined, each of which would have a particular effect on the incentives of either the Government or the lessor. As noted earlier, the Department is assuming, in drafting a competitive lease solicitation, that the Government would reserve to itself the right to make decisions among whatever options were specified in the contract. Before considering combinations of Government options, it might be useful to review the issues which would be associated with conferring such options on the lessor. In the following discussion, it is assumed that one alternative available for capital recovery, but not necessarily the only alternative, would be a return of wet barrels, since this is a feature which helps create a lease, rather than deferred purchase, contract.

\section{(1) Investor Perspective}

\section{(a) Capital Recovery -- Wet Barrel Delivery Vs. Extension}

If at maturity a lessor could decide between receiving the wet barrels or extending the lease for an additional period, the lessor would be protected against the possibility of a particularly "soft" market for oil at the time of lease maturity. This would alleviate some of the downside price risks of an SPR oil lease investment and create, through the extension option, a floor value for the lcasc.

However, conferring the extension option on the lessor would also expose the Government to a substantial contingent liability for the lease contract and would add significantly to appropriation requirements at the start of the lease. 


\section{(b) Capital Recovery -- Wet Barrel Delivery Vs. Oil-Price-Based Payment}

The availability of an oil price-based payment in lieu of wet barrels would be attractive to an investor for a variety of reasons. First, it would alleviate the need for the investor to establish and maintain the ability to receive and resell or refine the crude oil at maturity. Second, as discussed earlier in the context of basis risk, there is the potential for the actual value of the wet barrels to diverge from the price indices used for calculating the payment. Giving this option to the investor transfers this basis risk to the Government, since an investor would be able to pick whichever option yielded the highest return.

As discussed earlier, conferring this option on the lessor would increase the total financial exposure of the Federal Government considerably, and would add significantly to appropriation requirements at the start of the lease.

\section{(c) Capital Recovery -- Wet Barrel Delivery Vs. Fixed Cash Payment}

An investor would likely select between these options based on whether the resale value of the oil would exceed the fixed cash payment in the contract. If the oil had a higher value than the fixed price, the investor would opt for wet barrel return; thus the fixed price would become a floor on capital recovery.

Using terminology from the futures market, the lessor would be holding a "put" option from the Government, guaranteeing its ability to sell oil at a specific price. This would create a financial liability for the Federal Government and therefore add to the appropriation requirements at the start of the lease.

\section{(2) Government Perspective}

If these same pairs of options were left to the choice of the Government, the following would likely be the Government's considerations at the point of decision.

\section{(a) Capital Recovery -- Wet Barrel Delivery Vs. Lease Extension}

The Government would have the opportunity to make choices at basically two different levels. First, it would be able to decide whether to continue the SPR program at the current level or to phase down the SPR by gradually returning the leased barrels to the lessors. Second, even if the Government decided to continue the SPR at the current inventory level, it would further be able to decide whether an extension of an individual lease was preferable to some alternative method of SPR oil acquisition. If oil prices had declined at the time of maturity, the Government could decide to go into the market for new oil to replace the leased oil being returned. Alternatively, the Government could choose to issue new leases.

If oil prices and/or interest rates were higher at the time of maturity than expected when the lease had been awarded, the Government would logically choose to extend the initial lease contract rather than employ some alternative means for oil acquisition. 
(b) Capital Recovery -- Wet Barrel Delivery Vs. Oil-Price-Based Payment

As with the extension option, this choice would permit the Government to consider whether to extend the life of this segment of the SPR program by acquiring the oil at market-like prices or to return the oil and reduce the size of the SPR.

A decision to continue this segment of the SPR would permit a choice between an oil-price-based payment for the leased barrels or acquisition of replacement oil in the open market. In this regard, the Government's position would be directly opposite to that of the lessor, in the sense that all basis risk would be transferred to the investor. If the replaccment cost for oil were below the indexed price, then the Government would return the wet barrels.

\section{(c) Capital Recovery -- Wet Barrel Delivery Vs. Fïxed Cash Payment}

Again, this alternative puts the Government and the investor in exactly opposing positions. The Government presumably would exercise its "call" option to acquire the oil only if the fixed price in question was below the market value of the oil. If the market price was below the fixed price, the Government would let the call option expire and would acquire replacement oil in the open market. It should be noted, however, that the Government would face the risk that it would let a valuable "call" option expire due to the lack of appropriated funds to acquire the oil at attractive prices. To avoid this situation, the DOE might be given authority to sell oil from the SPR or other leased oil at market prices to generate the funds to acquire the leased oil at attractive option prices.

In Section D below, the effects of these capital recovery alternatives are discussed as sensitivity analyses. For purposes of drafting the solicitation materials which accompany this study; the Department has assumed the following structure of capital recovery:

- Any options which are provided for in the contract would be vested in the Government rather than in the lessor.

- At any point during the lease term, the Government would have the right to liquidate its obligation by making a specific cash payment to the lessor.

- At the end of the lease term, the Government would have three options:

- Return wet barrels to the lessor, directly or by exchange;

- Make a specific cash payment to the lessor; or

Extend the lease term for an additional period. 
If the option to return the wet barrels were to be eliminated, the Government would need a source of funds to cover the potential purchase price of the lessor's oil. As noted above, if the purchase price under the lease contract is less than the market price, then one way to finance the acquisition of leased oil would be through the sale of a lesser number of Government-owned barrels.

\section{Lease Extension}

It would be possible to structure the lease contract to permit the lessor, or the lessee, or both of them by mutual consent, to decide to extend the arrangement beyond its initial maturity date. If this option were provided to the lessor, the Government would be required at the outset of the transaction to reflect the potential cost of the lessor's exercise of these options in its initial obligation of appropriated funds. Therefore, it is assumed that any option for lease extension would be vested exclusively in the Government, rather than in the lessor. Depending on the contract terms, this could be a valuable program and policy option for the Government, in the following respects:

- It could forestall the need to decide between making a significant payment to the lessor and returning the oil, especially under tight market conditions.

- Extension options could be used to alleviate emerging logistics problems associated with "wet barrel" capital recovery approaches.

However, a Government extension option could be unattractive to potential bidders, because:

- The indefinite nature of extension options would create the potential for a perpetuity, an investment for which principal is never repaid, but interest is paid forever.

- $\quad$ Some lessors who obtained third-party financing for the oil leased to the SPR could experience liquidity problems if principal came due on their commercial loans but the Government chose to defer return of capital.

- An investor might believe that the Government would extend the lease during periods of higher oil prices but not extend in periods of low oil prices. This form of behavior would tend to diminish the possibility of upside gain from oil price apprcciation at time of capital recovery.

One way of dealing wilh these issues would be to establish a floor price for the oil at maturity, giving investors more confidence that an extension by the Government would not result in a reduction in principal value at maturity.

A lease extension option could take a variety of forms. First, it would be possible to provide for a simple extension for one or more periods at the original lease payment. Any data series promulgated for the initial term (for cash payment linked to oil prices) could be extended into the future period. 
Second, it would be possible to make a one-time adjustment of the lease payment, possibly by a formula linked to oil price trends. Thus, if the lease payment had been, for example, $\$ 1$ per barrel per year over the initial 10 years, but oil prices increased by 50 percent during the initial term, an adjusted lease fee of $\$ 1.50$ per barrel per year could be used over the option period.

Two design variables which would need to be defined in the contract are the length of each option period and the number of such option periods available to the Government.

In the case of a disruption occurring belore maturity of thc lease contract, a decision by the Government to extend the lease contract may be viewed as the equivalent of continuing the lease to term, and thereby rejecting the exercise of any of the above options. It would be possible for the Government's contract with the lessor simply to guarantec that, at maturity, the Government either would return oil or make a cash payment, with no special provision for an intervening drawdown. So long as the lessor had this Government guarantee, it would be indifferent as to whether the Government sold the oil during the lease term.

\section{Lease Transferability}

The development of a secondary market for competitively awarded SPR oil leases could be a useful determinant of market acceptance of these instruments. Without transferability, the financial appeal of the lease is limited by the inability of the lessor to take advantage of changes in market expectations during the period of the lease. Furthermore, to the extent the Department chooses to reserve the right to extend the lease contract, transferability becomes an important means fur initial investors to maintain liquidity and meet their scheduled financial obligations to third parties.

The considerations affecting transferability provisions are as follows:
a. Form of transfer rights;
b. Quantity limits at redemption;
c. Foreign ownership; and
d. Performance by the lessor.

Legal issues associated with lease transfer are discussed in Section $G(6)$ of Chapter III.

\section{a. Form of Transfer Rights}

As noted earlier, an SPR oil lease could be awarded as a result of a competitive solicitation or through a non-competitive negotiation, such as with a major producing country. In the latter case, it is possible that a lease arrangement would be accompanied by, or even embodied within, an international agreement between the United States and a foreign government. In this event, transferability opportunities would likely be especially limited. 
In the case of a competitively awarded lease, there would at least be two different approaches to transferability. Under one approach, the contract could permit transfer, to a new party, of the full rights and even the responsibilities of the initial lessor. In this event, it would become important for the Department to be able to evaluate the capabilities of the proposed new lessor, to ensure that it could perform its functions under the lease.

A second form of transferability would be provisions which enabled the original lessor to subdivide its rights under the lease to obtain financial participation by additional investors. This could alleviate the marketability problems associated with large initial investments and would tap a broader segment of the capital market. To the extent that SPR leases could be structured as relatively standardized instruments (see Section 8 below on ancillary costs), there are a number of very large financial institutions, such as those now engaged in longer-term oil "swap" arrangements, which might be in a position to make a market in SPR oil leases on a continuous basis.

In drafting competitive oil lease solicitation materials, the Department has assumed that both types of transferability would be permitted, subject to certain limitations. In the case of full transfer of lease rights from one party to another, the Department would retain the right to approve transfers, based on a review of the performance capabilities of the new entity. However, full transferability would not be permitted until all oil had been delivered under the lease contract.

In the case of lease subdivision, the Department's competitive oil lease solicitation materials would permit the initial lessor to subdivide the lease rights, including the payment stream, among other investors. However, the original lessor would remain fully responsible for performance under the lease contract and for administration of any payment provisions to additional parties.

\section{b. Quanlily Limits at Redemption}

Depending on the time and nature of capital recovery at the end of leases, there would be the potential for individual large investors or groups of investors to try to establish a dominant position in the market; with the accompanying risk of non-cumpetitive behavior. This issue would be particularly important if the lease contract guaranteed "wet barrel" recovery of capital at the time of a disruption. Failure by a lessor to arrange for prompt receipt of the oil could create bottlenecks in SPR oil distribution and subvert the Government's objectives in calling for a drawdown.

The Department would know the identity of each initial lessor and would be able to monitor the extent of concentration in lease holdings. Since there would be periodic solicitations for such leases, if the Department became concerned over the potential for overconcentration, it could impose restrictions on eligibility of bidders.

With transferability of lease ownership in full, the Department would have, as indicated in the discussion above, the right to approve new lessors. This would provide another means for avoiding overconcentration. However, with transferability in the form of subdivision, it would be possible for partics to gain financial participation in multiple leases at once, working with different initial 
lessors. Indeed, since different leases would mature in different time periods, participation in multiple leases could be an attractive way for investors to hedge against price fluctuations.

Concentration in subdivided holdings of leases would not be as serious a problem as concentration in initial leases, since original lessors would remain responsible for performancc under the contracts. As such, the risk that a lessor would have the incentive to create problems at time of drawdown would be lessened. However, to the extent that the lease contract provided the Government with a number of options regarding lease extension or form of capital recovery, a concentration in holdings would entail having some parties with very strong economic interests in the Government policy and business decisions.

One way to monitor this situation would be to require registration of all interests in SPR oil leases, whether initial or subdivided. This would create a degree of transparency that would permit the Government to be aware of the extent of concentration of leases. However, imposing such restrictions on lessors would tend to increase the lease paymonts demanded.

\section{c. Foreign Ownership}

From time to time, there have been questions about whether SPR oil should be sold to foreign entities during an emergency drawdown. There have been two stated concerns: (1) that a foreign entity would be able to subvert the strategic purpose of the SPR by storing or hoarding the oil or by failing to take delivery on schedule, and (2) that a foreign purchaser of SPR oil would have an incentive to seek, directly or by exchange, to export the oil to other markets. Similar issues might be raised with regard to foreign participation in ownership of SPR oil leases, either directly or through subdivision.

The previous Administration took the position, in SPR Plan Amendment No. 4, that there should be no restrictions on the eligibility of bidders to acquire SPR oil during an emergency drawdown, other than the requirement that the purchaser be able and willing to perform under the terms of the sales contract and in accordance with U.S. laws and regulations. The argument is that the performance guarantees provided for in the SPR sales contract, coupled with ongoing enforcement of applicable U.S. laws governing exports, should be adequate to ensure that the effectiveness of the Reserve is not hampered by foreign purchasers.

Consistent with this position, the draft leasing solicitation does not prohibit the participation by foreign entities in SPR leasing transactions. As discussed further in Chapter IV, there are ways of avoiding the potential problems associated with foreign ownership of a portion of SPR through such provisions as price appreciation caps and other contractual conditions.

In any event, the analogy with SPR drawdown is limited in relevance to oil leasing by the options for capital recovery (i.e. lease extension and cash payment) other than wet barrel return.

\section{Ancillary Costs}

Most of the cost of SPR oil consists of the purchase price at origin plus the normal marine transportation costs, and these are reflected in the formulation of the Average Refiner Acquisition 
Costs for Imported Oil (IRAC) used by the Energy Information Administration. However, there are a number of ways in which SPR costs may differ from those of private U.S. refiners. The most prominent example of added costs involves compliance with the Cargo Preference Act, under which one half of the ton-miles of transportation of oil acquired for the SPR must be in U.S.-flag tankers.

Other costs which are incidental to SPR oil acquisition include terminalling fees, to the extent that commercial facilities are being used, transshipment costs, customs fees, environmental taxes, and, in a limited number of cases, pipeline tariffs. Furthermore, from time to time the quality of crude oil imported for the SPR varies from the average quality of crude oil imported by U.S. refiners. Over the history of the SPR, there have been periods in which SPR costs exceeded those of the average refiner, on a per-barrel basis, and there have been periods in which the SPR oil costs per-barrel were lower than the IRAC. Overall, however, SPR oil has cost somewhat above the average refiner cost. To project the effects of all of these possible sources of variance between SPR oil acquisition cost experience and that of the refining industry, a budgetary convention known as the "SPR Add-on" has been used by the DOE.

In designing a lease contract, the Department needs to decide how to treat the Cargo Preference Act requirements and the other ancillary costs regarding SPR oil acquisition. For purposes of this study, the Department has assumed that, given the use of U.S.-flag shipping, the additional costs for Cargo Preference will be borne by the Federal Government and will not be capitalized into the lease. Furthermore, it is assumed that the Federal Government and the lessor would make cash settlement at delivery for quality differentials. Finally, it is assumed that the current "SPR add-on" convention accurately describes these differentials.

This methodology helps to simplify some of the financial evaluation calculations presented below, and has the further advantage of creating a standardized SPR lease instrument. That is, even though some lessors delivered crude oil in U.S.-flag tankers and some in foreign-flag tankers, and even though there are likely to be quality differentials among lessors (and between deliveries by each lessor), there would be direct comparability between leases as to the basic commodity being stored. Standardizing the leases in this fashion would assist lessors in undertaking secondary market transactions. 


\section{SPECIFIC PROPOSALS}

In order to focus the evaluation section below, the Department has identified a set of specific leasing concepts for in-depth review:

\section{Solicitation Case}

The Department's draft solicitation materials assume the award of competitive, commercial leases with the following features:

- $\quad$ Minimum size: 5 million barrels

- $\quad$ Minimum Term: 10 Years

- DOE options on capital recovcry:

- $\quad$ Purchase oil at firm fixed price established in the contract;

- $\quad$ Return of wet barrels at delivery; or

- Extension of lease for an additional term.

This structure reflects some possible compromises between the Department's management objectives and the likely requirements of the public market. In the event of a particularly attractive oil lease opportunity, whlch could unly be realized through non-competitive negotiations, it is possible that the Department would arrange somewhat different terms. In the evaluation section below, the effects of alternative lease durations and optional purchase prices are considered as variations on this solicitation concept.

\section{Lease/Purchase Concept}

Another variation on the basic concept is for the Government to agree to acquire the oil, with payments under the lease credited toward such acquisition. This is effectively an installment purchase method, with the capital cost amortized over the financing period. All lease payments, plus any termination costs, would have to be appropriated in advance of the lease start date. 


\section{EVALUATION OF THE LEASING OPTION}

The purpose of this section is to provide an evaluation of the oil leasing concept, using the criteria described in Chapter I. Section $D(1)$ evaluates the extent to which the leasing option would meet the criterion to minimize the cost of the reserve, and Section $\mathrm{D}(2)$ evaluates leasing in terms of the non-financial evaluation criteria.

\section{Minimize The Cost Of The Reserve}

As discussed in Chapter I, there are a number of different ways to characterize the net economic effects of SPR development, and there are additional questions about the appropriate methods for characterizing the costs of alternative financing methods. The Department has adopted a sensitivity analysis approach which is intended to inform decision makers of the possible effects of policy alternatives under a broad range of assumptions about future oil market conditions and appropriate methodologies.

The principal measure of cost used for this analysis is the present value of life-cycle costs to the Federal Government, involving comparisons of lease costs to the costs of outright purchase of an equivalent amount of oil. This analysis proceeds in two stages. First, using the various price cases presented in Chapter V, a series of seven deterministic examples of lease/purchase comparisons are presented. Then, in examples 8 and 9, probabilistic concepts are introduced to reflect uncertainty as to the future price of oil.

Throughout this analysis, the results are presented in terms of "breakeven" lease payments. These are payment levels above which, under the lease/purchase comparison principles in OMB Circular A-104, it would be preferable for the Government to have bought the oil. The actual feasibility of any of these results would depend on the results of contract negotiations.

The following is a summary of the findings of the life-cycle cost analysis in Examples 1 through 9:

(1) Depending on contract terms and other factors, a very wide range of annual lease payments is theoretically possible, each of which could be considered a hreakeven solution (cost of lease is no more than cost of purchase) under particular assumptions.

(2) Factors that tend to increase breakeven lease payment levels are as follows:

\begin{tabular}{ll} 
- & Later leases \\
- & Longer lcases \\
- & Higher discount rates \\
- & Lower price appreciation caps \\
- & Higher Federal equity \\
\hline & Less definite capital recovery point
\end{tabular}

Following the life-cycle cost analysis, a range of budgetary effects are presented, for comparison purposes. 
One way to analyze the costs of SPR oil leasing is to assume that if the Government did not lease the oil, it would have purchased the same amount outright, with financing from additional deficit spending. Under this approach, the Government would incur borrowing costs to provide purchase financing up to the point at which the SPR oil is resold.

The following table compares the elements of cost for SPR purchases and leases, and establishes the notation that will be used throughout this section.

$$
\begin{aligned}
& \text { Oil cost } \\
& \text { Interest on oil } \\
& \text { Lease Payments } \\
& \text { Interest on funds } \\
& \text { borrowed to make } \\
& \text { lease payments } \\
& \text { Subtotal, costs to } \\
& \text { maturity } \\
& \text { Value at } \\
& \text { maturity }
\end{aligned}
$$

Net Costs (FV)

\section{$\underline{\text { Purchase }}$}

$$
\text { C }
$$

Io

$-$

$=$

C+Io

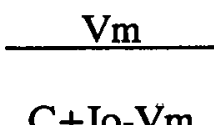

Lease

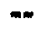

$--$

L

I(L)

$\mathrm{L}+\mathrm{I}(\mathrm{L})$

C+Io-Vm

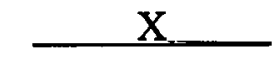

$L+I(L)-X$

In the case of the purchase alternative, the costs up to the point of resale can be expıessed as a Future Value (FV) consisting of the initial purchase cost $(\mathrm{C})$ and the compound Treasury interest costs (Io). Since the Government owns the oil, this cost is offset by the value of the oil ( $\mathrm{Vm}$ ) at the end of the analysis period. Thus the term "future value", as used here, is a life-cycle concept, under which a quantity of oil is acquired, held for some period, and then sold.

In the case of the lease, there is no initial cost for the oil, but the Government would make lease payments over the term of the lease, summing to L. Assuming that the Guvenument borrowed the funds to make these lease payments, there would also be compound interest on such borrowing, denoted above by $\mathrm{I}(\mathrm{L})$. At the end of the lease, depending on the structure of the cunlracl, llic Government might realize a gain, denoted as $X$. For example, if the contract sel a cap oui price appreciation at $\mathrm{Pc}$, and $\mathrm{Vm}$ was greater than $\mathrm{Pc}$, the Government might receive a value $\mathrm{X}$, calculated as $\mathrm{Vm}$ - Pc at the end of the lease term.

In the example above, the purchase and lease costs are both expressed in terms of Future Value (FV). The benefit of this approach is that it indicates how the transactions would appear over time in the Federal financial management system. However, calculating Future Value requires specifying a particular period of time over which interest costs are accumulated for each option. A different formulation, which permits one to analyze alternatives with varying maturities, is to calculate the Present Value (PV) of costs for each alternative. Using a discount rate which is the 
same as the interest rate used above in calculating Io and $\mathrm{I}(\mathrm{L})$, the Present Value of costs for these two policy alternatives would be as follows:

$\begin{array}{lll}\mathrm{PV}(\text { Purchase }) & = & \mathrm{C}-\mathrm{PV}(\mathrm{Vm}) \\ \mathrm{PV}(\text { Lease }) & = & \mathrm{PV}(\mathrm{L})-\mathrm{PV}(\mathrm{X})\end{array}$

If all other assumptions are held constant, then whenever the future value of a lease cost exceeds the future value of purchase costs, the present value of lease costs will also exceed the present value of purchase costs. Thus the two concepts can be used interchangeably.

In this analysis, we are assuming that the SPR "add-on" would be the same for either alternative, and are thus focusing on the major question of oil valuation, as reflected in the average refiner acquisition cost for imported oil (IRAC). Unless otherwise noted, we will be using the three (Base, High, and Low) oil price projections presented in Chapter V. For all cases, we have adopted the convention of assuming that payments are made in the middle of each year, whether for purchase or for lease, and have discounted them to the point of oil delivery.

\section{a. Deterministic Analysis}

In the following set of examples, we are assuming that there is no uncertainty regarding the future price of oil, though we are testing for different alternative expectations of what that certain price is. This assumption will be relaxed in subsequent examples.

In each case, the first step of the analysis is to determine the life-cycle cost of purchase. Then, employing the same economic assumptions, the equivalent lease payment level is calculated. Thus when the following examples show the lease and purchase alternatives to be identical, this should not be construed as a finding of the study, but rather an analytic step to estimate breakeven lease payments. 
EXAMPLE 1: Government and Lessor Have Same Expectations

\section{Assumptions}

Term of Lease: Oil delivered in FY 1991, lease matures in FY 2001 (10 Years)

USG Price Expectations: Base Case, excluding SPR add-on.

Lessor Price Expectations : Base Case, excluding SPR add-on.

USG Discount Rate : 8 Percent (assumed Treasury borrowing rate) ${ }^{1 /}$

Private Discount Rate: 8 Percent

No Cap on Price Appreciation

Results: Future Value Analysis

Breakeven Lease Payment: Lessor Pays USG \$.335/BBL/Year

USG Comparison:

\begin{tabular}{|c|c|c|}
\hline & $\underline{\text { Purchasc }}$ & $\underline{\text { Lcasc }}$. \\
\hline Oil Cost, FY91 & $\$ 17.19$ & --- \\
\hline Interest on Oil & 19.92 & --- \\
\hline Lease Payments & --- & $(\$ 3.35)$ \\
\hline Interest on Lease Payments & -- & $(\$ 1.51)$ \\
\hline Subtotal, Costs to Maturity & $\$ 37.11$ & $(\$ 4.86)$ \\
\hline $\begin{array}{l}\text { Oil Value, FY2001 } \\
\text { (Base Case) }\end{array}$ & $\$ 41.97$ & \\
\hline Net Cost (Gain) & $(\$ 4.86)$ & $(\$ 4.86)$ \\
\hline
\end{tabular}

1/ OMB Circular A-104 prescribes use of Treasury borrowing rates plus one eighth of a percent, for Federal lease purchase calculations. A flat 8 percent has been used in most of this chapter, to simplify calculations. Changes in this rate are examined in Example 5 bclow. 


\section{Results: Present Value Analysis}

$\begin{array}{lcc} & \underline{\text { Purchase }} & \underline{\underline{\text { Lease }}} \\ \text { Oil Cost, FY 91 } & \$ 17.19 & -. \\ \text { PV of Lease } & -\overline{-} & (\$ 2.25) \\ \text { PV of Oil in FY 2001 } & \$ 19.44 & -- \\ \text { NPV Cost(Gain) } & \overline{(\$ 2.25)} & \overline{(\$ 2.25)}\end{array}$

\section{Interpretation}

In this example, the value of the leased property is expected to increase by more than the assumed discount rate. Accordingly, an investor would be willing to pay the Government to hold a barrel of oil in storage for the lease term, and the Government would require such a payment for the life-cycle effects of the lease to be equal to the effects of direct purchase. This can be viewed as a storage fee which partially reimburses the Government for facilities costs.

Because the investor and the Government have identical -- and certain -- price expectations, and identical discount or interest rates, the breakeven position for each is the same: payment by the lessor of $\$ .335$ per barrel per year to the Government.

Example \#1 can be varied for different ten-year periods through the completion of SPR fill. Table VI-1 and Figure VI-2 present the breakeven lease payments that would be associated with the Base Case oil prices and a constant 8 percent interest rate.

Using the Base Case oil price and inflation assumptions, the breakeven annual payment for a ten-year lease increases gradually, from a negative payment by the Government of $\$ .335$ per barrel for a lease starting in FY 1991, to a positive payment of $\$ 2.123$ per barrel for a lease starting in the year 2005. There are two reasons for this increase over time. First, under Base Case assumptions, the expected ten-year percentage increase in oil prices declines over time. As a result, the benefits of price appreciation to the owner decline and there is an increase in the reliance by the investor on the receipt of lease payments to achieve the target rate of return. This is reflected in Table VI-1 in the growth of the ratio of the breakeven lease payment to the initial cost of the oil.

Second, the increase in the nominal dollar cost of the oil creates the need for larger nominal dollar lease payments to achieve the target 8 percent rate of return. Thus lease payments continue to increase even when the percentage stabilizes in the range of 2 percent to 4 percent.

Therefore, under the assumptions in this example, at least through the mid-1990's, the Government would require a storage payment from the lessor for a lease to be as attractive as a purchase. 
Table VI-1

Breakeven Lease Payments @ 8 Percent

Ten-Year Leases/Base Case Prices

\begin{tabular}{lrrrr}
\multirow{2}{*}{$\begin{array}{l}\text { Start } \\
\text { Date }\end{array}$} & \multicolumn{2}{c}{ Oil Price/BBL } & \multicolumn{2}{c}{ Annual Lease } \\
FY1991 & $\$ 17.19$ & $\$ 41.97$ & $\$(.335)$ & $(2.0)$ \\
FY1992 & 18.16 & 45.05 & $(.403)$ & $(2.2)$ \\
FY1993 & 19.76 & 48.02 & $(.370)$ & $(1.9)$ \\
FY1994 & 22.09 & 50.92 & $(.223)$ & $(1.0)$ \\
FY1995 & 24.47 & 54.04 & $(.084)$ & $(0.3)$ \\
FY1996 & 27.52 & 57.09 & .160 & 0.6 \\
FY1997 & 30.69 & 60.06 & .428 & 1.4 \\
FY1998 & 33.90 & 63.24 & .687 & 2.0 \\
FY1999 & 36.62 & 66.47 & .869 & 2.4 \\
FY2000 & 39.06 & 69.93 & .994 & 2.5 \\
FY2001 & 41.97 & 73.43 & 1.186 & 2.8 \\
FY2002 & 45.05 & 76.89 & 1.406 & 3.1 \\
FY2003 & 48.02 & 80.28 & 1.615 & 3.4 \\
FY2004 & 50.92 & 83.73 & 1.808 & 3.6 \\
FY2005 & 54.04 & 87.36 & 2.023 & 3.7
\end{tabular}

1/ Annual lease payment as a percent of the initial oil price.

EXAMPLE 2: Duration Sensitivity

This example provides a sensitivity analysis on the duration of the lease, building on the data in Table VI-1 above.

Assumptions

Term of Lease: Oil delivered in FY 1991, Lease term varies from 5 to 20 years.

All other assumptions the same as Example 1:

- Both lessor and USG believe Base Case price assumptions.

- Both lessor and USG use an 8 percent discount rate.

- No Cap on Price Appreciation. 


\section{Results}

Table VI-2 presents the breakeven lease payments for both the Government and the lessor for a range of lease maturities. In each case, the lease starts in FY 1991 at a price of $\$ 17.19$ per barrel and is calculated at an 8 percent yield to maturity.

Table VI-2

\section{Breakeven Lease Payments for Different Lease Terms \\ Start Date: FY 1991}

\begin{tabular}{|c|c|c|c|c|}
\hline \multirow{2}{*}{$\begin{array}{c}\text { Lease Terms } \\
\text { (Years) }\end{array}$} & \multirow{2}{*}{$\begin{array}{l}\text { End } \\
\text { Date }\end{array}$} & \multirow{2}{*}{$\begin{array}{c}\text { Base Case } \\
\text { Oil Price/BBL } \\
\text { End }\end{array}$} & \multicolumn{2}{|c|}{$\begin{array}{c}\text { Breakeven } \\
\text { Annual Lease Payments }\end{array}$} \\
\hline & & & $\$ / \mathrm{BBL}$ & Percent \\
\hline 5 & FY1996 & $\$ 27.52$ & $\$(.386)$ & $(2.2)$ \\
\hline 6 & FY1997 & 30.69 & $(.465)$ & (2.7) \\
\hline 7 & FY1998 & 33.90 & $(.498)$ & (2.9) \\
\hline 8 & FY1999 & 36.62 & $(.452)$ & (2.6) \\
\hline 9 & FY2000 & 39.06 & $(.376)$ & $(2.2)$ \\
\hline 10 & FY2001 & 41.97 & $(.335)$ & $(2.0)$ \\
\hline 11 & FY2002 & 45.05 & (.299) & (1.7) \\
\hline 12 & FY2003 & 48.00 & (.249) & (1.5) \\
\hline 13 & FY2004 & 50.9 & (.194) & (1.1) \\
\hline 14 & FY2005 & 54.04 & $(.147)$ & $(0.9)$ \\
\hline 1.5 & FY2006 & 57.09 & $(.094)$ & $(0.6)$ \\
\hline 16 & FY2007 & 60.06 & (.039) & $(0.2)$ \\
\hline 17 & FY2008 & 63.24 & +.011 & +0.1 \\
\hline 18 & FY2009 & 66.47 & +.060 & +0.4 \\
\hline 19 & FY2010 & 69.93 & +.103 & +0.6 \\
\hline 20 & FY2011 & 13.43 &,$+ 14 \%$ & +0.9 \\
\hline
\end{tabular}

\section{Interpretation}

Breakeven lease payments increase as lease terms are increased because, under the Base Case oil price assumptions, the rate of growth in oil prices is assumed to lessen over the course of the analysis period. With lease terms up to 17 years, lessors would need to be willing to pay the Government for oil storage, if the effects of leasing were to be equivalent to the effects of direct purchase. There is a crossover point at a 17-year lease, between a small payment to the Government, to a small payment by the Government (plus amounts are associated with costs), because the compound growth rate in oil prices drops below 8 percent at that point. This means that price appreciation alone would not satisfy the investor's need for a total rate of return of 8 percent, hence a positive lease payment would be required. 
In Example 2, we have used the same interest rate for all maturities. It should be noted that, in general, longer terms are associated with higher financing costs, so one would expect the effects of longer maturities to be somewhat more pronounced than the pattern shown on the above table.

\section{EXAMPLE 3: Oil Price Sensitivity}

This example analyzes the effects of different oil price expectations, using the High and Low cases presented in Chapter V. It is still assumed that the lessor and the Government share the same expectations.

\section{Assumptions}

Same as Example 1, except that High and Low oil price cases are used. An 8 percent discount rate is also assumed, as in prior cases. The lease terms are assumed to be ten years, with no cap on price appreciation.

\section{Results}

Table VI-3 below presents information in the same format as Table VI-1, concerning the annual lease rates that would be associated with ten-year leases starting at different dates.

Figure VI-2 plots the implicit breakeven lease payments for different delivery, or "start" dates for the Base, High, and Low oil price projections.

\section{Interpretation}

The three oil price paths yield similar patterns of breakeven lease payments for ten-year leases. For leases starting in the early 1990's, breakeven lease payments must be low or even negative for the effects of a lease to be equal to the effects of direct purchase, because of high expected growth rates in oil prices. For leases starting in the mid-1990's, all three price projections yield positive lease payments because of the projected tailing off in the growth rate of prices in future periods. For lcases starting in the year 2000, the lease payments must not exceed approximately $\$ 1.00$ per barrel per year, even though absolute value oil prices differ markedly. This is because the Low Price path assumes lower growth, and the lessor is thus more dependent on the lease payment to achieve a given investment yield. Conversely, while oil is more expensive under the High Price projection, the lessor expects more return in the form of further price appreciation and needs less from the annual lease payment. 
This illustrates that the expected rate of growth in oil prices over the term of the lease is a key factor in breakeven lease calculations, possibly more important than the absolute value of the oil.

Table VI-3

Breakeven Annual Lease Payments in Dollars/Barrel Ten-Year Maturities at 8 Percent

\begin{tabular}{|c|c|c|c|c|}
\hline \multirow{3}{*}{$\begin{array}{l}\text { Start } \\
\text { Date }\end{array}$} & \multicolumn{2}{|c|}{ HIGH OIL PRICE } & \multicolumn{2}{|c|}{ LOW OIL PRICE } \\
\hline & Ending & $\overline{\text { Lease }}$ & Ending & Lease \\
\hline & Price & Payment & Price & Payment \\
\hline FY1991 & $\$ 52.43$ & $\$(.475)$ & $\$ 32.19$ & $\$(.010)$ \\
\hline FY1992 & 56.06 & $(.456)$ & 34.20 & $(.014)$ \\
\hline FY1993 & 59.85 & $(.459)$ & 36.19 & +.052 \\
\hline FY1994 & 63.74 & $(.403)$ & 38.10 & +.145 \\
\hline FY1995 & 67.90 & $(.335)$ & 40.18 & +.204 \\
\hline FY1996 & 71.91 & $(.128)$ & 42.15 & +.339 \\
\hline FY1997 & 76.10 & +.131 & 43.97 & +.503 \\
\hline FY1998 & 80.38 & +.427 & 46.09 & +.631 \\
\hline FY1999 & 84.81 & +.733 & 48.26 & +.773 \\
\hline FY2000 & 89.72 & +1.032 & 50.32 & +1.006 \\
\hline FY2001 & 94.36 & +1.284 & 52.56 & +1.169 \\
\hline FY2002 & 98.69 & +1.542 & 54.96 & +1.303 \\
\hline FY2003 & 103.10 & +1.802 & 57.41 & +1.430 \\
\hline FY2004 & 108.10 & +2.044 & 59.66 & +1.560 \\
\hline FY2005 & 112.88 & +2.297 & 61.89 & +1.716 \\
\hline
\end{tabular}


Figure VI-2

SPR Leasing: Breakeven Lease Payments

Ten-Year Leases; No Price Caps
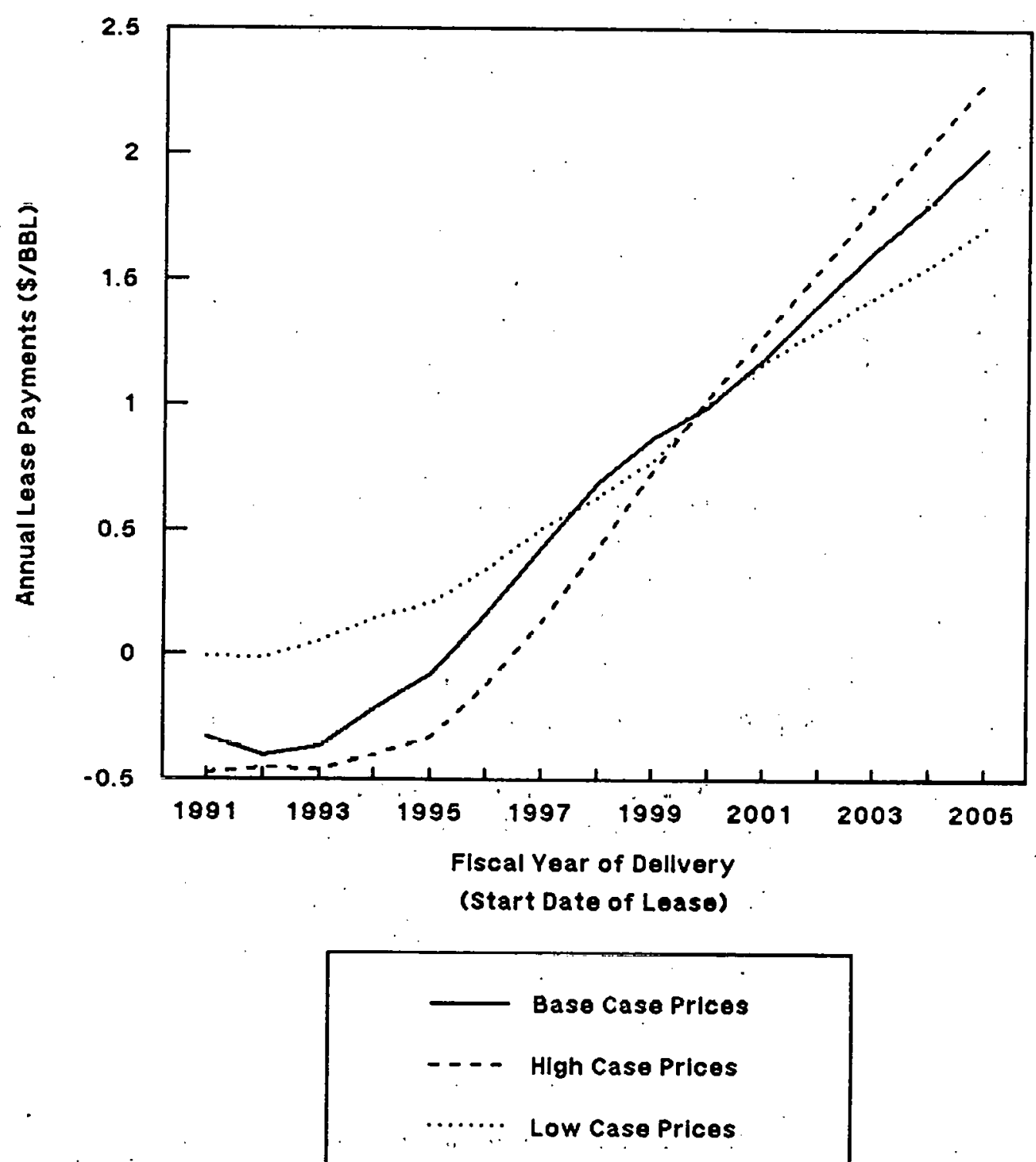


\title{
EXAMPLE 4: Government and Lessor Hold Different Expectations
}

In Examples 1 through 3, it was assumed that the Government and the lessor had identical expections about future oil prices. Combined with identical discount rates, both parties to the lease had the same breakeven position.

In Example 4 we introduce the possibility that the lessor would have either higher or lower price expectations than the Government. Example 4 is divided into two parts:

\section{A: Lessor believes Low Case Prices}

B: Lessor believes High Case Prices

In each part, the analysis identifies the combinations of the lessor's initial oil costs and the lessor's discount rate which would permit a lessor to offer lease payment terms which the Government would consider breakeven in its comparison to the effects of direct purchase.

\section{Assumptions}

- Government believes in Base Case prices in both parts of the example.

- Government discount rate is 8 percent

- Leases have 10-year maturities, running from FY1991 through 2001.

- No price caps; investor receives full market value of oil at maturity.

The following table summarizes the information on breakeven lease payments under common USG/lessor price expectations, from Examples 1 through 3.

\author{
Breakeven Lease Payments \\ FY1991 - 2001 Lease @ 8 percent \\ Price Case \\ Base Case \\ High Case \\ Low Case \\ ${\underline{\text { Lease Payment }(\$ / \mathrm{bbl})^{\mathrm{a} /}}}^{/ \mathrm{b} /}$ \\ a/ Amounts arc payments to the Government from the lessor. \\ b/ Base Case is from Example 1, High Case and Low Case are from Table \\ VI-3
}

\section{A: Lessor believes Low Case Prices}

If the Government believed the Base Case prices and adhered to an 8 percent discount rate, the Government would require a payment from the lessor of $\$ .335$ per barrel per year to break even with the purchase alternative. Yet it would appear from Table VI-3 that the lessor believing Low Case prices and requiring an 
8 percent discount rate would be willing to pay no more than $\$ .01$ per barrel per year, leaving no opportunity for mutual advantage.

However, there are two specific circumstances under which an arrangement could be made:

(1) If the lessor views the opportunity cost of oil in FY1991 to be less than $\$ 12.66$ per barrel, then a lessor might be willing to pay the $\$ .335$ per barrel (Government breakeven conditions) even under Low Case prices and an 8 percent discount rate.

The calculation for this, from the lessor's perspective, is as follows:

PV of Oil in 2001 (a) 8\%

Less PV of Lease Payments of $\$ .335$ per year

Implicit FY 1991 Value
$(\$ / \mathrm{BBL})$ $\$ 14.91$ (Low Case) 2.25 (Example 1)

$\$ 12.66$

Under the Low Case, the FY 1991 value of oil is expected to be $\$ 14.84$ per barrel. Therefore, at an 8 percent discount rate, the lessor would have to value the oil in 1991 at more than $\$ 2.18$ per barrel under the prevailing market price of $\$ 14.84$ (Low Case) and more than $\$ 4.50$ below the Base Case FY 1991 price of $\$ 17.19$ per barrel.

(2) If the lessor has a discount rate below the Government's in the range of 6 to 7 percent, then the lessor would be willing to pay the Government \$.335 per year.

Under this circumstance, the lessor has a different perspective on the time value of money. The lower the discount rate, the higher the present value of oil in the year 2001, but also the higher the present value of the $\$ .335$ per barrel per year in payments by the lessor to the Federal Government.

Table VI-4 presents the lessor's calculations at discount rates of 6 and 7 percent. It indicates that within this range, it would be possible for the lessor to expect to break even under terms by which the Government would also expect to break even.

\section{Interpretation}

Under circumstances in which the lessor believes the Low Case price assumptions for the year 2001 but the Government believes the Base Case, there are a series of combinations of discount rates and initial oil costs that permit the lessor to expect to break even under the same conditions under which the Federal Government would also expect to break even. These are presented in Table VI5 below. 
Table VI-4

\section{Breakeven Lease Payment as a Function of Discount Rate FY 1991-2001 Lease; Lessor Believes Low Case Prices}

\begin{tabular}{lrr} 
& 6\% Rate & 7\% Rate \\
\cline { 2 - 3 } PV of Oil in 2001 & $\$ 17.97$ & $\$ 16.36$ \\
PV of Lease Payments & & \\
to Government & 2.47 & 2.35 \\
Initial FY1991 Cost & $\frac{14.84}{.66}$ & $\frac{14.84}{(.83)}$ \\
Gain (Loss) to Lessor & .66
\end{tabular}

The general conclusion of this analysis is that if a lessor believed the Low Case prices but the Federal Government believed the Base Case prices for the year 2001, the lessor could only expect to break even or better under terms acceptable to the Government if the lessor placed a lower value on the oil in the year 1991, or had a lower discount rate, or a combination of a lower oil price and a lower discount rate.

\section{B: Lessor believes High Case Prices}

If the Government believed the Base Case Prices and adhered to an 8 percent discount rate, as in Part $\mathrm{A}$, the Government would require a payment from the lessor of $\$ .335$ per barrel per year to break even with the purchase alternative. However, from Table VI-3 we saw that the breakeven lease payment (from the lessor to the Government) for an investor with an 8 percent discount rate and a certain belief in High Case prices would be $\$ .475$ per barrel per year. Under these circumstances, there would likely be more opportunity for finding mutual advantage for the Government and the lessor, than under the Part A circumstances.

Table VI-6 below provides the breakeven (to the lessor) combinations of initial prices and discount rates which would be equivalent to a payment of $\$ .335$ per barrel to the Government.

Since the FY 1991 High Case oil price, as expected by the lessor, is $\$ 21.05$ per barrel, the lessor would be willing to pay the Government the $\$ .335 /$ barrel/year if the lessor's discount rate were in the range of 8 percent to 9 percent. Faced with an initial oil cost of $\$ 17.19$ per barrel (the Basc Casc for FY 1991), the lcssor's equivalent discount rate would be between 10 and 11 percent, or 2-3 percent above the Government's 8 percent rate. 


\section{Table VI-5}

Breakeven Combinations of Discount Rates and Initial Oil Prices (Lessor believes Low Case Price)

\begin{tabular}{|c|c|c|c|}
\hline $\begin{array}{l}\text { Lessor's } \\
\text { Discount } \\
\text { Rate } \\
\end{array}$ & $\begin{array}{l}\text { PV Price } \\
\text { in FY2001 }\end{array}$ & $\begin{array}{l}\text { PV of Lease } \\
\text { Payments }\end{array}$ & $\begin{array}{l}\text { Lessor's } \\
\text { Breakeven } \\
\text { Initial Price }\end{array}$ \\
\hline 1 & $\$ 29.14$ & $\$ 3.17$ & $\$ 25.97$ \\
\hline 2 & 26.41 & 3.01 & 23.40 \\
\hline 3 & 23.95 & 2.86 & 21.09 \\
\hline 4 & 21.75 & 2.72 & 19.03 \\
\hline 5 & 19.76 & 2.59 & 17.17 \\
\hline 6 & 17.97 & 2.47 & 15.50 \\
\hline 7 & 16.36 & 2.35 & 14.01 \\
\hline 8 & 14.91 & 2.25 & 12.66 \\
\hline 9 & 13.60 & 2.15 & 11.45 \\
\hline 10 & 12.41 & 2.06 & 10.35 \\
\hline 11 & 11.34 & 1.97 & 9.37 \\
\hline 12 & 10.37 & 1.89 & 8.48 \\
\hline 13 & 9.48 & 1.82 & 7.66 \\
\hline 14 & 8.68 & 1.75 & 6.93 \\
\hline 15 & 7.96 & 1.68 & 6.28 \\
\hline 16 & 7.30 & 1.62 & 5.68 \\
\hline 17 & 6.70 & 1.56 & 5.14 \\
\hline 18 & 6.15 & 1.51 & 4.64 \\
\hline 19 & 5.65 & 1.45 & 4.20 \\
\hline 20 & 5.20 & 1.40 & 3.80 \\
\hline
\end{tabular}


Table VI-6

Breakeven Combinations of Discount Rates and Initial Oil Prices

(Lessor believes High Price Case)

\begin{tabular}{|c|c|c|c|}
\hline $\begin{array}{c}\text { Lessor's } \\
\text { Breakeven } \\
\text { Discount Rate }\end{array}$ & $\begin{array}{c}\text { PV of } \\
\text { Price } \\
\text { in } 2001 \\
\end{array}$ & $\begin{array}{l}\text { PV of } \\
\text { Lease } \\
\text { Payment }\end{array}$ & $\begin{array}{c}\text { Lessor's } \\
\text { Initial } \\
\text { Price }\end{array}$ \\
\hline 1 & $\$ 47.46$ & $\$ 3.17$ & $\$ 44.29$ \\
\hline 2 & 43.01 & 3.01 & 40.00 \\
\hline 3 & 39.01 & 2.86 & 36.15 \\
\hline 4 & 35.42 & 2.72 & 32.70 \\
\hline 5 & 32.19 & 2.59 & 29.60 \\
\hline 6 & 29.28 & 2.47 & 26.81 \\
\hline 7 & 26.65 & 2.35 & 24.30 \\
\hline 8 & 24.29 & 2.25 & 22.04 \\
\hline 9 & 22.15 & 2.15 & 20.00 \\
\hline 10 & 20.21 & 2.06 & 18.16 \\
\hline 11 & 18.47 & 1.97 & 16.49 \\
\hline 12 & 16.88 & 1.89 & 14.99 \\
\hline 13 & 15.44 & 1.82 & 13.63 \\
\hline 14 & 14.14 & 1.75 & 12.40 \\
\hline 15 & 12.96 & 1.68 & 11.28 \\
\hline 16 & 11.89 & 1.62 & 10.27 \\
\hline 17 & 10.91 & 1.56 & 9.35 \\
\hline 18 & 10.02 & 1.51 & 8.51 \\
\hline 19 & 9.21 & 1.45 & 7.75 \\
\hline 20 & 8.47 & 1.40 & 7.06 \\
\hline
\end{tabular}

Figure VI-3 plots the data from Tables VI-5 and VI-6. The horizontal axis represents the discount rate of the lessor, and the vertical axis represents the initial oil price at the time the lease is commenced. In all cases, it is assumed that the lessor is paying the Federal Government $\$ .335$ per barrel annually for 10 years. The dashed line provides the information on breakeven combinations for the lessor with Low Case price expectations (from A) and the solid line provides comparable information for a lessor with High Case price expectations (from B). The point denoted "USG" reflects the Base Case assumptions with an 8 percent discount rate. For the lessor, only a combination of initial prices and discount rates below and to the left of its breakeven line will result in an expected gain from the lease; hence lessors with higher price expectations have a broader range of possible profit combinations than lessors with lower price expectations.

The conclusion can be drawn that investor expectations about the growth in the value of the commodity in storage, combined with the investor's attitude toward 
Figure VI-3

Breakeven Combinations of Discount Rates and

Oil Prices Supporting Payment of $\$ .335$ to USG

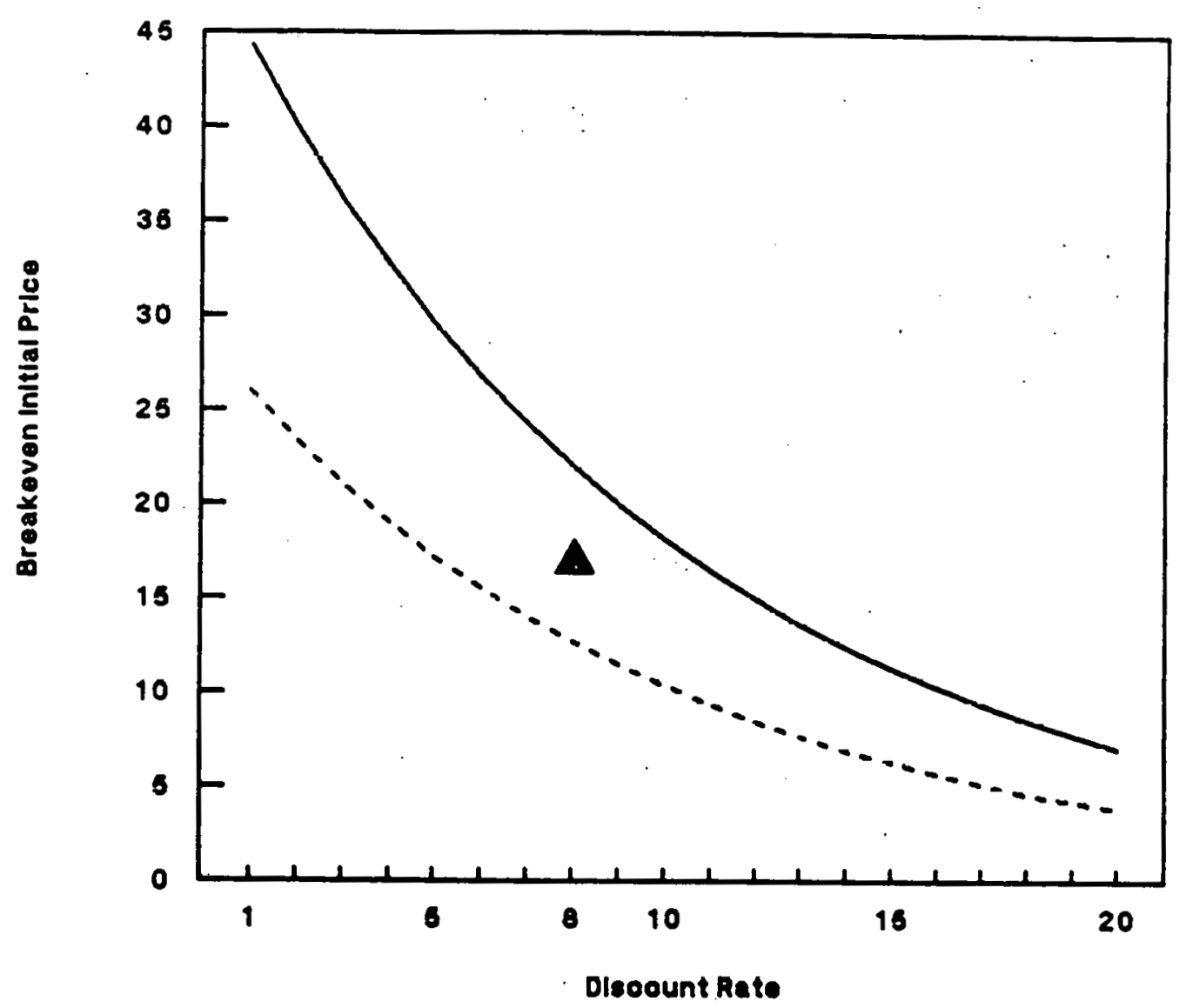

High Caso Prioes

- - Low Case Prlees

uso Assumptions 
risk, as reflected in discount rates, will be instrumental in determining whether a lease arrangement providing mutual advantage can be devised.

If there is no price appreciation cap in the lease, then the lessor's willingness to meet Government breakeven conditions is influenced by the lessor's price expections, opportunity cost for oil in the present, and discount rates. Lessors with lower price expectations than those of the Government would need to have lower discount rates or lower oil opportunity costs to derive advantage from a lease arrangement.

\section{EXAMPLE 5: Discount Rate Sensitivity}

In Example 5, the Government's breakeven analysis is changed to reflect the use of a 13 percent discount rate. Under the inflation assumptions set forth in Chapter $\mathrm{V}$, this nominal discount rate is approximately equal to the 10 percent real rate of return called for in OMB Circular A-94 for certain types of program and policy analysis.

For the 10-year lease period starting in FY 1991, when the Government holds the Base Case price assumptions, the Government would be willing to pay up to $\$ .889$ per barrel per year to the lessor to obtain use of the oil. Table VI-7 provides the present value analysis of the purchase and lease alternatives.

Table VI-7

Lcase/Purchase Analysis at

13\% Discount Rate

FY 1991-2001 Lease/Base Case Prices

$\begin{array}{lcc} & \text { Purchase } & \text { Lease } \\ \text { Oil Cost, FY 1991 } & \$ 17.19 & \\ \text { PV of Lease } & -- & \$ 4.83^{*} \\ \text { PV of Oil in 2001 } & \$ 12.36 & \overline{--} \\ \text { NPV Cost (Gain) } & \$ 4.83 & \$ 4.83 \\ \text { * Present value of } \$ .889 \text { per year for 10 years @ 13\%. }\end{array}$

At the 13 percent nominal discount rate, the present value of the oil in 2001 is much reduced, in comparison to the present value when an 8 percent discount rate is used. At the high rate, there is a net cost to the Government from purchase $(\$ 4.83)$ so the Government's breakeven lease payment is correspondingly higher. 


\section{Table VI-8}

Breakeven Lease Payments as a Function

of the Government's Discount Rate 1991-2001 Lease; Base Case Oil Prices

Discount

$\underline{\text { Rate (\%) }}$

5

6

7

8

9

10

11

12

13

14

15

16
Breakeven Lease

Payment

$\$(1.111)$

$(.849)$

$(590)$

$+.165$

$+.409$

$+.651$

$+.889$

$+1.126$

$+1.358$

$+1.588$

Figure VI-4

Breakeven Lease Payment as a

Function of Discount Rate

FY 1991-2001 Lease; Base Case Prices

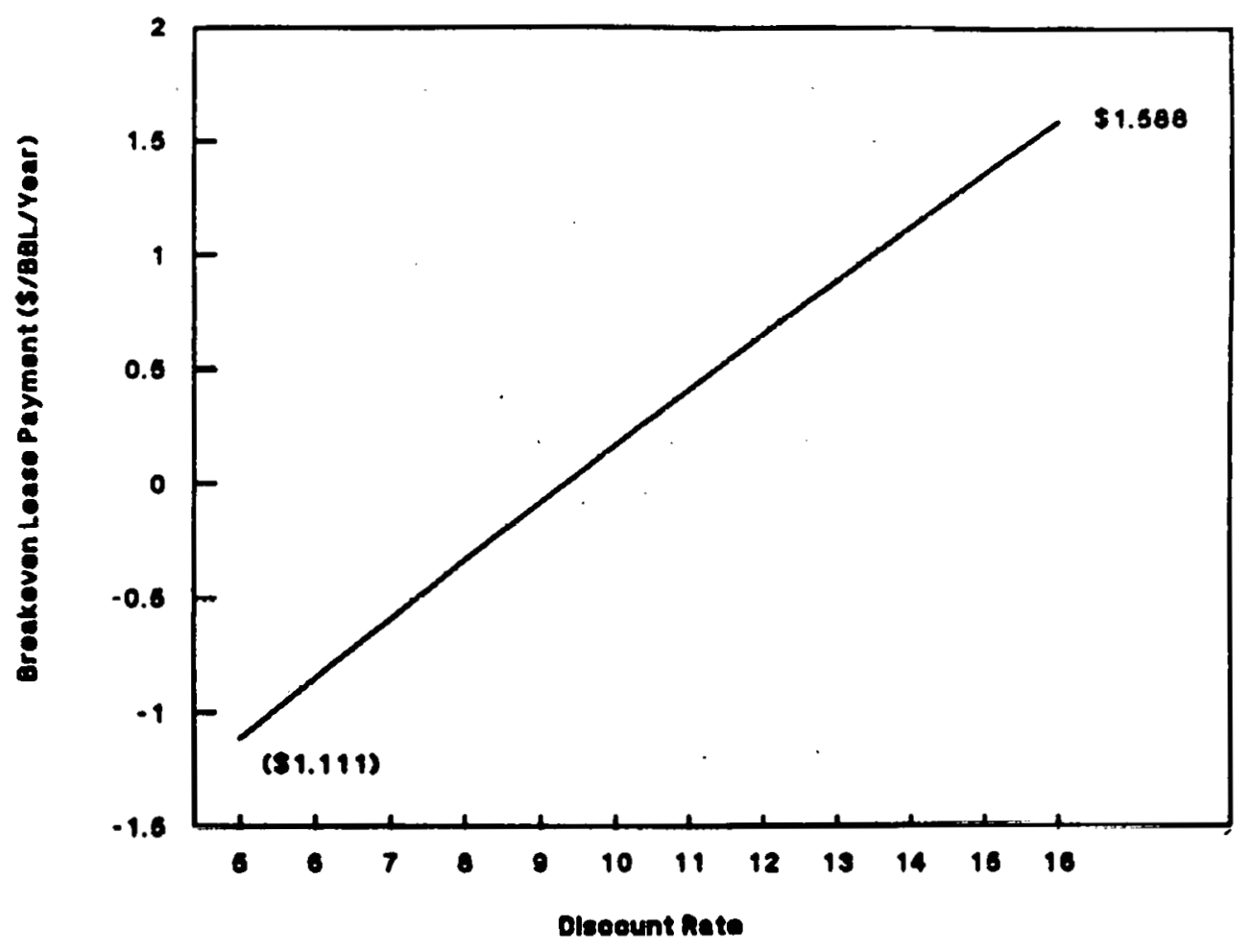


Table VI-8 and Figure VI-4 illustrate the sensitivity of the breakeven lease payment aluuuul to the clivice of discount ratcs.

While the relationship between discount rates and breakeven lease payments is not perfectly linear, over the range shown above, a one percent increase in the Government's discount rate represents approximately a $\$ .25$ per barrel increase in the Federal lease payment that the Federal Government may be willing to pay before the cost of leasing exceeds the cost of direct purchase.

OMB Circular A-104 requires the lease analysis to assume a nominal discount rate which is one-eighth of one percent above the Treasury borrowing rate for comparable maturities. This one-eighth of a percent spread between lease and purchase analysis is thus equivalent to a $\$ .03$ per barrel higher equivalent breakeven lease payment.

At a nominal discount rate of between 9 and 10 percent, the breakeven lease payment converts from a modest payment to the Government to a payment from the Government. This is because, for the FY 1991 to 2001 period, the Base Case price expectations call for a compound nominal growth rate in this percentage range. When the discount rate is below the expected rate of price appreciation, as was true for the 8 percent discount rate used in prior examples, the Government would require receipt of a payment from industry in order for the Government to be willing to forego the present value net benefits of purchasing oil. Conversely, when the discount rate is higher than the expected rate of price appreciation, as is true for the 13 percent case, there are present value costs to owning a barrel of oil and the Government may be willing to make a payment to the lessor to forego these ownership costs.

One interpretation of the change in lease payments from a negative $\$ .335$ per barrel to a positive $\$ .889$ per barrel is that the Federal Government would be willing to pay approximately $\$ 1.224$ per barrel per year as a form of "price risk insurance." Under OMB Circular A-104, the cost of services provided by the lessor is to be incorporated into lease/purchase analysis, and one key difference between the lease and purchase alternatives presented in these examples is that the lessor bears the risk and reward of price changes.

Regardless of what the Federal Government established as the maximum lease payment it is willing to make per barrel per year, the willingness of a lessor to participate would depend on three factors:

-- The lessor's discount rate;

-- The lessor's view of future oil prices; and

-- The lessor's view of the current value of oil at the time of lease award. 
Table VI-9

\section{Lessor Breakeven Conditions for a $\$ .889$ \\ Payment by the Federal Government 10 Year Term Starting in 1991}

\section{Lessor's Future Price Expectations}

$\begin{array}{cccr}\begin{array}{c}\text { Lessor's } \\ \text { Discount }\end{array} & \begin{array}{l}\text { Base } \\ \text { Case }\end{array} & \begin{array}{l}\text { Low } \\ \text { Case }\end{array} & \begin{array}{r}\text { High } \\ \text { Case }\end{array} \\ \underline{\text { Rate }} & & & \\ 5 \% & \text { (Lessor's Breakeven FY } & \text { 1991 Oil Value) } \\ 6 & \$ 32.63 & \$ 26.63 & \$ 38.98 \\ 7 & 29.98 & 24.52 & 35.76 \\ 8 & 27.58 & 22.61 & 32.84 \\ 9 & 25.41 & 20.88 & 30.20 \\ 10 & 23.43 & 19.30 & 27.81 \\ 11 & 21.64 & 17.87 & 25.63 \\ 12 & 20.03 & 16.57 & 23.66 \\ 13 & 18.54 & 15.39 & 21.87 \\ 14 & 17.19 & 14.31 & 20.24 \\ 15 & 15.96 & 13.32 & 18.93 \\ 16 & 14.84 & 12.42 & 17.40 \\ 17 & 13.81 & 11.59 & 16.16 \\ 18 & 12.87 & 10.84 & 15.02 \\ 19 & 12.02 & 10.14 & 13.99 \\ 20 & 11.23 & 9.51 & 13.04 \\ & 10.51 & 8.93 & 12.18\end{array}$

Table VI-9 illustrates the combinations of lessor views on these three factors that would permit the lessor to break even under the circumstances in which the Government would break even, on a 10 -year lease with an annual lease payment of $\$ .889$ per barrel.

The following observations made be made from this example:

(1) For all price expectation cases, the higher the lessor's discount rate, the lower must be its current valuation of oil to permit a breakeven position at the specified $\$ .889$ per barrel annual payment from the Federal Government.

(2) When the lessor shares the same Base Case price expectations as the Federal Government, and the same 13 percent discount rate, the lessor's breakeven initial oil price $(\$ 17.19 / \mathrm{bbl})$ is also identical to the 
initial oil price which the Government would have paid under the purchase alternative.

(3) If the lessor's price expectations are lower than those of the Federal Government (refer to Low Case column above), then the lessor would break even under the following sets of circumstances:

(a) The lessor shared the Government's 13 percent discount rate but placed a lower value on the oil $(\$ 14.31$ versus $\$ 17.19)$ at the time of lease award. This could be true for a lessor such as a major producing nation which perceived itself as facing the choice between leasing the oil to the SPR or leaving it in the ground until a future period. In this case the lessor would be placing a lower opportunity cost on the oil than its current market value.

(b) The lessor had a lower discount rate than the Federal Government. If the market value of oil in FY 1991 is approximately $\$ 17$ per barrel, per the Base Case price expectations, then the lessor with Low Case price expectations would break even only at a discount rate in the 10-11 percent range.

(4) If the lessor's price expectations are higher than those of the Federal Government (refer to High Case column on the above table) then a lessor can have a higher discount rate (about 15\%) and still be willing to pay $\$ 17$ per barrel for oil to be leased to the SPR.

\section{Extending the Analysis}

This particular form of analysis of divergent expectations cannot be usefully extended far into the future to cover the entire SPR program time horizon. The three price cases used in this analysis were based on a common starting point in 1988 , and by 1991 , expectations for 1991 deviated by $\$ 2.35$ per barrel (Low Case) to $\$ 3.86$ per barrel (High C'ase) trom the Base C'ase. In absolute terms, this deviation increases in each successive year. It may be unrealistic to believe, for example, that in 1999, as bids are prepared for leases to start in 2000 , near-term oil price expectations will deviate as much as $\$ 9$ per barrel for the coming year. Rather, one would expect that if the Base Case prices had been accurate up to that point, there would be a new, and more tightly clustered, set of High and Low prices which would bracket the actual current price.

Accordingly, a full analysis of the leasing concept for the life of the Reserve requires not only a set of assumptions about the actual trends in oil prices, but also a set of assumptions about the trends in expectations about yet further oil price developments.

However, one can use discount rate differentials as a proxy for expectation differentials. In Example 4, when the Government had an 8 percent discount rate, it was noted that a lessor with Low Case price expectations would break even at 
a 6-7 percent discount rate, but a lessor with High Case price expectations would break even at a discount rate of approximately 11 percent, using the same starting point for the value of oil in FY 1991. In Table VI-9 above, we estimated that, again starting with the same oil price at time of contract award, when the Government's criterion was a 13 percent discount rate, the lessor with the Low Price expectations had a breakeven discount rate of 10-11 percent, but a lessor with High Price expectations had a discount rate of $15-16$ percent.

To establish ranges for future price expectations, for the budget analysis below, we have assumed that the High Case lessor has a discount rate equivalent to 2 percent above the Federal rate, and that the Low Case lessor has a discount rate of 2 percent below the Federal discount rate, to establish the equivalent oil prices.

When the lessor and the Federal Government hold different price expectations, it is possible for each to expect to break even from the lease contract. However, at least one of the two parties will turn out to have been wrong. Table VI-10 provides an analysis of the circumstances under which the Federal Government turned out to have been correct in its price expectations, but the lessor had originally held different expectations. A ten-year (FY 1991-2001) lease is assumed, along with a Government lease payment of $\$ .889$ per barrel per year. An entry price of $\$ 17.19$ per barrel is assumed for all cases.

Table VI-10

Year 2001 Lease Outcomes for Lessors with Different Price Expectations Actual Outcome Equals Base Case

$\begin{array}{lcc} & \begin{array}{c}\text { Low Price } \\ \text { Case }\end{array} & \begin{array}{c}\text { High Price } \\ \text { Case }\end{array} \\ \text { Lessor Discount Rate } & 11 \% & 15 \% \\ \text { Initial Oil Cost } & \$ 17.19 & \$ 17.19 \\ \text { Lessor Borrowing Cost } & 31.62 & 52.35 \\ \text { USG Lease Payments } & (8.89) & (8.89) \\ \text { Interest on USG payments } & (5.98) & (9.16) \\ \text { Total Investment (FV) } & \$ 33.94 & \$ 51.49 \\ \text { Payback in } \$ 2001 & \$ 41.97 & \$ 41.97 \\ \text { Gain (loss) } & \$ 8.03 & (9.52)\end{array}$


By definition, the Government has broken even in this case, but the lessors face the possibility of significant losses or gains, depending on their original expectations. Some of these losses and gains may not be manifest in direct financial effects, such as actual interest paid on borrowing. Rather, given the price expectations and, as reflected in the discount rate, the attitudes of the investors toward risk and rate of return, these gains and losses represent deviations from the original intentions of the participants.

This analysis can be extended to situations in which the Government held Base Case price expectations and was wrong. Table VI-11 analyzes this possibility for both the 8 percent discount rate reflected in Examples 1 through 4 and the 13 percent discount rate reflected in Example 5. The top half of this table presents the future value of the cost or gain from a lease which, under Base Case price assumptions, was expected to breakeven with a purchase. The bottom half of the table presents three different hypothetical outcomes, based on different future prices, if the Government had chosen to purchase the oil.

\section{$\underline{8 \text { Percent Example }}$}

Addressing first the 8 percent discount rate case, it will be recalled from earlier examples that under Base Case price assumptions for the years 1991 and 2001, the Government would expect a gain, measured in future value terms, of $\$ 4.86$ per barrel from a purchase. The lease payment, in this case a payment to the Government, is structured to equate to the gain that would have been realized by a purchase and resale at Base Case Prices.

Under Low Price projections, there would have been a net cost to the Government of $\$ 4.92$ per barrel, on a future value basis, from the purchase and resale of oil. Instead, the lease method "locked in" a gain of $\$ 4.86$, so leasing turned out to benefit the Government by a total of $\$ 9.78$. That is, the lease cost was certain, once the lease instrument was awarded.

Under High Price expectations, the net gain from purchase and resale of the crude oil would have been $\$ 15.21$ at an 8 percent discount rate, By leasing the oil, the Government "locked in" a gain of only $\$ 4.86$ per barrel, giving up the opportunity for a $\$ 15.21$ per barrel gain, for a net loss of $\$ 10.35$.

\section{Percent Example}

Referring to the 13 percent column on Table VI-11, a similar pattern would obtain if the lease was structured so that, under Base Case prices, the Government would break even, with a net cost of $\$ 16.38$ per barrel. If the actual price path was the Low Case, then the loss from the purchase alternative would have been $\$ 26.16$ per barrel. Since the Government locked in a cost of $\$ 16.38$ per barrel, it would have avoided a further cost of $\$ 9.78$ by leasing. 


\section{Table VI-11}

Year 2001 Outcomes for the USG Under Different

Price Outcomes a/

\section{Discount Rate}

$\underline{8 \% \text { Rate } \quad 13 \% \text { Rate }}$

Breakeven Lease (Future Value)

Grovernment Lease

Payment (annual)

$+\$ .889$

Lease Cost (Receipt)

$\$ 8.89$

Interest on Lease

(1.51)

7.49

Total Lease Cost

(4.86)

$\$ 16.38$

Purchase Equivalent (Future Value)

Base Case

Low Price

Loss(Gain)

High Price

Loss(Gain)
16.38

$+4.92$

(9.78)

(15.21)

$+10.35$
$+26.16$

(9.78)

$+6.03$

$+10.35$

a/ It should be recalled that in these tables, a positive amount reflects a cost to the Government, and an amount in brackets reflects a gain, or a negative cost. 
Alternatively, if the High Case price path proved accurate, then the Government could have limited its costs to $\$ 6.03$ by purchasing the oil, hence the lease cost of $\$ 16.38$ represented a net loss of $\$ 10.35$ per barrel.

In sum, a straight leasing approach, with no caps or floors on the price appreciation (or decline) experienced by the investor, locks in for the Government a cost for the SPR which does not vary as market conditions change. Depending on actual market outcomes, the Government could gain or lose by transferring this risk to the lessor.

\section{EXAMPLE 6: Use of Price Appreciation Caps}

Examples 1 through 5 all assume that the return to the lessor is directly linked to future oil prices. This could be arranged either through the direct return of wet barrels or through a payment linked to oil market conditions. As discussed above in Section B of this chapter, it would be possible to substitute a fixed payment to the lessor for either a wet barrel return or a cash payment indexed to oil prices. If the Government reserved this fixed payment option to itself, then the payment would be the equivalent of a call option wherein the Government could acquire oil at a fixed price. Lessors would assume that the Government would only exercise this option when the fixed price was below the actual market price of the oil, hence the fixed price would act like a "cap" on the financial return to the lessor.

Figure VI-5 illustrates the ways in which various "caps" might interact with oil price expectations. The two alternative caps used in this Figure are calculated in terms of 5 percent and 10 percent annual compound growth rates starting in FY 1991 at the Base Case price of $\$ 17.19$ per barrel. The 10 percent cap starts out approximately equal to Base Case prices and somewhat below High Case oil prices in the early years, but there is a crossover point in the year 2006 after which the 10 percent cap exceeds the High Case expectations.

The 5 percent cap starts out above the Low Case price projections, but there is a crossover point in the late 1990's after which the five percent cap is actually below the Low Case prices.

Table VI-12 provides the price information for FY 2001 associated with each of the lines on Figure VI-5. 
Figure VI-5

Alternative Price Caps in

Relation to Study Projections

(Nominal \$ per Barrel)

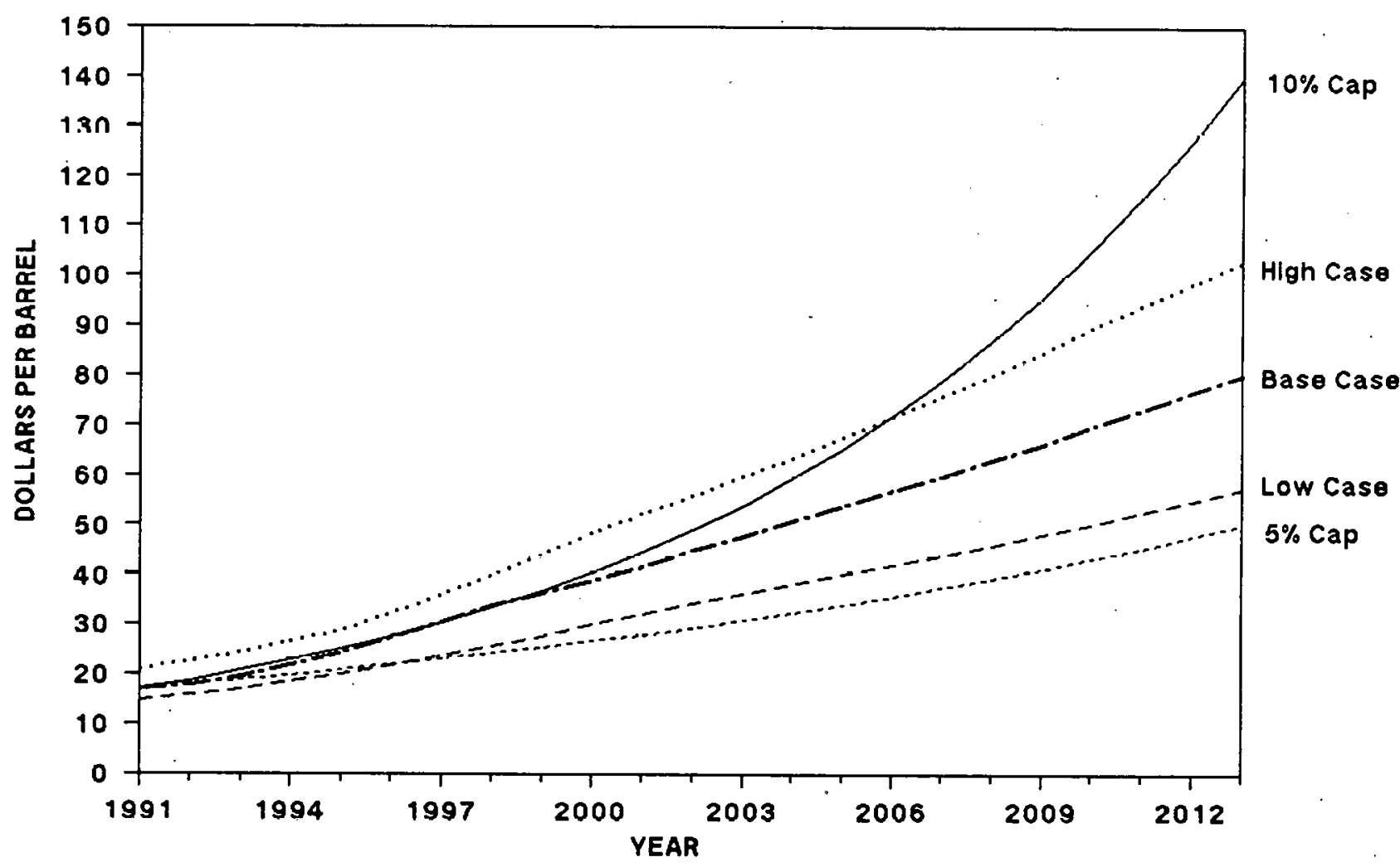


Table VI-12

\begin{tabular}{lc}
\multicolumn{2}{c}{ Alternative Oil Price Levels, FY 2001} \\
Base Case & $\$ 41.97$ \\
Low Case & $\$ 32.19$ \\
High Case & $\$ 52.32$ \\
$5 \%$ Cap & $\$ 28.00$ \\
$10 \%$ Cap & $\$ 44.59$
\end{tabular}

The effect of such cap arrangements on breakeven conditions for the Government and the lessor would depend on the price expectations of the two parties and also on the relationship between the cap price and the expected actual price at the time of lease maturity. The following are examples of different possible combinations of price expectations and cap levels.

\section{A: Both Parties Believe Base Case Prices}

\section{Percent Cap}

If both the lessor and the Federal Government were certain that Base Case prices would obtain, there would be no change in the breakeven lease arrangement for either party as a result of the imposition of a 10 percent cap. This is because both parties would assume that the lease would be liquidated in the year 2001 with the return of wet barrels. Otherwise, the Government would be exercising an option to acquire the oil at a price several dollars in excess of its market value:

If the Low Case projection of $\$ 32.19$ for the year 2001 prices turned out to be correct, rather than the Base Case of $\$ 41.97$, the lessor would lose, in Future Value terms, $\$ 9.78$ per barrel. The Government would gain an equivalent amount, based on foregone costs of purchasing the oil under Low Case outcomes, as described in previous examples, hence the results would be unaffected by the cap. This Future Value effect would be the same under any discount rate, so long as the Government and the lessor had employed the same discount rate in deriving the lease payment.

If the High Case projection of $\$ 52.32$ turned out to be accurate, the lessor would not gain the full $\$ 10.35$ per barrel presented in Table VI-11 above. Rather, the Government would be in a position to exercise its right to acquire the oil at the cap price of $\$ 44.59$ per barrel. Under this example, the lessor would only achieve a net gain of $\$ 2.62$ per barrel over the Base Case projection of $\$ 41.97$, whereas the Government would receive $\$ 7.73$ per barrel, the difference between the cap price of $\$ 44.59$ and the actual High Case price of $\$ 52.32$.

\section{Percent Cap}

A 5 percent cap would result in a price ceiling of $\$ 28$ per barrel in the year 2001 , a level even below the Low Case projection. If, as assumed in this example, both 
the lessor and the Government believed in Base Case assumptions, then the breakeven lease payment would depend on the discount rate used by each party (Table VI-13).

Table VI-13

Effect of a 5 Percent Cap ( $\$ 28$ per barrel)

Discount Rate

8 Percent

13 Percent

Present Value Analysis:

Initial Oil Price

$\$ 17.19$

$\$ 17.19$

PV of $\$ 28$ in 2001

$\frac{12.97}{4.22}$

8.25

NPV (Purchase)

8.94

Equivalent Annual

Lease Payment

Table VI-14 provides, in Future Value terms, the Federal Government Outcomes under the purchase and lease options, with different actual year 2001 prices. The 13 percent discount rate is used.

The payout in the year 2001 reflects the option price of $\$ 28$ per barrel. The net effects on the Federal Government are identical for leasing and purchasing relative to projected market prices. No risk is being shared with the lessor, since the option price is outside the range of expectations represented in the High and Low Case price projections.

For the lessor, the return is the same for all actual price outcomes, since, even under the Low Case assumptions, the actual price is expected to be above the 5 percent cap.

\section{B: Lessor Believes Low Case Prices}

In this example, the Federal Government believes in Base Case prices, but the lessor believes in Low Case prices. It will be recalled from prior examples that when the lessor has lower price expectations than the Federal Government, elthcr the lessor has a higher breakeven annual lease payment than that of the Federal Government or the lessor must have some combination of a lower discount rate or lower initial investment cost. 
Table VI-14

Federal Government Outcomes

FY 1991-2001 Lease With 5\% Cap (\$28 per barrel)

Future Value at $13 \%$

Purchase

Initial Purchase

Interest on Oil

Lease Payments

Interest on Lease

Subtotal

Payment in 2001

Base Case

Low Case

High Case

Total Cost

Net Cost (Gain)

Base Case (41.97)

Low Case (32.19)

High Case (52.32)
$\$ 17.19$

41.16

$---$

$\overline{\$ 58.35}$

$\underline{\text { Lease }}$
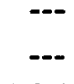

$\$ 16.48$

$\frac{3.87}{\$ 30.35}$

\begin{tabular}{cr}
$\cdots$ & $\$ 28.00$ \\
$\cdots$ & $\$ 28.00$ \\
-- & $\$ 28.00$ \\
\hline 58.35 & $\$ 58.35$
\end{tabular}

16.38

16.38

26.16

6.03

\section{Percent Cap}

A 10 percent cap is above both the Government's and the Low Case lessor's expectations. At the time the lease is arranged, neither party believes the cap will be binding, hence each pursues the course described in Part $A$ of Example 4. The only circumstances under which both parties could reach agreement on a breakeven lease payment would be if the lessor had either a lower initial oil cost or a lower discount rate than that of the Federal Government.

In the event that the lessor was correct and the Low Case oil prices prevailed, the Government would gain from the lease decision. The lessor would not lose, since its expectations had been borne out.

In the event that the Government was correct and Base Case prices prevailed, the Government would break even and the lessor would gain, in accordance with the estimates shown on Table VI-11. The 10 percent cap would not affect this outcome.

If both the lessor and the Government were wrong, and High Case prices actually prevailed, the 10 percent cap would moderate the gains to the lessor and the opportunity losses to the Government. The lessor would gain, in future value terms, the difference between its expected Low Case price of $\$ 32.19$ and the "cap" 
price of $\$ 44.59$, a net of $\$ 12.40$ per barrel. However, the lessor would not receive the additional $\$ 7.73$ increment between the cap price and the High Case price of $\$ 52.32$.

\section{Percent Cap}

In the case of a 5 percent cap which entails a maximum payback of $\$ 28$ to the lessor in the year 2001, even a lessor with Low Case price expectations will believe that the $\$ 28$ will be the actual outcome. So long as the lessor and the Government share the same discount rate requirements and initial oil values, both parties will have the same breakeven lease payments, notwithstanding the differences between the parties in terms of expectations for future prices. Thus one function of a low cap is to alleviate the effects of diversity of expectations.

Tablc VI-15 compares the breakeven lease payments of the Government (which adheres to Base Case prices) and the lessor, which believes in Low Case prices. For either discount rate, before a cap is imposed, the lessor would be unwilling to offer a lease payment acceptable to the Government. The "cap" increases the Government's breakeven payment to equal that of the lessor.

Table VI-15

Breakeven Lease Payments

Lessor Believes in Low Case Prices

(dollars per barrel per year)

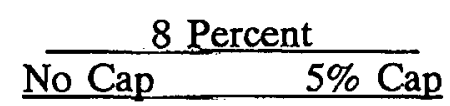

$(\$ .335)$

$\$ .340$
$\$ .629$

$\$ .629$

$\frac{13 \text { Percent }}{\text { No Cap } \quad 5 \% \text { Cap }}$

$\$ .889$

$\$ 1.648$

$\$ 1.420$ $\$ 1.648$

\section{C: Lessor Has High Case Expectations}

It will be recalled from previous examples that when the lessor has higher price expectations than the Federal Government, there is a broader range of cumdiliuns under which the Government and the lessor can arrive at a lease payment under which each expects to break even or actually gain from the lease transaction. The effect of a cap which is below the lessor's expectations is to reduce the range of "win/win" arrangements. As will be shown below, a very low cap can actually eliminate the opportunity for creating a win/win arrangement.

\section{Percent Cap}

From Table VI-12, it can be recalled that a lessor with High Case price expectations is projecting a year 2001 price of $\$ 52.32$ per barrel, whereas a 10 percent cap would result in a price of $\$ 44.59$ per barrel. For each discount rate, 
the breakeven lease payment, from the perspective of the lessor, would be higher than if there were no cap, but even this adjusted payment would be below that of the Federal Government, if it held to Base Case prices. Table VI-16 summarizes these initial breakeven payments for the parties:

Table VI-16

$$
\begin{aligned}
& \text { Breakeven Lease Payment Levels } \\
& \text { Lessor Believes High Case Prices } \\
& \text { (dollars per barrel per year) }
\end{aligned}
$$

Discount Rate

$\frac{8 \text { Percent }}{\text { No Cap } 5 \% \text { Cap }}$

USG

Lessor

\begin{tabular}{rr}
\multicolumn{2}{c}{13 Percent } \\
\hline No Cap & 5\% Cap \\
& \\
$\$ .889$ & $\$ .889$ \\
$\$ .327$ & $\$ .747$
\end{tabular}

The USG breakeven situation is unaffected by the cap, because the 10 percent cap is above the High Case price expectations. However, the cap increases the fee that the lessor demands or reduces the payment that the lessor would be willing to make, in both cases due to the reduction below the High Case in the expected payout at the end of the lease term.

When the lessor has higher price expectations than the Federal Government, but the same discount rate, then -- as shown in the "no cap" columns above -- there is an opportunity for mutual advantage, with the USG being willing to pay lease amounts at least as high as those demanded by the lessor. The effect of a price cap on the payout is to reduce this range of mutual advantage, but a 10 percent cap would not eliminate the range altogether.

\section{Percent Ciap}

A 5 percent cap would be considered even more constraining by a lessor which holds to High Case oil price expectations. Both the lessor and the USG would expect the cap at $\$ 28$ per barrel to be binding. Each would break even at the lease payments of $\$ .629$ per barrel ( 8 percent discount rate) and $\$ 1.648$ per barrel (13 percent discount rate) indicatcd for Examplc 6A abovc.

In sum, when a lessor has lower price expectations than the USG, a price cap can bring the parties closer together in arranging mutually acceptable terms. However, when a lessor has higher price expectations than the USG, a price cap can reduce the attractiveness of leasing. 


\section{EXAMPLE 7: Lease/Purchase Alternative}

One suggestion received by the Department over the course of the study was a lease/purchase alternative under which, at the end of the lease, the Department would own the oil in question. This alternative is analogous in form to setting a price cap which is below the price expectations of all participants, such as the 5 percent caps in Example 6, because there becomes a very high likelihood that the purchase option will be exercised. The difference is that, under this variation, purchase becomes a contractual certainty, rather than an option that could be later rejected by the Federal Government.

A key design variable would be how to structurc the cash flows: whether to seek a level payment over the term of the contract to amortize the principal or to have a "balloon" payment at the end to reflect principal, with intermediate payments reflecting only interest on the principal: In either case, the total payment of funds required would need to be appropriated in advance of the lease start date.

A second kcy variablc in this option is the purchase price to be paid for the oil. This could be set either at the market price at the time when the oil was delivered to the SPR or -- in the case of the balloon payment approach -- at some higher price such as the $\$ 28$ per barrel associated with the 5 percent cap discussed above.

Table VI-17 presents estimates of the annual payments required under each of these approaches, using an 8 percent discount rate. This discount rate appears to be the most relevant under this contract structure, since there is no price uncertainty for the lessor/seller.

\section{Table VI-17}

Lease/Purchase Approach

Annual Payments (\$/BBL)

10-Year Term Starting in FY 1991

\begin{tabular}{lcc} 
& \multicolumn{2}{c}{ Purchase Price } \\
& $\$ 17.19$ & $\$ 28.00$ \\
Amortization Approach & $\$ 2.562$ & NA \\
$\begin{array}{l}\text { Balloon Payment } \\
\text { Approach }\end{array}$ & $\$ 1.375$ & $\$ .629$ \\
& $\cdot$ &
\end{tabular}

Under the amortization approach, a total of $\$ 25.62$ is paid over the ten-year period, with no balloon payment at the end. The annual payment is thus akin to a mortgage at 8 percent, with increased proportions of the payment being attributable to principal over the life of the contract.

Under the balloon payment approach, one could set the final payment at $\$ 17.19$, the Base Case price for FY 1991, and then simply make interest payments at 8 
percent until the end of the contract. The total payments would equal $\$ 30.94$ per barrel, but the present value of these payments would be identical to that of the amortization approach.

Alternatively, one could set the balloon payment above the current oil price, with a lower payment in intermediate years. This defers some of the interest to the end of the contract period, in a manner similar to the "zero coupon" securities discussed in Chapter VII. This results in the highest aggregate value of payments (\$34.29), though it has the same present value as all of the other plans shown on Table VI-17.

\section{Summary of Deterministic Analysis}

The following are the major conclusions which can be drawn from Examples 1 through 7, each of which assumed that the participants (the Federal Government and the Lessor) had certain expectations about future oil price trends.

- Under the Base Case price path, which assumes oil price escalation in excess of the current ( 8 percent) interest rate on risk-free Federal borrowing, the Government would demand a negative oil lease payment to break even over the FY 1991-2001 period. This would be analogous to charging the lessor for storage, to permit price appreciation. (See Example 1)

- $\quad$ Since the rate of price appreciation is expected to tail off, under the Base Case forecasts, the longer the lease term, or the further into the future a ten-year lease is commenced, the higher the Federal Government lease payment (or the lower the Federal storage fee). (See Examples 1 and 2)

- Under High Case price expectations, the lease payments for leases with different start dates would start lower and end higher than under the Base Case. Under Low Case expectations, the lease payments would start higher and end lower than under the Base Case. These phenomena are attributable to the joint effects of differences in initial investment costs and expected rates of subsequent price appreciation. (Example 3)

- A lessor adhering to Low Case prices would require either a lower discount rate than the Federal Government or have access to lower-cost oil for delivery in order to break even under the same conditions whereby the Federal Government, if it adhered to Base Case prices, would expect to break even. (Example 4)

- Conversely, a lessor adhering to High Case expectations could have a higher discount rate than the Federal Government and still expect to break even. (Example 4). 
- Each one percent change in the Federal Government's discount rate results in approximately a $\$ .25$ per barrel per year change in the same direction in the breakeven Federal lease payment, under Base Case assumptions. Higher discount rates make the costs of a purchase/resale cycle higher, hence increase the equivalent lease payment (Example 5).

- While the Federal Government and the lessor may have different price expectations at the start of the lease and each may expect to break even, one or both may turn out to be wrong. On a life-cycle (net of resale value) basis, the purchase alternative could entail gains or losses of as much as 200 percent, but the lease approach transfers these risks and rewards to the lessor. (Example 5)

- $\quad$ Setting a cap on price appreciation may reduce some of the volatility in investment outcomes for both parties. If the cap is set relatively high, at a 10 percent price appreciation level, for example, it would tend to affect the breakeven position of only those lessors who adhered to High Case price expectations. However, even in this limited application, it would set boundaries on the potential profits foregone by the Government in employing the lease approach. (Example 6).

- $\quad$ Setting a lower cap at, for example, 5 percent annual appreciation) would bound the expectations of even lessors adhering to Low Case expectations, and would tend to close the gap between the Government's breakeven position and that of more bearish lessors.s. Positive lease payments of approximately $\$ .63$ per barrel would be associated with a Government breakeven position at an 8 percent discount rate, nearly approximating the payment which the Government would be willing to make -- with no price cap -- at a 12 percent discount rate. Thus setting a cap has the same effect as increasing the discount rate for the lessee.

- Under a lease/purchase approach, all uncertainty is removed regarding the amount to be paid for the oil, since the full terms and conditions are specified in the contract. 


\section{EXAMPLE 8: A Perpetuity}

Examples 1 through 7 all assume a definite, limited term for the investment analysis. Using the notations presented at the beginning of Section C, the purchase and lease alternatives have been compared, in present value terms, as follows:

$$
\begin{aligned}
& \mathrm{PV} \text { (Purchase) }=\mathrm{C}-\mathrm{PV}(\mathrm{Vm}) \\
& \mathrm{PV} \text { (Lease) }=\mathrm{PV}(\mathrm{L})-\mathrm{PV}(\mathrm{X})
\end{aligned}
$$

$\mathrm{PV}(\mathrm{Vm})$, in the purchase equation, is the present value of the future market value of the oil in question, while $\mathrm{C}$ is the initial oil price. PV (X) is the profit which the Government, as lessor, would realize at the end of the lease if the lease contract provided for a price cap which was lower than the actual future market price. Thus both formulations assume that either that the Government would actually sell the oil at the end of the investment period or would in some other manner realize the potential gain.

An alternative approach would be to assume that the time horizon for the investment analysis is infinite, because at least some quantity of SPR oil would be held in reserve for an indefinite period. Under this approach, the cost of the purchase alternative would converge toward the initial oil price $\mathrm{C}$ as the time period lengthens and the present value of the resale value $(\mathrm{Vm})$ approaches zero. $\mathrm{PV}(\mathrm{Vm})$ approaches zero over a long period of time if the rate of oil price growth is lower than the discount rate used in the present value analysis. As was seen in Example 1, the growth rate in the Base Case oil prices exceeds the 8 percent discount rate for a portion of the period under examination, but over the very long term, each of the three oil price cases has a compound growth rate of less than 8 percent.

For the lease alternative, the present value of the terminal value $\mathrm{X}$ would also approach zero over longer time periods, again, subject to the condition that $\mathrm{X}$ does not increase at a faster rate than the discount rate.

Accordingly, a lease would break even with a purchase when the present value of the lease payments (L) equaled the initial market price of the oil (C). For an infinite lease, the breakeven amount for $\mathrm{L}$ would be as follows:

$$
\mathrm{L} \text { (Brenkeven) }=\mathrm{C} \text { (Discount Rate) }
$$

In effect, the lease payment would simply represent the interest cost on the initial purchase price of the oil. The lease agreement would constitute what is termed a perpetuity, an investment comprised of a continuous series of periodic payments with no terminal payment reflecting recovery of principal.

Table VI-18 compares alternative lease payments under this alternative concept to those which have been presented in prior examples above. 
Table VI-18

Comparison of Definite and Indefinite Lease

\begin{tabular}{|c|c|c|c|c|c|c|}
\hline \multirow{2}{*}{$\begin{array}{l}\text { Start } \\
\text { Date }\end{array}$} & \multirow{2}{*}{$\begin{array}{c}\text { Term } \\
\text { (Years) }\end{array}$} & \multirow{2}{*}{$\begin{array}{l}\text { Price } \\
\text { Case }\end{array}$} & \multirow[b]{2}{*}{ Cap } & \multirow{2}{*}{$\begin{array}{l}\text { Disc. } \\
\text { Rate }\end{array}$} & \multicolumn{2}{|c|}{ Annual Payments } \\
\hline & & & & & Definite & Indefinite \\
\hline FY 1991 & 10 & Base & No & $8 \%$ & $(\$ .335)$ & $\$ 1.375$ \\
\hline FY 2001 & 10 & Base & No & 8 & 1.186 & 3.358 \\
\hline FY 1991 & 20 & Base & No & 8 & 147 & 1.375 \\
\hline FY 1991 & 10 & Base & No & 13 & .889 & 2.235 \\
\hline FY 1991 & 10 & Base & $5 \%$ & 8 & .629 & 1.375 \\
\hline
\end{tabular}

It should be noted that the amounts estimated for the indefinite lease represent breakeven levels from the Federal Government perspective under the assumptions shown, rather than an independent estimate of what the private sector would charge. However, these amounts may be illustrative of the amounts that would be offered by the private sector if the Government solicited lease proposals under a contract framework which implied that the Government would reserve the right, through a series of lease renewals at original fee levels, to renew the lease and thus defer the date of capital recovery. That is, just as the Government might be willing to pay a higher lease fee if it expected no measurable present value profit from the resale of purchased oil, the lessor would likewise seek to obtain a higher fee if it believed that its capital recovery would be delayed and that it could expect no appreciation in the value of its capital.

This suggests that one variable in the leasing approach is the likelihood that leased (or purchased) barrels would be drawn down and converted to cash through sale by the owner, whether the Government or the lessor. The Government faces such questions in making SPR development decisions, including determining the appropriate size of the Reserve. A lessor, however, is not necessarily concerned about the totality of the SPR oil inventory and the timing of its use in a disruption; rather, the lessor is concerned about the time horizon for capital recovery on its particular ownership interest. Therefore, in addition to the complex questions about the likelihood and timing of either an emergency SPR drawdown (or an eventual liquidation of the Reserve under non-disruption conditions if it is no longer needed), a lessor would face uncertainty as to whether, even if there were an SPR inventory drawdown, the Government would exercise its option to acquire the lessor's oil and thus provide for capital recovery.

The lease contract could include terms which would reduce the lessor's uncertainty. At one extreme, the contract could assure the lessor that its oil would be (or would be deemed to be) the last oil drawn down out of the SPR during an emergency, and other terms could make it highly likely that the Government would extend the lease contract beyond its initial term. With such conditions, a lessor would face less uncertainty, but would also tend to view the lease as a perpetuity investment as described above, with a commensurately higher annual payment. 
Alternatively, the lease contract could be very specific about (a) the use of the lessor's oil early in a disruption and (b) the lessor's ability to command a cash repayment, possibly bounded by a cap and/or a floor), at the end of the initial lease term. These types of provisions would likewise reduce investor uncertainty, but would tend to reduce the annual payment required by the lessor.

In Example 9 below, the question of how probabilities might bear on the economics of a lease is explored in more detail.

\section{EXAMPLE 9}

In prior examples, it has been noted that the lessor and the Federal Government might have divergent views as to the future price of oil, with consequent effects on the willingness of lessors to meet the Government's breakeven criteria. Example 4 dealt explicitly with the possibility that a lessor adhered to Low Case prices, reducing the range of circumstances under which both the lessor and the Government could achieve mutually satisfactory arrangements. Example 5 introduced the possibility of using higher discount rates as a way of recognizing uncertainty, and Examples 6 and 7 addressed the use of price caps or lease/purchase arrangements to help both parties cope with uncertainty.

\section{Probability Distribution A: Base Case Expected Value}

In this example, we are extending the analysis by broadening the range of possible price outcomes and assigning hypothetical probabilities to different market conditions. For Example 9A, a price probability distribution was developed, reflecting the following parameters:

- The expected value (probability-weighted average) of prices was approximately equal to the Base Case forecasts which have been used in prior examples.

- It was assumed that there was a 50 percent chance in any given year that the actual oil price would be between the High Case and Low Case forecasts. There would be a 25 pcrcent chance of exceeding the High Case, and a 25 percent chance of being below the Low Case.

- A lognormal probability distribution was used. This has the effect of an assymetrical probability distribution, as shown in Figure VI-6 below. This distribution reflects the view that there is a much longer tail of the probability distribution on the high price range than on the low price range, because there are more definite limits, due to production cost factors, on how low oil prices could drop. 
- At the outer boundaries of the distribution, there would be a 5 percent chance that the price by the year 2001 would be as high as $\$ 65$ per barrel and an equal chance that it would be below $\$ 15$ per barrel, in comparison to the expected price of $\$ 42.20$ per barrel, approximately the $\$ 41.97$ per barrel Base Case price for FY 2001 (Table VI-1).

For SPR oil leasing purposes, it is necessary to define circumstances, such as an emergency drawdown, that would involve exercise of purchase options before maturity. Two different definitions were used. First, it was assumed that the probability of early exercise was approximately 5 percent per year, which would reflect, for the year 2001, SPR use under the circumstances wherc oil prices had reached $\$ 67$ per barrel. Second, it was assumed that the chance of SPR use was about 1 percent per year, hence the equivalent price threshold in the year 2001 would be about $\$ 75$ per barrel.

Under this probability distribution, a series of breakeven lease payments for a ten year lease starting in FY 1991 can be calculated, depending on the probability of early exercise, the discount rate used, and the price cap established for limiting the capital recovery of a lessor. Table VI-19 presents the breakeven or indifference levels of annual lease payments for the Federal Government under these circumstances.

The amounts that the Government would be willing to pay with an 8 percent discount rate and a 5 percent lessor appreciation cap, are very similar to the $\$ .63$ per barrel annual payment for the 5 percent cap as presented in Example 6A, Table VI-13 above. However, in Example 6A, when the Federal Government held to Base Case price expectations, it was noted that the 10 percent cap would not have any effect on the Government's breakeven lease payment of (\$.336) as presented in Example 1, which was a deterministic approach. Yet when a probabilistic approach is introduced, the imposition of a price cap; even if it is above the most likely or expected case, would increase the lease payment which the Government would be willing to make.

An increase in the Govcrnment's discount rate, as previously discussed, will increase thc brcakcven lease payment that the Government would be willing to make. Price caps affect breakeven lease payments under any discount rate; but price caps can also be seen as complementing discount rate changes. Each onc pcrcent increase in the discount rate increases the Government's breakeven lease payments by approximately $\$ .20$ to $\$ .25$ per barrel per year, whereas each one percent increase in the cap rate of price increase tends to decrease the breakeven lease payment by $\$ .12$ to $\$ .17$ per barrel per year. 
Figure VI-6

Alternative Probability Distributions

FY 2001 Price Per Barrel
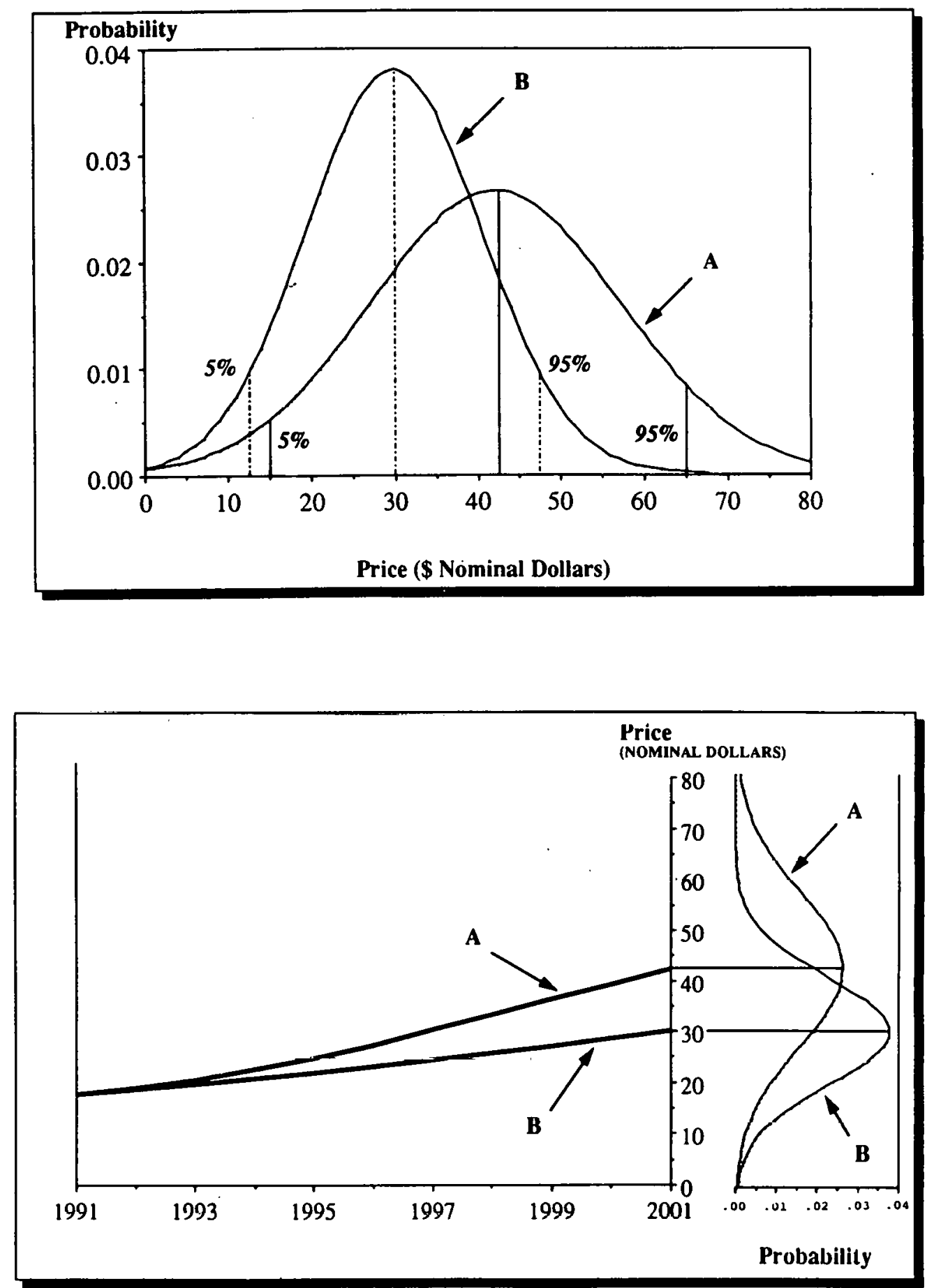
Table VI-19

Breakeven Annual Lease Payments

Year 1991-2001 Lease, Probability Distribution A

$\begin{array}{cccc}\begin{array}{c}\text { Discount } \\ \text { Rate }\end{array} & \begin{array}{c}\text { Probability of } \\ \text { Early Exercise }\end{array} & \begin{array}{c}\text { Cap } \\ \text { Rate }\end{array} & \begin{array}{c}\text { Lease } \\ \text { Payment }\end{array} \\ 8 \% & 1 \% & 5 \% & \$ .74 \\ 8 & 5 & 5 & .69 \\ 8 & 1 & 10 & (.01) \\ 8 & 5 & 10 & (.14) \\ 13 & 1 & 5 & 1.76 \\ 13 & 5 & 5 & 1.70 \\ 13 & 1 & 10 & 1.17 \\ 13 & 5 & 10 & 1.01\end{array}$

\section{Probability Distribution B: Low Case Expected Value}

For this example, a different price probability distribution was developed -- one in which the expected value of the price is closely aligned with the Low Case price path. Key parameters for this distribution, which is graphed on Figure VI-6, are as follows:

- The expected oil price in FY 2001, after the end of a 10-year lease, is $\$ 30$ per barrel, which compares to the Low Case price of $\$ 32.19$ per barrel.

- At the upper end, the 95th percentile is a price of $\$ 47$ per barrel.

- At the lower end, the 5th percentile is a price of $\$ 12$ per barrel.

As previously explained, lower oil price expectations increase the net present value of the costs of purchasing oil for the SPR, hence lower oil price expectations would also be accompanied by a higher breakeven lease payment from the Federal perspective.

Therefore, for each of the cases presented above in Table VI-19, the amount which the Government would be willing to pay to lease, rather than own, the oil would increase substantially.

Table VI-20 below, presents a revised set of breakeven annual lease payments for the FY 1991-2001 period, based on the probability distribution in Figure VI-6. Amounts in brackets reflect the comparable breakeven payment levels under the assumptions in Table VI-19, where price expectations were higher. 
Table VI-20

Breakeven Annual Lease Payments

Year 1991-2001 Lease, Probability Distribution B

$\begin{array}{cccccc}\begin{array}{c}\text { Discount } \\ \text { Rate }\end{array} & \begin{array}{c}\text { Probability of } \\ \text { Early Exercise }\end{array} & \begin{array}{c}\text { Cap } \\ \text { Rate }\end{array} & & \begin{array}{c}\text { Lease } \\ \text { Payment }\end{array} & \begin{array}{c}\text { From Table } \\ \text { VI-19 }\end{array} \\ 8 \% & 1 \% & & & & \\ 8 & 5 & 5 \% & \$ 1.05 & {[\$ .74]} \\ 8 & 1 & 5 & .94 & {[.69]} \\ 8 & 5 & 10 & .76 & {[(.01)]} \\ 13 & 1 & 10 & .64 & {[(.14)]} \\ 13 & 5 & 5 & 2.04 & {[1.76]} \\ 13 & 1 & 5 & 1.92 & {[1.70]} \\ 13 & 5 & 10 & 1.869 & {[1.17]} \\ & & 10 & 1.749 & {[1.01]}\end{array}$

Several different effects are evidenced in this table:

- Under the revised probability distribution (B), the breakeven lease payment level is not as sensitive as under probability distribution $\mathrm{A}$. The reason from this is that under distribution $B$, the chances of actually exceeding the caps are significantly reduced, so neither the lessor nor the Government would be as concerned over a change in the cap from 5 percent to 10 percent.

- Under the 5 percent cap alternatives, the shift in the probability distribution from $\mathrm{A}$ to $\mathrm{B}$ increased the breakeven lease payment by approximately $\$ .22$ to $\$ .31$ per barrel per year. With the 10 percent cap, the increase was more pronounced, from $\$ .69$ to $\$ .78$ per barrel per year. Again, this is due to the reduced sensitivity of payment levels upon the shift from $A$ to $B$.

- The effect of an increase in the discount rate from 8. percent to 13 percent remains about the same under $B$ as under A: approximately. a $\$ 1$ per barrel per year increase with a 5 percent increase in discount rate.

Both probability distributions reflect a high degree of uncertainty regarding future oil market conditions, and there is considerable overlap. Nevertheless, viewed from the perspective of an owner, or potential owner, of oil assets, distribution B is more conservative. 


\section{E. BUDGET ANALYSIS}

The purpose of this section is to compare the budgetary effects of an oil leasing approach to those of the current method of acquiring and financing SPR oil.

Under the current approach, the Department of Energy budgets for the principal cost of SPR oil. Budget authority is obtained for such purchases on an annual basis. In prior years, when the SPR was acquiring oil through a combination of term and spot contracts, the Congress followed the practice of providing the Department with sufficient budget authority in any given fiscal year to acquire half of the oil intended to be delivered in the subsequent fiscal year. Over time, this six months "advance orders" practice converted to a three month "advance orders" practice: Then, during the period in which the SPR acquired oil at flexible delivery rates only from Petroleos Mexicanos (PEMEX), the Congress adopted the practice of providing advance appropriations, in lieu of advance orders funding. The key difference is that instead of using, for example, FY 1989 appropriations to acquire oil for the first three months of FY 1990, the Congress provided, in the FY 1989 budget process, an advance appropriation for FY 1990 which became available on October $1,1989$.

Outlays follow relatively promptly after delivery. Under the PEMEX contract, the standard industry practice of paying within 30 days is followed. When this payment approach is combined with the advance appropriation approach described above, the SPR liquidates typically all but one month's equivalent of its appropriation in any given year.

For purposes of this analysis, it is assumed that even this one-month lag does not exist, such that SPR budget authority (BA) and budget outlays (BO) for oil are the same in each year, equalling a multiple of the price paid times the number of barrels delivered.

Under the current financing method, the Government pays for the vil delivered to the SPR from the General Fund, using an undifferentiated mix of current Federal revenues and borrowing proceeds. In the tables below, two different sets of budget aggregates are used for illustrative purposes -- direct DOE budget amounts, reflecting no interest charges for the purchase alternative, and total Federal cost amounts, which assume that Treasury is borrowing funds to meet SPR cash requirements, including requirements for lease payments.

Three different policy. alternatives are compared, all using Base Case price assumptions:

- $\quad$ Fill of the SPR at 75,000 barrels per day from FY 1991 through FY 2005, through direct purchases;

- $\quad$ Leasing SPR oil with an option to buy at the 5\% cap levels (termed "Lease/Option" approach); and

- Lease/purchase approach, using the amortization option presented in Table VI-17. 
For the Lease/Option approach, two variations for lease liquidation are shown, each applying to those barrels leased for ten years where the lease term expires before 2005: lease renewal for a further term and lease liquidation through purchase at the "cap price."

\section{(1) Lease/Option Versus Purchase}

\section{(a) Direct DOE Budget Effects}

Under the illustrative lease/option approach, the Department would make a fixed annual payment to the lessor for 10 years; during which period the Department would have the option to buy the oil (and thereafter cease making lease payments) at a price which would represent, for any given year, a five percent compound increase on the initial value of the oil. From Table VI-15, it will be recalled that at an 8 percent interest rate, using Base Case oil prices, the Department would break even at lease payments of $\$ .629$ per barrel per year from FY 1991 through 2001 . Table VI-21 presents the comparable charges for leases starting in each subsequent year.

In this analysis, it is assumed that the SPR fill rate is 75,000 barrels per day throughout the FY 1991-2005 period, achieving one billion barrels in storage. It is also assumed that the Department would be responsible for the additional costs of Cargo Preference Act compliance and the other elements of cost reflected in the so-called SPR Add-On as presented in Chapter V. Furthermore, it is assumed that to enter into such a lease, the Department would require, at the outset, budget authority sufficient not only for the SPR Add-On but also for the 10 years of lease payments.

\section{Table VI-21}

\section{DOE Breakeven Lease/Option Payments}

\begin{tabular}{cc} 
Start Date (FY) & Dollars/bbl/Year \\
\hline 1991 & $\$ 0.63$ \\
1992 & 0.66 \\
1993 & 0.72 \\
1994 & 0.81 \\
1995 & 0.90 \\
1996 & 1.01 \\
1997 & 1.12 \\
1998 & 1.24 \\
1999 & 1.34 \\
2000 & 1.43 \\
2001 & 1.54 \\
2002 & 1.65 \\
2003 & 1.76 \\
2004 & 1.86 \\
2005 & 1.98
\end{tabular}

Figure VI-7 illustrates the effects of these assumptions on the DOE's BA and Outlay BO profile during the FY 1991-2005 period if, at the end of each 10-year lease, the Department enters into a new lease, rather than exercise the purchase option. Throughout the period under analysis, both 
DOE's BA and its $\mathrm{BO}$ are lower, on an annual basis, than the budget cost for direct purchase (termed "Buy" in the Figure). The effects on BO are more pronounced, because the BA amounts include, for each year, the equivalent of 10 years of lease payments.

Starting in the year 2001, when the initial FY 1991 leases expire, the BA costs for leasing rise substantially, because in 2001, the Department would not only need to lease a further 75,000 barrels per day for delivery in FY 2001, but also arrange for the refinancing -- assumed here to be re-leasing -- of the oil delivered in FY 1991 under a 10-year lease/option contract.

Table VI-29 provides the annual BA and BO associated with this alternative.

It should be recalled that while the budget profile of the Lease/Option differs from that of a purchase, the Lease/Option illustration used is derived from an analysis indicating that the present values of the two alternatives are identical under the assumptions used. 
Figure VI-7

Annual Budget Effects of Lease/Option With No Purchase (75,000 bbl/d, FY 1991-2005)

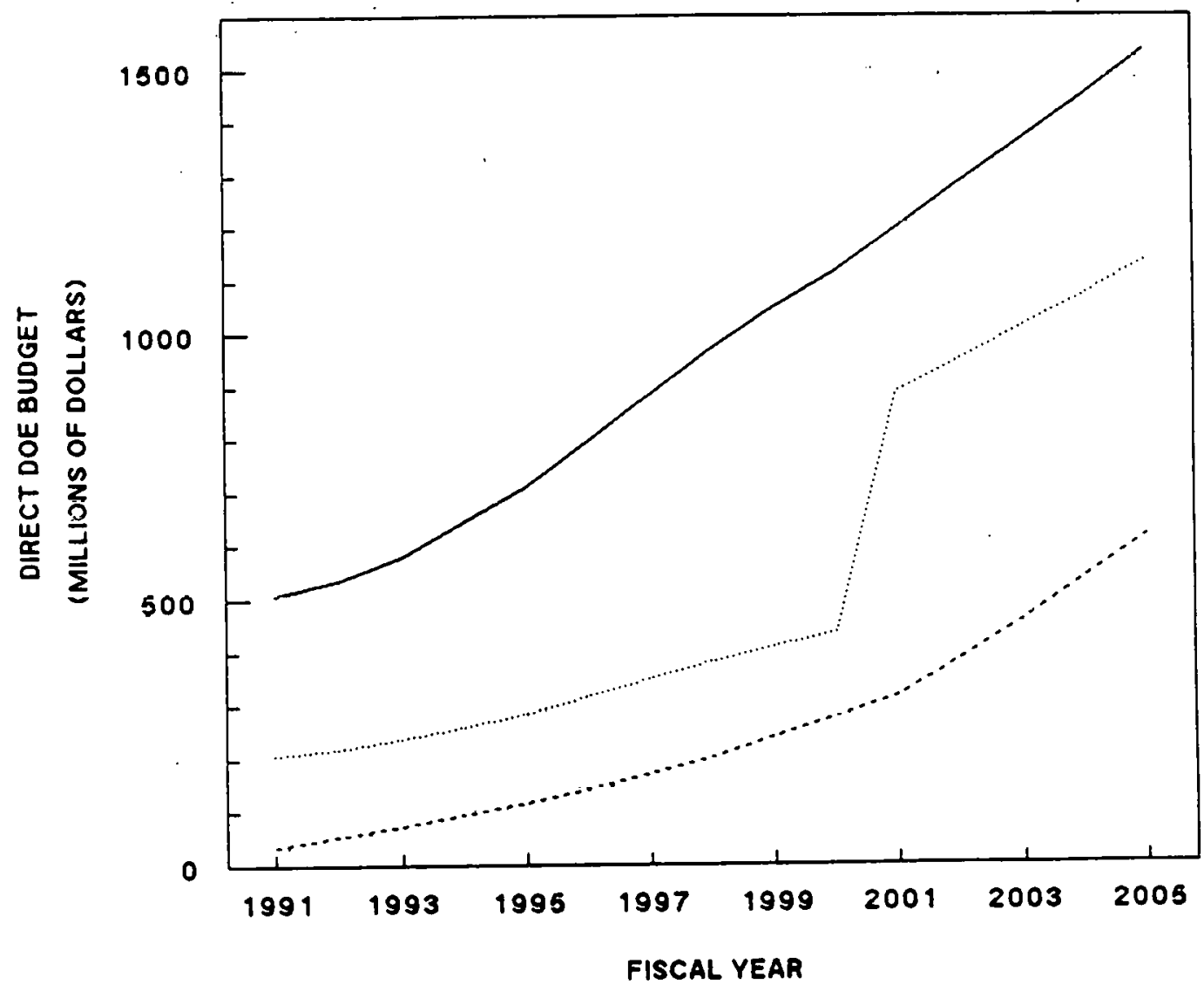

BUY (BA/Q)

LEASE/BO

LEASE/BA 
Overall, for this 15-year period, the cumulative direct DOE budget requirements would be as shown in Table VI-22. Annual amounts are displayed on Table VI-29.

Table VI-22

\section{Lease/Option Approach: Direct DOE Budget Requirements}

(FY 1991 - FY 2005, in Billions)

\begin{tabular}{lrr} 
& \multicolumn{1}{c}{$\mathrm{BA}$} & $\mathrm{O}$ \\
\cline { 2 - 3 } Purchase & $\$ 15$ & $\$ 15$ \\
Lease/Option a/ $^{\prime}$ & 8 & 4
\end{tabular}

a Assumes lease roll-over at the market rates in effect at time of original lcase expiration.

(b) Total Federal Budget Effects

Under the purchase alternative, since direct DOE outlays would be higher than for the lease, and because the lease payments are spread through time, the interest costs to the Treasury would be lower for the lease than for the purchase. Table VI-23 compares the interest costs and the total costs (principal and interest) for the purchase and the lease/option alternative.

Table VI-23

Lease/Option and Purchase Costs

(FY 1991 - FY 2005)

(Total USG Outlays in \$ Billions)

\begin{tabular}{lrr} 
& $\underline{\text { Interest }}$ & Total \\
Purchase & $\$ 10$ & $\$ 25$ \\
Lease/Option a/ & \\
& & \\
\hline a/ Assumes lease roll-over. &
\end{tabular}

Thus cumulative Federal outlays through the year 2005 under the lease approach could be as little as one-fourth the cost of direct purchase, for the same amount of oil delivered to the SPR. 
However, under the lease/option approach shown above, the Government would not own any of the oil delivered to the SPR after FY 1990, whereas the Government acquired full ownership of more than 400 million barrels under the direct purchase approach.

A hybrid approach, combining some of the effects of the lease/option and purchase approaches discussed above would be for the Federal Government to begin acquiring the oil at the option prices as each ten-year lease expired. Thus over the period FY 2001 through 2005, the Department would liquidate a portion of its lease obligations through payments to the lessors on the first 137 million barrels (five years @ 27.4 million barrels or 75,000 barrels per day). delivered after FY 1990. Figure VI-8 presents the annual budget authority and outlay profile under this approach.

The spending levels through FY 2000 for this approach would be the same as for the lease/option alternative illustrated in Figure VI-7. In the year 2001, the Government would start making large payments to acquire the oil on expiring leases at the predefined "cap" prices which, it will be recalled, would be substantially below the current Base Case prices forecasted for that period. In order to take advantage of these attractive purchase opportunities, however, annual spending levels would have to increase dramatically, to as much as $\$ 1.7$ billion in the year 2005 . Table VI-24 provides estimates of the 15-year budget requirements, both direct DOE and total Federal requirements, under this approach. Table VI-29 provides estimates for each fiscal year.

Table VI-24

Lease/Option Budget Requirements Assuming Purchase After 10 Years

(FY 1991-2005; \$ Billions)

$\begin{array}{crrc} & \text { DOE } & \text { Interest } & \text { Total } \\ \text { Purchase } & & & \\ \text { BA } & \$ 15 & \$ 10 & \$ 25 \\ \text { BO } & 15 & 10 & 25 \\ \text { Lease/Option } & & & \\ \text { BA } & \$ 10 & \$ 3 & \$ 13 \\ \text { BO } & 8 & 3 & 10^{2 /}\end{array}$

a/ Row does not add due to rounding. 
Figure VI-8

Budget Effects of Lease

(Purchase After 10 Years)

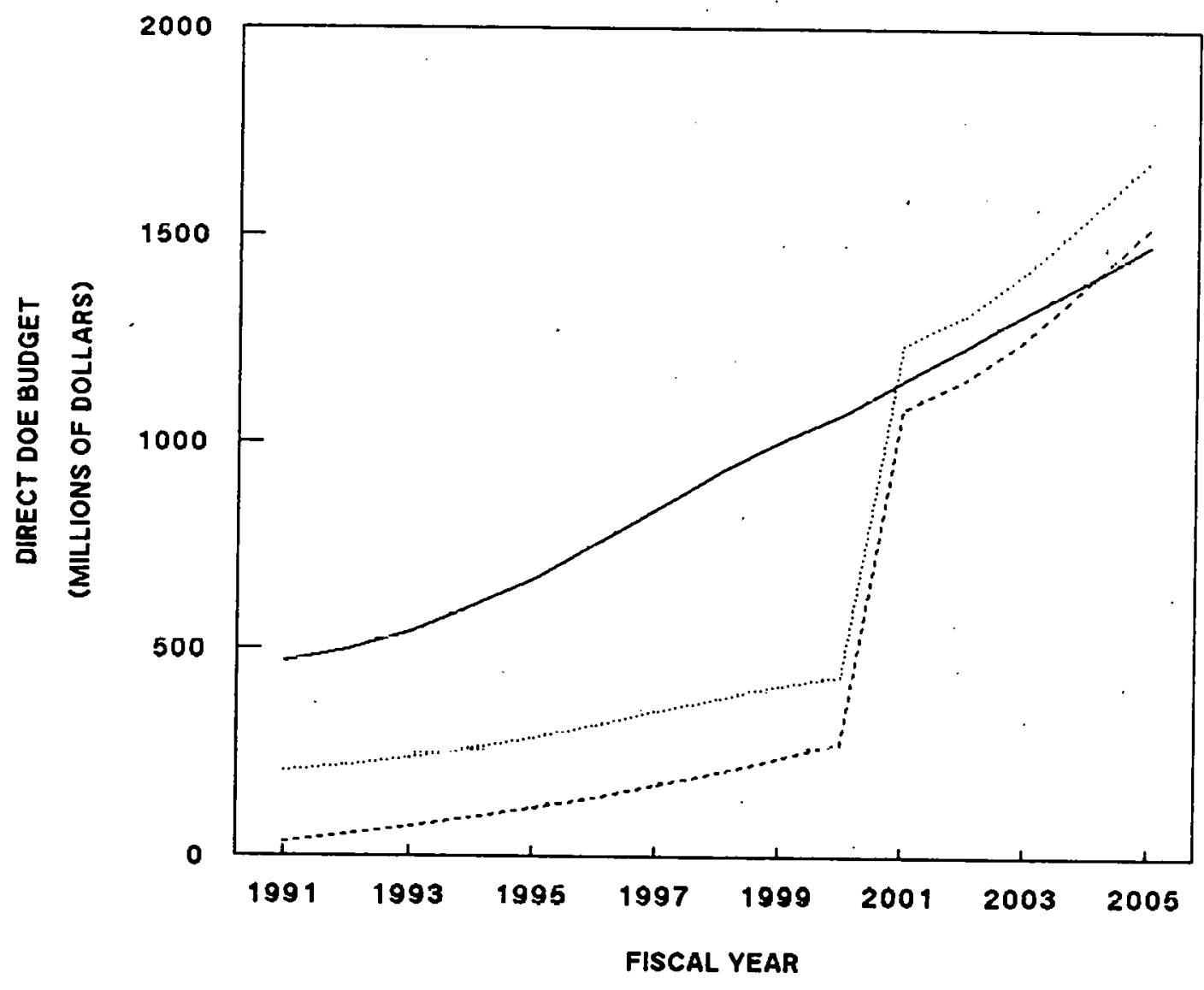

BUY (BA/O)

LEASE/BO

LEASE/BA 
In terms of direct DOE budget effects, the costs of the lease/option approach are nearly equivalent to those of direct purchase. The differences between these alternatives are two-fold:

(1) Since the DOE outlays are deferred in time under the lease/option method, the Treasury interest costs are lower, and

(2) Under the lease/option approach, DOE has acquired full ownership of only one-third of the barrels which have been delivered. DOE has a contingent claim on the remaining barrels, but not full ownership.

In budget costs for lease/option with purchase after 10 years are higher than those for lease/option with no purchase. For example, in FY 2001, when the first ten-year lease expires, with no purchase of the oil, the Department would need an estimated $\$ 889$ million in budget authority, not only to lease the $27.4 \mathrm{MMB}$ delivered in FY 2001 but also to renew a lease, directly or by exchange, of the 27.4 MMB leased originally in FY 1991. However, if the FY 1991 lease/option contract ended with exercise of the purchase option of $\$ 28$ per barrel, a total of $\$ 1,235$ million on BA would be needed in FY 2001. Outlays for the purchase would occur immediately with consequent effects on Treasury borrowing costs.

In sum, the budget effects of the lease/option approach are determined by future decisions on whether and when to exercise the options. Under the Base Case price assumptions, the Department would presumably want to exercise the options, which have been structured to result in an exercise price below projected market prices. However, to avoid losing the economic value of the cptions, the Department would require very substantial amounts of budget authority.

If options are exercised as leases mature, the overall $\mathrm{DOE}$ budget requirements for a lease are still less than those for full purchase. The budget savings from the lease approach accrue to the Treasury in the form of lower borrowing requirements because of the deferral of DOE payments within the period.

\section{(2) Lease/Purchase Versus Purchase}

\section{(a) Direct DOE Budget Requirements}

Under this policy approach -- following the amortization method -- there would be no uncertainty as to whether and when the Department would acquire title to the oil, nor would there be uncertainty as to the purchase price. However, the cash outlays for the purchase would be spread over time and would include payment for principal as well as imputed interest.

Table VI-25 presents the per-barrel costs for the lease/purchase approach, assuming Base Case oil prices, an 8 percent interest rate, and a 10-year amortization period.

As was true for the lease/option analysis above, we are assuming that the Department would be responsible for the payment of the SPR Add-On amounts previously discussed.

The effect of the lease/purchase method is to stretch out DOE cash payments, but also to internalize into the DOE budget much of the interest costs which would be borne by the Treasury 
under the direct purchase option. Since we are continuing to assume that the DOE would need sufficient budget authority to make these payments over the ten-year contract life, the lease purchase method requires the Department to have much more BA on an annual basis than would be required under the direct purchase approach.

\section{Table VI-25}

Annual Per Barrel Costs for Lease/Purchase

\begin{tabular}{cr} 
Fiscal Year & \$/BBL Pay \\
\cline { 2 - 2 } 1991 & $\$ 2.56$ \\
1992 & 2.71 \\
1993 & 2.94 \\
1994 & 3.29 \\
1995 & 3.65 \\
1996 & 4.10 \\
1997 & 4.57 \\
1998 & 5.05 \\
1999 & 5.46 \\
2000 & 5.82 \\
2001 & 6.25 \\
2002 & 6.71 \\
2003 & 7.16 \\
2004 & 7.59 \\
2005 & 8.05
\end{tabular}

Figure VI-9 displays the annual requirements over the FY 1991-2005 period. Annual BA requirements for lease purchase are approximately fifty percent higher than those for purchase, for the same 75,000 barrels per day fill rate. However, the outlay requirements start out lower than those for a purchase, crossing over after the year 2000 to exceed purchase requirements. For example, in the year 2000 the Department would still be making annual payments on all oil delivered in the previous nine years, and these payments would begin to exceed the annual costs of dircct purchase.

Because we have assumed that interest rates and oil prices would be the same for the direct purchase and lease/purchase options, the total economic costs to the Federal Government would be the same. However, such costs would be redistributed both between the Treasury and the Department of Energy and over time. Table VI- 26 presents the cumuiative budget requirements through the year 2005 under each option, and amounts for individual years are provided on Table VI-29. 
Figure VI-9

Budget Effects of Lease/Purchase

(Purchase Over 10 Years)

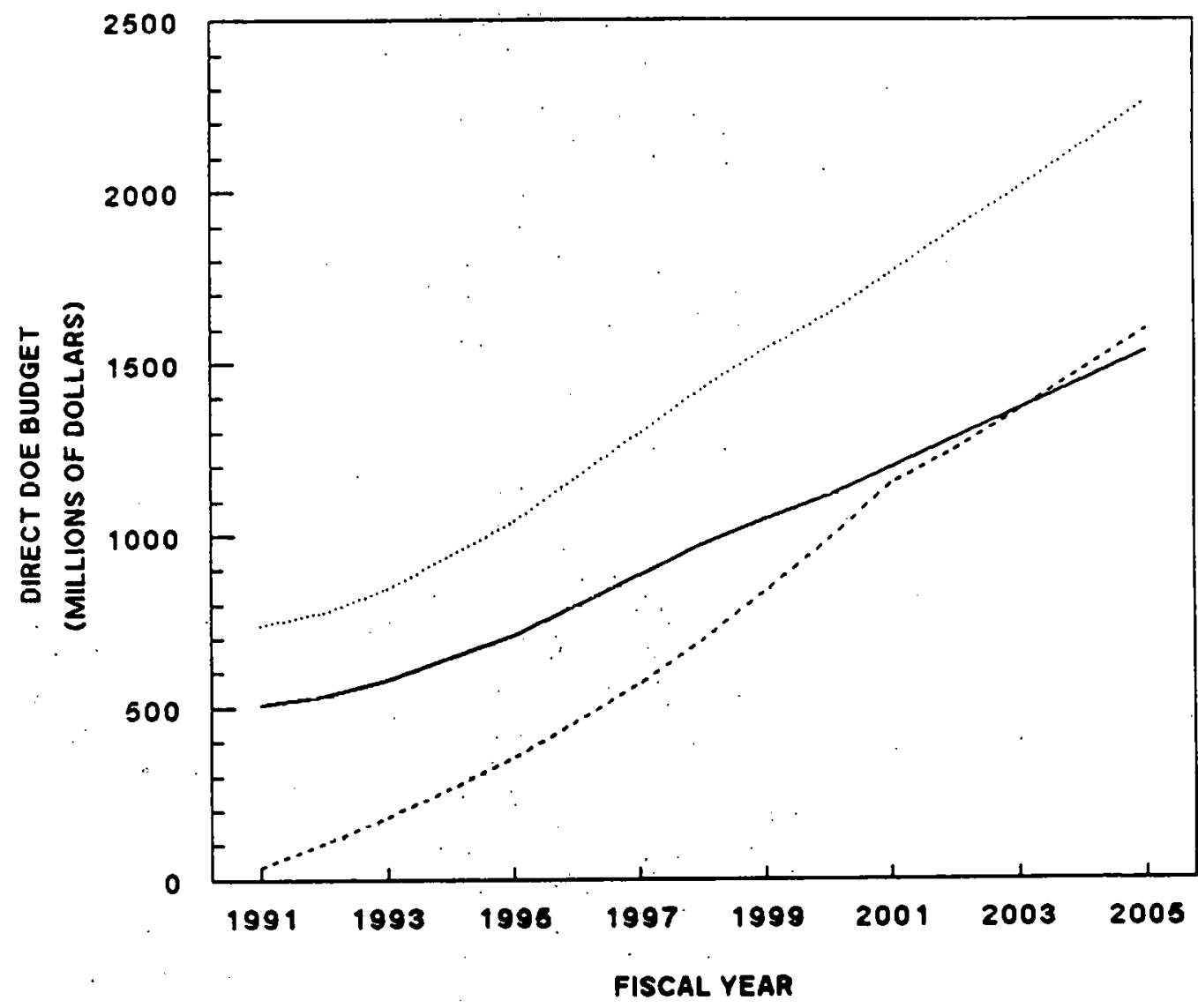

BUY (BA/O)

L/P 80

L/P BA 
Table VI-26

Budget Requirements for Lease/Purchase Option ( $\$$ in Billions, FY 1991-2005)

\begin{tabular}{|c|c|c|c|}
\hline & $\underline{D O E}$ & $\begin{array}{l}\text { Treasury } \\
\text { Interest }\end{array}$ & Total \\
\hline $\begin{array}{l}\text { Purchase } \\
\text { Lease/Purchase }\end{array}$ & $\$ 15$ & $\$ 10$ & $\$ 25$ \\
\hline $\mathrm{BA}$ & $\$ 21$ & $\$ 5$ & $\$ 27^{a /}$ \\
\hline
\end{tabular}

a/ Row does not add due to rounding.

BA under the lease/purchase approach is higher than under direct purchase because the contracts provide for ten year's worth of interest, hence some contracts include interest beyond the year 2005 date of the analysis. DOE outlays, including the indirect interest payments included therein, approach the cost of direct purchase, but total USG outlays are reduced because the DOE budget has assumed part of the interest payments which Treasury would otherwise bear.

Under the lease/purchase approach, DOE would not have completed payment for all of the oil by the year 2005 -- another $\$ 10$ billion remains to be paid if all contracts run to term. However, if DOE has the option to liquidate the obligations by paying remaining principal amnunts, by the year 2005 it would have acquired ownership interests as follows:

Table VI-27

Lease/Purchase Approach

USG Equity in 2005

Year of Delivery MBB

Owned in 2005

FY $91-95$

FY 1996

FY 1997

FY 1998

FY 1999

FY 2000

FY 2001

FY 2002

FY 2003

FY 2004

TOTAL 


\section{(3) Comparison of Financing Approaches}

In this section, we have taken three financing approaches with similar net present value economics and compared the budget effects. The one way in which the alternatives are dissimilar is that the nature and extent of the Federal Government's ownership interest in the oil varies. The following Table VI-28 summarizes the findings, and Table VI-29 provides year-by-year amounts.

Table VI-28

Budget Effects: Comparison of Lease/Purchase Financing Options

$\begin{array}{cccc}\text { Direct } & \text { Lease } & \text { Lease } & \\ \text { Option/No } & \text { Option/ } & \text { Lease } \\ \text { Purchase } & \underline{\text { Purchase }} & \underline{\text { Purchase }} & \text { Purchase }\end{array}$

DOE Budget

Thru 2005 (billion\$)

BA

$\$ 15$

BO

$\$ 8$

$\$ 10$

$\$ 21$

8

Total USG Budget

Thru 2005 (billion\$)

BA

25

$\$ 10$

$\$ 13$

$\$ 27$

BO

25

6

10

17

Oil Owned (MMB)

$411^{\mathrm{a} /}$

0

137

260

Contingent Claim

on Oil (MMB)

0

411

274

151

a/ For purposes of this analysis, it was assumed that 27.4 million barrels in annual deliveries occurred under each option for a full 15 years.

The lowest budget profile is for the lease/option approach under which it was assumed that the Government would not, at least within the period of analysis, exercise its purchase rights. It should be noted that the annual fee for this option was calculated for a Federal breakeven position with exercise of the option, so by assuming no exercise, the Government has either foregone a potential profit or managed in some manner to have the lessor account for this non-exercise in its lease extension or roll-over terms. 
Table VI-29

Budget Effects of Leasing
FY 1991 through FY 2005
(Dollars in Millions)

$\begin{array}{lllllllllllllll}\text { FY } & \text { FY } & \text { FY } & \text { FY } & \text { FY } & \text { FY } & \text { FY } & \text { FY } & \text { FY } & \text { FY } & \text { FY } & \text { FY } & \text { FY } & \text { FY } & \text { FY }\end{array}$

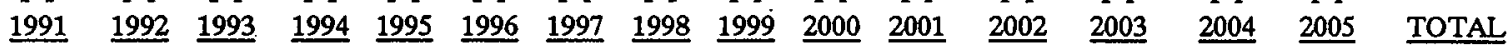

\section{Direct Purchase (Current Method)}

\begin{tabular}{|c|c|c|c|c|c|c|c|c|c|c|c|c|c|c|c|c|}
\hline DOE B $\Lambda$ & 507 & 535. & 580 & (1444 & 710 & 795 & $8 R 3$ & 972. & 1nas & 1116 & 1187 & 1283 & 1366 & 1117 & 1534 & 14617 \\
\hline \multicolumn{17}{|l|}{ Treasury } \\
\hline BAVO & 20 & 64 & 113 & 171 & 239 & 318 & 411 & 518 & 640 & 778 & 933 & 1107 & 1301 & 1518 & 1758 & 9889 \\
\hline \multicolumn{17}{|l|}{ Total } \\
\hline BA & 527 & 599 & 693 & 815 & 949 & 1113 & 1294 & 1490 & 1688 & 1894 & 2130 & 2390 & 2667 & 2965 & 3292 & 24506 \\
\hline 0 & 527 & 599 & 693 & 815 & 949 & 1113 & 1294 & 1490 & 1688 & 1894 & 2130 & 2390 & 2667 & 2965 & 3292 & 24506 \\
\hline \multicolumn{17}{|c|}{ Lease/Option Without Purchase } \\
\hline DOE BA & 208 & 219 & 236 & 260 & 285 & 316 & 350 & 383 & 411 & 437 & 889 & 950 & 1013 & 1072 & 1137 & 8166 \\
\hline DOE BO & 36 & 54 & 74 & 94 & 117 & 142 & 171 & 203 & 239 & 277 & 317 & 384 & 459 & 537 & 619 & 3724 \\
\hline \multicolumn{17}{|l|}{ Treasury } \\
\hline \multicolumn{17}{|l|}{ Total } \\
\hline 0 & 38 & 60 & 81 & 112 & 145 & 183 & 228 & 279 & 339 & 405 & 480 & 588 & 713 & 851 & 1004 & 5509 \\
\hline \multicolumn{17}{|c|}{ Lesase/Option Then Purchase } \\
\hline DOE BA & 208 & 219 & 236 & 260 & 285 & 316 & 350 & 383 & 411 & 437 & 1235 & 1309 & 1413 & 1548 & 1687 & 10297 \\
\hline DOE BO & 36 & 54 & 74 & 94 & 117 & 142 & 171 & 203 & 239 & 277 & 1084 & 1153 & 1254 & 1388 & 1524 & 7811 \\
\hline \multicolumn{17}{|l|}{ Trcasury } \\
\hline BA/O & 1 & 5 & 11 & 18 & 28 & 41 & 57 & 76 & 100 & 129 & 193 & 298 & 418 & 557 & 719 & 2652 \\
\hline \multicolumn{17}{|l|}{ Total } \\
\hline BA & 210 & 224 & 247 & 278 & 313 & 357 & 407 & 459 & 511 & 566 & 1428 & 1607 & 1831 & 2105 & 2406 & 12949 \\
\hline
\end{tabular}

Lease/Purchase

\begin{tabular}{|c|c|c|c|c|c|c|c|c|c|c|c|c|c|c|c|c|}
\hline DOE BA & 738 & 779 & 845 & 941 & 1039 & 1164 & 1295 & 1427 & 1540 & 1641 & 1761 & 1887 & 2011 & 2131 & 2260 & 21459 \\
\hline \multicolumn{17}{|l|}{ Treasury } \\
\hline $\mathrm{BA} / \mathrm{O}$ & 1 & 7 & 19 & 39 & 67 & 105 & 154 & 217 & 295 & 392 & 509 & 645 & 801 & 979 & 1180 & 5410 \\
\hline \multicolumn{17}{|l|}{ Total } \\
\hline BA & 739 & 786 & 864 & 980 & 1106 & 1269 & 1449 & 1644 & 1835 & 2033 & 2270 & 2532 & 2812 & 3110 & 3440 & 26870 \\
\hline 0 & 38 & 115 & 202 & 303 & 421 & 560 & 723 & 913 & 1131 & 1379 & 1656 & 1894 & 2162 & 2457 & 2778 & 16732 \\
\hline
\end{tabular}




\section{(4) Possible Fill Rate Effects}

All of the budget analysis above assumes that the SPR fill rate does not vary with the financing approach; a 75,000 barrels per day fill rate is assumed in all cases. However, as noted in Chapter I, it is conceivable that the Congress and the President would agree to a set of budget targets for the Reserve and then let the fill rate adjust to the types of terms and conditions which the Department was able to achieve through an alternative financing approach, such as oil leasing. In assessing this eventuality, assumptions are needed as to the following variables:

- The level and timing of the SPR oil budget constraint;

- Decision on whether the constraint applied to BA or $\mathrm{BO}$;

- Sclection between the structural alternatives presented above.

For purposes of illustration, it is assumed that the SPR has a one-time BA constraint of $\$ 3$ billion, which is approximately the total required, under Base Case assumptions, to achieve 75,000 barrels per day fill over the FY 1991-1995 period, or approximately 138 million barrels. A BA constraint was selected for this illustration because, with unconstrained BA but constrained BO, the Department theoretically could acquire an unlimited amount of oil on a simple deferred payment approach. A fill capacity constraint of 150,000 barrels per day was assumed. Table VI-30 compares the amounts of oil which could be acquired under the lease/option approach.

Table VI-30

\section{Maximum SPR Delivery for $\$ 3$ Billion Budget Authority Lease/Option Approach}

$\begin{array}{cccc}\text { FY } & \frac{\text { Deliveries }}{(\mathrm{MMB})} & \frac{\mathrm{BA}}{(\$ \mathrm{MM})} & \frac{\mathrm{BO}}{(\$ \mathrm{MM})} \\ 1991 & 54.8 & \$ 418 & \$ 72 \\ 1992 & 54.8 & 434 & 109 \\ 1993 & 54.8 & 471 & 147 \\ 1994 & 54.8 & 522 & 188 \\ 1995 & 54.8 & 572 & 233 \\ 1996 & 50.4 & 583 & 278\end{array}$

A total of 324 million barrels could be obtained under the $\$ 3$ billion BA constraint. Annual outlays would increase steadily throughout the period as additional annual payment obligations were incurred. After FY 1996, but before leases expired in FY 2001, a steady state outlay level of approximately $\$ 255$ million per year would be achieved. The U.S. Government would not own any of the oil in question, but would have achieved a cumulative fill level that was 186 million barrels higher than under the direct purchase method:

Under the lease/purchase approach, with amortization of the purchase cost, the $\$ 3$ billion would permit the acquisition of only 108.4 million barrels, less than even the direct purchase alternative. This is because the lease/purchase option internalizes the interest costs on the SPR into the DOE 
budget along with the principal. The following table summarizes the near-term effects of this option.

Table VI-31

\section{Maximum Acquisition from \$3 Billion BA Lease/Purchase Method}

FY Deliveries

1991

1992

1993
(MA

54.8

53.6

0 $\frac{\text { Use }}{(\$ M M)}$

$\$ 1476$

1577
$\underline{B O}$

$(\$ \overline{M M})$

$\$ 72$

213

285

Annual outlays of $\$ 285$ million would be made through the end of the decade, at which time the Federal Government would own the oil.

\section{d. Summary Of Cost Analysis}

The following are the major findings and conclusions of this analysis, as regards the financial and budgetary effects of SPR oil leasing.

- The amount of the annual lease payment could vary substantially, based on such variables as start date, term, the parties' expectations as to future oil prices, discount rates, lease conditions regarding caps or other limits on capital recovery, and the nature of any Federal equity interest which is acquired as a result of the lease payments Table VI-32 provides examples of combinations of circumstances that could lead to lease payments in different ranges.

- In general, the following factors tend to increase Federal Government lease payment levels equivalent to purchase costs:

-- Later leases (in terms of starting dates)

-- Longer leases

-- Lower future oil price expectations

-- Higher discount rates

-- Lower price appreciation caps

-- $\quad$ Higher Federal equity acquisition

-- $\quad$ Less definite capital recovery point 
Table VI-32

\section{Alternative Breakeven USG Payment Levels}

\section{Payment Range}

(\$/bbl/year)

\section{Conditions}

Lessor Pays USG - FY 1991-2001 lease @ 8\% discount, no cap on price appreciation, High or Base Case expectations.

- Lessor has Low Case expectations, but either access to low-cost oil or funds.

No Payment $\quad$ - FY 1996-2006 lease @ 8\% discount, no cap on price appreciation, Base Case expectations.

- FY 1991-2001 lease @ 8\% discount, no cap, Low Case expectations, or Base Case with 9-10\% discount rate.

- FY 1991-2008 lease @ 8\% discount, no cap, Base Case expectations.

- FY 1991-2001 lease, 8\% discount, 10\% cap, Base Case expectations with Probability Distribution A.

$\$ 0$ to $\$ .50$

- 10-year lease @ 8, Base Case or High Case expectations, late 1990's.

- 10-year lease in early 1990's @ 10-12\% discount rate, Base Case expectations.

$\$ .50$ to $\$ 1.00$ - FY 1991-2001 lease @ 13\% discount, no cap, Base Case expectations.

- FY 1991-2001 lease @ 8\% discount, with 5\% cap, Base Case expectations or Probability Distribution A.

$\$ 1.00$ to $\$ 1.50 \quad-$ Indefinite lease starting in FY $1991(8 \%$

- FY 1991-2001 lease with 10\% cap, $13 \%$ discount rate, Probability Distribution A expectations.

- FY 1991-2001 lease with 5\% cap, 8\% discount rate, Probability Distribution $\mathrm{B}$.

$\$ 1.50$ to $\$ 2.00 \quad$ - FY 1991-2001 lease @ 13\% discount, with 5\% cap, Base Case expectations.

- FY 1991-2001 lease@ @ 13\% discount, with Low Price expectations, with 5\% cap.

- FY 1991-2001 lease with 5\% cap, $13 \%$ discount rate, Probability Distribution A expectations.

- FY 1991-2001 lease with $10 \%$ cap, $13 \%$ discount rate, and Probability Distribution $\mathrm{R}$ expectations.

$\$ 2.00$ to $\$ 3.00 \quad$ - Amortization of FY 1991 lease/purchase @ 8\% in early 1990's.

- Indefinite FY 1991 lease @ 13\% discount.

- The budgetary effects of lease/option approaches, in comparison to outright purchases, are as follows: 
- The budgetary effects of lease/option approaches in comparison to outright purchases, are as follows:

-- Near-term outlays are lower than for purchase;

-- Some reduction in budget authority, but not as significant as effects on cash outlays; Transfer of principal cost from the DOE to the lessor, but transfer of interest cost from the Treasury to the DOE;

-- Federal Government can control more oil in the nearterm from a fixed amount of budget authnrity than under purchase approach;

-- Significant out-year requirements if the USG wishes to continue the SPR through lease renewal or exercise of purchase options.

- Compared to the lease/option method, the budgetary effects of lease/purchase approaches are as follows:

-- Higher near-term outlays (to include amortization)

-- $\quad$ Significantly higher BA, since the DOE budget would cover both principal and interest;

-- Possibly a lower effective interest cost because of reduced lessor uncertainty on payback;

-- Less oil controlled (but more USG equity) for a given amount of budget authority.

\section{Non-Financial Evaluation Factors}

The purpose of this subsection is to summarize the effects of the oil leasing approach on the last four of the evaluation criteria set forth in Chapter I.

\section{a. Orderly Development of the Naval Petroleum Reserve}

SPR oil leasing alternatives are essentially independent of decisions regarding the Naval Petroleum Reserves, as addressed in Chapter VII. One could lease oil through the use of a varicty of funding sources, including either the NPR net revenues in a revolving finnd or the proceeds from some form of NPR privatization.

As such, SPR oil leasing appears to have no direct effects on the Naval Petroleum Reserves.

\section{b. Minimize U.S. Vulnerability to Oil Supply Disruptions}

It is possible for the oil leasing method to either reduce or increase the vulnerability of the United States to a major energy supply interruption. 


\section{(1) Potential to Reduce U.S. Vulnerability}

- Oil leasing could increase the amount of the strategic oil inventory under the control of the President in the near-term, particularly if budget authority levels were adjusted to accommodate the outlay stretch-out associated with this financing method.

- Oil leasing agreements could create a relationship of trust between lessors and the Federal Government. If oil leasing with major producers led toward an enhanced degree of cooperation in energyrelated matters, it is conceivable that this acquisition method could create the basis for a reduction in the risks of supply interruption.

\section{(2) Potential to Increase U.S. Vulnerability}

- Some forms of oil leasing could give lessors an important financial stake in USG decisions on whether and when to use the SPR and create constituencies for particular USG policy responses. In the case of foreign oil-producing nations who wcre lessors, it is hypothetically possible that ownership of oil inventories in the U.S. would tend to create a financial incentive to take actions that would cause significant price growth. These issues could be dealt with in a number of ways through contract provisions, including price appreciation caps.

- There is the potential, under certain conditions, for the amounts of oil being added to the SPR through leasing to be partially offset thorough reduction in other oil inventories, whether held by the U.S. private sector or by international oil companies. The potential for such offsetting effects could be minimized by contract tcrms.

\section{c. Minimization of Impacts in Market Forces}

Two different leasing approaches have been described in this Chapter. In one case, the Department would issue competitive solicitations for oil leases; in another case, the Department would negotiate lease provisions directly with a major oil-producing nation.

If the use of the oil leasing approach caused the Government to increase the fill rate of the SPR, oil leasing could be deemed to have some effect, albeit very minor, on the demand for -- and hence price of -- oil. It should be noted, however, that this effect derives from the fill rate, rather than from the financing method itself.

This effect could be offset by any incremental production which became available as a result of the SPR leasing method. In the case of SPR oil leasing from a major oil-producing nation with excess production capacity, it would be possible for enough additional oil to be produced not only to alleviate the effects of incremental SPR fill, but also to offset the base level of SPR fill that would be associated with continued direct purchases at lower rates. 


\section{d. Encouragement of Competition in the Petroleum Industry}

Use of an oil leasing approach is unlikely to have identifiable effects on the structure of the petroleum industry.

\section{F. LEGISLATION TO AUTHORIZE OIL AND FACILITIES LEASING}

Public Law No. 101-46 requires that this report contain "a draft of the legislative changes that would be necessary to authorize the most significant alternative financial arrangements studied by the Secretary [of Energy] (including long-term leasing of crude oil and storage facilities) . . . ." Section (b)(2). The law also requires that the Secretary provide his "recommendations ... with respect to the need for and desirability of such financial arrangements (including long-term leasing of crude oil and storage facilities)." Id. However, the requirement for "recommendations" is separate from the requirement for a "draft of the legislative changes that would be necessary."

The purpose of this section is to fulfill the statutory obligation to furnish a draft of the legislative changes that, in the estimation of the DOE, would be necessary in order to authorize the long-term "leasing" $2 /$ of crude oil and storage facilities. The draft provisions which follow are not, and should not be confused with, "recommendations" of the Secretary; neither should they be construed as indicative of the attitude of the DOE as to the feasibility or desirability of undertaking such leasing. Rather, what follows is a statutorily mandated "drafting service," by which the DOE is providing the Congress with technical assistance in addressing potential legal obstacles to the implementation of the leasing conccpt.

Moreover, the legislative changes discussed here have not been subject to interagcncy coordination and clearance under the provisions of OMB Circular A-19 and, therefore, should not be construed to represent the views of the Administration on such changes.

Our presentation of these draft legislative changes is divided into two sections. Section $\mathrm{E}(1)$ presents a cohesive set of draft provisions, which generally would authorize the DOE to conduct oil and facilities leasing, but without necessarily eliminating all significant obstacles to the most effective possible implementation of such leases. The second part of the presentation, Section $\mathrm{E}(2)$, addresses individually a series of legislative changes, involving trade-otts with other public policies, that arguably could enhance the effectiveness with which oil and facilities leasing can be implemented.

2/ Depending on the particulars of the transaction, there may be little, if any, substantive difference between an oil "lease" and other arrangements involving the provision of privately owned oil to the SPR, such as an "option." The intent is to authorize the storage of privately owned oil under circumstances that serve U.S. strategic storage objectives, regardless of the nomenclature. Likewise, privately owned facilities could be used for SPR oil storage under a "services contract," as well as under a "lease." Here and elsewhere in this study the term "lease" often is used as a shorthand for a broader category of possible contractual relationships. 


\section{General Leasing Authority}

The DOE long has maintained that the Energy Policy and Conservation Act (EPCA) empowers it to store "leased" oil in the SPR, as well as to use leased facilities for SPR oil storage. But the DOE also has recognized that, as described in Section A(2) of Chapter III of this study, the EPCA's preconditions for withdrawals of oil from the SPR pose a potential limitation on alternative financing approaches. Except for the hypothetical case in which oil might be made available for SPR leasing "in perpetuity," there is a need for new statutory authority to permit the return of leased oil to, or other recovery of capital by, a lessor at the end of a lease term, in order to facilitate oil leasing.

In actuality, the return of oil at the end of a lease term involves two very different kinds of situations. One is the situation where the Federal Government has committed itself to a firm multiyear term, e.g., ten years, and is faced with having to return the oil at the end of that multiyear term. Such an approach would minimize the immediate budget outlays associated with oil acquisition, but not the DOE's need for budget authority to obligate against the full term of the ten-year lease. The other situation involves a series of U.S. Government options to extend the lease on a year-by-year basis throughout a prescribed period, such as ten years; in that case, the DOE's need for budget authority is reduced to one year at a time, along with the budget outlays. But in either instance, there is a potential obligation to return leased oil at a time certain, whether it be one year or ten years thence. $\frac{3}{3}$

Moreover, as reported in this chapter's Section A discussion of the oil leasing consultations which the DOE and the Department of State conducted with foreign oil producing countries, it presently is uncertain whether an oil-return provision would be acceptable to these countries. If not, the effectuation of an oil leasing agreement with them would necessitate identifying some other means of allowing these oil lessors to recover a finite amount of capital at the end of a lease term. And, of course, it would be desirable to do this without the necessity for the enactment of sufficient appropriations to obligate against the full amount of this contractual contingency, or for the expenditure of such appropriations. One way to accomplish the objective would be to authorize the DOE to sell the leased oil and, to any extent necessary to satisfy the contract price owed to the lessor, to sell additional amounts of SPR oil (or additional leased oil) and use the proceeds to pay the lessor.

However, the question of when oil stored in the SPR can be drawn down and distributed is central to the operation of the SPR program. The Congress, in enacting the EPCA, made clear the very limited circumstances under which oil withdrawals from the SPR were allowed. The stringency of the drawdown restriction was emphasized by the House Report on the Energy Policy and Conservation Amendments Act of 1985, Public Law No. 99-58, authorizing an actual SPR test sale, wherein it was stated that the prohibition on drawdown in non-emergency periods admits of "no exceptions, even for modest drawdowns and sales undertaken for test purposes." H.R. Rep. No. 152, 99th Cong., 1st Sess. 6.

3/ Of course, the oil "returned" may not be the very same physical barrels delivered; in substance, there could be a time exchange, with quantity and possibly quality adjustments. 
As a matter of legislative drafting, therefore, amendments to permit the withdrawal of leased oil, or indeed the sale of additional quantities of SPR oil, are not readily inserted into the SPR's statutory charter in Title I, Part B of the EPCA, without altering the SPR's fundamental character. Partly for this reason, the draft legislative changes to authorize leasing (Exhibit $A$ at the end of this chapter) have been constructed as a cohesive set of new provisions relating exclusively to future oil storage, rather than as amendments to the SPR's existing charter.

There are additional reasons for taking this drafting approach. As explained earlier, the DOE has confined its study of alternative financing to incremental future oil acquisitions, rather than analyzing the refinancing of the existing SPR inventory. It stands to reason, then, that any new statutory authorities should be enacted with specific reference to volumes of oil that will supplement the existing SPR stocks. Further, sections 160(c) and (d) of the EPCA respectively impose an SPR oil fill mandate, and a sanction for failing to achieve a specified rate of SPR fill; it would seem inappropriate to treat all leased oil as being in the SPR for purposes of these provisions, irrespective of the terms of the leases.

Accordingly, the draft legislative changes at Exhibit A would add a new Part $\mathrm{C}$ to Title I of the EPCA (with the existing Part $C$ being redesignated), authorizing a "Supplementary Oil Reserve" program, potentially consisting of "leased" or other non-U.S. Government-owned oil, and possibly facilities.

Draft section 171 would declare that it is U.S. policy, to the extent consistent with the SPR program, to encourage supplementation of the SPR and other domestic oil inventories with additional oil stocks owned by private firms or foreign governments -- but not in any manner which reduces the effectiveness of the SPR program or diminishes Executive Branch control over SPR drawdown or distribution. Section 171 explains that, to this end, the new Part $C$ would empower (but not require) the Secretary of Energy to lease oil, and to store it in either leased facilities or in otherwise unused SPR storage facilities.

Draft section 172 would adopt the same definitions used for Part B.

Draft sections 173 and 174 both would authorize the storage of oil owned by private firms or foreign governments; the intent is to authorize such storage under lease, pursuant to an option ${ }^{4 /}$, or on another contractual basis. Section 173 also would authorize contracting for storage facilities expressly for the purpose of supplementary oil storage; the intent is to permit leases, service contracts, or other arrangements. The two sections differ in that section 173 would encompass the storage of privately owned or foreign government-owned oil in leased or other non-U.S. Government-owned facilities, 5/ whereas section 174 is directed at the storage of such oil in otherwise unused SPR facilities established under Part B. Given the variety of types of arrangements that might be negotiated under section 174 , the section recognizes that the

4/ See the discussion of options at Section $D(1)(f)(1)$ of Chapter III.

5/ The facilities leasing authority in section 173 in no way derogates from the Secretary's existing authority under Title I, Part B, to lease facilities for the storage of SPR oil as such. 
Government might either pay or receive payment from the oil's owner, or permit storage without charge. Under either section, the oil stored is to be fully within the control of the Secretary, and can be drawn down and distributed just as if it were in the SPR.

Draft section 175 contemplates the possibility that contracts entered into under authority of the new Part $\mathrm{C}$ might, for their duration, achieve strategic benefits comparable to SPR storage. If so, then following congressional notification to that effect by the Secretary, the supplementary storage achieved by methods such as leasing would be considered to satisfy all legal requirements for the storage of equivalent volumes of oil in the SPR.

Draft section 176 would permit waiver of the SPR's statutory fill mandates where an effort is being made to acquire oil under this new Part -- because efforts to contract for non-Government-owned oil in a given fiscal year conceivably could have the effect of curtailing or even excluding outright oil purchase activities during that period.

Draft section 177 contains several provisions connected with implementation of supplementary storage. It would authorize the use of all SPR appropriations to carry out this Part, and eliminate any doubt that funds in the EPCA section 167 SPR Petroleum Account could be used to return capital to a lessor at the end of a lease (see the discussion in Section D(3) of Chapter III). In addition, it would expressly authorize the Secretary, as consideration for the leasing of oil to the Federal Government, to agree to the lessor's storage of additional amounts of oil for commercial purposes; as explained in Section G(1) of Chapter III, similar authority already exists in Part B of Title I of the EPCA. Further, this section would waive any requirement to amend the SPR Plan in connection with oil or facilities leasing, and clarify that the Supplementary Oil Reserve, like the SPR, would not be subject to state jurisdiction for purposes of oil allocation or eminent domain.

In addition to this cohesive set of amendments, there is one revision to Title I, Part B of the EPCA which seems necessary to implement the oil leasing alternative. As noted in Section G(2) of Chapter III of this study, there is a need to clarify that the shipment of privately owned oil through SPR pipelines and other transportation facilities will not cause them to become common carriers. This could be accomplished by adding at the end of either section 159 or section 160 of the EPCA a new subsection, providing that, "A storage or related facility of the Strategic Petroleum Reserve owned by or leased to the United States is not subject to the Interstate Commerce Act."

\section{Specific Issues}

This section sets out a series of legislative changes that could enhance the effectiveness with which oil and facilities leasing can be implemented. But each of these changes involves some public policy issue trade-offs, and therefore no inference should be drawn, from this discussion, as to what position the Administration might take on any of these issues. Rather, this section further carries out the mandate of Public Law No. 101-46 by presenting draft legislative changes that arguably could further promote the effectiveness of a leasing effort. 


\section{a. Authority to Sell Oil}

As discussed above, consultations with oil producer countries left open to question whether it will be possible to arrive at an oil lease agreement with them which gives the U.S. Government the option to return leased oil to the lessor at the end of the lease term. Even if this should prove agreeable in the case of a firm multiyear lease, it might not be acceptable on the kind of year-by-year basis that would reduce the DOE's need for budget authority along with a reduction in near-term budget outlays. An alternative that could have this effect might involve sale of the leased oil and, potentially, of additional amounts of SPR oil.

Under this alternative, the lease contract might allow the Federal Government yearly extension rights, but it also would provide that, at one or more specified stages of the lease, either the U.S. Government or the lessor, or both, would have options to liquidate the lease at a price specified in the lease or on the basis of a formula set out in the lease, perhaps subject to a price ceiling and possibly to a price floor. When the option to liquidate was exercised, the U.S. Government could conduct a competitive sale of the lessor's oil or, alternatively, of approximately the same amount of other oil that was contractually deemed to be the lessor's oil. This could be either leased oil that is in the Supplementary Oil Reserve or oil that is in or being delivered to the SPR.

The proceeds from that sale might suffice to cover the lessor's contractually determined capital recovery. To the extent that they did so, they would be transferred to the lessor by the Government. However, if they would not suffice to do so, additional amounts of Supplementary or SPR oil could be sold competitively, insofar as estimated to be necessary to pay the amounts owing to the lessor. So long as the transaction was structured to avoid an indefinite, indeterminate, or potentially unlimited U.S. Government obligation, the net result would be to limit the DOE's current budgetary requirements to the yearly rental fee, plus the excess of the Government's estimated liability over the estimated value of the lessor's oil.. -

On the other hand, an oil lease provision of this kind would run a risk that the country's strategic reserves could be diminished, potentially at the very time when tight world oil markets and increasing oil prices were being experienced. The magnitude of this risk would depend in part on the financial terms of the oil leases, and on the volume of oil covered by such leases. However, the risk could be reduced if the option to liquidate was exclusively that of the Federal Government, which could instead elect to further extend the lease.

6/ This approach would be subject to certain logistical limitations. The DOE's existing commercial terminalling contracts omit provision for recurrent, non-emergency, oil distribution; only the SPR's Bayou Choctaw and Weeks Island, Louisiana, storage facilities have access to the Government-owned St. James docks on the Mississippi River, where no such obstacle exists. Furthermore, only the Weeks Island site, a conventional salt mine (as opposed to a leached cavern using fresh water injection for oil discharge) is capable of repetitive large-scale drawdowns without risking ultimate degradation of cavern integrity. 
The following draft language would authorize implementation of this approach:

The Secretary may incur obligations in excess of available appropriations to pay for petroleum products upon the expiration, termination or other conclusion of a contract for petroleum product acquisition entered into under this Part, and may sell sufficient petroleum products from the Supplementary Oil Reserve or the Strategic Petroleum Reserve to generate funds to pay any amount due upon such expiration, termination or other conclusion. A sale under this Part shall be conducted by competition to the maximum extent practicable.

In addition, both section 161(b) and section 167(b)(3) of the EPCA would need to be amended by adding a reference to this provision.

Although this language involves a form of "contract authority," " the language also provides a means of liquidating the obligations created, and has similarities to the approach recently endorsed by the Congress and the previous Administration for funding of the Bonneville Power Administration. See Public Law No. 100-371 (July 19, 1988); H.R. Conf. Rep. No. 724, 100th Cong. 2d Sess. 40 (June 22, 1988); 134 Cong. Rec. H4953 (June 30, 1988); 134 Cong. Rec., S8872 (July 6, 1988).

\section{b. Taxes}

Part F of Chapter III of this study describes the Federal, state, and local taxes potentially applicable to oil or facilities lease transactions. Part $A$ of this chapter, reporting on the results of U.S. Government discussions with oil-producing countries, cites the potential tax situation as a major obstacle to the fulfillment of an oil leasing transaction with these countries, which generally are not now subject to U.S. taxes on their crude oil exports to the U.S.

There are a number of different ways the tax issues might be addressed legislatively. A difficulty of addressing them now is that it is impossible at this juncture to describe with any precision the oil leasing or other transactions that might be involved, for which tax relief could prove necessary.

One possible solution to this problem would be to evaluate the need for tax law changes in the specific context of particular bilateral, government-to-government oil "leasing" or similar agreements. But in order for the negotiation of such agreements to be feasible, there would need to be an assurance that the Congress would act reasonably promptly on any necessary implementing legislation. Both of these objectives could be accommodated if the Congress afforded, to tax

II See the discussion at Section $\mathrm{D}(1)(\mathrm{e})$ of Chapter III. Assuming an agreement which permits the U.S. Government to sell the lessor's oil (or other oil "deemed" to be the lessor's) and pass through the proceeds to the lessor, the extent of the need to use this authority from time to time would depend upon the estimated market value of the leased oil, in relation to the size of the potential liability upon liquidation; i.e., it would depend on the extent to which that potential liability might exceed the proceeds from sale of the lessor's oil, a calculation which would have to be adjusted periodically. See the discussion of principles involved in the obligation of funds, at Section $D(1)(a)$ of Chapter III. 
legislation associated with international oil leasing agreements, the so-called "fast-track" treatment now enjoyed by certain trade legislation, including the recent U.S.-Canada Free-Trade Agreement. Under "fast-track" legislation, the President would be authorized to submit to the Congress a draft bill to implement a government-to-government oil leasing agreement; and each House of the Congress would act on that draft bill, without amendment, within a prescribed period of time. Of course, it would be expected that before draft legislation ever was submitted to the Congress, the Executive Branch would have consulted with the jurisdictional Congressional committees, and a so-called "non-mark-up" would have been held, as is the practice with regard to "fast-track" treatment of trade agreements. Even before that, it would be essential for the Executive Branch to consult closely with the Congress and keep the Congress fully informed of the status of bilateral, government-to-government negotiations that could result in the submission of draft legislation to Congress.

The following is a draft provision to afford "fast-track" treatment to tax legislation which might be proposed in implementation of international agreements entered into pursuant to the new draft Part C of EPCA Title I:

Section 3(c) of the Trade Agreements Act of 1979 (19 U.S.C. 2504(c)) shall apply to a bill affecting Federal or state taxation, or both, submitted by the President in implementation of an international agreement negotiated in fulfillment of this Part, as if the international agreement were an agreement approved under section 2(a) of that Act when the President determines that it is necessary or appropriate to amend, repeal or enact a statute of the United States to implement a requirement of, or amendment to, the international agreement.

Cf. section 102(e) of the United States-Canada Free-Trade Agreement Implementation Act of 1988, Public Law No. 100-449 (Sept. 28, 1988).

It should be noted that this same kind of procedure could be used to address other legislative changes, unrelated to taxes, that might best be dealt with in the context of a particular international agreement.

\section{c. Environmental Impact Statements}

Section $\mathrm{B}(2)$ of Chapter III of this study indicates what Environmental Impact Statement (EIS) requirements may apply to oil and facilities leasing proposals. As reported in footnote 15 of Chapter III, the leadtime for the SPR's programmatic EIS was about one year, and the historical leadtime for site-specific EISs has been about a year and a half. Any relief from these requirements would require legislation.

A form of relief from the EIS requirement already is evidenced by EPCA section 160(h)(3)(A), which provides that:

No action relating to the storage of petroleum products in existing interim storage facilities in the Reserve shall be deemed to be "a major Federal action significantly 
affecting the quality of the human environment" within the meaning of that term as it is used in section 102(2)(C) of the National Environmental Policy Act of 1969.

This language provides a model for the Congress if it decides to exempt from the EIS requirement, oil or facilities leasing activity, pursuant to the draft Part C of EPCA Title I.

\section{d. Contractual Actions}

Chapter III spells out the contractual procedures that must be adhered to and the contractual clauses that must be utilized in oil or facilities leasing. Whatever their merit, these procedures can cause delays, and the required clauses can have a limiting effect on the contracting possibilities. On occasion, the Congress has seen fit to authorize waiver of applicable procurement laws and regulations. See, e.g., Chapter III, note 57. Were the Congress to elect to afford comparable relief in the present instance, one way to do so would be to provide as follows:

For purposes of any law or regulation affecting the solicitation, negotiation, execution or performance of contracts, contractual action pursuant to this Part need not comply with applicable laws and regulations (other than those directly relating to safety, health or the environment) governing construction, or the acquisition or provision of services or property.

\section{e. Cargo Preference}

Section E(2) of Chapter III of this study explains the requirements for use of U.S.-flag vessels that are imposed by the Cargo Preference Act. Section A of this chapter, reporting on the results of the Administration's discussions with foreign oil-producing countries in conducting this study, identifies the U.S.-flag shipping requirement as a subject of significant concern to these countries. At the least, this requirement represents a cost that would have to be borne by the U.S. Government in an oil lease transaction; at an extreme, it could be deal-breaker, although it is premature to reach this conclusion.

The discussion in Chapter III quotes the Department of Justice to the effect that the Cargo Preference Act's 50 percent U.S.-flag shipping requirement is not an "absolute duty," regardless of circumstances. That same Justice Department opinion also notes that the Cargo Preference Act appears to be a "procurement" act and thus within the scope of any applicable waiver of the procurement laws for SPR transactions. Op. cit. at 14-16.

The question of whether to insist upon, or instead to excuse the Executive Branch from, a Cargo Preference Act requirement, is appropriate for congressional resolution. As matters now stand, the 50 percent requirement would apply to oil leasing activities to the extent that U.S.-flag carriage is "practicable," but it is not an "absolute duty." Were the Congress to enact the draft contracting law waiver provided above, that waiver potentially would encompass the Cargo Preference Act requirement, unless the Congress made an exception for that Act. 


\section{f. Import Charges}

Section $\mathrm{F}(2)$ of Chapter III of this study points out that imports of crude oil that is to be leased to the SPR would be subject to customs duties and certain other Federal import charges. These costs presumably would be borne by the DOE either directly or indirectly.. They could be made inapplicable to leased oil by adding language such as the following to the draft Part $\mathrm{C}$ of title I of the EPCA:

Notwithstanding any other law, the importation of petroleum products which the Secretary of Energy certifies are for storage in the Supplementary Oil Reserve shall not be subject to any duty, tax or fee.

\section{g. Export Controls}

Section $G(3)$ of Chapter III shows how existing U.S. laws and regulations with respect to oil exports could make it difficult for an owner of imported oil that was stored in the Supplementary Oil Reserve to export that oil if the oil were returned to its owner by the U.S. Government. This may create a disincentive for a foreign oil producer government to participate in an oil lease or similar transaction. The problem could be alleviated by legislative language such as the following, which is patterned after the existing oil export control waiver for the International Energy Program and for the U.S.-Israel Supply Agreement, at section 7(d)(3) of the Export Administrative Act of 1979, as amended, 50 U.S.C. app. 2406(d)(3):

Notwithstanding any other law, the President may permit export of crude oil pursuant to a contract with a foreign government or agency thereof for storage of that crude oil in the Supplementary Oil Reserve.

The waiver authority would be vested in the President rather than the Sccretary since it presumably would be exercised by the Secretary of Commerce as the President's delegate for implementing the export control laws.

A separate question might remain, of assuring a producer government that oil stored for its own commercial purposes, as part of a larger transaction which included placing oil in the Supplementary Oil Reserve, could be removed from the United States.

\section{h. Arbitration of Disputes}

Section $E(2)$ of Chapter III describes the prevailing rule that express legislative authority is necessary in order to commit the Federal Government to binding arbitration of a contractual dispute. Binding arbitration could be an appropriate means of dispute resolution for an oil storage contract with an oil producing country. Language such as the following would permit this:

8) Applicable import charges have been paid directly by the Federal Government throughout the SPR's oil purchase experience. 
The Secretary may agree to binding arbitration of disputes under a contract with a foreign government or agency thereof for Supplementary Oil Reserve storage.

\section{i. Defense Petroleum Inventory}

Finally, initial consideration of the creation of a discrete oil reserve specifically for defense purposes predated enactment of the EPCA. The issue recently was raised by this Administration in the context of its 1989 legislative proposal to privatize the Naval Petroleum Reserves. Creation of a Supplementary Oil Reserve might be an opportune occasion for the dedication of some discrete quantity of oil to defense purposes. Enclosed at Exhibit B is draft legislative language to permit this. 


\section{EXHIBIT A \\ Draft Legislative Language Authorizing Oil Leasing}

\section{Part C: Supplementary Oil Reserve}

\section{Declaration of Policy}

Sec. 171(a). The Congress finds that budgetary constraints have hindered completion of a 1 billion barrel Strategic Petroleum Reserve, and that establishment of a Supplementary Oil Reserve can help diminish the vulnerability of the United States to the effersts of a severe energy supply interruption, and contribute to the effectiveness of the international energy program.

(b)(1) It is hereby declared to be the policy of the United States, to the extent consistent with the Strategic Petroleum Reserve program, to encourage supplementation of the Strategic Petroleum Reserve and other domestic petroleum product stocks by contracting for Supplementary Oil Reserve storage of petroleum products in, or readily accessible to, the United States by private firms or foreign governments in facilities not owned by the United States, and by contracting for Supplementary Oil.Reserve storage in government-owned facilities.

(2) The purpose of this Part is to add to the Secretary's existing authority under Part B to contract for petroleum products and storage and related facilities for the Strategic Petroleum Reserve by authorizing the Secretary to contract for Supplementary Oil Reserve storage in facilities other than those of the Strategic Petroleum Reserve, and for Supplementary Oil Reserve storage, in otherwise unused Strategic Petroleum Reserve storage facilities, of petroleum products owned by any person or government.

(3) It is the policy of the United States that the authorities provided by this Part shall be used as a complement to the Strategic Petroleum Reserve and not in any manner which reduces the effectiveness of, or diminishes the control of the President and the Secretary over, the drawdown or distribution of the Strategic Petroleum Reserve.

\section{$\underline{\text { Definitions }}$}

Sec. 172. Terms used in this Part have the same meaning that they have in Part B.

\section{Contracting for Petroleum Products and Facilities}

Sec. 173(a). The Secretary may contract for Supplementary Oil Reserve storage, in storage facilities other than those of the Strategic Petroleum Reserve, of petroleum products not owned by the United States.

(b) Petroleum products stored under such a contract are subject to the Secretary's authority under section 161 (except sections 161(e) and (g)) to draw down and distribute petroleum products, as if those petroleum products were in the Strategic Petroleum Reserve. 


\section{EXHIBIT A (continued) \\ Use of Strategic Petroleum Reserve Facilities}

Sec. 174(a). The Secretary may contract for Supplementary Oil Reserve storage, in otherwise unused Strategic Petroleum Reserve storage facilities, of petroleum products not owned by the United States, to the extent consistent with the purposes of Part B and of this Part. A contract entered into under this section shall not limit the discretion of the President or the Secretary to conduct a drawdown and distribution of the Strategic Petroleum Reserve.

(b) Petroleum products stored under any such contract are subject to the authority of the Secretary under section 161 (except sections 161(e) and (g)) to draw down and distribute petroleum products, as if those petroleum products were in the Strategic Petroleum Reserve.

(c) The Secretary may store petroleum products under this section with or without charge, or pay a fee for their storage.

\section{$\underline{\text { Strategic Petroleum Reserve Tie-In }}$}

Sec. 175(a). If the Secretary determines that one or more contracts or proposed contracts for Supplementary Oil Reserve-storage of petroleum products under section 173 or 174 would for their duration achieve benefits comparable to equivalent storage of petroleum products in the Strategic Petroleum Reserve and that, because of budgetary constraints, equivalent storage of petroleum products in the Strategic Petroleum Reserve cannot be accomplished, the Secretary may so notify each House of the Congress, including in his notification the same information required under section 154(e) with regard to storage and related facilities proposed to be included, or petroleum products proposed to be stored, in the Strategic Petroleum Reserve. From sixty calendar days after notification, all petroleum products actually stored under such a contract shall be counted as part of the Strategic Petroleum Reserve for purposes of Part B.

(b) Petroleum products counted as part of the Strategic Petroleum Reserve under this section, if otherwise eligible, qualify to satisfy any applicable provisions for Regional Petroleum Reserves or noncontiguous storage under Part B.

(c) Notwithstanding any other law, the expiration of a contract for the storage of petroleum products under section 173 or 174 is not a violation of any requirement concerning the size or rate of fill of the Strategic Petroleum Reserve. For purposes of section 160(d), the reduction in the quantity of crude oil in storage in the Strategic Petroleum Reserve attributable to expiration of such a contract is considered to occur between the end of the fiscal year in which expiration actually occurs and the beginning of the following fiscal year.

\section{Waiver of Fill Requirements}

Sec. 176. Sections 160 (c) and (d) do not apply for a given fiscal year if, during that fiscal year, the President transmits to the Congress a written certification that a good faith effort has been or is being made, using the authorities in this Part, to achieve Supplementary Oil Reserve storage 


\section{EXHIBIT A (continued)}

which, together with fill of the Strategic Petroleum Reserve, utilizes or would utilize substantially all appropriations available for these purposes.

\section{Implementation}

Sec. 177(a). Notwithstanding subsection 160(c), the Secretary may use, for the acquisition of petroleum products or of petroleum product storage under this Part, without further appropriation, funds available for the planning, administration, acquisition, and construction of storage and related facilities of the Strategic Petroleum Reserve, and funds available for the acquisition, transportation, and injection of petroleum products into the Strategic Petroleum Reserve. For the purposes of this section, the acquisition of petroleum products includes payments of amounts due upon the expiration, termination or other conclusion of the acquisition contract.

(b) The Secretary, as consideration for the storage of petroleum products in the Supplementary Oil Reserve, may allow the additional storage, in Strategic Petroleum Reserve facilities or in facilities contracted for under section 173, of petroleum products for commercial purposes.

(c) The Secretary, in any contract entered into under this Part, may provide for the acquisition by purchase or exchange of stored petroleum products by the United States, for storage in, or use in connection with, a drawdown and distribution of petroleum products from the Strategic Petroleum Reserve.

(d) An amendment of the Strategic Petroleum Reserve Plan is not required for any action taken under this Part.

(e) Petroleum products stored and facilities used in the Supplementary Oil Reserve have the same status as petroleum products and facilities owned by the United States for all purposes associated with the exercise of the laws of any state or political subdivision thereof.

(f) Contracts under this Part may be of such duration as the Secretary considers necessary or appropriate. 


\section{EXHIBIT B}

\section{Draft Legislative Language Authorizing Defense Petroleum Inventory}

\section{Defense Petroleum Inventory}

SEC. - (a) The Secretary may establish and maintain discrete storage and related facilities of the Supplementary Oil Reserve, including facilities of the Strategic Petroleum Reserve used under section 174, to meet petroleum product requirements of the Department of Defense, as a Defense Petroleum Inventory of petroleum products. Notwithstanding section 175(a), the Defense Petroleum Inventory shall not be counted as part of the Strategic Petroleum Reserve.

(b) Upon the request of the Secretary of Defense, petroleum products in the Defense Petroleum Inventory shall be drawn down and distributed by the Secretary to, or on behalf of, the Department of Defense for use, sale, or exchange. Petroleum products in the Defense Petroleum Inventory may be drawn down and distributed, used, sold, or exchanged, without regard to--

(1) whether the petroleum products have been commingled with petroleum of the Supplementary Oil Reserve;

(2) the requirements of this title concerning drawdown of the Strategic Petroleum Reserve; or

(3) otherwise applicable Federal contracting statutes and regulations.

The Secretary shall exercise the authority provided by this subsection in a manner which does not adversely affect drawdown of the Strategic Petroleum Reserve.

(c) Upon the request of the Secretary of Defense, and subject to the availability of funds from the Department of Defense, the Secretary shall acquire and store in the Defense Petroleum Inventory petroleum products to replace petroleum products drawn down under subsection (b).

(d) The Department of Defense shall reimburse the Department of Encrgy for--

(1) drawdown and distribution services provided under this section, in amounts that the Secretary of Energy determines to be reasonable; and

(2) all costs of acquiring and storing in the Defense Petroleum Inventory any petroleum products in excess of 10 million barrels.

(i) Any funds available to the Secretary for the development of storage and related facilities of the Supplementary Oil Reserve may be used to construct storage and related facilities for the Defense Petroleum Inventory. 


\section{CHAPTER VII. OIL-INDEXED BONDS}

\section{A. GENERAL}

\section{Introduction}

Chapter VI discussed oil leasing methods whereby the form of the investment was the delivery of "wet barrels" to the SPR. This chapter addresses oil-indexed bonds, whereby the form of the investment would be a cash payment to the Federal Government to acquire SPR oil. The form of capital recovery would likewise be financial, through a cash payment back to the investor.

Notwithstanding this difference in the form of the investment, the intention of an oil-indexed bond could be similar to one form of an oil lease: to use the potential for growth in the value of the principal as the basis for achieving a lower annual direct cost of borrowing. In this regard, it would be possible to structure an oil bond to be identical, in private sector financial terms, to a certain kind of oil lease. As noted below in cross references to Chapter VI, many of the key design issues with an oil-indexed bond have clear parallels to the design issues associated with an oil lease.

The issuance of a bond whose value is linked to the price of oil would be a departure from normal Government practice. Conventional U.S. Treasury debt carries a fixed and known cost to the Government. An oil-indexed bond, on the other hand, would have a yield tied to the price of oil and therefore would represent an unknown cost to the Government. However, while the Government's financial liabilities would fluctuate with changes in oil prices, the assets acquired by the Government with the debt proceeds would also fluctuate in value. Thus, as remarked by one respondent to the Notice of Inquiry, oil-denominated bonds would represent financing in which assets are matched to liabilities. This departs from general Federal financing practices and raises the question about the extent to which the SPR oil would be considered a financial asset, given its strategic character.

In assessing any form of oil-based financing, the following criticism must be borne in mind: to the extent that capital markets function efficiently, the use of oil-linked bonds would not be expected to achieve a lower true economic cost of financing than direct Treasury financing. Indeed, one could presume that investors in such securities would demand higher expected rates of return than on less risky, far more liquid, Treasury instruments. Thus, this financing method poses two policy issues: (1) whether the Government should be willing to pay higher expected rates to compensate investors for bearing oil price risk, and (2) whether it is appropriate for the Government to seek to take advantage of any divergence between market expectations regarding future oil prices and the Government's own projections. This second issue raises the further question of why market and Government expectations might differ and which forecasts should be used in Government financing decisions. 
Oil-indexed bonds conceivably could perform a number of functions with respect to the SPR:

(1) The Government could issue the bonds directly, with the proceeds of such sales used to finance SPR oil acquisition. This is the primary case for which design features are discussed below. Oil bond financing could be used for all, or only a portion, of future SPR financing needs.

(2) A lessor providing oil to the SPR pursuant to an oil lease might be able to sell oil denominated bonds as a method for refinancing the investment. In this case, one would expect the terms and conditions of the bond to be tailored to the lease contract terms.

(3) If the Government were to enter into arrangements whereby other consuming nations provided financing for strategic oil storagc, oil-denuminated bonds possibly could be used to define the financial interrelationships of the parties.

A key difference between an oil-indexed bond and an oil lease involves Federal budget authority requirements. From Chapter VI, it will be recalled that the Department expects that budget authority would be required at the time an oil lease contract would be awarded for all of the future annual lease payments tied to the firm initial term of the lease. However, assuming that the Government would have an option to return the oil to the lessor at the end of the lease term, the Government would not need budget authority for the purchase of the oil until such time as the Government would choose to exercise a purchase option. The exreption would be that, if the lease contract required eventual Government oil purchase (a lease/purchase method that is distinguished from the lease/option method), the Department would need budget authority at the outset to cover not only the lease payments but also the eventual purchase price.

In the case of an oil bond, wherein the Government would not have the option to conclude the arrangement with the return of wet barrels, the financial obligation at the time the bond were issued would reflect both cumulative interest payments and the principal repayment. Thus, even if a bond were identical to a lease in all other respects, the bond approach would entail significantly higher budget authority requirements.

These observations about budget authority are based on the assumption that the bond instrument would be analogous to a contract obligation of a Federal agency, reflected in the normal budget process. As discussed in Chapter I, this study does not address changes in institutional structures or budgct scorekeeping methods such as excluding SPR bond sale transactions from debt limits or budget scorekeeping controls. Other technical issues such as relationship to statutory debt limitations also have not been explored fully and would need to be addressed.

The actual budget scorekeeping for outlays would need to be defined if this option were implemented. For example, the Federal budget now treats as outlays the accrued interest on Treasury-issued zero coupon bonds, even though bondholders do not receive a cash payment until maturity. 


\section{Taxpayer vs. Investor Financing}

A key policy choice associated with oil-indexed bonds, as with the oil leasing concept, would be whether the Government should continue to finance the SPR, or whether, instead, the risks and rewards of financing should in whole or in part be shifted to a particular group in the private sector. If the SPR were ever drawn down, the financial gains from high oil prices would accrue to the investor group. Because this would occur during an energy disruption, accompanied by a Presidential declaration of an energy emergency, charges of "profiteering" could be raised.

Investor financing could also introduce a highly interested constituency group into SPR policy (namely the SPR oil investor group), which potentially could attempt to influence Presidential drawdown decisions. Realization of capital gains by bond holders would depend both on the incidence of a substantial supply disruption and on the President's decision to use the SPR.

In addition, investor financing would involve the contingent liability of the U.S. Government to the investor group. That is, in any plan where the holder of the financial instrument would be entitled to receive the proceeds from the sale of SPR oil (even if it is offset by sales revenues), the Government would have an indeterminate contingent liability. Or, if no oil disruption were to occur, the Government would have a contingent liability upon the maturity of the financial instrument, again indeterminate since it is linked to the price of oil at the time.

One way to handle these issues would be to put a ceiling on the amount of speculative profits that could be earned. By virtue of "capping" the rate of return, any investor financing proposal might become more politically acceptable. Of course, a likely trade-off would be the requirement of a minimum interest yield, since investors would demand some fixed return if their potential for reward were limited.

Decisions on whether and how to impose caps on bond redemption could be viewed as expressions of policy regarding oil price levels during an oil supply disruption and could prompt inappropriate public inferences regarding future tax and pricing policies in the event of energy supply emergencies.

\section{Previous Oil Bond Proposals}

Over the past decade, there have been numerous proposals to finance the SPR with private sector funds, including bonds indexed to the price of oil, certificates of equity ownership in SPR oil, and trust receipts backed by title to SPR oil. In all of these proposals, the DOE (or perhaps a new quasi-government corporation) would sell financial instruments to investors conveying rights to all or part of the appreciation in the value of oil in the SPR.

One of the first oil bond proposals was Senator Gramm's 1981 Petroleum Equity Certificate proposal (H.R. 2304). Both the Senate and the House held hearings on this concept in 1981. In 1987 the DOE internally evaluated a concept for an indexed bond, and several reports were completed on this subject. Recently, in response to the Notice of Inquiry (NOI) with respect to this study, the DOE received a proposal for a 30 -year oil-price-indexed bond. The bond would have a fixed 3 percent annual yield; in addition, should oil prices rise over the life of the bond, the investor would receive at maturity a sum of money equal to that price appreciation. Should oil 
prices decline, however, the investor would still receive the original par value. Another proposal involved a trust receipt concept where the DOE would contract with the private sector to store its own oil for a fixed period of time. Under the terms of the contract, storage costs would be borne by the Government, which would issue a trust receipt to the owner of the oil, paying an annual interest coupon (an "energy security fee"). Because the trust receipts could be resold in a secondary market, they would resemble a long-term futures contract or medium-term indexed bond.

In all these cases, the provisions of the financial contract between the Government and the private sector would influence investor receptivity and therefore the ability to raise the requisite amount of capital. Such contractual terms involve level of interest return, maturity, beneficial interest should a supply disruption occur (with or without an SPR release), the terms of an SPR release (and whether or not it would be dependent on Presidential action), and certain rights to the oil (or its value) if a disruption did not occur before a fixed maturity date. The trust receipt concept is an in-kind placement of privately owned oil into U.S. Government storagc with clearly defined Government controls, while the equity certificate and indexed bond approaches would provide financing for the Government to purchase oil but convey similar beneficial ownership rights (ie., price appreciation) to the investor.

In addition, a major New York bank in 1987 and 1988 indicated a willingness to loan DOE the funds to fill at $75,000-100,000$ barrels per day for the next five years under the following terms:

- Semi-annual interest payments at $25-50$ basis points below the prevailing five-year Trcasury note rate.

- Quarterly payment by the DOE of the difference between an agreedupon floor price and the prevailing spot price, should that spot price go below the agreed-upon floor price.

Principal would be repaid at the end of five years. Presumably, the deal could be renegotiated at the end of each tive-year period, thereby avoiding DOE cash repayment of the principal. However, under current budget procedures, the DOE might nevertheless need the budget authority sufficient to repay the principal.

Table VII-1 lists the main contractual terms of each of the financing proposals. All of the proposals presumably could be modified to maintain Presidential discretion on timing of the SPR drawdown, although some of the proposals initially suggested the use of a market price trigger. A key concern of the investor, however, would likely be the possibility that prices could rise significantly without a Presidential decision to use the SPR. By maturity, the price could have fallen again. Except for the New York bank's proposal referred to above, where the Government would be the beneficiary of the price appreciation, what is at issue is what assurance the investor would have that he would be able to benefit from a sharp price rise. 
Table VII-1

Previous Oil Bond Proposals

\begin{tabular}{|c|c|c|c|c|c|}
\hline & & CONTRACT & L TERMS & & \\
\hline - & INTEREST COST & MATURITY & $\begin{array}{l}\text { PAYMENT } \\
\text { SCHEDULE } \\
\end{array}$ & $\begin{array}{l}\text { BENEFICIAL } \\
\text { INTEREST }\end{array}$ & $\begin{array}{c}\text { OIL } \\
\text { OWNERSHIP } \\
\end{array}$ \\
\hline $\begin{array}{l}\text { INDEXED BONDS } \\
\text { DOE/EFG } \\
\text { (Internal } \\
\text { Discuseions) } \\
1987-88\end{array}$ & $\begin{array}{l}\text { BID DISCOUNT EROM } \\
\text { INTERMEDIATE } \\
\text { TERY T'BOND YIELD } \\
\text { AS FLOOR, OR } \\
\text { OIL PRICE, WHICH- } \\
\text { EVER IS HIGHER }\end{array}$ & $\begin{array}{l}7-12 \\
\text { YEARS }\end{array}$ & $\begin{array}{l}\text { ZERO } \\
\text { COUPON }\end{array}$ & $\begin{array}{l}\text { INVESTOR, } \\
158 \text { CEILING, } \\
\text { INVESTOR CAIL } \\
\text { ON REDEMPTION, } \\
\text { USG CAIL ON } \\
\text { PRES. DECL. }\end{array}$ & USG \\
\hline $\begin{array}{l}\text { LONG-TERM } \\
\text { INDEX BONDS } \\
1988-89\end{array}$ & $\begin{array}{l}38 \text { ANNUAL YIELD } \\
\text { PLUS OIL PRICE } \\
\text { APPRECIATION AT } \\
\text { MATURITY, NOT } \\
\text { LESS THAN PAR }\end{array}$ & 30 YEARS & $\begin{array}{l}\text { QUARTERLY } \\
\text { OR SEMI- } \\
\text { ANNUAL } \\
\text { COUPON }\end{array}$ & $\begin{array}{l}\text { INVESTOR, } \\
\text { USG CALL ON } \\
\text { PRESIDENTIAL } \\
\text { DECLARATION }\end{array}$ & USG \\
\hline $\begin{array}{l}\text { PETROLEUM } \\
\text { EQUITY } \\
\text { CERTIEICATES } \\
\text { GRAMM, } 1981\end{array}$ & NONE & $\begin{array}{l}10 \text { YEARS } \\
\text { WITH DOE } \\
\text { BUY-BACK }\end{array}$ & NONE & $\begin{array}{l}\text { INVESTOR, } \\
\text { USG CALL ON } \\
\text { PRESIDENTIAL } \\
\text { DECLARATION }\end{array}$ & USG \\
\hline $\begin{array}{l}\text { TRUST RECEIPTS } \\
1986\end{array}$ & $\begin{array}{l}\text { 1/2 T'BOND RATE } \\
\text { AS FIOOR, OR } \\
\text { OIL PRICE, WHICH- } \\
\text { EVER IS HIGHEK }\end{array}$ & 5 YEARS & $\begin{array}{l}\text { ANNUAL } \\
\text { COUPON }\end{array}$ & $\begin{array}{l}\text { LENDER, } \\
158 \text { CEILING, } \\
\text { USG CALI ON } \\
\text { PRESIDENTIAL } \\
\text { DECLARATION }\end{array}$ & LENDER \\
\hline
\end{tabular}


A related issue is how the indexing itself would work in conjunction with investor concern for liquidity. If the bond could not be redeemed as oil prices go up, investors would likely project oil prices and interest rates to fluctuate together, and thus would demand at least a current market rate of interest. In having the oil price linkage on-going, coupled with an investor call feature, a liquid secondary market would be more likely to develop. Such secondary market liquidity is vital, should a series of oil-indexed bond sales be conducted by the Federal Government over a period of years.

The Trust Receipt and the Intermediate Term Indexed Bond are very similar financial instruments. In addition to minimum yield, which could be bid at the time of sale, a maximum yicld could be set to prevent inordinate appreciation and to determine the Government's maximum liability. The key difference between the two kinds of instruments is ownership, because with the Trust Receipt, the oil is loaned (or leased) to the Government. The contractual terms of the Trust Receipt would have to define explicitly what happens at expiration, should no drawdown occur. The DOE could either pay the oil lender for the value of the oil at that time (subject to the ceiling rate of return), or return the leased barrels via some kind of time exchange. In the case of the Indexed Bond, the analogous issue is refinancing, which would generally be easier to do since the financial instrument conveys no ownership rights.

The unique feature of the New York bank proposal is the price floor. The bank would in effect buy put options from the DOE for 50 basis points, committing the DOE to a purchase price floor. The bank, in turn, would sell put options to third parties (e.g., oil producers) at lower price levels, possibly profiting on the difference. If prices fell below the floor, the DOE would have to pay the bank the differential, which would be used to offset the bank's losses on its third party put options. If prices remained above the floor, the bank would earn the full premium because its third-partyput options would expire worthless.

From the foregoing discussion, it can be concluded that the "oil bond" alternative is actually a type of financing approach and that a variety of features could be included in such proposals. The relative effects of different approaches could change over time depending on trends in market conditions. The following part of this chapter discusses one particular approach to structuring an oil-indexed security. 


\section{B. BOND DESIGN FEATURES}

The purpose of this part of the chapter is to discuss the alternatives identified by the Department for the design features of an oil-indexed bond. The following is a listing of these features.

$\begin{aligned} \text { 1. } & \text { Term } \\ 2 . & \text { Offer Size and Denomination } \\ \text { 3. } & \text { Method of Bond Sale } \\ \text { 4. } & \text { Sale Frequency } \\ \text { 5. } & \text { Bidding Structure } \\ 6 . & \text { Yield Structure } \\ \text { 7. } & \text { Maximum Yield } \\ \text { 8. } & \text { Oil Price References } \\ 9 . & \text { Call Features } \\ \text { 10. } & \text { Redemption Procedures } \\ \text { 11. } & \text { Refinancing Issues } \\ \text { 12. } & \text { Collateral : } \\ \text { 13. } & \text { Resale Market } \\ \text { 14. } & \text { Other Implementation Issues }\end{aligned}$

An example of how the bond might work is provided at the end of Part B.

\section{Term}

An intermediate maturity of 10 years is assumed as a primary case for analysis. A term of less than five years would, absent a drawdown of the SPR, entail frequent refinancing and higher transaction costs. However, a term of more than 10 years might be too long in terms of private sector ability to assess oil market risks. (In this regard, see the discussion of lease term in Section VI-(B)).

As discussed further below, an extension in the maturity of a zero-coupon oil-indexed bond would have a more pronounced effect on initial budget authority requirements than would be the case for coupon-bearing bonds. The reason for this is that in a zero-coupon bond the interest is compounded and the entire amount is paid at maturity. Each year of an extension would involve not only an additional year's interest on the original investment, but also a year's interest on accrued interest value as well.

It is assumed that it would not be possible to include unilateral options for the Government to extend the financial obligation of the bonds with the original bondholders. Rather, it is assumed that at the cnd of each term, the Government would be required to make payment in full to the original bondholders, requiring the Government to decide whether to refinance the SPR through conventional Treasury borrowing or to issue a new set of oil bonds in the public market.

\section{Offer Size and Denomination}

To reach an SPR size of one billion barrels by 2005 at the minimum prescribed fill rate, the Department estimates a total cost of $\$ 18.8$ billion over the next 15 years, including both the cost of expanded facilities and an oil fill rate of 75,000 barrels per day. Meeting the oil costs alone 
through indexed bonds would entail annual bond financings of around \$1.0 billion. The bonds could be offered for sale annually, semi-annually, or quarterly in regular sequence, depending on the scheduling of SPR financing requirements.

In contrast to oil leases, where the minimum individual contract would be five million barrels (approximately $\$ 100$ million), oil bonds could be issued in smaller denominations, attracting a broader range of investors. Based on current expectations, for the next several years an oil bond denominated for 50 barrels, for example, would represent an investment of approximately $\$ 1,000$. The decision on the denomination would need to be made after further market research, and would likely reflect a trade-off between the administrative costs of smaller denominations and the constraints on competition in the case of larger denominations.

\section{Method of Bond Sale}

Because of the oil index feature, the bond's risk-return profile will not be familiar to the gcneral public, at least initially. As a result, it would seem preferable to market the bond through a limited number of underwriters who would bid for resale rights. Winning bond dealers would then resell the bond to institutional or individual investors. Since the oil-indexed bond would be new to many investors, some education would be required to market the bond. The bidding underwriters would undertake this education process for the Federal Government.

Because a larger size denomination could be used with the bond house underwriting approach, the DOE administrative costs would likely be less. The underwriters might then reduce the size of the Guvernment instrument for resale in smaller lots and might "strip" the bond between its minimum fixed yicld value and its fluctuating oil index value.

The Working Group did not obtain estimates of the additional costs which would be associated with the use of an underwriter, nor did the Working Group address the manner in which an underwriter would be selected. These are issues that would likely arise if the oil bond approach were to be adopted.

\section{Sale Frequency}

Frequency of bond sales should be established within some reasonable boundaries so that investors would be aware of the SPR bond market's general character, including its potential size, frequency of new sales, and the Government's overall intentions with respect to the financial instrument. Bond sales should be conducted on at least an annual basis, with authority to issue bonds quarterly, as necessary. Consistency in the frequency and size of bond sales would give investors a more reliable guide for adjusting their portfolios of SPR bond holdings. That is, bondholders would be able to balance their time profile beyond 1999 if a consistent series of bond sales were made from 1990-1999.

Several other issues are raised in the context of establishing a bond sale schedule. First, the uncertainty of the instrument, particularly in its first auction, might necessitate changes to the announced sale schedule. Second, financing objectives might change, prompting changes in the schedule or volume at each sale. Third, sale frequency and size might require adjustment. For example, during a disruption, a moratorium on bond sales might be necessary. Finally, some 
discretion in bond sale frequency and volume would be recommended as a strategy for controlling the size of the bond's redemption pool.

With annual bond sales, the bonds would contain a serial progression from the oldest to the newest. If no disruption occurred within 10 years, the first bond issue would require redemption, and very likely refinancing. The first bond series would then be retired and in its place, an eleventh bond series could be issued or the first series could be refinanced with standard public debt instruments. This progression would continue until either a disruption occurred, all issues were refinanced with standard public debt, or the U.S. Government chose to sell off all or a portion of the SPR and thereby call the outstanding bonds. On the other hand, if a disruption occurred, bonds could be redeemed in serial fashion, on a first-issued/first-redeemed basis. This chronological specification would be part of the bond's contract terms at the time of issue.

\section{Bidding Structure}

Bidding for bonds could occur in a variety of ways. One common way would be for the issuer to set a fixed price at redemption (the face value of the bond) and a series of fixed annual "coupon" or interest payments that would be made on each bond. Market participants would then indicate what price they would be willing to pay for this security, and the bonds would be sold to those bidding the highest prices. Depending on market conditions, the price paid for the bonds could be higher or lower than the face value at maturity.

One problem with using this approach to issue oil-indexed bonds is that the price paid, on a perbarrel basis, could be higher or lower than the cost to the Government to acquire the barrel for the SPR. To alleviate the problem, the Government could fix the price of the bond at a level approximately equivalent to expected costs of SPR oil acquisition. Under this approach, one of the other variables, such as the coupon payment or the value at maturity, would have to become the compelitively bid variable.

For this study the Department has chosen to fix the initial bond price at an SPR oil cost cquivalent and also fix -- at zern -- the annual coupons. The bidding variable would be the minimum payback to the investor at maturity.

There are arguments for different bidding structures, such as fixing annual coupon payments at a level above zero. A zero-coupon approach was selected because it most clearly illustrates the effects of the oil-indexed bond approach as compared to conventional Treasury securities.

\section{Yield Structure}

The bund would have three distinct yield patterns and would be designed as a discount, ur "zeirocoupon," bond where interest would not be paid until redemption. Redemption could occur either at maturity or at the time of an oil disruption and SPR drawdown.

\section{a. Minimum Yield-to-Maturity}

Investors would be asked to bid a minimum 10 -year yield-to-maturity with no annual payout (zerocoupon feature). 


\section{b. Oil Value Index}

Above that minimum, the bond's value would be linked to the oil price according to a reference formula. The bond would be worth a fixed number of barrels (fixed at the time of issue), so that its oil value linkage could be easily determined.

\section{c. Maximum Yield-to-Maturity}

The bond would have a maximum 10-year yield-to-maturity, equivalent to a predetermined maximum oil price increase. In other words, if the rate of increase of oil prices were to cxceed the predelermined maximum increase, the investor could not earn more than that maximum at redemption.

The following graph illustrates the principle of these three yield structures.

Figure VII-1

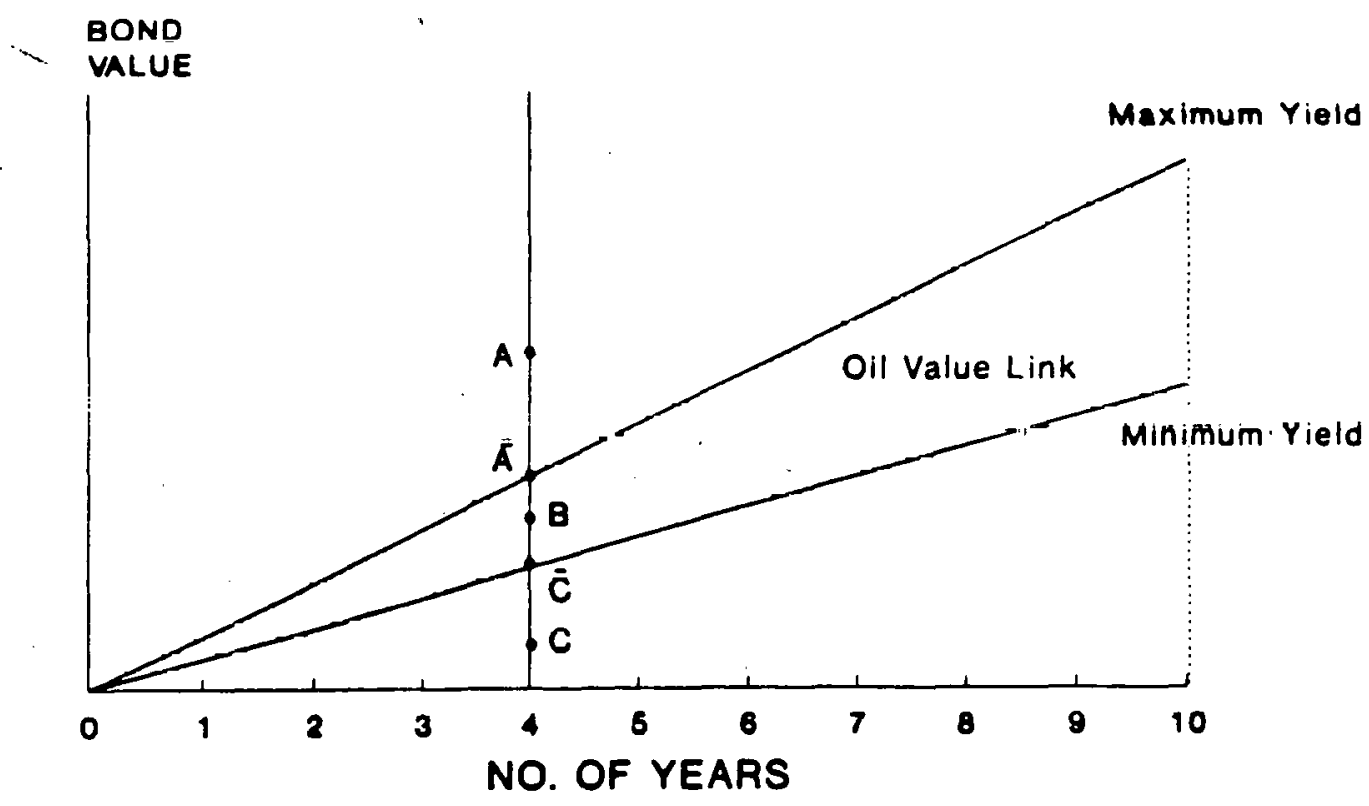

In the illustration, the bond's maximum and minimum values are shown by the associated boundary lines over the 10-year life of the bond. Should an oil disruption occur, for example, in year 4, then the bond's value is bounded by the points $\bar{A}$ and $\bar{C}$ If oil prices rise to point $A$, the maximum the investor would earn is $A ;$ if oil prices rise only to point $C$, the investor would still earn $\bar{C}$ if oil prices rise to point, $B$, between $A$ and $\bar{C}$, the investor would then earn $B$. 
In general, therefore, the investor's rate of return would be capped by the maximum yield, and would be indeterminate below that yield, but could not fall below the minimum yield. The minimum yield would be determined by competitive bidding at the time of issue. Since the Government would be setting a ceiling price and an unknown value link below that ceiling, the Government would be asking investors the minimum yield which they would require for the opportunity to earn as much as the predetermined maximum.

The Government can always raise funds through borrowing with conventional debt instruments having a fixed and known yield. The key reason why the Government might choose to sell an oil-indexed bond would be to create the possibility of a borrowing cost below the cost of conventional Government debt. As a result, acceptable bids on the bond's minimum yield would have to be below conventional Government borrowing costs for similar maturities at the time of bond issue. This investor would, in effect, be trading off the certain return on conventional Government bonds for the opportunity to earn as much as the rate of return specified by the maximum yield. Yields between the maximum and minimum would be determined by oil prices. The minimum yield as bid by investors, therefore, would reflect their acceptance of some risk of not achieving the return on conventional Government bonds in order to have the opportunity to earn a rate of return commensurate with their expectations of oil prices. The extent to which investor oil price expectations over the 10-year period exceed the return on conventional Government bonds would determine the level of their minimum bids. The higher these oil price expectations, the lower would be the minimum bids, and conversely.

\section{d. Zero-Coupon Feature}

A zero-coupon bond has the feature of not paying out a yield to the investor on a periodic basis over the life of the bond, but rather accumulating all of the interest due until maturity. For example, at time of issue, a 10 percent $\$ 1000$ zero-coupon bond would be worth $\$ 2,594$ at the end of year 10. This is equivalent to an annual 10 percent yield, or $\$ 100$ per year, reinvested each year at 10 percent. With the annual yield being paid out to the investor, a bond would be worth only its initial principal of $\$ 1000$ at the end of year 10 . With a zero-coupon bond, the interest would be accumulated by the bond issuer and paid off in one lump sum at bond maturity.

The zero-coupon feature would, therefore, have the additional advantage to the Government of not requiring annual cash outlays to pay interest although annual interest accruals could be charged against the Federal budget. This would be consistent with the purchase and storage of oil in the SPR, which generates no cash flow until the oil is sold. As a result, the Government would be postponing its obligated interest payments until the bond is either redeemed due to a disruption, at which point the SPR oil would be sold, generating the necessary funds, or until maturity when the Government could refinance the expiring bond issue. There is, of course, the higher level of budget authority required to pay the investor at maturity, should no oil disruption occur.

\section{Maximum Yield}

Setting the maximum yield for the bond would be in many respects equivalent to setting a fixed cash payment schedule for liquidating an oil lease obligation. For the investor, it would establish 
the upper bound limit on the profitability of the investment. For the Government, the maximum yield has two functions:

- It permits the Government to realize a portion of the profits that would have been associated with an outright purchase if oil prices would rise above the levels originally anticipated.

- It mitigates the policy problems that could be associated with permitting private investors or even foreign governments to achieve significant profits as a result of the price increases associated with a supply disruption.

Setting the maximum yield thus involves both business and policy judgments. In general, the maximum yield should be somewhat above the Government's current price expectations, and also above Treasury borrowing rates. A key feature of the oil bond approach would be to induce investors to offer a lower minimum yield in exchange for the possibility of a higher yield, based on oil market developments. The lower the maximum yield, the higher the likely bids on minimum yield.

\section{Oil Price References}

At time of issue, the bond would be denominated in barrels; that is, the bond would have a value equal to the price of oil times the number of denominated barrels. Since, at time of issue, the bond would also have a dollar value, there would be an implied initial price of oil, or Base Price. This Base Price would have to be determined by the Government at time of issue in order to calculate the number of barrels that the bond would be worth for a given dollar bond size. (E.g., a given bond size of $\$ 1,000$ at a $\$ 20$ Base Price would mean a bond whose value equals the value of 50 barrels of oil.)

Once the Base Price is determined, a market price reference must be defined. That is, to calculate the bond's value at any point in time, a specific oil price reference is needed. In this regard, the discussion of alternative oil price indicators in Chapter VI is directly relevant. (See pages VI-19 to VI-24 and pages VI-30 to VI-31.)

In addition to the selection of a particular market reference, and back-up references should the primary reference become unavailable, the issue of the time period over which that reference is measured should be addressed. While it is theoretically possible to link the bond's value to the daily fluctuation of oil prices, such a practice would be cumbersome for the investor and almost impossible administratively for the Government. A monthly or quarterly average of the daily reference price would be easier to administer and would be in keeping with the way physical oil is actually traded in the oil markets. This monthly or quarterly average would need to be known in advance, so that the previous month's or quarter's average would be the likely price reference. This numerical value would stay in effect for the entire concurrent period, until another numerical value would be established. That is, the previous month's or quarter's average would stay in effect until the next month or quarter had passed and a new average could be calculated. Subject to the established maximum and minimum yields, the bond would have a value at any point in time as measured by the ongoing oil price reference, albeit lagged by one month or one quarter. 


\section{Call Features}

A critical element in the design of an oil-indexed bond would be its particular call features: the designation of who has the right to bond redemption prior to maturity and when that right could be exercised. When refers to time of disruption or business-as-usual times, and who refers to the U.S. Government or the investor.

\section{a. Call Rights at Disruption Exercisable by the Government}

In this alternative, the Government would have the right, but not the obligation, to redeem the bond during an oil supply disruption and consequent sale of SPR oil. At that point in time, it is likely that the bond's value would exceed its minimum, since oil prices probably would be rising rapidly. Subject to the value of the ceiling price at that point in time, the bond would be redeemed at the value indicated by the designated oil price reference, which in the case of a disruption could be the actual price received at the SPR drawdown sale.

On the other hand, the Government could choose not to exercise its call rights during a disruption and let the bond remain outstanding until maturity. In this case, an investor could see prices rise substantially and not be able to benefit at that time. The investor would bear the risk that prices could decline after the disruption and be substantially lower at bond maturity. As a result, an oilindexed bond carrying this type of call feature would be more difficult to sell and would likely require a higher minimum yield-to-maturity.

\section{b. Call Rights at Disruption Excrcisable by the Investor}

In this alternative, the bond's contract terms would permit the investor to redeem the bond at the time of disruption and attendant SPR drawdown. It is likely that most investors would exercise that right, probably achieving a yield exceeding the minimum yield at that time. There could be a subgroup of investors, however, who might choose not to redeem, especially if oil prices at the disruption had not achieved the maximum yield.

This alternative could create some administrative problems for the Government in terms of determining which bonds were redeemed, and at which permissible values, and which bonds were still outstanding. The problem could be dealt with through a numerical sequencing of the bond issues, and a specification in the bond's contract terms that older bonds would always be redeemed first, until the Government either ran out of SPR sales proceeds or had paid off all investors wishing to redeem their bonds. With this call right, investors would likely bid a lower minimum yield, since they should expect the maximum yield to be attained at the time of a disruption. Among other things, this feature could make the oil-indexed bond an attractive investment for a major oil consumer concerned about the potential for a rapid increase in oil prices during a disruption. The call feature would permit the investor to receive cash sufficient to purchase the needed oil at market prices.

A variation on the call feature at the time of the disruption would be to permit the use of SPR uil bonds as payment to the DOE for SPR oil during an emergency drawdown. Instead of a Government payment of cash directly to the bondholders, bondholders could resell the bonds to oil companies which had successfully bid for and contracted to purchase SPR oil. If this feature 
were selected, procedures would need to be developed for making quality and quantity adjustments, maintaining serial priorities, and so conducting SPR sales as to include payments via SPR bonds.

\section{c. Call Rights with No Disruption, Exercisable by the Government}

If there were no disruption, it is likely that resolution of the issue of call rights would depend primarily on interest rate expectations. Most full-faith-and-credit conventional U.S. Government bonds carry call protection provisions, while Government agency bonds would vary, with some containing "deferred" call protection provisions. This deferral might not be for the full life of the bond but may extend well into its life, with the timing of the deferral being dependent on projections of cash flows available for redemption.

With no disruption, investors in oil-indexed bonds would likely wish to reduce or eliminate the risk that the Federal Government would call the bonds early because intcrest rates have declined. To the extent that investors had little or no call protection, they would demand a commcnsurately higher minimum yield at the time of bond issue.

\section{d. Call Rights with No Disruption, Exercisable by the Investor}

If the investor were given call rights throughout the life of the bond, the investor would be able to "cash-out" at any time when he determined that oil prices had risen substantially. By conferring such a redemption right on the bondholder, possibly after a minimum mandatory waiting period, the bond's marketability would be substantially enhanced. A bondhnlder would know that he could always redeem the bond at the prevailing oil price, thereby substantially enhancing the liquidity of the resale market. An investor who thought that oil prices were about to decline could easily sell the bond to a different investor who thought that oil prices were about to increase. Without this bondholder redemption right, the bearish bondholder would have no other resale alternative, and would thereby be forced to sell to the bullish investor at a potentially substantial discount from the prevailing oil price. During most of the bond's life, that discount would force the bond's value to its minimum yield upon date of issue, and severely limit its linkage to oil prices during most of its life.

The disadvantage of granting this redemption feature is the budget effect. That is, after the waiting period, the DOE theoretically would be responsible for redeeming all outstanding bonds. To the extent that this would be a problem, a solution could be found in the use of financial community market-makers who could offer the redemption privilege. That is; the Government financial instrument would not grant the investor a redemption privilege, but the market-makers would stand ready to buy the bond back at or near the prevailing price. These market-makers would likely demand some discount from the value set by the prevailing oil price, but because of their other oil hedging and financial relationships, they could more easily find new buyers. In fact, offering that redemption privilege could be a condition of the initial underwriting.

Giving the call right to the investor is known as a "putable" feature. A limited example of this feature is the Series EE U.S. Savings Bond.

A possible middle ground among these four alternatives would be to make the Government redemption mandatory at disruption, and permit the investor call feature at all other times. At 
disruption, the investor would be assured of "cashing out," most likely at the maximum yield, while for business-as-usual periods the bond would likely trade at its oil-linked value.

\section{Redemption Procedures}

For the investor, the critical issue is assurance of redemption at disruption. This raises two potential questions. First, what would the rules be for sale of Government beneficiary SPR oil relative to sales of investor beneficiary SPR oil; i.e., whose oil will be considered sold first? Second, would the SPR drawdown necessarily generate sufficient funds to redeem all outstanding bonds?

The answer to the first question should be straightforward. In the event of a disruption, all investor beneficiary oil would be considered sold ahead of Government beneficiary oil. To do otherwise would distort the risk/return expectations of potential bond investors at the time of bond issue.

To a large extent, the answer to the second question depends on the number of outstanding bonds at time of disruption relative to the scale of the SPR drawdown. Suppose, for example, that by the year 2005, the Government had sold 400 million barrels worth of oil-indexed bonds, so that the SPR stood at one billion barrels, containing 60 percent Government beneficiary oil and 40 percent investor beneficiary oil. If a disruption occurred requiring the release of less than 400 million barrels, then the SPR sale might not generate sufficient funds to redeem all outstanding bonds. In this case, three alternative procedures could be used:

- The Federal Government could reserve the right to prorate its redemption according to the proportion of available SPR sales proceeds relative to the value of the outstanding bonds. All investors would then get partial payment with the balance extending to maturity or another disruption.

- The Government could reserve the right to redeem outstanding bonds in serial fashion, with the oldest bonds redeemed first until the SPR sales proceeds were exhausted. Unredeemed bonds would then remain outstanding until either maturity or another disruption.

- The Government could promise to redeem all outstanding bonds and utilize general Government revenues, if necessary. While this would be an unconditional assurance to the iivestor, it might require additional budget authority and would not be in keeping with the "self-financing" goal of the index bond program.

While the possibility of insufficient funds would need to be provided for in the bond's contract terms, it seems improbable for at least three reasons. First, if a disruption occurs, it is likely to involve a larger drawdown rather than a smaller one, thereby generating sufficient SPR revenues for full redemption. Second, even if the SPR drawdown is smaller in scale, the oil price at the time of disruption might exceed the maximum value to which the bondholder would be entitled, thereby generating additional revenues for bond redemption. For example, if 320 million barrels 
were sold for $\$ 100$ per barrel, but investors were only entitled; based on the maximum yield provisions, to $\$ 80 / \mathrm{barrel}$, then the full 400 million barrels could be redeemed. Finally, the bond program itself could be kept somewhat smaller in scale, say, not to exceed 25 percent of the total SPR level, in which case it is likely that any drawdown could cover the redemption of all outstanding bonds.

\section{Refinancing Issues}

If the first index bond series were issued in 1991 with a 10-year maturity, the bond would need to be refinanced in the year 2001, assuming that no disruption took place over the decade. The precise amount of budget authority needed for that refinansing wnild be indeterminate, although it could be bounded by the maximum yield-to-maturity established at that time.

The receptivity of the bond market after the year 2000 to a refinancing of an oil-indexed bond would depend upon what the actual rate of return on the maturing bond would have been, how that would compare to competing investment alternatives, and the outlook for oil prices in the year 2000 looking ahead to the year 2010. In 1990, it is impossible to make any reliable projections of the trends in such expectations. Suffice it to say that if the bond market were not receptive to an index bond refinancing, then conventional Treasury bonds could be used at that time. On the other hand, a lack of market receptivity to an oil-indexed bond refinancing in the year 2000 would most likely be predicated on a 1990's history of low or declining oil prices. In that case, the Government would likely be refinancing at the minimum yield-to-maturity, which means the Government would have at least borrowed the funds in the 1990's at lower than conventional Treasury bond rates. And this goal is central to the whole idea of an index bond in the firsi place.

\section{Collateral}

Bidder confidence and, therefore, the bid price (ie., minimum return rates), would be partly determined by collateral. The bond could finance an independent financial entity through the creation of a "bond redemption" or revolving fund. This fund could be built by proceeds from bond sales, which might initially exceed near-term financial requirements.

The SPR bund could be proposed as an agency issue. However, uncertainties surrounding the ability of the agency (the DOE) to generate a redemption fund of sufficient size to satisfy the program's potentially high financial exposure could be too great to enable the bond to succeed as an agency issue. In the budget analysis below, it is assumed that the financial liability represented by the bond would be fully backed by normal appropriations by the Congress, as contractual obligations that were, in turn, backed by the full faith and credit of the Federal Government.

Without this feature or some similar legal provision, the bond might suffer some loss of value. This would be particularly true for a new bond issue with a rather unique and untested value reference. 


\section{Resale Market}

In order for the index bond to enjoy investor receptivity at time of issue, conditions for resale would have to be established which generally promote the liquidity of a secondary market. In addition to the pricing and call features already discussed, three additional issues must be addressed.

\section{a. Ownership Restrictions}

Any decision to preclude nationals of selected foreign countries from participating probably would be nearly impossible to enforce, since a restricted foreign national could set up qualified entities in any number of ways and control those entities through various intermediaries.

\section{b. Use of Bonds to Pay for SPR Oil}

As discussed earlier, in the event of an oil disruption and SPR drawdown, the Government could permit bondholders of record to pay for SPR oil with the index bonds. Since each bond would be worth a given number of barrels, the bondholder would need only to swap the bonds for the oil. This would likely enhance the secondary market by bringing in a number of oil companies who might want easy access to physical oil in the event of a disruption.

\section{c. Quantity Limits at Redemption}

The Government could limit the number of bonds which an investor of record could use for purchase of SPR oil in a disruption. If a single large investor were to acquire and then withhold a large number of barrels from the market during an SPR drawdown, this action could impede the very purpose of the drawdown. While such an action might appear improbable, there are instances of large individual traders attempting to corner certain forward oil markets from time to time. As a result, quantity limits could be imposed on the use of bonds for the purchase of physical oil in an emergency drawdown.

\section{Other Implementation Issucs}

In addition to the design features enumerated above, several additional issues have been identified concerning implementation of an oil-indexed bond. These include the following:

- Tax treatment of a zero-coupon indexed security, involving IRS determination of interest versus changes in capital value. It is possible that only the minimum yield would be subject to taxes as current. interest income, with taxes on any further appreciation due to oil market conditions being deferred until maturity. Under such circumstances, the Government would need to consider adjusting its criteria for accepting offers from prospective bondholders, to reflect the likely costs of tax deferral.

- Commodity Futures Trading Commission jurisdiction would need to be clarified. 
- Acceptability of the oil-indexed bond as tax and loan collateral to the Treasury.

- Determination of whether the oil-indexed bond would be on the commercial book entry system maintained by the Federal Reserve.

\section{Illustrative Financial Model}

To analyze financing cost in more depth, it is first important to illustrate the mechanics. of the oil bond concept. This section provides an example of how an oil bond might work, using the illustration of a bond issued in April 1992 for a 10-year term.

(a) The bond is worth the value of 56.53 barrels of oil on April 1, 1992. It has a par value of $\$ 1,000$, equivalent to a Base Price of $\$ 17.69$ per barrel.

(b) The bond carries a zero-coupon with a 10-year maturity. It has a maximum yield-to-maturity of 13 percent per annum from 1995 to 2001; from 1992 to 1994, it has a maximum yield of 1.443 times the base price, or the equivalent of $\$ 25.53$ per barrel. 1 . As a result, the bond's maximum value on or after April 1,2002, is $\$ 3,396$. The bond is redeemable by the investor on a quarterly basis.

(c) Investors would be asked to bid the minimum value which they require on April 1, 2002. To estimate what investors might bid, two key variables must be defined. First, because the investor would be likely to compare the expected yield on the index bond with the certain yield on a conventional Treasury bond, an assumption must be made on Treasury bond yields of 10-year maturity. This rate is assumed to be 8 percent. Second, because the bond's value is linked to oil prices, the investor's oil price expectations must be defined. The concept of a probabilistic expectation is critical to this analysis, since if the investor knew for certain that oil prices would rise by a given amount, he could simply compare that figure to the "risk-free" Treasury bond yield and determine which was higher. But, since the investor cannot know for certain what oil prices will be in the future, he would assume his best estimate with a certain probability and thereby implicitly assume a whole range of prices above and below that best estimate, such that the total probability of all his estimates will equal 100 percent.

(d) Table VII-2 illustrates a set of price expectations which could be held by the government and the investor. These are the same as those presented as Probability Distributions A in Chapter VI and are based on three price projections (Base, High, Low) assumed to be normally distributed around a mean value equal to the average of the three projections for each year (x-bar). The standard deviation ("s") is assumed to equal the High minus Low, divided by 1.35 , which effectively assumes that 50 percent of the probability distribution encompasses the three cases.

1/ In order to set a cap value which was unlikely to be exceeded in the early years, it was assumed that for the first three years, the cap would represent the equivalent to three years of price growth at $13 \%$ per annum. 
Table VII-2

Probability Distribution and Price Assumptions

(Fiscal Year, Nominal \$ per barrel)

\begin{tabular}{|c|c|c|c|c|c|c|c|c|}
\hline & \multicolumn{6}{|c|}{ Price Projections } & \multicolumn{2}{|c|}{ Sensitivity Cases } \\
\hline BASE & $\underline{\mathrm{HIGH}}$ & LOW & $\frac{\text { MAX YLD }}{(13 \%)}$ & $s$ & $\underline{x \text {-bar }}$ & $\begin{array}{l}\text { Disruption } \\
\text { Price } \\
\frac{\operatorname{Pr}(D)}{D}=.01\end{array}$ & $\frac{\text { MAX YLD }}{(18 \%)}$ & $\begin{array}{l}\text { Disruption } \\
\text { Price } \\
\operatorname{Pr}(D)=.05\end{array}$ \\
\hline 17.19 & 21.05 & 14.84 & & 4.60 & 17.69 & & & \\
\hline 18.16 & 22.91 & 15.75 & 25.53 & 5.30 & 18.94 & 31.30 & 29.07 & 27.69 \\
\hline 19.76 & 24.64 & 17.11 & 25.53 & 5.58 & 20.50 & 33.50 & 29.07 & 29.71 \\
\hline 22.09 & 26.82 & 18.62 & 25.53 & 6.07 & 22.51 & 36.66 & 29.07 & 32.53 \\
\hline 24.47 & 29.11 & 19.98 & 28.85 & 6.76 & 24.52 & 40.28 & 34.30 & 35.68 \\
\hline 27.52 & 32.45 & 21.80 & 32.60 & 7.89 & 27.26 & 45.64 & 40.48 & 40.27 \\
\hline 30.69 & 36.13 & 23.74 & 36.84 & 9.18 & 30.19 & 51.57 & 47.76 & 45.33 \\
\hline 33.90 & 40.10 & 25.54 & 41.63 & 10.79 & 33.18 & 58.31 & 56.36 & 50.98 \\
\hline 36.62 & 44.20 & 27.54 & 47.04 & 12.34 & 36.12 & 64.87 & 66.51 & 56.48 \\
\hline 39.06 & 48.48 & 30.06 & 53.15 & 13.64 & 39.20 & 70.99 & 78.48 & 61.71 \\
\hline 41.97 & 52.43 & 32.19 & 60.06 & 14.99 & 42.20 & 77.13 & 92.60 & 66.93 \\
\hline
\end{tabular}

(5) For the investor, there are three classes of possible outcomes:

- Actual oil price at maturity exceeds \$60.06, (Max Yield) such that the investor obtains a $13 \%$ yield.

- Actual oil price is at or under the minimum bid (Min Yield), such that investor obtains the Min Yield.

- Actual oil price is between the minimum and the maximum.

In selecting the minimum, the investor would affect both the yields and the likelihoods associated with the last two of these possible outcomes:

The following table presents, for Probability Distribution A, the expected yields associated with different minimum yields:

$\begin{array}{cr}\text { Minimum Yield (\%) } & \text { Expected Y } \\ 0 & 8.3 \\ 5 & 8.9 \\ 8 & 9.7\end{array}$

In all cases, the expected yield would be in excess of the 8 percent which we have assumed as a Treasury borrowing rate. 'The reason why this is the case, even when there is a 0 percent minimum, is that the Base Case price forecast, around which this probability distribution was built, entails a rate of oil price growth of more than 8 percent through 2001. Therefore, an oil bond with no maximum or minimum yields would be expected to exceed Treasury bond yields. Absent 
any risk premium being added to the oil bond, one would expect an investor to pay to make this investment, (or bid a modest negative minimum yield), just as there were instances cited in Chapter VI where a lessor would pay the SPR a small annual charge to hold the lessor's oil.

A shift to a more conservative Probability Distribution B affects these outcomes substantially. The following table provides the expected yields associated with three different minimum yield bids.

$\begin{array}{cc}\text { Minimum Yield (\%) } & \text { Expected Yield (\%) } \\ 0 & 5.1 \\ 5 & 6.5 \\ 8 & 8.3\end{array}$

With lower price expectations, the chances of hitting the maximum yield would decline, from 11 percent in Probability Distribution A to less than 1 percent under Probability Distribution B.

Under B, a minimum yield of approximately 7.5 percent would be associated with an expected yield equal to the Treasury borrowing rate of 8 percent, close to the 50 basis points cited in the major bank lending proposal discussed in Part A above.

\section{EVALUATION}

The purpose of this section is to provide an evaluation of the zero-coupon oil-indexed bond concept in accordance with the evaluation criteria set forth in Chapter I.

\section{Minimize The Cost Of The Reserve}

As discussed in Section A of this chapter, the cost of the oil bond approach cannot be determined in advance. This cost would depend on the minimum rate of return bid by prospective investors and by actual, rather than predicted, trends in oil prices. However, the weight of the evidence suggests that the expected, or probability-weighted, cost of the oil bond approach would exceed the cost of conventional Treasury borrowing.

The financial evaluation has been organized in three parts. First, building on the example presented above, an analysis is undertaken of the possible financial outcomes from conventional financing and oil bonds. Second, the question of likely market reaction to oil bonds is discussed. Third, an illustration is provided on the budget effects of oil bonds.

\section{a. Potential Financial Outcomes}

Under conventional Federal financing, if the Government acquires a barrel of oil for the SPR in FY 1991 at a price of $\$ 17.19$ per barrel and holds the oil for 10 years during which it pays 8 percent per year in conventional Treasury interest, the total interest charges through the year 2001 would be $\$ 19.92$, and the total investment cost would thus be $\$ 37.11$. For this life-cycle, the net outcomes would be directly dependent on the price at which the oil could be resold in FY 2001. 
For oil bonds, the net financial outcome for this same life-cycle would depend not only on the price of oil in the year 2001, but also on the minimum and maximum rates of return specified in the oil bond instrument. As indicated in the example above, when the maximum yield is set at 13 percent, the minimum yield bid by investors would reflect two judgments. First, investors would need to establish their target levels of expected, or probability weighted, yields, and second, investors would need to develop projections about the range of possible oil price outcomes at the maturity of the bond. Investors demanding higher expected rates of return, to reflect risk judgments, and investors with lower oil price expectations would tend to bid higher minimum yields. Alternatively, investors demanding lower expected rates of return or who had higher oil price expectations would tend to bid lower minimum yields.

For purposes of this illustration, two alternative minimum yields are assumed: 5 percent and 7.5 percent. The lower minimum yield is associated with the investor holding Probability Distribution A price expectations, who demanded an expected rate of return of between 8 percent and 9 percent. The higher minimum yield is associated with the investor holding Probability Distribution B oil price expectations, who also demanded an expected rate of return on the range of 8 to 9 percent.

Under either minimum yield case, the maximum payout at maturity would be $\$ 58.34$, reflecting the 13 percent maximum yield. The minimum payout at a 5 percent minimum yield would be $\$ 28.00$, and the minimum payout at a 7.5 percent minimum yield would be $\$ 35.42$.

Table VII-3 presents the actual net Federal financial outcomes for conventional financing and for these two oil bond examples under different year 2001 oil price levels. In each case, the term net Federal financial outcome refers to the difference between the value of the asset the Federal Government has acquired and the cumulative principal and interest cost through the ten year period.

Under conventional Federal financing, the Government would bear all risk of low oil prices, but would gain all profit from higher prices. Under the oil bond approach, the Government bears a part of the risk for lower prices. There would be a price range (between the minimum and the maximum) within which the investor would bear all risk of price fluctuation, and at higher prices, the Government would obtain a portion of the price appreciation.

The higher the minimum yield bid, the more downside price risk the Federal Government would bear. At higher minimum yields, the range in which the Government would break even (the zero entries in the above table), would be reduced. At an 8 percent minimum yield, for example, the Government would bear all of the downside price risk of conventional financing, but only a portion of the potential upside benefits, hence one would expect the Government to reject bids with minimum yields as high as Treasury horrowing rates.

\section{b. Anticipated Market Response}

There is evidence that the private financial markets would bid higher, rather than lower, minimum yields and that the expected cost of oil bond financing to the Federal Government would be higher than the expected cost of Trcasury financing. 
Table VII-3

\section{Net Federal Financial Outcomes \\ (dollars per barrel in FY 2001)}

\begin{tabular}{|c|c|c|c|}
\hline & Conventional & & \\
\hline & Financing & $5 \% \mathrm{Min}$ & $7.5 \% \mathrm{Min}$ \\
\hline Maximum Cost & $\$ 37.11$ & $\$ 58.34$ & $\$ 58.34$ \\
\hline Minimum Cospt & 37.11 & 28.00 & 35.42 \\
\hline $\begin{array}{l}\text { Oil Price in } \\
\text { FY } 2001\end{array}$ & & & \\
\hline$\$ 10$ & -27.11 & -18.00 & -25.42 \\
\hline$\$ 20$ & -17.11 & -8.00 & -15.42 \\
\hline$\$ 30$ & -7.11 & 0 & -5.42 \\
\hline$\$ 40$ & +2.89 & 0 & 0 \\
\hline$\$ 50$ & +12.89 & 0 & 0 \\
\hline$\$ 60$ & +22.89 & +1.76 & +1.76 \\
\hline$\$ 70$ & +32.89 & +11.76 & +11.76 \\
\hline
\end{tabular}

First, as discussed in Chapter IV, it appears that the oil price expectations of the private sector are lower than the Federal Government estimates used in this study. Accordingly, private investors would expect less in the way of upside potential gains and would therefore tend to bid higher minimum yields to avoid potential downside losses.

Second, one would expect investors to add a risk premium to Treasury borrowing rates in establishing their expected rates of return. Higher expected rates are derived from higher minimum yield bids, since the maximum yield, under this formulation, is established by the Government.

Finally, there are clear indications that there would be a premium paid because the private market would accept these new securities less readily than conventional Treasury securities. There are several reasons for this. Federal agencies other than the Treasury would pay more than the Treasury does to borrow in the market, even though the credil backing for the security may be the same as that for Treasury securities. The reason for this is that securities that are issued or guaranteed by Government agencies and Government sponsored enterprises do not enjoy the market liquidity of Treasury securities. The Federal Financing Bank was established in 1973 to remove securities that are issued or guaranteed by Federal agencies from the market and finance them at lower cost through the FFB, which obtains its financing through the Treasury.

There are several categories of Government-related financing in the market, all of which are more expensive than Treasury financing. The yield comparisons in the information below do not include the effect of commissions and fees, which increase the total cost. 
(1) Direct Federal agency borrowing. In November 1989, for example, the Tennessee Valley Authority issued 40-year power revenue bonds in the market. Those bonds, which are not explicitly backed by Government, were priced to yield 110 basis points above long-term Treasury securities, while a seven-year noncallable issue of TVA bonds was priced at the same time to yield 52 basis points above comparable Treasuries. A basis point is one one-hundredth of a percentage point. Current spreads between the TVA bonds and Treasuries have narrowed slightly.

(2) Guarantees of bonds issued by others. The largest, most active market for Governmentguaranteed securities is the market for Government National Mortgage Association guaranteed mortgage backed securities. Those securities, whose average life compares most closely with 10-year Treasury securities, have been trading recently at 100 basis points above Treasuries. GNMAs have prepayment risk that is not present with Treasury securities, which in part accounts for the width of the spread.

The Rural Electrification Administration guaranteed securities issued in the market by Big Rivers Electric Cooperative in February 1988 at a spread of 103 basis points above comparable Treasury 30-year securities and 60 basis points above 10-year Treasuries. A more recent July 1989 REA-guaranteed issue by Cajun Electric Cooperative was priced at a 75-basis point spread above 20-year Treasuries. Current market yield information is not available for these REA-guaranteed securities.

Foreign military sales obligations guaranteed by the Department of Defense were sold in the market in 1988 and 1989. Their yields on original issue were 35 basis points above Treasuries at three years maturity, and 45 to 50 basis points above Treasuries at 10- and 20-year maturities. The Financial Assistance Corporation of the Farm Credit System has issued several tranches of 15 -year bonds, each with a yield between $3 / 8$ and $1 / 2$ percentage point above comparable maturity Treasuries. There is also a paucity of current trading in these issues.

(3) Government sponsored enterprise issues. The Government sponsored enterprises (GSEs), such as the Federal National Mortgage Association and the Federal Home Loan Banks (FHLBs), do not have full faith and credit backing of the U.S. Government. Their borrowing cost are generally lower than those of Federal agencies other than Treasury and federally-guaranteed borrowers, because they have established markets over the years and issue securities frequently. These factors have contributed to market liquidity. GSE securities are currently trading at about 30 basis points above Treasuries at three years maturity and 50-100 basis points for longer maturities.

Second, an oil-indexed bond market does not presently exist, indicating a lack of demand for the instrument. Absent substantial underwriting margins or commissions, underwriters would have little incentive to develop a market for the instrument. Commissions and fees in excess of the one percent or more of proceeds realized by issuers common on commercial offerings of established debt instruments would be expected.

- Deferral of some taxation as discussed above, could reduce minimum yield bids by increasing after-tax expected yields. (This factor would not, however, reduce the cost to the overall Federal budget.) 
- The potential for a call on the bonds at the maximum yield of 13 percent prior to maturity, would tend to reduce the minimum yields bid.

- If investors believed the annual risk of a disruption to be high, there could be further reductions in the minimum yield by raising the maximum yield.

- There may be some value added to oil-index bonds as an general inflation hedge for many investors, as an oil price escalation hedge for major consumers, or as a unique oil-denominated security related to existing oil futures, options, or swap markets.

One must be careful with any argument that suggests that oil bonds create economic value by providing investors with a new hedging or speculative device. The private market already provides many such opportunities. In cases where it doesn't -- e.g., the ability to hedge oil price outcomes many years into the future -- it must be assumed that there is little economic use to having the trading opportunity in the first place. There is no reason to believe that the private market does not provide a sufficient level of innovation in financial products.

Whether the Federal Government could deem an oil-index bond concept to be successful would depend on three major factors:

- The relationship of Federal Government oil price expectations to those of the financial markets;

- The willingness of the Federal Government to accept higher minimum bids to reflect the transfer of risk to investors; and

- The success in designing and selling the security, including education of a target group of purchasers.

\section{c. Budget Effects}

In comparison to current financing methods, oil-bonds issued through a DOE contractual instrument would have significantly different effects on BA and outlays. For budget authority, using 10-year bonds with a 13 percent upper bound as an annual growth in liabilities, the Department could be required to have as much as $\$ 60$ in BA for each $\$ 17$ barrel acquired in FY 1991. Of this differential of over $\$ 40$, approximately one-half is attributable to the compound interest being transferred from 'Treasury to the DOE budget and from the future into the present, since Treasury receives annual budget authority to pay interest on conventional debt. The other half of the additional BA reflects the possibility that the Federal Government would be liable for a higher rate of return, up to the 13 percent maximum yield cap.

Once the bonds were redeemed, a portion of this budget authority might be freed up. For example, if the Department of Energy obligated $\$ 58.34$ per barrel, as presented in Table VIII-3 above, to cover its maximum liability under the oil bonds, and if the actual redemption value was 
$\$ 40.00$ then $\$ 18.34$ could be deobligated at maturity. Thus, the budget authority effect of oil bonds would ultimately equal the life-cycle net financial results presented in Table VII-3, but would be higher in the early years before the full financial liability was certain.

Budget outlay effects would depend on decisions made concerning budget scorekeeping. Actual cash outlays would be fully deferred until maturity, due to the zero-coupon feature. At maturity, budget outlays would converge to equal the ultimate amount of net budget authority. However, in the case of certain Treasury issued zero coupon instruments, the decision has been made to score budget outlays for the interest on an accrual basis. Applying this precedent to SPR oil bonds, there would be some scorekeeping of outlays in advance of actual cash payments.

While most of the evidence suggests that higher costs would be paid, there are other factors which would tend to reduce the minimum and expected yields bid. These are considered below.

\section{Other Evaluation Criteria}

\section{a. Orderly Development of the NPR}

The NPR concepts are unaffected by oil-index bonds.

\section{b. Minimization of Vulnerability}

There are essentially three ways in which oil-index bonds could affect U.S. vulnerability to supply disruptions:

\section{(1) Effects on SPR Fill Rate}

Under fixed budget authority levels, the SPR till rate from oil index bunds could dccline dramatically because as discussed above, the initial DOE BA requirements for bonds could be much higher than those for direct purchase to cover the potential liabilities.

However, if outlay scorekeeping is the constraint and, as presented above, the proceeds of the bond sale are treated as a net cash receipt in the DOE budget, then zero-coupon oil-indexed bonds could defer DOE net outlay requirements substantially and possibly permit an increase in the SPR fill rate.

\section{(2) Effects on Non-SPR Inventories}

It is possible that the availability of an oil-indexed bond instrument could be viewed in some market segments as an attractive alternative to storing oil. A major consumer, for example, could buy such securities as a way of hedging against major increased in oil prices.

The degree of this effect cannot be reliably quantified. There are other financial instruments, though typically of shorter maturity, that already perform this hedging function. Also, one would not expect integrated oil companies to be a major market for these securities since they typically already have oil reserve assets that would change in value in relation to oil price developments. 


\section{(3) Effects on Disruption Characteristics}

As noted in Section B, it hypothetically is possible for the involvement of private investors in the oil-indexed bond approach to create a constituency whose financial well-being is linked to rapid increases in oil prices and, except at maturity, an SPR drawdown that would trigger all provisions. This is a purely hypothetical possibility but could be a consideration in voluntary financing concepts.

(c) Minimization of Impact on Market Forces and (d) Encouragement of Competition in the Petroleum Industry.

Each of these criteria was intended to relate to the method of SRR "wetl lantel" vil acquisition. The oil-indexed bond approach provides a source of funds for SPR oil acquisition, but would not necessarily affect the rate or manner in which SPR oil was acquired. Therefore, there would be no direct effect on the oil market or the petroleum industry from the use of the oil bond approach. 


\section{CHAPTER VIII. NAVAL PETROLEUM RESERVES ALTERNATIVES}

\section{A. BACKGROUND}

The Federal Government owns substantial assets that could be divested to reduce the national debt or finance programs such as the SPR. This study has not investigated funding the SPR by the sale of any of these assets, with the single exception of the Naval Petroleum Reserves (NPR). This chapter considers the interrelationship of the NPR and the SPR. Some consider the two programs to be interrelated; others disagree. The chapter considers direct use of NPR oil for filling the SPR, creation of a revolving fund, leasing the NPRs, and selling the NPRs as options for financing the SPR.

The history of the NPR and the SPR have been linked in a variety of ways: In addition, the rationale for their original creation was similar. Overlap between the programs is now apparent.

The Naval petroleum reserves were set aside in the first two decades of this century to fuel the Navy's fleet as it converted from coal to oil. Debates at the time reveal a concern that oil might be in short supply, and this possibility could make the fuel change ill-advised. There was limited confidence in the ability of the economy to provide a continuing supply of oil.

Similarly, the strategic petroleum reserve was inspired by problems in the oil supply system. Gasoline lines and shortages in the 1970's widely attributed to the oil embargo, convinced many that government intervention was needed to assure a supply of oil to supplement that supplied by the private economy. The demand for the SPR continues to be motivated, in part, by a concern similar to that which inspired the set-aside of the Naval petroleum reserves, that a supplemental oil supply held by the government is useful for supplementing the market economy.

The following is a short history of the interrelationships between these two programs:

\section{Program Authorization}

Both programs were the subject of major legislation as a result of the 1973-74 oil embargo. As part of the FY 1974 budget, the Congress determined that, due to their undeveloped status, the Naval Petroleum Reserves were incapable of performing their mission of providing emergency supplies of crude oil to the armed services. While the Department of the Navy could point to a massive resource at Elk. Hills, the wells and surface facilities did not exist to extract the oil at a rate which would be effective in supplying the armed forces during an emergency. The FY 1974 appropriations contained enough money to commence the drilling of wells and full development of the facilities at Elk Hills.

At about the same time, the National Petroleum Council conducted two studies on a Strategic Petroleum Rcserve. One of its conclusions was that an effective emergency reserve would have to be stored in manmade caverns, rather than in natural oil fields held in a reserve state, in order to achieve the higher drawdown rates needed to mitigate the effects of a major interruption in imported oil supplies. 
In 1975, the Congress passed enabling legislation for the creation of a Strategic Petroleum Reserve, Title I, Part B of the Energy Policy and Conservation Act. The authorized size was up to one billion barrels.

In 1976, the Congress passed the Naval Petroleum Reserves Production Act of 1976, Public Law No. 94-258, Title II, which, among other things, required that the Naval Petroleum Reserves be produced at their "maximum efficient rates" for a period of six years. The Act also authorized an indefinite number of extensions of up to three years upon a Presidential finding, and certification to Congress, that continued production was in the national interest.

The two programs had similarities and differences. Both were inspired by a conviction that the government needed to supplement the workings of the marketplace. However, they nriginally had different missions. The NPR was established to meet fuel needs of the armed forces. The. SPR was established to meet the needs of the entire economy. With the enactment of NPR and SPR legislation in 1975, the NPR was used to produce oil; the SPR was placed in stand-by status for use only in emergencies. The oil produced at the NPRs is now used by the civilian economy, but that use could be interrupted in case there were an emergency requiring use of the NPRs to meet defense needs.

In 1980, the enactment of Public Law No. 96-294 amended the Naval Petroleum Reserves Production Act of 1976 to authorize the Secretary of Energy to transfer the Government's share of NPR production to the Department of Defense upon the request of the Secretary of Defense, 10 U.S.C. Chapter 641, 7430(1). To implement this statute, the departments cooperatively created a Petroleum Transfer Agreement in 1981. The agreement details the method of transfer and paymerit for the petroleum and was used from 1981 through 1986, when the Department of Defense took varying amounts of NPR crude oil in support of its fuel supply assurance program. The agreement is still in effect, and all sales contracts for NPR petroleum are qualified to make clear that the sales may be terminated if the Department of Defense requests the transfer of NPR petroleum.

The legislation establishing the SPR and opening up the NPRs for use by the civilian economy authorized use of NPR crude to fill the SPR and established a special account that would keep a running tally of NPR receipts. These amounts could then be appropriated to meet the financial need of the NPR and SPR programs.

Section 160 of the EPCA states in part:

(a) The Secretary is authorized, for purposes of implcmcnting the Strategic Petroleum Reserve Plan, ... to place in storage, transport, or exchange --

(1) crude oil produced from Federal lands, including crude oil produced from the Naval Petroleum Reserves to the extent that such production is authorized by law;

(b) The Secretary shall, to the greatest extent practicable, acquire petroleum products for the Reserve . . . in a manner consonant with the following objectives: 
(2) orderly development of the Naval Petroleum Reserves to the extent authorized by law; ...

Similarly, the Naval Petroleum Reserves Production Act of 1976, 10 U.S.C. Chapter 641, provided for the creation of a Naval Petroleum Reserves Special Account into which all receipts from sales of petroleum from the Naval Petroleum Reserves would be deposited. The funds in the Special Account were to be made available through annual appropriations for a number specified activities, including the procurement of petroleum for, and the construction and operation of facilities associated with, the Strategic Petroleum Reserve. The Special Account was in fact the source of $\$ 440$ million in funding for the SPR, before the account was abolished by Public Law No. 96-137, effective December 12, 1979. Thus, the authorizing legislation for both programs envisioned the possibility of financial or physical interrelationships.

\section{SPR Fill Rate Linkages}

In 1980, Congress more directly linked the two Reserves by amending the Energy Policy and Conservation Act to require that the Secretary of Energy fill the SPR to 500 million barrels of oil at an average rate of 100,000 barrels per day in any fiscal year, and providing that, if such a fill rate was not met, the Government's share of production from Naval Petroleum Reserve Number 1, Elk Hills, could not be disposed of other than to the SPR. This provision has been in effect since that time, although the SPR statutory target level has been raised to 750 million barrels and the minimum fill rate has been lowered to 75,000 barrels per day.

\section{NPR Production Reauthorizations}

Under the provisions of the Naval Petroleum Reserves Production Act of 1976, the President had to make and transmit to Congress a finding in October 1981 on whether it was in the national interest to continue production at the NPRs. President Reagan decided that it was in the national interest to continue production for another three years. The investigation report that accompanied the finding recognized the evolution of the functions of the Reserves. The report emphasized that the primary responsibility for providing strategic protection had become the duty of the SPR, that the function of providing protection associated with the NPRs could be best performed by continuing NPR production, and that non-strategic aspects of the Naval Petroleum Reserves were gaining in importance. Similar findings were made in 1984, and again in 1987, for the triennial reviews of the desirability of continuing NPR production.

These conclusions also noted the diminution in the importance of the NPRs to emergency defense fuel requirements. For example, one of the conclusions of the 1987 investigation was that:

NPR-1 would have little impact in a national defense emergency since the Reserve could not resume production in a timely manner at a rate significant enough to meet a national emergency crude oil shortfall. A short-term crude oil supply shortage can be more effectively met by the drawdown of the Strategic Petroleum Reserve (SPR). (Investigation on the Continued Production of the Naval Petroleum Reserves Beyond April 5, 1988, DOE/FE-0091, September 1987.) 


\section{Naval Petroleum Reserves Price Legislation}

In 1986, Congress once again emphasized the interrelationships between these two programs by passing Public Law No. 99-413. This law requires, in effect, that the proposed sales prices for NPR crude oil be measured against the cost of transporting the NPR oil to the SPR and the purchase price for SPR oil, and only allows the NPR crude oil to be sold if it results in cost savings compared to movement of the crude oil to the SPR. This underscores the link which some parties see between the Naval Petroleum Reserves and the Strategic Petroleum Reserve.

\section{Naval Petroleum Reserves Divestiture}

In 1987, the Department of Energy further amplified its views, expressed in its studies on continued production when it reported to the Congress on divestiture of the Naval Petroleum Reserves (Divestiture of the Naval Petroleum Reserves, DOE/FE-0089, June 1987). The DOE study considered that "the Strategic Petroleum Reserve is an integral part of the National Energy Policy Plan and NPR divestiture would, in practical effect, supply needed investment capital to complete the SPR." The report advised that the Naval Petroleum Reserves were not integral to the Federal Government's "business strategy."

\section{Revenue Linkage}

While Congress did not enact the Administration's divestiture plan, it did adopt, in a limited manner, the concept of linking the fill of the SPR to the revenue from the sale of NPR petroleum. As part of the FY 1988 appropriations act, all NPR revenues in excess of $\$ 836$ million were to be deposited in the SPR Petroleum Account. Because oil prices in FY 1988 were low, NPR revenues never reached the threshold, and all NPR revenues continued to be placed in the Miscellaneous Receipts account in the U.S. Treasury. Nevertheless, the Congress continued with this concept, and as part of the FY 1990 budget, provided that all NPR revenues in excess of $\$ 510$ million would be deposited in the SPR Petroleum Account. With this lower threshold, there is a high probability that revenues will be placed in the SPR Petroleum Account during the last two months of FY 1990.

It has been argued, however, that this approach to providing funding for the SPR would not conform with the rules Congress established to meet Gramm-Rudman-Hollings budget targets. It allocates amounts from within a mandatory budget account (that for NPR receipts) to increase discretionary spending (for oil for the Strategic Petroleum Reserve). One general argument against the concepts discussed in this chapter is that they tend to reduce control over budget spending patterns.

\section{1989 Divestiture Proposal}

Finally, the Administration drew the most direct connection between the two Reserve programs when it proposed legislation for divestiture during 1989. The draft bill sent to the Congress by the Administration proposed that Naval Petroleum Reserves Numbered 1 and 3 be divested, and that the sales price would include a requirement to deliver some 109.5 million barrels of oil to the SPR, plus another 10 million barrels of oil to be delivered to the SPR for a "Defense Petroleum Inventory;" there also was to have been a cash bonus of at least $\$ 1$ billion. This proposal implied 
that, for strategic purposes, 119.5 million barrels of oil in the SPR was more suitable for emergency energy requirements than the larger reserves of oil in the Naval Petroleum Reserves.

Table VIII-1 and Figure VIII-1 show how the reserves of oil at Elk Hills have been produced since opening in 1976 as the reserves at the Strategic Petroleum Reserve have been built up. It illustrates that approximately as much crude oil has been produced from the largest NPR field as has been acquired for the SPR.

There are three Naval Petroleum Reserves and three Naval Oil Shale Reserves. At the present time, NPR-1, Elk Hills in California, is generating nearly all of the net revenues from these resources, and the NPR/SPR financial linkage concepts discussed below address only the use of Elk Hills to finance the SPR. The financial results would not change substantially if the other Reserves were also included.

\section{Table VIII-1}

\begin{tabular}{|c|c|c|c|c|}
\hline & \multicolumn{2}{|c|}{$\begin{array}{c}\text { NPR-1 Total Crude Oil } \\
\text { Production } \\
\text { (Million Barrels) }\end{array}$} & \multicolumn{2}{|c|}{$\begin{array}{l}\text { SPR Crude Oil } \\
\text { Fill } \\
\text { (Million Barrels) }\end{array}$} \\
\hline & Annual & Cumulative & Annual & Cumulative \\
\hline 1976 & 3.8 & 3.8 & 0.0 & 0.0 \\
\hline 1977 & 37.0 & 40.8 & 7.2 & 7.2 \\
\hline 1978 & 43.5 & 84.3 & 61.3 & 68.5 \\
\hline 1979 & 52.6 & 136.9 & 23.2 & 91.7 \\
\hline 1980 & 58.3 & 195.2 & 16.1 & 107.8 \\
\hline 1981 & 62.6 & 257.8 & 122.5 & 230.3 \\
\hline 1982 & 60.7 & 318.5 & 63.5 & 293.8 \\
\hline 1983 & 57.3 & 375.8 & 85.3 & 379.1 \\
\hline 1984 & 50.5 & 426.3 & 71.4 & 450.5 \\
\hline 1985 & 47.7 & 474.0 & 43.2 & 493.7 \\
\hline 1986 & 42.2 & 516.2 & 18.8 & 512.5 \\
\hline 1987 & 39.8 & 556.0 & 29.0 & 541.5 \\
\hline 1988 & 39.3 & 595.3 & 18.9 & 560.4 \\
\hline 1989 & 35.2 & 630.5 & 16.9 & 577.3 \\
\hline
\end{tabular}


Figure VIII-1

\section{Cumulative NPR-1 Production vs. SPR Fill}

(Since 1976)

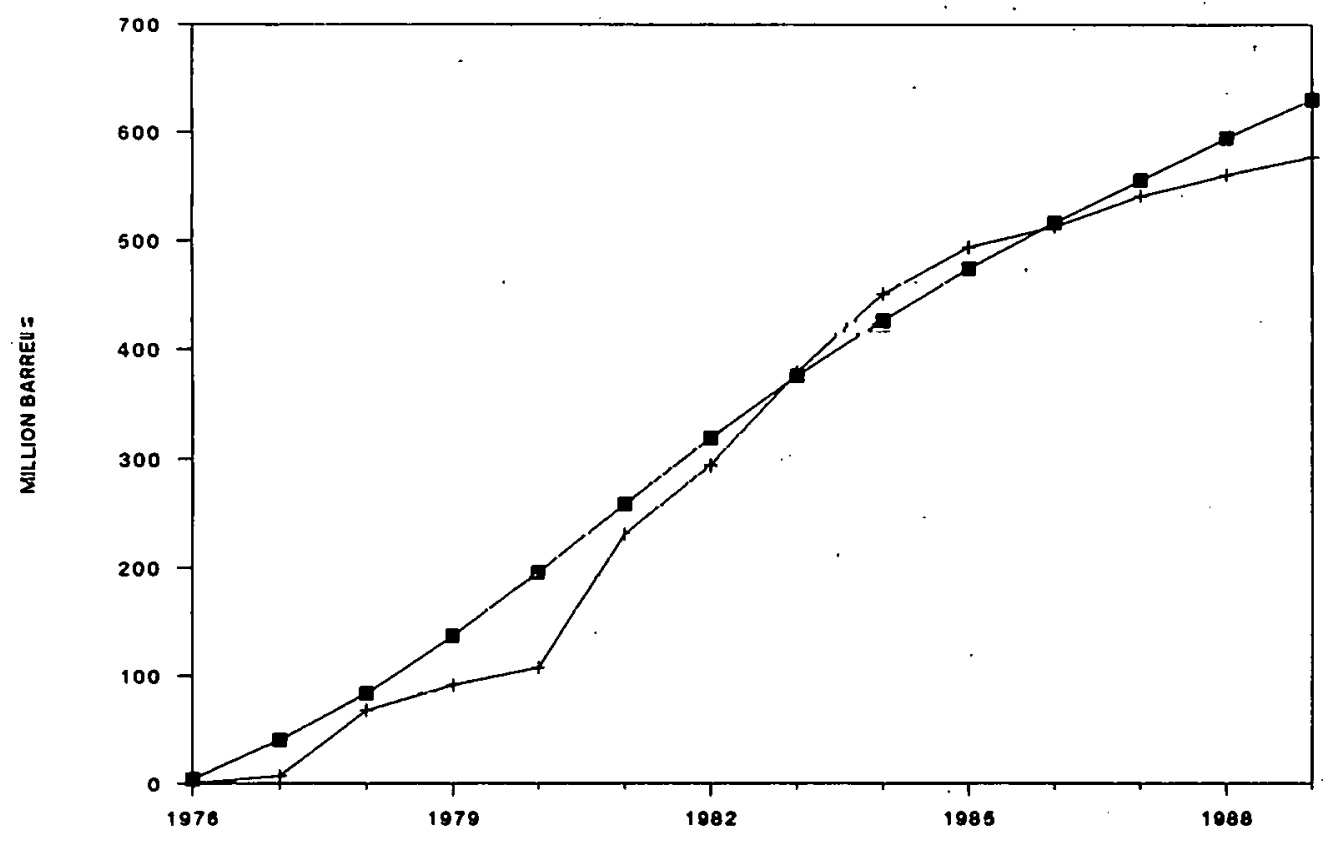

- MPR-1 PRODUCTIOR

+ SPR Reserves

In summary, the relationship of the Strategic Petroleum Reserve to the Naval Petroleum Reserves has evolved in legislation, history, and common goals so that there now exists a close linkage between the two programs. Therefore, the study of the Naval Petroleum Reserves as the source of oil or funds to expand the SPR is warranted. The four approaches considered for using the NPRs to provide resources for the SPR are as follows:

(1) Direct delivery of NPR crude oil to the SPR;

(2) Creation of a revolving fund to permit NPR profits to be used for the SPR;

(3) Outright sale of the NPRs, with proceeds used for the SPR; and

(4) Leasing the NPRs to provide funds for the SPR. 


\section{B. ALTERNATIVE 1: THE MOVEMENT OF NPR-1 OIL TO THE SPR}

A question frequently asked is why the government is selling NPR in California and Wyoming, but buying oil to inject into the SPR in Texas and Louisiana. Why not pump it from the NPRs directly into the SPR? This section considers these questions. In short, oil has moved directly from the NPRs to the SPRs. However, in general it is less costly to sell NPR oil and buy SPR oil in separate transactions.

\section{Elk Hills Crude Oil as an Input to the SPR}

The Strategic Petroleum Reserve accepts crude oil, the characteristics of which fall into one of five distinct categories, established according to API gravity, sulphur content, yield percentages, and certain other physical qualities, as shown in Table VIII-2.

Table VIII-2

SPR Crude Oil Specifications ${ }^{a}$

\section{Characteristics}

API Gravity [ $\left.{ }^{\circ} \mathrm{API}\right]$

Total Sulphur [Wt. \%] Max.

Pour Point $\left[{ }^{\circ} \mathrm{F}\left({ }^{\circ} \mathrm{C}\right)\right]$, Max.

Salt Content

[Lbs./1,000 Bbls.] Max.

Viscosity

[SUS@60F (cSt@15.6 $@$ )]

Viscosity

[SUS@100'F (cSt@37.8 @ C)]

Reid Vapor Pressure

[Psia@100 $\left.\mathrm{F}\left(\mathrm{kPa} @ 37.8^{\circ} \mathrm{C}\right)\right]$, Max.

Total Acid Number [mg KOH/g], Max.

Water and Sediment [Vol. \%], Max.

Yields [Vol. \%]

Naphtha $\left[<375^{\circ} \mathrm{F}\left(<191^{\circ} \mathrm{C}\right)\right]$

Distillate $\left[375-620^{\circ} \mathrm{F}\left(191-327^{\circ} \mathrm{C}\right)\right]$

Gas Oil $\left[620=1050^{\circ} \mathrm{F}\left(327-566^{\circ} \mathrm{C}\right)\right]$

Residuum [ $\left.>1050^{\circ} \mathrm{F}\left(566^{\circ} \mathrm{C}\right)\right]$

\begin{tabular}{|c|c|c|c|c|}
\hline \multicolumn{5}{|c|}{ Categories b } \\
\hline I & II & III & IV & $\mathbf{V}$ \\
\hline $30-45$ & $40-45$ & $30-40$ & $34-40$ & $36-41$ \\
\hline 1.99 & 0.25 & 0.50 & 0.25 & 0.50 \\
\hline $50(10)$ & $50(10)$ & $50(10)$ & $50(10)$ & $50(10)$ \\
\hline 50 & 50 & 50 & 50 & 50 \\
\hline $150(32)$ & $150(32)$ & $150(32)$ & $150(32)$ & $150(32)$ \\
\hline $70(13)$ & $.70(13)$ & $70(13)$ & $70(13)$ & $70(13)$ \\
\hline $11(76)$ & $11(76)$ & $11(76)$ & $11(76)$ & $11(76)$ \\
\hline 0.40 & 0.40 & 0.40 & 0.40 & 0.40 \\
\hline 1.00 & 1.00 & 1.00 & 1.00 & 1.00 \\
\hline $24-30$ & $35-42$ & 21-29 & $29-36$ & $30-38$ \\
\hline $17-31$ & $21-35$ & $23-37$ & $31-45$ & $19-33$ \\
\hline $26-38$ & $20-34$ & $28-42$ & $20-34$ & $23-37$ \\
\hline $10-19$ & $4-9$ & $7-14$ & $0-5$ & $7-14$ \\
\hline
\end{tabular}

Primary ASTM

Test Method

D 1298

D 1552

D 97

D 3230

D $445 \&$ D 2161

\section{323}

D 664

D $473 \&$ D 4006

D 2892 \& D 1160

a Mäketable virgin crude petroleum suilable for normal refinery processing and free of foreign contaminants or chemicals including, but not limited to, chlorinated and/or oxygenated hydrocarbon, and lcad.

b For SPR acquisition and storage purposes, crude oil meeting the characteristics of Category I is designated as sour, while crude oil meeting the characteristics of Categories, II, III, IV, and V is designated as sweet.

c To the illaximum extent practicable, the primary ASTM test methods listed are to be used in characterizing crude oil.. While other methuds may be uscd when the primary method is unavailable, the primary method is designated as the binding method should results of the alternative method be questioned. 
The two major types of crude oil produced at Elk Hills come from the Stevens Zone and the Shallow Oil Zone. The main characteristics of these oils are shown in Table VIII-3.

Table VIII-3

Qualities of Elk Hills Crude Oil

Stevens Zone

(at $18 \mathrm{G}$ )

Shallow Oil Zone

(at 10G)

API Gravity ( $\left.{ }^{\circ} \mathrm{API}\right)$

34.4

25.9

@60

Specific Gravity

0.846

0.899

@60

Sulphur (not to exceed)

0.64

0.68

(\% by weight)

Reid Vapor Pressure

5.9

3.0

Viscosity

44.4

78.7

@100

Shallow Oil Zone oil does not meet the requirements of any of the five categories of SPR oil based upon API gravity, the lowest acceptable gravity being $30^{\circ}$. The Stevens Zone crude oil does meet the requirements for SPR Category I crude oil in all respects, and it is this crude oil which theoretically could be moved to the Strategic Petroleum Reserve, if logistics and economics permitted.

The volume of Stevens Zone oil available for shipment to the Strategic Petroleum Reserve is expected to decline at a rate whirh, if relied upon as the cxclusive $3 P R$ suurce, would postpone the time at which the SPR reached its target lcvel of 750 million harrels. Specifically, the volume available in FY 1991 is estimated to be approximately 50,000 barrels per day, the lowest of the three fill rates considered in Chapter V. Moreover, this rate may decline by as much as 10 percent annually, depending on investment decisions in future periods. Accordingly, NPR Stevens Zone oil would not be viable as an exclusive option for providing fill to take the SPR to one billion barrels.

\section{Logistics}

The map of Elk Hills (Figure VIII-2) shows the two locations from which Stevens Zone crude oil leaves NPR-1 and enters the commercial pipeline systems, the 18G LACT station and the $24 \mathrm{Z}$ LACT station. The oil located at the $24 Z$ LACT unit can go into four different pipelines or to a truck loading rack. Two of the pipelines potentially could be the first step in the transport of the oil to the SPR: the Celeron Gathering System, associated with the Celeron All American Pipeline, and the Anchor Pipeline which immediately connects with the Four Corners Pipeline. 
The Celeron Gathering system is designed to deliver crude oil to the main trunkline of the All American Pipeline. Entry into this system would take the oil to either Wink or McCamey, Texas. Celeron Gathering is purchasing 5,000 barrels per day of NPR Stevens Zone oil from October 1, 1989, through April 1, 1990, and is moving it over this exact route. Once the oil reaches west Texas there are a number of pipeline routes that would enable the oil to reach the SPR.

If the oil at the $24 \mathrm{Z}$ location goes into the Anchor Pipeline, it transfers to the Four Corners Pipeline, which is capable of taking the oil south and east. The oil could then be transferred either to the All American Pipeline or to the Texas-New Mexico Pipeline, either of which could move the oil to west Texas. A computer matchup of data collected by the National Petroleum Council for its 1989 study of pipelines shows that there are 120 combinations of pipelines which could move the NPR oil to the SPR.

The Stevens Zone oil delivered to the other NPR-1 custody transfer location, the 18G LACT unit on the south side of Elk Hills, must go into the Four Corners Pipeline. As with the oil going through the 24Z LACT, this oil can be transferred to either the All American Pipeline or the Texas-New Mexico Pipeline, and ultimately to the SPR.

\section{Segregation of Oil}

There have been two occasions when the Government actually moved Elk Hills oil to the SPR, in 1982 and in 1986-1987. Both moves predated the availability of the All American pipeline, and, therefore, the oil moved through the Four Corners Pipeline. The Four Corners Pipeline is an unheated, uninsulated pipeline which carries much of the heavy crude oil produced in Kern County, California, to refineries in Bakersfield and Los Angeles. Because of the low API gravity of this oil, the Four Corners Pipeline blends in as much light oil with it as possible, to improve the viscosity to the point where the oil will flow in the pipeline. Elk Hills crude oil is much favored for this purposc. When the oils are blended, the composite gravity of the oil in the pipeline becomes approximately $28^{\circ}$ API. This is sufficient for pipeline movement, but is too low a gravity to qualify for injection into the SPR.

Because of this problem, the Government has required the pipelines to segregate the NPR oil and movc it in batches, to avoid the degradation of the original oil. 'This has led to a number of logistical problems. Since the pipelines do not habitually segregate crude oils over the long distance between California and Texas, and because there are a number of pipelines involved, the transfer of segregated oil from one system to another is difficult to coordinate. As a practical matter, when the oil was moved between systems during the 1987 transfer, the oil was shuttled into tanks at each step along the way. The oil would then await an opportunity to be batched through the next step. At times, the oil would be kept in tanks for days, and, as a result, the actual delivery of oil to the SPR did not occur until 4 months after it was put into the Four Corners Pipeline. 

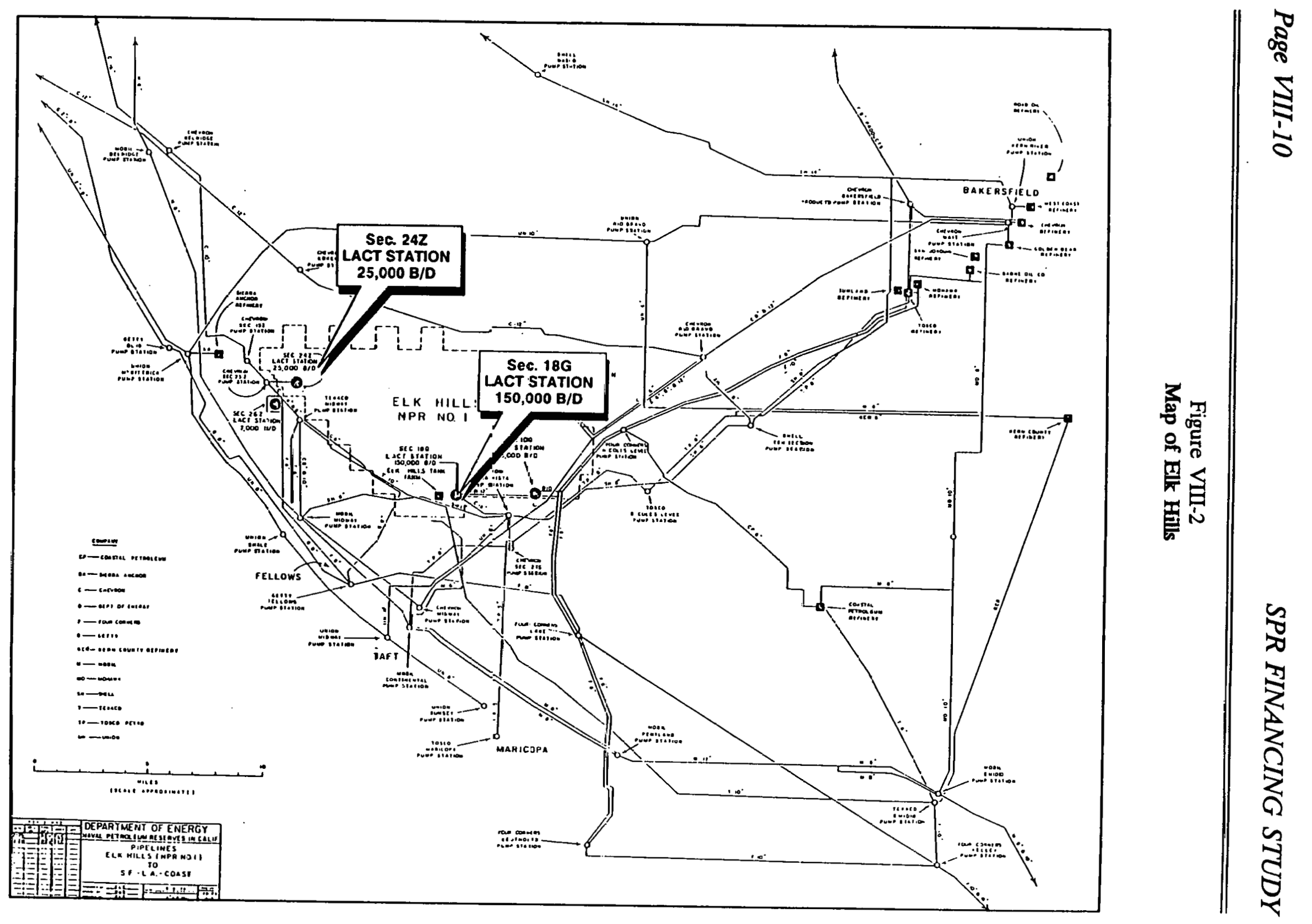
While these system tests showed the feasibility of moving small amounts of crude oil to the SPR, there is a general consensus among the Department's engineers and the pipeline companies that the segregation of large amounts of crude oil over time would be very difficult. The terminal facilities are not sufficient to maintain the integrity of the batches that would be required, and coordination between the pipelines is not sufficient to allow the oil to simply move directly from one system to another.

The value of the services provided by the pipelines would also present financial problems which would be difficult to resolve. In attempting to determine what the tariff would be for moving all of the Stevens Zone crude oil through the Four Corners Pipeline, the Four Corners Pipeline Company detailed the following problem. If Elk Hills stops providing NPR-1 Stevens Zone oil that Four Corners can blend with the heavier crude oils of the San Joaquin Valley, the average API gravity of the other oils in the line will fall and the throughput capability of the whole line will be reduced. Four Corners Pipeline notes that their current tariffs are based on assumed throughput rates and that the sum of tariffs and throughputs yields enough revenue to cover costs and provide a reasonable return on investment. If a decision by the Government to segregate Elk Hills oil reduced throughput, the tariffs would have to rise to provide the same revenue. Four Corners said that it was not clear how the tariff change would be designed, but that there could be a persuasive case made before regulatory agencies to put the full weight of the tariff increase on segregated oils, i.e., on the Elk Hills Stevens Zone crude oil. The conclusion of this report is that the logistical and financial efficacy of segregating and shipping large volumes of segregated Elk Hills oil would be very much in doubt.

\section{Transportation Costs}

The costs of moving crude oil over pipeline transportation systems are composed of three parts: (1) the cost in dollars per barrel for the service; (2) a separate cost in dollars per barrel for the energy cost of muving the oil through the pipeline; and (3) a shrinkage cost associated with the formation of deposits in the pipeline, which is a percentage of the oil moved. Because these costs are continually changing, it is impossible to be definitive about the total cost of the tariff to provide service until the time that the service is actually rendered. However, the Department does have the history of its 1986-87 movement of Elk Hills crude oil to the SPR. The oil passed through four pipeline systems at a total cost of $\$ 2.77$ per barrel. At the time, the United States was also buying oil from Mexico for the SPR. The cost of moving the Mexican oil to the SPR by ship was $\$ .54$ per barrel. Thus, the transportation differential between NPR-1 oil and Mexican oil at the time was $\$ 2.23$ per barrel of oil.

In 1986, Public Law No. 99-413 was enacted. As part of its compliance with the Act's "minimum price" criteria, the Department of Energy compares bid prices for its crude oil with the most recent prices paid for oil delivered to the SPR. Since the passage of the law, the Department has not rejected a bid in favor of actually moving the NPR oil to the SPR. Because oil can now be moved more easily from the west coast to the higher value market on the Gulf Coast, we expect that, with adequate competition for NPR-1 crude oil, it is unlikely that a situation would arise in which the DOE would have to reject bids and move NPR-1 crude oil in order to comply with Public Law No. 99-413. We believe that if this experience continues to hold into the future, it should continue to be advantageous to sell NPR-1 crude oil in California and to purchase oil for the SPR from the open market. 


\section{Budget Effects}

On the two occasions when NPR oil was moved to the SPR, the DOE paid to the NPR the fair market value of the oil, on behalf of the SPR. Therefore, the accounting for the transfer was similar to that in conventional NPR sales and SPR purchases. If the transfer of oil from NPR-1 to the SPR were planned for and adopted as a policy, the Congress could decide not to appropriate funds for the SPR, and could direct that the NPR not receive payment. The result of such a decision would be that the SPR budget requirements would be less, revenues would be less by an identical amount, the Department's net outlays would be exactly the same, and the budget deficit would be unaffected.

Such an approach would not be consistent, however, with current budget practices. It would eliminate annual appropriations for the SPR program, for example. This would make it morc difficult for the President and the Appropriations Committees in the Congress to exercise their judgment and discretion on the NPR and SPR programs. By excluding receipts and spending from the budget, it would result in the illusion that the Federal budget were smaller than in fact is the case.

\section{Other Effects}

Currently, NPR-1 oil is either used in California or moved to Texas, depending on the relative market values in those locations. If the DOE were to make NPR-1 crude oil the centerpiece of its SPR fill policy, it would continue to move oil from west to east, even though oil might become relatively scarce in California. A rigid policy such as this could have been considered inappropriate during the short period of time following the 1989 Alaskan oil spill in Prince William Sound, when prices for petroleum in California rose quickly.

Similarly, for a number of years, the Department of Energy has implemented a preference policy, under which it aims to award about 25 percent of the Government's oil to small refineries. Studies of competition done by the Department in 1987 showed that the oil market in California is relatively concentrated, and that the major integrated oil companies dominate the market. The Department is the largest independent source of domestic crude oil available to independent refiners. If the decision were made to move NPR-1 Stevens Zone oil to the SPR, the supply of this oil made available to independent refiners by the Naval Petroleum Reserves would be eliminated.

The Department is also concerned that a drop in throughput on the Four Corners Pipeline in the San Joaquin Valley, due to segregating NPR-1 light crude oil (discussed above) would cause a drop in heavy oil production from the San Joaquin Valley. This drop in production would be counterproductive to the United States balance of payments and to U.S. attempts to gain a higher level of energy self sufficiency. 


\section{ALTERNATIVE 2: A REVOLVING FUND LINK BETWEEN NPR-1 AND THE SPR}

From 1976 until 1979, the funds generated by the Naval Petroleum Reserves from the sale of petroleum were deposited into the Naval Petroleum Reserves Special Account at the Treasury. The establishment of the Special Account was so designed that appropriations were intended to be made from that account for certain expenses of the National Petroleum Reserve in Alaska, the Naval Petroleum Reserves, and the Strategic Petroleum Reserve. In practice, however, only one appropriation was made and that was for SPR petroleum acquisition. Other needed appropriations were made from the General Fund, and the Special Account continued to grow in size. Because all of the three programs that were to be the beneficiaries of the Special Account were receiving full funding, and the maintenance of the Special Account appeared to have no apparent benefits, the Congress abolished it in 1979.

This special account that at one time existed for the NPR and SPR program illustrates the advantages and disadvantages of a special account that Congress might want to consider for financing the SPR:

- $\quad$ For programs where there is a close relationship between spending and receipts, it may provide a valid way of viewing the program and increasing flexibility for program managers.

- For programs where there is not this close relationship (e.g. the NPRs and the SPR), it can formalize an agreed upon relationship e.g. that spending on the SPR should be linked with NPR receipts.

- This kind of account runs the risk of eliminating control by the Congress and the President unless it is subject to the condition that funds are to be made available only through the normal appropriations process. Congress and the President can always make larger or smaller amounts available for the SPR through the normal appropriations process. That process has the advantage of flexibility and annual reviews. The special fund lacks these advantages.

- Unless funding is made subject to the appropriations process, creating such a fund is arguably a onetime appropriation equal to the amount of expected spending over the life of the programs in question.

- Such an approach could create the illusion that spending on the program is free. That, of course is not the case since, if the spending did not occur, NPR receipts would be used to reduce the budget deficit. A special account thus invites uncontrolled spending. It encourages spending that is inconsistent with broader budget priorities.

A revolving fund is a fund established to finance activity from receipts generated by that activity. There are three generally recognized types of revolving funds: public enterprise funds, intragovernmental funds, and trust funds. See Comptroller General of the United States for the 
Task Force on Budget, 95th Cong., 2d Sess., Revolving Funds: Full Disclosure Needed for Better Congressional Control 1, 7 (Comm. Print 1977); OMB Circular A-34, Section 21.1, at page II-5.

The fact that NPR revenues are generated through public sales of petroleum would indicate that a revolving fund for them should be categorized as a public enterprise fund, which is defined as a fund authorized by Congress to be credited with receipts, primarily from the public, that are gencrated by, and earmarked to finance, a continuing cycle of business-type operations. Id.

An example of a current governmental enterprise that falls into this category is the Bonneville Power Administration. See 16 U.S.C. 838i. Each such fund must be created by specific statute, the form of which varies from program to program.

\section{NPR/SPR Revolving Fund}

For the purposes of this study, our analysis is limited to revenues from NPR-1, the Elk Hills, California, Reserve. A revolving fund that would fund SPR oil acquisitions and NPR operations must assure that the money generated by the NPR program is availablc to both programs when needed. This is seen as an advantage for any program that has time-sensitive opportunities which will not wait for the budget calendar. The SPR program has these opportunities when prices drop and the opportunity to buy more than an average amount of oil is at hand. Similarly, the NPR program would be able to finance unforeseen operational requirements, such as those arising out of increased environmental regulations, and highly profitable but time sensitive projects, such as offset wells.

On the other hand, this increased flexibility for program managers may mean decreased control for Congress and the President unless the revolving fund is combined with the need for annual appropriations. Congress originally specified a requirement for a 100,000 barrcl per day SPR fill rate, for example. Congress moditied this in the legislative process in view of other budgetary priorities. Maintaining this flexihility is important to avoid "overspending" un a program. But once the requirement is stated to comply with the normal appropriations process, much of the rationale for a revolving fund is diluted.

The revolving fund concept also would confirm thc evolving relationship between the NPR and the SPR. As the NPRs are produced, there would be a link between their financial value and the resources needed for filling the SPR. In comparison to the direct oil delivery method (Option 1), a revolving fund would avoid the diseconomies of oil transportation and would provide the SPR with access to the financial benefits of all Elk Hills production rather than only Stevens Zone crude.

Revolving funds subject to annual appropriations are less flexible than those funds that are adequately capitalized. Essentially, due to the earmarking of appropriations, such a fund protects the budget authority from being used for any purpose other than that apprnved by Congresi, but the annual appropriations process may prevent the summed deposits from ever revolving back into the authorized programs and may cause time sensitive opportunities to be missed. The Naval Petroleum Reserve Special Account was a revolving fund of this type; it did not allow either the NPR or SPR offices to plan on the expenditure of any of the funds in the account, regardless of the time sensitivity of opportunities. A capitalization type fund could allow for effective long-term planning, the flexibility to react to market opportunities, and the investment in economic capital 
improvements when the need occurs. Commitments of funds could then take place without the lag in the budget process. Ultimately, however, Congress and the President decide the degree of flexibility a revolving fund will be allowed. Such a fund increases program management discretion but decreases Congress' and the President's control and ability to revise priorities in light of changing circumstances.

\section{Authorization to Draw From the Fund}

If the revenues generated by NPR were to be put into a revolving fund, there could be several logical uses for the available pool of resources. First, the continuing operations and the capital expenditures required for NPR-1 would be the highest priority. Without the funding for continuing operations and development, the flow of revenues into the revolving fund would cease and a lower priority would cause net revenue to be reduced. Second, the oil fill requirements of the SPR would probably be considered the next highest priority. This would be consistent with the concept that the NPR and SPR are part of the same Reserve system, and that the SPR is slowly displacing the NPR as our protection against oil disruptions. The third possible candidate is the facilities development and maintenance requirements of the SPR, but the probability is very low of the revolving fund having resources for this aspect of the reserves based on NPR-1 revenue projections.

The long-range funding requirements for NPR-1 are in the range of $\$ 200-250$ million per year, including the share of costs borne by Chevron U.S.A. Inc., as part owner of Elk Hills. Under the Unit Plan Contract executed in 1944, Chevron and the Government "unitized" their Elk Hill interests and thus provided for the joint development of Elk Hills. The NPR funds allow for exploration, drilling wells, facilities, and operations and maintenance. While the demand for drilling rigs and oil field services is sensitive to the price of oil, in general the total outlays at NPR-1 are not highly sensitive to changes in the price of oil.

Based on the prioritization described above, the surplus in the revolving fund could be directed toward the purchase of crude oil for the SPR. Unlike NPR-1 facilities costs, the cost of crude oil purchases for the SPR will be directly proportional to the unit price of oil. Therefore, as price trends unfold, the size of the revolving fund available for SPR oil purchases should vary with the cost of filling the SPR. There is some basis risk in this approach in that the future revenue from NPR-1 will be generated more from natural gas and natural gas liquids and lcss from crude oil than has been the historical case. Therefore, if the price of oil rose relative to natural gas, the effectiveness of the revolving fund for buying crude oil would be more limited. Similarly, if natural gas prices rose relative to crude oil, the revolving fund would be more effective in generating purchasing power for SPR oil acquisition.

Table VIII-4 shows the level of funding that would be available for the SPR from the revolving fund, given three different crude oil price paths, assuming NPR-1's first priority to available funds. Two projections of production rates and costs are used: a "Planning Case," which was derived from the 1989 Long Range Plan, adjusted for FY 1991 budget decisions, and the "Bergeson Case," derived from a reserves report prepared by a private engineering firm in 1988. 
Table VIII-4

SPR Fill Equivalent to NPR Net Revenue - Planning Case

\begin{tabular}{|c|c|c|c|c|c|c|c|}
\hline \multirow[b]{3}{*}{$\begin{array}{l}\text { Fiscal } \\
\text { Year }\end{array}$} & \multirow{3}{*}{$\frac{\text { DOE Net }}{\frac{\text { Costs }}{(\mathrm{MM})}}$} & \multicolumn{3}{|c|}{ DOE Net Annual Revenue } & \multicolumn{3}{|c|}{ SPR Equivalent Annual Fill } \\
\hline & & \multicolumn{3}{|c|}{ (MM\$) } & \multicolumn{3}{|c|}{ (MMB) } \\
\hline & & $\underline{\text { High }}$ & Base & $\underline{\text { Low }}$ & $\underline{\text { High }}$ & Base & Low \\
\hline 1991 & $\$ 165$ & $\$ 507$ & $\$ 382$ & $\$ 302$ & 22.7 & 20.6 & 18.7 \\
\hline 1992 & 171 & 541 & 391 & 316 & 22.3 & 20.1 & 184 \\
\hline 1993 & 163 & 604 & 448 & .365 & 23.2 & 21.2 & 19.7 \\
\hline $19 y 4$ & 162 & 620 & 476 & 374 & 22.0 & 20.2 & 18.7 \\
\hline 1995 & 167 & 625 & 489 & 365 & 20.5 & 18.9 & 17.0 \\
\hline 1996 & 170 & 643 & 512 & 362 & 19.0 & 17.6 & 15.5 \\
\hline 1997 & 162 & 679 & 545 & 376 & 18.0 & 16.9 & 14.9 \\
\hline 1998 & 163 & 668 & 533 & 351 & 16.0 & 15.0 & 12.9 \\
\hline 1999 & 158 & 943 & 745 & 508 & 20.6 & 19.5 & 17.4 \\
\hline 2000 & 169 & 937 & 713 & 499 & 18.7 & 17.5 & 15.7 \\
\hline & & & & TAL & 202.9 & 187.5 & 169.0 \\
\hline
\end{tabular}

Calendar

Year

$1991^{*}$

1992

1993

1994

1995

1996

1997

1998

1999

2000
$\$ 165$

163

162

167

163

158

169
TOTAL
SPR Fill Equivalent to NPR Net Revenue - Bergeson Case

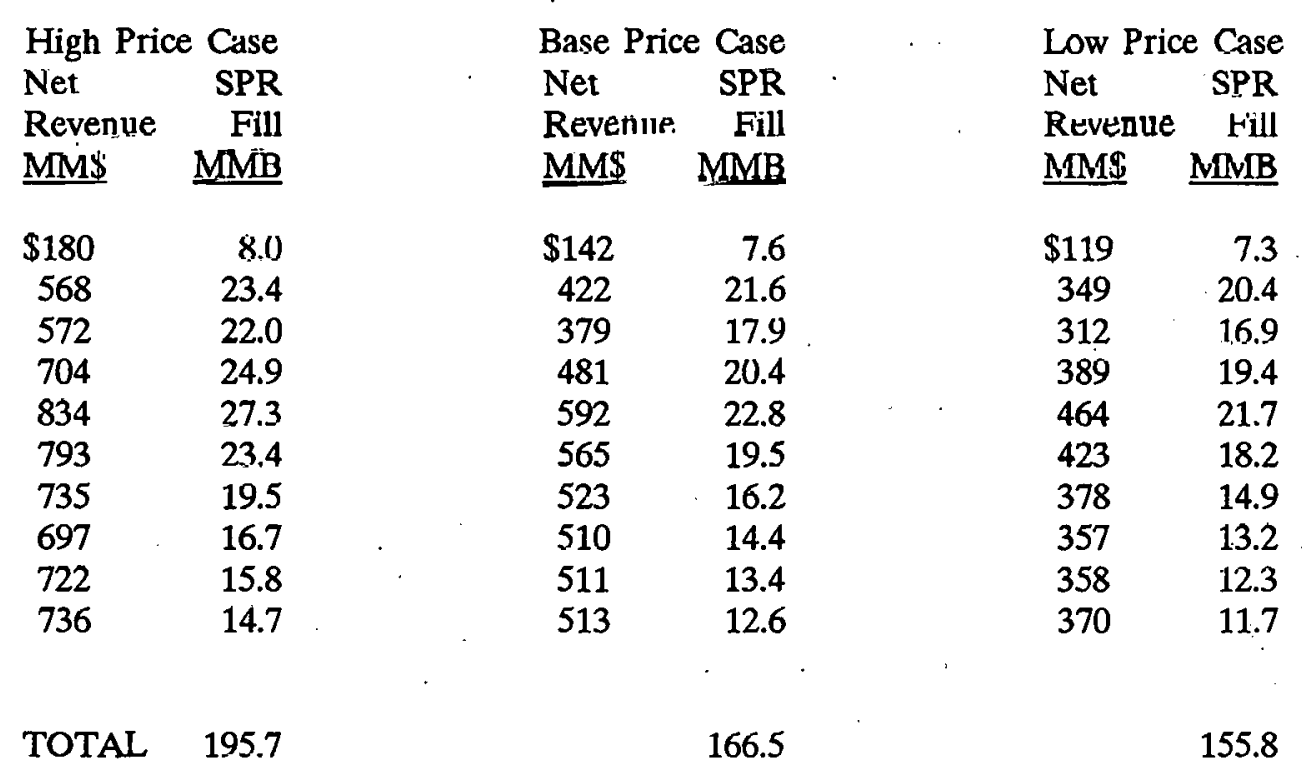

*Included only 3 months of 1991 
It must be remembered, however, that Elk Hills production already has passed its peak, which occurred in July 1981. The production of oil from NPR-1 now is dropping, and regardless of what production forecast is assumed, the expectation is that production will continue to decline. While price increases could stabilize net revenues, the effective purchasing power for the SPR would likewise tend to decline. Overall, it is estimated that approximately 150-200 million barrels of oil could be added to the SPR by the year 2000 through the use of NPR-1 receipts.

\section{Capitalizing the Revolving Fund}

Because the input to a Petroleum Reserves revolving fund would be the revenues from NPR-1, which is run on a business-like basis, the Department could, if authorized, enter into the capital markets and borrow against the future flows of cash into the revolving fund. This would solve two potential concerns. First, by borrowing a fixed amount of money against future NPR-1 cash flow, the fill rate of the SPR could be increased either to meet a specific rate, such as 75,000 barrels of oil per day, or to allow the managers of the SPR to purchase extra amounts of oil when prices appear to be depressed, thereby lowering the average cost of SPR fill. The second advantage would be related to budget appropriations. Under the current system, a revolving fund would require some time to accumulate the cash required for the operating needs of NPR-1 and the SPR fill. During the time when working capital would be created, the Petroleum Reserves would be dependent upon appropriated funds unless another source of capital, such as borrowing, was used.

\section{Other Considerations}

While not by definition a revolving fund, another way to accomplish many of the same objectives would be to reorganize the Naval Petroleum Reserves and the SPR into a Government Corporation with a charter to convert its resources to a form most useful in a supply shortage. This could have several beneficial effects. First, by removing itself from rules and regulations that apply to the Government, the reconstituted Reserves could improve its efficiency and the profitability of its operations by having streamlined policies and procedures more suitable to a business rather than to the Government as a whole. Second, the sales program of the Naval Petroleum Reserves side of the Corporation could act as a private oil producer might act in negotiating to get the best price for the production, rather than using the present cumbersome sales process. It also could allow the prugrain to takc advantage of "windows of opportunity" that cannot easily be accommodated by Federal budget cycles.

On the SPR side of such a corporation, the buyers of oil would now consider not only taking advantage of low prices of oil relative to expected future prices but also the value of money, because such a corporation would be able to invest its cash balances in interest-bearing Treasury instruments. The corporation could also allow the Government to fully utilize the established financial markets for futures to reduce costs, and to sell put options and other financial inistruments to raise revenue from transactions that are not utilized hy strictly Governmental organizations. 


\section{ALTERNATIVE 3: DIVESTITURE OPTIONS}

A method of making the most oil available to the SPR as fast as possible would be to capitalize all of the future value of NPR-1 and use those funds to purchase oil. The previous Administration and the current Administration have proposed the divestiture of the Naval Petroleum Reserves, with the proceeds being tied to the Strategic Petroleum Reserve either by an earmarking of funds or by accepting payment at least partially in the form of oil.

The legislation proposed by the Administration in 1989 provided that the purchasers would have to deliver to the SPR specification oil at the rate of 50,000 barrels per day for six years, the equivalent of 109.5 million barrels of oil. In addition, the buyers would have to deliver another 10 million barrels of oil to the SPR for a "Defense Petrolenim Inventory:" Nlso, the buyer wuuld have to compete for NPR-1 by bidding a sum of cash not less than $\$ 1$ billion. Under this proposal, the cash collection would be placed in the Treasury with no direct linkage to the Strategic Petroleum Reserve.

For the purpose of this study, we have simplified the analysis by assuming that NPR-1 could be sold for cash and that all of the cash could be earmarked for the SPR through the passage of the authorizing legislation. The rate of fill of the SPR would then be limited only by the ability of SPR facilities development to accept oil until the funds generated by the NPR sale were depleted.

In June 1987, the Department submitted a report to Congress on the divestiture of the Naval Petroleum Reserves. That report addressed the major issues associated with the divestiture of NPRs 1 and 3, including: defense requirements; foreign ownership; impacts on state and local governnients, employees, and current customers, including independent refiners and producers. Because none of the indirect effects of divestiture have changed appreciably since the June 1987 report, no effort has been made to update that analysis. Howcver, thcre have been material changes in the level of production since that time and the price paths which were assumed are now different. The Department since that time has updated its analysis of production, investments, and costs, and portions of the analysis have been changed to reflect the proposals made by the field office for future development and production. The other major difference between this analysis and the June 1987 DOE Divestiture report concerns the treatment of state and local taxes. In its 1987 rcport, the Department estimated the net present value of the state and local taxes at $\$ .5$ to $\$ .7$ billion, and stated:

a key policy question affecting interpretations of these forecasts and estimates is whether the Federal Government takes a neutral approach to increased benefits to state and local governments, as recommended by the Department, or whether it focuses exclusively on the Federal Government financial effects. (Divestiture of the Naval Petroleum Reserves, DOE/FE-0088, June 1987, page 12.)

While the equivalency of state and local taxes to Federal taxation is an appropriate subject of discussion, it is quite clear that the net present value of state and local taxation will not be available to fill the SPR. Thus, the divestiture portion of this analysis deals only with the funds that could be captured as the result of divestiture.

In the 1987 NPR Divestiture study, the Department estimated the net present value of the expected Federal income taxes to be $\$ .8$ to $\$ 1.0$ billion. However, those numbers do not directly 
affect alternative methods to achieve SPR crude oil fill and are not taken into consideration in this report. Therefore, this analysis of the divestiture of NPR-1 converts the current stream of income into a cash payment that very easily could be earmarked for the Strategic Petroleum Reserve and the "Defense Petroleum Inventory" and the analysis will disregard the income tax portion of the net present value of the field, which would devolve to the Treasury general fund.

The Department used a net present value analysis approach to determine the sales value of NPR-1. The oil prices were those presented in Chapter V but were converted to lower prices to reflect the difference between national average prices and the California market. The natural gas and natural gas liquids prices were developed to maintain a historical relationship to oil, except that the value of natural gas relative to crude oil is allowed to rise somewhat over time.

The specific prices used in the analysis for crude oil and natural gas are shown in Table VIII-5 for the three price paths defined in Chapter $\mathrm{V}$.

Using two different production and cost estimates, a full sale in September of 1991 would bring the following estimated payments when valued at a 13 percent discount rate:

Sale Value of NPR-1

(\$ Million)

\begin{tabular}{lccc} 
& \multicolumn{3}{c}{ Price Cases } \\
\cline { 2 - 4 } & High Case & Base Case & Low Case \\
Bergeson & $\$ 3,006$ & $\$ 2,086$ & $\$ 1,560$ \\
Planning Casc & $\$ 3,605$ & $\$ 2,670$ & $\$ 1,848$
\end{tabular}


Table VIII-5

\begin{tabular}{|c|c|c|c|c|c|c|c|c|c|c|c|c|}
\hline \multirow[b]{3}{*}{ Year } & \multicolumn{3}{|c|}{ U.S. Average } & \multicolumn{3}{|c|}{ Sweet Crude } & \multicolumn{3}{|c|}{ Sour Crude } & \multicolumn{3}{|c|}{ Natural Gas } \\
\hline & & $(\$ / B B I$ & & & \$/BBL) & & & (\$/BBI & & & $\mathrm{MMB}^{\prime}$ & \\
\hline & $\underline{\text { High }}$ & $\underline{\text { Base }}$ & Low & $\underline{\text { High }}$ & Base & Low & $\underline{\text { High }}$ & Base & Low & High & Base & Lor \\
\hline 1990 & 19.24 & 16.07 & 13.83 & 17.75 & 14.80 & 12.72 & 16.25 & 13.30 & 11.22 & 2.45 & 2.45 & \\
\hline 1991 & 21.05 & 17.19 & 14.84 & 19.43 & 15.84 & 13.66 & 17.93 & 14.34 & 12.16 & 2.70 & 2.20 & \\
\hline 1992 & 22.91 & 18.16 & 15.75 & 21.16 & 16.74 & 14.50 & 19.66 & 15.24 & 13.00 & 2.98 & 2.36 & \\
\hline 1993 & 24.64 & 19.76 & 17.11 & 22.87 & 18.23 & 15.77 & 21.37 & 16.73 & 14.27 & 3.24 & 2.60 & \\
\hline 1994 & 26.82 & 22.09 & 18.62 & 25.05 & 20.40 & 17.17 & 23.55 & 18.90 & 15.67 & 3.58 & 2.95 & \\
\hline 1995 & 29.11 & 24.47 & 19.98 & 27.34 & 22.70 & 18.44 & 25.84 & 21.20 & 16.94 & 3.99 & 3.30 & \\
\hline 1996 & 32.45 & 27.52 & 21.80 & 30.68 & 25.75 & 20.13 & 29.18 & 24.25 & 18.63 & 4.48 & 3.75 & \\
\hline 1997 & 36.13 & 30.69 & 23.74 & 34.36 & 28.92 & 21.97 & 32.86 & 27.42 & 20.47 & 5.02 & 4.22 & 3. \\
\hline 1998 & 40.10 & 33.90 & 25.58 & 38.33 & 32.13 & 23.81 & 36.83 & 30.63 & 22.31 & 5.60 & 4.69 & 3.4 \\
\hline 1999 & 44.20 & 36.62 & 27.54 & 42.43 & 34.85 & 25.77 & 40.93 & 33.35 & 24.27 & 6.21 & 5.09 & 3. \\
\hline 2000 & 48.48 & 39.06 & 30.06 & 46.71 & 37.29 & 28.29 & 45.21 & 35.79 & 26.79 & 6.84 & 5.45 & 4.I \\
\hline 2001 & 52.43 & 41.97 & 32.19 & 50.66 & 40.20 & 30.42 & 49.16 & 38.70 & 28.92 & 7.42 & 5.88 & 4.4 \\
\hline 2002 & 56.06 & 45.05 & 34.20 & 54.29 & 43.28 & 32.43 & 52.79 & 41.78 & 30.93 & 7.95 & 6.33 & 4.7 \\
\hline 2003 & 59.85 & 48.02 & 36.19 & 58.08 & 46.25 & 34.42 & 56.58 & 44.75 & 32.92 & 8.51 & 6.77 & 5.0 \\
\hline 2004 & 63.74 & 50.92 & 38.10 & 61.97 & 49.15 & 36.33 & 60.47 & 47.65 & 34.83 & 9.08 & 7.19 & 5.3 \\
\hline 2005 & 67.90 & 54.04 & 40.18 & 66.13 & 52.27 & 38.41 & 64.63 & 50.77 & 36.91 & 9.69 & 7.65 & 5.6 \\
\hline 2006 & 71.91 & 57.09 & 42.15 & 70.13 & 55.32 & 40.38 & 68.63 & 53.82 & 38.82 & 10.28 & 8.10 & 5.9 \\
\hline 2007 & 76.10 & 60.06 & 43.97 & 74.32 & 58.29 & 42.20 & 72.82 & 56.79 & 40.70 & 10.90 & 8.54 & 6.1 \\
\hline 2008 & 80.38 & 63.24 & 46.09 & 78.60 & 61.47 & 44.32 & 77.10 & 59.97 & 42.82 & 11.53 & 9.01 & 6.4 \\
\hline 2009 & 84.81 & 66.47 & 48.26 & 83.04 & 64.70 & 46.49 & 81.54 & 63.20 & 44.99 & 12.18 & 9.48 & 6.8 \\
\hline 2010 & 89.72 & 69.93 & 50.32 & 87.95 & 68.16 & 48.55 & 86.45 & 66.66 & 47.05 & 12.90 & 9.99 & 7.1 \\
\hline
\end{tabular}

By capitalizing the cash flow of the NPR-1, the SPR program would then be able to outlay funds quickly for a rapid fill of the existing SPR facilities. How much oil would be purchased depends on how close the Government's actual oil prices are as compared to the expectations of the buyer. For example, assume Bergeson reserve estimates and further assume that at least one company expects oil prices to be no less than those in the High Price Case and makes a winning bid of $\$ 3,006$ million. If one then assumes that the SPR is scheduled to fill at the rate of 75,000 barrels of oil per day, and that the cost is determined at the time of purchase, it is apparent that the lower the prices the greater the ultimate fill of the SPR, and the higher the prices the lower the fill. Table VIII-6 shows the annual and cumulative fill levels for the SPR based on the actual prices turning out to be the high, base, and low price cases. 
Table VIII-6

\section{SPR Fill At a Rate of 75,000 Barrels Per Day Until $\$ 3,006$ Million is Exhausted (Bergeson High Price Case)}

\begin{tabular}{|c|c|c|}
\hline \multicolumn{3}{|c|}{ HIGH PRICE CASE } \\
\hline Annual & Cum & \\
\hline (\$ $\frac{\text { Outlay }}{\text { Million) }}$ & (\$ Million) & $\frac{\text { Fill }}{(\mathrm{mmb})}$ \\
\hline
\end{tabular}

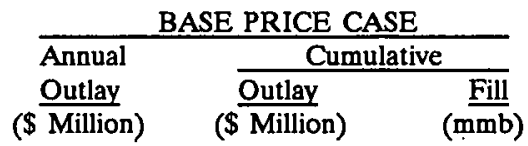

27.4
54.8
82.1
109.5
110.1

$\begin{array}{lrr}534 & 534 & 27.4 \\ 579 & 1,113 & 54.8 \\ 644 & 1,757 & 82.1 \\ 709 & 2,466 & 109.5 \\ 540 & 3,006 & 128.1\end{array}$

\begin{tabular}{|c|c|c|}
\hline \multicolumn{3}{|c|}{ LOW PRICE CASE } \\
\hline \multirow{3}{*}{$\begin{array}{l}\text { Annual } \\
\text { Outlay } \\
\text { (\$ Million) }\end{array}$} & \multicolumn{2}{|c|}{ Cumulative } \\
\hline & Outlay & Fill \\
\hline & (\$ Million) & $(\overline{\mathrm{mmb}})$ \\
\hline 468 & 468 & 27.4 \\
\hline 506 & 975 & 54.8 \\
\hline 549 & 1,523 & 82.1 \\
\hline 586 & 2,110 & 109.5 \\
\hline 637 & 2,747 & 136.9 \\
\hline 259 & 3,006 & 147.1 \\
\hline
\end{tabular}

In this case, because the expectation of the buyer was for a relatively high price path, the divestiture remittance gives the SPR a long-term fill in any of the scenarios.

However, if the expectation of the most optimistic NPR bidder is for the base or low price path, under the Bergeson case the proceeds from the sale of NPR-1 would be the $\$ 2,086$ or $\$ 1,560$ million, with a higher relative chance that the actually occurring prices would be above the expected path which the bid was based upon. Tables VIII-7 and VIII-8 show the extent of SPR fill, also based on a fill rate of 75,000 barrels per day under the Bergeson assumptions. Tables VIII-9 through VIII-11 provide the same information under the Planning Case assumptions. Table VIII-12 summarizes the results of this analysis.

Table VIII-7

SPR Fill At a Rate of 75,000 Barrels Per Day Until \$2,086 Million is Exhausted (Bergeson Base Price)

\begin{tabular}{ccr}
\multicolumn{3}{c}{ HIGH PRICE CASE } \\
\hline Annual & \multicolumn{2}{c}{ Cumulative } \\
\cline { 2 - 3 } Outlay & Outlay & Fill \\
Million) & (\$ Million) & $(\mathrm{mmb})$ \\
664 & & \\
713 & 664 & 27.4 \\
709 & 1,377 & 54.8 \\
& 2,086 & 79.96
\end{tabular}

\begin{tabular}{|c|c|c|}
\hline \multicolumn{3}{|c|}{ BASE PRICE CASE } \\
\hline \multirow{2}{*}{$\begin{array}{l}\text { Annual } \\
\text { Outlay }\end{array}$} & \multicolumn{2}{|c|}{ Cumulative } \\
\hline & (\$ Millay & $\frac{\text { Fill }}{(\mathrm{mmb})}$ \\
\hline 534 & 534 & 27.4 \\
\hline 579 & 1,113 & 54.8 \\
\hline 641 & 1,757 & 82.1 \\
\hline 329 & 2,086 & 94.8 \\
\hline
\end{tabular}

\begin{tabular}{|c|c|c|}
\hline \multicolumn{3}{|c|}{ LOW PRICE CASE } \\
\hline \multirow{2}{*}{$\begin{array}{l}\text { Annual } \\
\text { Outlay }\end{array}$} & \multicolumn{2}{|c|}{ Cumulative } \\
\hline & Outlay & Fill \\
\hline (\$ Million) & (\$ Million) & $(\mathrm{mmb})$ \\
\hline 468 & 468 & 27.4 \\
\hline 506 & 975 & 54,8 \\
\hline 549 & 1,523 & 82.1 \\
\hline 563 & 2,086 & 108.4 \\
\hline
\end{tabular}


Table VIII-8

SPR Fill At a Rate of 75,000 Barrels Per Day Until

$\$ 1,560$ Million is Exhausted (Bergeson Low Price Case)

YEAR

HIGH PRICE CASE

$\begin{array}{llc}\text { Annual } & \text { Cumulative } \\ \text { Outlay } & \text { Futlay } & \text { Fill }\end{array}$

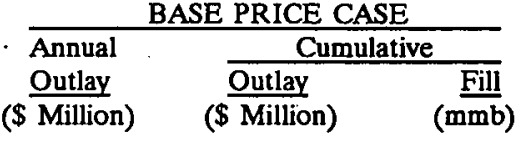

\begin{tabular}{|c|c|c|}
\hline \multicolumn{3}{|c|}{ LOW PRICE CASE } \\
\hline$\overline{\text { Annual }}$ & $\mathrm{Cu}$ & \\
\hline 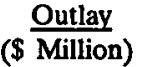 & (\$ $\frac{\text { Outlay }}{\text { Million })}$ & $\frac{\text { Fill }}{(\mathrm{mmb})}$ \\
\hline
\end{tabular}

1992

1993

1994

iับyัs
(\$ Million)
(\$ Million)
(mmb)

$\begin{array}{rrr}664 & 664 & 27.4 \\ 713 & 1,377 & 54.8 \\ 183 & 1,560 & 61.2\end{array}$

$\begin{array}{lrl}534 & 534 & 27.4 \\ 579 & 1,113 & 54.8 \\ 447 & 1.560 & 77 n\end{array}$

$\begin{array}{rrr}468 & 468 & 27.4 \\ 506 & 975 & 54.8 \\ 519 & 1,533 & 02.1 \\ 37 & 1,560 & 83.8\end{array}$

Table VIII-9

SPR Fill At a Rate of 75,000 Barrels Per Day Until $\$ 3,605$ Million is Exhausted (Planning High Price Case)

YEAR

\begin{tabular}{|c|c|c|}
\hline \multicolumn{3}{|c|}{ GH PRICI } \\
\hline Annual & Cum & \\
\hline (\$ $\frac{\text { Outlay }}{\text { Million) }}$ & (\$ Outlay & $\frac{\text { Fill }}{(\mathrm{mmb})}$ \\
\hline
\end{tabular}

\begin{tabular}{|c|c|c|}
\hline \multicolumn{3}{|c|}{ BASE PRICE CASE } \\
\hline Annual & $\mathrm{Cun}$ & \\
\hline$\underset{\text { (\$ Outlay }}{\text { Million) }}$ & (\$ Outlay & $\frac{\text { Fill }}{(m \mathrm{mb})}$ \\
\hline
\end{tabular}

\begin{tabular}{lcc}
\multicolumn{3}{c}{ LOW PRICE CASE } \\
$\qquad \begin{array}{c}\text { Annual } \\
\text { Outlay } \\
(\$ \text { Million })\end{array} \quad\left(\$ \frac{\text { Outlay }}{\text { Million })}\right.$ & $(\underline{m m b})$
\end{tabular}

1992

1993

1994

1995

1996

1997

$\begin{array}{rrr}664 & 664 & 27.4 \\ 713 & 1,377 & 54.8 \\ 773 & 2,150 & 82.1 \\ 836 & 2,986 & 109.5 \\ 619 & 3,605 & 127.7\end{array}$

$\begin{array}{rrr}534 & 534 & 27.4 \\ 579 & 1,113 & 54.8 \\ 644 & 1,757 & 82.1 \\ 709 & 2,466 & 109.5 \\ 791 & 3,260 & 136.9 \\ 345 & 3,605 & 147.6\end{array}$

$\begin{array}{rr}468 & 468 \\ 506 & 975 \\ 549 & 1,523 \\ 586 & 2,110 \\ 637 & 2,747 \\ 692 & 3,439 \\ 166 & 3,605\end{array}$

Table VIII-10

SPR Fill At a Ratc of 75,000 Barrels Per Day Until \$2,670 Million is Exhausted (Planning Base Price Case)

HIGH PRICE CASE

Annual Cumulative

(\$ Outlay

$\frac{\text { Cumulative }}{\left(\$ \frac{\text { Fill }}{\text { Million })} \quad \text { (mmb) }\right.}$

664

713

773

520

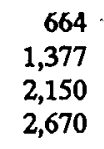

1,377

2,670

\begin{tabular}{rr}
664 & 27.4 \\
1,377 & 54.8 \\
2,150 & 82.1 \\
2,670 &. \\
\hline
\end{tabular}

1995
1996
BASE PRICE CASE

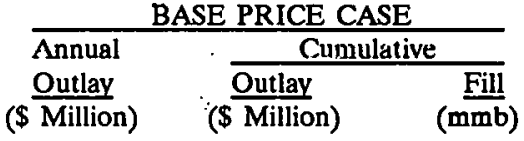

$\begin{array}{rrr}534 & 534 & 27.4 \\ 579 & 1,113 & 54.8 \\ 644 & 1,757 & 82.1 \\ 329 & 2,466 & 109.5 \\ 204 & 2,670 & 116.5\end{array}$

LOW PRICE CASE

\begin{tabular}{|c|c|c|}
\hline \multirow{2}{*}{$\begin{array}{l}\text { Annual } \\
\text { (\$ Outlay } \\
\text { Million) }\end{array}$} & \multicolumn{2}{|c|}{ Cumulative } \\
\hline & (\$ $\overline{\text { Outlay }}$ & $\frac{\text { Fill }}{(m \mathrm{mb})}$ \\
\hline 468 & 468 & 27.4 \\
\hline 506 & 975 & 54.8 \\
\hline 549 & 1,523 & 82.1 \\
\hline 563 & 2,110 & 109.5 \\
\hline 560 & 2,670 & 133.6 \\
\hline
\end{tabular}


Table VIII-11

SPR Fill Ät a Rate of 75,000 Barrels Per Day Until

$\$ 1,848$ Million is Exhausted (Planning Low Price Case)

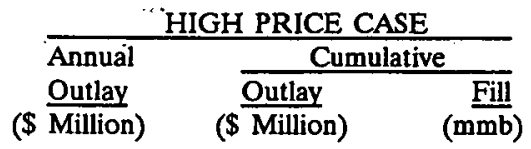

$\begin{array}{rrr}664 & 664 & 27.4 \\ 713 & 1,377 & 54.8 \\ 471 & 1,848 & 71.4\end{array}$

\begin{tabular}{ccc}
\multicolumn{3}{c}{ BASE PRICE CASE } \\
$\begin{array}{ccc}\text { Annual } \\
\text { Outlay } \\
\text { (\$ Million) }\end{array}$ & $\begin{array}{c}\text { Cumulative } \\
\text { Outlay }\end{array}$ & $\begin{array}{c}\text { Fill } \\
(\mathbf{m m b})\end{array}$ \\
534 & & \\
579 & 534 & 27.4 \\
644 & 1,113 & 54.8 \\
91 & 1,757 & 82.1 \\
& 1,848 & 85.6
\end{tabular}

Table VIII-12 summarizes the results of this analysis.

Table VIII-12

\section{SPR Fill From Elk Hills Divestiture Proceeds}

(MMB by Year 2000)

Production

Forecast

Bergeson

Planning

Bergeson

Planning.
Bidder's

Price Assumption

High

Base

Low

High

Base

Low.

\section{Actual Oil Prices}

$\begin{array}{cccc}\text { High } & \text { Base } & \text { Low } \\ 110 & & \\ 80 & 128 & & 147 \\ 61 & 95 & 108 \\ & 77 & & 84 \\ 128 & & & \\ 99 & 148 & 170 \\ 71 & 117 & : & 134 \\ & 86 & 97\end{array}$

\section{$\underline{\text { Revolving Fund Equivalents }}$}

196

167

156

203
LOW PRICE CASE

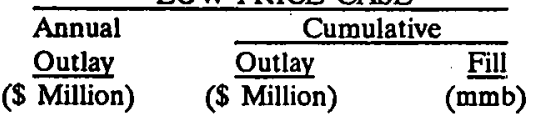

$\begin{array}{lrl}468 & 468 & 27.4 \\ 506 & 975 & 54.8 \\ 549 & 1,523 & 82.1 \\ 325 & 1,848 & 97.3\end{array}$


If the bidder has a higher price expectation than the Government, his offer will also be high and the Government would expect to be able to buy more SPR oil than at its own lower price expectation. The converse would be true if the bidder has lower price expectations than the Government. As the seller of this property, the Government would hope that the pool of potential bidders is characterized by a higher-than-average price expectation.

Similarly, the amount of income tax that would be generated by an acquiring company would vary, depending on the price of petroleum. However, the imputed income tax generated by the Reserve will also vary, depending on the prices. Therefore, there is no distinction between the options based on price interaction with income tax. The primary distinction is that a revolving fund, based on continued Government ownership of the Reserve, would capture the imputed income tax, whereas divestiture would allow the income tax to be deposited into the General Fund of the Treasury, implying a lower level of SPR fill. Thus, as illustrated in Table VIII-11, in nearly all cases (except under the Planning Case forecast where the buyer assumed High Case prices but Low Case prices occurred), the revolving fund yields a higher level of SPR purchases by the year 2000. However, divestiture would permit more rapid fill early in the 1990s.

Finally, the divestiture option differs from the revolving fund in that one type of risk is exchanged for another. As the owner of Elk Hills, the Government is exposed to operating risks and declines in petroleum prices. In exchange for accepting those risks, the Government is certain of receiving all revenue from the sale of the products.

Divestiture eliminates both the operating risks and the downside price risks. In exchange, the Government accepts that prices might increase above expectations between the time it receives its income from sale and when it spends that money to buy SPR fill. 


\section{E. ALTERNATIVE 4: LEASING}

Naval Petroleum Reserves, No. 1 (Elk Hills) and No. 3 (Teapot Dome), are operated by the Department of Energy using contractor support. This is not the only way the oil fields could be managed. In fact, running the oil fields directly is the exception rather than the rule with respect to Federal Management of natural resources. For example, the Interior Department leases the Federal government's interest in oil and gas production on the Outer Continental shelf. An alternative approach involving direct Federal development of OCS properties would likely raise questions about the appropriate role of the Government. These same questions are relevant in assessing NPR options.

Leasing the NPRs could have two advantages compared to selling them. When the properties are leased, they remain the property of the Federal government. Congress has been reluctant to sell these properties outright, and this policy would be more compatible with that philosophy. Second, leasing the NPRs would have budgetary advantages under Gramm-Rudman-Hollings lcgislation. Proceeds from the sale of assets cannot be credited toward meeting GRH budget targets; however lease bonus payments and royalty payments can be so credited.

Proceeds from the leasing the NPRs could be credited to a special fund and made available with or without appropriations for buying oil for the SPR. Providing them with appropriations would maintain Presidential control over these amounts. Providing a onetime earmarking of these amounts would increase program management flexibility, but with a loss of control and discretion in the budget process.

In order to lease the oil fields, the Government would need to decide what mix of bonus and royalty payments to charge for leasing the NPRs. The up-front lease bonus payment received by the Treasury (and credited to any NPR/SPR special account) would be higher the lower the royalty payment. The government's share in any price appreciation (or price decline) would be greater the higher the royalty rate.

The Government might specify an up-front bonus payment and let bidders compete for the right to operate the NPRs. Bidding would be expressed in terms of the royalty rate the bidder would be willing to pay the government if he won the bid; the properties would be ledsed to the highest bidders. In this case, the higher the up-front payment the Congress decided upon, the greater the effect of the lease in reducing the budget deficit in the year the bonus payment was received and the larger the amount credited to any NPR/SPR special account. The greater the bonus payment the bidders were asked to make, the lower the expected royalty rate and degree of Federal participation in subsequent price increases and decreases.

Crediting these leasing payments to a special account is a financing technique for the SPR that would imply an obligation to spend a comparable amount on the SPR. Such an approach has the advantages and disadvantages noted above in the section on revolving funds and special accounts.

In any bidding scheme, the NPRs would be leased competitively to the highest bidder. This presents an opportunity for the government to take advantage of fact that future price are uncertain. Given this uncertainty there may well be bidders willing to lease the properties who expect oil properties to be higher than the government now expects them to be. DOE has estimated that bonus payments of $\$ 3$ billion and more may be possible under price assumptions 
spelled out below in the next section of this report. Under those circumstances, leasing could produce higher income for the government than continuing government operation of the NPRs.

In general, the leasing approach to privatization would yield a cash flow stream, and an attendant SPR purchasing capability, between that of full divestiture, as presented in Section D, and continued Federal ownership, as presented in Section C. This intermediate status is due to several classes of effects:

- Deferred payments of equivalent net present value will be higher in nominal value. In Section $D$, we did not assume that the SPR would have access to interest earnings on the lump-sum divestiture payments. Rather, we assumed that such earnings, along with any Federal income tax proceeds, would be deposited into the Treasury with no earmarking for the SPR.

- While a full analysis of the tax effects of a leasing approach has not been accomplished, it is believed that continued Federal ownership of the assets could reduce the payments for local government property taxes. It is also assumed that any continuing royalty payments to the Department would derive from pre-tax income and hence reduce the Federal income tax liabilities of the lessees. Taken together, these tax effects imply that a larger share of gross revenues from Elk Hills in future years would be available for sharing directly between the lessee and the Department.

Using the Planning Case production and cost assumptions discussed above and in Annex A, the study team estimated the effects of using lease bonus and royalty payments for the SPR under the following conditions:

- A lease award at the end of FY 1991, with royalty provisions effective for FY 1992;

- $\quad$ A fixed bonus of $\$ 1.1$ billion, payable as $\$ 600$ million in FY 1991 and \$250 million in each FY 1992 and FY 1993;

- The prospective lessees would bid percentage royalties on expected revenues. The three price cases from Chapter V were used to reflect different market expectatinns on prices, but a single production scenario was employed;

- It was assumed that the lessees would use a 13 percent after-tax rate of return for this opportunity; and

- The SPR use of these proceeds would be on a cash-on-cash basis, in the sense that annual SPR costs would be equal to annual lease proceeds. Elsewhere in this study, it is noted that revolving fund approaches for the SPR would require, among other things, 
provisions for working capital to permit the SPR to contract for oil deliveries in advance of the availability of cash from the earmarked revenue source.

Based on these assumptions, the study team estimated that the following royalty percentages would be bid, under Planning Case production assumptions, by prospective lessees holding different price expectations, as follows:

$\begin{array}{cc}\text { Price Lessee's Expectations } & \text { Percentage Royalty } \\ \text { Low Case } & 28 \% \\ \text { Base Case } & 44 \% \\ \text { High Case } & 54 \%\end{array}$

It should be noted that the same production/cost forecasts were employed for each price case. This is a simplifying assumption which does not conform to the practice in some parts of the oil industry of assuming that the escalation in operating costs will track closely with the escalation in oil prices. The logic behind this alternative approach is that when oil prices are higher, there is a higher demand for oil field services, equipment, and materials, and that this higher demand is accompanied by higher prices.

By making this simplifying assumption, we may have overstated the sensitivity of percentage bids to changes in price expectations. However, it is nevertheless plausible that since the royalty is applied to gross revenues irrespective of cost and profit levels, and since some of the operating costs at Elk Hills are relatively fixed in the near term, the royalty bidding process would be affected by bidders' price expectations.

The actual price outcomes would not necessarily conform to the bidders' expectations, so there are nine possible sets of cash flow streams, each relating to a combination of initial expectation and actual outcomes. Table VIII-13 is based upon the Planning Case production and cost assumptions and summarizes these cash flow cases through the year 2000 . 
Table VIII-13

Estimated Bonus and Royalty Payments (Planning Case)

(Dollars in Millions)

\begin{tabular}{|c|c|c|c|c|c|c|c|c|c|}
\hline \multirow[b]{2}{*}{ Fiscal Year } & \multicolumn{3}{|c|}{$28 \%$} & \multicolumn{3}{|c|}{$44 \%$} & \multicolumn{3}{|c|}{$54 \%$} \\
\hline & Low & Base & High & Low & Base & $\underline{\text { High }}$ & Low & Base & High \\
\hline 1991 & 600 & 600 & 600 & 600 & 600 & 600 & 600 & 600 & 600 \\
\hline 1992 & 433 & 453 & 507 & 538 & 569 & 654 & 603 & 642 & 746 \\
\hline 1993 & 449 & 472 & 528 & 563 & 599 & 687 & 634 & 678 & 786 \\
\hline 1994 & 204 & 234 & 287 & 321 & 368 & 451 & 393 & 452 & 534 \\
\hline 1995 & 204 & 242 & 292 & 321 & 381 & 460 & 393 & 468 & 564 \\
\hline 1996 & 203 & 251 & 300 & 319 & 395 & 472 & 392 & 485 & 579 . \\
\hline 1997 & 208 & 264 & 314 & 327 & 415 & 494 & 401 & 509 & 606 \\
\hline 1998 & 203 & 266 & 318 & 319 & 418 & 499 & 392 & 513 & 613 \\
\hline 1999 & 201 & 263 & 321 & 316 & 414 & 504 & 388 & 508 & 619 \\
\hline 2000 & 205 & 262 & 328 & 322 & 412 & 516 & 395 & 506 & 633 \\
\hline
\end{tabular}

This analysis creates the possibility of nine alternative levels of SPR fill which could be financed. Table VIII-14 provides the level of fill for the SPR through the year 2000 that would be associated with each of the foregoing royalty rates and price expectations.

Table VIII-14

SPR Fill From Elk Hills Bonus/Royalty Proceeds (Millions of Barrels by FY 2000)

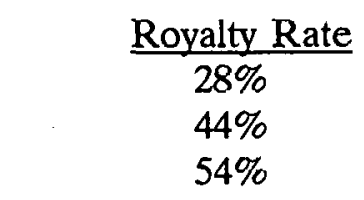

Revolving Fund Equivalent

\begin{tabular}{ccc}
\multicolumn{3}{c}{ Actual Price Case } \\
\hline$\underline{\text { Low }}$ & $\underline{\text { Base }}$ & $\underline{\text { High }}$ \\
144 & 135 & 126 \\
189 & 180 & 172 \\
218 & 207 & 200
\end{tabular}

164
199

The diagonal on this table indicates the cases in which the lessee was correct in its oil market assessment and bid the breakeven percentage royalty. In general, the number of SPR barrels purchased from the revolving fund would be greater than the amount acquired from lease bonus and royalty proceeds, among other things because of the application of State taxes to the lessee which the Federal Government does not pay. $\underline{1 /}$ However, this table also illustrates that a broader

1/ All analysis was performed through the year 2000. Extension of the results to subsequent years would affect the magnitude of these differences among policies. 
range of outcomes is plausible. If high prices occur but the lessee bid a 28 percent royalty payment, then the amount that could be acquired from a straight revolving fund would be considerably in excess of the amount that could be acquired from a 28 percent royalty.

However, if the lessee bid a 54 percent royalty predicated on high prices but low prices occurred instead, then the amount of SPR oil which could be acquired from the lease proceeds could actually exceed the amount associated with a revolving fund.

This analysis does not specifically address the policy question of whether and how a "Defense Petroleum Inventory" would be created from the disposition of Elk Hills. In prior years, the Executive Branch has advocated creation of such an inventory to meet the emergency petroleum requirements of the Department of Defense. This concept could be incorporated into any of the foregoing options: the revolving fund, full divestiture, or the lease concept.

\section{Total Budget Impacts}

Throughout this analysis, the annual production and sales from Elk Hills varies only slightly within the Planning Case and within the Bergeson case. As a result, gross revenues and costs also are comparable within each plan. The impact of changing the NPR-1 organizational structure is felt because the net revenues accrue to different organizations and the interest associated with the receipt of revenues also accrues to different organizations and accounts within the Treasury.

The following tables indicate the impacts of distributing the income from NPR-1 according to the different organizational options. For this purpose, the tables are based only upon the planning case using the base case price assumptions. The results illustrate the changing division of the revenues, and would be similar under the Bergeson production/cost case or the alternative price cases.

Table VIII-15 shows the net revenue expected to be deposited in the Treasury either under the status quo or under a revolving fund, assuming that the revolving fund would not draw interest. Interest earned under the status quo is kept in the general fund by the Treasury, and under the revolving fund concept analyzed in this chapter, interest would still accrue to the general fund even through the net revenue from NPR-1 sales would be deposited into a revolving fund account. When compared with Tables VIII-15 and VIII-16, Table VIII-14 shows that the Government receives more direct income from the continued operation of NPR-1 than either of the other two options.

Table VIII-16 examines the division of net revenue if NPR-1 were divested. It can be seen that Elk Hills has been assumed to generate the same income in total if it is divested but that the distribution of that income is considerably different and more complex. Kern County would take a share of the income in the form of a real property tax and the state of California would take both income tax and a severance tax based on production. The Federal Government would then tax income at the corporate rate of 34 percent, and the buyer would take the remainder of the net income. 
Table VIII-15

Total Budget Impacts for Revolving Fund

Base Case Price - Planning Case Production \& Costs

(Dollars in Millions)

\begin{tabular}{ccc}
$\begin{array}{c}\text { Calendar } \\
\text { Year }\end{array}$ & $\begin{array}{c}\text { Net } \\
\text { Revenue } \\
\text { Generated }\end{array}$ \\
\cline { 2 - 3 } & & \\
& 1991 & 520 \\
& 1992 & 568 \\
& 1993 & 598 \\
& 1994 & 598 \\
& 1995 & 627 \\
& 1996 & 700 \\
& 1997 & 743 \\
& 1998 & 748 \\
& 1999 & 738 \\
& 2000 & $\underline{725}$ \\
Subtotal & & 5972
\end{tabular}

Table VIII-16

Total Budget Impacts for Divestiture

Basc Case Price - Planning Case Production \& Costs

(Dollars in Millions)

\begin{tabular}{|c|c|c|c|c|c|c|c|}
\hline $\begin{array}{c}\text { Calendar } \\
\text { Yedı } \\
\end{array}$ & $\begin{array}{c}\text { Net } \\
\text { Revenue } \\
\text { Generried } \\
\end{array}$ & $\begin{array}{c}\text { Royalty To } \\
\text { Federal } \\
\text { Guvernment }\end{array}$ & $\begin{array}{c}\text { Siale \& } \\
\text { Local } \\
\text { lax }\end{array}$ & $\begin{array}{c}\text { Federal } \\
\text { Income } \\
\text { l'ax } \\
\end{array}$ & $\begin{array}{c}\text { Remainder } \\
\text { To } \\
\text { Capitalize }\end{array}$ & $\begin{array}{c}\text { Purchase } \\
\text { Bonus To } \\
\text { SPR } \\
\end{array}$ & $\begin{array}{l}\text { Total } \\
\text { Federal } \\
\text { Revenuc } \\
\end{array}$ \\
\hline 1991 & & & & & & 2670 & 2670 \\
\hline 1992 & 520 & 0 & 115 & 72 & 332 & & 72 \\
\hline 1993 & 568 & 0 & 125 & 89 & 353 & & 89 \\
\hline 1994 & 598 & 0 & 132 & 105 & 360 & & 105 \\
\hline 1995 & 627 & 0 & 137 & 117 & 373 & & 117 \\
\hline 1996 & 700 & 0 & 142 & 136 & 421 & & 136 \\
\hline 1997 & 743 & 0 & 149 & 152 & 442 & & 152 \\
\hline 1998 & 748 & 0 & 150 & 159 & 438 & & 159 \\
\hline 1999 & 738 & 0 & 148 & 160 & 429 & & 160 \\
\hline 2000 & 725 & $\underline{0}$ & 147 & 160 & 416 & & 160 \\
\hline Subtotal & 5972 & 0 & 1248 & 1154 & 3569 & 2670 & 3825 \\
\hline
\end{tabular}


Table VIII-17

\section{Total Budget Impacts for Leasing \\ Base Case Price - Planning Case Production \& Costs \\ (Dollars in Millions)}

\begin{tabular}{|c|c|c|c|c|c|c|c|}
\hline $\begin{array}{l}\text { Calendar } \\
\text { Year } \\
\end{array}$ & $\begin{array}{c}\text { Net } \\
\text { Revenue } \\
\text { Generated } \\
\end{array}$ & $\begin{array}{c}\text { Royalty To } \\
\text { Federal } \\
\text { Government }\end{array}$ & $\begin{array}{c}\text { State \& } \\
\text { Local } \\
\text { Tax } \\
\end{array}$ & $\begin{array}{c}\text { Federal } \\
\text { Income } \\
\text { Tax } \\
\end{array}$ & $\begin{array}{l}\text { Remainder } \\
\text { To } \\
\text { Capitalize }\end{array}$ & $\begin{array}{l}\text { Lease } \\
\text { Bonus To } \\
\text { SPR } \\
\end{array}$ & $\begin{array}{l}\text { Total } \\
\text { Federal } \\
\text { Revenue } \\
\end{array}$ \\
\hline 1991 & & & & & & 1100 & 1100 \\
\hline 1992 & 520 & 319 & 38 & 37 & 125 & & 356 \\
\hline 1993 & 568 & 348 & 42 & 46 & 131 & & 395 \\
\hline 1994 & 598 & 368 & 44 & 54 & 131 & & 422 \\
\hline 1995 & 627 & 380 & 46 & 59 & 141 & & 440 \\
\hline 1996 & 700 & 395 & 47 & 71 & 185 & & 466 \\
\hline 1997 & 743 & 414 & 50 & 79 & 199 & & 494 \\
\hline 1998 & 748 & 418 & 50 & 81 & 197 & & 499 \\
\hline 1999 & 738 & 413 & 49 & 81 & 193 & & 495 \\
\hline 2000 & 725 & 411 & 49 & 80 & 184 & - & 491 \\
\hline Subtotal & 5972 & 3470 & 419 & 591 & 1490 & 1100 & 5162 \\
\hline
\end{tabular}

In exchange for the rights to that income, the buyer would be expected to pay approximately $\$ 2.67$ billion in September 1991. The fact that total Federal receipts are reduced from nearly $\$ 6$ billion to $\$ 3.8$ billion in this 10 year period is substantially offset by the receipt of $\$ 2.67$ billion at the very start of the analysis. The interest earned on this sales revenue would improve the Treasury's accounts and is reflected by discounting in our net-present-value analysis.

Table VIII-17 illustrates the division of net income under the lease option, if the bonus payment were $\$ 1.1$ billion and the royalty rate is 44 percent. The total revenue to the Federal Government is $\$ 5.16$ billion, between the direct revenue of continued Federal ownership and the revenue from a divestilure. In this option the total revenue is higher than in the divestiture option because a substantial portion of the Government's revenue comes from the royalty payments which occur over the course of time. However, the royalty feature does reduce the front end payment to $\$ 1.1$ billion, a reduction of $\$ 1.6$ billion relative to divestiture, and implies that the interest earned by the Treasury will be substantially less than under the divestiture option. Again, this factor is accounted for in the net-present-value analysis because of the discounting of future values. 


\section{F. SUMMARY}

There are multiple ways in which the value of Elk Hills could be used to finance the SPR, ranging from a direct use of the Elk Hills profits under continued ownership of the NPR within the context of a revolving fund, to the full capitalization associated with the divestiture concept. Mid-range alternatives, such as the leasing concept, might also be used.

The amount of SPR oil that could be derived from these funding sources is dependent on: (a) the degree to which the option causes a portion of the current profits to be reflected as Federal, state, or local taxes; (b) the timing of any privatization proceeds; (c) the expectations of any private participants in these mechanisms; and (d) the actual oil market outcomes. Basic production and operating cost levels will also influence the nutcome as reflested in the variances between the Bergeson and Planning case scenarios. Table VIII-18 summarizes, through the year 2000, the SPR fill levels which would be associated with each of the alternatives considered. In this table, the cases are limited to instances in which, under the privatization cases, the hyyer or lessee of Elk Hills held expectations which turned out to be accurate. However, an even broader range of outcomes would be possible if actual conditions diverged from expectations.

Finally, the revolving fund option is not exclusive of other forms of SPR financing. It could be adopted in tandem with other options in order to take the Petroleum Reserves off budget, accelerate the availability of funds for SPR oil purchases, and allow the Naval Petroleum Reserves to be more profitable by being responsive to market and engineering opportunities independent of the annual budget cycle. 
Table VIII-18

SPR Fill Through 2000 From Elk Hills

(Millions of Barrels)

\author{
Actual Oil Prices \\ Low Case Base Case High Case
}

Planning Case

Production Assumptions

Revolving Fund

Divestiture

Lease

144

180

200

Bergeson Production Assumptions

Revolving Fund

Divestiture

Lease
156

84

125

167

95

154
196

110

191 


\section{CHAPTER IX. FEES AND CHARGES ${ }^{1 /}$}

\section{A. GENERAL}

The purpose of this chapter is to examine certain petroleum fees and similar charges as an alternative means of financing the SPR. Three different types are examined as possible financing sources: an oil import fee; a gasoline charge; and a general petroleum charge. There could be three interrelated purposes associated with these different types of charges. First, the costs of the SPR would be "internalized" to some degree into the price paid for the petroleum by end-users. The argument for this approach is that since the SPR has been established as protection against a disruption in petroleum supplies, some or all SPR costs should be taken into account by consumers in making their decisions. Second, such a charge would transfer the costs of the SPR between two overlapping groups, from general taxpayers to oil consumers. Thirdly, such charges would increase Federal revenue in a manner that would offset some or all of the deficit impacts of SPR development expenditures.

Any of these specific concepts could involve a cash inflow to the Federal Government linked, directly or indirectly, to the level of spending for the SPR. However, in the primary form of each alternative, as discussed below, the charges would not affect the manner in which SPR oil is acquired, stored, or sold. Thus, these charges could coexist with a broad range of other SPR policy design features, including size, schedule, fill rate, storage method, and distribution approach.

In some cases, charges included in the price of petroleum products could qualify as "user fees." User fees, in one form or another, have long been employed in the United States. Examples of user fees funding specific projects or programs include the gasoline taxes that fund highway construction, which are paid into the Highway Trust Fund. Thus, the concept of a user fee is well established.

The Office of Management and Budget (OMB) defines user charges quite specifically. A user fee may be charged, "Where a service (or privilege) provides special benefits to an identifiable recipient above and beyond those which accrue to the public at large. ..." However, charges may not be made where "the service can be primarily considered as benefitting broadly the general public. ..." Thus, while all of these charges would directly or indirectly be paid by petroleum users or a segment of the petroleum industry, there are questions about the linkage to the SPR, ie., whether those paying the charges could be construed as "identifiable recipients" of SPR benefits.

In light of the OMB definition, the three charges identified above may not qualify as user fees. Oil import fees historically have been imposed as a national security measure to reduce import vulnerability and protect domestic industry, not to fund specific projects; a gasoline user charge to fund the SPR would levy a fee on the users of one particular refined petroleum product to finance the storage of crude oil. Neither charge seems to fit the OMB definition of "user fees."

1/ $\quad$ The Bush Administration continues to strongly oppose any increase in petroleum fees, charges or taxes. The discussion in this chapter has been included solely to address the Congress' request for consideration of a broad range of policy alternatives. These alternatives have been rejected by the Administration for policy reasons. 


\section{B. DESIGN FEATURES}

Three specific options are considered in this chapter. The amount of the fee or charge depends on assumptions about the rate of fill for the SPR, future crude oil prices, and assumptions about future economic activity.

\section{Oil import fee}

An oil import fee could be levied either exclusively on foreign crude oil or on both foreign crude oil and refined products. Assuming no exceptions from the fee, except for Canadian imports in light of the provisions of the United States-Canada Free Trade Agreement, and assuming no drawback to exporters of refined products or petrochemicals, and using the Reference Case assumptions, the size of the fee is estimated to range from $\$ .23$ to $\$ .56$ per barrel for crude oil alone. For crude oil plus refined products, making the same assumptions, the fee would range from $\$ .18$ to $\$ .44$ per barrel.

\section{Gasoline charge}

A gasoline charge, similar to the current gasoline highway tax, would be incorporated into the price of all gasoline sold commercially in the United States. The Reference Case cost would range from $\$ .19$ to $\$ .55$ per barrel, which translates into $.5 \notin$ to $1.3 c$ per gallon.

\section{Petroleum charge}

The proposed petroleum charge would be levied on consumption of all crude oil, domestic or foreign, and on consumption of foreign products. The charge would range from $\$ .10$ to $\$ .26$ per barrel for the Reference Case scenario.

Designing and evaluating any of the three options requires consideration of three categories of issues:

- Legislative changes;

- Payment levels; and

- Implementation.

\section{Legislative Changes}

Two of the three options discussed above would likely require new legislative initiatives. The oil import fee might be justified under existing law, depending on the rationale.

\section{a. Oil Import Fee}

For much of the past three decades, the imposition of petroleum import quotas or fees was used as a means of achieving a national policy of protecting and promoting U.S. exploration and production during periods when low cost foreign crude oil was flooding the market, as well as protecting the U.S. refining industry. Primarily, though, the use of petroleum import quotas or 
fees has been rationalized as a way to protect the United States from excessive dependence on vulnerable foreign petroleum supplies.

Section 232(b) of the Trade Expansion Act of 1962 provides that if, upon investigating, a finding is made by the Secretary of Commerce that a commodity is being imported into the United States "in such quantities or under such circumstances as to threaten to impair the national security," the President may "take such action, and for such time, as he deems necessary to adjust the imports of such article and its derivatives so that such imports will not threaten to impair the national security". 2 '

Actions taken by the President during the first 20 of the last 30 years under section 232 as regards petroleum imports centered around the Mandatory Oil Import Program (MOIP). The MOIP was established in $1959 \underline{3}$ as a quota system to replace the Voluntary Oil Import limitation plan implemented in 1957. Foreign crude oil from the Middle East was underselling domestically produced crude oil, and quotas were imposed largely as a means of protecting the domestic crude market and encouraging domestic exploration and development. A complex quota system based on historic imports was developed.

The MOIP quota system remained in effect until early 1973. Domestic demand for crude oil began to exceed domestic supply and the quotas started causing severe distortions in the market. Accordingly, in April of 1973 the quota system was eliminated and replaced by a system of feepaid licenses, while at the same time customs tariffs on imports of petroleum and petroleum products were suspended. 4 / The MOIP, with various amendments, lasted until 1983, although fees chargeable for the issuance of import licenses were suspended in 1979, never to be reimposed.

The authority of the President under section 232 of the Trade Expansion Act of 1962 to impose license fees on petroleum imports was upheld by the Supreme Court in Algonquin SNG v. FEA, 426 U.S. 548 (1976). In that decision, the Court cited with approval those portiuns of the legislative history of section 232 which would support the widest possible interpretation of the President's authority.

Presidential authority under section 232 has been exercised with respect to petroleum, based on the national securily finding, to impose quotas on volumes of imports, establish license-fee systems on imports, limit imports from specific countries, and allocate fee-exempt imports to specific refineries. The legislative history "firmly establishes that increasing the domestic production of oil

21 19 U.S.C. 1982(b). The authority granted to the President under this section had its origin in the Trade Agreements Extension Act of 1955, 69 Stat. 166.

3/ Proclamatiun No. 3279, 24 F.R. 1781 (March 10, 1959).

4/ Proclamation No. 4210, 38 F.R. 9645 (April 19, 1973). 
is a legitimate national security aim ..." and recent practice "suggests that reducing the consumption of oil may similarly be a legitimate national security aim". 5 ]

There is no historical precedent under section 232 for retaining petroleum import fees and using them for a specific purpose other than making refunds to exporters or for unused licenses, correcting errors, or the like. Under the MOIP, most fees were deposited in the Treasury. Article I, section 9, clause 7, of the U.S. Constitution states, "no money shall be drawn from the Treasury, but in consequence of appropriations made by law. . .." Although there exists a permanent appropriation for monies erroneously deposited in the Treasury, ${ }^{6 /}$ under which refunds could be paid or errors corrected, there is no precedent for retaining import fees to pay for an independent program such as strategic oil reserve acquisition.

Thus, while the question is not free of doubt, to impose an import fee on petroleum with the specific aim of financing the SPR could require action by the President under sertinn 232, combined with enactment of the necessary appropriations by the Congress, or, alternatively, a new legislative initiative that is specifically directed to using petroleum import fees to finance the SPR.

Conceptually, any import fee imposed would have an impact on the price of domestic crude oil and on overall demand, resulting in a fall in demand and ultimately a decline in world oil prices. In reality, the level of fee needed to finance the SPR is so low that it would be hard to argue convincingly that it would result in a significant decrease in imports, which would be a major underlying aim of action taken under section 232 .

\section{b. Gasoline charge}

A Federal excise tax on transportation fuels historically has been used to raise revenue specifically for the construction and maintenance of the interstate highway system. Under existing law, a 9 cents per gallon tax is imposed on gasnline. and a 15 cents per gallon tax on diescl fuel. Revenues from the taxes are deposited into the Highway Trust Fund and specifically earmarked for highway construction and maintenance. ${ }^{7}$

In 1979, while the MOIP was still in effect, the Secretary of the Treasury conducted an investigation of imports of crude oil and petroleum products under section 232 of the Trade Expansion Act of 1962. The findings concurred with the conclusions of the previous investigations of 1959 and 1975 that the high level of imports threatened national security. In addition, gasoline

5/ Memorandum of Law: Legal Authorities Available to the President to Respond to a Severe Supply Interruption or Other Substantial Reduction in Available Petroleum Products, U.S. Department of Justice, Office of Legal Counsel, November 15, 1982, p. 43, reprinted, 6 Opinions of Office of Legal Counsel 644 (1982).

6) $\quad 31$ U.S.C. $1322(\mathrm{~b})(2)$.

II 25 U.S.C. 9503. 
and its high level of consumption in the United States was singled out as the main cause for the increasing dependence on imports. $\frac{8}{}$

On April 2, 1980, President Carter issued a proclamation announcing establishment of the "Petroleum Import Adjustment Program" (PIAP).. / The PIAP had a three-fold aim: to revise those parts of the MOIP that were no longer relevant due to changed circumstances; to impose a fee on gasoline imports; and, most important, to establish a program that would ensure that the burden of the fee on crude oil imports would fall on gasoline.

In its decision in Algonquin SNG v. FEA, 426 U.S. 548 (1976), the Supreme Court had upheld the President's power to impose fees on crude oil imports under section 232. However, it had cautioned that the decision "in no way compels the further conclusion that any action the President might take, as long as it has even a remote impact on imports," is also authorized..$^{10 /}$ (Emphasis in original.) This dictum resulted in the overturning of the PIAP's "gasoline conservation fee" by a District Court. Congress then rescinded the fee prior to appellate review.

Clearly, while there is historical precedent for the imposition of a gasoline charge as a "user fee," there was a good deal of doubt as to whether it could be applied as a national security measure under section 232. This now seems academic in any event, since the 1980 action depended not only on the authority of section 232, but also on use of the Emergency Petroleum Allocation Act of 1973 , which has since expired. $\frac{11}{}$

Whether a gasoline charge is a user fee depends on the relationship between user and beneficiary. The connection between the present Federal gasoline tax that is paid into the Highway Trust Fund and the benefits accruing to the payee is very clear. A problem with levying a charge on gasoline to fund the SPR is that a charge would be levied on one specific product to fund a strategic inventory of crudc oil to be made available to all petroleum users through sale into the market at the time of a disruption.

\section{c. Petroleum charge}

A broad-based petroleum charge could be the most effective means of internalizing the costs of the SPR into the petroleum price structure. There is no direct historical precedent for such a measure, but there are analogous charges in other areas. For example, under section 4611 of the Internal Revenue Code, a tax is imposed both on domestic crude oil and on foreign petroleum imported into the United States or into a Foreign Trade Zone or deepwater port, to be used to finance the Hazardous Substance Superfund and the Oil Spill Liability Trust Fund. $\underline{12}$ The

8/ 44 F.R. 18818 (March 29, 1979).

9/ Proclamation No. 4744, 45 F.R. 22864 (April 2, 1980).

426 U.S. at 571.

See 15 U.S.C. $760(\mathrm{~g})$. 
recipient refinery pays the tax on domestic crude oil and the importer of record pays the tax on foreign petroleum.

If a similar charge were levied on behalf of the SPR, one design feature that could increase the linkage between the charge and the benefits of the SPR would be to permit a rebate of the payment at the time of an emergency drawdown of the SPR. Refiners and product importers paying the charge would be issued transferable certificates that could be used to pay for SPR oil at the time of an SPR sale. In this manner, the charge would effectively represent a mandatory loan to the Federal Government, for financing SPR fill. The redemption value of the certificate could be a fixed dollar amount, such as the amount of the charge paid; alternatively, the redemption value could change in value annually based on interest rates, oil price trends, or some other factor. Provision would need to be made for the possibility that more certificates would be issued than could be redeemed at the first drawdown sale.

Providing refiners and product importers an asset in return for their compulsory contribution to the SPR would create a financing structure that approaches that of the mandatory storage options discussed in Chapter X. However, unless certificate redemption values were linked to oil prices, the Federal Government would continue to experience the full risk and reward of oil ownership.

The redemption feature poses a number of complex legal and financial questions. For example, whereas an outright charge on petroleum with no redemption would be deductible immediately as a business expense, a mandatory financial contribution with a redemption value might be treated in a different manner. Also, it is unclear how the asset value would be treated in industry tinancial reporting, since the redemption value would be difficult to estimate without knowing when an emergency drawdown would occur.

New legislation, possibly similar in some respects to that establishing the Superfund program, would be required to implement a general petroleum charge.

\section{Payment Levels}

Estimates of the charges required to cover SPR costs have been made for all three alternatives. In the case of the oil import fee, two options were examined: the cost of a fee levied on foreign crude oil alone, and the cost of a fee on both foreign crude oil and foreign products.

An important question in designing any of these alternatives is the extent of intended coverage of SPR costs. For this report, it is assumed that the charges would be set to cover the costs of incremental expansion of the SPR, including the direct purchase of oil at 75,000 barrels per day and the costs of facilities development, operation, and maintenance for additional storage capacity. However, both higher and lower fee levels could be employed, as follows:

- Higher fee levels would result if the costs of the existing SPR also were transferred to petroleum consumers. For example, the Government has invested approximately $\$ 20$ billion in the SPR to date, and the annual interest costs on this investment would be approximately $\$ 1.6$ billion. An even higher charge could be derived 
by considering the capitalized cost of the SPR to include the compounding of all past interest charges.

- Lower fee levels would result if decisions were made to exclude facilities costs, to cover only a portion of the oil fill costs, to combine fees or taxes with other financing sources, or to employ any of these financing options in conjunction with oil leasing, to cover only the annual rental payments rather than the costs of outright purchase.

- Fee levels also would depend on the selection of SPR size and on fill rate targets and on actual trends in oil prices.

Selection of a cost basis for the fee calculation is in part related to the methods used for linking the fee proceeds to the SPR. Two different approaches could be employed. First, the fee could be characterized as a simultaneous offset to normal SPR spending activity, with the Government making concurrent estimates of the annual costs of the SPR and the appropriate fee levels. Under this approach, there would be approximately equal annual revenues and spending, for a neutral effect on the deficit, even if the fee proceeds were not legislatively earmarked for the SPR.

Second, the legislation establishing the fee could require that the proceeds be credited to the SPR's appropriations accounts, creating a form of budget authority from which obligations could be incurred. In this case, there would be a direct linkage between the fees and the level of SPR development.

Under this second approach, it would be important, particularly in the early years, to be cognizant of the lag-times that would exist between the consumption act establishing the basis for the fee and the point at which the funds would become available for SPR use. There are essentially four time increments that would need to be considered:

- The lag between the point of oil use and the date on which the fee is collected. For a gasoline charge, this lag would be very short, becausc the charge could be imposed at the point of consumption. Under some other mechanisms, a firm might be required to make periodic payments or post a bond (monthly, quarterly, or annually) based on oil transactions in a prior period.

- Collection period. There could be delays between the time the charge was levied and the time the Treasury received the payments.

- Apportionment/Allotment period. This addresses the time elapsed between the point of Treasury collection of the fee and the point at which funds become available for obligation for the SPR.

- Contract execution period. This is the normal delay between the time SPR funds are obligated, whether for oil or for facilities development, and the lime the goods and services are delivered. 
Over an extended period, barring major year-to-year shifts in oil prices, consumption levels, and SPR development activities, one could expect the importance of these lags to diminish. In the following quantitative analysis, it is assumed that resources become available for the SPR in any given year, matching oil price requirements in that year. However, for the early years of any of the financing options considered in this chapter, it would be necessary for the SPR to have access to an alternative source of obligation authority, such as a one-time "working capital" allocation, to permit the program to continue until proceeds became available under the new financing mechanism.

The assumptions used were those associated with the Reference Case in Chapter V:

- $\quad$ The Base Case oil price projection from the Energy Information Administration's Annual Energy Outlook 1989.

- Gasoline consumption, crude oil and product imports and domestic crude production are all taken from the Annual Energy Outlook 1989.

- Canadian import projections are taken from the National Energy Board of Canada's Canadian Energy: Supply and Demand 19872005.

- Costs calculated in constant 1991 dollars and in nominal dollars, using the OMB annual rates of inflation specified in Chapter V.

- $\quad$ SPR fill rate of 75,000 barrels per day is assumed.

- Alternative scenarios were examined using the high and low oil priccs from the Annual Energy Outlook 1989.

Table IX-1 shows the required charges for all three options assuming oil fill from 600 million barrels to 1 billion barrels, and facilities and operation and maintenance costs from 750 million barrels to 1 billion barrels. Figures $\mathrm{DX}-1$ to $\mathrm{IX}-4$ show the variations induced by changes in the price of oil and fill rates. Charges were calculated on a cash flow basis, as discussed above.

In all cases, there is a gradual upward trend reflecting the expected increases in crude oil prices. Also, there is a temporary peak level in 1994-1995, which is assnoiated with the high facilities development outlays in those years if facilities were developed for expansion beyond 750 million barrels. 


\begin{tabular}{|c|c|c|c|c|c|}
\hline \multicolumn{6}{|c|}{ Table IX-1 } \\
\hline \multicolumn{6}{|c|}{$\begin{array}{c}\text { SPR Alternative Financing: User Fees } \\
\text { (nominal dollars) } \\
\text { Crude Oil, Construction Costs, and O \& M Costs: } \\
\text { Reference Case } \\
75,000 \text { bpd fill rate }\end{array}$} \\
\hline & \multicolumn{2}{|c|}{ Oil Import Fee } & \multirow{2}{*}{$\begin{array}{l}\text { Petroleum Charge on } \\
\text { Domestic Crude \& Foreign } \\
\text { Products and Crude } \\
(\$ / B B L)\end{array}$} & \multicolumn{2}{|c|}{ Gasoline Charge } \\
\hline$\underline{\text { Year }}$ & $\begin{array}{l}\text { Foreign } \\
\text { Crude } \\
(\$ / B B L)\end{array}$ & $\begin{array}{l}\text { Foreign Crude } \\
\frac{\& \text { Product }}{(\$ / B B L)}\end{array}$ & & $\frac{\text { Gasoline }}{(\$ / B B L)}$ & $\frac{\text { Gasoline }}{\text { (c/gal) }}$ \\
\hline 1990 & .00 & .00 & .00 & .00 & .0 \\
\hline 1991 & .24 & .18 & .10 & .19 & .5 \\
\hline 1992 & .23 & .18 & .10 & .20 & .5 \\
\hline 1993 & .31 & .24 & .14 & .29 & .7 \\
\hline 1994 & .56 & .44 & .26 & .55 & 1.3 \\
\hline 1995 & .41 & .32 & .20 & .41 & 1.0 \\
\hline 1996 & .32 & .26 & .16 & .34 & .8 \\
\hline 1997 & .35 & .28 & .17 & .37 & .9 \\
\hline 1998 & .38 & .30 & .19 & .40 & 1.0 \\
\hline 1999 & .39 & .31 & .20 & .43 & 1.0 \\
\hline 2000 & .39 & .32 & .20 & .43 & 1.0 \\
\hline 2001 & .41 & .33 & .21 & .46 & 1.1 \\
\hline 2002 & .42 & .34 & .23 & .49 & 1.2 \\
\hline 2003 & .44 & .36 & .24 & .52 & 1.2 \\
\hline 2004 & .46 & .37 & .25 & .54 & 1.3 \\
\hline 2005 & .37 & .31 & .21 & .45 & 1.1 \\
\hline
\end{tabular}


Figure IX-1

Import Fee: Foreign Crude

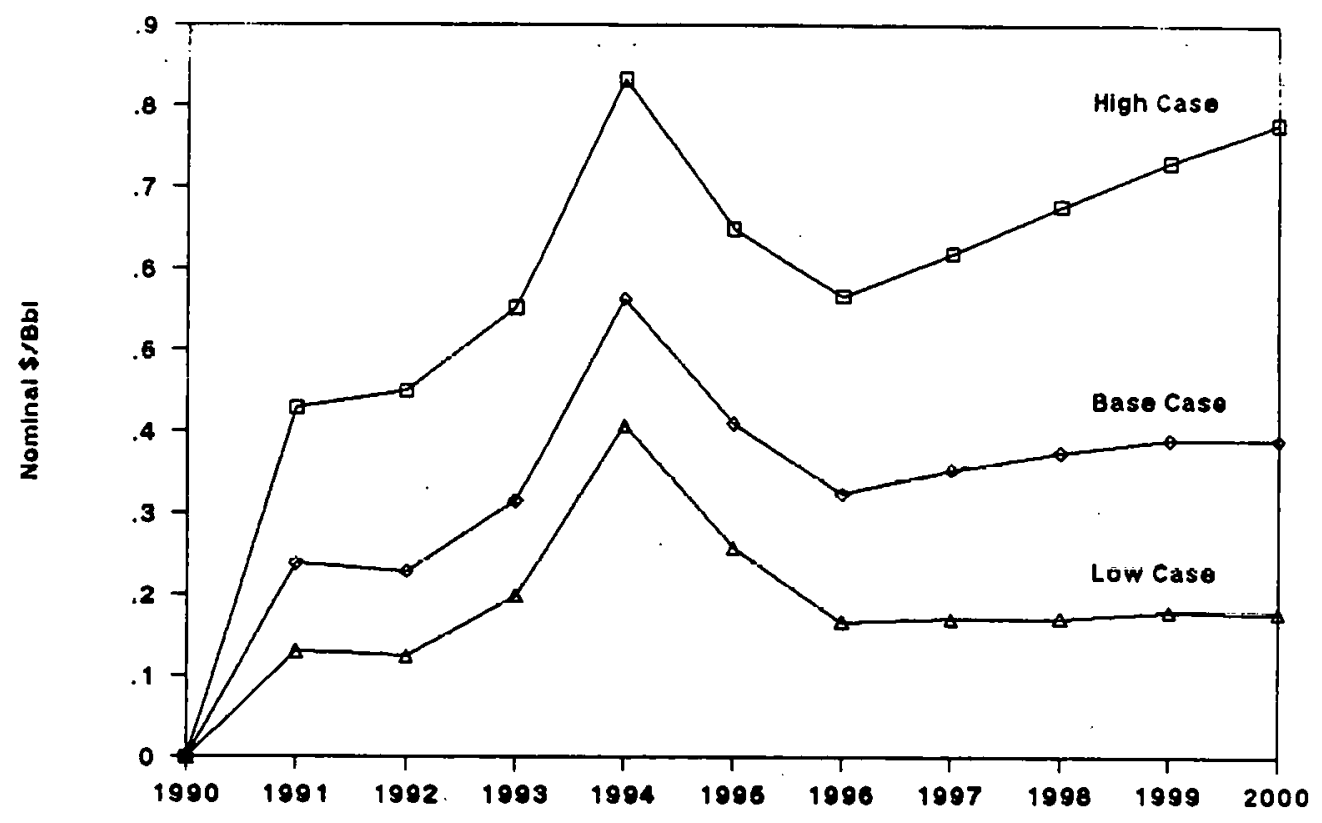

Figure IX-2

Import Fee: Foreign Crude and Products

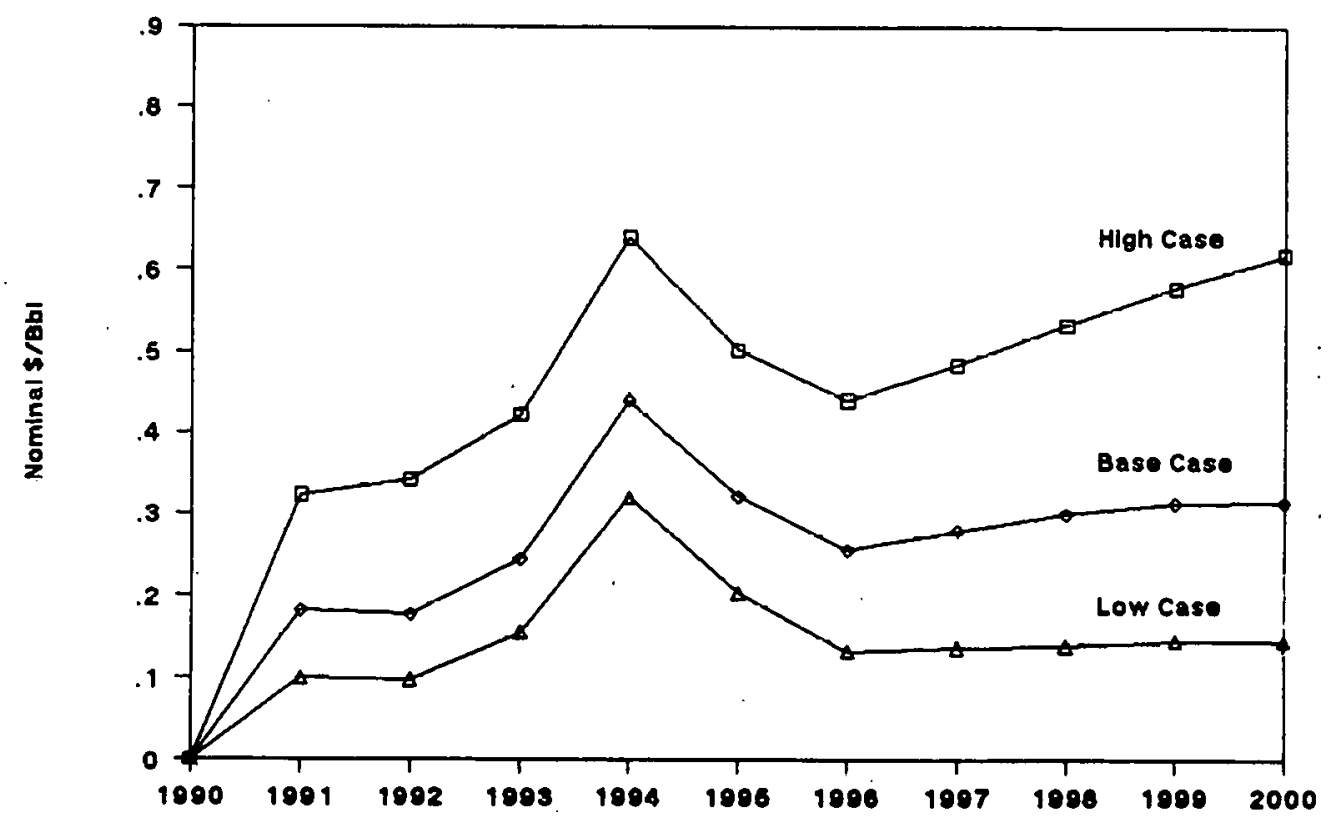


Figure IX-3

Petroleum Charge on All Crude and Foreign Products

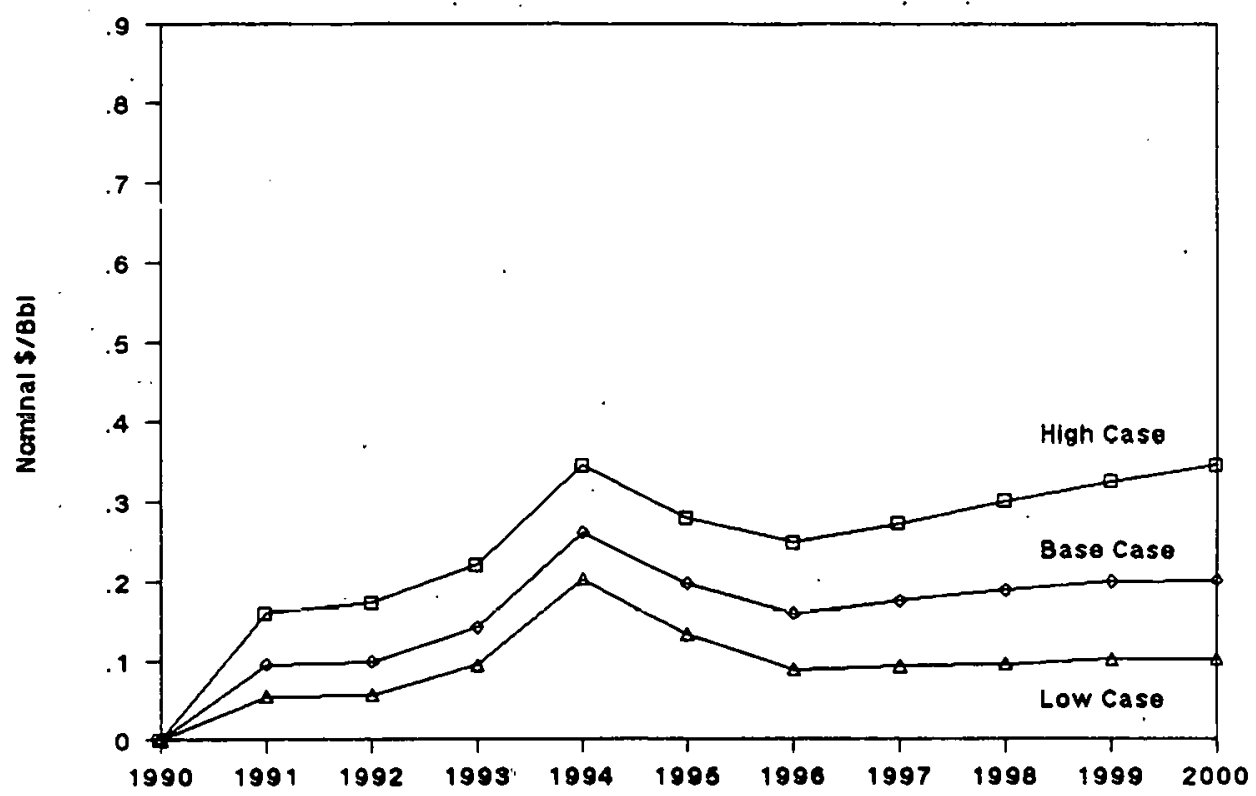

Figure IX-4

\section{Gasoline Charge}

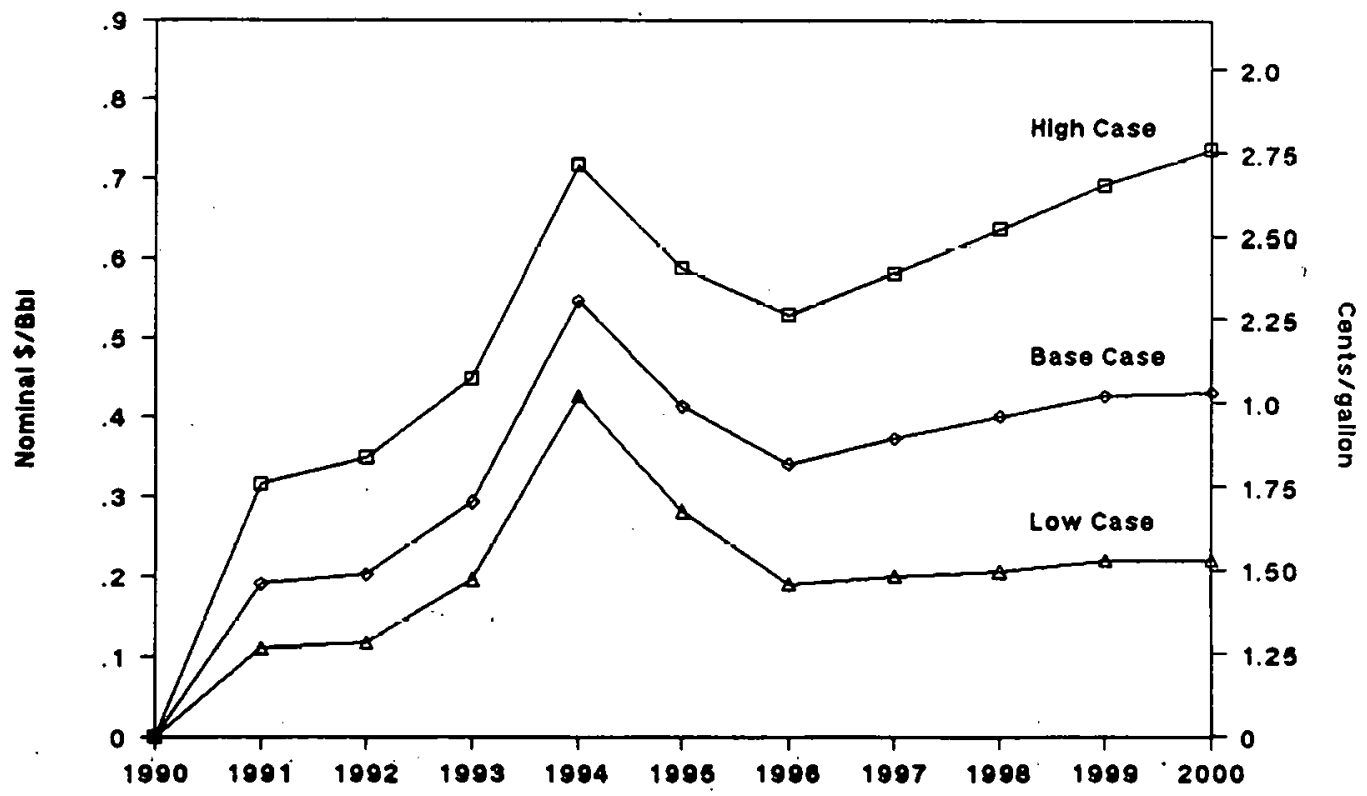




\section{Implementation}

Of the three options examined, all may require some degree of legislative action. All three options also have potential implementation problems, many of which will impact on the form any legislation takes.

\section{a. Oil Import Fee}

The imposition of an import fee raises a number of design and implementation issues, among them:

- $\quad$ Should the fee be on crude oil imports or crude oil and petroleum product imports?

- If the import fee is on both crude oil and products, should the size of the fee be the same for each?

- What problems would emerge in regard to the United States' international trade obligations?

- Rather than impose a separate import fee, should the existing customs mechanism be utilized by increasing customs duties?

The argument has been made that, if an import fee is imposed on crude oil alone, U.S. refineries will be placed at a competitive disadvantage vis-à-vis foreign refineries. Since the domestic crude oil price will likely rise to match that of imported foreign crude after the import fee, all U.S. refiners will be paying more for their feedstocks than will foreign refineries, and, consequently, U.S. product costs will be higher. If this resulted in a flood of product imports, the domestic refining industry would be put at risk and the question of national security would be raised again.

Should it be decided to impose an import fee on products as well as crude oil, the question then is presented whether the product fee should be the same as that for crude. Under the MOIP, there were four different levels of fees for the following: crude oil; unfinished oils and finished products (except residual fuel oil); natural gas products; and residual fuel oil. The differentiation brings with it increased complexity and administrative burden. On the other hand, if rebates need to be made, the differentiation makes it easier to be more specific. However, if the fee for imported products is higher than that of crude oil, it places the refineries in U.S. territories and the increasing number of U.S. refineries operating within Foreign Trade Zones at a competitive disadvantage with other U.S. refineries. To compensate for this problem, more complexity and thus a larger administrative burden must be introduced.

The imposition of an import fee, whether it be on crude oil or crude oil plus petroleum products, raises issues with regard to U.S. obligations under the General Agreement on Tariffs and Trade (GATT), U.S. bilateral trade agreements, and the United States-Canada Free-Trade Agreement.

Crude oil duties have not been bound under the GATT since its inception, but U.S. refined product duties are generally bound. However, U.S. obligations with respect to crude oil do exist 
by virtue of concessions originally made in a 1939 U.S. trade agreement with Venezuela, $\underline{13 /}$ as a result of which other nations may have "most favored nation" rights. An individual country under the GATT, may impose additional import fees if it can justify this under Article XXI of the GATT which provides for a "national security" exception; similar "national security" exceptions often exist under bilateral trade agreements. But it is likely that strong objections would be made by countries from which the U.S. imports significant levels of petroleum. If the United States could not justify its national security claim under Article XXI, which historically has been used very sparingly, and under treaties granting most favored nation benefits, then it is likely to be faced with demands for compensation or threats of retaliation.

Apart from problems under the GATT and various bilateral agreements, the implementation of a petroleum import fee presents special problems under the United States-Canada Free-Trade Agreement. Under the Agreement, the United States effectively is obliged to exempt any petroleum of Canadian origin from an import fee. If a fee is imposed and Canadian imports are exempted, then distortions are introduced into both the U.S. and Canadian markets. The Agreement gives recognition to this problem but does not set out specific remedies, other than consultation.

As an alternative to imposing an import fee on petroleum to finance the SPR, customs duties could be increased by the necessary amount. However, a whole new set of implementation issues are associated with this approach:

- Customs law is relatively inflexible.

- Duties are paid to the Treasury, so appropriations for the SPR would be necessary.

- Under customs law, products made trom imported petroleum on which any duty has been paid receive rebates when exported.

- An increase in duties could be challenged under the GATT and under bilatcral trade agreements.

- The use of customs duties would necessitate potentially complex solutions to deal with product imports from the Virgin Islands and the Foreign Trade Zone refineries, which are outside the U.S. customs territory, and which would be placed at a competitive disadvantage vis-à-vis, domestic refiners if the additional duties were greater on refined products than on crude oil.. 


\section{b. Gasoline charge}

The administrative machinery for collecting a gasoline charge is already in place. Assuming legislation established a specific fund for the SPR into which the charges would be paid, some administrative expansion would be required. Of the three options proposed, this particular charge probably requires the fewest administrative changes or additions to implement.

\section{c. Petroleum charge}

A general petroleum charge comes close to being a value-added tax or revenue-raising procedure. To be a true user fee, those paying the fee would have to receive a specific benefit in return. However, the current SHK Urawdown Plan provides for SPR oll distribuliun by price cumpetiliun, with competition by a wide universe of bidders being contemplated. Consequently, the implementation of a rebate system would require issuance of transferable certificates to avoid major administrative problems. Assuring SPR oil distribution to those paying the charges would not be possible without a total revision of the SPR distribution procedures.

\section{EVALUATION}

The purpose of this part is to evaluate the three different type of petroleum charges addressed in this chapter in accordance with the criteria set forth in Chapter I.

\section{Minimize Cost of SPR}

In general, the three petroleum charge concepts examined do not change the fundamental direct costs of the SPR except through the dampening effect higher oil prices might have on oil demand if the fees are passed through to consumers. As noted earlier, these charges cuan be empluyed as a source of financing in conjunction with a broad array of STF developiment levels, timetables, amd contracting approaches.

The charges do, however, transfer SPR custs between different, though overlapping, scgments of society. Taxpayers are relieved of the burden for such costs, reducing the direct effects of the SPR on the budget deficit. However, since some of the charges could, to varying degrees, be reflected as increased business expenses for oil-consuming entities, there would likely be a reduction in Federal income tax receipts, equivalent to some fraction of the charges collected.

Moreover, all three charges would tend to place upward pressure on the prices paid for petroleum products and for goods and services requiring petroleum inputs. This could have effects on overall levels of economic activity, as well as tend to reduce petroleum consumption.

These macroeconomic effects of petroleum fees or charges are uncertain. In all cases, the amount of the proceeds would be small relative to the total trade on which the charges would be levied. For example; the charge with the broadest base (total crude input to refineries plus foreign products) would amount to $\$ .20$ per barrel by 1995 , when Base Case projections suggest 1995 oil price levels of $\$ 26$ per barrel. This fee level would constitute less than one percent of the total price and slightly more than ten percent of the average annual growth in price which is projected by the Base Case for the first half of the 1990's. 
Some modelling results suggest that the macroeconomic effects, while small in relation to the total economy, could be large relative to the amount of revenue collected. A general conclusion is that the narrower the base of the charge, the more significant the effect on GNP due to adjustment costs in the economy.

\section{Budget Scorekeeping Effects}

The approaches examined in this chapter are revenue-producing alternatives. As such, their impacts on budget scorekeeping are relatively simple to determine. Funds would be derived from the charges and either (1) deposited in general Treasury accounts, with the SPR continuing to receive its funding through the appropriations process, or (2) somehow directly dedicated to the SPR for oil and/or facilities' expenses.

In the first case, the only impact on budget scorekeeping would be the addition of revenues derived from the charges; SPR appropriations would remain the same. In the second case, there would be no added revenues reflected in budget scorekeeping; however, revenues from the charges would be used to fund the SPR directly, so existing SPR appropriations would be unnecessary. In both cases, the deficit would be reduced -- in the first case because Government revenues increased, and in the second case because Government appropriations decreased.

\section{Effects on Supply Levels and Market Forces}

All of the proposed charges examined in this chapter are small -- on the order of less than one cent per gallon on petroleum products. While any import or petroleum charge would have some impact, conceptually, those discussed here are so small that any effect on markets or supply should be minimal.

An import fee, whether on crude oil or products, should result in slightly higher U.S. oil prices and therefore could provide some minor incentive for U.S. crude oil producers. An import fee on crude oil only could also raise the price of imported products. A charge on domestic gasoline should have the same effect. In any event, however, the impact would be small because the charges being considered are so small.

\section{Effects on Competition}

From a competitive point of view, the most equitable fee is the gasoline charge, since it would be collected on all of a particular product at a single point in the petroleum distribution system. All retail sales of gasoline would be subject to a fee, and all users would pay the fee. Thus, competitors -- e.g., refiners and product importers -- would all be subject to the charge and would have to compete on equal footing.

By contrast, any charge that is not applied to all users at comparable levels of the petroleum distribution system would create competitive inequities. Thus, a charge solely on domestic crude oil would give an advantage to importers of crude oil and vice versa. A charge on all crude oil only, would give a similar advantage to product importers, since they would be competing with products made from more expensive crude oil. It is possible to structure a petroleum charge that 
applies to imported products as well as to domestic and imported crude, but determining equitable fee levels for crude and different products and administering the fee becomes extremely complex.

Some assessments suggest that an import fee would cause an equal increase in the price of domestic oil, and thereby stimulate additional domestic production. However, since the fees being considered are so small, there is no reason to expect that an import fee would provide a major incentive to increase domestic oil production.

\section{Effects of SPR Drawdown}

Absent rebate provisions, the financing mechanisms discussed in this chapter would have no effect on SPR sale procedures.

Under a rebate approach which provided a purely financial rehate expressed as dollar-denominated certificates used to pay for SPR oil, the sales process itself would be unaffected, but additional procedures for recording payments would be needed.

A rebate approach linked to wet barrel deliveries from the SPR would create serious complications in the drawdown management process and would probably be unworkable.

\section{Implementation Requirements}

Both an oil import fee and a petroleum charge could be difficult to administer. While there are administrative procedures in place in other Federal agencies to collect analogous charges, the availability of the existing administrative apparatus would be affected by the design of the charges. Any special SPR provisions such as rebate certificates, and any special waivers or exemptions which differed from existing approaches, would make it less feasible to use existing mechanisms and could create the need for new administrative structures.

Finally, as was discussed earlier in this chapter, imposition of an oil import fee would pose a number of issues with regard to U.S. obligations under various trade agreements. 


\section{CHAPTER X. INDUSTRIAL PETROLEUM RESERVES}

\section{A. GENERAL}

\section{Introduction}

Proposals considered elsewhere in this study are designed to pay for a Government-managed -- if not owned -- expansion of the SPR. Alternatively, section 156 of the Energy Policy and Conservation Act (EPCA), as amended, authorizes creation of an Industrial Petroleum Reserve (IPR) as part of the Strategic Petroleum Reserve. The Secretary of Energy has discretionary authority to require refiners and importers of oil to acquire, store, and maintain, in readily available inventories, up to 3 percent of the previous year's throughput or imports, as long as this IPR is accomplished in a manner that is appropriate to the maintenance of an economically sound and competitive petroleum industry. The Secretary is also authorized to exempt firms that are inequitably affected or otherwise incur special hardships. Proposals considered in this chapter draw upon the IPR concept.

The rationale for an IPR would be based on the following three major premises: (1) for reasons of equity and efficiency the oil industry and oil consumers -- instead of all taxpayers -- should pay for strategic petroleum inventories; (2) the introduction of competitive market forces into oil storage activities could offer economic efficiencies not otherwise obtainable; and (3) it is the availability of oil inventories in the U.S. in a disruption that is important, not who owns them. In previous examinations of the feasibility of establishing an IPR, the focus has been on an approach in which the Government requires private oil companies to purchase oil for strategic purposes and store it in their own facilities. This approach is consistent with the first premise in that it could lead to the shifting of SPR costs from the general taxpayer to the oil companies and the oil consumers. However, this "traditional" approach to an IPR is inconsistent with the second and third premises of improving competitiveness and efficiency and improving the availability of oil inventories. In the following chapter, the limitations associated with the traditional approach to creating an IPR are identified. The chapter then proceeds to discuss several alternative approaches to creating an IPR that could eliminate or reduce the problems associated with the traditional approach.

In assessing any form of mandatory approach, three related points must be borne in mind. First, all else being equal, a mandatory approach is necessarily more costly than direct purchase. Regulation may obscure the true costs of a program, but these costs exist nonetheless, and can be very substantial.

Second, one approach discussed in this chapter, based on the concept of insurance, offers efficiency gains in several areas. It must be emphasized that these gains arise not from the new regulations, but rather from introducing more market forces into the stockpiling process. Any SPR design could benefit by the introduction of more market forces. The current SPR design, for example, contains its own inefficiencies, and one goal of policy would be to reduce such inefficiency.

Third, while a mandatory approach may be thought of as a way to concentrate the costs of the SPR on its more immediate beneficiaries, the same thing can be accomplished through the 
appropriate choice of user fees. Moreover, user fees, like general Treasury financing, necessarily involve a lower overall cost to society than mandatory storage.

The remainder of this part sets the stage by examining the rationale for private strategic oil stockpiling. Exhibit A to this chapter examines the use of IPRs by other nations. The third part presents three alternative IPR approaches that might be suitable in the U.S., and the fourth part evaluates them.

\section{Private Oil Inventory Practices}

The petroleum industry maintains substantial working stocks of crude oil and refined products in order to meet technical requirements (such as pipeline fill) and customer needs at all levels. These stocks are held by refiners, wholesalers, and retailers throughout every region of the country. Firms hold sufficient inventories to avoid shortages that might ntherwise result from operating contingencies (e.g., tanker delays, pipeline shutdowns, refinery turnarounds, seasonal variations in petroleum product demand, etc.). Maintaining sufficient inventories to supply customers in the face of these contingencies is necessary to sustain confidence in the reliability of individual firms. By the same token, oil industry inventories are typically managed very carefully and kept as low as possible to minimize inventory carrying costs as well as minimize normal operating contingencies. Market incentives give oil companies reason to protect themselves against supply developments. Firms may modify inventory holdings or purchase futures contracts in anticipation of significant price changes.

Private oil companies make inventory adjustments in order to maximize company profits and do not take into account the economic costs that a future supply disruption would impose on the company or the nation as a whole. Consequently, there is a divergence between the optimal level of operating inventories held by private oil companies and the level of strategic oil stocks that will be optimal for the nation as a whole. In general, it is in the national interest that U.S.-based oil stocks be maintained at levels higher than the private sector would normally maintain under competitive conditions.

Like a private firm, the Government needs to evaluate the economic level of national stocks by weighing the risks of disruptions, the costs to the economy, and the price of protecting against this possible loss. Thus far, the U.S. Government has accumulated national oil stocks in addition to commercial levels primarily by spending general revenues on a Federally-owned and -managed crude oil stockpile. The Strategic Petroleum Reserve is intended to protect the nation in the event of severe petroleum supply disruptions.

However, it is the level of national strategic stocks which provides the protection against the disruptive effects and losses of a price hike, not who owns or manages them. Thus, there are other ways to build national security stocks than through direct government stockpiles.

It is important to consider both government and private stockpiling behavior when analyzing the financing of any expansion of national security stocks. Investment in private inventories above levels necessary to meet normal competitive pressures is costly. An expansion in the size of government-owned stockpiles could lead some firms to downgrade their assessment of the risk of politically-motivated disruptions. Firms might also anticipate that the rapid release of govern- 
ment-owned stocks would drive down their own returns from stockholding. As government-owned security stocks increase, both of these considerations could encourage firms to reduce that portion of their inventories held for precautionary reasons. To the extent that private firms might reduce crude and product inventories in response to building of strategic stocks by government, the government's actions serve to shift costs of that function from oil consumers to the general taxpayer rather than enhance the nation's petroleum security.

\section{Rationale for Private Financing of Strategic Stockpiles}

Like the fee and tax options discussed in Chapter IX, an IPR could reallocate the responsibilities for financing the SPR away from the general taxpayers to oil companies, suppliers, and consumers. Because competitive forces do not induce oil firms to hold petroleum inventories voluntarily at levels that would protect the nation adequately in an oil supply disruption, the costs of U.S. national strategic oil stocks are not reflected in the prices of petroleum products. Financing oil security stockpiles with general tax revenues fails to reflect associated costs in petroleum prices. Because all relevant costs associated with petroleum supply conditions are not fully reflected in oil prices, petroleum consumption is, in effect, subsidized at the taxpayer's expense. This subsidy fosters increased imports and renders the United States more vulnerable to external supply disruptions. Further, equity considerations argue that those who benefit - consumers and firms using oil - should pay the costs of insuring against disruptions, rather than passing on these costs to taxpayers in general.

The allocation of public funds to build storage facilities and acquire petroleum stockpiles is based in part on the premise that the nation as a whole benefits from the SPR program and therefore the nation as a whole should pay for the strategic stockpile. However, government financing of security reserves also subsidizes oil consumption and, thus, oil imports, tending to increase the nation's vulnerability to disruptions. In addition, the benefits of drawing down the SPR would accrue most directly to oil consumers generally and only indirectly to the economy as a whole.

It is also possible that efficiencies can be realized by injecting greater competition into the strategic stockpiling function. Competition could be allowed at each stage of the stockbuilding program, whether in crude acquisition, transportation, facilities development, storage, or drawdown. The efficiencies realized by removing the Government's monopoly and monopsony position as the sole buyer and provider of national security stocks possibly can be gained without compromising the protective value of the security stocks. It is arguably the availability of supplies to the private sector that would moderate a price increase during a disruption, and the effectiveness of these stocks in serving this function may not depend on who owns or manages them before release.

Most of the countries, other than the United States, participating in the International Energy Agency impose some form of compulsory storage obligation on the oil companies doing business within their borders. A brief description of these storage programs is appended as an exhibit to this chapter. 


\section{B. IPR DESIGN ISSUES}

This part examines basic issues that would have to be confronted in designing and implementing an IPR in the United States. Consistent with section 160(b) of the EPCA and with the purposes of the Strategic Petroleum Reserve generally, any IPR should seek to:

- $\quad$ Reduce the vulnerability of the United States to sharp oil price increases by increasing petroleum inventories available to counter supply disruptions;

- Promote conscrvation of cncrgy supplies;

- Maintain an economically sound and competitive petroleum industry; and

- $\quad$ Avoid "unfair distribution of burdens."

A further objective assumed but not mentioned in section 160(b) should be to enhance economic efficiency wherever possible.

The specific design issues discussed here are as follows:

$\begin{array}{ll}\text { - } & \text { Size } \\ \text { - } & \text { Configuration } \\ \text { - } & \text { Donitoring } \\ & \text { Drawdown }\end{array}$

\section{Size}

The EPCA gives the Secretary of Energy authority to require refiners and importers of oil to acquire, store and maintain in readily available inventories, up to 3 percent of the previous calendar year's throughput or imports. Based on 1988 data on refinery throughput and imports of petroleum products, an IPR could be 183 million barrels, which would represent 18.3 percent of a one billion barrel SPR.

Most of the issues relative to the appropriate size of an IPR are those which are discussed in the interagency study on the size of the overall U.S. emergency oil stockpiling program. However, size becomes a design issue for the IPR in the following respects:

- There appear to be economies-to-scale in salt dome storage. Private development of such storage on behalf of industrial customers seeking to satisfy their regulatory obligations would be contingent on having sufficient demand for storage to warrant investment in solution-mining infrastructure.

- Decisions would need to be made on the timing for IPR development. Smaller scale IPR efforts might rely on existing storage 
capacity, but larger scale programs would require lead-time to develop new facilities.

\section{Configuration}

An IPR program design would require decisions about the manner in which oil companies would be permitted to satisfy their storage obligation. In general, the IPR program would impose less cost on participating companies if each company was provided the flexibility to select the manner in which it satisfied its obligations. However, there would be some tradeoffs between the benefits of providing this flexibility and the need to assure that any IPR effort resulted in a net increase in available emergency stocks.

One approach to establishing an IPR would require private oil companies to purchase oil for strategic purposes and store it in their own facilities. In the following section, the benefits and limitations of this traditional approach are discussed first.

This part of the chapter then describes two variations on the traditional approach that address some of its problems. Finally, the part presents an alternative IPR proposal, based on the idea of insurance, which would seek to maximize the flexibility accorded the program participants.

\section{a. The Traditional Approach: Private Oil Ownership and Storage}

In the traditional approach to creating an IPR, oil importers, or importers and refiners, would be required to store strategic oil stocks in facilities of their own. As discussed in the annex to this chapter, this is the approach used, at least in part, in many IEA countries for maintaining strategic storage.

This approach would likely result in a broad range of storage configurations, as each company sought to comply with its storage obligation. Some larger companies would likely be in a position to employ larger scale and, on a unit basis, less costly storage techniques. Other companies might avail themselves of existing storage capacity in their individual commercial networks. Some companies, including smaller firms, would be less able to accommodate the storage obligation and might need to undertake to build smaller scale steel tank facilities.

There would also be differences between companies in terms of the location of storage and the type of petroleum commodity stored. In general, crude oil is the cheapest commodity to store because of its longer "shelf life" and lower facilities costs, but companies with no access to refining capacity would facc higher costs for storage of refined products.

There are equity issues associated with this approach, relative to the others discussed below. Compliance costs could vary substantially among different segments of the industry, and the ability of firms to pass through such costs to consumers would also vary.

There are also efficiency issues posed by this approach. Since the SPR was authorized in 1975 , there have been arguments that some of the SPR inventory should consist of refined products stored at decentralized locations around the country. The counter-argument has been that decentralized storage is more expensive, largely because of the likely need to use steel tanks. The 
"traditional" IPR approach could entail the costs of decentralized storage, but without its benefits, since there would be no guarantee that the optimal mix of products would be stored in the most appropriate locations. Furthermore, as discussed below, there would be a need to monitor industry compliance, and resources would need to be devoted to this purpose. In particular, the Government would need to confirm that the stocks being held were truly available for use during an emergency.

\section{b. Private Oil Storage in Federal Facilities}

An alternative approach might be to require refiners, oil importers, or importers and refiners, to contribute crude oil for storage in Federally owned, centralized storage facilities. One possible benefit of this approach would be the economies of scale that could be achieved from the use of centralized salt dome storage facilities. The per barrel cost of salt dome storage is only about onethird of the cost of new steel storage tanks. Thus, the total costs of the IPR could be reduced by the use of Federally-owned, centralized storage facilities. Total Federal budget outlays for the SPR might be limited to the cost of storage and maintenance. Storage of IPR oil in Federal facilities would also simplify compliance monitoring and drawdown procedures.

Apart from lower storage costs, an IPR using Federal storage facilities would incur many of the same costs private firms would incur if required to store their own oil. Administrative costs for this approach would probably be slightly higher than the costs of the current SPR. Drawdown plans would have to be more complex than is now the case because it would be necessary to define the sequence in which private and public stocks would be used; regulations defining contributions would have to be written; and monitoring of compliance would be required. The legal issue of taking private property without just compensation would probably arise with an IPR in Federal storage facilities, but could also arise under other options.

\section{c. Private Storage Corporation}

Another alternative would be a special corporation that would hold strategic oil stocks contributed by industrial shareholders. Variations of this approach have been used in Denmark, France, the Netherlands, and West Germany.

The capital costs required to create the IPR could be funded by private debt. The repayment of the debt as well as the operating costs of the IPR would be the responsibility of the private company shareholders. Participants might include oil refiners, importers, and wholesale distributors. Participation in the IPR could be based on market shares and product sales.

Relative to the traditional approach, the benefits of the economies of scale achievable from the use of centralized storage facilities could be realized under this approach. The total costs of maintaining strategic oil stocks could also be reduced if private sector firms were able to operate the facilities more efficiently than the Government.

Many issues would have to be resolved in order to implement the special corporation approach to creating an IPR. Establishment of a special corporation to create an IPR was not considered at the time the EPCA was enacted, so new legislation might be required to compel the establishment of this kind of IPR. The form, funding, and administration of the corporation would have to be 
delineated clearly, either strictly by legislation and regulation or in an agreement among participants. The role of the Federal Government in monitoring the IPR and managing its drawdown during a national emergency would have to be resolved. The allocation of shares among oil industry participants would have to be carefully evaluated in order to avoid inequitable treatment. Once again, the legal question of taking private property could still be at issue.

\section{d. Certified Access to Oil}

The previous sections described earlier IPR concepts, explaining that they offer some advantages and some disadvantages in comparison with the current SPR. This section describes a new IPR idea based on the concept of insurance.

A Federal requirement for private firms to maintain strategic petroleum inventories could require firms to demonstrate access to the required quantity of petroleum in an emergency rather than to purchase and hold oil inventories. This approach would use the concepts employed by the insurance industry and in futures markets. A system of Commercial Responsibility Standards (CRSs) similar to requirements to maintain auto liability insurance might be established, requiring only a contractual, contingent claim on petroleum inventories owned by others. The extent of that claim and the probability of occurrence of the contingency would determine the amount of the premium. If a suitable oil call option market were developed, responsibility standards written to accept such options on petroleum supplies committed to release only on occurrence of a particular event (or combination of events) could offer firms a less expensive alternative to holding inventories directly.

Private sector demand for petroleum inventories could be created by imposing regulatory requirements and permitting the private sector to develop independent reserve inventories and facilities in response to the demand created by those regulatory requirement. The DOE would require refiners and/or oil importers to establish -- possibly in the form of a certificate or ticket - that they had access to additional quantities of strategic oil stocks over and above normal inventory levels.

'I'he DUE would detine minimum physical facility and inventory standards (quality and type of petroleum to be maintained as backing for CRS contracts). Participating storage facilities would be inspected and inventories audited periodically to insure that outstanding contracts were fully backed by inventory. Firms affected by the regulations could be given a choice between depositing qualifying petroleum inventories in DOE-licensed facilities and paying storage fees, or purchasing call options on inventories owned by petroleum storage operators. To ensure that firms complied fully with their obligatory inventory responsibilities, a central registry of Petroleum Reserve Certificates (PRCs) and options issued by licensed petroleum depositories would be maintained. Market intermediaries would be allowed to operate, packaging PRCs and options to enhance flexibility, lower costs, and achieve economies of scale in storage.

Use of conditional claims on assets held by another party implicitly assumes the presence of verifiable inventories held by others. Either issuing claims on SPR inventories or permitting the operation of independent storage facilities would be necessary to implement the approach. Licensing or otherwise authorizing private firms to operate independent storage operations dedicated to IPR services could permit greater flexibility and make it easier to address equity 
concerns. For instance, in addition to conditional contracts, independent IPR operators could issue depository receipts for those firms that might find it economically advantageous to invest directly in inventories. Once exercise conditions are satisfied, option holders could either exercise the option or sell the option contract, at the holder's discretion. The price paid for the oil on exercise of the option would be less than or equal to the value necessary for exercise of the contract. The circumstances for exercising an option need not be the same as for an SPR drawdown.

Creating or licensing private operators to establish separate storage facilities to serve multiple importers or refiners could simplify enforcement and reduce administrative costs. In addition, independent facilities would open the IPR approach to use of call options or other conditional contracts to reduce capital requirements for affected firms. The use of registered Petroleum Depository Receipts and IPR call options could permit further simplification of the enforcement problem. In particular, it would address the problem of periodic changes in individual corporate storage obligations, as market conditions shift or companies enter or leave the petroleum business.

For instance, customs officials could require documentation of importer compliance with IPR obligations at point of entry for each shipment. IPR options fees could be collected along with Superfund taxes or customs duties whenever firms lack certification of sufficient claims on inventories in IPR facilities. Even importers that sought to evade the inventory requirement by creating corporate shells to import, say, a single tanker load and then dissolve, could be held accountable. Customs agents could collect options fees necessary to bring the "importer" into compliance on the shipment before allowing entry.

Allowing IPR business operators and affected firms to negotiate the terms and denominations of contracts would clearly be preferable, from an equity point of view, to administrative decisions by a regulatory authority. Alternatively (or additionally), free trading of call options and depository receipts could be allowed. From an enforcement standpoint, however, standardized contracts would be easier and less expensive to monitor.

One set of design issues associated with this insurance-type approach is that it is based on the possibility that third parties would provide compliance services to oil industry participants. For such third parties to enter this type of business, there would need to be some assurance to them and to those providing financial backing that the Government would maintain its IPR policy for a sufficient period of time for the tixed costs of creating new storage facilities to be amortized.

\section{Monitoring}

Any approach to an IPR would require some form of monitoring effort to enforce the program requirements. The extent and form of the monitoring effort would depend on the other design decisions made, include those associated with the discussion above of size and configuration.

Compliance monitoring would first require a definition of which companies had storage obligations and the size of each company's obligation. Under current law, the IPR obligation of a particular company could change over time, as the volumes of petroleum which it imported or refined would change. 
The second compliance issue would be to ascertain whether the company's storage obligation had been met. This could involve on-site inspection of inventory records and actual physical verification of inventory availability.

\section{Drawdown}

Decisions would be required on how to cause the inventories to be deployed during an energy emergency. When the privately-owned oil is in storage in Federal facilities, the physical drawdown of the inventory could be closely monitored, but there would arise questions, not dissimilar to those raised in Chapter VI regarding storage of leased oil, regarding whose oil would be withdrawn first from such facilities.

When oil is stored in decentralized facilities, whether owned by individual companies or third-party providers, it would be possible for a drawdown to take the form of releasing the companies from their storage obligations, permitting market incentives to influence decisions on whether and when to sell the oil into the market.

\section{EVALUATION}

The alternative approaches to establishing an IPR examined in this chapter are evaluated in this part according to the study's evaluation criteria. The evaluation is focused on the Certified Access concept described in Part B above.

\section{Minimize the Cost of the Reserve}

The basic effect of having an IPR, rather than continuing to use Federal appropriations to fill the SPR, would be to eliminate or reduce costs to the Federal Government for oil and facilities development and maintenance. However, the costs to the U.S. economy would not be eliminated, and a key evaluation question is whether such overall economic costs would increase or decrease from a decision to implement an IPR rather than develop an equivalent level of SPR storage.

\section{a. Economic Costs̄}

The argument that costs would be higher under an IPR approach has rested primarily on the belief that there are economies-to-scale in strategic storage, most notably in terms of use of salt cavern storage methods. Thus one question would be whether an IPR could be designed to take advantage of such storage methods.

The argument that economic costs would be lower under an IPR approach rests primarily on the belief that introducing competition into the strategic stockpiling effort could achieve efficiencies which are not obtainable under direct Federal provision of this service. The following paragraphs pursue this argument in terms of the three major areas of SPR cost: oil acquisition, transportation, and facilities development.

Private stockpiling firms might be able to entice foreign suppliers of crude to bear some of the capital cost of relocating oil to the U.S. This could be particularly true in a competitive IPR environment where facilities operators competed with other firms for business and faced pressures 
to keep option and deposit rental fees low. Further, some foreign oil producing countries might find it easier to enter contracts with private operators than with the U.S. Government agencies because they could retain more control over their oil.

Unlike Federal SPR oil purchases, private acquisition of foreign petroleum supplies would not generally be subject to requirements to transport the supplies on U.S.-flag vessels. As presented in Chapter III, at recent tanker rates, use of U.S.-flag vessels could be expected to add between $\$ .15$ - $\$ .95$ per barrel to delivered costs of crude depending upon length of voyage. (Additional costs associated with using U.S.-flag vessels on voyages from Mexico are roughly $\$ .15$ and about $\$ .95$ on voyages from the Persian Gulf. Since the Cargo Preference Act requires 50 percent U.S.flag shipping by mileage, one-half of the U.S.-flag differential is added to the cost of SPR deliveries.) With proven world petroleum reserves increasingly concentrated in the Middle East, a rising proportion of U.S. supplies can be expected to originate in that region. Thus, transportation savings potential with an IPR approach would be expected to rise over time.

If excess storage capacity exists now, private security storage could take advantage of it, using this excess capacity before building additional facilities. Also, as profit maximizers with incentive to recover invested capital, private firms arguably might pay closer attention to developmental costs for storage facilities than does the Federal Government.

\section{b. Budget Effects}

Implementation of an IPR program, in lieu of expanding the SPR, could affect the Federal budget in three ways. First, outlays for storage facilities and inventory acquisition would not be Federal expenditures, except under the alternative that utilized Federal facilities. Thus, there would be no DOE budget outlays for oil for SPR fill and no outlays for facilities and maintenance except under that one alternative. Second, DOE budget outlays for personnel to administer the IPR would likely rise to provide for regulatory oversight. Finally, shifting the costs of storage facilities and inventory to the private sector would also affect general revenue receipts in the form of taxes. Firms affected by the regulatory requirements would deduct from taxable income those costs incurred as a result of the regulations. However, except for those costs related to acquisition of inventories, these deductible expenses would be reported as income elsewhere in the economy. Inventory acquisition costs would ultimately be paid to foreigners and therefore may not be reported as income to another U.S. taxpayer. Rental or lease payments to foreigners would be fully deductible from U.S. taxable income by private IPR facility operators, whereas only a portion of the value of purchased inventories could be deducted in the year acquired.

\section{Orderly Development of the Naval Petroleum Reserves}

This criterion is not directly applicable to the IPR.

\section{Minimize Vulnerability to Supply Disruptions}

An IPR could be designed to involve approximately the same amount of oil as would be stored in the SPR. However, the exact amount of oil in IPR storage at any given point would fluctuate with market conditions, to the extent that company liabilities were linked to their volumetric throughput of crude oil or petroleum products. 
As noted earlier, the IPR approach, as with the fee mechanisms discussed in Chapter IX, would internalize strategic storage costs into the price of oil. This could cause reductions in U.S. oil consumption and import levels which would in turn reduce the vulnerability of the U.S. to supply disruptions.

At a policy level the current statutory criteria as to when to draw down the SPR need not be changed if an IPR is used in conjunction with the existing SPR. (Other alternatives, such as a price-induced drawdown, have been discussed in other forums; they are not addressed in this study.) The question of how to draw down the reserves is another matter, however.

A regulatory mechanism for drawing down the IPR in combination with the SPR would have to be developed. The alternative approaches to this question are addressed in Part B above.

\section{Minimization of Market Impacts}

While an IPR approach would reduce the Government's role in some respects -- i.e., purchasing oil -- it would usually increase it in others. Any IPR would require the development of a new regulatory organization to manage the IPR.

The new regulatory organization would exist primarily to: levy requirements on participants; monitor storage facilities to assure that strategic stocks were being kept; and manage drawdown. Under some alternatives, these tasks could be very complicated, and could involve a range of market effects.

The legality of the IPR program might be challenged by the petroleum industry. Such a challenge could be protracted, potentially delaying the achievement of SPR size and fill targets. One of the major legal issues pertaining to the creation of an IPR concerns the possibility that Government attempts to compel the storage of oil in -- and ultimately the sale of oil from -- an IPR, could be viewed as a taking of private property.

\section{Encouragement of Competition}

An IPR could introduce competitive forces into oil stockpiling by removing the Government as the sole provider of this service. However, within the private sector petroleum industry, an IPR regulatory program could disadvantage some firms relative to others and change the existing degree of competition.

The nature of this change would depend in large measure on the design for the IPR and the universe of participants who incur storage obligations. An IPR targeted on oil importers, for example, would involve many of the same competition issues as an oil import fee.

An IPR will receive political pressure and demands for exceptions, both to contributing and to drawing down oil. For example, the Northeast might ask for exceptions on imports of home heating oil and of residual fuel for utilities. Subsidies of storage expenses might be sought. Those exceptions could well be granted to prevent the proposal from being regressive. Similarly, exceptions to regulatory requirements might be sought and granted for "small" refiners claiming 
exposure to unusual competitive pressures. Farmers and the defense industry might well demand preferential treatment in the event of drawdown. If the regulatory requirements were written to apply to imported petroleum only, pressures to exempt Canada, Mexico and Venezuela -- at a minimum -- would be expected. 


\section{EXHIBIT A}

\section{Petroleum Reserves In Other Countries}

\section{EEC and IEA Stockholding}

In 1968, the European Economic Community (EEC) required member countries to enact legislation obligating their oil companies to maintain minimum stock levels. This first directive established a minimum stock level (or "commercial responsibility standard") equivalent to at least 65 days of average daily internal consumption, measured over the prior calendar year. In 1972, the minimum stock level was raised to 90 days. Stockholding requirements apply to at least 90 days of the previous year's consumption of three main petroleum product groups -- gasoline, kerosene, and fuel oils. Stocks of crude oil and blending components can be substituted for product stocks for up to 40 percent of the obligation. Up to 15 percent credit can be given for indigenous crude production. Many countries have authority to impose penalties for non-compliance with these requirements.

As a result of the 1973 oil embargo, the United States and most of the other countries of the industrialized Free World negotiated the 1974 Agreement on an International Energy Program forming the International Energy Agency (IEA). The Agreement requires member countries to establish a common "emergency self-sufficiency" in oil supplies by maintaining emergency reserves equivalent to 90 days of net petroleum imports.

The various IEA member countries have adopted different strategies for creating emergency reserves in general and "strategic" oil stockpiles in particular. The United States heretofore has adopted an approach of 100 percent Government ownership of strategic oil stocks, as well as storage facilities. In contrast, European countries and Japan have relied heavily on nongovernment ownership of strategic oil stocks.

All but three IEA member countries (the U.S. being one of the three) impose stockholding requirements on companies operating within their borders. This is illustrated by Table $\mathrm{X}-1$, which categorizes EEC and IEA member oil stockpile programs. 
Table X-1 Government Emergency Reserve Programs
of EEC $\$$ and IEA $/$ Member Nations

\begin{tabular}{|c|c|c|c|c|}
\hline & $\begin{array}{c}\text { Industry } \\
\text { Compulsory }\end{array}$ & $\begin{array}{c}\text { Government } \\
\text { Owned }\end{array}$ & $\begin{array}{c}\text { Public } \\
\text { Corporation }\end{array}$ & $\begin{array}{c}\text { No } \\
\text { Program }\end{array}$ \\
\hline Australia & $x$ & - & - & - \\
\hline Austria & $\mathbf{x}$ & - & - & - \\
\hline Belgium & $\mathbf{x}$ & - & - & - \\
\hline Canada & - & - & - & $\mathrm{x}$ \\
\hline Denmark & $\mathbf{x}$ & - & $\mathbf{x}$ & - \\
\hline Greece & $\mathbf{x}$ & - & - & - \\
\hline France & $\mathrm{x}$ & - & $\mathbf{x}$ & - \\
\hline Ireland & $\mathbf{x}$ & - & - & - \\
\hline Italy & $x$ & $\mathrm{x}$ & - & - \\
\hline Japan & $\mathbf{x}$ & $\mathrm{x}$ & - & - \\
\hline Luxembourg & $\mathbf{x}$ & - & - & - \\
\hline Netherlands & $\mathbf{x}$ & - & $\mathbf{x}$ & - \\
\hline New Zealand & - & - & - & $\mathbf{x}$ \\
\hline Norway & $\mathbf{x}$ & - & - & - \\
\hline Portugal & $\mathbf{x}$ & - & - & - \\
\hline Spain & $x$ & - & - & - \\
\hline Sweden & $\mathbf{x}$ & $\mathbf{x}$ & - & - \\
\hline Switzerland & $\mathbf{x}$ & - & $\mathbf{x}$ & - \\
\hline Turkey & $\mathbf{x}$ & - & - & - \\
\hline United Kingdom & $x$ & - & - & - \\
\hline United States & " & $\mathbf{x}$ & - & $=$ \\
\hline West Germany & $\mathrm{x}$ & $\mathbf{x}$ & $\mathbf{x}$ & - \\
\hline
\end{tabular}

a/ Current European Economic Community members are Belgium, Denmark, France, Greece, Ireland, Italy, Luxembourg, the Netherlands, the United Kingdom and West Germany.

b/ Current International Energy Agency members are Australia, Austria, Belgium, Canada, Denmark, Greece, Ireland, Italy, Japan, Luxembourg, the Netherlands, New Zealand, Norway, Portugal, Spain, Sweden, Switzerland, Turkey, the United Kingdom, the United States and West Germany.

Comparative strategic stockpile levels are shown in Figure X-1. As the figure indicates, the national government does not own any of the strategic oil stocks in Denmark, France, the Netherlands, or the United Kingdom. In Germany and Italy, the government owns only a small proportion of total strategic stocks. Of the countries examined, only in Japan does the government own a major proportion of strategic oil stocks. 
Figure X-1

Ownership of International

Strategic Oil Stockpiles

(Crude Oil and Petroleum Products)

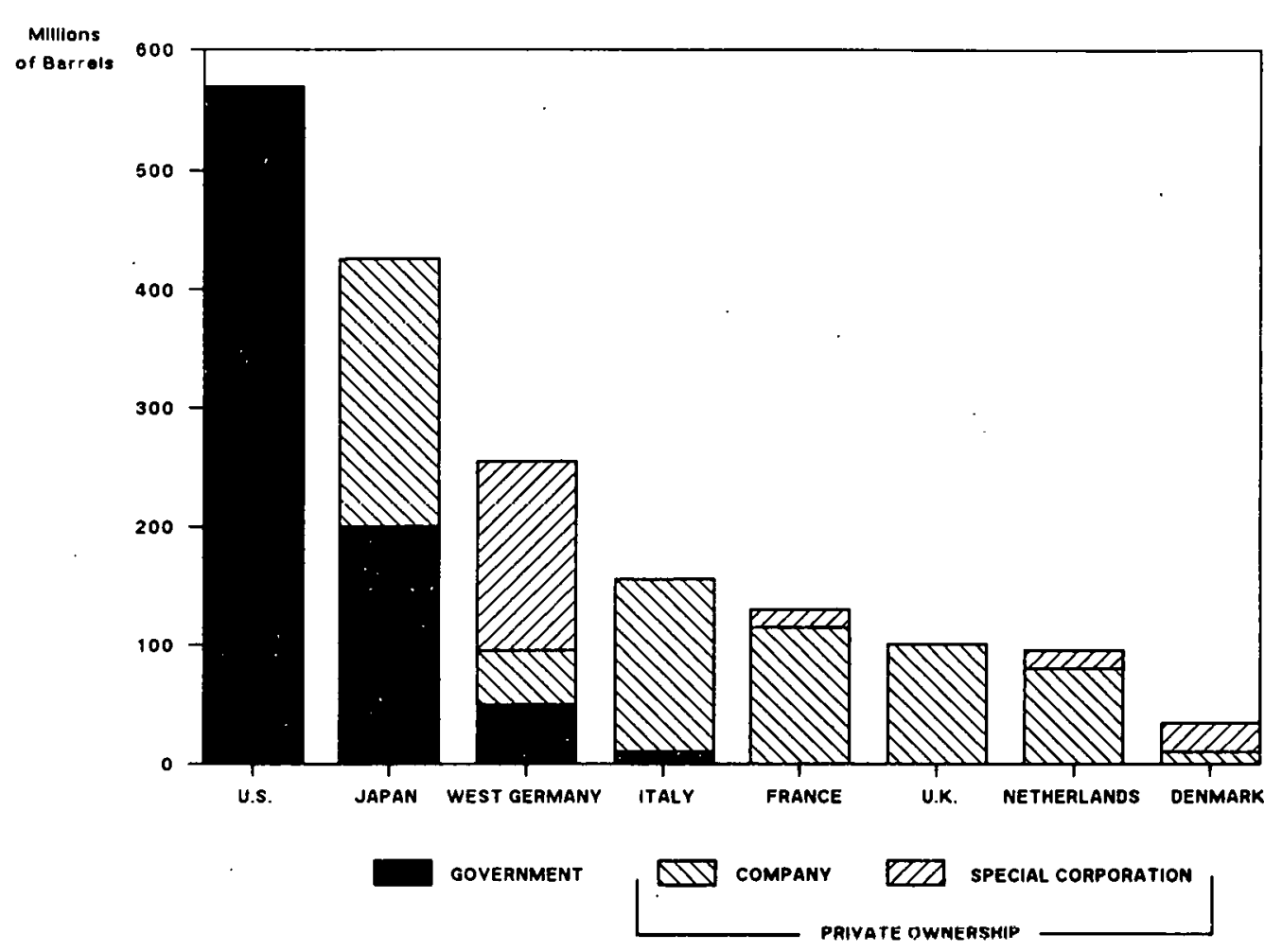

Source: Based on data from PEL, North America: Stratesic Petroleum Stockpiling Programs in Other OECD Countries, January 1990.

\section{Private Ownership Approaches}

Non-government ownership of strategic oil stocks in other IEA countries has been approached in two ways. A study for DOE of seven member countries of the IEA shows that each has relied on private oil companies to obtain and store strategic stocks of crude oil and petroleum products. Some countries have established special corporations whose exclusive purpose is to hold strategic oil stockpiles in addition to private oil company ownership.

In countries that require private oil companies to hold strategic stocks, oil importers, refiners, and, in some cases, distributors are required to maintain minimum stock levels. In these cases, strategic

1/ $\quad$ Krapels, E. International Strategic Stockpiling Programs (draft), 1989. 
oil stocks typically are commingled with company working oil inventories. Consequently, the extent to which the governments can verify inventory volumes and identify and control the drawdown of privately held oil stocks in an energy emergency is not clear. The United Kingdom has 100 percent of its strategic oil stocks held by private oil companies. In France, Italy, and the Netherlands, most strategic oil stockpiles are owned by private oil companies. In Japan, private oil companies hold roughly half of the country's private oil stocks. In Denmark and West Germany, private oil companies account for a significant, but much smaller, proportion of their countries' strategic oil stocks.

In addition to private oil company stockpiles, Denmark and West Germany, and to a lesser extent France and the Netherlands, have also utilized special corporations created expressly for the purpose of holding strategic oil stockpiles. Oil importers, refiners, and, in some cases, wholesalers and large industrial customers are required to become shareholders in the special corporation. Representation in the corporation typically is in proportion to oil products delivered to inland consumption.

Statutory authority to regulate the drawdown of privately held, mandated stocks is available to most governments once an emergency has been declared.

\section{Financing Private Ownership of Strategic Oil Stocks}

In most of the IEA countries reviewed, private oil strategic stockpiles are financed by the individual oil companies and ultimately in turn by the consumer. However, in Japan, the national government subsidizes the cost of private oil stockpiles by providing low interest financing for the construction and maintenance of the storage facilities and for the purchase of crude oil and petroleum products.

The original capital costs for the special corporations created to store strategic oil stocks came from a combination of loans, credits, and public offerings. In Denmark and the Netherlands, for example, the original obligations of the special corporations were guaranteed by the government. The capital costs of the special corporations are repaid by membership or shareholder fees. Operating costs for the special corporation are also paid by the member companies. These membership fees, which cover all aspects of the corporation, such as interest charges on the debt, retirement of the debt, and regular operating costs, are in turn funded by consumers. The members have been given authority to collect a tax on products, especially on gasoline, that will cover the membership fees. The contributions of the various private companies are based on market shares and product sales.

\section{Comparison with the U.S.}

The IEA countries reviewed rely on private oil companies and special corporations to provide most of the countries' required strategic oil storage. With the exception of Japan, government-owned oil stocks account for a relatively small proportion of strategic stocks. This may appear to suggest that the U.S. should look to private oil companies to meet at least part of the Strategic Petroleum Reserve goals. However, there are different circumstances in the countries reviewed than in the United States and these must be considered in examining the appropriateness of private ownership approaches in use elsewhere. 
Most IEA countries have a long history of government regulation of the petroleum industry and, in some cases, government ownership of oil companies. Thus, these nations have existing, longstanding regulatory frameworks, and their oil industries expect some form of government control. Sometimes, this is exercised through formal regulation, and other times it is handled through more informal or even subtle arrangements. There has been a history of government ownership of oil firms in Japan (Japan National Oil Company), Italy (ENI), and France (Elf Aquitaine). In other countries, there is a special relationship between the national government and a major domestic oil company. Such special relationships exist in the United Kingdom with British Petroleum and in the Netherlands with Royal Dutch Petroleum. This history of government ownership of domestic oil operations is very different from the history of private ownership of oil operations in the United States.

The oil industry in each of these countries -- including the size of the domestic petroleum market, the size of oil reserves, the number of oil companies, and the scale of the distribution network - is much smaller and far less dispersed than in the United States, both in terms of geography and in terms of the petroleum market. Thus, it will be much easier for the national government in these countries to administer and monitor the oil storage activities within their borders than it would be in the United States.

Finally, in the United States, Government ownership of the oil and the strategically located storage facilities assures that oil reserves would be available for distribution in an oil supply disruption. In contrast, all of the other countries reviewed rely on private oil companies to maintain part of their strategic oil stockpile. In these cases, the commingling of strategic oil stocks with private company working inventories raises the issue of whether the government can identify and deploy these reserves in the event of an oil supply disruption or national emergency. 


\section{CHAPTER XI. FACILITY FINANCING ALTERNATIVES}

\section{A. INTRODUCTION}

This chapter presents an economic and budgetary evaluation of leasing as an alternative to purchasing storage facilities for SPR crude oil. It also provides a framework that can be used to evaluate alternative leasing proposals in response to a competitive solicitation for SPR storage facilities which might be undertaken by the DOE in the future.

Two types of facility leases are evaluated in this chapter. The primary focus of the analysis is an evaluation of a long-term lease of salt dome storage facilities in the U.S. Gulf Coast region. As specified in OMB guidelines, the long-term lease analysis compares the discounted costs of leasing those of purchasing a storage facility for SPR oil. For this lease - versus - purchase analysis, the main assumptions about the storage facility, including construction cost and schedule, are taken from the Reference Case assumptions detailed in Chapter V of this report.

Many of the assumptions about lease terms used for this evaluation, such as lease length, were based on discussions with industry representatives. The preliminary facilities lease solicitation presented in Volume II of this report benefitted from these discussions with industry, and is consistent with the lease assumptions used for this analysis. The major components of the preliminary solicitation are summarized in this chapter.

In addition to a long-term lease evaluation, a separate analysis was also conducted on a short-term (or "interim") leasing of a storage facility. 1 " Short-term leasing could be used to achieve a certain fill rate when permanent storage is not available. For example, short-term leasing sometimes may be needed to achieve fill rates above 75,000 barrels per day or if construction of long-term storage facilitics is delayed.

The discussion of facility financing alternatives proceeds as follows: First, Part B discusses the history of leasing within the SPR program. In Part C, major lease design issues are discussed, including lease length, facility location, and facility size. The next part presents a discussion of the results of the long-term lease-versus-purchase analysis. This part presents the results of the Reference Facility Lease Case as well as sensitivity cases. This part of the chapter also examines the cost savings, or the reduction in finance charges, that would be required for leasing to have the same present value costs as purchasing a storage facility. The chapter concludes with a discussion of the short-term lease analysis. $\stackrel{2}{I}$

1/ See the discussion of "interim" facilities in section $\mathrm{A}(1)$ of Chapter III.

21 No draft legislative changes are enclosed with this chapter. The discussion at Section $A(1)$ of Chapter III points out that existing law authorizes the leasing of SPR storage facilities, and the draft legislation in Part E of Chapter VI covers the leasing of facilities as part of a new "Supplementary Oil Reserve." 


\section{B. HISTORY OF FACILITIES LEASING EFFORTS IN THE SPR PROGRAM}

In the late summer of 1978, the DOE decided that the development of the SPR storage facilities, which theretofore had been performed by Government contractors to Government specifications on Government-owned sites, might be accelerated and technically improved by greater reliance on the private sector. The concept was to provide minimum technical criteria and allow industry the greatest possible flexibility and responsibility to develop innovative approaches for construction of the SPR.

An acquisition plan was formulated, proposing two distinct "turnkey" 3/ procurement efforts: (1) sole source negotiations for the development of three previously identified sites having a total capacity of about 80 million barrels; and (2) a competitive solicitation of offers for storage capacity and possibly for oil. Noncompetitive requests for proposals (RFPs), which contemplated both lease and purchase transactions, were sent to the individual firms controlling the sites in November and December 19"78. Concurrently, a competitive RFP was issued in November 1978 following favorable responses from industry to a Commerce Business Daily request in October 1978 for expressions of interest. A fully-dedicated interdisciplinary DOE source evaluation board was established to draft the RFP and evaluate proposals. Award of any contract was to be subject to approvals from the Office of Management and Budget, the Congress and the President, and to the appropriation of funds.

The competitive RFP was structured as a two-step negotiated procurement, inviting offers of sites with at least 20 million barrels capacity, for a total maximum amount of up to 600 million barrels. Under step one, technical and business proposals were submitted and evaluated against a set of minimum technical requirements. Step two involved the submission and negotiation of pricc and contract proposals. Industry was free to offer any innovative approach meeting the technical requirements, ranging trom leased storage priced on a per-barrel basis, to sale of storage sites developed on a "turnkey" basis. Proposals could, but need not, include an option for the provision of crude oil along with the sites.

Potential offerors were advised that the RFP sought to place the maximum amount of responsibility on the contractors and to minimize the Government's involvement in the development of the stornge facilitics.

The evaluation of the proposals under the competitive RFP was complex, as it provided for the consideration of technical, price, and business/contract areas, with the technical aspects being of greater importance than the other two areas combined, and price and business/contract factors were each given approximately equal weight. The final selections for award, however, were to be made

The term "turnkey" refers to an effort in which the contractor has responsibility for the total completion of a construction/development project such that, upon contract performance, the owner only has to "turn the key" to obtain a functioning building or site. In the SPR context, the contractor was to perform, inter alia, all necessary real estate acquisition, environmental work and permitting, construction, initial operations and maintenance, and related functions for the development and fill of the crude oil storage complex. 
with consideration given to unweighted "Programmatic Selection Factors," from among those offers that were considered to be in the competitive range. The Programmatic Selection Factors were designed to enable the Government to make an award, or combination of awards, that would result in total SPR storage and distribution facilities that would best serve the country's needs. These factors were: (1) location and system capability; (2) fill rate schedule; (3) total usable storage capacity; and (4) risk assessment of the site's technical feasibility, schedule, environmental risks, and acceptability to state and local government and populace.

In early 1979, 23 unpriced technical proposals were submitted by 18 firms. Following oral and written discussions, 12 priced proposals were submitted in June 1979. These proposals, which included numerous lease proposals, were evaluated, but before a competitive range was established, the solicitation was cancelled in August 1979.

The Decision Memorandum, which was dated August 28, 1979, cancelling the procurement, and signed by the Under Secretary, gave the following reasons for cancellation:

- Change in Program Requirements

- Uncertainties in oil availability due to Iranian crisis and restrictions on SPR fill due to import ceilings.

- Turnkey solicitation issued under plans for earliest possible fill with oil availability not a constraint; turnkey proposals require early long-term commitment due to "special purpose" nature of facilities and nature of lease agreement.

- Limited industrial acceptance of liability and responsibilities for storage containers and crude oil significantly diminishes the benefits of the turnkey approach.

- At this point, there are no apparent cost advantages or technical innovations to offset the programmatic risks associated with continuing the turnkey approach under this solicitation.

- In view of the above factors, a different facilities development approach is indicated (ie., further development or expansion on a building block approach to be consistent with crude availability and fill schedules as yet to be defined.)

The sole source negotiations for the three specific sites ultimately also were discontinued for a number of reasons, including: one firm's insistence upon integrating SPR storage into its other commercial operations (e.g., with normal industry security); one firm's lack of good title to the property sufficient to satisfy Justice Department requirements; and practical difficulties of filling and distributing oil from one site. 
While world events, at least in part, resulted in a change in program requirements and thus played a role in the cancellation of the turnkey procurements, the DOE's experience in these actions indicates that the creation and lease of SPR storage facilities by industry was problematic. That is to say, even without the turmoil in the world oil market, awards might not have been made under these procurements, partly for technical or financial reasons. In the view of the DOE at that time, the industry participants in these procurement actions were largely unwilling or unable to offer the sort of assurances the DOE considered necessary with respect to such matters as the integrity of the storage medium, liability for loss of oil, fill and distribution capability, and site security. Additionally, although price was to be weighed less than the technical merits of the proposals, there appeared to be no cost advantages to private sector development.

\section{LEASE DESIGN ISSUES}

As part of the facility financing alternatives analysis, the DOE has prepared a preliminary draft solicitation for long-term leasing of oil storage facilities. This preliminary draft solicitation, which is contained in Volume II of this report, was prepared by the DOE in order to comply with Public law No. 101-46, which requires in section 2(a)(5) that the Secretary of Energy:

Produce (and submit to Congress by February 1, 1990) preliminary written solicitations for proposed alternative financial arrangements (including long-term leasing of crude oil and storage facilities) to assist in filling the Strategic Petroleum Reserve to one billion barrels. (Emphasis added.)

The Department's understanding of the Congressional intent is that leasing solicitation should be produced and submitted to the Congress, without regard to whether such an arrangement is "proposed". The draft facilities leasing solicitation enclosed in Volume II is preliminary in nature; it is not necessarily the solicitation that would be issued in the event that a decision was made to pursue a facility leasing arrangement. In the event of such a decision, further attention would need to be given to this solicitation within the specific context of that decision.

The preliminary solicitation was broken into two steps in order to focus initially on the technical merits of the offers. In the first step, DOE would ask for technical proposals for the leasing of long-term storage facilities. The first step technical proposals would be used to screen out clearly insufficient or unacceptable offers. In the second step of the solicitation, business/contract and price proposals would be submitted. Additional, more comprehensive environmental and technical requirements also would be included as part of the second step of the solicitation. This approach also reduces the cost and effort of the potential lessor in developing the facility lease proposals and the cost and effort of the Government in evaluating the proposals.

In addition to soliciting for a storage facility, the preliminary solicitation includes optional bid items for the provision of operation and maintenance, and for security services at the storage facility. As discussed further below, some potential lessors may view operation, maintenance, and security as completely separable items, which they do not want to provide. Other bidders may insist on providing operations, maintenance, and security services, however, particularly if the leased facility is a multi-user site, in order to limit interference with ongoing operations at the site. 
Consideration was also given to incorporating solicitation provisions allowing the offerors to provide crude oil at their option. In view of the highly preliminary nature of the solicitation, as well as the fact that a separate draft oil leasing solicitation also is being transmitted in Volume II of this report, it was decided not to incorporate a crude oil option. Such an option could be added, if a solicitation ultimately is issued.

The budget effects of leasing storage for SPR oil, relative to purchasing the same facility, would depend on the terms of the lease. The major issues affecting the relative cost of leasing a storage facility are discussed below.

\section{Length of Lease}

A fundamental issue to be considered in deciding on the length of a storage facility lease is the trade-off between minimizing total SPR budget authority requirements and reducing annual budget outlays. It is likely that lease charges will reflect the lessor's capital costs; thus, the periodic lease payment may be viewed as embodying an interest charge. One key feature of the lease approach would be the transfer within the Federal Government of interest costs, from the Treasury to the SPR program. Under current OMB guidelines, // budget authority must be obtained for the full firm Government commitment under the conditions of the lease. A long-term lease would tend to increase total budget authority because of the higher lease payments that must be paid out of the DOE budget over its term. But, by spreading the payment of principal over a larger number of years, annual budget outlays would be reduced.

On the other hand, a short-term ( 5 to 10 year) lease would reduce near-term total budget authority required by reducing the number of years for which interest costs would be incurred. Firms consulted by DOE on this issue indicated that they would require recovery of all principal and interest costs during the firm fixed term of the lease, regardless of the length. Thus, because the lessor's and the lender's principal would have to be recovered in a shorter period of time, initial annual payments for a short-term lease would be higher than a longer-term lease.

As the length of a lease becomes shorter, recovery of principal is compressed into ever shorter time periods, and annual budget outlays for the lease would approach those that would be incurred if the storage facility had been purchased. However, even though budget outlays may be similar for a short-term lease and a purchase, the DOE would have no legal right to a leased facility after the expiration of the short-term lease, and would presumably have to obtain additional storage facilities at that time, unless specified otherwise in the lease.

One possible compromise between a short-term and long-term lease might be a short-term lease with renewal options. However, given the limited demand for salt dome storage facilities, the lessor would likely require that the termination or cancellation penalties in a short-term lease be structured to provide full pay-out of lessor costs plus a reasonable rate of return over the base period of the lease. Thus, the annual lease payments for a short-term lease with renewal options would probably be about the same as for a short-term lease without renewal options.

4/ See discussion of OMB Circular A-104, applicable finance-related laws, and financial procedures in Chapter III. 
An additional factor to be considered in fixing the term of a storage facility lease is the oil to be stored in that facility. If the Government stored its own oil or oil obtained under a long-term lease in a facility with a short-term lease, additional costs would be incurred if the lease terminated and the oil had to be transferred from the short-term storage facility to another storage site.

Based on the above considerations, the length of the lease for the preliminary solicitation was set at 20 years with one 5-year renewal option. Further consideration would need to be given to the question of lease length if a decision were made to lease oil storage facilities.

\section{Size of Storage Site}

In general, larger storage facilities can lead to lower SPR costs due to economies of scale. Conversely, multiple smaller sites, which are dedicated to SPR use, can result in higher SPR costs due in part to the duplication of surface equipment and distribution facilitics. The fixed custs of a small storage site, when spread over the fewer barrels of stored oil, would tend to increase storage costs per barrel. However, smaller sites with multiple users could lower SPR leasing costs by permitting the sharing of construction and operation and maintenance costs with other users.

In order to permit the possibility of inclusion of smaller existing, multi-user sites, the size specifications for the preliminary solicitation have been set as broadly as possible with a minimum size of at least 10 million barrels at each geographic location.

The possibility has been raised that storage capacity might be developed to serve dual-use or even multiple-use purposes. For example, a single facility could hold both commercial stocks, possibly owned by an oil producer country, and oil leased to the U.S. Government for the SPR by that country. Such an arrangement might well achieve economics of scale that would benefit all users of the facility. This type of arrangement is not excluded by the DOE's draft preliminary solicitation, although an offeror on such a basis might wish to take exception to or deviate from certain specifications of the draft RFP, such as those on site sccurity.

However, it should be recognized that a competitive solicitation such as the preliminary draft leasing RFP prepared in the course of this study may not be the best vehicle for exploring dualuse or multiple-use arrangements, particularly in the context of an oil leasing deal with a producer country. As pointed out in Section $A(5)$ of Chapter VI, some producing nations have indicated that they might wish to pursue their own cnmmercial interests in the U.S. markel, in conjunction with an oil lease for the SPR and also that they are unlikely to respond to a traditional competitive solicitation. Moreover, the nature of individual countries' specific interests, and the potential physical arrangements to accommodate those interests, are likcly to differ substantially from case to case, necessitating negotiation on a bilateral basis.

It also follows from what has been said about dual- or multiple-use facilities, that it would be very difficult to provide a financial analysis that will accurately reflect their economic attractiveness. 


\section{Location and Distribution}

The April 1989 DOE report to Congress on SPR expansion concluded that the most beneficial expansion configuration would consist of storage facilities in the Gulf Coast and possibly on the East Coast. Distribution would occur from these sites by pipeline and by water.

The conclusions in the DOE report to Congress were based on the premise that SPR expansion would occur through the purchase of storage facilities. Optimal locations for SPR expansion could possibly be in other locations if substantial cost savings could be achieved from leasing multi-user storage facilities, particularly existing ones. One objective of the 1978-79 "turnkey" solicitation, referred to above, was to ascertain whether there were advantageous storage facility opportunities of which DOE was not then aware. A similar function could be performed by another solicitation if decisions were made to expand the SPR.

The only geographic restriction specified in the preliminary solicitation for leased SPR storage facilities is that sites must be located in the U.S., Canada, or Mexico. In terms of distribution, the preliminary solicitation indicates that storage facilities will be evaluated, in part, on the basis of their accessibility to regions and refining centers having the highest dependence on non-Canadian imported crude oil. Excerpts from the April 1989 DOE report to Congress on SPR expansion are provided in the solicitation as an exhibit, to provide insight into the SPR's distribution requirements. Crude oil distribution is a highly weighted evaluation criterion in the preliminary solicitation. Consequently, the lessor's proposed crude oil distribution plan would be an important factor in evaluating its proposal.

\section{Design and Construction Technical Requirements}

In the past, SPR storage facilities have had to meet rigorous design and construction specifications, including: cavern roof thickness; separation between caverns; and height, width, and sump specifications. An alternative approach would be to announce performance specifications in terms of storage capacity, fill rates, and drawdown capacity. Industry representatives have asserted that cost savings may be achieved if the lessor is permitted to design the site to meet performance rather than design specifications, with only some design and construction requirements being specified. However, they are also disinclined to guarantee the integrity of the caverns after acceptance, even if criteria are used instead of performance design specifications.

Design and construction requirements in the preliminary solicitation have been made as flexible as possible. However, under the preliminary solicitation, leased storage facilities would have to meet the standards for existing SPR sites in terms of safety and security, oil quality and quantity, drawdown and distribution, and system availability. All industry standards and relevant Federal and state regulations related to design and construction of oil storage facilities obviously would also apply equally to a leased facility.

\section{Operation and Maintenance}

The DOE has rigorous operation and maintenance requirements for SPR storage sites. If the lessor has little experience with operating storage facilities, it may be reluctant to provide such services for the leased site. If the storage site is located very near to an existing SPR storage 
facility, the DOE may be able to gain cost savings from sharing infrastructure and pooling overhead costs for the two sites, by providing operation and maintenance. However, in most cases it is expected that the lessor would offer to provide these services if it can recover its costs plus a reasonable rate of return.

In contrast, if the site is a multi-user facility, the lessor may insist upon handling operation and maintenance in order to minimize Federal Government interference with the non-Government storage activity at the site. In some cases, it simply may be infeasible for a third party to provide operation and maintenance for only the Government portion of a multi-user storage site.

The lessor's preference for providing operation and maintenance services would depend in part on the lease technical requirements. As noted above, industry representatives have asserted that some cost savings could be achieved from using performance rather than technical design and construction specifications. If performance-related specifications were set out in the lease, some lessors would prefer to provide facility operation and maintenance. Without control over these services, the lessor might not be willing to ensure the performance of the site. Conversely, if design and construction specifications were used in the lease, the lessor might be more willing to permit others to provide these services. However, the lessor might prefer to provide operation and maintenance services regardless of the type of technical requirements specified, in order to protect the value of the storage facility, which would, under most circumstances, probably revert to its control at the termination of the lease.

In order to provide the greatest flexibility and promote competition, the provision of operation and maintenance services has been included as a separate bid item in the preliminary solicitation. Thus, bidders would have the option of only offering to lease storage facilities, or of offering also to provide operation and maintenance services for the facility.

\section{Security}

The DOE also has strict security requirements that include frequent inspections and security exercises. Some of the potential lessors contacted as part of this alternative financing analysis indicated that the DOE's special security requirements could cause them to decline to lease storage facilities to the Government. Those potential bidders with existing operating storage facilities particularly viewed the DOE security requirements as a serious problem. Other potential lessors contacted, including those that stated that they would strongly prefer to provide operation and maintenance services, indicated that they may be willing to let a third party provide security at the site in order to avoid the added problems caused by special DOE requirements. However, these firms stated they would be willing to provide security if they could recover their costs plus a reasonable rate of return.

Security services for the storage site were included, along with operation and maintenance, as separate bid options. Thus, the potential lessor would have the option of offering these services itself or permitting others to do so. 


\section{Liability}

The provision to the United States, by a contractor, of leased storage facilities and of the associated storage of SPR oil in that facility, raises issues concerning liability for the integrity of the facility and for the loss or contamination of the oil while in storage. As discussed above, in the past, the design and construction of SPR storage facilities have been conducted pursuant to detailed Government specifications, where the DOE took responsibility for the design of the facilities. In those cases, the contractor's performance according to the design specifications essentially fulfilled the contractor's responsibilities and relieved the contractor of liability relating to the facilities' design. The existing SPR sites, however, are all Government-owned sites and the Government has a longstanding policy of self-insurance. No explicit provisions are made in the budget for such self-insurance. Therefore, one effect of the lease approach, to the extent lessor insurance premiums are included in annual lease fees, would be to increase the explicit budget requirements for the SPR.

The facility lease presents different considerations. In the situation where the contractor provides the storage facility as lessor, an issue arises as to the degree of liability the contractor should assume for the integrity of the facility. This is a question both of the level of liability and of the duration of the liability. In the SPR leasing context, lease terms of 10,20 , or 30 years are not beyond the realm of possibility when considering long-term strategic storage of oil. The SPR program in the past has based its facilities planning on an expected useful life of at least 20 years.

Traditionally, in construction contracting, a contract containing performance specifications, which is the type reflected in the DOE's draft facilities leasing solicitation prepared in the course of this study, places the most responsibility, or liability for defects, on the contractor. This is particularly so where the site is owned by the contractor, in that the Government may not be in a position to provide detailed design specifications. In other contexts, however, it is not unusual for responsibility to shift to the lessee upon acceptance of a site (e.g., certification of cavern usability and integrity), especially if the owner/lessor is not performing operation and maintenance services throughout the lease term.

Associated with the issue of integrity of the storage facility is a separate issue involving liability for the loss or contamination of the oil stored in the facility. This is an issue irrespective of whether the lessor of the facility provides the oil, the oil is leased or owned by the Government, or the lessor of the facility is providing operation and maintenance services for the site. That is, liability for the oil is an issue that stems from provision of the site.

The DOE's relevant past experience includes the preparation of two solicitations for the provision of storage facilities: (1) a 1983 solicitation for "interim" storage facilities, which envisioned a 9month term with three 6-month options; and (2) the 1978 "turnkey" procurement discussed above in Part B of this chapter. The interim storage solicitation, which was cancelled shortly after issuance, contemplated that the contractor would take custody of Government-owned oil for shortterm storage and would redeliver the oil at a later date. The draft solicitation held the contractor liable for all oil except for those operational losses not in excess of one-fifth of 1 . percent. The contractor was to provide evidence of its financial capability to cover this risk prior to award. 
Similarly, in the turnkey procurement, the contractor was to be responsible for the loss of oil beyond operational losses then recognized in industry (i.e., one-half of 1 percent) and for any contamination of Government-owned oil. The standard in the turnkey RFP for the contractor's responsibility for any loss in volume and for the contamination was if such loss or contamination occurred "due to negligence, gross negligence, bad faith, or willful misconduct on the part of the Contractor or his agents or subcontractors of any tier." Both the turnkey and the interim solicitations contained force majeure clauses, which would have excused the contractor from liability for damages arising from unforeseeable causes that were beyond the control of, and without the fault or negligence of, the contractor and its subcontractors.

Based on the DOE's experience in the 1978 turnkey procurement, and hased on discussions with industry in the course of conducting this study, the issue of liability is expected to be a difficult one in any lease storage contract negotiation. For example, not one of the 1978 turnkey proposers agreed to assume the level of liability set out in the Government's original RFP. In recent discussions, firms that provide current commercial storage services have indicated that they do not assume risk of loss for oil in their commercial contracts and would not be inclined to do so for the Government. Similarly, although firms that were interested in creating new facilities generally preferred that the Government provide performance specifications rather than design specifications, they were largely unwilling to accept the liability logically associated with that approach.

\section{Environmental Requirements}

In light of the requirements of the National Environmental Policy Act of 1969 (NEPA) and the DOE's implementing NEPA guidelines (see Chapter III, Section B(2)(a)), leasing new oil storage facilities for the SPR may require the preparation of an Environmental Impact Statement (EIS) addressing the environmental impacts associated with the development and nperation of the facility, and the transportation of petroleum to and from the site 5/ However, leasing certain storage facilities in existence in 1982 might qualify for the waiver of the NF.PA requirements contained in section 159(h) of the Energy Policy and Conservation Act, applicable to the storage of petroleum products in "existing interim storage facilities." See Chapter MI, Section $\mathrm{B}(2)(\mathrm{c})$.

The DOE's implementing NEPA guidelines (Section C.4) require the DOE, to the fullest extent possible, to integrate NEPA compliance with other Federal, state, and local environmental review requirements. See Chapter III, Section $\mathrm{B}(2)(\mathrm{c})$, note 10.

A major environmental issue pertaining to the leasing of SPR storage facilities situated in salt domes located along the Texas and Louisiana coasts would be compliance with Federal and state requirements intended to minimize the destruction, loss, or degradation of wetlands, pursuant to the Clean Water Act, the Coastal Zone Management Act, Executive Order No. 11990 ("Protection of Wetlands"), the DOE's regulations implementing Executive Order No. 11990 contained in 10 C.F.R. Part 1022, and state laws and regulations. The EPA and the U.S. Army Corps of Engineers are developing a memorandum of understanding that is intended to clarify the EPA's present guidelines under section 404 of the Clean Water Act pertaining to permits for dredge and fill operations in navigable waters and wetlands that are issued by the Corps of Engineers. In

5/ See Chapter III, Section B(2)(c), note 15 , for a description of the SPR program's prior EIS history. 
addition, an interagency task force is examining strategies and mechanisms to implement the President's policy of no net loss of wetlands.

The DOE's NEPA guidelines establish procedures that would be applicable to procurement actions for leasing storage facilities for the SPR. For projects involving noncompetitive procurements, the DOE guidelines provide that the DOE will prepare, consider, and publish the relevant environmental document before making a "go/no-go" decision on the project. If the project requires an EIS, the guidelines state that, "DOE will not take an action concerning the project which would have an adverse environmental effect or which would limit the choice of reasonable alternatives until the required record of decision is issued." Section B.3(c)(1). In the case of the competitive acquisition of a major system or project, the guidelines state that the DOE will require submission of environmental data as a discrete part of an offeror's proposal and will compare and evaluate environmental impacts of each proposal before selection. For proposals in the competitive range, the guidelines indicate that the DOE will prepare, and consider before selection, an environmental impact analysis. However, the environmental impact analysis is not to contain business, confidential or trade secret information which is protected from public disclosure by 18 U.S.C. 1905. Following the selection, the DOE will make public a selection statement to record how the relevant environmental consequences of reasonable alternatives have been evaluated in the selection process. If the proposal selected is likely to have significant effects on the quality of the human environment, the guidelines require the DOE to "phase subsequent contract work to allow publicly available EIS's to be prepared, considered and published in full conformance with the [Council on Environmental Quality NEPA guidelines] and in advance of a go/no-go decision." Section B.3(c)(2). This effectively would require that the DOE condition contract award on the completion of the EIS process in these cases.

For the preliminary draft solicitation, environmental data submission requirements have been developed for each of the two steps of the process. For the first step, which requests unpriced technical proposals, offerors would be required to provide environmental information pertaining to their proposed sites. Information required to be submitted would include: (1) a description of the environmental impact (including a wetlands assessment) of any construction and operation of the proposed facility; (2) an identification of any known impacts on endangered species and/or historic or archaeological resources; and (3) a description of the potentially impacted sensitive biotic communities in the event of an oil spill.

In the second step of the solicitation process, those offerors remaining in the competition would be required to submit additional environmental information along with their business, management, and price proposals. The DOE would then prepare an environmental impact analysis for each of these proposals. Any lease awards would be conditioned on the successful completion of the review process required under the NEPA, including the preparation of an EIS if appropriate. 


\section{METHODOLOGY AND ASSUMPTIONS}

The SPR has never received a definitive facilities lease proposal that can be compared to direct development of a Government site. Therefore, the approach taken to evaluation has been sensitivity analysis, oriented toward illustrating (a) the budgetary effects of leasing, even when the fundamental economics are identical to those of direct development, and (b) the effects of different assumptions on the cost of leasing as compared to purchase.

The analysis of the long-term lease-versus-purchase of SPR storage facilities was conducted based on the guidelines detailed in OMB Circular A-104. The OMB guidelines stipulate that a leaseversus-purchase analysis compare the present value (discounted) life of the lease costs with the cost of buying an identical asset. Accordingly, the Reference Case for the long-term lease analysis uses the same construction costs, timing, and related assumptions developed for the Reference Case as reported in Chapter V of this report.

The starting point for the long-term lease-versus-purchase analysis was a simplified Reference Case in which all financial terms were assumed to be the same for the private sector lessor as in the U.S. Government purchase case. In addition, a zero tax rate was assumed in the Reference Case. This simplified Reference Case was used as the basis for examining the effects of altering different assumptions on an incremental basis. Sensitivity analysis was conducted based on the following alternative long-term lease assumptions:

- $\quad$ Changing the lessor's construction costs by plus or minus 10 percent

- Changing the lessor's finance charges by plus or minus 2 percent

The base leasing case and each of the sensitivity cases were evaluated relative to the Reference Case scenario in which storage facilities were assumed to be purchased. '1 he discounted costs (net present value) of leasing versus purchasing were calculated. In addition to the comparison of net present value costs, the lease-versus-purchase alternatives were evaluated on the basis of SPR budget outlays. SPR budget outlays essentially correspond to the undiscounted nominal dollar costs of leasing. Real dollar costs were also calculated for the reference lease and purchase cases.

The final step in the long-term facility lease analysis was to conduct an analysis of the reduction in facilities costs and, separately, the reduction in facility finance charges that would be required to make the discounted costs of leasing a storage facility equal the discounted costs of purchasing an identical facility. These break-even test cases were conducted using financial, economic, and tax assumptions consistent with current market conditions and statements made by potential offerors who were contacted as part of this analysis. 


\section{E. ANALYSIS OF FACILITY LEASE REFERENCE CASE}

This section presents the results of the Reference Facility Lease-versus-purchase case. As noted above, simplified economic, financial, and tax assumptions have been made for this Reference Case so that clear insights can be obtained from the sensitivity analysis discussed below.

The Reference Case focuses on the acquisition of storage capacity to expand the SPR from 850 million barrels to 1 billion barrels. The storage facility construction costs and schedule were assumed to be the same as in the Reference Purchase Case discussed in Chapter IV of this report.

Table XI-1 lists the assumptions used for the Reference Facility Lease Case. The lease was assumed to begin in the year 2000 and to last for 20 years. All additional costs associated with the lease, including such costs as closing costs and debt service charge, were assumed to be zero.

All economic and financial assumptions were assumed to be the same for the private lessor as for the Government purchase case. Thus, the lessor's interest payments on long-term debt were assumed to be the same as the Government's cost of borrowed money, which was taken from the Reference Purchase Case to be 8.13 percent. 6 . The lessor was assumed to borrow 100 percent of the funds required for construction of the storage facility. Thus, the lessor's equity contribution to the construction costs was assumed to be zero.

All Federal and state taxes in this simplified reference case were assumed to be zero. All state investment tax incentives were also assumed to be zero.

\section{Reference Case SPR Budget Outlays}

As shown in Table XI-2, in the Reference Facility Lease Case, SPR budget outlays would increase by $\$ 2.0$ billion, if the storage facility were leased rather than purchased. The estimated increase in budget outlays relative to the purchase case was due to the additional interest costs that the DOE would pay over the assumed 20 years of the lease term. However, there would be an identical decrease in Treasury interest costs through the same period. This demonstrates the shift in financing custs between the two agencies under the lease method. Furthermore, under current procedures, DOE would need the total budgct authority for the lease ( $\$ 3$ billion) at the time the lease was awarded, whereas Treasury budget authority requirements for interest would be deferred.

6/ In general, this study is assuming a Treasury borrowing rate of 8 percent. OMB Circular A-104 calls for a discount rate of one-eighth of a percent above Treasury borrowing rates, hence the 8.13 percent used in this example. 
Table XI-1

Facility Lease Reference Case Assumptions

Lease Assumptions

Effective Lease Length

Lease Start Date

20 years

Construction Start Date

2000

Lease Pre-Payments

Closing Costs

Debt Service Charge

1991

Lease Signing Expense

0

0

0

Termination Costs

Tax Indemnity

0

Economic/Financial Assumptions

Discount Rate (pre-tax)

$8.13 \%$

Inflation Rate

$3.00 \%$

Interest on Long-Term Debt

$8.13 \%$

Interest on Closing Cost Debt

N/A

Equity Contribution

$0.00 \%$

Debt Contribution

$100.00 \%$

Return on Equity

N/A

Tax Assumptions

Federal Income Tax Rate

$0.00 \%$

Stale Income Tax Rate

$0.00 \%$

Investment Tax Credit

N/A

State Investment Tax Incentives

N/A

Depreciation Allowance

N/A

Property Tax

N/A 
Table XI-2

\author{
Financial Summary \\ Reference Case (FY 1991-2019) \\ Facility Lease Versus Purchase Analysis \\ (millions of dollars)
}

\section{Financial Measures}

Budget Outlays

DOE

Treasury Interest

Total

Avg. Annual DOE Outlays

FY 1991-1999

FY 2000-2019

Present Value Costs

$\begin{array}{ccr}\begin{array}{c}\text { Facility } \\ \text { Purchase }\end{array} & \begin{array}{c}\text { Facility } \\ \text { Lease }\end{array} & \text { Change } \\ & & \\ 1,101 & 3,106 & 2,005 \\ \frac{6,105}{7,206} & \frac{4,100}{7,206} & \frac{-2,005}{0}\end{array}$

122

0

155

809

809

0

\section{Reference Case Average Annual Budget Outlays}

If the storage capacity for the last 150 million barrels of SPR crude oil were leased rather than purchased, budget outlays would be postponed and spread out over a much longer time frame. No budget outlays would be incurred in the 1991 to 1999 time frame because the Government would not begin lease payments until the facility was available to store oil. The first budget outlay for lease payments would occur in the year 2000. Beginning in that year, annual lease payments of $\$ 155$ million would continue throughout the 20-year lease term. In contrast, if the storage facility was purchased, budget outlays would average $\$ 159$ million over the 1991-1996 time period and $\$ 49$ million from 1997 to 1999 . No budget outlays would be incurred after 1999 if the facility were purchased.

\section{Reference Case Present Value Costs}

The present value of the cost of leasing the storage facility was calculated to be the same as would be incurred if the facility was purchased. This result is strictly due to the assumptions made in this simplified Reference Case. Namely, all construction and finance costs, and the schedule, were assumed to be the same for the lessor as they would be for the Government if it purchased the same facility.

Thus, in this Reference Case, the lessor acts as an intermediate entity that incurs no additional costs, realizes no efficiencies, and obtains no net profit. The lessor calculates lease payments such that their present value is identical to the sum of its construction costs and its cost of capital. 
In the other examples presented below, the analysis of Treasury interest costs is not included on the ground that this effect is captured in the present value analysis and need not be reflected in the future value analysis as well.

\section{F. FINANCE CHARGE SENSITIVITY ANALYSIS}

The cost to the Government of leasing SPR storage facilities can be affected by changes in a number of variables. This sensitivity analysis scenario demonstrates the effect of changes in the lessor's interest payments on long-term debt. Two finance charge sensitivity cases were run. In the first case, the lessor's interest rate on borrowed funds was assumed to be reduced 2 percentage points below the reference case, from 8.13 percent to 6.13 percent. In the second case, the lessor's interest rate was increased by 2 percentage points to 10.13 percent. The first case is introduced for sensitivity analysis purposes only, since the study team is unaware of circumstances under which a private commercial lessor would have lower borrowing costs than the Federal Government. All other assumptions, including 100 percent debt financing, were left unchanged from the Reference Lease Case.

As detailed below, a decline in the lessor's finance costs leads to lower Government costs for leasing storage facilities. This decline in Government leasing costs is due to the lower interest payments that must be paid over the 20-year lease term. An increase in lessor finance costs leads to a nearly symmetric increase in the Government's cost of leasing SPR storage facilities. Table XI-3 presents the results of this finance charge sensitivity analysis.

\section{Finance Charge Sensitivity Case SPR Budget Outlays}

Decreases or increases in the lessor's interest rate on borrowed funds have a roughly symmetric affect on total SPR budget outlays. A decline in the lessor's interest rate of 2 percentage points leads to a decline in total SPR budget outlays of $\$ .6$ billion, or 21 percent, relative to the Reference Lease Case. However, even with this reduced lessor interest cost, total SPR budget outlays remain over $\$ 1.3$ billion above the Reference Purchase Case.

An increase in the lessor's interest rate of 2 percentage points would increase total SPR budget outlays by nearly $\$ .8$ billion above the Reference Lease Case, and yields total SPR budget outlays of nearly $\$ 2.8$ billion above the Reference Purchase Case.

\section{Finance Charge Sensitivity Case Average Annual Outlays}

A decline in the lessor's interest rate of 2 percentage points would lead to a decline in average annual budget outlays to $\$ 123$ million, which would be $\$ 32$ million below the Reference Case Lease payments. An increase in the lessor's interest rate of 2 percentage points would cause average annual budget outlays to increase to $\$ 193$ million, an increase of $\$ 38$ million relative to the Reference Lease Case. In percentage terms, the impact of changes in the lessor's interest rates would be the same as for total budget outlays. 


\section{Table XI-3 \\ Financial Summary \\ Finance Charge Sensitivity Analysis \\ (millions of dollars)}

Financial Measures

SPR Budget Outlays

Avg. Annual Outlays

FY 1991-1999

FY 2000-2019

Present Value Costs

\section{Facility}

Purchase

1,101

122

0

809
Facility
Lease

Finance Charge

Sensitivity

$-\underline{2.0 \%}+\underline{2.0 \%}$

3,106

2,465

3,863

0

155

0
123

0

193

809

$642 \cdot 1,006$

\section{Finance Charge Sensitivity Case Present Value Costs}

A decline in the lessor's interest rate of 2 percentage points would result in present value costs of $\$ 642$ million, which would be $\$ 167$ million below the Reference Lease and Purchase Cases. An increase of 2 percentage points would lead to present value costs for the leased storage facility of $\$ 1.0$ billion, $\$ .2$ billion above present value costs in the Reference Lease and Purchase Cases. 


\section{G. CONSTRUCTION COST SENSITIVITY ANALYSIS}

In these sensitivity cases, the effect of changes in the lessor's storage facility construction costs relative to the Reference Lease Case are examined. Two cost sensitivity cases were simulated. In the first case, lessor construction costs were assumed to be 10 percent below the construction costs in the Reference Case. In the second case, lessor costs were assumed to be 10 percent above the Reference Case. All other assumptions were left unchanged from the Reference Lease Case. The results of the cost sensitivity cases are presented in Table XI-4.

\section{Construction Cost Sensitivity SPR Budget Outlays}

A reduction in lessor construction costs of 10 percent would have a smaller effect on SPR budget requirements than would the 2 percentage point reduction in lessor interest rates examined above. Total SPR budget outlays would decline to about $\$ 2.8$ billion, a rcduction of about $\$ .3$ billion from the Reference Lease Case. An increase in lessor construction costs of 10 percent would increase SPR budget requirements for the storage facility to $\$ 3.4$ billion.

Table XI-4

Financial Summary

Construction Cost Sensitivity Analysis

Facility Léase Versus Purchase Analysis

(millions of dollars)

$\underline{\text { Financial Measures }}$

Purchase

Reference

Construction Cost

Lease

Scnsitivity

$$
-\underline{-10.0 \%}+\underline{10.0 \%}
$$

Total Budget Outlays

1,101

3,106

2,796

3,417

Avg. Annual Outlays

FY 1991-1999

FY 2000-2019

122

0

155

0

0

0

809

728

Present Value Costs

809

890

\section{Construction Cost Sensitivity Average Annual Budget Outlays}

A decrease in lessor construction costs of 10 percent would result in average annual budget outlays of $\$ 140$ million, a $\$ 15$ million decrease below the Reference Lease Case. An increase in lessor construction costs of 10 percent would increase average annual budget outlays for the storage facility by $\$ 15$ million. 


\section{Construction Cost Sensitivity Present Value Costs}

If the lessor cut construction costs by 10 percent, the present value costs of the storage facility would decline to $\$ 728$ million, which would be $\$ 81$ million below the Reference Case present value costs. An increase in lessor construction costs of 10 percent would lead to an $\$ 81$ million dollar in the present value costs of the storage facility relative to the Reference Case.

\section{H. BREAK-EVEN ANALYSIS: FINANCE CHARGES AND CONSTRUCTION COSTS}

This part of the chapter examines the reduction in finance charges or in construction costs that would be required for the leasing of an SPR storage facility to have the same present value costs to the Government as would result from the purchase of the same storage facility.

In the Reference Lease Case and related sensitivity analyses discussed above, simplifying assumptions about lease terms, economic and financial conditions, and taxes were made in order to illustrate the effects of alternative assumptions on Federal Government costs. In contrast, for the following break-even analysis, the Reference Lease Case assumptions were modified to more realistically reflect conditions that might prevail should the Government proceed to lease SPR storage facilities. The assumptions used for the finance charge/construction costs break-even analysis are presented in Table XI-5.

Two separate cases were developed for this break-even analysis. In the first case, an estimate was made of the reduction in the lessor's construction cost that would be required in order for the present value of Government leasing costs to be equal to the present value of Government costs for purchasing an identical storage facility. In the second break-even case, an estimate was made of the reduction in the lessor's construction costs that would be required in order for the present value of the Government's cost of leasing a storage facility to be the same as the cost of purchasing that facility.

\section{Lease Assumptions}

The assumptions concerning lease start date, lease length, and construction start date remain unchanged from the Reference Lease Case. However, the Reference Case assumptions were modified to include the additional costs that would be incurred if the Government were to lease SPR storage facilities rather than purchase them. These additional lease costs include:

- Closing costs, which were assumed to be 2 percent of the total capital costs of the project

- Debt Service Charges, which were set at 1 percent of the borrowed amount

- Lease signing expense, which was assumed to be $\$ 100,000$ 
Table XI-5

Assumptions for Finance Charge/Construction Cost Break-Even Analysis

Lease Assumptions

Effective Lease Length

Lease Start Date

20 years

Construction Start Date

2000

Lease Pre-Payments

1991

Closing Costs (\% of capital cost)

0

Debt Service Charge

Lease Signing Expense

Termination Costs

Tax Indemnity

Economic/Financial Assumptions

Discount Rate (pre-tax)

$8.13 \%$

Inflation Rate

$3.00 \%$

Interest on Long-Term Debt

$8.75 \%$

Interest on Closing Cost Debt

$8.75 \%$

Equity Contribution

$20.00 \%$

Debt Contribution

$80.00 \%$

Return on Equity (pre-tax)

$15.00 \%$

Tax Assumptions

Federal Income Tax Rate

$34.00 \%$

State Income Tax Rate

$4.00 \%$

Investment Tax Credit

N/A

State Investment Tax Incentives

N/A

Depreciation Allowance

Property Tax

MACRS 40 year, SLN

N/A 
Lease prepayments, termination costs, and tax indemnity costs were assumed to be zero for this break-even analysis. It was also assumed that there would be no insurance costs to the lessor that are not borne -- albeit implicitly through self-insurance -- by the Federal Government.

\section{Economic and Financial Assumptions}

The economic and financial assumptions were also modified to approximate conditions that might prevail should the Government proceed to lease SPR storage facilities. The Government's discount rate and the inflation rate were assumed to remain unchanged for the Reference Case. The remaining economic and financial assumptions were modified as follows:

\section{a. Debt/Equity Ratio}

Nearly all of the potential lessor companies contacted as a part of this analysis indicated that they would try to keep their equity contribution to project financing for an SPR storage facility to a minimum. However, according to current IRS regulations, a project must have a minimum of 20 percent equity financing in order to obtain the full tax benefits of a "true lease." Consequently, the Reference Case assumption of 100 percent debt financing was modified to reflect minimum IRS requirements. As shown in Table XI-5, a debt/equity ratio of $80 / 20$ was assumed for this break-even analysis.

\section{b. Interest on Long-Term Debt}

All of the potential lessor companies contacted for this analysis commented that a long-term, noncancellable lease to the Federal Government would be viewed as a relatively low-risk project that would probably qualify for the lowest private interest rate available. During the 1980's the spread between the Treasury rate and low-risk corporate bond rates, such as Moody's Corporate Aaa bond rate, was about .75 percent. Consequently, for this break-even analysis, the interest rate on long-term debt was set at 8.75 percent, which was three-quarters of a percentage point above the Treasury rate assumed for the Reference Purchase Case, before adjustment by one-eighth of a percent to mirror Circular A-104 procedures.

\section{c. Return on Equily}

The lessor's required return on equity investment to finance the project was assumed to be 15 percent. This is consistent with comments made by the potential lessor companies contacted for this analysis. Each of the companies contacted stated that 15 percent was probably the minimum rate that a lessor would accept for an SPR storage facility lease with the Federal Government.

\section{Tax Assumptions}

For the Reference Lease Case presented above, all Federal and state taxes were assumed to be zero. Lessor depreciation allowances were also ignored. Here, Federal and state taxes and depreciation allowances were included for the break-even analysis. 


\section{a. Federal Income Tax Rate}

The tax rate used for the break-even analysis was 34 percent, which is the current maximum rate of tax on corporate profits. This represents an estimate of the marginal rate of tax on the income generated by the lease. In fact, the income generated by the lease ultimately flows to a wide variety of entities, including corporations, some of which may have losses that offset their income from the lease, tax-exempt institutions, and individuals. Some of these entities may face marginal tax rates that differ from the maximum rate on corporate profits. It is impossible, however, to trace the income generated by the lease to each ultimate recipient, or to determine. the exact marginal tax rate faced by each one.

Therefore, this lease-versus-purchase cost analysis assumes that all of the income generated by the lease is taxed at the maximum rate for corporate profits. Thus, Federal income tax rates are assumed to be 34 percent for both lessors and lenders. Although this rate is acceptable for the lessors, the average tax rate for lenders could be lowër because many non-proflt organizatiuns participate in debt financing. Since the DOE storage facility project, with the Government as the lessee, is a relatively low risk project, there is reason to expect that the long-term lenders may included non-taxed organizations, i.e., low risk investors (pension funds).

\section{b. State Income Tax Rate}

State tax rates vary from state to state. For this analysis, the storage facility site location was not specified. Consequently, a mid-range state tax rate of 4 percent was used.

\section{c. Investment Tax Credits}

The Federal investment tax credit (ITC) is no longer available for investors (with few exceptions). In addition, ITCs, even if available, are not allowed by the IRS on leases to the Federal Government. Therefore, the study assumes no ITC. If available, an ITC could reduce the cost of leasing to the DOE, but not to the total Federal budget.

\section{d. State Investment Incentives}

Many states have established incentive programs to encourage investment. If an SPR storage facility was leased in a state with investment incentive programs, the DOE's lease costs could be reduced. However, because it is not known which state an SPR storage facility may be located in or what state investment incentives will apply, this study assumes no state investment incentives.

\section{e. Depreciation Allowance}

For this analysis, it was assumed that a salt dome storage facility would qualify for the 40 year, straight-line depreciation recovery schedule under the Modified Accelerated Cost Recovery System (MACRS). This study also assumed that a maximum of 80 percent of the construction cost would qualify for depreciation allowance. 


\section{Results of Finance Charge/Construction Cost Break-Even Analysis}

Table XI- 6 compares the Reference Lease to a lease which reflects all of the assumptions on Table XI-5. It illustrates that, with no construction savings or financing savings, the present value cost of a purely commercial lease would exceed these of the Reference Lease, hence the purchase alternative.

As shown in Table XI-7, the results of the break-even analysis indicate that the lessor would have to reduce construction costs for an SPR storage facility by about 6 percent in order for the present value of lease costs to be equal to the present value costs of purchasing an identical facility.

Alternatively, a reduction in the interest rate on long-term debt of .62 percent below the 8.75 percent shown in Table XI-5 would be required in order for leasing to breakeven with a purchase of an SPR storage facility on a present value basis. The resulting interest rate on the lessor's longterm debt would be reduced to 8.13 percent, which is the assumed Federal rate.

By design, the present value costs for the two break-even cases are equal to those estimated for the purchase case. Total present value costs were estimated to be $\$ 809$ million. 


\section{Table XI-6}

Financial Summary

Lease Incorporating Table XI-5 Assumptions

(millions of dollars)

$\underline{\text { Financial Measures }}$

Total SPR Budget Outlays

Avg. Annual DOE Outlays

FY 1991-1999

Present Value Costs

$\underline{\text { Financial Measures }}$

Total SPR Budget Outlays

Avg. Annual Outlays

FY 1991-1999

FY 2000-2019

Present Value Costs
Purchase

1,101

122

809
Reference
Lease

3,106

15.5

809
Table XI-5

Lease

3,282

165

861

Table XI-7

Financial Summary

Break-Even Analysis

(millions of dollars)
Facility

Purchase

1,101

122

0

809
$1.0 \%$ Reduction in Construction

Costs

3,106

0

$155^{\circ}$

809
$.6 \%$ Reduction

in Finance

Costs

3,106

809 


\section{FILL RATE/INTERIM STORAGE ANALYSIS}

Under the proposed construction schedule to expand facilities to accommodate a total of one billion barrels, the SPR can purchase crude oil at a constant rate of 75,000 or 50,000 barrels per day without meeting any storage problems. This assumes that facilities development would be initiated in FY 1991 and does not run into any unanticipated delays. If, however, crude oil is purchased at a constant rate of 100,000 barrels per day (bbl/d), there could be a period of approximately three and one half years when the acquisition of crude oil would outpace the availability of permanent storage. Interim or temporary storage would be required to sustain a $100,000 \mathrm{bbl} / \mathrm{d}$ fill rate in each year. This assumes the development profile set forth in Chapter V, and further that no existing storage facilities are acquired.

The question arises: Why, if the Government is aware of the shortfall in permanent storage, would it still purchase crude oil that would require the additional interim storage costs? The answer is that, if the perception of future crude oil prices were such that prices were expected to rise steeply in the future, it might be cost effective to purchase the crude oil up front, despite the additional storage costs.

This part of the chapter compares the costs of purchasing crude oil at a constant rate of 75,000 $\mathrm{bbl} / \mathrm{d}$ with the costs of a constant purchase rate of $100,000 \mathrm{bbl} / \mathrm{d}$ plus the costs of interim storage, for a three and one half year period beginning in 1994. It was assumed that irrespective of the fill rate scenario, permanent storage facilities would proceed at the same pace and cost. Consequently, permanent storage facilities costs are not included in this particular analysis but are examined elsewhere in the chapter.

It was assumed under the $100,000 \mathrm{bbl} / \mathrm{d}$ scenario that crude oil would be purchased at a constant rate. Beginning in 1994, interim storage would be required, as the planned facilities for 750 million barrels will have been filled and new permanent facilities will not yet be available. The amount of storage required peaks at approximately 55 million barrels and then declines as permanent storage becomes increasingly available. By mid-year 1997 the permanent storage available will be sufficient and no further interim storage will be required.

For the fill rate/interim storage analysis, the following assumptions were used:

- $75,000 \mathrm{bbl} / \mathrm{d}$ fill rate was assumed completed by the end of 2005 ; $100,000 \mathrm{bbl} / \mathrm{d}$ fill rate was assumed completed by the end of 2002 .

- The Reference Case oil price projections were used for both fill rates.

- $\quad$ SPR "add-on" costs were incorporated into oil prices to cover the cost of moving the crude oil to the salt caverns.

- An average cost of $3 / 4$ cent per barrel per day was used for interim storage. 
- An average cost of $\$ 1.00$ per barrel was used to cover the cost of unloading into the interim storage facilities and for subsequent reloading and transporting to the permanent SPR sites.

- A 10 percent discount rate was used.

- The cost and schedule for permanent facilities were assumed to be the same for the different fill rates, so the analysis focuses only on the SPR oil budget.

\section{Fill Rate/Interim Storage SPR Budget Outlays}

As shown in Table XI-8, SPR oil budget outlays would be $\$ 1.7$ billion, or 13 percent, greater if a fill rate of $75,000 \mathrm{bbl} / \mathrm{d}$ was used. This is because of the oil purchased in the post-2000 period, when oil prices are projected to grow substantially.

Table XI-8

Financial Summary

Fill Rate/Interim Storage Analysis

(millions of dollars)

Costs at

$100,000 \mathrm{bbl} / \mathrm{d}$ Fill Rale

Oil Purchase Costs

75,000 bbl/d Fill Rate

Oil Purchased

Interim Storage

Total

Total Budget Outlays:

14,331

12,183

472

12,655

Average Annual Outlays:

FY 1991-1996

634

1,008

846

1,344

65

20

911

FY 1997-2000

1,299

347

1,364

FY 2001-2005

11,699

10,608

429

11,036

Present Value Costs:

5,439

5,864

253

6,117

\section{Fill Rate/Interim Storage Annual Budget Outlays}

The distribution of the average annual budget outlays reflects the rising oil prices in the later years of purchase. Under the $100,000 \mathrm{bbl} / \mathrm{d}$ fill rate, budget outlays peak in the mid to late 1990 's, reflecting the impact of interim storage. Under the $75,000 \mathrm{bbl} / \mathrm{d}$ fill rate, budget outlays rise steadily, reflecting the increasing cost of crude oil. 


\section{Fill Rate/Interim Storage Real Dollar Costs}

Undiscounted real dollar costs would be $\$ .7$ billion, or 6 percent, higher if the $75,000 \mathrm{bbl} / \mathrm{d}$ fill rate were pursued. As with total budget outlays, the higher cost is associated with the volume of crude oil purchased in the latter years.

\section{Fill Rate/Interim Storage Present Value Costs}

The present value costs of the $100,000 \mathrm{bbl} / \mathrm{d}$ fill rate plus storage are calculated to be $\$ 0.7$ billion greater than the present value costs of the $75,000 \mathrm{bbl} / \mathrm{d}$ fill rate.

\section{J. FILL RATE BREAK-EVEN ANALYSIS: REDUCED OIL PRICE}

This part of the chapter examines the change in oil prices that would be required for the 100,000 $\mathrm{bbl} / \mathrm{d}$ fill rate scenario to have the same present value costs to the Government as the $75,000 \mathrm{bbl} / \mathrm{d}$ fill rate.

The assumptions for this analysis were those listed under Part I above with the exception of the projected price of crude oil. The results are shown in Table XI-9. In order for the present value costs of the $100,00 \mathrm{bbl} / \mathrm{d}$ fill rate to equal those of the $75,000 \mathrm{bbl} / \mathrm{d}$ fill rate, the estimated crude oil prices would have to be 12.2 percent lower than the Reference Case price throughout the period.

\section{Total Budget Outlays.}

With a 12.2 percent reduction in the crude oil price stream for the $100,000 \mathrm{bbl} / \mathrm{d}$ fill rate, the cost differential between the two fill rates would widen even more. The $75,000 \mathrm{bbl} / \mathrm{d}$ fill rate would now result in total budget outlays of $\$ 3.1$ billion, or 28 percent, more than the $100,000 \mathrm{bbl} / \mathrm{d}$ fill rate.

\section{Average Annual Budget Outlays}

The distribution pattern of the average annual budget outlays would follow that of the Reference Case, the one difference being the lower numbers in the $100,000 \mathrm{bbl} / \mathrm{d}$ fill rate, due to lower crude oil prices.

\section{Real Dollar Costs.}

In the Fill Rate/Interim Storage Analysis, the spread between the real dollar costs for the two fill rates was 6 percent. Under this related break-even analysis the spread has widened to 19 percent.

\section{Present Value Costs}

By design, the present value costs for the break-even analysis of the $100,000 \mathrm{bbl} / \mathrm{d}$ fill rate are set equal to these of the $75,000 \mathrm{bbl} / \mathrm{d}$ fill rate. Total present value costs are estimated to be $\$ 5.4$ billion. 
Table XI-9

Financial Summary

Break-even Analysis: Reduced Oil Price

Fill Rate/Interim Storage

(millions of dollars)

Oil Purchasc Costs at 75,000 bbl/d Fill Rate

Total Budget Outlays:

14,331

1,299

11,699

5,439

FY 1997-2000

634

1,008

FY 2001-2005

Present Value Costs:

Real Dollar Costs (\$1991)
Costs at $100,000 \mathrm{bbl} / \mathrm{d}$ Fill Rate (12.2\% Reduction in Oil Price)

Interim Storage
Average Annual Outlays:
10,768

748

1,187

306

$\underline{\text { Total }}$

9,377

5,186

429

253

65

20

1,207

306

9,806

472

11,240

Oil Purchased

0

5,439 
APPENDIX I

INTERAGENCY STEERING GROUP

STRATEGIC PETROLEUM RESERVE

ALTERNATTVE FINANCING AND SIZE STUDIES 
INTERAGENCY STEERING GROUP

STRATEGIC PETROLEUM RESERVE

\section{ALTERNATIVE FINANCING AND SIZE STUDIES}

Linda Stuntz, Chairman

Deputy Under Secretary

Department of Energy

Michael R. McElwrath, Vice Chairman

Acting Assistant Secretary for Fossil Energy

Department of Energy

Robert A. Speir, Coordinator

Office of Oil Policy

Department of Energy

Todd Buchholz

Deputy Executive Secretary

Economic Policy Council

Lou Gallegos

Assistant Secretary for Policy,

Budget, and Administration

Department of the Interior

Robort Grady

Associate Director for Natural Resources, Energy, and Science

Office of Management and Budget

Sidney Jones

Assistant Secretary for Economic Policy

Department of the Treasury

Jack Katzen

Assistant Secretary for Production and Logistics

Department of Defense

Eric Melby

Director for International Economic

Affairs

National Security Council 
INTERAGENCY STEERING GROUP

STRATEGIC PETROLEUM RESERVE

ALTERNATIVE FINANCING AND SIZE STUDIES

(CONTINUED)

Joseph A. Moreland

Assistant Associate Director

for Mobilization Preparedness

Federal Emergency Management Agency

William C. Ramsay

Deputy Assistant Secretary for International Energy Resources and Food Policy

Department of State

John Richards

Deputy Assistant Secretary for Industrial Resource Management

Department of Commerce

Richard L. Schmalensee

Member, Council of Economic Advisors

Richard Stakem

Director of Global Issues

Central Intelligence Agericy 


\section{ÄPPENDIX II}

INTERAGENCY WORKING GROUP

STRATEGIC PETROLEUM RESERVE

ALTERNATIVE FINANCING STUDY 
INTERAGENCY WORKING GROUP

STRATEGIC PETROLEUM RESERVE

ALTERNATIVE FINANCING STUDY

Howard G. Borgstrom, Chairman

Office of Petroleum Reserves

Department of Energy

Robert G. Bidwell, Jr., Coordinator

Office of Petroleum Reserves

Department of Energy

Interagency Members

L. Stuart Allan

Department of State

Daniel G. Baucum

Internal Revenue Service

Roberl A. Berman

Department of the Interior

Julia Billingsley

Department of State

Todd Buchholz.

Economic Policy Council

David S. Curry

Department of the Treasury

E. Bill Dinkelacker

Office of Management and Budget

Edward Dyckman

Department of Defense

Mark Finley

Central Intelligence Agency 


\section{Interagency Members, Continued}

Jeffrey A. Jones

Department of Defense

George D. Kenney

Department of State

James D. Mietus

Office of Management and Budget

Jolnn R. Pfeiffer

Office of Management and Budget

Ray Squitieri

Department of the Treasury

Jeremy C. Stein

Council of Economic Advisors

William A. Weingarten

Department of State

Daniel M. Zelikow

Department of the Treasury

\section{Department of Energy Members}

Craig S. Bamberger, Office of General Counsel

Samuel M. Bradley, Office of General Counsel

William J. Brennan, Office of Intergovernmental Affairs

John Brodman, Office of International Affairs

Guy Caruso, Office of Energy Emergencies

Edward G. Connor, Office of Energy Emergencies

Mary H. Egger, Office of General Counsel 


\section{Department of Energy Members, Continued}

Lise C. Howe, Office of General Counsel

John C. O'Connor, Office of Petroleum Reserves

Robert H. Pafe, Office of Budget

Mark E. Rodekohr, Energy Information Administration

\section{Other Participants/Contributors}

\section{Interagency}

Susan Baker

Internal Revenue Service

Lewis Baylor

Department of Justicc

Virginia Butler

Department of Justice

Norman Carleton

Department of the Treasury

Richard Chewning

Internal Revenue Service

Andrew Kettler

Internal Revenue Service

Steven R. Lainoff

Internal Revenue Service

Edward Schwartz

Internal Revenue Service

Rom Watson

Department of the Treasury 


\section{Other Participants/Contributors, Continued}

Department of Energy

Office of Petroleum Reserves

Walter J. Chilman

Walter H. Delaplane

Duryea de B. Gray

F. Jerome Hinkle

Fred Hutchinson

Frank M. Hydro

David F. Johnson

Ralph LaMonda

Lynnette le Mat

Nancy Marland

Arthur S. Roemer

John Shages

Richard Smith

Strategic Petroleum Reserve Project Management Office

Charles T. Dobson

Michael McWilliams

Ray M. Patarnostro

Anthony J. Sanchez

Edward H. Whitfield

Office of Policy, Planning, and Analysis

Robert A. Speir

Vito A. Stagliano

Office of General Counsel

Harvetta M. Asamoah

Michael S. Yanock

Office of Public Affairs

David C. Benton 


\section{Other Participants/Contributors, Continued}

\section{Office of Procurement and Assistance Management}

Arnold Gjerstad

Michael Hethmon

Stanley Kaufman

Thomas S. Keefe

Office of Project and Facilities Management

Roger E. Arola

Donald G. Trost 


\section{Consultants}

ICF Resources Incorporated

John Blaney

Theodore R. Breton

Jim Carey

Ed Chu

Stephen Horn

Asa Janney

Barbara Lundien

Susan MacMillan

George W. Nugent

Jacqueline Peppers

Zeta R. Rosenberg

Patricia Ann Skinner

Edward Tolliver

Donna Whitlock

Energy Futures Group, Inc.

Rutherford S. Poats

Arnold E. Safer

Oak Ridge National Laboratory

Russell Lee

Paul Leiby 


\section{APPENDIX III}

INTERIM REPORT

STRATEGIC PETROLEUM RESERVE

ALTERNATIVE FINANCING STUDY 


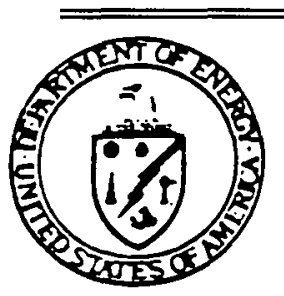

\section{The Deputy Secretary of Energy \\ Washington, DC 20585}

October 13, 1989

The Honorable Robert C. Byrd

Chairman, Subcommittee on

Interior and Related Agencies

Committee on Appropriations

United States Senate

Washington, D.i. 20510

Dear Mr. Chairman:

Public Law 101-46 requires the Department of Energy to prepare a study on alternative. financing methods for the Strategic

Petroleum Reserve (SPR). The final report is due on February 1 , 1990, with an Interim Report due on October 15, 1989.

Enclosed for your information is the Interim Report referred to in Public Law 101-46. The report describes the progress which the Department has made in undertaking this study. As reflected by the activities described in the Interim Report, the Department has mobilized the capabilities of a broad range of organizations both inside and outside the Federal Government.

Evaluating options for leasing crude oil and storage facilities is a particularly interesting aspect of the ongoing study. Many variations are possible on lease term, lease payments, purchase options, and disposition of the proceeds in the event of a drawdown of SPR oil. To date our discussions with potential lessors have been exploratory but encouraging. We are optimistic that, in the coming months, continuing the dialogue will help us in our analysis of leasing options.

We intend this study to be an objective appraisal of the SPR financing options, assuming a SPR of one billion barrels as the Congress directed. We.also are studying the closely related issue of the appropriate size of the Reserve. Assessing these two issues in an objective way will allow us to make informed decisions on whether to expand the SPR and on how to pay for the expansion if it is warranted.

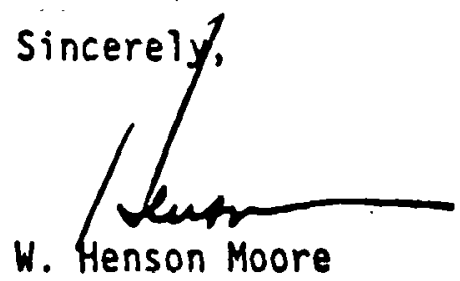




\section{Strategic Petroleum Reserve Financing Study Interim Report to Congress}

I. Introduction

Public Law 101-46 requires the Secretary of Energy to undertake a study of alternative methods for financing the Strategic Petroleum Reserve (SPR). The final report is to be submitted to the Congress by February 1, 1990, along with drafts of any legislative changes that would be necessary to authorize the most significant financing alternatives (See Attachment $A$ ). The purpose of this paper is to provide a status report to Congress by Detober 15, 1989.

11. Department of Energy's (OOE's) Activities in Support of Study

The Department is interested in innovative methods of finaricing the SPR. While various studies of this subject have been conducted in the past, the current effort differs from prior efforts in two major respects. First, the Department is reviewing SPR financing policy in close coordination with a policy review of the appropriate size of the Reserve on the ground that there are close relationships between these two policies. Consistent with direction from the President, we need to make an informed decision on the benefits and costs of expanding the SPR as well as atternate ways of paying for expansion if it is warranted. Second, the Department is actively seeking new ideas and participation from a broad range of persons and organizations both from within and outside the Executive Branch. The overall organization of the study can be broken down into three areas:

A) Interagency Steering and Working Group

B) The Internal DOE effort

C) Public and Foreign Government participation

Each of these is discussed further below. Since staff, contractor and other resources devoted to this study are contributed from various agencies and from existing contracts it is not possible at this time to provide specific estimates of the personnel and funding committed to the study.

\section{A. Interagency Steering and Working Groups}

To enhance the SPR size and financing studies, the Department has created an Interagency Steering Group comprised of representatives from interested departments and agencies. On August 11, 1989, DOE Deputy Secretary Henson Moore requested participation from the following: The Departments of Commerce, Defense, the Interior, State, and the Treasury, the Central Intelligence Agency, the Council of Economic Advisors, the Federal Emergency Management Agency, the Office of Management and Budget, the National Security Council and the White House. A list of agency designees is included as Attachment $B$. 
This Steering Group, which is chaired by DOE Deputy Under Secretary Stuntz, first met on September 15, 1989, to review draft work plans prepared by DOE staff, discuss key policy issues, and organize working level groups to provide technical input to the study efforts.

Interagency working groups are meeting on specific study items, and the Department has asked certain agencies for assistance on key topics. For example, the Associate General Counsel (International) of the Internal Revenue Service is analyzing the Federal income tax issues involved in the leasing of oil or storage facilities from foreign persuns.

\section{B. The Internal DOE Effort}

Within the Department, the Strategic Petroleum Reserve study efforts have been divided into two areas. The Assistant Secretary for Fossil Energy has the responsibility of conducting the SPR Financing Study. The Assistant Secretary for International Affairs and Energy Emergencies has responsibility for the SPR size analysis. The Deputy Under Secretary for Policy, Planning and Analysis will assure coordination and policy review of the two studies. Representatives from throughout the Department have been assigned to work on these studies. The efforts to date have been organized in accordance with three major functions: study preparation, facilities lease solicitation drafting and oil lease solicitation drafting.

\section{1.) Study Preparation}

While the Department intends to remain open to public participation throughout the conduct of the study, it is cognizant of the need to provide Congress with a report on schedule. To focus the study preparation effort, the Department has established some preliminary policy guidelines and selected a series of policy options for more extensive review. The primary financing alternatives under review by the study team include:

- Leasing storage facilities in the event the SPR is expanded beyond 750 millian barrels;

- Leasing oil for the SPR (to complete 750 million barrels and to expand the Reserve to one billion barrels);

- Selling oil-denominated bonds, with proceeds used to acquire SPR oil;

- Use of the Naval Petroleum Reserves to finance SPR oil acquisition, either through full divestiture with proceeds dedicated to SPR fill, through leasing, or through the establishment of a revolving fund which would permit the cash 
flow from Naval Petroleum Reserve No.1 (Elk Hills, California) to be appropriated for operating the oil fields and for SPR oil acquisition; and

- Establishment of an SPR user fee based on U. S. oil imports or consumption.

The Department anticipates that further alternatives will be identified during the course of the study.

Progress to date has included:

- Development of a study structure;

- Working group review of basic economic assumptions;

- Interagency discussions of possible oil lease design features;

- Interagency identification of possible policy issues that will require further discussion or study; and

- Identification of key legal issues.

The Energy Information Administration is working with the study teams to provide documentation for basic economic assumptions. The Office of General Counsel has developed preliminary analyses on a variety of legal questions, as well as draft legislation on leasing, and is working with the Department of the Treasury on tax issues. The Office of International Affairs and Energy Emergencies is preparing a summary analysis of oil stockpile financing methods used by U.S. partners in the International Energy Agency. effort.

These other organizations are assisting the Department in this

- Energy Futures Group, Inc., of Bethesda, Maryland has undertaken preliminary analyses of the oil leasing and bond alternatives, as well as the Naval Petroleum Reserves revolving fund concept. These analyses are being used to identify key design questions which need to be addressed.

- Oak Ridge National Laboratory is responsible for operating a number of Strategic Petroleum Reserve planning models, and plans have been made to use at least one of these mode is to evaluate private financing alternatives.

- ICF Resources, Inc., of Fairfax, Virginia has developed a preliminary analysis of facilities leasing and is assisting the Department in assembling background information and preparing the final study document. 
- TMS, Inc:, of Germantown, Maryland has developed methods for analyzing supply disruption risk assumptions and is advising on economic evaluation methods.

- Boeing Petroleum Operations, Inc., the management and operating contractor for the SPR, has been asked to assess the availability of existing private storage capacity.

In working with these organizations, the Department is ensuring that it complies with current legislative restrictions on the use of appropriated funds for studies of Naval Petroleum Reserves divestiture.

\section{2.) Facilities Lease Solicitation Drafting}

The Department is preparing a draft solicitation within the framework of Federal procurement requirements for real estate and equipment. This approach could be used to acquire either permanent or temporary storage. The Planning and Analysis Division of the Office of Strategic Petroleum Reserve with support from the SPR Project Management Office, the Office of General Counsel, and the Office of Chief of Real Property has accomplished the following:

- Discussions with the Office of NEPA Project Assistance and General Counsel concluded with establishment of strategies for addressing National Environmental Policy Act (NEPA) requirements in a facility leasing solicitation.

- Preliminary decisions have been made to structure the draft solicitation as a 2-step negotiated procurement.

- Initiated preparation of technical and performance criteria for addressing requirements for storage media, facilities development, environment, security, operations, and maintenance for the Statement of Work part of the preliminary solicitation.

- Topics for discussions with private industry have been prepared and the Department has initiated contacts with industry to arrange for meetings to share views on all aspects of industry leasing crude oi.l storage facilities to the Government.

\section{3.) Oil Lease Solicitation Drafting}

The Operations and Readiness Division of the Office of Strategic Petroleum Reserve has the lead responsibility for this effort, working with the Office of General Counsel and the SPR Project Management office. The Department has begun writing a draft preliminary solicitation for use in seeking competitive offers to lease crude oil to the Federal government for storage in the SPR. To date, utilizing the crude oil acquisition supply contract terms and conditions employed by the Defense Fuel Supply Center, as well as the Department's provisions previously utilized in purchasing crude oil from domestic sources and from Petroleos Mexicanos (Mexico's state oil company), lease 
solicitation provisions have been drafted relating to oil quality specifications, means for determining oil quality and quantity, meeting U. S. - flag vessel cargo preference requirements, means of delivery, determination of laytime and demurrage, etc. Additionally, various standard contract clauses required under Federal Acquisition Regulations have been identified for inclusion in the draft solicitation.

C. Public and Foreign Government Participation

Representatives of the Department have met with a number of parties to obtain ideas on new approaches to financing the SPR. As of late September, meetings had been held with several oil companies, investment banks, and foreign governments. The Department plans further meetings in the coming months to obtain broad input to the analysis effort. In addition, a Notice of Inquiry has been issued to broaden public participation.

On August 29, 1989, the Assistant Secretary of Energy for International Affairs and Energy Emergencies notified other members of the Governing Board of the International Energy Agency of the requirements of Public Law 101-46 and invited them to share ideas on ways to finance the SPR. The Department also has worked with the Department of State to arrange discussions with representatives of foreign governments. To date, representatives of the Department have shared ideas with official representatives from Mexico, Saudi Arabia, Japan, Norway, the United Kingdom and Belgium. Meetings with other countries are planned, as well as follow-on meetings with countries already contacted.

The Department's discussions, to date, with both private sector and governmental representatives have been useful. Some participants have given considerable thought to possible SPR financing approaches, and the study effort will benefit from the broad variety of ideas which have been shared.

The Department has made no policy decisions on which, if any, of the financing alternatives is preferable to the current financing method. Discussions have been exploratory in nature without commitment to undertake specific actions. 
Public Law 101-46

101st Congress

June 90,1989

[S. 694]

12 USC 6251.

50 USC app. 2071 notes.

42 USC 6240 note.

\section{An Act}

To extend title $I$ of the Enersy Policy and Conservation Act.

Bc it enacted by the Senate and House of Representatives of the United States of America in Congress assembled,

SECTION 1. EXTENSION.

Title 1 of the Enerry Policy and Conservation Act (42 U.S.C. 6211 et seq.) is amended-

(1) in section 171, by striking out "June 30,1989 " each place it appears and inserting in lieu thereof "April 1, 1990"; and

(2) in section 104(b)(1), by striking out "June 30,1989 " and inserting in lieu thereof "April 1, 1990".

SEC. 2. STUDY AND REPORT ON OIL LEASING AND OTHER ARRANGEMENTS TO FILL SPR TO ONE BILLION BARRELS.

(a) In General.- The Secretary of Energy shall carty out a study on potential financial arrangements (including long-term leasing of crude oil and storage facilities) that could be used to provide additional, alternative means of financing the filling of the Strategic Petroleum Reserve to one billion barrels. In carrying out such study, the Secretary shail-

(1) assume that the legislation that extends title I of the Energy Policy and Conservation Act beyond April 1, 1990, will require the Secretary to amend, by July 1, 1990, the Strategic Petroleum Reserve Plan to provide plans for completion of storage of one billion barrels of petroleum products in the Reserve at an average fill-rate of at least seventy-five thousand barrels per day;

(2) consider a broad array of such arrangements;

(3) consult with persons in the private sector who might be interested in leasing crude oil or storage facilities;

(4) initiate, in cooperation with the Department of State, to the extent consistent with the interests of the United States, discussions with representatives of foreign governments and other entities as to the types of financial arrangements (includ. ing crude oil leasing arrangements) that would interest them; and

(5) produce preliminary written solicitations for proposed alternative financial arrangements (including long-term leasing of crude oil and storage facilities) to assist in filling the Strategic Petroleum Reserve to one billion barrels.

(b) REPORTS. - (1) The Secretary shall, no later than October 15, 1989, transmit to the Committee on Energy and Natural Resources of the Senate and the Committee on Energy and Commerce of the House of Representatives an interim report containing-

(A) an enumeration of the specific resources (both personnel and funding) committed to the study described in subsection (a);

(B) a description of the progress made toward completing the study; and 
date.

(C) any preliminary findings and conclusions made by such

(2) The Secretary shall, no later than February 1, 1990, transmit to such committees a copy of the solicitations described in paragraph (5) of subsection (a) and a final report containing the findings and conclusions of the study carried out under this section, together with a draft of the legislative changes that would be necessary to authorize the most significant alternative financial arrangements studied by the Secretary (including long-term leasing of crude oil and storage facilities) and recommendations of the Secretary with respect to the need for and desirability of such financial arrangements (including long-term leasing of crude oil and storage facilities).

(c) ENForcement. - Notwithstanding any other provision of law, no portion of the United States share of crude oil in Naval Petroleum Reserve Numbered 1 (Elk Hills) may be sold or otherwise disposed of pursuant to any contract or other agreement entered into or extended on or after February 1, 1990, other than to the Strategic Petroleum Reserve (either directly or by exchange) until the Secretary of Energy has transmitted the solicitations and the final report described in subsection $(b)(2)$ (including the legislative changes and recommendations described in such subsection) to the committees described in subsection (b)(1), except for the purposes provided in section $160(\mathrm{~d} \times(2)$ of the Energy Policy and Conservation Act.

Approved June 30, 1989.

LEGISLATIVE HISTORY-S. 694 (H.R. 2539):

HUUSE REFURTS: No. 1U1-86 accompanying H.R. 2539 (Comm. on Energy and Commerce).

SENATE REPORTS: No. 101-33 (Comm. on Energy and Natural Resources).

CONGRESSIONAL RECORD, Vol. 135 (1989).

May 31 , considered and passed Senate.

June 20, H.R. 2539 considered and passed House; proceedings vacated and S. 694 , amended, passed in lieu.

June 23 , Senate concurred in House amendment with an ameadment.

June 28, House concurred in Senate amendment.

WFFKI.Y MMPIL.ATTON OF PRFSINFNTIAL DOCUMENTS, Vol. 25 (1989): June 30, Presidential statement. 


\section{ATTACHMENT B}

Below is a list of the interagency representatives for SPR size/financing studies.

INTERAGENCY REPRESENTATIVES FOR SPR SIZE/FINANCING STUDIES

INTERIOR: Lou Gallegos (Policy Group)

Assistant Secretary, Policy, Budget \& Administration

DEFENSE: Jack Katzen

Assistant Secretary of Defense for Production \& Logistics

COMMERCE: James M. LeMunyon

Deputy Assistant Secretary for Export Administration

CIA: Richard J. Stakem

Director, Office of Global Issues

OMB: $\quad$ Robert Grady

Associate Director for Natural Resources, Energy and Science

STATE: William Ramsey

Deputy Assistant Secretary for Energy Resources and Food Policy

TREASURY: Richard Porter

Deputy Assistant Secretary for Policy Review and Analysis

CEA: Richard Schmalensee

Member Designate for Council of Economic Advisors

FEMA: Joseph A. Moreland

Assistant Associate Director for Mobilization Preparedness

NSC: Eric Melby

Director for International Economic Affairs

WHITE HOUSE: Todd Buchholz

Economic Policy Council 


\title{
APPENDIX IV
}

\section{PUBLIC RESPONSES TO}

\author{
NOTICE OF INQUIRY
}

On October 2, 1989, the Department of Energy issued a Notice of Inquiry requesting ideas for or comments about alternative financing methods for completing Strategic Petroleum Reserve development and oil fill. The Department specifically expressed an interest in approaches that would reduce the total cost of the SPR to the Federal Government or would reduce near-term effects on the Federal budget without significantly raising the SPR's total costs. This appendix presents brief summaries of the eleven responses to the Notice of Inquiry. 


\section{ALTERNATIVE FINANCING PROPOSAL SUMMARY}

Firm name: $\quad$ American Petroleum Institute (API)

Address: $\quad 1220$ L Street NW Washington, D.C. 20005

Date: $\quad$ October 20, 1989

Signatory: Charles E. Sandlẹ

Title: $\quad$ Vice President

\section{SUMMARY}

API recommends that 'the U.S. Government consider oil and/or storage facility leasing. API is ambivalent toward pre-crisis sales of rights to SPR oil but opposes industrial user charges to finance the SPR. 


\section{ALTERNATIVE FINANCING PROPOSAL SUMMARY}

Firm name: Ashland Oil, Inc.

Address: $\quad$ P.O. Box 391, Ashland, KY. 41114

Date: October 19, 1989

Signatory: William E. Perrine

Title: Administrative Vice President

\section{SUMMARY}

Ashland, which is a partner in the Louisiana Offshore Oil Port (LOOP), recommends that the Government consider storing SPR oil in the LOOP salt dome caverns located in the Louisiana Gulf Coast, if the Government decides to lease storage facilities. LOOP is a deepwater port facility capable of unloading large supertankers. Its unloading platform is located about 20 miles offshore; the oil is pumped onshore to salt dome storage caverns located near Galliano, LA. The caverns are then connected by numerous crude oil pipelines serving southern and midwestern refineries. LOOP currently has cavern storage capacity of around 40 million barrels, and can be leached to store much larger quantities, which could then be isolated for Government use. 


\section{ALTERNATIVE FINANCING PROPOSAL SUMMARY}

Firm name: Cambrian Capital Corporation

Address: $\quad 8713$ Susanna Lane, Chevy Chase, MD. 20815

Date: $\quad$ October 19, 1989

Signatory: Rande Leonard

Title: Consultant for Special Projects

\section{SUMMARY}

Mr. Leonard recommends moving SPR oil acquisition off budget by creating a private, Government-owned corporation that would purchase existing SPR oil by issuing $\$ 20$ billion of 25 to-30-year oil bonds, either conventional or oil based. Funds in excess of those needed to purchase existing SPR oil would be used to purchase additional oil for the SPR at a rate of 150,000 barrels per day. Coverage would extend to the full one billion barrels of stored oil. The bonds' principal would be pre-paid by zero coupon Treasury bonds. The purpose of the recommendation is two-fold: to reduce the impact of expenditures for buying SPR oil on the Federal budget; and to lower the cost of financing per se. The corporate bonds would be structured to offer investors a fixed or varying yield and would be long or short term depending on the current and projected financial market circumstances. The basic rationale for this recommendation involves the hypothesis that bondholders, guaranteed principal, would be willing to accept a 3 percent interest rate plus the right to convert an oil-backed bond into the dollar equivalent of oil instead of, in the case of Government bonds, perhaps an 8 percent interest rate (the difference being made up of compensation for inflation). Should the investment market accept these terms, financing would cost an SPR corporation a fraction of Government financing costs. Mr. Leonard claims $\$ 18$ billion of Federal budget savings.

As an alternative, Mr. Leonard outlined a bond proposal in which the U.S. and the bondholder would share in price appreciation during an SPR drawdown. 


\section{ALTERNATIVE FINANCING PROPOSAL SUMMARY}

Firm name: $\quad$ CBI Industries, Inc.

Address: $\quad 1101$ 17th Street NW, suite 812, Wash., D.C. 20036

Date: $\quad$ October 29, 1989

Signatory: Stephen J. Toth

Title: Manager, Washington office

\section{SUMMARY}

CBI (a division of Chicago Bridge \& Iron Co.) recommends that the Government review CBI's previous proposal that the Government lease CBI's 40 million barrel above-ground steel tank oil storage facility located at White Castle, LA. 


\section{ALTERNATIVE FINANCING PROPOSAL SUMMARY}

Firm name: Corporate Investment International

Address: $\quad 4550$ Post Oak Place, Suite 107, Houston, TX.77027

Date: $\quad$ October 19, 1989

Signatory: Charles Faust/Dale Steffes

Title: $\quad$ President, CII/Planning \& Forecasting Consultants

\section{SUMMARY}

Recommends that the Government establish a lease/purchase agreement with the private sector to provide facilities for storage of the remaining 430 million barrels of SPR oil. Claimed advantages include speed of development and cost économies. The latter are estimated to run as much as 54 percent below U.S. Government construction costs. Using the data provided in the recommendation, and applying it to the storage of 430 million barrels of SPR oil, savings of leasing storage from the private sector are estimated by the proposal to range between $\$ 1.08$ billion and $\$ 1.51$ billion to the Government's advantage. Applied to the purchase of $\$ 20 / \mathrm{bbl}$ oil (for example), this would account for between 13 and 18 percent of the remaining 430 million barrels of oil to be bought. (The recommendation also observes that monies thus saved could be applied to purchasing SPR oil.) 


\section{ALTERNATIVE FINANCING PROPOSAL SUMMARY}

Firm name: $\quad$ State of Hawaii, Dept. of Business \& Econ.. Dev.

Address: $\quad$ Kamamalu Bldg., 250 S. King St., Honolulu, HA.

Date: October 19, 1989

Signatory: Roger A. Ulveling

Title: Not given

\section{SUMMARY}

Hawaii observes that the Federal Government should establish a Regional Petroleum Reserve for Hawaii to provide it with the same degree of protection afforded by the SPR for the contiguous 48 states. It believes that such a Reserve could be facilitated by the State of Hawaii's leasing land for that purpose at a nominal rate to the Federal Government; by private sector users of oil capitalizing and constructing above-ground tanks for that purpose on the state land; and then by leasing the entire facility (including the necessary pipeline, offshore mooring, and fencing infrastructure) to the Federal Government on a "turnkey" basis. Appended to Hawaii's comments was a copy of the November 1988 report, "A Review of Factors Relating to the Establishment of a Regional Petroleum Reserve in Hawaii," by Bruce W. Wilson. Hawaii had previously provided this report to the Department in late 1988. The extent of coverage would be 10 million barrels of crude and commercial grade jet fuel (to be supplied by the Federal Government). 


\section{ALTERNATIVE FINANCING PROPOSAL SUMMARY}

Firm name: National Council of Farm Cooperatives (NCFC)

Address: $\quad 50$ F Street NW, suite 900, Wash., D.C. 20001

Date: $\quad$ November 3, 1989

Signatory: $\quad$ R. Thomas Van Arsdall

Title: Vice President

\section{SUMMARY}

NCFC makes several points with regard to alternative financing of SPR oil and facilities. Regarding oil leasing, NCFC comments:

(1) All leased oil should be stored within the United States;

(2) Leasing could eventually cost considerably more than buying; that is, short-term budget savings could be swamped by higher long-term true economic costs;

(3) Alternative financing could include the notion of call option trading by the Government -- a right to buy oil at a fixed "strike price";

(4) Alternatively, it could offer the right to buy at prevailing market prices. In this, the private sector would enjoy an opportunity to make dramatic "windfall" profits during a disruption;

(5) Financing should not be linked to oil user fees, somcthing which NCFC believes would work particular hardship on farmers and others;

(6) Any system of alternative financing should avoid sharing policy control of the oil with foreigners. In like manner, oil, when drawn down, should not be sold to foreign refiners;

(7) An alternative financing approach which appeals to NCSC is trading foreign debt for oil;

(8) Reflecting on current SPR storage costs, NCFC believes significant operating savings could be achieved by privatizing oil storage;

(9) Finally, NCFC supports countertrade -- farm products for oil -- as a way of reducing oil buying costs. 


\title{
ALTERNATIVE FINANCING PROPOSAL SUMMARY
}

\author{
Firm name: Louisiana Land and Exploration Company (LL\&E) \\ Address: 909 Poydras St. PO Box 60350, New Orl., LA.70160 \\ Date: October 19, 1989 \\ Signatory: H. Leighton Steward \\ Title: Chairman, CEO, and President
}

\section{SUMMARY}

LL\&E recommends use of leased private storage facilities to store SPR oil, suggesting this would save as much as 50 percent in storage costs. Another advantage noted would be recasting the SPR budget toward an annualized "holding" cost (versus a one-time capital outlay as in the case of Government-owned facilities). The proposal implicitly suggests this would spread costs out over time and allow the purchase of more oil at a more rapid rate. Salt dome storage is considered the best alternative, particularly from the perspective of security. The Gulf Coast basin contains over 500 such salt domes (and is located near the largest center of petroleum refining and distribution in the United States).

LL\&E also recommends leasing private sector oil from producer nations with excess productive capacity willing to rent at lower-than-market prices. Advantages would be the same as for leasing; there would only be an annual payment, resulting in the ability to lease more oil, more quickly than when buying. LL\&E's illustrative calculations suggest, in general, that leasing oil would be cheaper when its use would not be likely; whereas buying oil would be cheaper when its use would be likely.

LL\&E identifies several issues surrounding oil or facilities leasing, including the 34 percent corporate income tax; oil import duties; the Superfund Tax; various state oil taxes (all of which would add to the Government's oil leasing costs); liability; and moditication of the Energy Policy and Conservation Act to allow leasing, and withdrawal of oil, absent a Presidential drawdown declaration. 


\section{ALTERNATIVE FINANCING PROPOSAL SUMMARY}

Firm name: $\quad$ Petroleum Industry Research Foundation, Inc. (PIRINC)

Address: $\quad 122$ E. 42nd St., New York, N.Y. 10168

Date: October 18, 1989

Signatory: John H. Lichtblau

Title: President

\section{SUMMARY}

To meet a need for accelerating the rate of SPR fill beyond the currently anticipated 75,000 barrels per day level in order to maintain 90 days of import coverage as oil imports grow, the current (Gramm-Rudman-Hollings) envirnnment of budget constraint must be ovcrcome by effecling economies in the present program. These economies could arise from two sources:

(1) Leasing oil storage facilities from the private sector below U.S. Government cost. The ability of private sector leasing to speed up development of these facilities would also contribute to maintaining the 90-days-of-import-coverage goal. The recommendation specifically refers to the Louisiana Land and Exploration Company's 300 million barrel salt dome proposal. The proposal extends the recommendation to the entire remaining 430 million barrels yet to be filled.

(2) Leasing oil at a cost discounted from market levels by excess-capacity foreign producers. These othcrwise lost revenues would motivate such producers found among OPEC partners and Norway. Excluded would be Mexico and others whose output is already at maximum. One formula for leasing would involve reimbursing the lessor government for actual cash lifting and transportation costs plus the foregone interest on the money spent -- in total, however, only a fraction of oil's market price. 


\section{ALTERNATTVE FINANCING PROPOSAL SUMMARY}

Firm name: $\quad$ Planning \& Forecasting Consultants (P\&FC)

Address: $\quad$ P.O. Box 820228, Houston, TX. 77282-0228

Date: October 19,1989

Signatory: Dale W. Steffes

Title: $\quad$ Principal \& Founder

\section{SUMMARY}

P\&FC proposes that foreign energy producers store their own oil in SPR facilities free of charge. The proposal is based on the notion that the United States has an oil security supply problem, and producers such as Saudi Arabia have an oil security demand problem. P\&FC says that joint use of the SPR in this way would solve both problems. 


\section{ALTERNATIVE FINANCING PROPOSAL SUMMARY}

Firm name: Not applicable

Address: 609 N.E. Mulberry, Lee's Summit, MD 64063

Date: October 20, 1989

Signatory: Ron Brown (private letter)

Title: $\quad$ Not given

\section{SUMMARY}

Recommends that oil companies store their own oil in the SPR facility for a fee. Oil would be drawn out during a declared supply emergency. 
OFFICIAL BUSINESS

PENALTY FOR PRIVATE USE, $\$ 300$

F $[-4.31$ 